37450

PUBLIC SECTOR GOVERNANCE AND

ACCOUNTABILITY SERIES

LOCAL GOVERNANCE IN DEVELOPING COUNTRIES

Edited by ANWAR SHAH

THE WORLD BANK 



\section{LOCAL GOVERNANCE IN DEVELOPING COUNTRIES}




\section{Introduction to the Public Sector Governance and Accountability Series}

Anwar Shah, Series Editor

A well-functioning public sector that delivers quality public services consistent with citizen preferences and that fosters private market-led growth while managing fiscal resources prudently is considered critical to the World Bank's mission of poverty alleviation and the achievement of the Millennium Development Goals. This important new series aims to advance those objectives by disseminating conceptual guidance and lessons from practices and by facilitating learning from each others' experiences on ideas and practices that promote responsive (by matching public services with citizens' preferences), responsible (through efficiency and equity in service provision without undue fiscal and social risk), and accountable (to citizens for all actions) public governance in developing countries.

This series represents a response to several independent evaluations in recent years that have argued that development practitioners and policy makers dealing with public sector reforms in developing countries and, indeed, anyone with a concern for effective public governance could benefit from a synthesis of newer perspectives on public sector reforms. This series distills current wisdom and presents tools of analysis for improving the efficiency, equity, and efficacy of the public sector. Leading public policy experts and practitioners have contributed to this series.

The first 13 volumes in this series, listed below, are concerned with public sector accountability for prudent fiscal management; efficiency, equity, and integrity in public service provision; safeguards for the protection of the poor, women, minorities, and other disadvantaged groups; ways of strengthening institutional arrangements for voice, choice, and exit; means of ensuring public financial accountability for integrity and results; methods of evaluating public sector programs, fiscal federalism, and local finances; international practices in local governance; and a framework for responsive and accountable governance.

Fiscal Management

Public Services Delivery

\section{Public Expenditure Analysis}

Local Governance in Industrial Countries

Local Governance in Developing

Countries

Intergovernmental Fiscal Transfers:

Principles and Practice

\section{Participatory Budgeting}

Budgeting and Budgetary Institutions

Local Budgeting and Financial Management

Tools for Public Sector Evaluations

Accountability for Performance

Macrofederalism and Local Finances

Citizen-Centered Governance 


\section{PUBLIC SECTOR GOVERNANCE AND ACCOUNTABILITY SERIES}

\section{LOCAL GOVERNANCE IN DEVELOPING COUNTRIES}

Edited by ANWAR SHAH

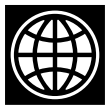

THE WORLD BANK

Washington, D.C. 
(C)2006 The International Bank for Reconstruction and Development / The World Bank 1818 H Street, NW

Washington, DC 20433

Telephone: 202-473-1000

Internet: www.worldbank.org

E-mail: feedback@worldbank.org

All rights reserved

\section{6}

This volume is a product of the staff of the International Bank for Reconstruction and Development / The World Bank. The findings, interpretations, and conclusions expressed in this volume do not necessarily reflect the views of the Executive Directors of The World Bank or the governments they represent.

The World Bank does not guarantee the accuracy of the data included in this work. The boundaries, colors, denominations, and other information shown on any map in this work do not imply any judgement on the part of The World Bank concerning the legal status of any territory or the endorsement or acceptance of such boundaries.

\section{Rights and Permissions}

The material in this publication is copyrighted. Copying and/or transmitting portions or all of this work without permission may be a violation of applicable law. The International Bank for Reconstruction and Development / The World Bank encourages dissemination of its work and will normally grant permission to reproduce portions of the work promptly.

For permission to photocopy or reprint any part of this work, please send a request with complete information to the Copyright Clearance Center Inc., 222 Rosewood Drive, Danvers, MA 01923, USA; telephone: 978-750-8400; fax: 978-750-4470; Internet: www.copyright.com.

All other queries on rights and licenses, including subsidiary rights, should be addressed to the Office of the Publisher, The World Bank, 1818 H Street, NW, Washington, DC 20433, USA; fax: 202-522-2422; e-mail: pubrights@worldbank.org.

ISBN-10: 0-8213-6565-7

ISBN-13: 978-0-8213-6565-6

eISBN-10: 0-8213-6566-5

eISBN-13: 978-0-8213-6566-3

DOI: $10.1596 / 978-0-8213-6565-6$

\section{Library of Congress Cataloging-in-Publication Data}

Local governance in developing countries / edited by Anwar Shah.

p. cm. - (Public sector governance and accountability series)

Includes bibliographical references and index.

ISBN-13: 978-0-8213-6565-6

ISBN-10: 0-8213-6565-7

1. Local finance-Developing countries. 2. Local government-Developing countries. 3. Finance, Public-Developing countries. 4. Public administration-Developing countries. I. Shah, Anwar. II. Series. 


\section{Contents}

Foreword xvii

Preface xix

Acknowledgments $\quad x x i$

Contributors xxiii

Abbreviations and Acronyms xxvii

1 The New Vision of Local Governance and the Evolving Roles of Local Governments 1

by Anwar Shah with Sana Shah

Introduction: Local Government and

Local Governance 1

The Theory: Conceptual Perspectives on

Local Governance and Central-Local Relations 3

The Practice: Alternative Models of Local

Governance and Central-Local Relations $\quad 26$

A Comparative Overview of Local

Government Organization and Finance

in Selected Developing Countries 33

Concluding Remarks

42

Acknowledgments

44

References 44 


\section{vi Contents}

\section{Africa}

2 Local Government Organization and Finance:

South Africa 47

by Chris Heymans
A Brief History
47

The Legal Status and Autonomy of Local Government

Composition of Revenues and Expenditures: General Patterns

The Structure and Administration of Local Government

Local Government Expenditure Responsibilities

Local Governments' Own Taxes and Charges

67

Intergovernmental Transfers 73

Local Government Borrowing $\quad 80$

Assessment

83

Lessons for Developing Countries

Notes $\quad 90$

References 91

3 Local Government Organization and Finance:

Uganda $\quad 93$

by Jesper Steffensen

Background 94

Legal Status and Autonomy $\quad 94$

Structure of Local Governments $\quad 98$

Brief Overview of Revenue and Expenditures 101

Local Government Expenditures 104

Local Government Revenues 109

Financial Management Capacity 128

Overall Assessment and Lessons $\quad 129$

Notes 133

References 134

\section{Asia}

4 Local Government Organization and Finance:

China 137

by Baoyun Qiao and Anwar Shah

Local Government Expenditure Responsibilities 
Local Revenues 149

Intergovernmental Fiscal Transfers 155

Local Government Borrowing 160

Local Government Administration 162

An Impressionistic View of Local Government

Finances in China 163

Lessons for Developing Countries 165

Notes 166

References $\quad 166$

5 Local Government Organization and Finance:

Urban India 169

by Om Prakash Mathur

Expenditure Domain of Municipalities $\quad 172$

Revenue Base of Municipalities $\quad 179$

Center-State-Municipal Fiscal Relations 181

Borrowing by Municipal Governments 190

The Finances of Municipalities: An Assessment 195

Concluding Remarks 201

Notes 201

References 203

6 Local Government Organization and Finance:

Rural India 205

by V. N. Alok

Evolution of Rural Local Government 205

The Legal Framework 208

Functional Domain 211

Own-Source Taxes 213

Borrowing 219

Intergovernmental Fiscal Transfers $\quad 219$

National Finance Commission $\quad 220$

Centrally Sponsored Schemes 224

Fiscal Autonomy versus Dependency 225

Issues and Lessons $\quad 227$

Notes 229

References 230 
7 Local Government Organization and Finance:

Indonesia 233

by Sebastian Eckardt and Anwar Shah

A Brief History of Local Government in Indonesia 233

Current System of Local Governments: Legal, Fiscal, and Political Overview 235

Local Government Expenditure Responsibilities $\quad 240$

Local Government Own-Source Taxes and Charges 246

Shared Taxes and Revenues $\quad 249$

Intergovernmental Fiscal Transfers 250

Local Government Borrowing $\quad 260$

Local Government Administration 262

An Overall Assessment of Local Government

Finances and Organization Reforms 265

Lessons for Developing Countries 268

Notes 271

References 273

\section{Europe and Central Asia}

8 Local Government Organization and Finance:

Kazakhstan 275

by Meruert Makhmutova

Local Government Structure in the New Republic $\quad 276$

Local Government Expenditure Responsibilities 281

Local Governments' Own Taxes and Charges 283

Shared Taxes 285

Intergovernmental Fiscal Transfers 286

Local Government Borrowing $\quad 288$

Local Government Administration 289

An Overall Assessment of Local Government Finances $\quad 290$

Lessons for Other Developing Countries 291

Annex 8A: Oblast Budget Expenditures 294

Annex 8B: Rayon Budget Expenditures 296

Annex 8C: Oblast Budget Tax and Nontax Revenues 
Annex 8D: Rayon Budget Tax and Nontax Revenues

Notes 302

References $\quad 302$

9 Local Government Organization and Finance:

Poland 303

by Pawel Swianiewicz

Local Government System 304

Local Government Expenditure Responsibilities $\quad 307$

Local Governments' Own Taxes and Charges 312

Shared Taxes $\quad 322$

Grants to Local Governments 324

Local Government Borrowing 336

Local Government Administration $\quad 340$

Overall Assessment and Lessons for Other Countries 340

Notes 343

References $\quad 344$

\section{Latin America and the Caribbean}

10 Local Government Organization and Finance:

Argentina 347

by Miguel Angel Asensio

An Overview 349

Constitutional Status and Institutional Aspects 351

Spending Responsibilities of Local Governments $\quad 352$

Local Governments' Taxation and User Charges 356

Tax Sharing with Local Governments 361

Other Transfers to Local Governments 364

Fiscal Imbalances and Relative Financial Autonomy 366

Local Government Borrowing 368

Local Government Administration $\quad 371$

Overall Assessment of Local Finances 373

Lessons for Developing Countries $\quad 374$

Notes 375

References $\quad 377$ 


\section{Local Government Organization and Finance:}

Brazil 381

by José Roberto Rodrigues Afonso and Erika Amorim Araújo

Local Government Expenditure Responsibilities $\quad 385$

Taxes and Charges Levied by Local Governments $\quad 390$

Local Revenues from Other Governments 393

Federative Imbalance $\quad 400$

Local Government Borrowing $\quad 404$

Local Government Administration: Personnel Spending

Local Government Accountability to Citizens $\quad 410$

Lessons for Developing Countries 412

Notes 415

References $\quad 416$

12 Local Government Organization and Finance:

Chile $\quad 419$

by Leonardo Letelier S.

Local Governments' Responsibilities $\quad 421$

Local Governments' Taxes and Charges 423

Structure of Subnational Government Financing $\quad 424$

The Case of Regions and Provinces 427

The Case of Municipalities 431

Lessons to Be Learned from the Chilean Case $\quad 443$

Conclusions $\quad 445$

Notes 446

References $\quad 446$

Index $\quad 449$

BOXES

1.1 Local and Metropolitan Finance: Options for Own-Source Revenues 14

3.1 The Poverty Action Fund, the Heavily Indebted

Poor Countries Initiative, and the Fiscal

Decentralization Strategy 117

3.2 Fiscal Decentralization Strategy: Recurrent Transfer Scheme 118 
3.3 Main Features of Local Development Grants under the Local Government Development Program 122

6.1 Classification of Functions Listed in the 11th Schedule 209

12.1 Municipal Functions $\quad 422$

12.2 The Common Municipal Fund 432

\section{FIGURES}

1.1 A Comparative Perspective on Local Government Share of Consolidated Public Expenditures 34

1.2 Local Expenditures as a Share of National GDP 35

1.3 Composition of Operating Revenues for Local Authorities 38

1.4 Composition of Local Tax Revenues 38

2.1 Schematic Portrayal of Intergovernmental Relations in South Africa 52

3.1 Local Council Elections 99

3.2 Development in Local Government Expenditures 102

3.3 Composition of Total Local Government Revenue 103

3.4 Sector Distribution of Local Government Expenditures, Budget 2002/03 104

4.1 Structure of Government in China, $2003 \quad 139$

7.1 Local Government Expenditures and Revenues, FY 1997-FY $2003 \quad 237$

7.2 Imbalanced Decentralization: Subnational Shares in Total Revenues and Expenditures, FY $2003 \quad 238$

7.3 Subnational Revenue Sources, FY 2003239

7.4 Lorenz Curves for Per Capita Revenues, FY $2003 \quad 258$

7.5 DAU and Fiscal Capacity, FY 2003259

7.6 Subnational Government Borrowing, FY 1983-FY 2004262

7.7 Composition of Subnational Debt, FY 1978-FY 2004262

7.8 Typical Organizational Structure of Subnational Government 264

8.1 Structure of Public Administration in Kazakhstan 281

9.1 Budget Spending by Tier of Government, 2004308

9.2 Local Government Investment, 1991-2004 311

9.3 Typology of Local Tax Policies 318

9.4 The Dynamics of Local Government Debt, 1995-2004 338

12.1 Government's Decentralized Funds in Chile $\quad 426$ 
12.2 Municipal Contribution to the FCM versus Grant Received 433

12.3 Share of FCM in Municipal Income versus Net of FCM Municipal Income Per Capita 434

\section{TABLES}

1.1 Representative Assignment of Expenditure Responsibilities 8

1.2 Assignment of Local Public Services to Municipal and Regional or Metropolitan Governments 10

1.3 A Representative Assignment of Taxing Powers 12

1.4 Principles and Better Practices in Grant Design 15

1.5 Key Elements of Citizen-Centered Governance 23

1.6 Size Distribution of Municipal Governments in Developing Countries $\quad 36$

1.7 Average Population per Local Authority in Developing Countries 37

1.8 Intergovernmental Transfers as a Share of Local Government Revenues in Developing Countries, 2003

1.9 Role of a Local Government under the New Vision of Local Governance 43

2.1 Municipal Budget Trends, FY 2002/03-FY 2005/06 56

2.2 Revenues from Property Rates and RSC Levies in Different Municipalities, FY 2002/03-FY 2005/06 59

2.3 Local Government Functions 65

2.4 Elements of Local Revenue 69

2.5 Direct Transfers as a Share of Total Municipal Expenditure, FY 2002/03-FY 2005/06 74

2.6 National Transfers to Local Government, FY 2002/03-FY 2008/09 76

2.7 The Equitable Share: Purpose and Allocations, FY 2003/04 79

2.8 Distribution of National Direct Transfers to Categories of Municipalities, FY 2003/04 81

2.9 Borrowing by Category of Municipality 83

3.1 Functional Assignments for Local Services in Uganda 105

3.2 Local Government Aggregate Own-Source Revenues 110

3.3 Tax Autonomy and Control 112

3.4 Developments in Grants and Composition 115

3.5 Composition of the Development Grants 120 
4.1 Population, Area, and Per Capita GDP across Provinces, $2003 \quad 138$

4.2 Expenditure Responsibilities of Various Orders of Government 143

4.3 Expenditure Shares of Various Orders of Government, $2003 \quad 144$

4.4 Local Responsibilities and Relative Importance, $2003 \quad 148$

4.5 Government Personnel of Various Levels of Government, $2003 \quad 149$

4.6 Revenue Shares of Various Orders of Government, $2003 \quad 149$

4.7 Bases, Rates, and Relative Importance of Local Taxes and Charges 151

4.8 Bases, Rates, Sharing Arrangements, and Percentages of Total Local Government Revenues for Shared Taxes 154

4.9 Intergovernmental Transfers, $2003 \quad 156$

4.10 Transfers as a Percentage of Total Expenditures of Levels of Government, $2003 \quad 159$

5.1 Numbers of Municipalities and Their Populations 172

5.2 Linkage of Schedule 12 Functions with the State List and Concurrent List $\quad 174$

5.3 Linkage of Schedule 12 Functions with Municipal Functions Listed in State Laws 175

5.4 Per Capita Revenue Expenditure on Core Services 180

5.5 Revenue Powers of Municipalities across Major States 182

5.6 Criteria Used by the Central Finance Commission for Determining the Allocation of Grants to States for Urban Local Bodies 189

5.7 Share of Municipalities in State's Resources as Recommended by the First State Finance Commission

5.8 Key Features of Tax-Free Municipal Bonds 194

5.9 Revenue Significance of Municipalities 196

5.10 Per Capita Revenue Expenditure 197

5.11 Per Capita Expenditure on Salaries and Wages 198

5.12 Cost of Salaries and Wages Exceeds Own-Source Revenue Income, 2001/02 199

5.13 Operations and Maintenance Expenditure 200

6.1 Number of Rural Governments by State and Union Territory, April 1, $2005 \quad 210$

6.2 Current Progress on Activity Mapping 213

6.3 Per Capita Expenditure in PRIs (All Tiers) 214

6.4 Revenue Power of Rural Governments in States at Each Tier 215 
6.5 Own-Source Revenue of PRIs, All Tiers 217

6.6 Per Capita Own-Source Revenue of PRIs, All Tiers 218

6.7 Contribution of Own-Source Revenue in Total Expenditure of PRIs, All Tiers 218

6.8 Significance of PRIs' Own-Source Revenue 220

6.9 SFC Recommendations for Share in State Resources 221

6.10 Criteria Adopted by National Finance Commissions for Distribution among Themselves of Grants to States for PRIs 224

6.11 Schemes of the Union Ministries That Primarily Deal with the Functions of PRIs 225

7.1 Obligatory Functions of Subnational Governments under Laws 22/1999 and 32/2004 240

7.2 Distribution of Functions across Levels of Government

7.3 Expenditures by Level of Government, FY $2002 \quad 245$

7.4 Local Government Expenditure Composition, FY 2001/02

7.5 Subnational Taxes 247

7.6 Arrangements for Tax and Revenue Sharing under Law 33/2004 250

7.7 DAK Allocations by Sector, FY $2005 \quad 256$

7.8 Fiscal Disparities across Local Governments, FY $2003 \quad 258$

7.9 Distribution of Civil Service Employment across Levels of Government before and after Decentralization 263

7.10 Responsibilities in Civil Service Management 265

8.1 Administrative and Territorial Units in Kazakhstan, January 1,2006 278

8.2 Central and Local Budget Expenditures, 2002-05 283

8.3 Structure of Local Budget Revenue 284

8.4 Tax Bases and Rates for Various Taxes 285

8.5 Withdrawals to and Subventions Received from the National Budget, by Oblast 287

9.1 Territorial Division of Poland, Average Sizes and Ranges 305

9.2 Role of Local Government Finance in the National Economy 309

9.3 Structure of Revenues in Different Types of Local Governments, $2004 \quad 315$

9.4 Revenues from Physical Persons and Legal Entities, by Size of Local Government, 2000316 
9.5 Results of Reductions, Exemptions, and Releases

from Property Tax, by Size of Local Government, 2001

9.6 Shares of Local Governments in Revenues from

Personal and Corporate Income Taxes 323

9.7 Structure of the General-Purpose Grant, 2004 327

10.1 Number of Municipalities and Communes, December $2003 \quad 350$

10.2 Distribution of Local Governments by Size

10.3 Local Government Revenue and Expenditure: Budgetary Performance, 2001353

10.4 Expenditure Assignment in Local Governments, 1999354

10.5 Local Government Spending by Main Categories, $1999 \quad 355$

10.6 Functional Profile of Local Governments 356

10.7 Local Government Revenue Structure, $2001 \quad 357$

10.8 Main Taxes, Charges, and Fines of Local Governments, $1997 \quad 358$

10.9 Assignment of Taxing Powers to Argentine Municipalities 360

10.10 Structural Characteristics of Some Local Taxes and Rates 361

10.11 Revenue Sharing with Local Governments 363

10.12 Significance of Transfers in Local Governments' Finances 365

10.13 Imbalances and Financial Autonomy in Argentine Local Governments 367

10.14 Financial Autonomy and Vertical Imbalance of Local Governments 368

10.15 Provincial Constitutional Framework for Local Borrowing

11.1 Municipalities by Group of Inhabitants, 2005383

11.2 Municipal Revenues and Expenditures, 2004 385

11.3 Local Expenditure Responsibilities 387

11.4 Municipal Outlays by Function of Government, 2004388

11.5 Municipal Tax Burden, 2005391

11.6 Revenue Sharing and Transfers to Municipalities, 2005395

11.7 Federative Division of the National Tax Burden, 2005397

12.1 Decentralized Public Funds, 1999-2003 425

12.2 Decentralized Public Investment Funds: Primary Distributive Criteria $\quad 428$

12.3 Regionally Decided Public Investment Funds, 1999-2003 431

12.4 FCM Resources, 1999-2003 432

12.5 Delegated Functions, 1999-2003 436

12.6 Social Programs Allocated by the CAS-II Card, 1999-2003 



\section{Foreword}

In Western democracies, systems of checks and balances built into government structures have formed the core of good governance and have helped empower citizens for more than two hundred years. The incentives that motivate public servants and policy makersthe rewards and sanctions linked to results that help shape public sector performance-are rooted in a country's accountability frameworks. Sound public sector management and government spending help determine the course of economic development and social equity, especially for the poor and other disadvantaged groups, such as women and the elderly.

Many developing countries, however, continue to suffer from unsatisfactory and often dysfunctional governance systems that include rent-seeking and malfeasance, inappropriate allocation of resources, inefficient revenue systems, and weak delivery of vital public services. Such poor governance leads to unwelcome outcomes for access to public services by the poor and other disadvantaged members of the society, such as women, children, and minorities. In dealing with these concerns, the development assistance community in general and the World Bank in particular are continuously striving to learn lessons from practices around the world to achieve a better understanding of what works and what does not work in improving public sector governance, especially with respect to combating corruption and making services work for poor people.

The Public Sector Governance and Accountability Series advances our knowledge by providing tools and lessons from practices in improving efficiency and equity of public services provision and strengthening institutions of accountability in governance. The series 


\section{xviii Foreword}

highlights frameworks to create incentive environments and pressures for good governance from within and beyond governments. It outlines institutional mechanisms to empower citizens to demand accountability for results from their governments. It provides practical guidance on managing for results and prudent fiscal management. It outlines approaches to dealing with corruption and malfeasance. It provides conceptual and practical guidance on alternative service delivery frameworks for extending the reach and access of public services. The series also covers safeguards for the protection of the poor, women, minorities, and other disadvantaged groups; ways of strengthening institutional arrangements for voice and exit; methods of evaluating public sector programs; frameworks for responsive and accountable governance; and fiscal federalism and local governance.

This series will be of interest to public officials, development practitioners, students of development, and those interested in public governance in developing countries.

Frannie A. Léautier

Vice President

World Bank Institute 


\section{Preface}

Globalization and the information revolution are motivating a large and growing number of countries around the globe to reexamine the roles of various levels of government and their partnership with the private sector and civil society. These reforms typically involve shifting responsibilities to local governments and beyond government providers, with the objective of strengthening local governance. This movement has generated a large interest in learning from the history of nations as well as from current practices across countries on local government organization and finance. This book caters to this interest by providing comparative reflections on local governance in developing countries.

The book develops a comparative institutional framework for responsive, responsible, and accountable governance in developing countries. It provides a synthesis of analytical literature on local governance. It traces the historical evolution of local governance and presents a stylized view of alternative models of local governance practiced in various countries. It also presents case studies for 10 countries by leading national and international scholars. The country case studies present an in-depth view of local government organization and finance in each country.

The book advances the World Bank Institute agenda on knowledge sharing and learning from cross-country experiences in reforming public governance and is intended to assist policy 
xx Preface

makers and practitioners in developing countries in making more informed choices on strengthening local governance and improving social outcomes for their citizens.

Roumeen Islam

Manager, Poverty Reduction and Economic Management

World Bank Institute 


\section{Acknowledgments}

This book brings together country briefs on local governance prepared for various World Bank Institute learning programs directed by the editor over the past three years. In view of this background, the individual chapters are of different vintages. These learning programs were financed by the governments of Canada, Italy, Japan, the Netherlands, and Switzerland. We are grateful to the Canadian International Development Agency, the government of Italy, the Policy and Human Resources Development program of Japan, the Bank-Netherlands Partnership Program, and the Swiss Agency for International Development for financial support for the development and publication of this book. The editor is also grateful to Sana Shaheen Shah of Washington University at St. Louis, who first proposed the idea of such a compilation during her brief internship at the World Bank.

The book has benefited from contributions to World Bank Institute learning events by senior policy makers from Argentina, Australia, Brazil, Canada, Chile, China, India, Indonesia, Kazakhstan, the Kyrgyz Republic, Mexico, Pakistan, Poland, the Russian Federation, South Africa, Switzerland, Thailand, and the United States.

The editor is grateful to the leading scholars who contributed chapters and to the reviewers who provided comments. Sandra Gain, Mike Lombardo, Sana Shah, Theresa Thompson, and Jan Werner helped during various stages of preparation of this book and provided comments and contributed summaries of individual chapters. Maria Lourdes Penaflor Gosiengfiao provided excellent support for this project. 



\section{Contributors}

JOSÉ ROBERTO RODRIGUES AFONSO, a Brazilian national, has been an economist at the National Bank for Economic and Social Development since August 1984 and technical adviser to the Chamber of Deputies of Brazil since December 2002. He received his master's degree in economics from the Federal University of Rio de Janeiro in 1989 and is also trained in accounting. He has been a consultant to the World Bank, the Inter-American Development Bank, the Economic Commission for Latin America and the Caribbean, and the Brazilian Bank for Economic and Social Development, as well as to other national and international organizations. He is the author of many articles and book chapters, with a particular emphasis on tax reform, fiscal decentralization, fiscal responsibility, municipal finance, and public budgeting.

V. N. ALOK is on the faculty of the Public Finance Department and chairman of the Centre of Urban Studies at the Indian Institute of Public Administration in New Delhi. He has previously been associated with the National Institute of Educational Planning and Administration and the National Institute of Public Finance and Policy, both in New Delhi. He has served on the Local Finance Division of the 12th National Finance Commission of India and the 1st State Finance Commission of Delhi. He is part of a six-member committee of the Union Ministry of Home Affairs to study the issues of restructuring the Delhi Municipal Corporation. He has contributed reports to the state governments and articles to reputed journals and economic dailies on various subjects, including fiscal decentralization, and he has conducted workshops and training programs for senior civil servants. 
ERIKA AMORIM ARAÚJO, a Brazilian economist, works at the Fiscal Forum of the Brazilian States and the Getúlio Vargas Foundation. She received her master's degree in economics from the University of Campinas. She has been an occasional consultant to the Inter-American Development Bank, the Economic Commission for Latin America and the Caribbean, and the Brazilian Bank for Economic and Social Development.

MIGUEL ANGEL ASENSIO is director of the Master in Public Administration Program and on the faculty of Economic Sciences at the Universidad Nacional del Litoral, Santa Fe, Argentina. He is former secretary of public finance and minister of public finance of the province of Santa Fe. He received his degree of public accountant at the Universidad Nacional del Litoral and his $\mathrm{PhD}$ in applied economics at the University of Alcalá, Spain. He was a Fulbright scholar at the University of Pittsburgh, Pennsylvania, United States, and free researcher of the Consejo Nacional de Investigaciones Científicas y Técnicas de Argentina. He directed courses for graduate students in Córdoba, Entre Ríos, and Rosario, Argentina. He is a member of the Asociación Argentina de Economía Política and the International Institute of Public Finance, based in Saarbrücken, Germany. He was a fellow of the Canadian government and a visiting professor at the universities of Montreal, Ottawa, and Toronto, as well as at McGill, Queen's, Laval, and Carleton universities. He has performed consulting work for the Organization of American States and the World Bank.

SEBASTIAN ECKARDT is associated with the University of Potsdam and the German Business Foundation. His current research blends quantitative and qualitative forms of evidence in an attempt to understand public finance and fiscal decentralization reforms in developing countries and in an effort to discover links to public service outcomes, growth, and poverty reduction. He has been working as a consultant on governance and decentralization reforms with various donor agencies, including the Deutsche Gesellschaft für Technische Zusammenarbeit (GTZ), the World Bank, and the U.S. Agency for International Development.

CHRIS HEYMANS, at the time of writing, was at GHK Consulting in London, but he has recently joined the Water and Sanitation Program at the World Bank Country Office in New Delhi, India, as a senior municipal development specialist. He previously worked as a consultant and for a number of development agencies on local government, intergovernmental relations, and governance issues in several countries in Africa and South and Southeast Asia. In South Africa, he was a member of the technical committee that 
drafted the Local Government White Paper (in 1998) and editor of two National Treasury Intergovernmental Fiscal Reviews (in 2000 and 2001).

Meruert makhmutova is director of the Public Policy Research Center (PPRC) in Almaty, Kazakhstan. As such, she conducts research and provides advice to public and private bodies, as well as to the international donor community, related to strategic policy. She is editor-in-chief and author of two PPRC journals: Quarterly Prediction (an analytical journal on the Kazakhstan economy) and Policy Studies. In 2000, she graduated with a PhD from the Kazakh State Academy of Management, with a focus on intergovernmental fiscal relations in Kazakhstan.

OM PRAKASH MATHUR is professor of housing and urban economics at the National Institute of Public Finance and Policy, New Delhi. Before taking up this position, he was director of the National Institute of Urban Affairs, New Delhi. He has worked as a senior economist with the United Nations Centre for Regional Development in Nagoya, Japan, and as the United Nations Development Programme project manager of a regional planning project in Iran. He has served as a short-term consultant to the United Nations University, Asian Development Bank, United Nations Economic and Social Commission for Asia and the Pacific, and United Nations Children's Fund (UNICEF). He is an economist by discipline and has been a visiting fellow at the Massachusetts Institute of Technology in Boston.

BAOYUN QIAO received his $\mathrm{PhD}$ in economics from Georgia State University. $\mathrm{He}$ is a professor of economics at Shanghai University, China. Dr. Qiao's primary research interests are local governance, intergovernmental fiscal relations, and fiscal decentralization.

LEONARDO LETELIER S. is a researcher at the Institute of Public Affairs of the University of Chile, where he is the director of graduate studies. He holds a $\mathrm{PhD}$ in economics from the University of Sussex in the United Kingdom. His research field is fiscal decentralization, an area in which he has published extensively. He has participated as a consultant for the World Bank and the Inter-American Development Bank in related topics and teaches a course on fiscal decentralization at the University of Chile.

ANWAR SHAH is lead economist and program/team leader for public sector governance at the World Bank Institute, Washington, DC. He is also a fellow of the Institute for Public Economics, Alberta, Canada. He has previously 
served the Canadian Ministry of Finance in Ottawa and the government of the province of Alberta, and held responsibilities for federal-provincial and provincial-local fiscal relations, respectively. He has written extensively on public and environmental economics issues and has published books and articles dealing with governance, global environment, fiscal federalism, and fiscal management issues. He has also lectured at leading educational institutions around the globe.

SANA SHAH is an undergraduate student at Washington University, St. Louis, Missouri.

JESPER STEFFENSEN is a partner in the Nordic Consulting Group, Denmark. He is a public administration reform and decentralization specialist. He has comprehensive working experiences from positions in central government and local government associations and project experiences from assignments in more than 25 countries over the past 15 years. His fields of expertise are central and local government administration and organization, public finance, intergovernmental fiscal relations (including grant design, revenue sharing, and taxation), decentralization, local government finance and financial management, division of tasks and service provision, decentralization indicators and surveys of systems of local government finance, assessment and benchmarking of performance, and design of local development programs.

PAWEL SWIANIEWICZ holds a $\mathrm{PhD}$ in economics and an MA and $\mathrm{PhD}$ in economic geography. He is currently a professor at Warsaw University, Poland, where he teaches courses on local government finance, urban economics, and comparative local government politics. He has been extensively involved as a consultant to the U.K. Department for International Development, the Council of Europe, the United Nations Development Programme, and Open Society Institute in several countries of Eastern Europe and Central Asia. He was a research fellow in the School of Advanced Urban Studies, University of Bristol (1990), United Kingdom, and in the Norwegian Centre for Organization and Management, University of Bergen (1994). In 1993, he was a senior Fulbright scholar at the University of Chicago. From 1995 to 2001, he was director of the British Know-How Fund Local Government Assistance Program in Poland. He has published more than 15 books and more than 100 articles on various dimensions of local government reforms in Central and Eastern Europe. 


\section{Abbreviations and Acronyms}

\begin{tabular}{|c|c|}
\hline $\begin{array}{l}\mathrm{MC} \\
\mathrm{RV}\end{array}$ & $\begin{array}{l}\text { Ahmedabad municipal corporation } \\
\text { annual ratable value }\end{array}$ \\
\hline LA & black local authority \\
\hline AA & Constitution (73rd Amendment) Act (India) \\
\hline $\mathrm{AO}$ & chief administrative officer \\
\hline AS & $\begin{array}{l}\text { Caracterización Social (File of Social Characteristics) } \\
\text { (Chile) }\end{array}$ \\
\hline MIP & $\begin{array}{l}\text { Consolidated Municipal Infrastructure Programme } \\
\text { (South Africa) }\end{array}$ \\
\hline ORE & Consejo regional (regional council) (Chile) \\
\hline $\begin{array}{l}\text { RISIL } \\
\text { SS }\end{array}$ & $\begin{array}{l}\text { Credit Rating Information Services of India Ltd. } \\
\text { centrally sponsored scheme }\end{array}$ \\
\hline AK & $\begin{array}{l}\text { Dana Alokasi Khusus, or Special Allocation Fund } \\
\text { (Indonesia) }\end{array}$ \\
\hline AU & $\begin{array}{l}\text { Dana Alokasi Umum, or General Allocation Fund } \\
\text { (Indonesia) }\end{array}$ \\
\hline BSA & Development Bank of Southern Africa \\
\hline$E C$ & utivermmitto \\
\hline DORA & Division of Revenue Act (South Africa) \\
\hline DPLG & $\begin{array}{l}\text { Department of Provincial and Local Government } \\
\text { (South Africa) }\end{array}$ \\
\hline SC & district service commission \\
\hline $\mathrm{EU}$ & European Union \\
\hline FCM & $\begin{array}{l}\text { Fondo Común Municipal (Common Municipal Fund) } \\
\text { (Chile) }\end{array}$ \\
\hline & \\
\hline & financial management grant \\
\hline
\end{tabular}


FNDR Fondo Nacional de Desarrollo Regional (National Fund for Regional Development) (Chile)

FOCJ functional, overlapping, and competing jurisdictions

FOSIS Fondo de Solidaridad e Inversión Social (Social Investment and Solidarity Fund) (Chile)

FY financial year

GDP gross domestic product

GSDP gross state domestic product

G-tax graduated tax (Uganda)

HIPC Heavily Indebted Poor Countries (Initiative)

IDB Inter-American Development Bank

INCA Infrastructure Finance Corporation

INDAP Instituto de Desarrollo Agropecuario (Institute of Agriculture Development) (Chile)

IRAL Inversión regional de asignación local (locally allocated regional investment) (Chile)

ISAR Inversión sectorial de asignación regional (specific-sector regionally allocated investment) (Chile)

ISRDP Integrated Sustainable Rural Development Programme (South Africa)

JUNAEB Junta Nacional de Auxilio Escolar y Becas (National Committee of School Assistance and Scholarships) (Chile)

JUNJI Junta Nacional de Jardines Infantiles (National Board of Playgrounds) (Chile)

LEM Lectura, Escritura y Matemática (Reading, Writing, and Arithmetic Program) (Chile)

LGA Local Government Act of 1997 (Uganda)

LGDP Local Government Development Program (Uganda)

LGFC Local Government Finance Commission (Uganda)

LGPAC local government public accounts committee

LGTA Local Government Transition Act of 1993 (South Africa)

Men-PAN Menteri Pendayagunaan Aparatur Negara (Ministry for Administrative Reform) (Indonesia)

MFMA Municipal Finance Management Act of 1994 (South Africa)

MIDEPLANMinisterio de Planificación y Cooperación (Ministry of Planning and Cooperation) (Chile)

MinMECs committees for ministers and members of executive councils

MoFPED Ministry of Finance Planning and Economic Development (Uganda)

MoLG Ministry of Local Government (Uganda) 
MoPS Ministry of Public Service (Uganda)

MSIG municipal systems improvement grant (South Africa)

NGO nongovernmental organization

NIE new institutional economics

NPM new public management

NRM National Resistance Movement (Uganda)

OECD Organisation for Economic Co-operation and Development

PAF Poverty Action Fund

PASIS pensiones asistenciales (assistance pensions) (Chile)

PME Proyectos de Mejoramiento Educativo (Educative Improvement Projects) (Chile)

PMU Programa de Mejoramiento Urbano y Equipamiento Comunal (Urban and Communal Equipment Improvement Program) (Chile)

PR proportional representation

PRI Panchayati raj institution (India)

PRODESALPrograma de Desarrollo Local (Local Development Program) (Chile)

PROFIM Programa de Fortalecimiento Institucional Municipal (Municipal Institutional Strengthening Program) (Chile)

RDPI regionally decided public investment

RSC regional services council

SALGA South African Local Government Association

SC scheduled caste

SDO subsidi daerah otonomi, or autonomous government subsidy (Indonesia)

SEREMIS secretarías regionales ministeriales (regional branches of specific national ministries) (Chile)

SERPLAC secretaría regional de planificación y coordinación (regional secretariat of planning and coordination) (Chile)

SFC State Finance Commission (India)

SOE state-owned enterprise

ST scheduled tribe

SUBDERE Subsecretaría de Desarrollo Regional y Administrativo (Undersecretariat of Regional and Administrative Development) (Chile)

TDF total decentralized funds

TSS Tax-Sharing System (China)

URP Urban Renew Programme (South Africa)

USAID U.S. Agency for International Development

VAT value added tax 

The New Vision of Local Governance and the Evolving Roles of Local Governments

A N WA R SHAH With S A N A S A H

We will strive increasingly to quicken the public sense of public duty; that thus ... we will transmit this city not only not less, but greater, better, and more beautiful than it was transmitted to us.

-Oath of office required of council members in the ancient city of Athens

\section{Introduction: Local Government and Local}

\section{Governance}

Local government refers to specific institutions or entities created by national constitutions (Brazil, Denmark, France, India, Italy, Japan, Sweden), by state constitutions (Australia, the United States), by ordinary legislation of a higher level of central government (New Zealand, the United Kingdom, most countries), by provincial or state legislation (Canada, Pakistan), or by executive order (China) to deliver a range of specified services to a relatively small geographically delineated area. Local governance is a broader concept and is defined as the formulation and execution of collective action at the local level. Thus, it encompasses the direct and indirect roles 


\section{Anwar Shah with Sana Shah}

of formal institutions of local government and government hierarchies, as well as the roles of informal norms, networks, community organizations, and neighborhood associations in pursuing collective action by defining the framework for citizen-citizen and citizen-state interactions, collective decision making, and delivery of local public services.

Local governance, therefore, includes the diverse objectives of vibrant, living, working, and environmentally preserved self-governing communities. Good local governance is not just about providing a range of local services but also about preserving the life and liberty of residents, creating space for democratic participation and civic dialogue, supporting market-led and environmentally sustainable local development, and facilitating outcomes that enrich the quality of life of residents.

Although the concept of local governance is as old as the history of humanity, only recently has it entered the broad discourse in the academic and practice literature. Globalization and the information revolution are forcing a reexamination of citizen-state relations and roles and the relationships of various orders of government with entities beyond governmentand thereby an enhanced focus on local governance. The concept, however, has yet to be embraced fully by the literature on development economics, because of the longstanding tradition in the development assistance community of focusing on either local governments or community organizations while neglecting the overall institutional environment that facilitates or retards interconnectivity, cooperation, or competition among organizations, groups, norms, and networks that serve public interest at the local level.

Several writers (Bailey 1999; Dollery and Wallis 2001; Rhodes 1997; Stoker 1999) have recently argued that the presence of a vast network of entities beyond government that are engaged in local services delivery or quality of life issues makes it unrealistic to treat local government as a single entity (see also Goss 2001). Analytical recognition of this broader concept of local governance is critical to developing a framework for local governance that is responsive (doing the right thing-delivering services that are consistent with citizens' preferences or are citizen focused); responsible (doing the right thing the right way-working better but costing less and benchmarking with the best); and accountable (to citizens, through a rights-based approach). Such analysis is important because the role of local government in such a setting contrasts sharply with its traditional role.

This chapter traces the evolution and analytical underpinnings of local governance as background to a better understanding of the case studies of developing countries in this book. The next section outlines analytical approaches to local governance that can be helpful in understanding the role 
of governments and comparing and contrasting institutional arrangements. It further develops a model of local governance that integrates various strands of this literature. This model has important implications for evaluating and reforming local governance in both industrial and developing countries. The third section presents stylized models and institutions of local governance as practiced in different parts of the world during past centuries. It compares and contrasts the ancient Indian and Chinese systems of local governance with Nordic, Southern European, North American, and Australian models. The last section provides a comparative overview of local government organization and finance in selected developing countries as an introduction to the in-depth treatment of these countries in the rest of the book.

\section{The Theory: Conceptual Perspectives on Local Governance and Central-Local Relations}

Several accepted theories provide a strong rationale for decentralized decision making and a strong role for local governments, on the grounds of efficiency, accountability, manageability, and autonomy.

Stigler's menu. Stigler (1957) identifies two principles of jurisdictional design:

- The closer a representative government is to the people, the better it works.

- People should have the right to vote for the kind and amount of public services they want.

These principles suggest that decision making should occur at the lowest level of government consistent with the goal of allocative efficiency. Thus, the optimal size of jurisdiction varies with specific instances of economies of scale and benefit-cost spillovers.

- The principle of fiscal equivalency. A related idea on the design of jurisdictions has emerged from the public choice literature. Olson (1969) argues that if a political jurisdiction and benefit area overlap, the free-rider problem is overcome and the marginal benefit equals the marginal cost of production, thereby ensuring optimal provision of public services. Equating the political jurisdiction with the benefit area is called the principle of fiscal equivalency and requires a separate jurisdiction for each public service.

- The correspondence principle. A related concept is proposed by Oates (1972): the jurisdiction that determines the level of provision of each public good should include precisely the set of individuals who consume the good. This 
principle generally requires a large number of overlapping jurisdictions. Frey and Eichenberger $(1995,1996,1999)$ have extended this idea to define the concept of functional, overlapping, and competing jurisdictions (FOCJ). They argue that jurisdictions could be organized along functional lines while overlapping geographically, and that individuals and communities could be free to choose among competing jurisdictions. Individuals and communities express their preferences directly through initiatives and referenda. The jurisdictions have authority over their members and the power to raise taxes to fulfill their tasks. The school communities of the Swiss canton of Zurich and special districts in North America follow the FOCJ concept.

The decentralization theorem. According to this theorem, advanced by Oates (1972, p. 55), "each public service should be provided by the jurisdiction having control over the minimum geographic area that would internalize benefits and costs of such provision," because

- local governments understand the concerns of local residents;

- local decision making is responsive to the people for whom the services are intended, thus encouraging fiscal responsibility and efficiency, especially if financing of services is also decentralized;

- unnecessary layers of jurisdiction are eliminated;

- interjurisdictional competition and innovation are enhanced.

An ideal decentralized system ensures a level and combination of public services consistent with voters' preferences while providing incentives for the efficient provision of such services. Some degree of central control or compensatory grants may be warranted in the provision of services when spatial externalities, economies of scale, and administrative and compliance costs are taken into consideration. The practical implications of this theorem, again, require a large number of overlapping jurisdictions.

The subsidiarity principle. According to this principle, taxing, spending, and regulatory functions should be exercised by lower levels of government unless a convincing case can be made for assigning them to higher levels of government. This principle evolved from the social teaching of the Roman Catholic Church and was first proposed by Pope Leo XIII in 1891. Subsequently, Pope Pius XI highlighted the principle of subsidiarity as a third way between dictatorship and a laissez-faire approach to governance. The Maastricht Treaty adopted it as a guiding principle for the assignment of responsibilities among members of the European Union (EU). This principle is the polar opposite of the residuality principle typically applied in a unitary country, where local governments are assigned functions that the central government is unwilling or thinks it is unable to perform. 


\section{Implementation Mechanisms}

Achieving the optimal number and size of local jurisdictions requires the operation of community formation processes and the redrawing of jurisdictional boundaries.

Voting with feet. According to Tiebout (1956), people consider tax costs and the public services menu offered by a jurisdiction in deciding where to live. Thus, voting with feet leads to the formation of jurisdictions, creating a market analog for public service provision. Oates (1969) argued that if people vote with their feet, fiscal differentials across communities are capitalized into residential property values. This conclusion has been refuted by formal tests of allocative efficiency proposed by Brueckner (1982) and Shah $(1988,1989,1992)$. Both tests suggest that optimal provision of public services is not ensured by voting with feet alone but depends also on rational voting behavior.

Voting by ballot. This line of research suggests that collective decision making may not ensure maximization of the electorate's welfare, because citizens and their governmental agents can have different goals.

- Voluntary associations. Buchanan (1965) postulates that the provision of public services through voluntary associations of people (clubs) ensures the formation of jurisdictions consistent with the optimal provision of public services.

- Jurisdictional redesign. An important process for community formation in modern societies is redrawing the boundaries of existing jurisdictions to create special or multipurpose jurisdictions.

\section{Roles and Responsibilities of Local Governments: Analytical Underpinnings}

There are five perspectives on models of government and the roles and responsibilities of local government: (a) traditional fiscal federalism, (b) new public management (NPM), (c) public choice, (d) new institutional economics (NIE), and (e) network forms of local governance. The federalism and the NPM perspectives are concerned primarily with market failures and how to deliver public goods efficiently and equitably. The public choice and NIE perspectives are concerned with government failures. The network forms of governance perspective is concerned with institutional arrangements to overcome both market and government failures. 


\section{Local government as a handmaiden of a higher government order: Traditional fiscal federalism perspectives}

The fiscal federalism approach treats local government as a subordinate tier in a multitiered system and outlines principles for defining the roles and responsibilities of orders of government (see Shah 1994 for such a framework for the design of fiscal constitutions). Hence, one sees that in most federations, as in Canada and the United States, local governments are extensions of state governments (dual federalism). In a few isolated instances, as in Brazil, they are equal partners with higher-level governments (cooperative federalism), and in an exceptional case, Switzerland, they are the main source of sovereignty and have greater constitutional significance than the federal government. Thus, depending on the constitutional and legal status of local governments, state governments in federal countries assume varying degrees of oversight of the provision of local public services. In a unitary state, subnational governments act on behalf of the central government. Therefore, a useful set of guidelines for the assignment of responsibilities for local public services in a unitary state would be the following:

Policy development and standards of service and performance are determined at the national level.

- Implementation oversight is carried out at the state or provincial level.

- Services are provided by the local governments or by the metropolitan or regional governments.

In all countries, the production of services can be public or private, at the discretion of local or regional governments. Responsibilities for public services other than such purely local ones as fire protection could be shared, using these guidelines.

The assignment of public services to local governments or to metropolitan or regional governments can be based on considerations such as economies of scale, economies of scope (appropriate bundling of local public services to improve efficiency through information and coordination economies and enhanced accountability through voter participation and cost recovery) and cost-benefit spillovers, proximity to beneficiaries, consumer preferences, and budgetary choices about the composition of spending. The particular level of government to which a service is assigned determines the public or private production of the service in accordance with considerations of efficiency and equity. Large metropolitan areas with populations in excess of 1 million could be considered for subdivision into a first tier of municipal governments of smaller size responsible for neighborhood-type services 
and a second tier of metropolitanwide government providing areawide services. The first-tier governments could be directly elected, and elected mayors of these governments could form the metropolitan council at the second tier. Two-tier structures for metropolitan governance have been practiced in Melbourne, Australia; Vancouver, Canada; Allegheny county, Pennsylvania, United States; and Stockholm, Sweden.

In industrial countries, special-purpose agencies or bodies deliver a wide range of metropolitan and regional public services, including education, health, planning, recreation, and environmental protection. Such bodies can include library boards; transit and police commissions; and utilities providing water, gas, and electricity. These agencies deal with public services whose delivery areas transcend political jurisdictions and are better financed by loans, user charges, and earmarked benefit taxes, such as a supplementary mill rate on a property tax base to finance a local school board. If kept to a minimum, such agencies help fully exploit economies of scale in the delivery of services where political boundaries are not consistent with service areas. A proliferation of these agencies can undermine accountability and budgetary flexibility at local levels. Accountability and responsiveness to voters are weakened if members of special-purpose bodies are appointed rather than elected. Budgetary flexibility is diminished if a majority of local expenditures fall outside the control of local councils.

Table 1.1 presents a matrix for a normative assignment of spending responsibilities among different orders of government. Table 1.2 provides a subjective assessment of how various allocative criteria favor local or metropolitan assignment and whether public or private production is favored for efficiency or equity. The criteria and the assessment presented in this table are arbitrary; practical and institutional considerations should be applied to this analysis, and the reader may well reach different conclusions using the same criteria.

Private sector participation can also take a variety of forms, including contracting through competitive biddings, franchise operations (local government acting as a regulatory agency), grants (usually for recreational and cultural activities), vouchers (redeemable by local government with private providers), volunteers (mostly in fire stations and hospitals), community self-help activities (for crime prevention), and private nonprofit organizations (for social services). Thus, a mix of delivery systems is appropriate for local public services. In most developing countries, the financial capacities of local governments are quite limited. Fostering private sector participation in the delivery of local public services thus assumes greater significance. Such participation enhances accountability and choice in the local public sector. 
TA B LE 1 . 1 Representative Assignment of Expenditure Responsibilities

\begin{tabular}{|c|c|c|c|c|}
\hline Function & $\begin{array}{l}\text { Policy, standards, } \\
\text { and oversight }\end{array}$ & $\begin{array}{l}\text { Provision and } \\
\text { administration }\end{array}$ & $\begin{array}{l}\text { Production and } \\
\text { distribution }\end{array}$ & Comments \\
\hline \multicolumn{5}{|l|}{ Interregional and international conflicts } \\
\hline resolution & U & $\mathrm{U}$ & $\mathrm{N}, \mathrm{P}$ & Benefits and costs international in scope \\
\hline External trade & U & U,N,S & $\mathrm{P}$ & Benefits and costs international in scope \\
\hline Telecommunications & $\mathrm{U}, \mathrm{N}$ & $\mathrm{P}$ & $P$ & Has national and global dimensions \\
\hline Financial transactions & $\mathrm{U}, \mathrm{N}$ & $P$ & $\mathrm{P}$ & Has national and global dimensions \\
\hline Environment & $\mathrm{U}, \mathrm{N}, \mathrm{S}, \mathrm{L}$ & $\mathrm{U}, \mathrm{N}, \mathrm{S}, \mathrm{L}$ & N,S,L,P & $\begin{array}{l}\text { Externalities of global, national, state, } \\
\text { and local scope }\end{array}$ \\
\hline Foreign direct investment & $\mathrm{N}, \mathrm{L}$ & $\mathrm{L}$ & $P$ & Local infrastructure critical \\
\hline Defense & $\mathrm{N}$ & $\mathrm{N}$ & $\mathrm{N}, \mathrm{P}$ & Benefits and costs national in scope \\
\hline Foreign affairs & $\mathrm{N}$ & $\mathrm{N}$ & $\mathrm{N}$ & Benefits and costs national in scope \\
\hline Monetary policy, currency, and banking & $\mathrm{U}, \mathrm{ICB}$ & ICB & $\mathrm{ICB}, \mathrm{P}$ & $\begin{array}{l}\text { Independence from all levels essential; } \\
\text { some international role for common } \\
\text { discipline }\end{array}$ \\
\hline Interstate commerce & Constitution, $\mathrm{N}$ & N & $\mathrm{P}$ & $\begin{array}{l}\text { Constitutional safeguards important for } \\
\text { factors and goods mobility }\end{array}$ \\
\hline
\end{tabular}




\begin{tabular}{|c|c|c|c|c|}
\hline Immigration & $\mathrm{U}, \mathrm{N}$ & $\mathrm{N}$ & $\mathrm{N}$ & U because of forced exit \\
\hline Transfer payments & $\mathrm{N}$ & $\mathrm{N}$ & N & Redistribution \\
\hline Criminal and civil law & $\mathrm{N}$ & $\mathrm{N}$ & $\mathrm{N}$ & Rule of law, a national concern \\
\hline Industrial policy & $\mathrm{N}$ & $\mathrm{N}$ & $P$ & $\begin{array}{l}\text { Intended to prevent "beggar thy } \\
\text { neighbor" policies }\end{array}$ \\
\hline Regulation & $\mathrm{N}$ & $\mathrm{N}, \mathrm{S}, \mathrm{L}$ & $\mathrm{N}, \mathrm{S}, \mathrm{L}, \mathrm{P}$ & Internal common market \\
\hline Fiscal policy & $\mathrm{N}$ & $\mathrm{N}, \mathrm{S}, \mathrm{L}$ & $\mathrm{N}, \mathrm{S}, \mathrm{L}, \mathrm{P}$ & Coordination possible \\
\hline Natural resources & $\mathrm{N}$ & $\mathrm{N}, \mathrm{S}, \mathrm{L}$ & $\mathrm{N}, \mathrm{S}, \mathrm{L}, \mathrm{P}$ & $\begin{array}{l}\text { Promotes regional equity and internal } \\
\text { common market }\end{array}$ \\
\hline Education, health, and social welfare & $\mathrm{N}, \mathrm{S}, \mathrm{L}$ & $\mathrm{S}, \mathrm{L}$ & $S, L, P$ & Transfers in kind \\
\hline Highways & $\mathrm{N}, \mathrm{S}, \mathrm{L}$ & $\mathrm{N}, \mathrm{S}, \mathrm{L}$ & $S, L, P$ & Benefits and costs vary in scope \\
\hline Parks and recreation & $\mathrm{N}, \mathrm{S}, \mathrm{L}$ & $\mathrm{N}, \mathrm{S}, \mathrm{L}$ & $\mathrm{N}, \mathrm{S}, \mathrm{L}, \mathrm{P}$ & Benefits and costs vary in scope \\
\hline Police & $S, L$ & $\mathrm{~S}, \mathrm{~L}$ & $\mathrm{~S}, \mathrm{~L}$ & Primarily local benefits \\
\hline Water, sewer, refuse, and fire protection & L & L & $L, P$ & Primarily local benefits \\
\hline
\end{tabular}

Source: Shah 1994, 2004.

Note: $\mathrm{U}=$ supranational responsibility, ICB $=$ independent central bank, $\mathrm{N}=$ national government, $\mathrm{S}=$ state or provincial government, $\mathrm{L}=$ local government, $\mathrm{P}=$ nongovernmental sectors or civil society. 
Firefighting

Police protection

Refuse collection

Neighborhood parks

Street maintenance

Traffic management

Local transit service

Local libraries

Primary education

Secondary education

Public transportation

Water supply

Sewage disposal

Refuse disposal

Public health

Hospitals

Electric power

Air and water pollution

Special police

Regional parks

Regional planning

\section{Allocation criteria for provision}

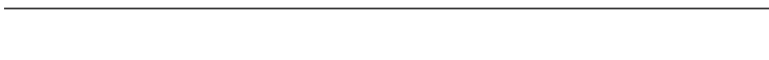

\section{Economies Economies Benefit-cost Political Consumer} of scope spillover proximity sovereignty

Economic

evaluation of

sectoral

choices

Composite

L

Source: Shah 1994

Note: $\mathrm{L}=$ local government, $\mathrm{M}=$ regional or metropolitan government, $\mathrm{P}=$ private sector, $\mathrm{G}=$ public sector.
Allocation criteria for public vs. private production

Efficiency Equity Composite

$\begin{array}{ccc}P & G & P \\ P & G & G \\ P & P & P \\ P & G & G \\ P & P & P \\ P & P & P \\ P & P & P \\ G & G & G \\ P & G & P, G \\ P & G & P, G \\ P, G & G & P, G \\ P & G & P, G \\ P, G & P, G & P, G \\ P & P & P \\ G & G & G \\ P, G & G & P, G \\ P & P & P \\ G & G & G \\ G & G & G \\ G & G & G \\ G & G & G \\ & & \end{array}$


However, assigning responsibility for the provision of service to a specific level of government does not imply that government should be directly engaged in its production. Limited empirical evidence suggests that private production of some services promotes efficiency and equity.

Fiscal federalism literature also provides guidance on financing choices for local governments. Four general principles require consideration in assigning taxing powers to various governments. First, the economic efficiency criterion dictates that taxes on mobile factors and tradable goods that have a bearing on the efficiency of the internal common market should be assigned to the center. Subnational assignment of taxes on mobile factors may facilitate the use of socially wasteful "beggar thy neighbor" policies to attract resources to own areas by regional and local governments. In a globalized world, even central assignment of taxes on mobile capital may not be very effective in the presence of tax havens and the difficulty of tracing and attributing incomes from virtual transactions to various physical spaces. Second, national equity considerations warrant that progressive redistributive taxes should be assigned to the center, which limits the possibility of regional and local governments following perverse redistribution policies using both taxes and transfers to attract high-income people and repel lowincome ones. Doing so, however, leaves open the possibility of supplementary, flat-rate, local charges on residence-based national income taxes. Third, the administrative feasibility criterion (lowering compliance and administration costs) suggests that taxes should be assigned to the jurisdiction with the best ability to monitor relevant assessments. This criterion minimizes administrative costs as well as the potential for tax evasion. For example, property, land, and betterment taxes are good candidates for local assignment because local governments are in a better position to assess the market values of such assets. Fourth, the fiscal need or revenue adequacy criterion suggests that to ensure accountability, revenue means (the ability to raise revenues from own sources) should be matched as closely as possible with expenditure needs (see table 1.3 for a representative assignment of taxing responsibilities). The literature also argues that long-lived assets should primarily be financed by raising debt, so as to ensure equitable burden sharing across generations (Inman 2005). Furthermore, such large and lumpy investments typically cannot be financed by current revenues and reserves alone (see box 1.1).

These four principles suggest that user charges are suitable for use by all orders of government, but the case for decentralizing taxing powers is not as compelling as that for decentralizing public service delivery. This is because lower-level taxes can introduce inefficiencies in the allocation of resources 
TA B LE 1. 3 A Representative Assignment of Taxing Powers

\begin{tabular}{|c|c|c|c|c|}
\hline Types of tax & $\begin{array}{l}\text { Determination } \\
\text { of base }\end{array}$ & $\begin{array}{l}\text { Determination } \\
\text { of rate }\end{array}$ & $\begin{array}{l}\text { Collection and } \\
\text { administration }\end{array}$ & Comments \\
\hline Customs & $\mathrm{F}$ & $\mathrm{F}$ & $\mathrm{F}$ & International trade taxes \\
\hline Corporate income tax & $\mathrm{F}, \mathrm{U}$ & $\mathrm{F}, \mathrm{U}$ & $\mathrm{F}, \mathrm{U}$ & Mobile factor, stabilization tool \\
\hline \multicolumn{5}{|l|}{ Resource taxes } \\
\hline Resource rent (profits and income) tax & $\mathrm{F}$ & $\mathrm{F}$ & $\mathrm{F}$ & High, unequally distributed tax bases \\
\hline $\begin{array}{l}\text { Royalties, fees, charges; severance } \\
\text { taxes; and production, output, and } \\
\text { property taxes }\end{array}$ & $S, L$ & $S, L$ & $S, L$ & Benefit taxes and charges for state-local services \\
\hline Conservation charges & $S, L$ & $S, L$ & $S, L$ & Intended to preserve local environment \\
\hline Personal income tax & $\mathrm{F}$ & $\mathrm{F}, \mathrm{S}, \mathrm{L}$ & $\mathrm{F}$ & Redistributive, mobile factor, stabilization tool \\
\hline \multicolumn{5}{|l|}{$\begin{array}{l}\text { Wealth taxes (taxes on capital, wealth, } \\
\text { wealth transfers, inheritances, and } \\
\text { bequests) }\end{array}$} \\
\hline Payroll tax & $F, S$ & $\mathrm{~F}, \mathrm{~S}$ & $F, S$ & Benefit charge, such as social security coverage \\
\hline Multistage sales taxes (value added tax) & $\mathrm{F}$ & $\mathrm{F}$ & $\mathrm{F}$ & $\begin{array}{l}\text { Border tax adjustments possible under federal } \\
\text { assignment; potential stabilization tool }\end{array}$ \\
\hline \multicolumn{5}{|l|}{$\begin{array}{l}\text { Single-stage sales taxes (manufacturer, } \\
\text { wholesale, and retail) }\end{array}$} \\
\hline Option A & S & $S, L$ & $S, L$ & Higher compliance cost \\
\hline Option B & $\mathrm{F}$ & $S$ & $\mathrm{~F}$ & Harmonized, lower compliance cost \\
\hline
\end{tabular}




\begin{tabular}{|c|c|c|c|c|}
\hline \multicolumn{5}{|l|}{ "Sin" taxes } \\
\hline Excises on alcohol and tobacco & $\mathrm{F}, \mathrm{S}$ & $\mathrm{F}, \mathrm{S}$ & $\mathrm{F}, \mathrm{S}$ & Health care a shared responsibility \\
\hline Betting and gambling taxes & $S, L$ & $S, L$ & $S, L$ & State and local responsibility \\
\hline Lotteries & $\mathrm{S}, \mathrm{L}$ & $\mathrm{S}, \mathrm{L}$ & $\mathrm{S}, \mathrm{L}$ & State and local responsibility \\
\hline Racetrack taxes & $S, L$ & $S, L$ & $S, L$ & State and local responsibility \\
\hline \multicolumn{5}{|l|}{ Taxation of "bads" } \\
\hline Carbon tax & $\mathrm{F}$ & $\mathrm{F}$ & $\mathrm{F}$ & Intended to combat global or national pollution \\
\hline Energy taxes & $F, S, L$ & $\mathrm{~F}, \mathrm{~S}, \mathrm{~L}$ & $F, S, L$ & Pollution impact may be national, regional, or local \\
\hline Motor fuels tolls & $\mathrm{F}, \mathrm{S}, \mathrm{L}$ & $\mathrm{F}, \mathrm{S}, \mathrm{L}$ & $\mathrm{F}, \mathrm{S}, \mathrm{L}$ & Tolls on federal, provincial, and local roads \\
\hline Effluent charges & $\mathrm{F}, \mathrm{S}, \mathrm{L}$ & $\mathrm{F}, \mathrm{S}, \mathrm{L}$ & $\mathrm{F}, \mathrm{S}, \mathrm{L}$ & $\begin{array}{l}\text { Intended to deal with interstate, intermunicipal, } \\
\text { or local pollution issues }\end{array}$ \\
\hline Congestion tolls & $\mathrm{F}, \mathrm{S}, \mathrm{L}$ & $\mathrm{F}, \mathrm{S}, \mathrm{L}$ & $F, S, L$ & Tolls on federal, provincial, and local roads \\
\hline Parking fees & $\mathrm{L}$ & $\mathrm{L}$ & $\mathrm{L}$ & Intended to control local congestion \\
\hline \multicolumn{5}{|l|}{ Motor vehicles } \\
\hline $\begin{array}{l}\text { Registration, transfer taxes, } \\
\text { and annual fees }\end{array}$ & $S$ & $S$ & $S$ & State responsibility \\
\hline Driver's licenses and fees & $S$ & $S$ & $S$ & State responsibility \\
\hline Business taxes & $S$ & $S$ & $S$ & Benefit tax \\
\hline Excises & $S, L$ & $\mathrm{~S}, \mathrm{~L}$ & $\mathrm{~S}, \mathrm{~L}$ & Residence-based taxes \\
\hline Property tax & $S$ & $\mathrm{~L}$ & $\mathrm{~L}$ & Completely immobile factor, benefit tax \\
\hline Land tax & $S$ & $\mathrm{~L}$ & $\mathrm{~L}$ & Completely immobile factor, benefit tax \\
\hline Frontage and betterment taxes & $\mathrm{S}, \mathrm{L}$ & $\mathrm{L}$ & $\mathrm{L}$ & Cost recovery \\
\hline Poll tax & $\mathrm{F}, \mathrm{S}, \mathrm{L}$ & $\mathrm{F}, \mathrm{S}, \mathrm{L}$ & $\mathrm{F}, \mathrm{S}, \mathrm{L}$ & Payment for local services \\
\hline User charges & $\mathrm{F}, \mathrm{S}, \mathrm{L}$ & $\mathrm{F}, \mathrm{S}, \mathrm{L}$ & $\mathrm{F}, \mathrm{S}, \mathrm{L}$ & Payment for services received \\
\hline
\end{tabular}

Source: Shah 1994.

Note: $\mathrm{U}=$ supranational agency, $\mathrm{F}=$ federal, $\mathrm{S}=$ state or province, $\mathrm{L}=$ municipal or local government. 


\section{B O X 1.1 Local and Metropolitan Finance: Options for Own-Source Revenues}

The fiscal federalism literature argues for local assignment of the following taxes and charges in addition to debt finance for long-lived assets: user charges; property and land taxes; frontage and betterment taxes and charges; poll taxes and charges; single-stage (retail) sales taxes; piggyback flat tax on residence-based national income taxes; duties on hotel rooms, airport use, entertainment, taxis, and rental cars; vehicle registration fees; single business or profession permits; resource royalties; severance taxes; local conservation charges; taxes on local "bads" (BTU taxes, congestion tolls, parking fees, and effluent charges); and "sin" taxes (taxes on betting, gambling, lotteries, racetracks).

Source: Author.

across the federation and cause inequities among people in different jurisdictions. In addition, collection and compliance costs can increase significantly. These problems are more severe for some taxes than others, so the selection of which taxes to decentralize must be made with care, balancing the need to achieve fiscal and political accountability at the lower levels of government against the disadvantages of having a fragmented tax system. The tradeoff between increased accountability and increased economic costs from decentralizing taxing responsibilities can be mitigated by fiscal arrangements that permit joint occupation and harmonization of taxes to overcome fragmentation and by fiscal equalization transfers that will reduce the fiscal inefficiencies and inequities that arise from different fiscal capacities across regional and local governments (see table 1.4 on the design of fiscal transfers).

The fiscal federalism perspectives presented above are helpful, but in practice they have resulted in some major difficulties-especially in developing countries-because the practice seems to emphasize fiscal federalism's structures and processes as ends rather than as means to an end. These structures and processes were designed as a response to market failures and heterogeneous preferences with little recognition of government failures or the role of entities beyond government. The NPM and the NIE literature (synthesized in the following paragraphs) sheds further light on the origins of these difficulties. This literature highlights the sources of government failures and their implications for the role of local government. 
TA B L E 1 . 4 Principles and Better Practices in Grant Design

\begin{tabular}{|c|c|c|c|}
\hline Grant objective & Grant design & Better practices & Practices to avoid \\
\hline Bridge fiscal gap & $\begin{array}{l}\text { Reassignment of } \\
\text { responsibilities, } \\
\text { tax abatement, or } \\
\text { tax-base sharing }\end{array}$ & $\begin{array}{l}\text { Tax abatement in } \\
\text { Canada and } \\
\text { tax-base sharing } \\
\text { in Brazil, Canada, } \\
\text { and Pakistan }\end{array}$ & $\begin{array}{l}\text { Deficit grants; } \\
\text { tax-by-tax sharing }\end{array}$ \\
\hline $\begin{array}{l}\text { Reduce regional fiscal } \\
\text { disparities }\end{array}$ & $\begin{array}{l}\text { General } \\
\text { nonmatching } \\
\text { fiscal capacity } \\
\text { equalization } \\
\text { transfers }\end{array}$ & $\begin{array}{l}\text { Fiscal equalization } \\
\text { programs of Canada } \\
\text { and Germany }\end{array}$ & $\begin{array}{l}\text { General revenue } \\
\text { sharing with } \\
\text { multiple factors }\end{array}$ \\
\hline $\begin{array}{l}\text { Compensate for benefit } \\
\text { spillovers }\end{array}$ & $\begin{array}{l}\text { Open-ended } \\
\text { matching } \\
\text { transfers with } \\
\text { matching } \\
\text { rate consistent } \\
\text { with spillover } \\
\text { of benefits }\end{array}$ & $\begin{array}{l}\text { Grant for teaching } \\
\text { hospitals in } \\
\text { South Africa }\end{array}$ & \\
\hline $\begin{array}{l}\text { Set national minimum } \\
\text { standards }\end{array}$ & $\begin{array}{l}\text { Nonmatching block } \\
\text { transfers with } \\
\text { conditions } \\
\text { on standards of } \\
\text { service and access }\end{array}$ & $\begin{array}{l}\text { Roads and primary } \\
\text { education grants, } \\
\text { as in Indonesia } \\
\text { (now defunct); } \\
\text { education } \\
\text { transfers, as in } \\
\text { Colombia and Chile; } \\
\text { health transfers in } \\
\text { Brazil and Canada }\end{array}$ & $\begin{array}{l}\text { Transfers with } \\
\text { conditions on } \\
\text { spending alone; } \\
\text { ad hoc grants }\end{array}$ \\
\hline $\begin{array}{l}\text { Influence local priorities } \\
\text { in areas of high national } \\
\text { but low local priority }\end{array}$ & $\begin{array}{l}\text { Open-ended } \\
\text { matching } \\
\text { transfers } \\
\text { (preferably with } \\
\text { matching rate to } \\
\text { vary inversely } \\
\text { with fiscal capacity) }\end{array}$ & $\begin{array}{l}\text { Matching transfers } \\
\text { for social } \\
\text { assistance }\end{array}$ & Ad hoc grants \\
\hline Provide stabilization & $\begin{array}{l}\text { Capital grants with } \\
\text { maintenance } \\
\text { possible }\end{array}$ & $\begin{array}{l}\text { Limited use of } \\
\text { capital grants and } \\
\text { encouragement } \\
\text { of private sector } \\
\text { participation by } \\
\text { providing political } \\
\text { and policy } \\
\text { risk guarantee }\end{array}$ & $\begin{array}{l}\text { Stabilization } \\
\text { grants with } \\
\text { no future } \\
\text { upkeep } \\
\text { requirements }\end{array}$ \\
\hline
\end{tabular}




\section{Local government as an independent facilitator of creating public value: New public management perspectives}

Two interrelated criteria have emerged from the NPM literature in recent years determining, first, what local governments should do and, second, how they should do it better.

In discussing the first criterion, the literature assumes that citizens are the principals but have multiple roles as governors (owner-authorizers, voters, taxpayers, community members); activist-producers (providers of services, coproducers, self-helpers obliging others to act); and consumers (clients and beneficiaries) (see Moore 1996). In this context, significant emphasis is placed on the government as an agent of the people to serve public interest and create public value. Moore (1996) defines public value as measurable improvements in social outcomes or quality of life. This concept is directly relevant to local and municipal services, for which it is feasible to measure such improvements and have some sense of attribution. The concept is useful in evaluating conflicting and perplexing choices in the use of local resources. The concept is also helpful in defining the role of government, especially local governments. It frames the debate between those who argue that the public sector crowds out private sector investments and those who argue that the public sector creates an enabling environment for the private sector to succeed, in addition to providing basic municipal and social services.

Moore (1996) has argued that, rather than diverting resources from the private sector, local governments use some of the resources that come as free goods-namely, resources of consent, goodwill, Good Samaritan values, community spirit, compliance, and collective public action. This argument suggests that the role of public managers in local governments is to tap these free resources and push the frontiers of improved social outcomes beyond what may be possible with meager local revenues. Thus, public managers create value by mobilizing and facilitating a network of providers beyond local government. Democratic accountability ensures that managerial choices about creating public value are based on broader consensus by local residents (see Goss 2001). Thus, the local public sector continuously strives to respect citizen preferences and to be accountable to them. This environment, focused on creating public value, encourages innovation and experimentation, bounded by the risk tolerance of the median voter in each community.

The main current of the NPM literature is concerned not with what to do but with how to do it better. It argues for an incentive environment in which managers are given flexibility in the use of resources but held accountable for results. Top-down controls are thus replaced by a bottom-up focus 
on results. Two NPM models have been implemented in recent years. The first model is focused on making managers manage. In New Zealand, this goal is accomplished through new contractualism, whereby public managers are bound by formal contracts for service delivery but have flexibility in resource allocation and choice of public or private providers. Malaysia attempts to achieve the same through client charters, under which public managers are evaluated for their attainment of specified service standards (Shah 2005).

The second model creates incentives to let managers manage. It applies the new managerialism approach, as used in Australia and the United States, whereby government performance in service delivery and social outcomes is monitored, but there are no formal contracts, and accountability is guided by informal agreements. In China and the United Kingdom, autonomous agency models are used for performance accountability. Canada uses an alternative service delivery framework: public managers are encouraged to facilitate a network of service providers and to use benchmarking to achieve the most effective use of public monies. The emerging focus on client orientation and results-based accountability is encouraging local governments to innovate in many parts of the world (Caulfield 2003).

\section{Local government as an institution to advance self-interest: The public choice approach}

Bailey (1999) has conceptualized four models of local government:

- A local government that assumes it knows best and acts to maximize the welfare of its residents conforms to the benevolent despot model.

- A local government that provides services consistent with local residents' willingness to pay conforms to the fiscal exchange model.

- A local government that focuses on public service provision to advance social objectives conforms to the fiscal transfer model.

- A local government that is captured by self-interested bureaucrats and politicians conforms to the leviathan model, which is consistent with the public choice perspectives.

In the same tradition, Breton (1995) provides a comprehensive typology of models of government. He distinguishes two broad types of government. The first embodies the doctrine of the common good, and the second acts to preserve the self-interest of the governing elites. The second type can assume either a monolithic or a composite structure. In a monolithic structure, local government is subject to capture by bureaucrats or interest groups. Also, local 
government may maximize economic rents for dominant interest groups (as in the leviathan model) or may advance compulsion or coercion. If the self-interest model assumes a composite structure, it may encourage Tiebout-type competition among local governments.

The public choice literature endorses the self-interest doctrine of government and argues that various stakeholders involved in policy formulation and implementation are expected to use opportunities and resources to advance their self-interest. This view has important implications for the design of local government institutions. For local governments to serve the interests of people, they must have complete local autonomy in taxing and spending and they must be subject to competition within and beyond government. In the absence of these prerequisites, local governments will be inefficient and unresponsive to citizen preferences (Boyne 1998). Bailey (1999) advocates strengthening exit and voice mechanisms in local governance to overcome government failures associated with the self-interest doctrine of public choice. He suggests that easing supply-side constraints for public services through wider competition will enhance choice and promote exit options and that direct democracy provisions will strengthen voice (see also Dollery and Wallis 2001). The NIE approach discussed below draws on the implications of opportunistic behavior by government agents for the transaction costs to citizens as principals.

\section{The government as a runaway train: NIE concerns with the institutions of public governance}

The NIE provides a framework for analyzing fiscal systems and local empowerment and for comparing mechanisms for local governance. This framework is helpful in designing multiple orders of government and in clarifying local government responsibilities in a broader framework of local governance. According to the NIE framework, various orders of governments (as agents) are created to serve the interests of the citizens as principals. The jurisdictional design should ensure that these agents serve the public interest while minimizing transaction costs for the principals.

The existing institutional framework does not permit such optimization, because the principals have bounded rationality; that is, they make the best choices on the basis of the information at hand but are ill informed about government operations. Enlarging the sphere of their knowledge entails high transaction costs, which citizens are not willing to incur. Those costs include participation and monitoring costs, legislative costs, executive decision-making costs, agency costs or costs incurred to induce compliance by agents with the compact, and uncertainty costs associated with unstable 
political regimes (Horn 1997; Shah 2005). Agents (various orders of governments) are better informed about government operations than principals are, but they have an incentive to withhold information and to indulge in opportunistic behaviors or "self-interest seeking with guile" (Williamson 1985, p. 7). Thus, the principals have only incomplete contracts with their

agents. Such an environment fosters commitment problems because the agents may not follow the compact.

The situation is further complicated by three factors - weak or extant countervailing institutions, path dependency, and the interdependency of various actions. Countervailing institutions such as the judiciary, police, parliament, and citizen activist groups are usually weak and unable to restrain rent-seeking by politicians and bureaucrats. Historical and cultural factors and mental models by which people see little benefits to and high costs of activism prevent corrective action. Further empowering local councils to take action on behalf of citizens often leads to loss of agency between voters and councils, because council members may interfere in executive decision making or may get co-opted in such operations while shirking their legislative responsibilities. The NIE framework stresses the need to use various elements of transaction costs in designing jurisdictions for various services and in evaluating choices between competing governance mechanisms.

\section{Local government as a facilitator of network forms of local governance}

The NIE approach provides an evaluation framework for alternative forms and mechanisms of local governance. It specifically provides guidance in dealing with government failures in a hierarchical form of public governance. The framework is also suitable for examining local government involvement in a partnership of multiple organizations. Dollery and Wallis (2001) extend the NIE approach to these issues. They argue that a structure of resource dependency vitiates against collective action in the interest of the common good because of the tragedy of commons associated with common pool resources. This scenario results in failures in horizontal coordination in a multiorganization partnership.

One possible solution is to introduce a market mechanism of governance, whereby a contract management agency enters into binding contracts with all partners. However, this solution is unworkable because the potential number of contingencies may simply be too large to be covered by such contracts. A second approach to overcome horizontal coordination, the socalled hierarchical mechanism of governance, relies on institutional arrangements to clarify roles and responsibilities and to establish mechanisms for consultation, cooperation, and coordination, as is done in some 
federal systems. Such institutional arrangements entail high transaction costs and are subject to a high degree of failure attributable to the conflicting interests of partners.

Given the high transaction costs and perceived infeasibility of market and hierarchical mechanisms of governance for partnerships of multiple organizations, a network mechanism of governance has been advanced as a possible mode of governance for such partnerships-the kind to be managed by local governments. The network form of governance relies on trust, loyalty, and reciprocity between partners with no formal institutional safeguards. Networks formed on the basis of shared interests (interest-based networks) can provide a stable form of governance if membership is limited to partners that can make significant resource contributions and if there is a balance of powers among members. Members of such networks interact frequently and see cooperation in one area as contingent on cooperation in other areas. Repeated interaction among members builds trust. Hope-based networks are built on the shared sentiments and emotions of members. Members have shared beliefs in the worth and philosophy of the network goals and have the passion and commitment to achieve those goals. The stability of such networks is highly dependent on the commitment and style of their leadership (Dollery and Wallis 2001).

Local government has an opportunity to play a catalytic role in facilitating the roles of both interest-based and hope-based networks in improving social outcomes for local residents. To play such a role, local government must develop a strategic vision of how such partnerships can be formed and sustained. But then the local government requires a new local public management paradigm. Such a paradigm demands local government to separate policy advice from program implementation, assuming a role as a purchaser of public services but not necessarily as a provider of them. Local government may have to outsource services with higher provision costs and subject inhouse providers to competitive pressures from outside providers to lower transaction costs for citizens. It also must actively seek the engagement of both interest-based and hope-based networks to supplant local services. It needs to develop the capacity to play a mediating role among various groups.

\section{A synthesis: Toward a framework for responsive, responsible, and accountable local governance}

We have reviewed ideas emerging from the literature on political science, economics, public administration, law, federalism, and the NIE with a view to developing an integrated analytical framework for the comparative analysis of local government and local governance institutions. 
The dominant concern in this literature is that the incentives and accountability framework faced by various orders of government is not conducive to a focus on service delivery consistent with citizen preferences. As a result, corruption, waste, and inefficiencies permeate public governance. Top-down hierarchical controls are ineffective; there is little accountability because citizens are not empowered to hold governments accountable.

Fiscal federalism practices around the world are focused on structures and processes, with little regard for outputs and outcomes. These practices support top-down structures with preeminent federal legislation (that is, federal legislation overrides any subnational legislation). The central government is at the apex, exercising direct control and micromanaging the system. Hierarchical controls exercised by various layers of government have an internal rule-based focus with little concern for their mandates. Government competencies are determined on the basis of technical and administrative capacity, with almost no regard for client orientation, bottom-up accountability, and lowering of transaction costs for citizens. Various orders of government indulge in uncooperative zero-sum games for control.

This tug of war leads to large swings in the balance of powers. Shared rule is a source of much confusion and conflict, especially in federal systems. Local governments are typically handmaidens of states or provinces and given straitjacket mandates. They are given only limited home rule in their competencies. In short, local governments in this system of "federalism for the governments, by the governments, and of the governments" get crushed under a regime of intrusive controls by higher levels of governments. Citizens also have limited voice and exit options.

The governance implications of such a system are quite obvious. Various orders of government suffer from agency problems associated with incomplete contracts and undefined property rights, as the assignment of taxing, spending, and regulatory powers remains to be clarified-especially in areas of shared rule. Intergovernmental bargaining leads to high transaction costs for citizens. Universalism and pork-barrel politics result in a tragedy of commons, as various orders of government compete to claim a higher share of common pool resources. Under this system of governance, citizens are treated as agents rather than as principals.

On how to reverse this trend and make governments responsive and accountable to citizens, the dominant themes emphasized in the literature are the subsidiarity principle, the principle of fiscal equivalency, the creation of public value, results-based accountability, and the minimization of transaction costs for citizens, as discussed earlier. These themes are useful but should be integrated into a broader framework of citizen-centered governance, to 
create an incentive environment in the public sector that is compatible with a public sector focus on service delivery and bottom-up accountability. Such integration is expected to deal with the commitment problem in various levels of government by empowering citizens and by limiting their agents' ability to indulge in opportunistic behavior.

C I t I ZEN-CENTERED L O CA L G OVERNANCE. Reforming the institutions of local governance requires agreement on basic principles. Three basic principles are advanced to initiate such a discussion:

Responsive governance. This principle aims for governments to do the right things- that is, to deliver services consistent with citizen preferences.

- Responsible governance. The government should also do it right-that is, manage its fiscal resources prudently. It should earn the trust of residents by working better and costing less and by managing fiscal and social risks for the community. It should strive to improve the quality and quantity of and access to public services. To do so, it needs to benchmark its performance with the best-performing local government.

- Accountable governance. A local government should be accountable to its electorate. It should adhere to appropriate safeguards to ensure that it serves the public interest with integrity. Legal and institutional reforms may be needed to enable local governments to deal with accountability between elections-reforms such as a citizen's charter and a provision for recall of public officials.

A framework of local governance that embodies these principles is called citizen-centered governance (Andrews and Shah 2005). The distinguishing features of citizen-centered governance are the following:

- Citizen empowerment through a rights-based approach (direct democracy provisions, citizens' charter);

Bottom-up accountability for results;

- Evaluation of government performance as the facilitator of a network of providers by citizens as governors, taxpayers, and consumers of public services.

The framework emphasizes reforms that strengthen the role of citizens as the principals and create incentives for government agents to comply with their mandates (table 1.5). 
TA B L E 1 . 5 Key Elements of Citizen-Centered Governance

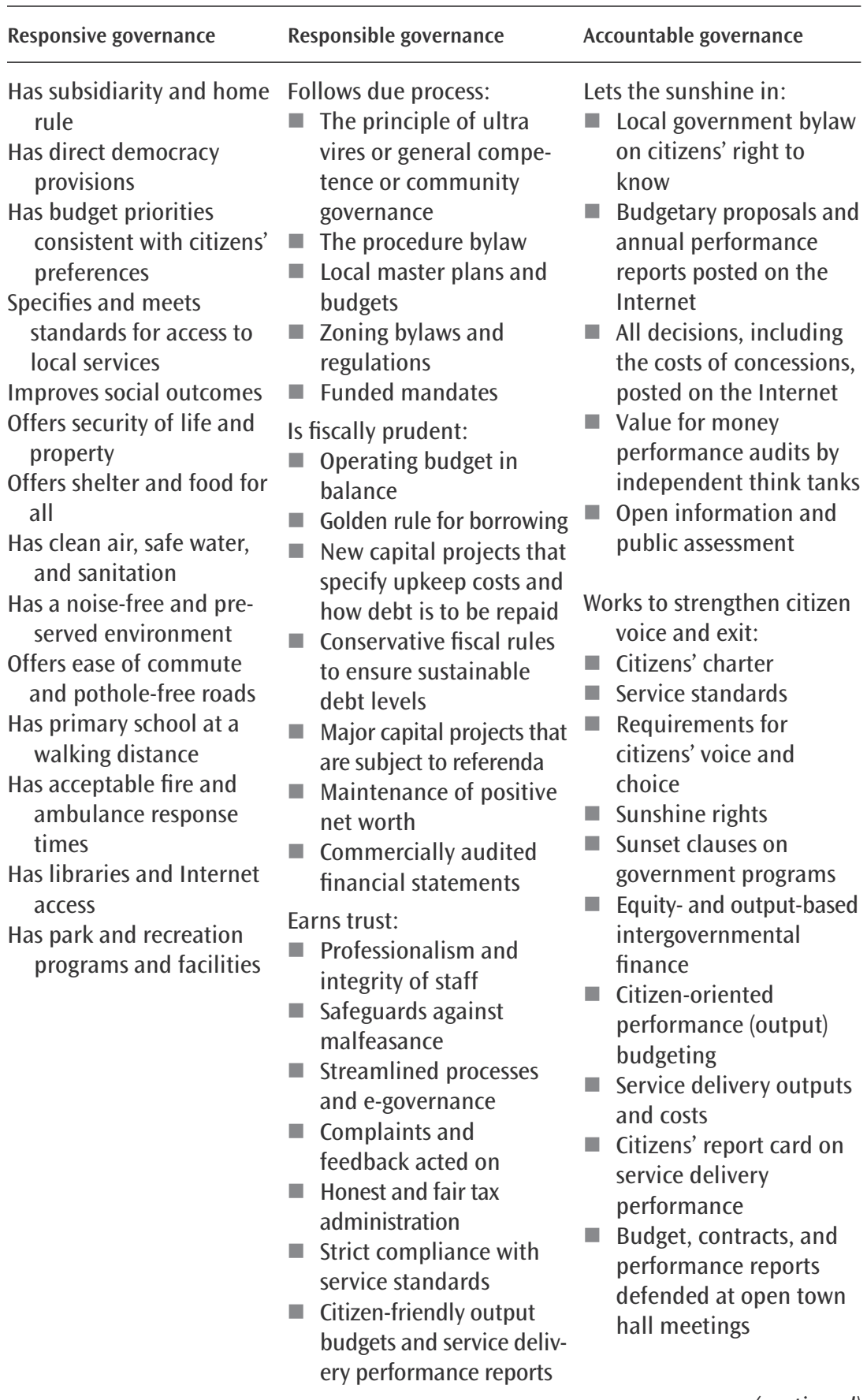


24 Anwar Shah with Sana Shah

T A B L E 1.5 Key Elements of Citizen-Centered Governance (continued)

\begin{tabular}{|c|c|c|}
\hline Responsive governance & Responsible governance & Accountable governance \\
\hline & 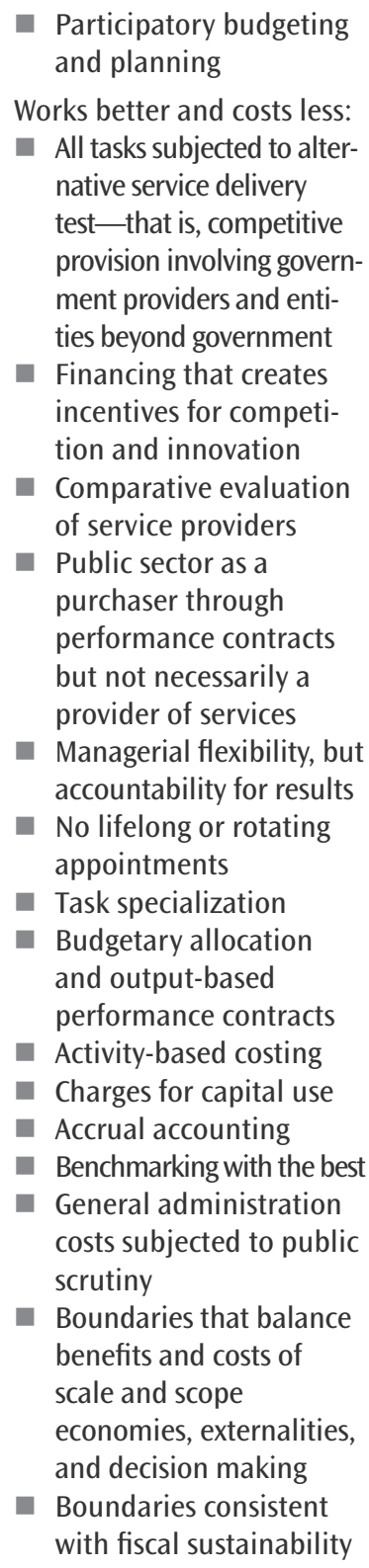 & $\begin{array}{l}\text { All documents subjected } \\
\text { to citizen-friendly } \\
\text { requirements } \\
\text { Open processes for } \\
\text { contract bids } \\
\text { Mandatory referenda on } \\
\text { large projects } \\
\text { Steps taken so that at } \\
\text { least } 50 \text { percent of } \\
\text { eligible voters vote } \\
\text { Citizens' boards to } \\
\text { provide scorecard and } \\
\text { feedback on service } \\
\text { delivery performance } \\
\text { Provisions for popular } \\
\text { initiatives and recall of } \\
\text { public officials } \\
\text { Bylaw on taxpayer rights }\end{array}$ \\
\hline
\end{tabular}


The commitment problem may be mitigated by creating citizen-centered local governance-by having direct democracy provisions, introducing governing for results in government operations, and reforming the structure of governance, thus shifting decision making closer to the people. Direct democracy provisions require referenda on major issues and large projects and require that citizens have the right to veto any legislation or government program. A "governing for results" framework requires government accountability to citizens for service delivery performance. Hence, citizens have a charter defining their basic rights as well as their rights of access to specific standards of public services. Output-based intergovernmental transfers strengthen compliance with such standards and strengthen accountability and citizen empowerment (Shah 2006b).

\section{Implications for division of powers within nations: Role reversals for central and local governments}

The framework described above has important implications for reforming the structure of government. Top-down mandates on local governance will need to be replaced by bottom-up compacts. Furthermore, the role of local government must be expanded to serve as a catalyst for the formulation, development, and operation of a network of both government providers and entities beyond government. Local government's traditionally acknowledged technical capacity becomes less relevant in this framework. More important are its institutional strengths as a purchaser of services and as a facilitator of alliances, partnerships, associations, clubs, and networks for developing social capital and improving social outcomes. Two distinct options are possible in this regard, and both imply a pivotal role for local governments in the intergovernmental system. The options are (a) local government as the primary agent, subcontracting to local, state, and federal or central government authorities and engaging networks and entities beyond government, and (b) local, state, and national governments as independent agents.

OP TION A: L OCAL GOVER NMENTSAS PRIMARY A G N T S O F C I T I Z E N S. In this role, a local government serves as (a) a purchaser of local services, (b) a facilitator of networks of government providers and entities beyond government, and (c) a gatekeeper and overseer of state and national governments for the shared rule or responsibilities delegated to them. This role represents a fundamental shift in the division of powers from higher to local governments. It has important constitutional implications. Residual functions reside with local governments. State governments perform intermunicipal services. The national government is assigned 
redistributive, security, foreign relations, and interstate functions such as harmonization and consensus on a common framework. The Swiss system bears close affinity to this model.

OPTION B：VARIOUS ORDERS OF GOVERNMENT AS INDEPENDENT A GENTS. An alternative framework for establishing the supremacy of the principals is to clarify the responsibilities and functions of various orders as independent agents. This framework limits shared rule. Finance follows function strictly, and fiscal arrangements are periodically reviewed for fine-tuning. Local governments enjoy home rule, with complete tax and expenditure autonomy. The Brazilian fiscal constitution incorporates some features of this model, albeit with significant deviations.

F E A S I B I L I T Y O F OP T I O N S . Option A is well grounded in the history of modern governments and is most suited for countries with no history of internal or external conflict in recent times. It is already practiced in Switzerland. War, conquest, and security concerns have led to a reversal of the roles of various orders of governments and to a reduction in local government functions in more recent history. Globalization and the information revolution have already brought pressures for much larger and stronger roles for local governments (see Shah 2001). Although a majority of governments have done some tinkering with their fiscal systems, the radical change recommended here is not in the cards anywhere. This is because the unlikelihood of overcoming path dependency-a tall order for existing institutions and vested interests—makes such reform infeasible. Under such circumstances, option B may be more workable, but here the clarity of responsibilities may not be politically feasible. In general, there is unlikely to be political will to undertake such bold reforms. Piecemeal adaptation of this model will nevertheless be forced on most countries by the effects of globalization and by citizen empowerment, facilitated by the information revolution.

\section{The Practice: Alternative Models of Local Governance and Central-Local Relations}

Local governance historically predates the emergence of nation-states. In ancient history, tribes and clans established systems of local governance in most of the world. They established their own codes of conduct and ways of raising revenues and delivering services to the tribe or clan. Tribal and clan 
elders developed consensus on the roles and responsibilities of various members. Some tribes and clans with better organization and skills then sought to enlarge their spheres of influence through conquest and cooperation with other tribes. In this way, the first Chinese dynasty, the Xia, was established (2070 BC to 1600 BC) (see Zheng and Fan 2003). A similar situation prevailed in ancient India, where in the third millennium BC (about 2500 BC) a rich civilization was established in the Indus Valley (now Pakistan). This advanced civilization placed great emphasis on autonomy in local governance and enshrined a consensus on division of work for various members of the society. This emphasis led to the creation of a class society in which each member had a defined role: upholder of moral values, soldier, farmer, tradesperson, worker. Each community formed its own consensus on community services and how to accomplish them.

Native American tribes in North America and tribes and clans in Western Europe also enjoyed home rule. Subsequent conquests and wars led to the demise of these harmonious systems of self-rule in local governance and to the emergence of rule by central governments all over the world. This development (roughly around 1000 BC in Western Europe) ultimately led to the creation of unique systems of local governance and central-local relations in most countries. Those systems can nevertheless be classified into the following broad categories for analytical purposes.

\section{The Nordic Model}

In the 15th century, Denmark, Norway, and Sweden were ruled by a Danish king. Residents in those countries contributed to the king's coffers but were allowed to run local affairs autonomously (Werner and Shah 2005). In the absence of central intrusion, the seeds for a locally run, client-oriented, welfare state were sown. As a result, local governments assumed most functions of the state while the central government largely assumed a ceremonial role and foreign relations functions. Local governments therefore assumed responsibility not only for local service delivery but also for social protection and social welfare functions. Local governments in Nordic countries serve their residents from cradle to grave. They deliver property-oriented as well as people-oriented services.

In modern times, the central governments in Nordic countries have assumed wider regulatory and oversight functions, but the predominance of local government-more than 30 percent of gross domestic product (GDP) in Denmark - and its autonomy are still preserved because of citizen satisfaction with local government performance. The Nordic model emphasizes small 
local governments (average jurisdiction of fewer than 10,000 inhabitants) that are primarily self-financing. In Denmark and Sweden, nearly 75 percentand in Norway, 64 percent-of local expenditures are financed from own-source revenues. Personal income taxes (piggybacking on a national base) are the mainstays of local finance (almost 91 percent of tax revenues), and property taxes contribute a pitiful 7 percent of tax revenues.

\section{The Swiss Model}

The origins of the Swiss Confederation can be traced to the defensive alliance signed by the cantons of Uri, Schwyz, and Unterwalden in 1291. Before that event, the Swiss territories were under the control of independent local governments (cantons). This tradition of local government domination continues in the Swiss system today: local governments enjoy autonomy not only in fiscal matters but also in such areas as immigration, citizenship, language, and foreign economic relations.

This tradition of strong local government is further strengthened through direct democracy provisions in the Swiss constitution, including (a) people's initiatives, (b) referenda, and (c) petitions. The people's initiatives empower citizens to seek a decision on an amendment that they want to make to the constitution. A people's initiative may be formulated as a general proposal or as a precisely formulated text whose wording can no longer be changed by parliament or the government. For such an initiative to be considered, the signatures of 100,000 voters must be collected within 18 months. A popular majority and a majority of all cantons are required for the acceptance of such an initiative.

Through the referenda provision, the people are entitled to pronounce their judgments on matters under consideration by the legislature or the executive or matters on which a decision has already been made. In the latter case, the referendum acts as a veto. Federal laws and international treaties are subject to optional referenda, provided that 50,000 citizens request it within 100 days of the publication of the decree. Under the petition provision, all eligible voters can submit a petition to the government and are entitled to receive a reply. Switzerland consists of 26 cantons and 2,842 communes. Each canton has its own constitution, parliament, government, and courts. The communes are handmaidens of the cantons. They perform some delegated tasks such as population registration and civil defense, but they have autonomous competencies in education and social welfare, energy supply, roads, local planning, and local taxation (Government of Switzerland 2003). 


\section{The French Model}

In the French model, the primary role of local governments is to allow citizens at the grassroots level a sense of political participation in decision making at the national level. The system embodies the thinking of Rousseau and Voltaire on rationality and social cohesion and that of Napoleon on a sense of order and an unbroken chain of command. The national government and its agencies represent the apex of this system, with an unbroken chain of command through regional and departmental prefects to chief executives and mayors of communes at the lowest rung of the system. There is a similar chain of command through line and functional ministries. Therefore, the model is sometimes referred to as the dual supervision model of local governance.

The system permits cumul des mandats (concurrent political mandates or holding multiple offices or positions concurrently) to provide elected leaders at lower echelons with a voice at higher levels of governments. Public service delivery remains the primary responsibility of the national government, and its agencies may be directly involved in the delivery of local services. The average size of local government jurisdiction is small (covering fewer than 10,000 inhabitants), and local governments have a limited range of autonomous service delivery responsibilities. Local governments use a mix of local revenue instruments and rely significantly on central financing. This model, with its focus on strong central command and dual supervision, proved very popular with colonial rulers from France, Portugal, and Spain, as well as with military dictators, and was widely replicated in developing countries (Humes 1991).

\section{The German Model}

The German model emphasizes subsidiarity, cooperation, and administrative efficiency. It entrusts policy-making functions to the federal level and service delivery responsibilities to geographically delineated states and local governments, to which it gives a great deal of autonomy in service delivery. All purely local services are assigned to local governments. The average local government covers 20,000 inhabitants, and local expenditures constitute about 10 percent of GDP. General revenue sharing serves as a major source of local finances.

\section{The British Model}

The British model has elements of the French dual supervision model. It emphasizes a stronger role for centrally appointed field officers and sectoral 
and functional ministries in the provision of local services. Local governments must coordinate their actions with these officials. Local governments are given substantial autonomy in purely local functions, but they can access only a limited range of revenue instruments. Local governments play a dominant role in such property-oriented services as road maintenance, garbage collection, water, and sewerage and a limited role in such people-oriented services as health, education, and social welfare. Property taxes are the mainstay of local governments. Local governments typically derive two-thirds of their revenues from central transfers. They do not have access to personal income taxes. The role of the chief executive is weak, and local councils play a strong role in local decision making. The average local government is large, covering about 120,000 inhabitants, and local expenditures account for about 12 percent of GDP (McMillan forthcoming). In former British colonies, the role of field officers was strengthened to provide general supervision and control of local governments on behalf of the central colonial government.

\section{The Indian Model}

India had one of the oldest traditions of strong self-governance at the local level. In the pre-Moghul period, local government was in operation more extensively in India than anywhere else in the world. Small villages and towns were regulated by custom and community leadership, with authority normally vested in an elders' council headed by a sarpanch or numberdar. The apex institution was the panchayat, with responsibilities for law and order, local services, land management, dispute resolution, administration of justice, provision of basic needs, and revenue collection. These institutions enabled each village and town to function harmoniously.

Subsequent wars and conquest led to a weakening of local governance in India. During the Moghul period, panchayats were required to collect central taxes, but local government autonomy was not disturbed (Wajidi 1990). During the British Raj, with its central focus on command and control and little concern for service delivery, the system of local governance received a major setback. Powers were centralized, and loyalty to the British regime was rewarded with land grants, leading to the creation of a class of feudal aristocrats who dominated the local political scene on behalf of the British government. The central government also appointed roving bureaucrats to run local affairs. Since independence in both India and Pakistan, centralized governance has been maintained, while small steps have been taken to strengthen local autonomy. In India, feudal aristocracy was abolished through land 
reforms, but in Pakistan, such reforms could not be carried out. As a result, in areas of feudal dominance in Pakistan, local self-governance led to capture by elites.

\section{The Chinese Model}

This model places strong emphasis on making provincial and local governments an integral and dependent sphere of national government. This is accomplished in two ways: through democratic centralism, which integrates the local people's congress with the national People's Congress through a system of elections, and through dual subordination of local governments, whereby provincial and local governments are accountable to higher-level governments in general, but the functional departments are also accountable to higher-level functional agencies and departments. The personnel functions are also integrated among various orders of government. Because of its integrative nature, the model permits a large and expansive role for provincial and local governments in service delivery. The average local government jurisdiction is very large. Subprovincial local government expenditure constitutes 51.4 percent of consolidated public expenditures. Subprovincial local governments employ 89 percent of the total government workforce. Some clearly central functions such as unemployment insurance, social security, and social safety nets are assigned to provincial and local governments. Local autonomy varies directly with the fiscal capacity of a local government, with richer jurisdictions calling their own tunes while poor jurisdictions follow the pied piper of higher-level governments.

\section{The Japanese Model}

The local government system introduced in Meiji Japan in about 1890 had elements of the French and German models. It emphasized centralized control, as in the French model of local governments, through the Ministry of Interior appointing heads of regional governments (governors of prefectures), who controlled local districts and municipalities. The local government simply implemented policies determined by the central government. In the post-World War II period, direct elections of governors, mayors, and councils were introduced. The practice of agency delegation (German model) was retained, and local governments were expected to perform functions mandated by the central government and its agencies. The Ministry of Home Affairs, which had a supportive role for local governments, was introduced in 1960 (Muramatsu and Iqbal 2001). Income taxes are the mainstay 
of local government finance, contributing 60 percent of own-source tax revenues, followed by property taxes (about 30 percent) and sales taxes (about 10 percent).

\section{The North American Model}

In the early period of North American history, local communities functioned as civic republics (Kincaid 1967) governed by mutual consent of their members. The framers of the U.S. constitution did not recognize local governments. The Civil War led to the centralization of powers in the United States. Subsequently, the formal institutions of local government were created by states. The judiciary further constrained the role of local government through recognition of Dillon's rule: local governments may exercise only those powers explicitly granted to them under state legislation. Subsequently, most states have attempted to grant autonomy to local governments in discharging their specified functions through home rule provisions (Bowman and Kearney 1990).

Local governments in Canada are faced with circumstances similar to those in the United States. Thus, the North American model recognizes local government as a handmaiden of states and provinces but attempts to grant autonomy (home rule) to local governments in their specific areas of responsibility—predominantly delivery of property-oriented services. Local governments perform an intermediate range of functions. The average jurisdiction of local government in the United States is about 10,000 and in Canada about 6,000 inhabitants. Property taxes are the dominant source of local revenues. Local government expenditures constitute about 7 percent of GDP (see McMillan forthcoming).

\section{The Australian Model}

The Australian constitution does not recognize local governments. It is left to the states to decide on a system of local governance in their territories. Most states have assigned a minimal set of functions to local governments, including engineering services (roads, bridges, sidewalks, and drainage); community services (old-age care, child care, fire protection); environmental services (waste management and environmental protection); regulatory services (zoning, dwellings, buildings, restaurants, animals); and cultural services (libraries, art galleries, museums). Local governments raise only 3 percent of national revenues and are responsible for 6 percent of consolidated public sector expenditures. Property taxes (rates) and user charges are the mainstay (about 70 percent) of revenues, and central and state grants 
finance about 20 percent of local expenditures. Transportation, community amenities, and recreation and culture command two-thirds of local expenditures. Local government in New Zealand bears a close resemblance to the Australian model.

\section{A Comparative Overview of Local Government Organization and Finance in Selected Developing Countries}

The conceptual literature argues for a strong role of local governments in local development, thereby improving public services and quality of life at the local level. It would therefore be instructive to learn about the role of such governments in developing countries. The following paragraphs provide a bird's-eye view of local government organization and finance in 10 selected developing countries.

\section{Legal Status of Local Governments}

The legal status of local governments varies across developing countries. In Brazil, Chile, India, South Africa, and Uganda, local governments have a constitutional status. In Indonesia, Kazakhstan, and Poland, local governments were created by national legislation, in Argentina by provincial legislation, and in China by an executive order of the central government. It is interesting to note that there is no clear pattern in the autonomy and range of local services provided by local governments deriving their status from national and state constitutions or legislation. However, local governments that are created through legislation, in general, are significantly weaker-with the notable exception of Poland.

\section{Relative Importance of Local Governments}

The relative importance of local governments in developing countries is compared using two indicators: share of consolidated public sector expenditures (figure 1.1) and local expenditures as a percentage of GDP (figure 1.2). According to both criteria, local governments in China command the largest share-more than 51 percent of consolidated public expenditures and 10.8 percent of GDP-whereas in India, it is the smallest share- 3 percent of the expenditures and 0.75 percent of GDP. The rank order of some countries, however, is not consistent across both criteria. For example, South Africa does better than Brazil on the first and worse on the second criterion. On average in sample countries, local government 


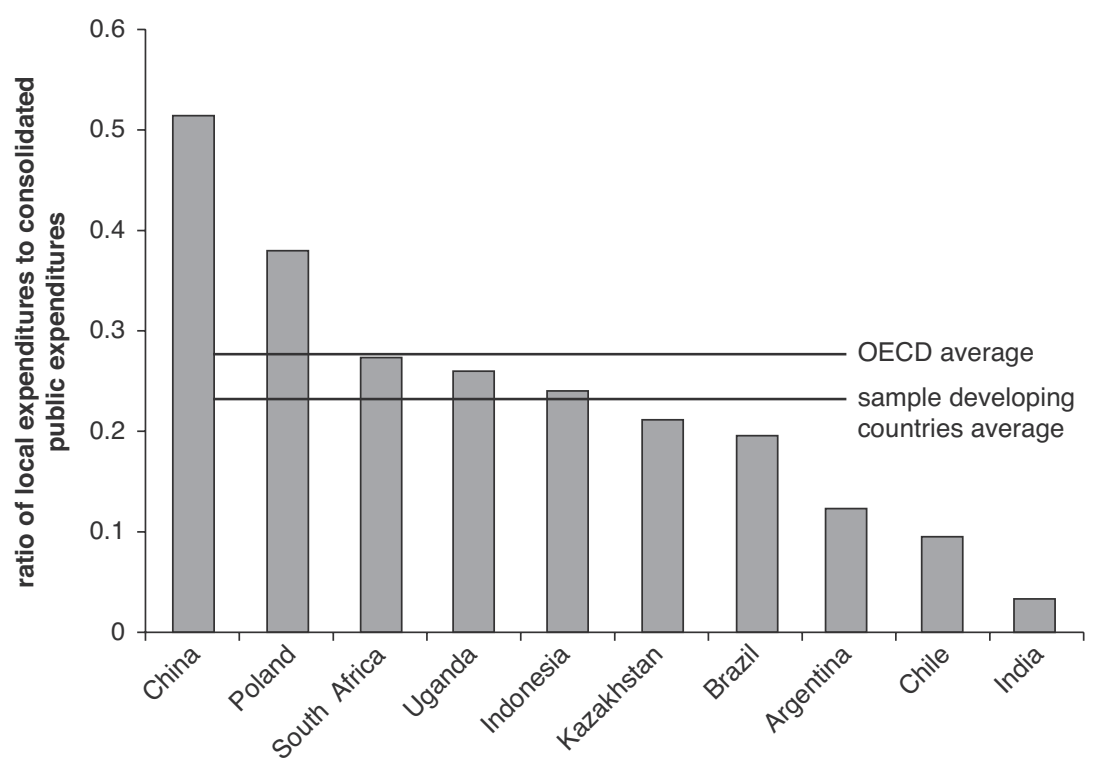

Source: Calculations based on World Development Indicators Online; government finance statistics; chapters 2-11 (this volume); and Werner forthcoming.

Note: The data are the latest available for each country-1997, Poland; 2001, Chile, Indonesia, and South Africa; 2002, India; and 2003, Argentina, Brazil, China, Kazakhstan, and Uganda.

\section{F I G U R E 1 . 1 A Comparative Perspective on Local Government Share of Consolidated Public Expenditures}

expenditures amount to 23 percent of consolidated public sector expenditures and 5.7 percent of national GDP. Comparable figures for a sample of Organisation for Economic Co-operation and Development (OECD) countries would be 28 percent of consolidated expenditures and 12.75 percent of GDP. Thus, local governments' role is large, but in comparison with central and intermediate governments in developing countries and local governments in OECD countries, it is relatively much smaller in most developing countries - with the exception of China and Poland. In China, subprovincial local governments employ 38.7 million people and account for 89 percent of total public employment.

\section{Population Size Covered by Local Governments}

There are wide variations in the number and median size of municipal governments in the sample countries. Uganda has only 70 municipal governments, whereas China has 43,965 (table 1.6). The mean population 


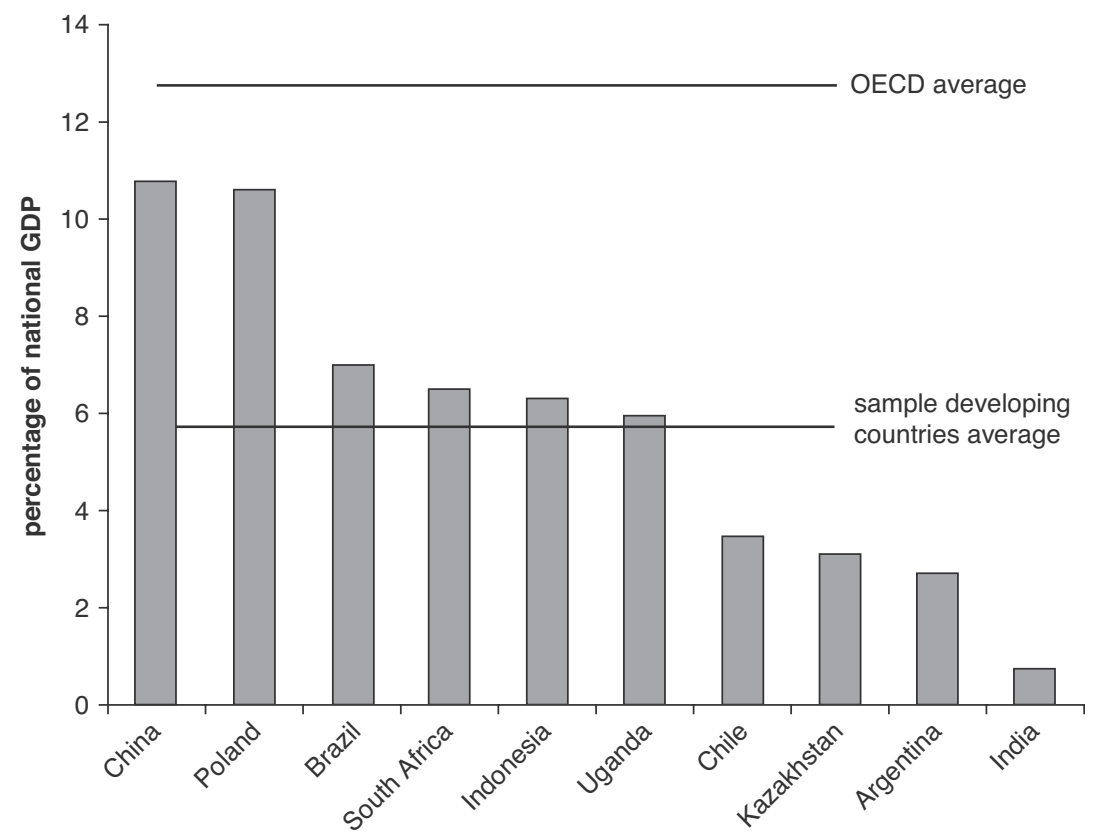

Source: Calculations based on World Development Indicators Online; government finance statistics; chapter 2-11 (this volume); and Werner forthcoming.

Note: The data are the latest available for each country—1997, Poland; 2001, Chile, Indonesia, and South Africa; 2002, India; and 2003, Argentina, Brazil, China, Kazakhstan, and Uganda.

\section{F I G U R E 1 . 2 Local Expenditures as a Share of National GDP}

covered by municipal government is fewer than 10,000 people in Indonesia and Kazakhstan and more than 100,000 people in China, South Africa, and Uganda. Argentina and Poland have mean populations of less than 20,000, and Brazil has a mean municipal government population of about 31,000. Municipal governments in Chile and India have mean populations between 60,000 and 70,000 (table 1.7).

\section{Local Spending Responsibilities}

Local governments vary in their responsibilities across developing countries. China grants most extensive expenditure responsibilities to local governments. In addition to traditional local and municipal services, local governments in China are responsible for social security (primarily pensions and unemployment allowances) and have a much larger role in local economic development than local governments in other countries. Local governments' role in delivering local services is minimal in India and South Africa and largely focused on delivery 
TA B LE 1, 6 Size Distribution of Municipal Governments in Developing Countries

\begin{tabular}{|c|c|c|c|c|c|c|c|c|c|c|}
\hline $\begin{array}{l}\text { Number of } \\
\text { inhabitants }\end{array}$ & $\begin{array}{l}\text { Argentina } \\
\text { (2001) }\end{array}$ & $\begin{array}{l}\text { Brazil } \\
(2002)\end{array}$ & $\begin{array}{l}\text { Chile } \\
(1992)\end{array}$ & $\begin{array}{l}\text { China } \\
(2004)\end{array}$ & $\begin{array}{l}\text { India } \\
(2001)\end{array}$ & $\begin{array}{l}\text { Indonesia } \\
(1990)\end{array}$ & $\begin{array}{c}\text { Kazakhstan } \\
(2002)\end{array}$ & $\begin{array}{l}\text { Poland } \\
(2003)\end{array}$ & $\begin{array}{l}\text { South Africa } \\
\text { (2001) }\end{array}$ & $\begin{array}{c}\text { Uganda } \\
\text { (2002) }\end{array}$ \\
\hline $0-4,999$ & 1,770 & 1,365 & 269 & 43,258 & 230,161 & 1,237 & 7,660 & 604 & 0 & 0 \\
\hline $5,000-9,999$ & $\downarrow$ & 1,316 & 16 & & 16,115 & 62 & 201 & 1,049 & 4 & 1 \\
\hline $10,000-19,999$ & 360 & 1,342 & 40 & & 5,536 & & 81 & 731 & 16 & 0 \\
\hline $20,000-24,999$ & $\downarrow$ & 989 & . & & $\downarrow$ & $\downarrow$ & I & $\mid$ & 7 & 0 \\
\hline $25,000-49,999$ & 24 & $\downarrow$ & & & 1,386 & 7 & $\downarrow$ & $\downarrow$ & 36 & 6 \\
\hline $50,000-99,999$ & 1 & 309 & & & 498 & $\downarrow$ & 7 & 54 & 61 & 6 \\
\hline $100,000-199,999$ & & 123 & & $\downarrow$ & 388 & 6 & 18 & 22 & 67 & 9 \\
\hline $200,000-499,999$ & & 82 & & 374 & 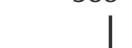 & 1 & $\downarrow$ & 13 & 52 & 31 \\
\hline $500,000-999,999$ & & 20 & & 283 & $\downarrow$ & & $\downarrow$ & 5 & 25 & 15 \\
\hline $1,000,000$ or more & $\downarrow$ & 14 & $\downarrow$ & 50 & 35 & $\downarrow$ & 1 & $\downarrow$ & 14 & 2 \\
\hline Total number of municipalities & 2,154 & 5,560 & 325 & 43,965 & 254,119 & 1,312 & 7,968 & 2,478 & 282 & 70 \\
\hline
\end{tabular}

Source: Chapters 2-11 (this volume); Werner forthcoming.

Note: An arrow indicates that the value is an aggregate and covers the range indicated. 
TA B LE 1.7 Average Population per Local Authority in Sample Developing Countries

\begin{tabular}{lc}
\hline Country & Average population per local authority \\
\hline India, rural & 3,278 \\
Kazakhstan & 4,331 \\
Indonesia & 5,915 \\
Argentina & 14,972 \\
Poland & 18,881 \\
Brazil & 30,099 \\
Chile & 64,592 \\
India, urban & 68,027 \\
China & 107,334 \\
South Africa & 238,839 \\
Uganda & 373,321 \\
All sample countries & 79,000 \\
\hline
\end{tabular}

Source: Table 1.6 (this volume).

of municipal services. In Kazakhstan, all local services are shared central-local responsibilities; local governments do not have independent budgets and have no fiscal autonomy. Education and health account for nearly half of local government expenditures in Argentina, Brazil, Chile, Indonesia, Kazakhstan, Poland, and Uganda. In Uganda, education alone accounts for about 40 percent of local expenditures. In India and South Africa, municipal services (such as water, sewer, and garbage) and municipal administration dominate local expenditures. In China, education, municipal administration, justice, and police account for nearly half of local expenditures.

\section{Local Revenues and Revenue Autonomy}

Local governments in sample countries raise 39.6 percent of revenues from taxes, another 9.5 percent from fees and charges, and the remaining 50.9 percent from higher-level transfers (figure 1.3 and table 1.8). Comparable figures for OECD countries are 49 percent for taxes, 16.6 percent for fees, and 34.4 percent for transfers. The role of fiscal transfers is much larger than average in Uganda (85.4 percent), Poland (76.0 percent), China (67.0 percent), Brazil (65.4 percent), and Indonesia (62.0 percent). The sample countries have diverse revenue structures. On average, they raise 32 percent of tax revenues from property taxes, 15 percent of revenues from personal income taxes, 4 percent from corporate income taxes, and the other 49 percent from a large number of small taxes, fees, and charges. In comparison, OECD countries raise 54 percent of local revenues from property taxes, 23 percent from 


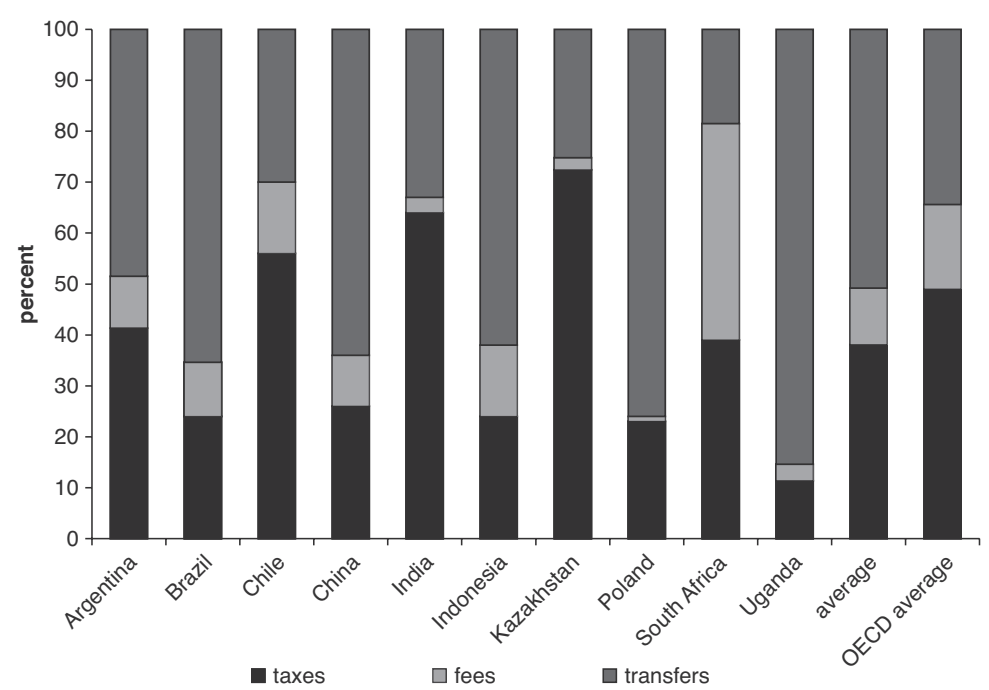

Source: Calculations based on World Development Indicators Online; government finance statistics; chapters 2-11 (this volume); Werner forthcoming.

Note: The data are the latest available for each country-1997, Poland; 2000, India: 2001, Chile, Indonesia, and South Africa; and 2003, Argentina, Brazil, China, Kazakhstan, and Uganda.

\section{F I G U R E 1 . 3 Composition of Operating Revenues for Local Authorities}

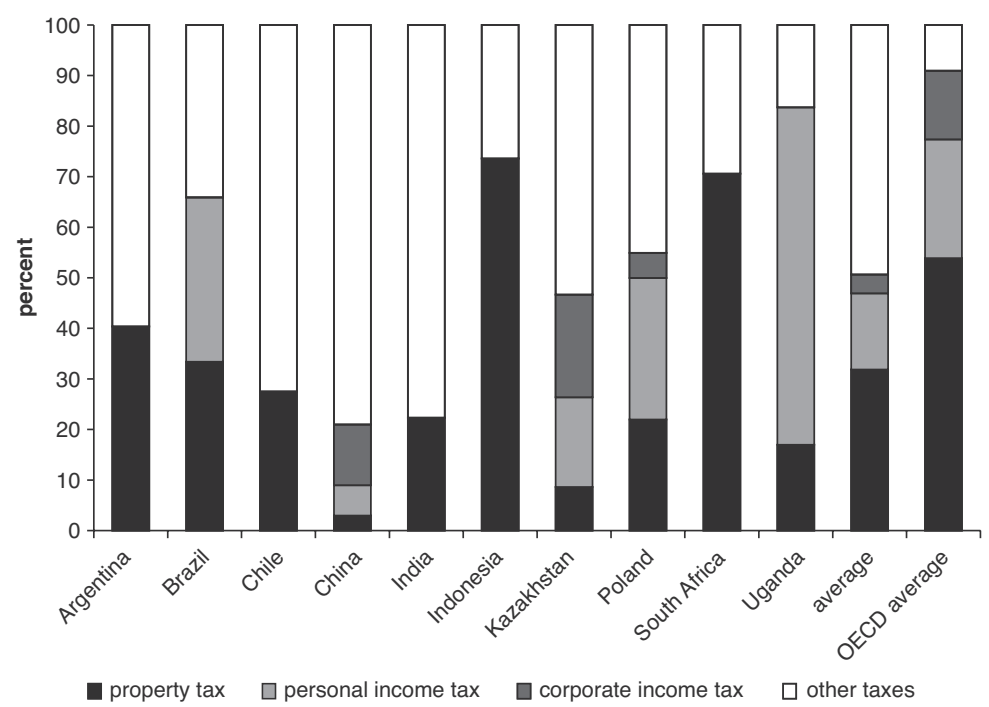

Source: Calculations based on World Development Indicators Online; government finance statistics; chapters 2-11 (this volume); Naresh 2004; Werner forthcoming.

Note: The data are the latest available for each country-1997, Poland; 2000, India: 2001, Chile, Indonesia, and South Africa; and 2003, Argentina, Brazil, China, Kazakhstan, and Uganda. 
TA B LE 1.8 Intergovernmental Transfers as a Share of Local Government Revenues in Developing Countries, 2003

Transfers as a percentage of total local revenues

$10-20$

20-30

$30-40$

$40-50$

$60-70$

70-80
Countries (listed in ascending order of the share of transfers)

South Africa

Kazakhstan, Chile

India

Argentina

Indonesia, Brazil, China

Poland, Uganda

Source: Chapters 2-11 (this volume).

Note: There were no countries with percentages in the 50-60 range.

personal income taxes, 14 percent from corporate taxes, and 9 percent from other taxes. Thus, local governments place a much greater reliance on property and income taxes in OECD countries than in developing countries. Property taxes raise only 3 percent of local revenues in China and 74 percent in Indonesia (centrally administered property tax) (figure 1.4).

For all developing countries, revenues from property taxes amount to 0.5 percent of GDP compared with about 2 percent ( 1 to 3 percent) of GDP in industrial countries. This finding suggests that property taxes may represent significant untapped potential for further exploitation. User charges are a significant source of revenues, but often such charges are poorly designed and administered and do not satisfy equity and efficiency principles or provide special safeguards for the poor. Autonomy in local tax base determination and administration is significant in Argentina, Brazil, and Poland; is limited in other countries; and does not exist in Kazakhstan. Overall, the degree of tax centralization in the sample countries is far greater than would be dictated by economic principles or political accountability considerations.

Sample countries in general follow a formula-based approach to generalpurpose transfers. Nevertheless, the transfers are often not well designed compared with principles and better practices laid out in table 1.4. China, Indonesia, Poland, and South Africa attempt to use fiscal capacity and fiscal need measures in their fiscal equalization transfers, whereas most other countries have revenue-sharing programs with multiple factors that work at cross-purposes. The practice of fiscal equalization transfers is welcome; however, none of the sample countries use explicit equalization standards that determine both the total pool and the allocation of these transfers. As a result, the transfers do not achieve jurisdictional fiscal equity goals. Specificpurpose transfers are usually ad hoc and do not create incentives to safeguard 
their objectives. In particular, none of the sample countries practice outputbased fiscal transfers to set national minimum standards of basic services and to enhance local accountability to citizens for results or performance. Thus, the reform of fiscal transfers to ensure equitable and accountable governance remains an unfinished task.

\section{Facilitating Local Access to Credit}

Local borrowing from capital markets is permitted in most of the sample countries with the exception of China, Chile, and Indonesia. In China, however, central government may borrow or issue bonds on behalf of local governments, and local enterprises owned by local governments can also borrow directly from the capital markets. In Argentina, Brazil, and Poland, local borrowing from domestic and international capital markets is allowed but constrained by fiscal rules, to ensure fiscal prudence and debt sustainability. In South Africa most such borrowing takes place from public agencies such as the Infrastructure Finance Corporation and the Development Bank of Southern Africa. The central government in South Africa provides regulatory oversight of all such borrowing and has the authority to intervene if a local government fails to meet its debt servicing obligations. South Africa has enacted a comprehensive framework for fiscal prudence at the local level, including provisions for declaring bankruptcy. In Kazakhstan, local governments can borrow only from the central government.

Large infrastructure deficiencies in developing countries call for significant access to borrowing by local governments. But local access to credit requires well-functioning financial markets and creditworthy local governments. In developing countries, undeveloped markets for long-term credit and weak municipal creditworthiness limit municipal access to credit. Nevertheless, the predominant central government policy emphasis is on central controls. Consequently, less attention has been paid to assistance for borrowing. In a few countries, such assistance is available through specialized institutions and central guarantees to jump-start municipal access to credit. These institutions are typically quite fragile, not likely to be sustainable, and open to political influences. Interest rate subsidies provided through these institutions impede emerging capital market alternatives. Furthermore, these institutions fail to smooth the transition to a marketbased capital finance system.

Thus, in developing countries, the menu of choices available to local governments for financing capital projects is quite limited, and the available alternatives are not conducive to developing a sustainable institutional 
environment for such finance. Such limitations exist because macroeconomic instability and lack of fiscal discipline and appropriate regulatory regimes have impeded the development of financial and capital markets. In addition, revenue capacity at the local level is limited because of tax centralization. A first transitory step to provide limited credit market access to local governments may be to establish municipal finance corporations run on commercial principles and to encourage the development of municipal rating agencies to assist in such borrowing. Tax decentralization is also important to establish private sector confidence in lending to local governments and sharing in the risks and rewards of such lending. Central government bailouts and guarantee of subnational debt should, however, be ruled out through enactment of comprehensive frameworks of fiscal responsibility and fiscal insolvency, as was done in Brazil and South Africa recently. Transparency in local budgeting and independent credit rating agencies are also essential to smooth the transition to a market-based approach to subnational lending.

\section{Some Conclusions about Local Governance in Developing Countries}

Recent years have seen positive developments regarding local governance in developing countries. Local governments are increasingly assuming a larger role in public services delivery. However, with the exception of a handful of countries such as Brazil, China, and Poland, local governments continue to play a very small role in people's lives. They typically are bounded by the principle of ultra vires and allowed to discharge only a small number of functions, which are mandated from above. They have limited autonomy in expenditure decisions and hardly any in revenue-raising decisions. Their access to own-source revenues is constrained to a few nonproductive bases. Political and bureaucratic leaders at the local level show little interest in lobbying for more taxing powers and instead devote all their energies to seeking higher levels of fiscal transfers.

As a result, tax decentralization has not kept pace with political and expenditure decentralization. Hence, one does not find many examples of tax-base sharing, and even the limited existing bases available to local governments are typically underexploited. Fiscal transfers typically account for 60 percent of revenues in developing countries (51 percent in sample developing countries) as opposed to only 34 percent in OECD countries. This distinct separation of taxing and spending decisions undermines accountability to local citizens because local leaders do not have to justify local spending decisions to their electorates. 
Local self-financing is important for strengthening governance, efficiency, and accountability. Although most countries have opted for formula-driven fiscal transfers, the design of these transfers remains flawed. They do not create any incentive for setting national minimum standards or accountability for results and typically do not serve regional fiscal equity objectives either.

Local governments also typically have very limited autonomy in hiring and firing local government employees. In a number of countries with decentralization, such as Indonesia and Pakistan, higher government employees are simply transferred to local levels; financing is then provided to cover their wage costs. This approach limits budgetary flexibility and opportunities for efficient resource allocation at the local level.

Overall, local governments in developing countries typically follow the old model of local governance and simply provide a narrow range of local services directly. The new vision, with the local governments assuming a network facilitator role to enrich the quality of life of local residents, as discussed earlier in this chapter, is yet to be realized in any developing country.

\section{Concluding Remarks}

We have presented a brief overview of the conceptual and institutional literature on local governance. A synthesis of the conceptual literature suggests that the modern role of a local government is to deal with market failures as well as government failures. This role requires a local government to operate as a purchaser of local services, a facilitator of networks of government providers and entities beyond government, and a gatekeeper and overseer of state and national governments in areas of shared rule. Local government also needs to play a mediator's role among various entities and networks to foster greater synergy and harness the untapped energies of the broader community for improving the quality of life of residents. Globalization and the information revolution are reinforcing those conceptual perspectives on a catalytic role for local governments.

This view is also grounded in the history of industrial nations and ancient civilizations in China and India. Local government was the primary form of government until wars and conquest led to the transfer of local government responsibilities to central and regional governments. This trend continued unabated until globalization and the information revolution highlighted the weaknesses of centralized rule for improving the quality of life and social outcomes. The new vision of local governance (table 1.9) presented here argues for a leadership role by local governments in a multicentered, multiorder, or multilevel system. This view is critical to creating 
TA B L E 1 . 9 Role of a Local Government under the New Vision of Local Governance

20th century: Old view

21st century: New view

Is based on residuality and local governments as wards of the state Is based on principle of ultra vires Is focused on government

Is agent of the central government

Is responsive and accountable to higher-level governments

Is direct provider of local services Is focused on in-house provision

Is focused on secrecy

Has input controls

Is internally dependent

Is closed and slow

Has intolerance for risk

Depends on central directives

Is rules driven

Is bureaucratic and technocratic

Is coercive

Is fiscally irresponsible

Is exclusive with elite capture

Overcomes market failures

Is boxed in a centralized system

Is based on subsidiarity and home rule

Is based on community governance

Is focused on citizen-centered local governance

Is the primary agent for the citizens and leader and gatekeeper for shared rule

Is responsive and accountable to local voters; assumes leadership role in improving local governance

Is purchaser of local services

Is facilitator of network mechanisms of local governance, coordinator of government providers and entities beyond government, mediator of conflicts, and developer of social capital Is focused on letting the sunshine in; practices transparent governance Recognizes that results matter Is externally focused and competitive; is ardent practitioner of alternative service delivery framework

Is open, quick, and flexible Is innovative; is risk taker within limits Is autonomous in taxing, spending, regulatory, and administrative decisions Has managerial flexibility and accountability for results

Is participatory; works to strengthen citizen voice and exit options through direct democracy provisions, citizens' charters, and performance budgeting

Is focused on earning trust, creating space for civic dialogue, serving the citizens, and improving social outcomes Is fiscally prudent; works better and costs less Is inclusive and participatory

Overcomes market and government failures Is connected in a globalized and localized world 
and sustaining citizen-centered governance, in which citizens are the ultimate sovereigns and various orders of governments serve as agents in the supply of public governance. In developing countries, such citizen empowerment may be the only way to reform public sector governance when governments are either unwilling or unable to reform themselves.

\section{Acknowledgments}

This chapter is an amended version of chapter 1 in Shah (2006a). It replaces the section on industrial countries with a section on developing countries; the rest of the chapter makes only minor revisions to the original chapter. This repetition of the substantive part of this introductory chapter was necessitated by the division of the original manuscript on local governance into two volumes. This chapter owes a great deal of intellectual debt to Professors Stephen Bailey, Brian Dollery, Sue Goss, Samuel Humes IV, Melville McMillan, and Joe Wallis, on whose works this chapter draws quite liberally. The principal author is also grateful to Sana Shah and Mike Lombardo for their briefs on local governance in developing countries and to Baoyun Qia for his help with data, tables, and figures for the section on developing countries.

\section{References}

Andrews, Matthew, and Anwar Shah. 2005. "Citizen-Centered Governance: A New Approach to Public Sector Reform." In Public Expenditure Analysis, ed. Anwar Shah, 153-82. Washington, DC: World Bank.

Bailey, Stephen. 1999. Local Government Economics: Theory, Policy, and Practice. Basingstoke, U.K.: Macmillan.

Bowman, Ann, and Richard Kearney. 1990. State and Local Government. Boston: Houghton Mifflin.

Boyne, George. 1998. Public Choice Theory and Local Government. Basingstoke, U.K.: Macmillan.

Breton, Albert. 1995. Competitive Governments. Cambridge, U.K.: Cambridge University Press.

Brueckner, Jan. 1982. “A Test for Allocative Efficiency in the Local Public Sector.” Journal of Public Economics 19: 311-31.

Buchanan, James. 1965. “An Economic Theory of Clubs.” Economica 32: 1-14.

Caulfield, Janice. 2003. "Local Government Reform in Comparative Perspective." In Reshaping Australian Local Government, ed. Brian Dollery, Neil Marshall, and Andrew Worthington, 11-34. Sydney: University of New South Wales Press

Dollery, Brian, and Joe Wallis. 2001. The Political Economy of Local Government. Cheltenham, U.K.: Edward Elgar. 
Frey, Bruno, and Reiner Eichenberger. 1995. "Competition among Jurisdictions: The Idea of FOCJ.” In Competition among Jurisdictions, ed. Lüder Gerken, 209-29. London: Macmillan.

_. 1996. "FOCJ: Competitive Governments for Europe." International Review of Law and Economics 16: 315-27.

- 1999. The New Democratic Federalism for Europe: Functional Overlapping and Competing Jurisdictions. Cheltenham, U.K., and Northampton, MA: Edward Elgar.

Goss, Sue. 2001. Making Local Governance Work. New York: Palgrave.

Government of Switzerland. 2003. The Swiss Confederation-A Brief Guide. Bern, Switzerland: Bundeskanzlei.

Horn, Murray. 1997. The Political Economy of Public Administration. Cambridge, U.K.: Cambridge University Press.

Humes, Samuel IV. 1991. Local Governance and National Power. New York: Harvester/Wheatsheaf.

Inman, Robert. 2005. “Financing Cities.” NBER Working Paper 11203, National Bureau of Economic Research, Cambridge, MA.

Kincaid, John. 1967. “Municipal Perspectives in Federalism.” Unpublished paper. Cited in Bowman and Kearney (1990).

McMillan, Melville. Forthcoming. "A Local Perspective on Fiscal Federalism: Practices, Experiences, and Lessons from Developed Countries." In Macrofederalism and Local Finances, ed. Anwar Shah. Washington, DC: World Bank.

Moore, Mark. 1996. Creating Public Value. Cambridge, MA: Harvard University Press.

Muramatsu, Michio, and Farrukh Iqbal. 2001. "Understanding Japanese Intergovernmental Relations: Perspectives, Models, and Salient Characteristics." In Local Government Development in Postwar Japan, ed. Michio Muramatsu and Farrukh Iqbal, 1-28. Oxford, U.K.: Oxford University Press.

Naresh, Gautum. 2004. "Property Taxation in India." In International Handbook of Land and Property Taxation, ed. Richard Bird and Enid Slack, 129-51. Northampton, MA: Edward Elgar.

Oates, Wallace. 1969. “The Effects of Property Taxes and Local Public Spending on Property Values: An Empirical Study of Tax Capitalization and Tiebout Hypothesis.” Journal of Political Economy 77: 957-71.

. 1972. Fiscal Federalism. New York: Harcourt Brace Jovanovich.

Olson, Mancur. 1969. "The Principle of Fiscal Equivalence: The Division of Responsibilities among Different Levels of Government." American Economic Review 59 (2): 479-87.

Rhodes, R. A. W. 1997. Understanding Governance: Policy Networks, Governance, Reflexivity, and Accountability. Buckingham, U.K.: Open University Press.

Shah, Anwar. 1988. "Capitalization and the Theory of Local Public Finance: An Interpretive Essay." Journal of Economic Surveys 2 (3): 209-43.

- 1989. "A Capitalization Approach to Fiscal Incidence at the Local Level." Land Economics 65 (4):359-75.

_ 1992. "Empirical Tests for Allocative Efficiency in the Local Public Sector." Public Finance Quarterly 20 (3): 359-77.

-1994. The Reform of Intergovernmental Fiscal Relations in Developing and Emerging Market Economies. Washington, DC: World Bank. 
2001. "Interregional Competition and Federal Cooperation-To Compete or to Cooperate? That's Not the Question." Paper presented at the International Forum on Federalism in Mexico, Veracruz, Mexico, November 14-17.

.2004. "Fiscal Decentralization in Developing and Transition Economies: Progress, Problems, and the Promise.” Policy Research Working Paper 3282, World Bank, Washington, DC.

2005. "A Framework for Evaluating Alternate Institutional Arrangements for Fiscal Equalization Transfers." Policy Research Working Paper 3785, World Bank, Washington, DC. http://ssrn.com/abstract $=873893$. ed. 2006a. Local Governance in Industrial Countries. Washington, DC: World Bank.

- 2006b. "The Principles and the Practice of Intergovernmental Transfers." In Intergovernmental Fiscal Transfers: Principles and Practice, ed. Robin Boadway and Anwar Shah. Washington, DC: World Bank.

Stigler, George. 1957. “The Tenable Range of Functions of Local Government.” In Federal Expenditure Policy for Economic Growth and Stability, ed. Joint Economic Committee, Subcommittee on Fiscal Policy, U.S. Congress, 213-19. Washington, DC: U.S. Government Printing Office.

Stoker, Gerry, ed. 1999. The New Management of British Local Governance. London: Macmillan.

Tiebout, Charles. 1956. "A Pure Theory of Local Expenditures." Journal of Political Economy 64 (5): 416-24.

Wajidi, Muhammad. 1990. "Origin of Local Government in the Indo-Pakistan Subcontinent.” Journal of Political Science 13 (1-2): 131-39.

Werner, Jan. Forthcoming. Das deutsche Gemeindefinanzsystem: Reformvorschläge im Kontext der unterschiedlichen Einnahmenautonomie der lokalen Gebietskörperschaften in Europa. [The Financing of Local Authorities in Germany: Future Fiscal Reforms and Methods of Resolution in the Neighboring European Countries.] Frankfurt am Main, Germany: Peter Lang.

Werner, Jan, and Anwar Shah. 2005. "Horizontal Fiscal Equalization at the Local Level: The Practice in Denmark, Norway, and Sweden.” Unpublished paper, World Bank, Washington, DC.

Williamson, Oliver. 1985. The Economic Institutions of Capitalism. New York: Free Press. Zheng Yingpin and Fan Wei, eds. 2003. The History and Civilization of China. Beijing: Central Party Literature Publishing House. 


\section{Local Government}

Organization and

Finance: South Africa

C H R I S H E Y M A N S

This chapter provides an overview of local government trends and issues in postapartheid South Africa. The first section outlines briefly the history of local government. It is followed by sections describing several features of the current system. The subsequent sections describe and reflect on issues in local government expenditure revenue and administration, as well as the place of local government in the broader system of intergovernmental relations.

\section{A Brief History}

South Africa's constitutional negotiators agreed in 1993 to include a specific chapter on local government in the constitution of 1994a feature that was enhanced in the 1996 constitution. Local government has also gone through several phases of reform since 1994, initially focusing on undoing the apartheid legacy and deracializing municipalities, and subsequently on stabilization and consolidation of structures and systems and far-reaching redemarcation of jurisdictional boundaries. The history of local government cannot be

This chapter was originally written in 2004 and has subsequently been updated. 
understood outside this context of transformation from apartheid to the new democratic system.

\section{Apartheid Local Government}

The entire system of local government before 1994 was racially defined. In fact, before 1977, local-level structures for black people were merely advisory or administrative. This system was in line with the general denial of permanent residential rights for Africans in urban areas outside the Bantustans, ${ }^{1}$ which in turn was intractably linked to denying them political rights. Persistent political unrest after 1976, the dependence of urban economies on black workers, and the increasing ineffectiveness of laws that attempted to contain the inflow of black people into urban areas led to a growing recognition of the permanence of Africans in urban areas and the need for political structures that included them at that level. However, although a system of elected community councils was introduced in 1977, the councils remained segregated from those for whites and the groups classified as "coloreds" and "Indians," ${ }^{2}$ had merely advisory functions, and were devoid of any significant powers and resources. Administration in their jurisdictions was entirely out of their control and was assigned to separate administration boards, which were dominated by white bureaucrats. These boards were tasked with many unpopular functions, such as housing and land administration, which in apartheid South Africa mostly went hand in hand with forced removals.

The community councils never gained political credibility. In 1982, they were replaced by new black local authorities (BLAs), which had elected councils and some administrative capacity but still worked closely with the administration boards. ${ }^{3}$ Meanwhile, coloreds and Asians were given voting powers for advisory committees in their areas, with even less power than the BLAs and no administrations of their own. White people, meanwhile, could vote for elected municipalities with administrative and fiscal capacities reminiscent—in theory, at least—of those found in many Western countries. As fiscal and political pressure mounted, regional services councils (RSCs) were introduced in the 1980s to develop functional links between the various racial local governments and to address the fiscal shortcomings of smaller white municipalities and BLAs. Levies on the wage bills and turnover of businesses (known generally as RSC levies) financed the RSCs. The levy revenue was intended to finance capital infrastructure in areas where it was lacking. This arrangement facilitated a flow of resources from rich to poor areas, and although RSCs were scrapped in the postapartheid era, the levies remain the second most important local tax after property rates. 
However, continued segregation fundamentally undermined the prospects for these structures outside white communities. When resistance against apartheid intensified in the 1980s, activists specifically targeted local government. This activism created vast pressure on the system, so that some significant negotiations occurred at this level before the constitutional process of 1993, often starting around service issues but inevitably shifting to a political and fiscal agenda amid demands such as "one city, one tax base." The call was for institutional unification of local governments across the racial divide, accompanied by the use of all local revenue to the benefit of all residents. Residents of the black segregated areas pointed out that they mostly worked in white local government jurisdictions and, by inference, contributed to the revenue of those areas - yet they received no benefits, because the funds were not spent where they lived. By the late 1980s, BLAs had all but collapsed, and despite the government's attempt to restore them through a mixture of repression and negotiations, the system remained effectively ungovernable until the negotiations to end institutionalized apartheid in 1994 (Swilling 1988).

\section{The Postapartheid Era}

The inclusion in the 1994 constitution of a chapter on local government paved the way for far-reaching reforms in three major phases.

The preinterim phase, which started with the 1993 negotiations, continued until 1995. It entailed the establishment of local government negotiating forums. Under the 1993 Local Government Transition Act (LGTA), new interim municipal structures combined predemocracy local governments with community structures. The new structures provided for the sharing of resources across racial boundaries but did not undo the racial bases entirely. They were mainly tasked with managing core services, preparing for the first postapartheid municipal elections, and negotiating transitional arrangements until local elections could be held. These elections eventually took place in 1995 (1996 in the provinces of KwaZulu Natal and Western Cape).

The elections marked the beginning of the interim phase, which until 1998 focused on deracializing municipalities. This second phase was referred to as interim pending a fuller investigation into future options for local government that would be properly aligned with the national constitutional process. The newly elected national assembly was tasked to draw up a final constitution (adopted in 1996, with a detailed local government chapter). The 1995/96 municipal elections gave rise to the creation of 843 
transitional municipalities, combining adjoining white and black areas that had been separated spatially, institutionally, and fiscally. Over the next three years, these structures began the arduous task of integrating systems and shaping a new institutional culture at the local level. The LGTA provided for a two-tier framework. In metropolitan areas, the two tiers were primary local governments (substructures) and overarching metropolitan councils. Elsewhere either transitional rural councils or transitional representative councils were the primary local governments, with district councils replacing the former RSCs as the coordinating tier. The LGTA was amended on a number of occasions to clarify the relationships between the different types of local government, their powers and functions, their financial accountability rules, and their codes of conduct for councils and employees. Its implementation was also affected by the fiscal and institutional weaknesses of many of the new local governments, especially-although not exclusivelyin smaller towns and rural areas. The consensus was that some form of consolidation would become necessary, either to reduce the number of local governments or to develop the capacity and management systems of existing ones.

The interim phase moved forward with a local government White Paper (Department of Constitutional Development 1998) that spelled out a comprehensive new vision for "developmental local government," with fresh ideas about the constitutional and functional roles of local government. Like the process of constitutional design, compiling the White Paper was a highly consultative process. It involved many discussions and debates, considerable research, a preliminary discussion document to help set the agenda, a Green Paper (Department of Constitutional Development 1997) that identified options, and finally the publication of the White Paper. Subsequently, though deracialization remained an important objective, the emphasis shifted to democratizing local government, bolstering its service delivery capacity, enhancing integrated development planning and management, structuring local government organizationally toward these ends, and achieving fiscal sustainability. Subsequent legislation such as the Municipal Structures Act of 1998 (amended in 2000), the Municipal Systems Act of 2000, the Intergovernmental Fiscal Relations Act, the 2004 Municipal Finance Management Act and related budget reforms, and the 2004 Property Rates Act provided the legal framework for the implementation of these policies. The Department of Provincial and Local Government (DPLG), National Treasury, and other departments also manage various transfers targeted at municipal infrastructure programs and capacity building. Cooperation with provinces is being extended to ensure more effective and 
coherent support to local government, especially since 2005 through Project Consolidate.

The third phase of reform started in 2000. The platform for this phase was a comprehensive process of demarcating municipal boundaries. The Demarcation Board was busy for more than two years, weighing economic, fiscal, and political considerations and evidence and consulting widely. Finally, it established six metropolitan councils, incorporated urban and rural areas in the same primary and district structures outside the six councils, and reduced the overall number of municipalities from 843 to 283 (284 until February 28, 2006). Demarcation was the starting point for another set of reforms, including an elaborate process to define the powers and functions of the different categories of municipalities and further evolution of the fiscal framework, as well as initiatives to deal with issues in sectors within the traditional domain of local government powers, such as electricity and water provision (Atkinson 2002; National Treasury 2003b). ${ }^{4}$

The new local governments are organized into three categories. Category A municipalities, of which there are six, are single-tier metropolitan governments (metros) located in the largest cities. Outside those areas is a two-tier system. In the first tier are 232 category B primary municipalities, with elected councils and certain administrative, regulatory, and service delivery functions. The second interim tier of 46 district municipalities or category $\mathrm{C}$ municipalities cuts across primary municipal boundaries. These municipalities are governed by district councils that are indirectly elected from the primary local governments. Their roles are mainly coordinating and facilitative; however, some have executing roles where primary local governments lack the required capacity.

The average population within a South African municipality is 149,654 - significantly smaller than Indonesia's average $(617,070)$ but much larger than India's $(2,892)$ (Rural Development Unit 2004). There is, however, a wide spectrum. Metropolitan governments cover jurisdictions ranging from Johannesburg, with more than 2.75 million people, to smaller metros, such as Port Elizabeth, with about 1 million people. Populations under district councils vary from just under 60,000 to well in excess of 1.6 million, whereas local councils could have populations ranging from more than 680,000 to fewer than 6,000 (http://www.demarcation.org.za).

\section{The Legal Status and Autonomy of Local Government}

This section discusses the current legal status of local government in South Africa. 


\section{Chris Heymans}

\section{The Broad Constitutional Framework}

Most constitutions make only passing reference to local government. South Africa is one of the exceptions, and both postapartheid constitutions have dedicated considerable attention to local government (see figure 2.1 for a schematic outline of intergovernmental relations). This interesting decentralist trait in the unitary system was chosen very consciously during the 1993 constitutional negotiations as an alternative to the federal system proposed by several negotiating parties.

The 1997 constitution extends the 1993 decentralist stance further, both in its general intergovernmental principles and through an extended section on local government. In principle, the constitution requires that municipalities be established for the "whole territory of the Republic," sometimes referred to as a wall-to-wall system of municipalities.

Three concepts in the 1997 constitution are particularly significant to the nature of intergovernmental relations. The first is the notion of three

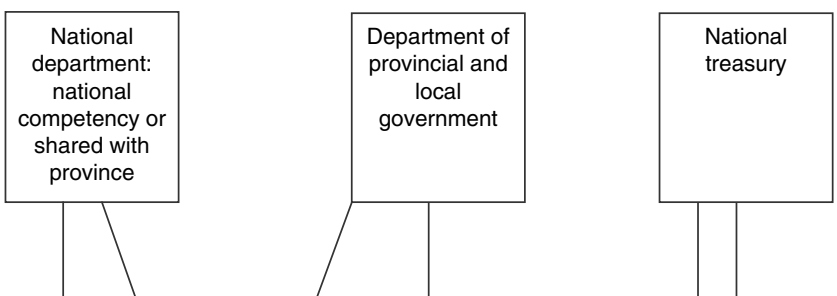

Intergovernmental forum, president's coordinating council on local government, committees for ministers and members of executive councils, budget forum, budget council, and technical committees

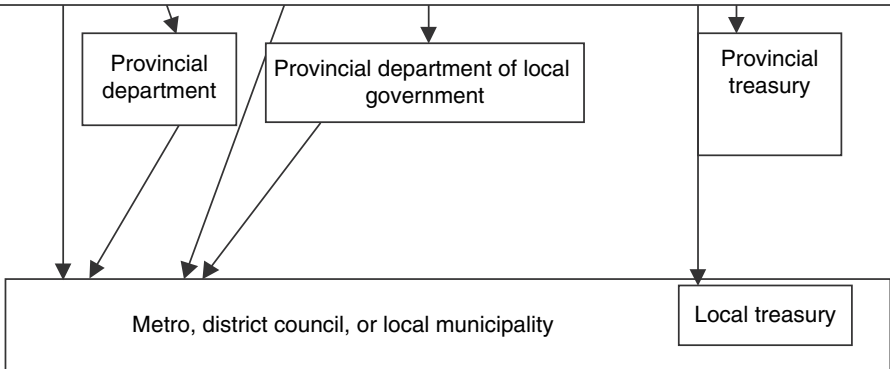

Source: Author's illustration based on the constitutions and local government legislation.

F I G U R E 2 . 1 Schematic Portrayal of Intergovernmental Relations in South Africa 
"spheres" rather than tiers of government outlined in section 40(1). The intent of this semantic nuance is to reflect that the national, provincial, and local governments are equal, separate, and autonomous. Second, the constitution stresses that the relationship between the spheres should be cooperative rather than hierarchical. The principle of cooperative governance obliges the three spheres of government to cooperate and negotiate political and budgeting issues between them. Third, section 156(4) entrenches the principle of subsidiarity, which implies that a function should ideally be performed by the lowest possible sphere of government.

The constitution assigns broad functions to the three spheres of government. ${ }^{5}$ National and provincial governments are concurrently responsible for such functions as school education, health, welfare, and housing, with the national government determining policy and the provincial governments responsible for implementing a few exclusive functions. Most local government functions involve such user fee services as electricity, water, and sanitation; the remaining involve the provision of public goods such as municipal and household infrastructure, streets, streetlights, and refuse collection.

But the constitution also mandates that national or provincial legislatures and executives transfer policy and implementation powers to municipalities. Sections 9 and 10 of the Municipal Systems Act, respectively, provide for general and specific assignments:

General assignments of functions require the passage of legislation, apply throughout South Africa (if made by the national parliament or a national minister) or in a whole province (if made by a provincial legislature or a member of a provincial executive), and are more permanent.

- Specific assignments (delegations) require agreement between the bodies concerned, focus on a specific municipality, and could be formalized by a provincial proclamation. Because they exist by agreement, ordinary contract law applies.

There have been debates about the extent to which transfers of functions have been accompanied by concomitant transfers of the resources required. Local governments complain that municipalities are often expected to take full responsibility for a delegated function (including the financing of it), but that they have not actually been assigned the powers to finance those 
functions. Currently, delegations are not controlled by any legislation, which opens the door for transfer of functions by stealth.

\section{National and Provincial Regulation of Local Government}

Policy makers and law makers continue to grapple with the appropriate balance between the legislative powers of municipal government in this cooperative intergovernmental framework, on the one hand, and the policy and support roles that national and provincial governments are supposed to play toward local government, on the other hand. The system hinges as much on distinctiveness between these spheres as it does on interdependence and interrelatedness.

Enabled by the constitution, national and provincial regulation of local government is governed mainly through the Municipal Systems Act and the Municipal Finance Management Act (MFMA). A new Intergovernmental Fiscal Relations Act is to be implemented in 2006. The Municipal Systems Act empowers the responsible national minister to establish essential national standards and minimum standards for any matter assigned to municipalities, whereas provinces have primary responsibility to monitor municipal performance. National or provincial governments remain the regulators of a function that was previously theirs and that they have assigned to municipalities. The MFMA, in turn, provides for national and provincial treasury oversight of local government financial management. National departments have executed their regulatory powers differently, ranging from having an independent regulator (for electricity) to keeping the regulatory role inside the department (for water). Many have expressed concern that provinces have not been able to monitor local government performance effectively because of capacity constraints in provincial departments.

The Municipal Systems Act, the MFMA, and the constitution enable national and provincial government to intervene when municipalities fail to perform "an executive obligation in terms of legislation" (section 139 of the constitution). Section 139 was amended amid some controversy in 2004 with the adoption of the MFMA. The amendments broadened the scope for national and provincial intervention in the affairs of municipalities that fail to meet objectives or fiscal mandates. The MFMA's passage provoked heated debate about the constitutional implications of these powers of intervention. Ultimately, the provincial executive has that responsibility first, and only if the provincial executive does not intervene effectively, is national intervention possible. In terms of the MFMA, the government is in the process of establishing a specialized agency to deal with financial emergencies in municipalities. 


\section{Arrangements to Facilitate Cooperative Intergovernmental Governance}

The constitution assumes, implies, and requires generally a cooperative relationship between the spheres, and the practice of government since 1994 has seen a number of measures to give effect to this principle. First, intergovernmental fiscal flows do not flow through the provinces, except where a municipality carries out a provincial function on behalf of the province.

Second, the constitution institutionalizes the role of organized local government. The Organized Local Government Act of 1998 recognizes the South African Local Government Association (SALGA) and the nine provincial local government associations as representatives of local government. SALGA can designate up to 10 part-time representatives to the National Council of the Provinces in the national parliament, and it can nominate two members of the Financial and Fiscal Commission, which advises the Finance Ministry on budget issues. These individuals participate in intergovernmental structures and are therefore able to influence national and provincial legislation relevant to local government.

Third, a number of intergovernmental forums facilitate exchange on general and sector issues. The Intergovernmental Forum, under the leadership of the President's Office, facilitates the general relationship between the national and provincial government. The President's Coordinating Council on Local Government includes all three spheres in discussions about policy and functional issues. Continuous exchange between the national and provincial spheres is also made possible through a series of sector-based committees for ministers and members of (provincial) executive councils (MinMECs) and parallel bodies for the officials who work under these ministers. One of these MinMECs is tasked with local government matters, is chaired by the minister of provincial and local government, and includes the participation of organized local government through SALGA. Under the minister of finance, the Budget Council and Budget Forum facilitate consultation on the budget process and on fiscal matters. The Budget Council comprises the national and provincial ministers of finance, and the Budget Forum consists of the members of the Budget Council and the national and provincial chairs of local government associations in each province.

\section{Composition of Revenues and Expenditures: General Patterns}

The first budgets developed fully under the new jurisdictions after the demarcations were completed were those of 2002/03. The National Treasury has 
been working with municipalities to achieve fully integrated budgets, rather than merely aggregating the different budgets from the previous municipalities that were amalgamated. There has been considerable progress toward such integration, although the institutional legacy and capacity shortcomings have made it a complex task. The outstanding demarcation issues-especially the undoing of cross-border municipalities-have also had to be dealt with. Table 2.1 provides a brief overview of main local government budget trends.

Municipal expenditure budgets have grown from R 54.9 billion in $1999 / 2000$ to R 101.2 billion in 2004/05, and they are estimated to touch on R 120 billion in 2005/06. ${ }^{6}$ Notable annual increases in budgeted income have occurred in several years, and budgeted figures for the increase from 2003/04 to $2004 / 05$ were as high as 36.8 percent. There have been some encouraging trends on the local revenue side: budgeted income from property rates has consistently grown at over 8 percent since 2001/02. Although observers have expressed caution about the potentially dampening effects of such increases on local economic growth, the increases do indicate a positive trend in local revenue

TA B LE 2 . 1 Municipal Budget Trends, FY 2002/03-FY 2005/06 (R billion)

\begin{tabular}{lrrrr}
\hline Budgeted expenditure & $2002 / 03$ & $2003 / 04$ & $2004 / 05$ & $2005 / 06$ \\
\hline Operating budget & 52.7 & 72.6 & 84.1 & 93.3 \\
Salaries & 22.9 & 25.5 & 17.9 & 27.6 \\
Bulk services (water and electricity) & 17.1 & 19.1 & 13.7 & 20.5 \\
Other (repairs, maintenance, provision & & & & \\
for uncollected revenue, loans) & 29.8 & 36.1 & 21.1 & 38.9 \\
Capital budget & 11.7 & 16.7 & 17.1 & 25.9 \\
$\quad$ Total budgeted expenditure & 64.4 & 89.3 & 101.2 & 119.9 \\
Budgeted operating income & 54.3 & 61.6 & 84.3 & 92.0 \\
Property rates & 11.5 & 12.5 & 15.7 & 17.0 \\
Service charges (mainly water and & & & & \\
electricity) & 25.0 & 28.0 & 38.9 & 41.5 \\
RSC levies & 3.9 & 4.4 & 5.7 & 6.5 \\
Intergovernmental grants & 3.6 & 6.7 & 12.1 & 13.2 \\
Others & 10.3 & 10.0 & 11.9 & 13.7 \\
$\quad$ Total operating income & 54.3 & 61.6 & 84.3 & 92.0 \\
\hline
\end{tabular}

Source: National Treasury 2003b, 2004b; National Treasury database.

Note: Totals may not add to 100 because of rounding, and the figures are based on estimates. The unusual increase in the revenue figures is yet to be revised, and it was not possible to ascertain at the time of writing what this increase could be attributed to. 
patterns. The National Treasury estimates that metropolitan governments now fund well over 70 percent of their budgets from property rates, and it also notes a marked upturn in collection of user charges in some areas.

\section{Expenditure Budgets}

More than 80 percent of total municipal expenditure occurs in South Africa's 23 largest urban municipalities, although basic service backlogs are more prominent in rural areas, where revenue potential is weaker and budget deficits occur frequently. The distribution of national transfers has attempted to account for this difference, with the bulk of allocations going to more rural municipalities and cities experiencing significant declines in the level of transfers. Metropolitan municipalities have been receiving less than 20 percent of all transfers in the past few years, and this figure is projected to decline further over the medium term.

Estimated total operating budgets amount to R 52.7 billion for the 2002/03 municipal year and R 72.6 billion in 2003/04, with estimates for 2005/06 at R 93.3 billion. Table 2.1 shows that salaries take up the largest share of municipal budgets, totaling R 25.5 billion in 2003/04, and they have been around 30 percent of operating budgets for a number of years. There have been some expectations that the amalgamation of local governments as an outcome of the demarcation process would bring down the salary component. However, transitional costs and the approach of several amalgamating municipalities to synchronizing salary packages upward—in line with higher-grade municipal posts rather than average or lower post levels- have thus far limited this potential effect. The National Treasury and DPLG are both attending to the issues and hope to redress it in the coming years. Table 2.1 also shows that R 17.1 billion was budgeted for expenditure for bulk purchases of water and electricity in 2002/03. Moreover, R 29.8 billion was budgeted for other expenditures in the same year (repairs and maintenance, general expenditure, and interest and redemption of loans and provisions for undercollection of revenue of the municipal operating budget).

The extent of capital expenditure remains a source of concern. Although budgeted allocations for capital for have grown from R 11.7 billion in $2002 / 03$ to more than R 25 billion in 2005/06, this growth may not represent an accurate picture of the actual levels of local development spending. First, some double counting occurs in capital budgets because of intramunicipal transfers from districts to local municipalities. Second, past performance indicates that actual capital expenditure is less than budgeted, mainly because multiyear budgeting is not yet adequately practiced at the local level, 
so many municipalities prepare one-year capital budgets, have poor cashflow and implementation plans, and secure funding sources only after the tabling of the budget. This situation causes underspending and delays. Nonetheless, National Treasury (2003b) analyses showed that more than 80 percent of the amounts budgeted for capital budgets were targeted at general infrastructure, especially housing, water reservoirs, and reticulation; roads, bridges, and pavements; and electricity distribution. Some 11 percent was earmarked for other assets, 6 percent for community infrastructure, and 1 percent for specialized vehicles.

\section{Revenue}

The national government's determination to use local government as the agent of service delivery is evident from substantial increases in funds for capital expenditure. In the 2004 national budget, the provision for the MediumTerm Expenditure Framework until 2006/07 shows real growth in resources allocated to the local government equitable share and infrastructure grants, above the average growth in national resources going to all spheres of government. The equitable share is projected to grow by more than 8 percent over this period, and infrastructure grants are to grow by more than 7 percent, against a national average of about 4 percent for all resources.

Revenue budgets have also shown marked improvement in recent years, with the revenue from property rates increasing from $\mathrm{R} 12.6$ billion in 2002/03 to R 15.7 billion in 2004/05, and income from RSC levies on business turnover and wages increased from R 4.4 billion to R 5.7 billion in the same period. The bulk of this income was generated in the six metropolitan areas, which accounted for about 70 percent of all RSC levies and property rates. Local or category $\mathrm{B}$ municipalities raised the remainder of income from property taxes, but District (category $\mathrm{C}$ ) municipalities do not have the power to impose property rates. They have been able to raise levies to which local municipalities have not had access. ${ }^{7}$ Table 2.2 gives some perspective on these revenues in local budgets over three fiscal years.

Certain qualifications need to be made about these revenue figures. First, property valuations are out of date in many municipalities, and a major priority related to reforming the relevant legislation has been to update these data and broaden the base of the property rates to also include development, not only land. Second, the substantial electricity and water components of the figures in table 2.1 for services income do not take account of overhead costs, such as salaries and administration, repairs and maintenance, capital 
TA B L E 2 . 2 Revenue from Property Rates and RSC Levies in Different Municipalities, FY 2002/03-FY 2005/06 ( $R$ billion)

\begin{tabular}{lcccc}
\hline & \multicolumn{4}{c}{ Fiscal year } \\
\cline { 2 - 5 } Revenue source / category & $2002 / 03$ & $2003 / 04$ & $2004 / 05$ & $2005 / 06$ \\
\hline Property rates & & & 11.0 & 11.8 \\
A (metro) & 8.9 & 10.1 & 4.7 & 5.3 \\
B (local) & 3.7 & 4.3 & n.a. & n.a. \\
C (district) & n.a. & n.a. & 15.7 & 17.1 \\
$\quad$ Total & 12.6 & 14.4 & & \\
Regional levies & & & 3.8 & 4.4 \\
A (metro) & 3.0 & 3.5 & n.a. & n.a. \\
B (local) & n.a. & n.a. & 1.9 & - \\
C (district) $\quad 1.7$ & 5.7 & - \\
$\quad$ Total & 1.4 & 5.2 & 5.7 & - \\
\hline
\end{tabular}

Source: National Treasury 2003a, 2003b, 2004a, 2004b.

Note: n.a. $=$ not applicable $;-=$ not available.

charges on interest, and redemption of loans. Thus, though these functions generated income of $\mathrm{R} 28$ billion in 2003/04, for example, they also incurred bulk costs of about R 15.4 billion. Under the leadership of the National Treasury, and guided by the MFMA, municipal accounting systems are being reformed to help address these information shortcomings. The national government has also been working with the local sphere to address the high level of water and electricity losses in many local areas.

\section{The Structure and Administration of Local Government}

This section discusses the categories and tiers of local government and the political and administrative structures.

\section{Categories and Tiers}

South Africa's 283 municipalities (284 until February 28, 2006) were created through the comprehensive two-year process of demarcation mentioned earlier. The Municipal Structures Act contains criteria for the categorization of municipalities: 
- Category A municipalities can be established only in metropolitan areas and are single-tier autonomous local authorities. The Municipal Demarcation Board determined that the local governments of Johannesburg (Igoli), Durban (Ethekwini), Cape Town, Pretoria (Tswane), East Rand (Ekurhuleni), and Port Elizabeth (Nelson Mandela) should be given metropolitan status. Until recently, other large urban centers such as Buffalo City (East London) and Pietermaritzburg also had incentive to aspire to metropolitan status, because such status would have given them control over RSC levies raised in their jurisdictions. However, since the government announced the scrapping of RSC levies, the incentive to acquire metro status may have weakened and will likely depend on whatever new funding and taxation arrangements replace it. Nevertheless, these cities that have aspired to be classified as metros have maintained that their urban environments pose service delivery challenges often different from those in smaller urban centers and rural areas and that institutional arrangements ought to give them greater powers to deal with those challenges.

- Category B municipalities function at the primary local level. They share many responsibilities with category $\mathrm{C}$ municipalities. There is considerable variation among the 232 category B municipalities. Many are weak in administrative and fiscal capacity, especially in rural areas, but some (such as Buffalo City) are much better positioned in terms of staff and other resources and seem to have missed out only narrowly on being classified as category A municipalities.

- Category C municipalities operate at district level, and each category B structure also falls within the boundaries of one of these district municipalities. There are 46 such structures, sharing several responsibilities with several local municipalities within their jurisdiction. District municipalities do not have authority over local municipalities but were created on the basis of three logical points: First, certain services are presumably better provided at larger scale because of scale economies. Second, there is a need for coordination of planning at a district scale. And third, such structures were believed to provide opportunities for redistribution on the district scale (Department of Constitutional Development 1998). All local councils fall within the boundaries of district municipalities, but 25 less populated portions of district municipalities' jurisdictions do not fall within local municipalities; these are called district management areas, and they include areas such as game parks.

The demarcation of the new boundaries was followed by elaborate processes of assigning and delegating powers. The minister of provincial and 
local government has had to assign the respective powers and functions of category B and C municipalities in nationally assigned functions-water supply, sanitation, electricity, and municipal health-whereas provincial members of the executive council of local government have had to do so for the remaining functions. Considerable controversy has surrounded issues such as the potential disruption of service delivery and the fiscal costs if functions were moved to new institutional homes. The Municipal Demarcation Board in particular generally favored shifting most shared functions to the district level. In the end, the Ministry of Provincial and Local Government adopted an asymmetrical approach that allocated functions to the level where a technical assessment suggested the appropriate capacity existed. The effect has been that a large number of category B municipalities have retained their powers over services, which they provide in some cases on an agency basis to districts. The general pattern is that districts have the municipal health function (now restricted to environmental health) as well as the water supply and sanitation function for areas where the capacity of local government is relatively low. The electricity function remains as it was before 2000, which implies that in the formally defined transitional local council areas (mainly urban areas) the function is assigned to local municipalities. Therefore, districts have little to do with electricity at present, contrary to the provisions of the Municipal Structures Act. Districts have certain responsibilities for municipal roads (district roads), although there is considerable uncertainty regarding roads functions (Palmer Development Group 2004).

The two-tier system is still taking root, and a number of difficulties confront both local and district municipalities within this system. Municipalities now include towns, farmland, and traditional villages, creating much more complex spatial dynamics with new administrative challenges. In many cases, local governments were split when they were included in the new demarcations-particularly in the case of rural councils. Rural areas that previously fell directly under regional services councils now constitute local municipalities in their own right but have virtually no institutional capacity for acting as such. Areas that include traditional authorities ${ }^{8}$ experience complex political dynamics, because land tenure in those areas has not been resolved and customary rules do not always fit with the formal public system. In many cases, the capacity of the district councils is also in question, and their ability to respond effectively to the challenges of the rural and many small town authorities is also negatively affected by the vast areas of jurisdiction.

The Palmer Development Group (2004) points out that political differences have in some cases affected the functioning of the two-tier system. In such cases, different parties control the local and district municipalities 
within a particular jurisdiction. There have also been uncertainties regarding the sharing of responsibilities, particularly because the definition of functions, including planning responsibilities, is often unclear. The risk of duplication exists where a district has been allocated the function for some local municipalities in its jurisdiction and not for others. And there has been friction relating to the allocation of financial resources by district municipalities to different local areas. Districts that include secondary cities also face uncertainties, given that some such cities may become metros, thereby substantially reducing the income to the district municipality.

\section{Political and Administrative Structures}

All metro, district, and local municipalities fall under the political control of an elected council. Council members are elected by a combination of electoral systems. Sixty percent of councilors on a local council are elected by means of "first past the post" ward-based elections, and the remaining 40 percent are elected by municipalitywide proportional representation (PR), which is based on support for political parties. Every council thus includes two types of local councilors: ward councilors and PR councilors.

The council approves policies and bylaws, passes a budget for its municipality each year, and sets the framework for development plans and service delivery for the municipal area. As single-tier governments, metropolitan councils cannot devolve their original municipal, legislative, and executive political responsibilities, but they may decentralize execution of functions to spatially dispersed administrative offices.

The work of the council is coordinated by a mayor, who is elected by the council. An executive or mayoral committee, made up of councilors, assists the mayor in overseeing the work of the municipal manager and department heads. In metropolitan areas, there are two types of executive systems: the mayoral executive system, in which legislative and executive authority is vested in the office of the mayor, and the collective executive committee, in which these powers are vested in the executive committee.

In all municipalities, ward councilors are expected to work with ward committees that give citizens a more direct say in local decisions. Ward committees provide scope for participation in integrated development planning, budgeting, and general monitoring of local government. The experiences have varied: some committees have become active parts of local consultation, and some remain vague concepts with little direct effect. The quality of municipal information remains weak, because it undermines the scope for informed and rational debate. For example, there have been concerns that 
the integrated development plans — which promised to be powerful instruments for participatory and accountable planning and resource allocationhave been open-ended exercises remote from real resource issues, where priorities are carefully measured and tested against resource constraints (DBSA 1998, 2000; Gildenhuys 2002; Pycroft 1998).

Municipal administrations execute local government functions. Each is headed by a municipal manager and staffed with relevant officials. According to the Municipal Systems Act, a municipality must "establish and organize its administration in a manner that would enable the municipality to ... be performance oriented and focused on ... its developmental duties as required by section 153 of the Constitution." This provision has opened the door for developing additional or alternative service mechanisms, such as public entities at the local level and public-private partnerships. Both have required considerable attention to governance arrangements, and especially to carefully defining issues of ownership, regulation, and execution. But in principle both public entities and publicprivate partnerships offer innovative instruments for service delivery and financing that provide operational focus, room for added investment, and dedicated skills.

Neither replaces the core municipal administration altogether, however. The scope of municipal administrations varies according to the size and location of the local government. For example, in larger centers, one could expect an administration with specialized posts from municipal manager through to several others: city secretary, city treasurer, and city engineer, as well as staff responsible for health, information technology and geographic information systems, security, fire, transport, parks and recreation, traffic and licensing, marketing, tourism, credit, building inspection, and purchasing. In smaller centers, the structure might contain merely the municipal manager, the town secretary, the chief of technical services and protection, and the chief of community services. In rural areas, provision is often made for subregional offices to ensure links between the core structure and specific localities.

Municipal managers are able to employ staff and are tasked with coordinating staff members to implement all programs approved by the council. Currently, local government staff members do not form part of the same civil service as national and provincial governments; hence, there is full local autonomy in hiring and retrenching. Although national benchmarks exist, the local level is in principle able to set its own standards. Lately, SALGA has played an active role in setting these benchmarks. There has, however, been pressure from parts of national government to integrate local government 
officials into the civil service, on the grounds that doing so would limit extraordinary remuneration packages and also allow deployment of staff members across the country where and when needed. This matter has been controversial, however, and many view it as a potential infringement of the autonomy of the local sphere. Moreover, concerns have been expressed that the full fiscal implications of such a shift have not yet been fully assessed.

\section{Local Government Expenditure Responsibilities}

\section{Formal Assignments}

In aggregate, local government expenditure accounts for almost one-fifth of government expenditure. The basis for local expenditure assignments is the constitution, which assigns functions to the three spheres of government. Schedules $4 \mathrm{~B}$ and $5 \mathrm{~B}$ set out a wide range of functions to be shared between spheres. Functions not listed in these schedules are referred to as plenary functions and are the sole responsibility of the national government.

Local government has no exclusive functions, but municipalities are the executing agencies for a range of public goods such as parks, sport and recreation, cemeteries, municipal roads, street lighting, traffic control, and bylaw monitoring and enforcement. Local government also provides several user-charged services, including water and sanitation, electricity and gas reticulation, refuse removal, municipal health services, and municipal transport and roads. Table 2.3 shows the allocation of functions in these schedules of the constitution.

For schedule $4 \mathrm{~B}$ and $5 \mathrm{~B}$ functions, the national government's role is primarily one of policy making, whereas provinces take on a mix of regulatory and implementation roles. As mentioned earlier, the joint national and provincial influence is to set norms and standards, monitor performance in relation to such norms and standards, and intervene when the standards are not being achieved. It is also possible for responsibilities at the higher levels to be shifted to local government through assignments and delegations, but in such cases, national and provincial governments retain their regulatory responsibilities and their roles in policy, legislation, and allocating financial resources.

Municipalities share their schedule 4 functions with the national and provincial governments; their schedule 5 functions fall under provincial governments' supervision. Section 156(1)(a) of the constitution provides that a municipality has executive authority and the right to administer the local government matters listed in these schedules. This provision is the primary 
TA B LE 2.3 Local Government Functions

\begin{tabular}{ll}
$\begin{array}{l}\text { Schedule 4B functions (national and } \\
\text { provincial oversight) }\end{array}$ & Schedule 5B functions (provincial oversight) \\
\hline Air pollution & Beaches and amusement facilities \\
Building regulations & Billboards and public advertisements \\
Child care facilities & Cemeteries \\
Electricity and gas reticulation & Cleansing \\
Firefighting services & Control of public nuisances \\
Local tourism & Control of liquor undertakings \\
Municipal airports & Facilities for the accommodation, care, \\
Municipal health services & and burial of animals \\
Municipal planning & Fencing and fences \\
Municipal public transport & Licensing of dogs \\
Municipal public works & Licensing and control of undertakings that \\
Pontoons, ferries, jetties, piers, and & sell food to the public \\
harbors & Local amenities \\
Stormwater systems & Local sport facilities \\
Trading regulations & Markets \\
Water and sanitation services & Municipal abattoirs \\
& Municipal parks and recreation \\
& Municipal roads \\
& Noise pollution \\
& Pounds \\
& Public places \\
& Refuse removal, refuse dumps, and solid \\
waste
\end{tabular}

Source: Constitution of the Republic of South Africa, 1996.

source of power for local government and, significantly, cannot be removed or amended by ordinary statutes or provincial acts, only by constitutional amendment. Section 156(1)(b) provides that a municipality has executive authority and the right to administer any other matter assigned to it by national or provincial legislation, either through general assignments or to individual municipalities.

\section{Expenditure Assignment Issues}

The current policy reform agenda in South Africa acknowledges a number of challenges in expenditure assignments. First, the open-ended and 
inconsistent constitutional definitions cause uncertainty, especially when services are shared with other spheres of government. For this reason DPLG has recently undertaken further analysis of the schedule 4 and 5 functions in the constitution, and the National Treasury is developing a matrix of expenditure and revenue responsibilities. These policy initiatives all reflect a need to redress any misalignment between expenditure requirements and revenue-raising capacity.

Second, sector legislation does not deal with assignments and delegations - and the assessment of their financial implications-consistently. The Palmer Development Group (2004) points out, for example, that although housing is a provincial function, the Housing Act allows its assignment to local government. In practice, several municipalities have already taken on more housing delivery activities, but the formal assignment and concomitant grant financing arrangements have not yet been made. Another example is evident from the National Health Act, which attempts to focus the role of local government on environmental health but simultaneously promotes the integration of environmental health and provincially controlled primary health care services within health districts aligned with municipal boundaries. Some of the most evident examples of the complexities that face sectors and local governments are in the water sector. Despite water functions at local or district municipality levels having largely been finalized at a legal level, many practicalities still need to be resolved. Giving practical effect to the distinction drawn in the Water Services Act between a water services authority and a water services provider was complicated when the Municipal Structures Act subsequently implied that district municipalities should be the water authorities, yet capacity realities have since required assigning this function in most cases to local municipalities.

Third, capacity varies considerably between municipalities, and the sensitivity of sectors to capacity limitations may need to be improved. For example, although environmental regulation is not formally a municipal function, an increasing range of environmental roles is being shifted to the local level, roles for which many are not equipped. The assignment of local economic development also remains a taxing challenge, because many local governments are uncertain about how to balance an interventionist role and an enabling one. And whereas the local roles in business regulation, land administration, and planning are quite clear, most municipalities lack capacity to manage these functions effectively.

The Municipal Systems Act has attempted to establish certain conditions to ensure that assignments to local governments are viable and do not constitute unfunded mandates. It requires sector ministries to consult with 
their local government and finance counterparts, as well as organized local government, and obtain an assessment of the financial implications from the Financial and Fiscal Commission. However, there are no firm rules to ensure the quality of consultations and assessments, to ensure the quality of the information to support them, or to guarantee the ability and willingness of sector agencies and organized local government to engage in these consultations effectively. There is perhaps a need, therefore, for a more detailed appreciation of this diversity and its relevance to specific expenditure assignments.

Fourth, the government's policy of free basic services demands a fine balance between expenditure assignment and fiscal capacity. National departments (notably the Department of Water Affairs and Forestry) have been developing policy and strategy on free services, with the provision of the services ultimately being the responsibility of local government. However, most municipalities - especially in rural areas-would need substantial fiscal assistance from the national government and adequate operational support from service providers with the required capacity (Palmer Development Group 2004).

Finally, the persistent growth in personnel expenditure has been notably high, generally outstripping other expenditure items. Over the past few years, the amalgamation process intensified this growth. The trend has been to aggregate salaries toward the highest common denominator when merging jurisdictions that were previously of different grades. There have also been significant increases in management remuneration, and national regulation of municipal personnel spending has been erratic. It is a difficult challenge; municipalities employ more than 200,000 people (National Treasury 2001).

\section{Local Governments' Own Taxes and Charges}

The constitution sets the broad framework for locally raised revenues. Provided that they do not prejudice the national economic interest (section $229(2)(a))$ and adhere to regulation by national legislation, local governments are exclusively empowered to impose property rates and surcharges on fees for services provided by or on behalf of the municipality (section 229(2)(b)). They are, however, prohibited from imposing income, value added, or general sales tax or customs duties. In addition, national legislation could enable specific categories of local government to impose other taxes, levies, and duties.

Aggregate figures would suggest that local government is largely selffinancing, raising between 80 and 90 percent of its own revenue (Momoniat 
2001; National Treasury 2001, 2003b). However, the aggregate figures mask the high variation among municipalities. In particular-albeit not exclusively—smaller and rural municipalities are significantly more dependent than this statistic would suggest. Nonetheless, local governments have, in principle, powers to raise several revenues locally, and several have attained a high degree of fiscal independence. In the 2006 national budget, the government formally abolished RSC levies (composed of a services levy and an establishment levy on local businesses), but until then these levies formed one stream of primary local revenue sources, together with property rates and charges for services such as water, sanitation, electricity, and refuse removal. A few observations can be made about each of these sources (see table 2.4).

\section{Property Rates}

Property rates are the prerogative of category A and category B municipalities. They have accounted for about one-fifth of local revenue in recent years, and well over 30 percent in some of the big urban centers (National Treasury 2001, 2003b, 2004b; Whelan 2002, 2004). However, since the 1998 White Paper on local government came out (Department of Constitutional Development 1998), the national government has attempted to enhance the reach of this tax, improve its administration, introduce a more consistent approach, and encourage more regular updating of valuation roles across local jurisdictions. After four years of considerable debate, a new Property Rates Act was passed in 2004.

Property rates were regulated by provincial ordinances in the era before 1994, resulting in much inconsistency. The ordinances allowed for further variation within their jurisdictions, with some municipalities taxing only site values, others taxing land and improvements at different rates, and others taxing the total improved value at a single rate. Flat rate systems have also been applied in some places. The 2004 Property Rates Act requires more consistency, but the bases defined in the ordinances can be retained for four years after the date on which the new legislation came into effect (mid-2004). Nonetheless, although the act leaves decisions about differential rating of different categories of property, as well as decisions about exemptions and rebates, to municipal councils, it sets out a common approach. It also attempts to systematize the process of setting property rates by requiring each council to adopt a policy that would set the framework for its decisions, rebates, and processes.

The legislation formally broadens the base of the tax beyond land value, to include the total improved value of property (the combined land and improvement value) as the tax base. The contention is that a land-only tax 
TA B LE 2 . 4 Elements of Local Revenue

\begin{tabular}{|c|c|c|c|c|}
\hline Revenue & Base & Rate & $\begin{array}{l}\text { Contribution to local } \\
\text { revenue, 2002/03 }\end{array}$ & $\begin{array}{l}\text { Intergovernmental } \\
\text { revenue sharing? }\end{array}$ \\
\hline Property rates & $\begin{array}{l}\text { Has varied in different } \\
\text { parts of the country, but } \\
\text { a new act will more } \\
\text { consistently use market } \\
\text { value of land and } \\
\text { buildings as the base. } \\
\text { Exclusions include } \\
\text { public infrastructure, } \\
\text { crops, equipment, } \\
\text { mining, beneficiaries } \\
\text { from land reform, and } \\
\text { tribal land. }\end{array}$ & Variable & $\begin{array}{l}20.2 \% \text { (more than } 30 \% \text { in } \\
\text { urban areas) }\end{array}$ & $\begin{array}{l}\text { No. It is raised and used } \\
\text { locally in category A and B } \\
\text { municipalities }\end{array}$ \\
\hline $\begin{array}{l}\text { RSC levy } \\
\text { (abolished from } \\
\text { 2006) }\end{array}$ & $\begin{array}{l}\text { Business turnover } \\
\text { and payrolls. }\end{array}$ & $\begin{array}{l}\text { Variable. The } \\
\text { implementing } \\
\text { legislation specified } \\
\text { that a taxing authority } \\
\text { could impose different } \\
\text { rates for each tax for } \\
\text { different types of } \\
\text { enterprise, subject to } \\
\text { the concurrence of the } \\
\text { national minister } \\
\text { of finance. }\end{array}$ & $7.1 \%$ & $\begin{array}{l}\text { No. The tax was raised } \\
\text { and used in category A and } \\
\text { C municipalities. It is being } \\
\text { replaced by national grants } \\
\text { in } 2006 \text {, and the } \\
\text { government is considering } \\
\text { new tax instruments } \\
\text { for the longer term. }\end{array}$ \\
\hline
\end{tabular}


TA B LE 2, 4 Elements of Local Revenue (continued)

\begin{tabular}{|c|c|c|c|c|}
\hline Revenue & Base & Rate & $\begin{array}{l}\text { Contribution to local } \\
\text { revenue, 2002/03 }\end{array}$ & $\begin{array}{l}\text { Intergovernmental } \\
\text { revenue sharing? }\end{array}$ \\
\hline User charges & $\begin{array}{l}\text { Consumption of such } \\
\text { services as water, } \\
\text { electricity, and refuse } \\
\text { removal. }\end{array}$ & $\begin{array}{l}\text { Variable. The MFMA } \\
\text { enables the "uniform } \\
\text { norms and standards } \\
\text { concerning the setting } \\
\text { of municipal tariffs." } \\
\text { The Municipal Structures } \\
\text { Act requires tariff } \\
\text { structures to facilitate } \\
\text { access to basic services } \\
\text { for the poor. The } \\
\text { responsible national } \\
\text { minister can issue } \\
\text { regulations. }\end{array}$ & $\begin{array}{l}45 \% \text {. Electricity provides } \\
\text { the biggest share, } \\
\text { followed by water } \\
\text { services. }\end{array}$ & $\begin{array}{l}\text { No. The local charges } \\
\text { go to the relevant local } \\
\text { government. }\end{array}$ \\
\hline
\end{tabular}

Source: Author's compilation based on local government legislation and data from National Treasury 2003b and 2004b. 
favors major property developers because the value of land on which offices are built is very low in relation to the value of the improvements on them. Such a tax base also favors middle-class homeowners who have made substantial improvements to their properties. These biases make a land-only tax notably regressive. Concerns have also been raised that the system of rebates and exemptions required to improve the equity of a land-only tax is too administratively complex and not transparent.

However, a number of complexities have arisen in the context of the new local government situation. For example, promulgation of the act was held up because of controversies around its application to tribal areas and farming land. The tribal issue has been dealt with by excluding communal land for 10 years and by excluding crops.

\section{RSC Levies}

RSC levies have been both an anachronism from the pre-1994 era and an important source of revenue for metros and district authorities. The tax was introduced in 1986 to finance the regional services councils—-themselves an invention of the apartheid government to mitigate the fiscal stresses of many local governments, undertake infrastructure development at the local level, and facilitate upgrading of less-developed areas. The levy was in essence a tax on business turnover and payrolls.

For some time, the current government has wanted to reform or abolish RSC levies, and in 2005 (Republic of South Africa 2005), it finally announced that this form of tax would be abolished for a number of administrative, economic, and fiscal reasons. The first concerned accountability and the manner in which the tax was assessed. Metros and district municipalities did not conduct their own assessment of the liabilities of taxpayers but relied on the assessments of the taxpayers themselves, with some recourse to the South African Revenue Services to verify assessments. However, assessments were not frequently verified, and there were no explicit penalties for nonpayment other than charging interest on arrears. The payroll element of the tax was also seen as a disincentive to employment creation. By setting rates nationally, the national government effectively compromised the fiscal autonomy of local governments. The government's general fiscal stance has also been that a local tax like the RSC levy does not provide the best vehicle for redistribution and that intergovernmental transfers provide more equitable instruments for redistribution across localities (National Treasury 2001). 
The 2006/07 national budget hence provides for a national grant of R 7 billion to replace the RSC levy, and this grant will be escalated in the following two fiscal years. The understanding is that the transfer grant will be an interim measure, but the government is still considering the options. The core policy debate concerns more than local fiscal capacity alone. It is also about accountability: there has been a concern that the more local governments rely on transfers, the less accountable they may become to local stakeholders (business, consumers, or others). The options the government has been considering include allowing municipalities to claim input credits on inputs used for services provided out of property rates; devolving part of the national fuel levy so that municipalities get a share based on fuel sales in their area, introducing an electricity levy, distributing property transfer duties to municipalities on the basis of where property sales take place, or introducing a new business tax.

\section{User Charges and Utility Fees}

The power of local governments to impose user charges is only implicit in the constitution, in that it grants them executive authority over matters reasonably necessary for or incidental to performing their functions (section 156). The ability to raise income from user charges is linked to the municipality (category B or C) authorized to perform a specific service.

Utility fees from trading services (water, sanitation, electricity, and refuse removal) have jointly constituted the major local revenue source for many years-on aggregate more than 30 percent in recent years. All three categories of municipalities are able to levy such charges, but the division of powers between category B (local) and category C (district) municipalities dictate which benefits in a particular context. Although the National Treasury has been concerned that surpluses have been overestimated because of inaccurate municipal cost estimates, these services—especially electricityhave made a significant contribution to local revenues.

In this context, a current prominent policy debate is about proposed changes in the electricity distribution industry that will shift distribution to regional entities and away from municipalities. Grave concerns have been expressed that even if municipalities were compensated in some way or were able to introduce a surcharge on electricity purchased in their areas, the changes mean a shift away from one of the best-known and most clearly established local revenue sources. The fiscal implications are not known. It has been argued, though, that a surcharge would be more predictable than a trading service (Bahl and Solomon 2000; National Treasury 2005). 


\section{Surcharges}

Although not widely used, surcharges (or consumption taxes) represent a potentially significant taxing power exclusive to local government. Municipalities' power to tax consumers on the amount of local government services they use and the national government's right to regulate this form of taxation through legislation are contained in section 229 of the constitution. In addition, the Systems Act (section 11(3)) provides for surcharges.

Protagonists of surcharges argue that they are more transparent than surpluses generated from profits on trading services (Bahl and Solomon 2000; Whelan 2004). However, they have not been widely used, in part because the national electricity regulator disallowed the use of this tax on electricity service on the grounds that it is not part of a national strategy, and in part because the practice of trading surpluses as a source of local revenue has continued. Surcharges may well become a more prevalent form of local revenue generation as the restructuring of service sectors unfolds. The introduction of regional distributors (as in the electricity sector) could increase the pressure for local governments to use this form of taxation.

\section{The Revenue Collection Issue}

Although many local governments enjoy considerable autonomy over local resources, revenue collection remains a concern. The National Treasury (2003b, 2004b) estimated total outstanding consumer debt to all municipalities in 2004 at R 28 billion. Annually, municipal accumulated debtor balances, mainly to metropolitan and local municipalities, have been rising in recent years by about 3 percent of annual expenditure. ${ }^{9}$ Despite National Treasury and DPLG initiatives to help municipalities improve service delivery, billing, and systems, capacity shortcomings and large household debts remain major impediments.

\section{Intergovernmental Transfers}

In aggregate, 10 to 16 percent of municipal expenditure is financed through intergovernmental transfers, but this range disguises significant variance between larger urban municipalities and others. Some smaller municipalities are almost fully dependent on grants. The 2005 announcement that the RSC levy is to be replaced-at least on an interim basis-by a new grant to district and metropolitan municipalities has introduced a new dimension, which it has not been possible to fully consider for this analysis. Table 2.5 reflects the relative contribution of transfers to municipal expenditure. 
T A B L E 2 . 5 Direct Transfers as a Share of Total Municipal Expenditure, FY 2002/03-FY 2005/06

\begin{tabular}{|c|c|c|c|c|}
\hline \multirow[b]{2}{*}{ Indicator } & \multicolumn{4}{|c|}{ Fiscal year } \\
\hline & $2002 / 03$ & $2003 / 04$ & $2004 / 05$ & 2005/06 \\
\hline \multicolumn{5}{|l|}{ Total local government expenditure } \\
\hline budget ( $\mathrm{R}$ billion) & 64.4 & 89.3 & 101.2 & 119.9 \\
\hline National direct transfers ( $\mathrm{R}$ billion) & 8.1 & 12.1 & 16.9 & 16.3 \\
\hline $\begin{array}{l}\text { National direct transfers as a } \\
\text { proportion of total local government }\end{array}$ & & & & \\
\hline expenditure (\%) & 12.5 & 14.1 & 16.9 & 13.6 \\
\hline $\begin{array}{l}\text { Provincial direct transfers (actual } \\
\text { and budgeted) (R billion) }\end{array}$ & 2.3 & - & - & - \\
\hline $\begin{array}{l}\text { Provincial direct transfers as a } \\
\text { proportion of total local government } \\
\text { expenditure (\%) }\end{array}$ & 3.5 & - & - & - \\
\hline Total direct transfers (R billion) & 10.4 & - & - & - \\
\hline $\begin{array}{l}\text { Total direct transfers as a } \\
\text { proportion of total local government } \\
\text { expenditure (\%) }\end{array}$ & 16.1 & - & - & - \\
\hline
\end{tabular}

Source: Personal communication based on budget data; National Treasury 2003b, 2004b. Note: $-=$ not available. Totals may not add to 100 because of rounding.

Reform of local government grants has been a priority since the 1998 White Paper. The number of fiscal instruments has been reduced, but transfer allocations have moved from R 4.4 billion to R 8.1 billion between 1998 and 2003, and they are expected to grow to R 16.3 billion in 2005/06. It has been one of the highest percentage increases in the past two budgets, albeit off a low base. Whelan (2003a, 2003b, 2004) points out, however, that per capita increases for national and provincial services have been higher than those for local government in actual monetary terms.

National allocations to local government are announced in an annual Division of Revenue Act (DORA), published to enhance predictability and transparency over a three-year period. Provincial treasuries are also required to publish their transfers to municipalities. Reporting requirements are stipulated in each DORA. Currently, every municipality receiving assistance under a grant program must submit monthly reports to the transferring national or provincial department. These reported are then submitted to the Treasury. In the cases of the financial management grant and restructuring grant, the National Treasury is the transferring department. Table 2.6 
provides a general overview of the major transfers to municipalities in FY 2002/03 to FY 2008/09.

\section{The Unconditional Equitable Share}

Grant consolidation started in 1998 with the introduction of the equitable share of nationally raised revenue for local government. It consolidated more than 20 operating grants from provinces and national departments to municipalities. The consolidation process continues, but it has not always been a smooth transition. For example, the water operating grant was prepared for consolidation into the equitable share by 2005/06, but this date was shifted to 2011 as the full scale of institutional changes required became more apparent.

Nonetheless, the equitable share had systematically grown to almost 53 percent of total national direct transfers by $2003 / 04 .{ }^{10}$ This growth acknowledges the vertical imbalance between the spheres and a gap between municipal fiscal capacity and expenditure assignments, especially to meet operating costs of providing infrastructure for poor households. Many municipalities are unable to match this demand; hence, nationally raised revenue is allocated in the form of the unconditional constitutional entitlement under the equitable share.

Allocations are made for three years, on the basis of priorities determined by the national cabinet, in consultation with the Budget Council and the Budget Forum and provincial premiers, and on considering recommendations from the Financial and Fiscal Commission. This political judgment comes on top of a baseline allocation in the budget, which is based on the previous budget. The constitution requires factors such as provincial and local fiscal capacity, expenditure efficiency, developmental needs and backlogs, and provision for emergency funding to be taken into account to help determine this division. The local government formula is based on six components, the major one of which targets households with expenditure of less than R 1,100 per month. Over time, additional considerations have been added. For example, in 2002 the formula was adjusted to target services and institutional support at "nodal" points identified in the new Integrated Sustainable Rural Development Programme and the Urban Renewal Programme. Since 2002/03, the equitable share has also been allocated to district municipalities that perform basic service delivery functions. In the 2003 budget, this shift has meant changes to the weights: of the portion for service delivery (the $S$ grant), 23.3 percent is directed to water supply, 41.9 percent to electricity, 11.6 percent to sanitation services, and 23.3 percent to refuse 
TA B L E 2.6 National Transfers to Local Government, FY 2002/03-FY 2008/09 (R million)

\begin{tabular}{|c|c|c|c|c|c|c|c|}
\hline \multirow[b]{2}{*}{ Type of transfer } & \multicolumn{3}{|c|}{ Outcome } & \multirow{2}{*}{$\begin{array}{c}\begin{array}{c}\text { Revised } \\
\text { estimate }\end{array} \\
2005 / 06\end{array}$} & \multicolumn{3}{|c|}{ Medium-term estimates } \\
\hline & $2002 / 03$ & $2003 / 04$ & $2004 / 05$ & & $2006 / 07$ & $2007 / 08$ & $2008 / 09$ \\
\hline \multicolumn{8}{|l|}{ Direct transfers to local government } \\
\hline Equitable share and related & 4,230 & 6,623 & 7,811 & 9,808 & 18,558 & 20,626 & 23,375 \\
\hline Equitable share & 4,187 & 6,350 & 7,678 & 9,643 & 18,058 & 20,076 & 22,775 \\
\hline Water and sanitation operation & 43 & 273 & 133 & 165 & 500 & 550 & 600 \\
\hline Infrastructure & 3,472 & 4,102 & 5,258 & 6,302 & 7,225 & 9,129 & 11,801 \\
\hline Municipal Infrastructure Grant & 1,865 & 2,442 & 4,440 & 5,436 & 6,265 & 7,149 & 8,053 \\
\hline Public Transportation Infrastructure and Systems & - & - & - & 242 & 519 & 624 & 1,790 \\
\hline Local Neighbourhood Development Partnership Grant & - & - & - & - & 50 & 950 & 1,500 \\
\hline National Electrification Programme & 225 & 245 & 196 & 313 & 391 & 407 & 458 \\
\hline Implementation of Water Services Projects & 999 & 1,022 & 208 & - & - & - & - \\
\hline
\end{tabular}


Disaster relief

Poverty relief funds and other ${ }^{b}$

Current

Restructuring Grant

Financial Management Grant

Municipal Systems Improvement Grant

Subtotal direct transfersc

Indirect transfers to local government

Water and Sanitation Operation

National Electrification Programme

Subtotal indirect transfers

$\begin{array}{rrr}- & - & 280 \\ 383 & 393 & 134 \\ 400 & 856 & 768 \\ 151 & 494 & 388 \\ 155 & 211 & 198 \\ 94 & 151 & 182 \\ 8,102 & 11,581 & 13,837\end{array}$

8,102

11,581

13,837

16,859

$\begin{array}{rrrrrrr}656 & 817 & 819 & 904 & 491 & 490 & 531 \\ 740 & 796 & 819 & 863 & 977 & 1,016 & 1,143 \\ 1,396 & 1,613 & 1,638 & 1,767 & 1,468 & 1,506 & 1,673 \\ 9,498 & 13,194 & 15,474 & 18,626 & 28,000 & 32,010 & 37,249\end{array}$

Source: National Treasury 2006-information provided to the author upon request.

Note: $-=$ not available.

a. Includes main local government equitable share, replacement of RSC levies, and special support for councilor remuneration.

b. Includes phasing out poverty relief grants and Urban Transport Fund.

c. Reflects local governments' share of the division of revenue. 
removal. Table 2.7 provides an overview of the funding windows, purposes, factors, and relative allocations under the equitable share in 2003/04.

\section{Specific-Purpose Capital Grants}

Capital grants constitute more than a third of direct national transfers, but they have been projected to drop in significance because of the strong growth in the equitable share. The biggest, fastest-growing capital grant has been the Consolidated Municipal Infrastructure Programme (CMIP). Other substantial flows have occurred through sector grants from the Department of Water Affairs and Forestry, the National Electrification Programme (managed by the Department of Minerals and Energy), the Local Economic Development Fund, the Community-Based Public Works Programme, and the Building for Sports and Recreation Programme.

In March 2003, the cabinet decided, in principle, to take consolidation forward by bringing all municipal infrastructure grants (including the CMIP) into a single, decentralized, non-sector-based, multiyear, and formula-driven capital allocation. The new municipal infrastructure grant has started (since 2003/04) to consolidate seven sector grant programs over three years, building on the limited consolidation first achieved through the CMIP. Municipalities are expected to need considerable support in adapting their organizations' decision-making and reporting processes to the requirements of the grant. Its conditions would therefore also entail requirements to support the development of such capacity. However, the grant is still in a pilot phase and its procedures and project management mechanisms are still being developed.

\section{Specific-Purpose Capacity Building and Recurrent Grants}

The transformation of local government has imposed many new demands on municipalities, and it has therefore been necessary to introduce a number of capacity enhancement measures. A one-off local government transition grant 2000/01 assisted with specific issues of amalgamation after the demarcation process, but more significantly, a number of measures have been supported to ensure long-term structural change.

The first among these has been through the local government restructuring grant, introduced in 2000 to assist large urban municipalities with modernizing their service delivery, fiscal, and institutional systems. It is awarded on application, and the relevant councils have to make proposals that are then evaluated by the National Treasury. Implementation has been 
TA B L E 2. 7 The Equitable Share: Purpose and Allocations, FY 2003/04

\begin{tabular}{|c|c|c|c|}
\hline $\begin{array}{l}\text { Window of } \\
\text { funding }\end{array}$ & Funding purpose & Factors in allocation & $\begin{array}{c}\text { Window as } \% \\
\text { total equitable } \\
\text { share }\end{array}$ \\
\hline S grant & $\begin{array}{l}\text { Fund operational } \\
\text { costs of basic } \\
\text { services in poor } \\
\text { households }\end{array}$ & $\begin{array}{l}\text { Number of poor households } \\
\text { and the relative difference } \\
\text { between the number of } \\
\text { poor individuals and } \\
\text { number of nonpoor } \\
\text { individuals; the costs of an } \\
\text { estimated basket of basic } \\
\text { services per household }\end{array}$ & 65.9 \\
\hline I grant & $\begin{array}{l}\text { Fund institutional } \\
\text { and governance } \\
\text { requirements }\end{array}$ & $\begin{array}{l}\text { Overhead operating costs } \\
\text { of municipality in relation } \\
\text { to population size; declines } \\
\text { as average municipal income } \\
\text { increases }\end{array}$ & 7.1 \\
\hline $\begin{array}{l}\text { Original } \\
\text { equitable } \\
\text { share (S grant + } \\
\text { I grant) }\end{array}$ & & & 73.0 \\
\hline $\mathrm{R} 293^{\mathrm{a}}$ & $\begin{array}{l}\text { Fund R293 staff } \\
\text { transferred from } \\
\text { provinces to } \\
\text { municipalities }\end{array}$ & $\begin{array}{l}\text { Historical distribution of } \\
\text { R293s; decision about the } \\
\text { number of R293 staff } \\
\text { allocated to the } \\
\text { municipality (and conversely } \\
\text { to the province) }\end{array}$ & 6.0 \\
\hline Nodal & $\begin{array}{l}\text { Fund projects } \\
\text { identified in the } \\
\text { local ISRDP and } \\
\text { URP planning } \\
\text { exercises }\end{array}$ & $\begin{array}{l}\text { Nodal areas-number } \\
\text { of poor people in nodes }\end{array}$ & 3.3 \\
\hline \multirow[t]{2}{*}{ Free services } & $\begin{array}{l}\text { Fund operational } \\
\text { costs of some key } \\
\text { services (excluding } \\
\text { electricity provision } \\
\text { to poor households) }\end{array}$ & $\begin{array}{l}\text { Average of number of poor } \\
\text { households and households } \\
\text { with basic services backlogs }\end{array}$ & 13.0 \\
\hline & $\begin{array}{l}\text { Fund operational } \\
\text { costs of electricity } \\
\text { provision to poor } \\
\text { households }\end{array}$ & $\begin{array}{l}\text { Average of number of poor } \\
\text { households and households } \\
\text { with basic electricity } \\
\text { backlogs }\end{array}$ & 4.7 \\
\hline
\end{tabular}

Source: National Treasury 2001, 2003b; Whelan 2003a, 2003b.

a. Named after the number of the regulation that classified towns under control of former Bantustan administrations. After apartheid, these towns were initially transferred to provincial administrations, but in the late 1990 s, they were transferred to municipalities as a result of a national decision. 
slow, because the stringent conditions require extensive negotiations between municipalities and the National Treasury.

To assist other municipalities, the government introduced a local government financial management grant (FMG) and a municipal systems improvement grant (MSIG). The FMG has been putting in place the systems defined in the MFMA. It supports a pilot program of technical assistance at the municipal level, supported through donor funding since 2001/02. The MSIG is mainly geared toward establishing Project Implementation and Management Support System centers, and funding routine running costs and capacity-building and support activities (mainly in the field of training).

In the past, a multiple grant system meant that other grants still continued to fund capacity-building initiatives. For example, a part of the CMIP that is allocated through the provinces also assists municipalities with capital project planning and alignment with integrated development plans, the water operating grant and water capital development grant support installation of cost-recovery systems with some emphasis on customer relations and responsiveness, and Project Viability assists in the development of information systems. Although Project Consolidate may be the beginning of a more coherent approach, the multiplicity of capacity-building support measures suggests that there is not yet a fully coherent capacity-building strategy. This lack of a clear strategy is likely to be a primary concern as the government attempts to improve the targeting of these funds in the near future. As the discussion here highlights, there are different needs in different types of municipalities, and it remains necessary to introduce a degree of nuance and differentiation to address their respective requirements. Table 2.8 provides a perspective on the relative contributions of the three major types of transfers to the major categories of municipalities.

\section{Local Government Borrowing}

Since the late 1990s, the South African government has been working on creating an enabling environment for municipal borrowing. It published a wide-ranging policy paper on this topic in mid-2000 and has incorporated conditions in the MFMA to create the legal conditions for borrowing by municipalities and municipal entities.

The 1996 constitution provides both implicit and explicit support for local-level borrowing. By recognizing the role of local government in governance and service delivery, it delineates a sphere of government and highlights the identity of local government and by implication the notion that it 
TA B LE 2.8 Distribution of National Direct Transfers to Categories of Municipalities, FY 2003/04

\begin{tabular}{|c|c|c|c|c|}
\hline Category & $\begin{array}{c}\text { Percentage } \\
\text { distribution } \\
\text { of total transfers }\end{array}$ & $\begin{array}{c}\text { Percentage } \\
\text { distribution } \\
\text { of equitable } \\
\text { share }\end{array}$ & $\begin{array}{c}\text { Percentage } \\
\text { distribution } \\
\text { of recurrent } \\
\text { grants }\end{array}$ & $\begin{array}{c}\text { Percentage } \\
\text { distribution } \\
\text { by capital } \\
\text { grants } \\
\text { (including } \\
\text { water } \\
\text { capital) }\end{array}$ \\
\hline A (metro) & 16.9 & 20.0 & 1 & 16.1 \\
\hline B (local) & 43.5 & 63.4 & 87 & 15.5 \\
\hline $\mathrm{C}$ (district) & 39.7 & 16.6 & 12 & 68.4 \\
\hline Total & 100.0 & 100.0 & 100 & 100.0 \\
\hline
\end{tabular}

Source: Division of Revenue Act 2003; Whelan 2003b.

Note: Totals may not add to 100 because of rounding.

is not hierarchically subject to national and provincial government. More specifically, the constitution allows municipalities to borrow, within a regulatory environment provided by the national government. The MFMA forms the core of this regulatory environment. However, sparked by its intentions with the MFMA, the government amended the constitution in 2003 to allow municipal councils to bind themselves and future councils in pledging security for debt and to enable government to intervene-through provincial executives at first, but if that approach fails, then directly-if a municipality fails to meet its obligation. The MFMA also allows for the establishment of an agency that governs recovery plans for such municipalities.

In reality, private sector lending to municipalities has remained subdued and has focused on short-term lending. Very little investment occurs in the long-term debt market - the pivotal area from which funding for infrastructure investment is supposed to be forthcoming. Almost half of the short- and long-term lending since 1997 has been provided by the Infrastructure Finance Corporation (INCA), a specialized municipal lending agency attached to one of the major commercial banks. The other half has come mainly from the Development Bank of Southern Africa (DBSA), a public sector financial intermediary supposedly targeted to the more risky market but in reality doing a substantial portion of its long-term lending in the more overtly commercially viable market. This scenario indicates the lackluster interest on the part of financial institutions at large to become involved in a market affected by considerable fiscal stress. Nonetheless, by 2004 private sector credit stood at R 12 billion, or 60 percent of municipal borrowing. 
Commercial banks and INCA accounted for 79 percent of the private sector market. Insurance and pension funds, which used to account for 35.3 percent of private sector lending to municipalities in 1997, now account for a mere 2.5 percent of private sector lending. The absence of tradable municipal securities poses a challenge to the development of a municipal bond market, although Johannesburg's issue in 2004 of a 12-year bond (supported by a partial guarantee from the International Finance Corporation) was a remarkable success, and the issue was significantly oversubscribed.

In principle, the government's policy stance is that all municipalities should have equal borrowing powers, because formal differentiation would be too complex and overregulated. The government would prefer that potential lenders decide whether to venture into lending. In practice, however, all municipalities are not equally attractive to lenders; the government has therefore tailored its capacity-building support around a conceptual differentiation between three risk categories of municipalities with different levels of readiness to borrow.

The first risk category does not require external assistance to achieve access to the bond market or to obtain commercial loans. This category is still relatively small. The second risk category is unlikely to attract private capital investment now or in the near future. These municipalities' constraints are structural; therefore, they will likely continue to depend to a great degree on intergovernmental transfers. The third risk category is perhaps of greatest interest from a reform point of view: local governments that could — with some adjustment — be made ready to access the bond market or at least obtain loans. In theory, this category typically forms the clientele of the Development Bank of Southern Africa (DBSA) (as the primary concessionary institution supporting municipal investments in infrastructure). However, the DBSA has not been lending extensively in this market, and the fact that it had not been receiving any new fiscal support since the mid-1990s has led it to adopt a risk profile perhaps lower than that assumed by its ostensibly facilitative role. Recently, the National Treasury has indicated that it wants the DBSA and other development finance institutions to adopt higher-risk profiles, and the DBSA is believed to be doing some modeling to scope its leeway in municipal lending to this end.

The relevance of such differentiation is demonstrated by the findings of a National Treasury survey in 2002/03 of municipalities participating in the FMG pilots. It found that more than 70 percent of total municipal borrowing occurred in 39 municipalities. This aggregate disguises the fact that the bulk of that borrowing has actually been made by the six metros, which have accounted for 93.4 percent of all borrowing. Category B municipalities have 
accounted for only 6 percent. Borrowing by category $\mathrm{C}$ municipalities has been negligible. Table 2.9 provides an overview of these findings. It highlights the interest in this market both among bigger municipalities and in the investment market, an interest confirmed by the successful floating of a municipal bond by Johannesburg within weeks of the MFMA being passed. The experience gained here promises to inform trends in the evolution of this market. However, the challenge of investment in areas where municipalities (the majority) are not likely to be able to borrow remains considerable. It is here that more information, more policy thinking, and a review of the institutional lending environment-including the role of development institutions such as the DBSA — become highly important for the future agenda.

The MFMA has created an important element of the legal framework for municipalities to borrow. The rules for engaging in borrowing and for dealing with defaults are clearer, which should in principle reduce the risk for both parties. With the new demarcations, a major uncertainty has been removed. And as national government borrowing has decreased, investor capital may become available for other investments. The challenge is from both a municipal infrastructure perspective and a capital markets perspective. The National Treasury is very interested in seeing high-quality, tradable, municipal securities on the market.

\section{Assessment}

South Africa has made remarkable progress in moving its system of local government from one that served apartheid to one concerned with democracy and service delivery. Since 1994, it has gone through the turbulence of rapid and far-reaching change in policies, legislation, structures, systems, and the very jurisdictional bases of local governments. Wisely, therefore,

TA B LE 2.9 Borrowing by Category of Municipality (R million)

\begin{tabular}{lrc}
\hline Category & Current borrowings & Planned borrowings \\
\hline A (metro) & 13,236 & 1,000 \\
B (local) & 851 & 223 \\
C (district) & 80 & 13 \\
\multicolumn{1}{c}{ Total } & 14,167 & 1,236 \\
\hline
\end{tabular}

Source: National Treasury 2003b. 
much emphasis has been placed on stabilizing and consolidating the reforms and the new system. And the primary challenges continue to revolve around those themes.

\section{Jurisdictional Challenges}

First, the potential of decentralization of power and functions for increasing accountability and responsiveness of government structures depends on a combination of sufficient powers, functions, and resources being available to local governments. Lower levels of government can be more responsive because they are more aware of the needs and demands of citizens, but they need the real ability to adjust service delivery accordingly. Achieving this capacity in South Africa demands jurisdictional, fiscal, and institutional measures.

The current review of the constitutional functions of the different spheres, as well as the analysis in 2002 to assist in dividing powers and functions between district and local councils, has contributed toward clarifying the jurisdictional uncertainties. The earlier analysis highlighted the need to take this work forward by clarifying the functional assignments in the constitution and other legislation as a basis for political accountability, resource mobilization, and effective management of services. The uncertainties thus far have been aggravated by inconsistencies in sector legislation and failure to take the financial implications of assignments and delegations into account. This situation has added institutional and fiscal stress on municipalities (DBSA 1998). The discussion earlier highlighted problems related to sharing the housing and health functions with provinces, as well as in working through the practicalities of the responsibilities now finally agreed on about the divisions of water functions in districts and local governments. Those uncertainties make it more difficult to hold local governments accountable and to ensure they have the necessary resources and capacity.

Apart from the debates on principle — and there have been many-it has become essential to gain a clearer perspective on actual cost implications and scope for developing capacity or mobilizing fiscal resources. The empirical bases for further policy work therefore must improve.

\section{Streamlining Intergovernmental Relations}

Streamlining intergovernmental relations remains a challenge. Clearly, the consolidation of transfers around an equity-based transfer, a capital grant, and a capacity-building channel is in line with international best practice. 
Moreover, policy work recently helped clarify the role of provinces somewhat. However, ambitious targets have not always been met: for example, the process of phasing the water subsidies into the equitable share has extended over a further five years. Table 2.6 shows clearly that there still are several grants, and that the (understandable) tensions between the need for sectorspecific transfers and consolidated ones have not yet been fully mediated. The encouraging news is that government departments continue to discuss these issues, that Treasury lately has been reviewing the key policy challenges and ways to measure fiscal impact, and that the principle of a streamlined system has clearly been acknowledged. This progress should assist further improvement of instruments to monitor and analyze trends and difficulties and to support appropriate responses.

\section{Municipal Fiscal Viability}

The context for South Africa's quest for municipal financial viability is at one level quite different from that in many other developing countries, but it is also not entirely dissimilar. Compared with most developing countries, municipalities in South Africa are relatively less grant dependent, but there are significant variances. A small number are largely self-sustaining, while the poorest depend almost entirely on transfers. Transformation has had important financial implications. The challenge is to build sustainable income sources and sound practices that would ensure that the new municipalities become financially viable. The announcement in 2005 that the RSC levy will be scrapped raised important questions about the relationship between fiscal dependence and local accountability. Finding an appropriate balance between national support and reform of local tax instruments will remain an important challenge.

There have also been initiatives to encourage municipal borrowing. As discussed, the state-owned DBSA is not the only lender of significance, and at least one private banking institution (INCA) now specializes in municipal lending. A number of others have included municipal lending in small part in their portfolios. Moreover, Johannesburg's seemingly successful floating of a bond shortly after the MFMA was passed may herald a new dynamic era of borrowing for the bigger municipalities. However, municipal creditworthiness remains a constraint, and the arrangements under the MFMA need to be carefully monitored to identify further practical challenges for the wider spectrum of local governments. How the government deals with the inability of most municipalities to access credit will be a crucial part of the agenda over the next few years. 


\section{No Business as Usual}

Reorientation of the way municipalities do business needs to continue. Most municipal structures are new and at an early stage of developing new institutional approaches to streamlining service delivery. Few manage key services on a commercial basis or as distinct cost centers, resulting in poor management systems and great inefficiencies. Alternatives such as private sector participation and corporatization are at an early stage but could offer progress to facilitate greater cost consciousness, financial scrutiny, and stricter credit control. However, those processes will continue to experience difficult political pressures, especially from trade unions, which will insist on enforcing a 1997 agreement with the government-an agreement that unconditionally asserted that direct municipal delivery is the "preferred option" for service delivery. Partnerships are also affected by the conditions outlined in the Municipal Systems Act, particularly a clause that gives the minister of provincial and local government wide discretionary powers to determine tariffs nationally and to determine the complex procedure for contracting out services. This clause has raised concerns among potential investors and requires further assessment. The Municipal Systems Act also complicates the procurement of service providers outside local government. It will be necessary to motivate partnerships by making the process more streamlined for both officials and potential contractors.

\section{The Capacity Challenge}

An ambitious reform program requires ambitious management, but more than that, it demands skills. South Africa needs skills at all levels, not only in municipalities but also in national and provincial governments. The reform program has not suffered from a lack of good ideas or access to knowledge about international best practice. But it has lacked the dedicated management capacity to sequence and plan, to introduce and drive performance management, and to set consistent policy on critical issues across the spectrum of service delivery, financing, and governance demands. This lack puts the well-conceptualized policy frameworks at risk.

New approaches are emerging. In recent initiatives the government has attempted to coordinate municipal capacity-building efforts across the levels of government more effectively, for example, through Project Consolidate, which was launched in 2005. Such donors as the World Bank, U.K Department for International Development, and Gesellschaft für Technische Zusammenarbeit have also moved to more targeted and intensive capacity 
support, and it is anticipated that Project Consolidate may provide a new framework for their joint efforts. Their local government programs are now more aligned and provide some dedicated operational expertise at the national and provincial policy and monitoring levels. Moreover, multiple donor involvement has made it possible to address different aspects of the reform agenda: the technical issues of fiscal and operational management, as well as accountability questions in governance of councils and their relationships with local media and civil society groups. This new, integrated approach takes the agenda of consolidation significantly forward. Provided it can draw on a wide cross-departmental support base within South Africa, it promises to enhance accountable delivery considerably.

\section{Lessons for Developing Countries}

The emergence and gradual consolidation of local government in South Africa has highlighted a number of important lessons, both from what South Africans have done right and from the challenges that they have found difficult to resolve. One could identify many lessons, but a few stand out.

\section{Lesson 1: The Power of Vision}

South Africans are quite self-critical about their emphasis on policy in recent years. The government has become impatient to prove that it is firmly in the business of delivery, not merely of policy making. Yet in articulating powerfully their vision for local government, South Africans have managed to move the reform agenda forward on scale and at a persistent pace. The beginnings were in the constitutional negotiations of 1993, followed by a few years of finding their feet through the complex challenges of undoing a deeply embedded, skewed system and introducing a new one that meets the aspirations of a democratic nation. The 1998 White Paper on local government's stance on developmental local government was an important landmark, but developing that vision has not stopped. It has continued in sectors, in the initiatives for partnerships with the private sector, and in the elaborate work of the National Treasury to define the fiscal framework more clearly and to set out tight fiscal policy and regulations that enhance monitoring as much as they allow innovations. The vision is developing-and with it the scope to test new ideas and explore new avenues by learning from both international and local experience. 


\section{Lesson 2: Formal Rules Are Just a Beginning}

Nowhere is this lesson more evident than in the jurisdictional domain identified earlier. Although the constitution clearly defines powers and functions, reality is shaped through many interactions. The optimal assignment of functions and sequencing of devolution constantly evolves in a decentralized system. These relationships change and evolve even in developed countries. Even if the division of powers and functions is clear, regulatory powers of national governments or their agencies can impose additional (cost) burdens on local governments. Changes and inconsistencies in national sector policies have not only hampered the scope for local autonomy but also complicated the pace of service delivery. South Africa shows that while the creative tension of policy debate is necessary for change, it is also necessary to work hard at filling in the practical details. South Africa continues to face many challenges and has a number of policy and operational tensions to resolve. For example, enhancing municipalities' creditworthiness was never going to be easy amid the uncertainty of transformation. And improving local revenue while exploring reform options in service sectors, particularly those that may remove sources of revenue (such as electricity charges) from local government, poses stringent challenges.

\section{Lesson 3: The Power of Information}

Budget processes proceed irrespective of the quality of information, but the ability to plan, work, and report effectively is in the end fundamentally tied to the nature of the information available. At one level, South Africa has tried to work on these issues through more robust auditing. The government has realized that poor audit capacity, poor quality of financial statements, or long delays in the completion of financial statements hamper attempts to understand trends, to introduce financial management, and ultimately to plan ahead. If actual expenditure and revenue are not monitored on a monthly basis and if such information is not available in time to inform the next budget, the quality of information will tend to be poor and unreliable, making budget decision making even harder.

South Africa has also identified the value of an open process of information management. The introduction of a regular Intergovernmental Fiscal Review — submitted to parliament—has benefited decision makers. This document has given provinces, municipalities, and officials at the national level incentives and public deadlines to work toward regarding the processing and interpretation of information. The process has already reaped benefits in 
sparking some lively civil society responses. For example, the Budget Information Service of Idasa, a major national nongovernmental organization has become a vigorous independent analyst of the Intergovernmental Fiscal Review, offering provocative critiques and encouraging and informing public debate.

\section{Lesson 4: The Need for Sequencing, but No Inevitable Linearity}

In a developing country, local capacity is often not immediately available. The shifting of functions must take this into account. However, one cannot assume that the requisite capacity is available at the national government level eitherthough many implicitly do make this assumption when they recommend a slow and ordered sequence of devolution. Thus, sequencing is not necessarily a linear process in which national government holds the strings and gradually hands over power as the other levels develop capacity (Bird 2003). It is a complex process that requires continuous attention and monitoring.

\section{Lesson 5: Fiscal Decentralization Is about a System, Not Its Parts Alone}

Roy Bahl's (2002) often-stated theorem about the need to view decentralization as a system is nowhere more relevant than in South Africa. The country's successes and frustrations have often come back to the realization that decentralization will not work if problems of capacity, budgeting, financial management, reporting, information, and transparency are not addressed simultaneously. Budget reforms and new legislation on financial management have consistently had a direct bearing on improved local decision making and the brokering of more effective relationships between politicians and officials. The point made about the power of information is critical in this respect: poor information has visibly compromised local budget processes, accountability, and the ability of national and provincial governments to respond effectively and in a timely fashion to local management challenges.

But the issue goes wider. Decentralization must be consciously pursued; centralization by stealth happens all too easily. For example, although the local sphere in South Africa is autonomous, not under the control of the provincial or national governments, national departments have been able to intervene directly in municipal affairs through the use of grants in aid for the delivery of services to the poor. This situation has on occasion led to a project focus that did not necessarily take into account local-level considerations 
about sustainability. For example, the national department responsible for water affairs has provided water and sanitation services and infrastructure to rural areas, while the national government also managed a parallel conditional grant for municipal infrastructure. All these grants fund specific projects. Although project-focused measures were necessary in 1994 to ensure speedy delivery, the difficulties in getting effective systems in place often seem related to national departments being too far removed from local areas to understand local demand for services. The project-based approach resulted in a lack of attention to sustainability considerations, such as the issue of who is responsible for maintaining infrastructure and the collection of user fees for such services. It has also led to poor coordination, where the spatial and delivery plans of provincial or local governments are often not followed. In this context, the systematic attempts to consolidate grants form a critical part of building an integrated approach, one that is targeted to specific issues, yet not fragmented —and in line with the overall vision that is so important.

\section{Notes}

1. Under apartheid, nine ethnically defined homelands or Bantustans were created as alternatives to giving black South Africans full political rights in the central political system. Initially, the ultimate apartheid vision was that all black people would reside in those areas, and that they would at most be temporary sojourners in "white South Africa," where their labor was still needed. By the 1980s, demographic and economic realities and heightening political pressure led to a relaxation of laws that attempted to control the inflow of black people to major urban areas, but even then black people who did not even live in Bantustans were deemed their citizens by law and could not obtain South African citizenship rights. The Bantustans were given some form of self-government, and four were even declared independent states by the South African government, but this independence was never internationally recognized or accepted by the black majority in South Africa. All the Bantustans remained economically and fiscally dependent on the South African government.

2. Apartheid South Africa revolved around a series of racial definitions that—although awkward—are difficult to avoid when discussing local government in that era. Apart from distinguishing between white people and others, those who were not white were legally differentiated as "black" (African), "colored" (of mixed race), and Indian.

3. These boards were renamed development boards in 1983 and community services divisions in 1986.

4. One of the controversies about demarcation was the creation of local governments that stretched across the borders of more than one province. Following representations by identified stakeholders and members of the public, the boundaries of these "cross-border" municipalities were redrawn. The new boundaries came into effect with the March 2006 local government elections. In the process, the overall total of local governments was reduced to 283 . 
5. Schedules 4 and 5 of the constitution divide functions on a concurrent and exclusive basis among the three spheres.

6. $\mathrm{R} 6.23=\mathrm{US} \$ 1.00$, as of January 2006 .

7. In the 2005 Medium-Term Budget Policy Statement, the government announced the scrapping of the RSC levies. In the interim, the levies will be replaced by a national government grant to the relevant municipalities, but the government is considering new tax instruments.

8. The status of indigenous traditional leaders in the local government system has been a bone of contention in South Africa's democratization. Different groups have had conflicting ideas about the compatibility of unelected leadership structures in a democratic system. After much debate, the Municipal Structures Act was amended in 2000 to allow for consultative procedures that involve traditional authorities in local government affairs and in cultural and customary functions and that allow them limited service oversight in rural areas. The amendments also allow them to raise certain fees to perform their functions. They are not local governments, however-merely part of governance processes in relevant rural local government jurisdictions.

9. District municipalities were less affected, because their main sources of revenue are transfers and regional levies.

10. According to Whelan (2004), the actual expenditures eventually added up to about 44 percent, and the 53 percent contribution is now expected to be reached by 2005/06.

\section{References}

Atkinson, Doreen. 2002. "The Passion to Govern.” Paper prepared for the Centre for Policy Studies, Johannesburg.

Bahl, Roy W. 2002. “Implementation Rules for Fiscal Decentralization.” In Development, Poverty and Fiscal Policy: Decentralisation of Institutions, ed. M. Govinda Rao. New Delhi: Oxford University Press.

Bahl, Roy W., and David Solomon. 2000. "The Regional Services Council Levy: Evaluation and Reform Options.” Unpublished paper presented to the National Treasury, Pretoria.

Bird, Richard. 2003. “Asymmetric Fiscal Decentralization: Glue or Solvent?” Andrew Young School of Public Studies, Georgia State University, Atlanta.

DBSA (Development Bank of Southern Africa). 1998. "Infrastructure: A Foundation for Development." DBSA Development Report, Midrand, South Africa.

—. 2000. "Building Developmental Local Government." DBSA Development Report, Midrand, South Africa.

Department of Constitutional Development. 1997. “Green Paper on Local Government.” Government Printer, Pretoria.

_. 1998. "White Paper on Local Government." Government Printer, Pretoria.

Gildenhuys, Burgert C. 2002. "The Demands of the Development Planning Process on the Municipal Financial Manager." IMFO, Official Journal of the South African Institute of Municipal Finance Officers, 2 (3).

Momoniat, Ismail. 2001. "Fiscal Decentralization in South Africa: Practitioner's Perspective." Paper presented at the World Bank, Washington, DC. http://www.worldbank.org/decentralization/regions. 


\section{Chris Heymans}

National Treasury. 2001. Intergovernmental Fiscal Review. Government Printer, Pretoria. 2003a. Budget Review. Government Printer, Pretoria.

2003b. Intergovernmental Fiscal Review. Government Printer, Pretoria.

2004a. Budget Review. Government Printer, Pretoria.

. 2004b. Trends in Intergovernmental Finances: 2000/01-2006/07. Government Printer, Pretoria.

. 2005. "Options for the Replacement of RSC and JSB Levies." Press release, National Treasury, Pretoria. http://www.finance.gov.za/documents/RSC $\% 20$ REPLACEMENT\%20OPTIONS\%20\%20Dec\%20\%202005.pdf.

Palmer Development Group. 2004. "Local Government Powers and Functions." Occasional Paper, Idasa Budget Information Service, Cape Town.

Pycroft, Chris. 1998. "Integrated Planning or Strategic Paralysis? Municipal Development during the Local Government Transition and Beyond." Development Southern Africa 15 (2): 151-63.

Republic of South Africa. 2005. "Medium-Term Budget Policy Statement.” Government Printer, Pretoria.

Rural Development Unit. 2004. "India: Fiscal Decentralization to Rural Local Governments." South Asia Division, World Bank, Washington, DC.

Swilling, Mark. 1988. “Taking Power from Below." In Government by the People? The Politics of Local Government in South Africa, ed. Chris Heymans and Gerhard Tötemeyer. Cape Town: Juta.

Whelan, Paul. 2002. "Local Government Revenue.” Occasional Paper, Idasa Budget Information Service, Cape Town.

2003a. “The Local Government Grant System, Paper One: A Researcher’s Guide to the Local Government Grant System." Occasional Paper, Idasa Budget Information Service, Cape Town.

. 2003b. "The Local Government Grant System, Paper Two: Evaluating the Local Government Grant System.” Occasional Paper, Idasa Budget Information Service, Cape Town.

2004. "A Review of Selected Local Revenue Reforms." Occasional Paper, Idasa Budget Information Service, Cape Town. 


\section{Local Government \\ Organization and Finance: Uganda}

J E S P E R S T E F F E N S E N

Tn recent years, most Sub-Saharan African countries have been involved in comprehensive reforms of their public administrative systems, focusing on decentralization as a major tool to improve efficiency in public service delivery and strengthen involvement of citizens in decision-making processes. ${ }^{1}$ Uganda has made a fundamental change in the organization of the public sector and the system of service delivery by embarking on radical decentralization.

This chapter provides a broad overview of the system of local government finance in Uganda. It briefly describes the structure of local government, expenditure and revenue assignments, overall system of local government finance, experiences with revenue mobilization, and intergovernmental fiscal relations, including transfer systems. It outlines some key lessons learned from fiscal decentralization from 1994 to 2004.

Uganda's decentralization represents a radical reengineering of the mechanisms of governance toward political, administrative, and fiscal devolution of power. It happened quickly and with strong political commitment from the top. Strong political belief in decentralization as a way to involve and get political support from the people (particularly in rural areas) and as a means to ensure more efficient service delivery-combined with the failure of the previous 
centralized systems-explains the initial speed of the reforms. The fiscal reform was an important pillar in this development, although it has taken place with less speed and more caution than reforms of administrative, legal, and political processes. However, in recent years, a number of innovative reforms have been initiated in that area as well.

\section{Background}

The local government system in Uganda can be traced to structures established by the British colonial powers around 1900. ${ }^{2}$ These structures were, in turn, based on the chief system of authority in Central Uganda (Buganda).

The most fundamental changes manifested in the present system are the post-1986 reforms, after the National Resistance Movement (NRM) took power. One of the first reforms was the countrywide introduction of the Resistance Council system. This system was a hierarchical structure of popularly elected councils and committees from village level to district level. The structure was based on experience gained from NRM's mobilization of the population during the protracted guerrilla war against the previous regimes (1981-86).

A number of legislative and administrative reforms followed. The policy aim was initially stated as empowering local residents for enhanced political participation and democratization (Decentralisation Secretariat 1994). Later phases of reform focused more on administrative aspects and also started to emphasize improved services. In 1994, the Ministry of Local Government (MoLG) summarized the decentralization policy objectives:

In sum, decentralisation is a democratic reform, which seeks to transfer political, administrative, financial, and planning authority from the centre to local government councils. It seeks to promote popular participation, empower local people to make [their] own decisions, and enhance accountability and responsibility. It also aims at introducing efficiency and effectiveness in the generation and management of resources and in the delivery of services (Decentralisation Secretariat 1994).

The implementation of the reform progressed rapidly and consistently from 1993 to 1997 with the introduction of a number of supportive laws (including the Local Government Statute of 1993), the establishment of district service commissions, and especially the enactment of the detailed constitution of 1995, followed by the Local Government Act of 1997 (LGA).

\section{Legal Status and Autonomy}

The autonomy of local governments is derived from the 1995 constitution and the 1997 LGA. 


\section{Uganda's 1995 Constitution}

The principles of a very decentralized system of local government, already outlined in the 1993 statute, were further entrenched in the constitution. The constitution deals elaborately with the system of local government. Chapter 11 outlines the principles and structures of local government, the main functions and finances of local governments (even the types of grants to be transferred to them), the establishment of district service commissions (DSCs), and (among other provisions) the establishment of the Local Government Finance Commission (LGFC).

\section{The Local Government Act of 1997}

The LGA, ${ }^{3}$ which is very detailed, contains a number of articles relevant to the expenditure and revenue assignments of local governments:

Schedule 2 describes these expenditure assignments in detail. Local governments' responsibilities for service provision are stipulated, but the law allows them flexibility in choosing methods of service delivery, for instance, by using nongovernmental organizations (NGOs) or the private sector. It thus allows district and urban councils to abolish offices (but not functions) in the public service (section 53).

- A distinction is made between local governments and local administrative units (sections 4 and 46). Local governments in the rural areas are the district councils and the subcounty councils; similar provisions are made for urban areas. These councils are corporate bodies. Local administrative units exist in the rural areas at county, parish, and village levels.

- Details are provided regarding how a number of administrative functions are separated from the councils. The DSCs, tender boards, and local government accounts committees are made more independent of the local councils. Thus, they need to be reconstituted, without members from the councils.

- It is specified that the subcounty councils retain at least 65 percent of locally raised revenue; lower-level urban councils retain 50 percent of locally raised revenue.

- The law stipulates that up to 15 percent of local revenue may be paid as allowances for councilors, executives, and members of the DSCs and other council committees (later this was changed to 20 percent). DSCs are now paid from the consolidated fund and not from local revenues.

Several measures are added to promote transparency, such as the publication of quarterly summaries of all tenders awarded (sections 92-98), and various details regarding audits and their follow-up (sections 87-91). 
The law details responsibilities for inspection, monitoring, and coordination of local government (part IX) by line ministries, the MoLG, and the inspector general of government, as well as the resident district commissioner (sections 71 and 72).

\section{Links between the Local Government Act and Sector Legislation}

During the decentralization process, a number of sector laws and regulations have been aligned with the LGA and the decentralization policy. However, reviews have identified a number of outstanding areas and specific issuesareas where sector regulations and practices are inconsistent and potentially undermine decentralized service delivery. A larger legal and regulatory harmonization process will be launched soon under the Joint Annual Review of Decentralisation, supported by the second Local Government Development Program (LGDP-II) (Steffensen, Ssewankambo, Tidemand, and others 2002).

\section{Status as of 2004}

In 2004, the decentralization process was at a critical stage. Assessments of experiences were debated, and reforms, some quite wide ranging, were considered.

The existing system has pursued improvements in the democratic legitimacy and accountability of local governments. Councils and their chairpersons are directly elected through a competitive system (however nonpartisan); provision has been made for minimum quotas of women, youth, and people with disabilities in councils. Democratic control of local government affairs is further enhanced through the committee system, which ensures the joint participation of elected councilors and civil servants in decisions on service delivery and management.

There is minimal interference in local affairs from the central government. No central appointees or national members of parliament sit in local government bodies, the role and powers of the resident district commissioners have been greatly diminished, and the MoLG has no powers to approve budgets. However, the sectoral allocation of funds through the earmarked conditional grant system has ensured detailed control of local government adherence to national priorities and targets, especially because the implementation of fiscal decentralization strategy has been slow.

Local governments have legal status and are formally accountable. They are autonomous corporate bodies, which can thus sue and be sued, manage funds, enter into contracts, employ staff, and be held legally accountable. 
Local governments have a clear mandate to provide services. The functions and services of central government and those of local governments at various levels are rather clearly distinguished to minimize overlap and conflict.

There is decentralization below district levels. Functions and resources are assigned to lower local governments and administrative structures to enable more effective public participation in making decisions and monitoring administrations.

Local governments have control over local civil servants. In 1993, local governments-through their DSCs-began to take on direct personnel management responsibility for all local civil servants deployed at the district level who are directly hired (and fired) by district councils. This step greatly reinforced the local accountability of civil servants.

Local governments have powers to enact local legislation to back up policy implementation-for example, to control the use of local natural resources or sanction urban pollution. They are also empowered to levy prescribed taxes. Furthermore, the lowest local government level is empowered to retain 65 percent of all revenue collected.

The local government system is enshrined in the 1995 constitution. That document describes the system in great detail and protects local governments against constitutional amendments that may substantially alter the system without their consent.

Despite these achievements, there are also great challenges facing the overall decentralization process.

\section{Constitutional Review and Legal Revisions}

Currently, Uganda is reviewing its constitution. The MoLG is also reviewing the LGA against practical experiences with its implementation. The two most important issues pertain to the possible introduction of a regional tier and forms of federal governance and the possible centralization of some elements of personnel management-in particular the appointment by the central government of the chief administrative officer (CAO). These two issues have been raised partly as a result of substantive political and cultural aspirations for greater autonomy in Buganda and partly as a result of concerns about the current levels of autonomy of local governments and the wish to strengthen control.

The proposals present some grave risks for the future of devolution in Uganda. Introduction of regional tiers is not well justified on technical grounds but pushed mainly for political and cultural considerations. Much 
will, however, depend on the practical approach to the possible introduction of regions (see Steffensen and Tidemand 2004).

The possible centralization of some elements of local government personnel administration constitutes a more fundamental threat to decentralization by devolution for two basic reasons: first, central government appointment of the $\mathrm{CAO}$ will cut a crucial accountability link between the elected local councils and the local government staff; second, such an approach to solving administrative problems in local governments (through centralization) may result in a snowball effect, whereby local accountability mechanisms become totally undermined.

\section{Structure of Local Governments}

Local government in Uganda is a multitier system with the district, city council, and municipalities as units under which are lower local government structures and administrative units (figure 3.1).

The local governments are corporate bodies, with perpetual succession and a common seal; they may sue or be sued in their corporate names (LGA, section 7). The chairs of all local governments are elected through universal adult suffrage and secret ballot. Local governments have powers to approve plans and budgets that incorporate plans of lower local councils. Unlike local governments, the administrative units ${ }^{4}$ are not corporate bodies.

Apart from county councils, both local governments and administrative units have autonomy in planning and initiating self-help projects. Both local governments and administrative units receive or retain a share of local revenues, resolve problems or disputes at their level, monitor delivery of services, and assist in the maintenance of law, order, and security.

\section{Political Structures}

At the district and city levels are the district and city councils, the highest political authorities in the local government's jurisdiction. The district or city council is composed of one councilor directly elected to represent each electoral area of a district, two councilors (one female) representing the youth in the district, and two councilors with disabilities (one female), representing people with disabilities. Women councilors form one-third of the council. The chair of the district council ${ }^{5}$ is the political head of the district and answerable to the council (1995 constitution, article 183; LGA, section 13) (see figure 3.1). 


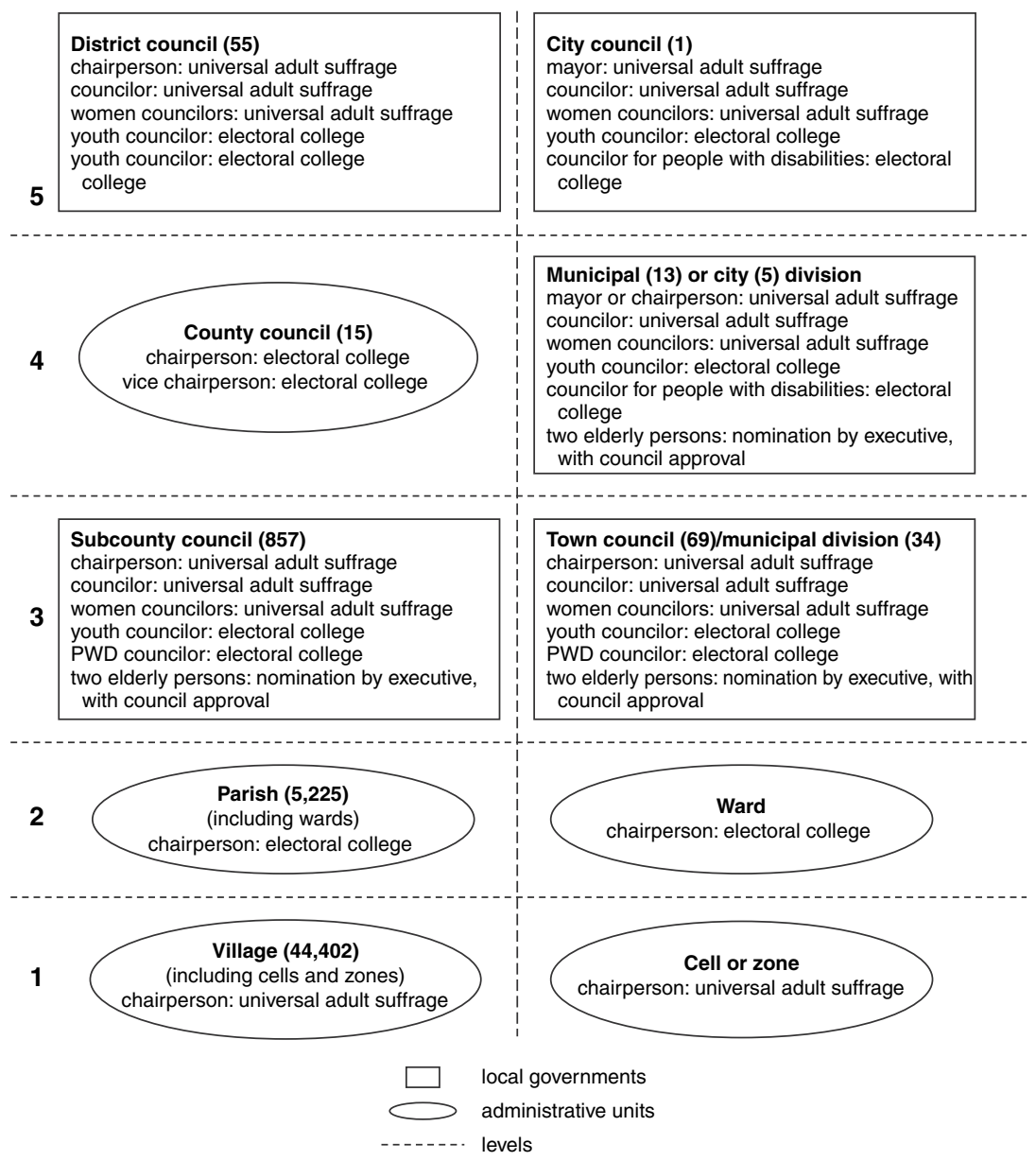

Source: Steffensen, Tidemand, and Ssewankambo 2004.

Note: All elections are by secret ballot.

\section{F I G U R E 3 . 1 Local Council Elections}

The district and city councils have planning, legislative, and executive powers (LGA, section 10). The district council is the planning authority of a district. Among the functions and powers of a local government council not to be delegated are approvals of annual budget estimates and development plans (LGA, schedule 4). Subject to the provisions of the constitution and any other law, a district or city may establish or abolish offices in the public service of a district or urban council in accordance with staff regulations made under the LGA (section 53). 
A district council has powers to make regulations not inconsistent with the constitution or any other law enacted by the legislature. Each district has a district executive committee (DEC), consisting of the district chairperson, the vice chairperson, and such number of secretaries (not exceeding five) as the council may decide. There are also several standing committees.

\section{Elections}

As at the national level, there are no political parties at the local government level. The local government elections are held under the movement political system, which is broad based, inclusive, and nonpartisan, relying on individual merit as a basis for election to political offices.

\section{Administrative Structure at District and City Councils}

The $\mathrm{CAO}$ for a district and the town clerk for a city are the chief accounting officers for the district and city, leading an elaborate administrative system with several sector departments. The DSC appoints the CAO or town clerk. The CAO or town clerk is responsible to-and subject to the general direction of - the chairperson and the district council.

Several statutory bodies, including the following, have been established to support local government administration and to ensure that certain functions are performed independently of day-to-day political influence:

- The DSC is appointed by the district council on the recommendation of the DEC, with the approval of the public service commission. The DSC is the hiring authority of the local governments.

- The local government public accounts committee (LGPAC) consists of four members appointed by the district council on the recommendation of the DEC (LGA, section 89). It examines the reports of the auditor general and chief internal auditor and any reports of commissions of inquiry and then reports to the local council and the minister responsible for local government, who is supposed to lay the report before parliament.

- Tender boards (district and urban) are formed in each district and are supposed to provide services to the district councils, subcounty councils, and administrative units in that district.

\section{Oversight Functions}

A number of institutions at the central government level are responsible for supporting local governments in delivering their mandated functions under 
the decentralized system. They include the MoLG, the Ministry of Public Service (MoPS), the Ministry of Finance Planning and Economic Development (MoFPED), and line ministries. The line ministries are responsible for ensuring implementation of national policies and adherence to performance standards on behalf of local governments, inspection, monitoring, technical advice, support, supervision, and training (LGA, section 97).

\section{Links between the Layers of Government}

Overall, the local government system is based on the principles of subsidiarity and integration without subordination. Every local government may, subject to the provisions of the constitution, enjoy or suffer anything that may be done, enjoyed, or suffered by a corporate body (LGA, section 7). Each local government therefore has the right and obligation to formulate, approve, and execute its budgets and plans, provided that the budgets are balanced (LGA, section 78). However, the comprehensive and integrated development plan prepared by the district is supposed to incorporate plans of lower local governments, and those governments are expected to prepare plans incorporating the plans of lower councils in their jurisdiction (LGA, section 36). The district is also supposed to mentor and support the lower local governments.

\section{Reforms of the Local Government Structure}

In 2001, the number of districts increased from 45 to 56 . In financial year (FY) 2003/04, six new town councils were formed, increasing the number of urban authorities to 69 . Some local governments are not viable - they are too small in terms of population and local revenue potential. Hence, they have become overly reliant on central government transfers, which are greatly earmarked, thereby affecting their autonomy. The establishment of new local governments has sometimes not been based on a thorough analysis of their economic sustainability — their ability to generate sufficient revenues and ensure administrative and political capacity to run council affairs efficiently. However, a more fundamental reform of the entire system of administration and structures is under consideration-namely, the introduction of a regional tier of government between the central government and the district level.

\section{Brief Overview of Revenue and Expenditures}

Fiscal decentralization is enshrined in the constitution of 1995 and in the LGA, which describes in detail the system for funding local governments' 
service delivery. The overall system of public government finance is characterized by a significant share of local government expenditure. However, most of it is financed by conditional grants from the central government.

\section{Local Government Expenditures}

The local government share of the total public sector increased significantly with the transfer of new tasks and responsibilities from the central to the local governments in the late 1990s. However, it has stabilized. Particularly, central government transfers to local governments as a share of the total public budget have increased considerably in recent years, to 36 percent in FY 2002/03 (excluding donor project funding and interest payments) - 27 percent including all funding sources. ${ }^{6}$ Using only this indicator, Uganda is one of the most decentralized countries in Africa. ${ }^{7}$

In nominal figures local government expenditures have increased nearly threefold from 1997/98 to 2002/03. They were budgeted at U Sh 735 billion in FY 2002/03, or approximately US\$17 per capita (figure 3.2).

\section{Local Government Revenues}

Local governments are heavily and increasingly dependent on transfers from the central government. Figure 3.3 illustrates the relative share of the grants and local governments' own-source revenues, showing the increasing dependency on central government transfers (see also table 3.1 on pages 105-8).

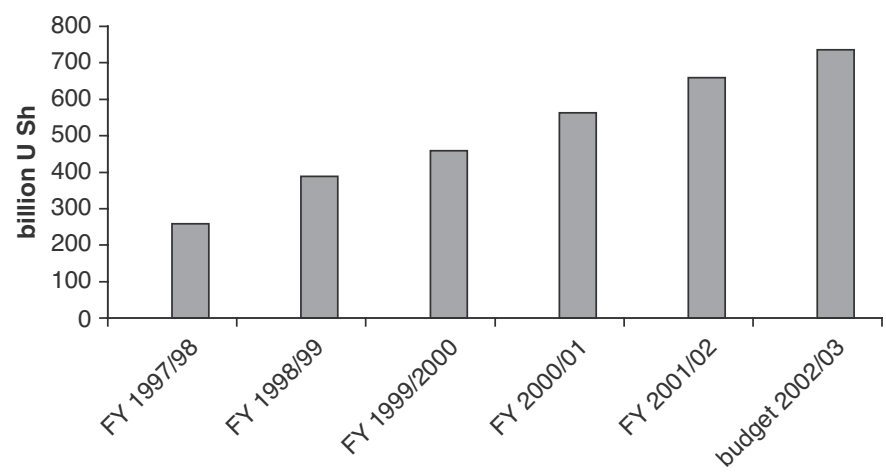

Source: MoFPED, accounts collected by Macro Economic Department, 2003; Steffensen and Tidemand 2004, annex 4.2 .

F I G U RE 3 . 2 Development in Local Government Expenditures 


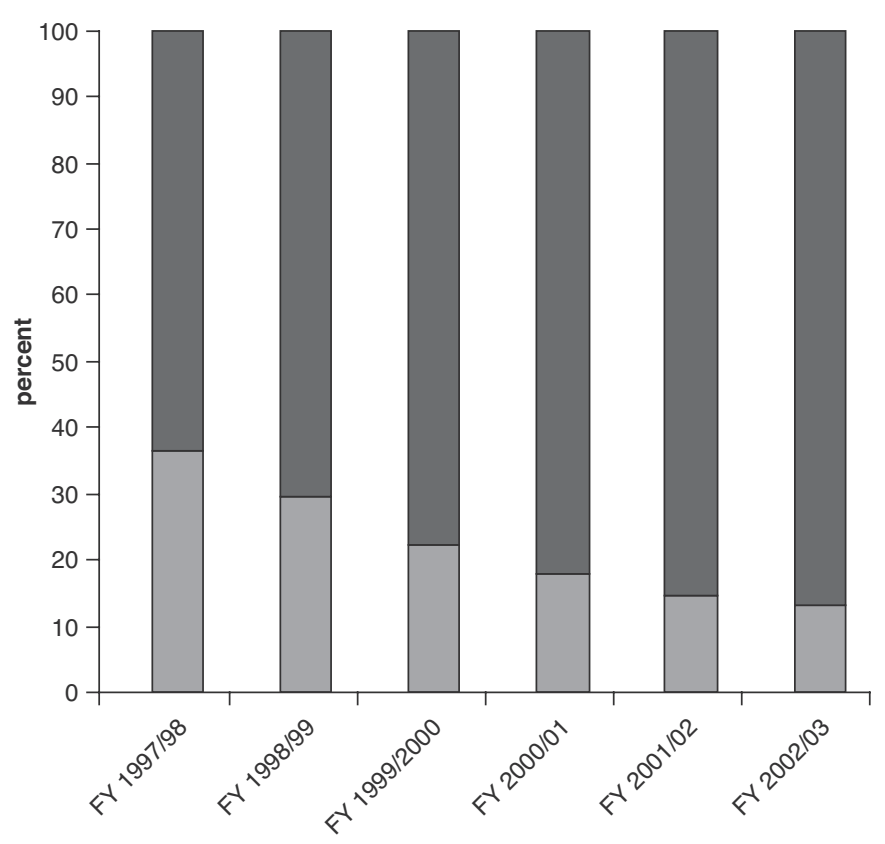

$\square$ local revenue as a percentage of total revenue

$\square$ total grants as a percentage of total revenue

Source: Based on figures received from the LGFC and Steffensen, Tidemand, and Ssewankambo 2004, annex 4.2, table set 4 .

Note: For FY 2002/03, figures for local government own-source revenues are based on a large sample from 2001/02 downsized by an expected decline (5 percent) to FY 2002/03.

\section{F I G U R E 3 3 3 Composition of Total Local Government Revenue}

Local governments' share of own-source revenue has declined significantly since $1997 / 98$. It contributes only 13 to 15 percent of all local government revenue-even less in the rural districts. The grants, most of them conditional, constituted 85 percent of all local government revenue in 2001/02. Although there were some signs of a smaller improvement in local government mobilization of own-source revenue in 2004, ${ }^{8}$ this trend could be reversed by the president's announcement that the graduated tax (G-tax) would be abolished in 2005/06 (New Vision May 1, 2004).

This downward trend has raised serious concerns about important issues such as (a) sustainability and viability of the system of local government; (b) local government ownership and incentives to perform efficiently; (c) risk of reduced accountability as the links between services and taxes are blurred; (d) reductions in local government autonomy and the ability to 
address local priorities and needs, because most of the transfers are conditional (earmarked); and (e) ability to maintain investments in terms of cofunding obligations, operational and maintenance costs, and so forth.

\section{Local Government Expenditures}

\section{Local Government Expenditure Assignments}

Local governments are responsible for most services to citizens, such as primary education, health, roads, agriculture extension, and water and sanitation. The central government is present in policy making, regulation of local governments, and certain national key functions. Table 3.1 outlines the key responsibilities for service provision in the main sectors and the extent to which legal or other issues are outstanding.

Figure 3.4 shows the sector distribution of local government expenditure in the 2002/03 budget. Education is by far the most important sector in terms of share of local government expenditure (more than 40 percent). It is followed by administration ( 25 percent $)$ - which also encompasses costs for political functions and for general and financial administration-and then by health (16 percent). The health and agriculture sectors, although small compared with education, have increased in importance.

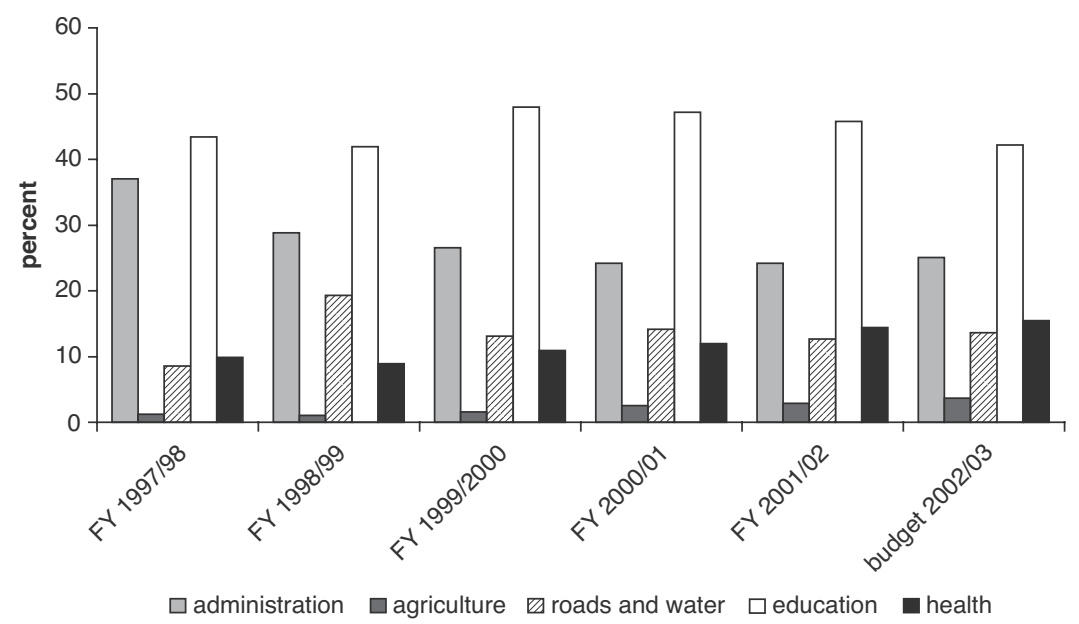

Source: MoFPED 2003b; Steffensen, Tidemand, Ssewankambo 2004.

F I G U R E 3 . 4 Sector Distribution of Local Government Expenditures, Budget 2002/03 
TA B L E 3 . 1 Functional Assignments for Local Services in Uganda

\begin{tabular}{|c|c|c|c|c|c|}
\hline Function & Water supply & Education & Health & Roads & Agriculture \\
\hline $\begin{array}{l}\text { Main local } \\
\text { government } \\
\text { functions }\end{array}$ & $\begin{array}{l}\text { Local governments are } \\
\text { responsible for providing } \\
\text { and maintaining water } \\
\text { supplies. However, the } \\
\text { Ministry of Water, Lands, } \\
\text { and Environment has } \\
\text { established water boards } \\
\text { and water user } \\
\text { associations to manage } \\
\text { water facilities in towns } \\
\text { and rural growth centers. }\end{array}$ & $\begin{array}{l}\text { Primary education: } \\
\text { Local governments are } \\
\text { responsible for } \\
\text { constructing classrooms } \\
\text { and teachers' houses, } \\
\text { inspecting schools, and } \\
\text { recruiting teachers. } \\
\text { Secondary education: } \\
\text { Functions are only partly } \\
\text { decentralized to local } \\
\text { governments. }\end{array}$ & $\begin{array}{l}\text { Local governments } \\
\text { are responsible for } \\
\text { medical and health } \\
\text { services. Local } \\
\text { governments are } \\
\text { responsible for } \\
\text { hospitals except for } \\
\text { referral and medical } \\
\text { training. }\end{array}$ & $\begin{array}{l}\text { Local governments } \\
\text { are responsible for } \\
\text { district and feeder } \\
\text { roads and all streets } \\
\text { in the municipalities } \\
\text { and cities, as well as } \\
\text { for community roads. }\end{array}$ & $\begin{array}{l}\text { Local governments } \\
\text { are responsible for } \\
\text { providing agriculture } \\
\text { extension services to } \\
\text { farmers. }\end{array}$ \\
\hline $\begin{array}{l}\text { Policy and sector } \\
\text { coordination }\end{array}$ & $\begin{array}{l}\text { The Ministry of Water, } \\
\text { Lands, and Environment } \\
\text { is responsible. }\end{array}$ & $\begin{array}{l}\text { The Ministry of Education } \\
\text { and Sports is responsible. }\end{array}$ & $\begin{array}{l}\text { The Ministry of } \\
\text { Health is responsible. }\end{array}$ & $\begin{array}{l}\text { The Ministry of } \\
\text { Works, Housing, and } \\
\text { Communication is } \\
\text { responsible. }\end{array}$ & $\begin{array}{l}\text { The Ministry of } \\
\text { Agriculture and } \\
\text { Animal Industries is } \\
\text { responsible. }\end{array}$ \\
\hline $\begin{array}{l}\text { Planning at local } \\
\text { level }\end{array}$ & $\begin{array}{l}\text { Rural areas: Local } \\
\text { councils and local } \\
\text { governments are } \\
\text { responsible. } \\
\text { Towns: Water boards in } \\
\text { liaison with local } \\
\text { governments are } \\
\text { responsible. }\end{array}$ & $\begin{array}{l}\text { Responsibility lies with } \\
\text { school management } \\
\text { committees, local } \\
\text { councils, the district } \\
\text { education office, and } \\
\text { district technical } \\
\text { planning committees. }\end{array}$ & $\begin{array}{l}\text { Responsibility lies } \\
\text { with health } \\
\text { management } \\
\text { committees, local } \\
\text { councils, the district } \\
\text { directorate of health } \\
\text { services, district }\end{array}$ & $\begin{array}{l}\text { Responsibility lies } \\
\text { with lower local } \\
\text { councils, the } \\
\text { directorate of works, } \\
\text { district technical } \\
\text { planning committees, } \\
\text { and the council. }\end{array}$ & $\begin{array}{l}\text { Lower local councils } \\
\text { (subcounties) }\end{array}$ \\
\hline
\end{tabular}


TA B L E 3 3 1 Functional Assignments for Local Services in Uganda (continued)

Financing

Costs are funded mainly by central government transfers, but also by community contributions (user fees), especially for operation and maintenance costs and especially in urban areas
Primary education:

Except for private schools, costs are funded entirely by central government transfers under the Universal Primary Education Program.

Secondary education:

Costs are partly funded by central government transfers (for salaries and limited supplies), but parents make huge contributions through school fees. The private sector is increasingly investing in education.
Health

Roads

Agriculture

planning

committees,

and the council.

Salaries and supplies are funded mainly by central government transfers. Patients pay in private health facilities or private wings of public facilities.

Rehabilitation and maintenance of feeder and district roads are funded by central government transfers.

Trunk roads are funded by the central government. Community and access roads are funded by local governments and (in poorer states) by community members.
A number of conditional grants are offered by the central government, especially for funding agriculture extension services. 
Monitoring and
regulation

\section{Construction and} implementation
The directorate of water development and district water office are responsible.

The Ministry of Education and Sports and district education office are responsible.
The Ministry of Health and distric directorate of health services are responsible.
The Ministry of Works, Housing,

The Ministry of

Agriculture and

and Communication Animal Industries is and (at the district responsible. level) directorate Various programs, of works are responsible.

such as the

Plan for the Modernisation of Agriculture secretariat, exist.

The tender board procures private contractors. Private contractors are in charge of implementation and construction. The district water office is in charge of supervision and certification. Water users also oversee construction.

The tender board
procures private
contractors. Private
contractors are in
charge of
construction. The
district education
office and district
engineer are in
charge of
supervision. School
management
committees also
oversee construction.

The tender board procures private contractors. Private contractors are

in charge of construction. The district directorate of health services and district engineer are in charge of supervision. Health management of supervi committees also oversee construction.
The tender board The tender board procures private procures private contractors. Private contractors. Local contractors are in governments have charge of construction, but in some difficulty distinguishing between private cases the districts and public implement directly. goods in the The Works Department is in charge productive sector to determine items eligible for central government funding. 
T A B L E 3 . 1 Functional Assignments for Local Services in Uganda (continued)

\begin{tabular}{|c|c|c|c|c|c|}
\hline Function & Water supply & Education & Health & Roads & Agriculture \\
\hline $\begin{array}{l}\text { Service delivery } \\
\text { operations and } \\
\text { facility } \\
\text { management }\end{array}$ & $\begin{array}{l}\text { Urban areas: Water } \\
\text { boards, water } \\
\text { associations, and } \\
\text { private operators } \\
\text { are responsible. } \\
\text { Rural areas: Water } \\
\text { user committees in } \\
\text { liaison with local } \\
\text { governments are } \\
\text { responsible. } \\
\text { The government has } \\
\text { established regional } \\
\text { technical support } \\
\text { units parallel to the } \\
\text { local governments. }\end{array}$ & $\begin{array}{l}\text { Schools and } \\
\text { school management } \\
\text { committees are } \\
\text { responsible. The } \\
\text { head teacher is } \\
\text { the secretary. }\end{array}$ & $\begin{array}{l}\text { Health unit } \\
\text { management } \\
\text { committees are } \\
\text { responsible. The } \\
\text { medical staff } \\
\text { member in } \\
\text { charge is the } \\
\text { secretary. }\end{array}$ & $\begin{array}{l}\text { Local government, } \\
\text { through the Works } \\
\text { Department, is } \\
\text { responsible. }\end{array}$ & $\begin{array}{l}\text { The government is } \\
\text { exploring the most } \\
\text { relevant way } \\
\text { to provide } \\
\text { agriculture extension. } \\
\text { It is moving from } \\
\text { full-time extension } \\
\text { workers employed } \\
\text { by local } \\
\text { governments to } \\
\text { private providers } \\
\text { engaged by local } \\
\text { governments } \\
\text { under the } \\
\text { National Agriculture } \\
\text { Advisory Service. }\end{array}$ \\
\hline
\end{tabular}

Source: Steffensen, Tidemand, and Ssewankambo 2004. Further detail is available in that source. 


\section{Budget Approval}

Local governments approve their own budgets without interference from the central government. However, a number of checks and balances ensure adherence to national priorities and targets, especially through the strong earmarking of the conditional grants, central government support to local government planning and budgeting in the form of capacity building and guidelines, and fiscal incentives in the development funding scheme to focus on the key poverty alleviation areas (education, health, roads, agriculture, and water and sanitation).

\section{Local Government Revenues}

\section{Composition of Local Government Own-Source Revenues}

Own-source revenue for rural local governments has decreased significantly from 1997/98 to 2001/02 in nominal and real terms, while urban authorities kept nearly to the status quo. The district councils and subcounties, including Kampala City Council, have in aggregate figures experienced a decline in local government revenue sources from U Sh 103.5 billion in 1997/98 (US $\$ 3$ per capita) to U Sh 79.4 billion in 2001/02 (US\$2 per capita) or 30.4 percent. ${ }^{9}$ In real figures, the decrease is 37 percent. If Kampala is excluded, the nominal decrease is from U Sh 89.7 billion in 1997/98 to U Sh 58.8 billion in 2001/02, equal to 34.4 percent in nominal figures and 45.9 percent in real terms. In 2001/02, the total own-source revenue of local governments, including municipalities and town councils, was estimated at US\$2.40 per capita.

Table 3.2 shows the composition of all local governments' own-source revenues. The G-tax is by far the most important source, especially for rural districts; however, a downward trend has been observed recently. ${ }^{10}$ The composition varies greatly across types of local government. In FY 2001/02, the G-tax contributed only 16 percent and 36 percent, respectively, of the municipal councils' and town councils' own-source revenues. The property tax is increasingly important in urban areas but is still insignificant in rural districts.

Studies of the reasons behind the observed decline in own-source revenues have shown that the problem is complex and that a number of factors interact:

Political interference from the center-especially competition to please voters during presidential election campaigns 
Local politicians going for "quick wins" instead of sustainable solutions

- The strong increase in transfers from the central government, leading to less incentive to collect local taxes

Unfavorable local government tax legislation

- Weak local government tax administration and enforcement capacity

- Lack of accountability and conducive links between local governments and citizens (low awareness, lack of trust)

- Increase in poverty in certain areas, although not a general trend.

The discouraging trend in local government revenues has led to a number of recent initiatives to boost revenue mobilization and to mitigate the challenges. Several studies have clarified the main problems and areas in need of support. The Local Revenue Enhancement Coordinative Committee, with key players from central and local government levels, has been established to coordinate all initiatives on local government taxation. Inventories of best practices have been carried out, and the findings were widely disseminated to all district and city councils. Local governments are required to plan and budget for a revenue enhancement strategy, and the LGFC has generally played a more active role in supporting the local governments technically in the field of revenue mobilization.

Probably most important, stronger incentives to improve local government revenues have been elaborated under the LGDP-II development transfer scheme, with performance rewards for good tax efforts in addition to cofunding obligations. Initiatives are under way to improve the legal framework for local government taxation - first and foremost, the Rating Act of 1979. LGDPII component 4 will assist in reforming some other tax assignments as well.

\section{TA B L E 3 , 2 Local Government Aggregate Own-Source Revenues} (percent)

\begin{tabular}{lccccrc}
\hline Year & G-tax & $\begin{array}{c}\text { Property } \\
\text { tax }\end{array}$ & $\begin{array}{c}\text { User fees } \\
\text { and charges }\end{array}$ & Licenses & $\begin{array}{c}\text { Other } \\
\text { revenue }\end{array}$ & Total \\
\hline $1997 / 98$ & 67.4 & 6.9 & 12.7 & 2.0 & 11.0 & 100 \\
$1998 / 99$ & 65.1 & 8.4 & 13.9 & 2.8 & 9.8 & 100 \\
$1999 / 2000$ & 64.2 & 9.3 & 14.7 & 3.0 & 8.9 & 100 \\
$2000 / 01$ & 62.2 & 6.0 & 10.8 & 1.8 & 19.2 & 100 \\
$2001 / 02$ & 52.0 & 13.6 & 18.5 & 3.6 & 12.3 & 100 \\
\hline
\end{tabular}

Source: Steffensen, Tidemand, and Ssewankambo 2004.

Note: The data should be treated with due caution; final accounts are not available for all districts, and extrapolations have been made. Totals may not equal 100 because of rounding. 
However, the effect of these initiatives will depend on support from the policy makers at the top_-political commitment to mobilize local revenues. The initiative to abolish one of the most important local government taxes, the G-tax, may undermine all other initiatives.

\section{Level of Local Government Autonomy over Own-Source Revenues}

The size of own-source revenues and amount of autonomy in local decision making depend on the abilities of local governments to adjust their ownsource revenues. Table 3.3 indicates the level of local government control of these taxes.

Local governments have certain autonomy to adjust their own-source revenues, within certain ceilings. Unlike in other countries, in Uganda budgets and revenue forecasts are not approved by the central government. However, the legal framework and the limited revenue assignments have generally not been favorable for local governments.

\section{Composition of Intergovernmental Fiscal Transfers}

Fiscal transfers are by far the most important local government revenue source. According to article 193 of the constitution, grants are typically classified as unconditional, conditional, and equalization grants:

- Unconditional grant (UCG) is the minimum grant that shall be paid to local governments to run decentralised services and shall be calculated in a manner specific in Seventh Schedule to this Constitution. ${ }^{11}$

- Conditional grants (CGrants) shall consist of moneys given to local governments to finance programmes agreed between the Government and the local governments, and shall be expended only for [the] purpose for which it was made and in accordance with the conditions agreed upon.

- Equalisation grant (EG) is money to be paid to local governments for giving subsidies or making special provisions for the least developed districts, and shall be based on the degree [to] which a local government unit is lagging behind the national average standards.

The intent of article 193 was that the unconditional grants should finance the gap between the revenue and expenditure assignments and finance part of the general administrative functions, whereas the conditional grants should finance the sector-specific tasks to enable local governments to achieve national sector targets. Equalization grants were supposed to equalize imbalances caused by disparities in revenue potential and expenditure needs. 
TA B LE 3.3 Tax Autonomy and Control

Level of government

\begin{tabular}{|c|c|c|c|c|}
\hline $\operatorname{Tax}$ & $\begin{array}{l}\text { Who sets rate } \\
\text { and ceilings? }\end{array}$ & $\begin{array}{l}\text { Who sets } \\
\text { tax base? }\end{array}$ & $\begin{array}{l}\text { Who collects } \\
\text { taxes? }\end{array}$ & $\begin{array}{l}\text { Who receives } \\
\text { yield? }\end{array}$ \\
\hline Income tax (pay as you earn) & Central & Central & Central & Central \\
\hline Corporate income tax & Central & Central & Central & Central \\
\hline Export-import tax and duties & Central & Central & Central & Central \\
\hline Value added tax & Central & Central & Central & Central \\
\hline $\begin{array}{l}\text { Graduated tax } \\
\text { (approximated income } \\
\text { and wealth tax) }\end{array}$ & $\begin{array}{l}\text { Central, for rates } \\
\text { and the tax bands } \\
\text { Local, for } \\
\text { assessments }^{\text {b }}\end{array}$ & $\begin{array}{l}\text { Local, for } \\
\text { identification } \\
\text { of taxpayersc }\end{array}$ & $\begin{array}{l}\text { Local, typically } \\
\text { through the } \\
\text { parish and sub- } \\
\text { county chiefs, } \\
\text { supported by } \\
\text { appointed revenue } \\
\text { collectors }\end{array}$ & $\begin{array}{l}\text { Local, with } \\
\text { revenue } \\
\text { sharing between } \\
\text { various levels } \\
\text { (lower local } \\
\text { governments } \\
\text { receive 65\%) }\end{array}$ \\
\hline
\end{tabular}

Comments and

main issues and

challenges

The yield has decreased significantly over recent years. It is hard to assess wealth in certain cases and define people in the correct bands. Low capacity and skills of tax collectors (such as the parish chiefs) are a problem. Serious flaws (including lack of registration and corruption) exist in the enumeration and assessment process in most local governments. There is discussion of abolishing this tax. 


\section{Property tax and tax}

on immovable property
Local, within a

ceilingd
Central and

locale
Local, but collection Local, with is sometimes privatized revenue sharing between various levels

\section{Market dues}

Licenses

Local

Loca
Local, but

collection is

typically privatized

Local, but

collection is often

privatized
Local, with revenue

sharing between

various levels

Local, with revenue

sharing between various levels
Valuation done by chief government valuer (centralized), which has led to severe bottlenecks. The tax is under reform. Under the Rating Act, the ceiling might be reduced. The key to improved yield is decentralization of valuation and flexibility to set the rates, ability to collect a flat rate from buildings not yet valued, and the extent to which persons and institutions are exempt - combined with strong capacity building in the local governments.

Multiple and overlapping dues and charges exist. Equity in the administration and collection procedures is a concern.

Handling of the contractors, especially delays, is a problem. Poor administrative practices exist in many local governments.

A large number of minor taxes and duties are collected by local governments (for example, bicycle tax).

Source: LGFC 2003 and various other sources.

Note: The Local Government Amendment Act of 2001, section 28 (amendment of section 81 of the LGA, states, "The minister may, by statutory instrument, and in consultation with the minister responsible for finance, declare the scale or rate of graduated tax to be levied by local governments throughout the country").

a. Levied on every male person 18 or older, and every female person of the same age engaged in gainful employment or a business. The LGA exempts certain groups of people. The minimum tax is U Sh 3,000 per month and the maximum is U Sh 100,000, stipulated by the minister of local government.

b. Assessment is typically done by the local government tax assessment teams, comprising technical staff from lower local governments.

c. Typically registration and enumeration is done by the village and parish chiefs.

d. There is a ceiling $(0-20$ percent of the rental value)

e. The tax is levied on the rentable value of land and buildings. The local government may grant complete or partial exemption from payment of rates. 
The grants were originally designed mainly to cover the recurrent budget. However, with the gradual decentralization of the development budget, especially after 1999/2000, development grants were introduced. They have characteristics of both unconditional and conditional grants.

In the first phases of the reform process, the costs of the decentralized services were not defined, and there has been continual discussion between the central government and local governments about the extent to which the grants have adequately compensated the additional costs (LGFC 2000b, 2002). Following is an overview of trends in the composition of the grants.

The share of unconditional grants has declined from 34.5 percent in $1995 / 96$ and 24 percent in 1997/98 to 11 percent in budget 2003/04 (table 3.4). The conditional development grants have increased from 0 percent to 25 percent over the same period. Of these development grants, sectorspecific conditional development grants constitute the largest share (63 percent). Conditional recurrent grants have decreased a bit, but taken together with conditional sector-specific development grants, the total sector-specific conditional grants have increased, constituting 79 percent in budget 2003/04 (up from 75 percent in 1997/98).

Along with the rapid increase in the size of the grants, the number of grants and the earmarking of each grant have increased as well. The number of grants has increased significantly, from 12 in FY 1996/97, to 19 in 2000/01, to 37 in FY 2003/04 (26 sectoral and 11 nonsectoral grant schemes)—each with their own modalities, grant allocation formulas, and reporting systems (Donor Sub-group on Decentralisation 2001; OnyachOlaa 2003; Steffensen and Tidemand 2004).

Most of the transfers are directed toward the key areas of the Poverty Eradication Action Plan—education, health, roads, water, and production. These conditional grants take up 78 to 79 percent of the total transfers. Most of the nonsectoral development grants are used in the same areas, bringing total transfers to these five areas up to 85 percent of all transfers. The remaining transfers are unconditional and other grants, which typically cover costs in the general administration.

The equalization grant is very small and constitutes only 0.4 to 0.5 percent of all transfers (see table 3.4).

\section{Unconditional Grants}

The unconditional grant was supposed to be paid to local governments to run the decentralized services. Although the grant has increased in nominal terms since 1997/98, it has decreased in relative importance, and it has been criticized for not tracking with the decentralization of tasks and responsibilities 
TA B LE 3 . 4 Developments in Grants and Composition

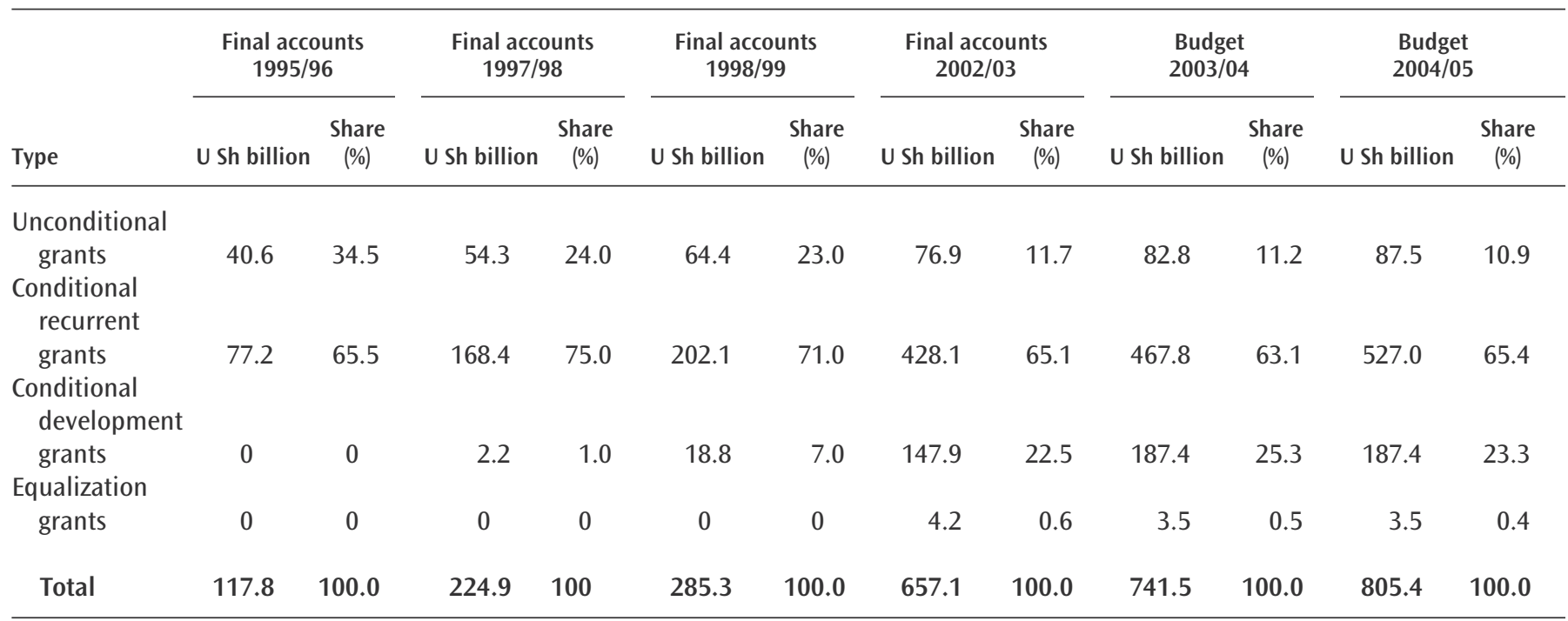

Source: Composed of figures from the Decentralisation Secretariat, MoLG, MoFPED, LGFC, and Steffensen, Tidemand, and Ssewankambo 2004

Note: Final accounts and releases are provisional. Columns may not sum to totals shown because of rounding. 
and the economic growth in the country (LGFC 2000b; ULAA and UAAU 2003). In budget 2003/04, the grant constituted U Sh 83 billion, or 11 percent of all grants to local governments.

Most unconditional grants are used for fixed salary costs in the local governments. The grant has become more a grant for funding fixed administrative salary costs of the basic local government administration (decentralized staff) than a genuine unconditional (discretionary) grant for service delivery and development. Some local governments cannot finance their fixed administrative costs for wages in the general administration even with the unconditional grants, whereas others have a surplus to be used for other cost items.

The allocation formula for the unconditional grant has changed twice. Initially, the formula contained four criteria: child mortality rate, school-age population, general population, and area. Subsequently only two criteriapopulation ( 85 percent weight) and area (15 percent) - were applied, after allocating a fixed amount to each local government for basic costs (U Sh 150 million) and some minor historical transfer items (accounting for 10 to 15 percent of the total) (Donor Sub-group on Decentralisation 2001, 16; Steffensen and Trollegaard 2000, 153). In practice, the unconditional grant has been divided into salary and nonsalary components. Because of problems with salary arrears in some local governments and imbalances between salary obligations (staff on the payroll) and the grants, the formula was changed again to take into consideration the existing payroll of local governments, on the basis of the size of the payroll of the administrative staff (58 percent), the population (36 percent), and the area ( 6 percent). The grant now provides about nine months of funding of the staff on payroll for each district, according to existing staff commitments (LGBC 2003, 56). The new allocation principles, which were put in place to reduce arrears in salary payment, reward districts with an already high number of staff on the payroll. These principles could introduce the incentive for local governments to increase administrative salary expenditures and are also unfair to local governments that have fewer staff members on the official payroll.

The reform of the entire structure of local government administration is expected to change the allocation formula to ensure funding of minimum staffing structures. Unresolved issues include the links between the administrative restructuring and the disparities across local governments in expenditure needs and revenue potentials and the links to the equalization grants, the incentives that the allocation criteria will provide, and the level of autonomy that local governments will be given in using the unconditional grant. 


\section{Conditional recurrent grants}

The expansion of the conditional grant system should be seen in connection with the Heavily Indebted Poor Countries (HIPC) Initiative and the establishment of the Poverty Action Fund (PAF) (box 3.1)

The large number of conditional grants has ensured funding for crucial service and infrastructure but has also created a number of challenges. Each grant has its own budget lines (restrictions on use), transfer modalities, and guidelines and reporting system, creating limited autonomy, flexibility, and efficiency in use-coupled with significant transaction costs for local governments in adhering to the complex modalities. This situation undermines the decentralization objectives and compromises the efficiency gains. ${ }^{12}$

\section{B O X 3. 1 The Poverty Action Fund, the Heavily Indebted Poor Countries Initiative, and the Fiscal Decentralization Strategy}

One of the vehicles for the large increase in transfers was the Poverty Action Fund (PAF), which was established in 1998. This fund was a mechanism to demonstrate and ensure that resources from debt relief from the Heavily Indebted Poor Countries Initiative (Uganda was granted debt relief in 1998) and additional donor funds were channeled to the key priority sector areas in the Medium-Term Expenditure Framework. Already in FY 2000/01, the PAF accounted for 30 percent of the total government budget, of which 73 percent was transferred to the districts (Donor Sub-Group on Decentralisation 2001) a share that has been fairly stable in recent years. The PAF system has had a very important effect on the entire system of local government finance. Through a detailed system of conditional grants, it has earmarked the transfers to specific sectors and subsectors, aiming at providing the government and donors with confidence in local government adherence to the overall Poverty Eradication Action Plan. PAF funds have increased significantly, from U Sh 98 billion in 1998/99 to U Sh 692 billion in 2002/03 (Donor Sub-Group on Decentralisation 2001; MoFPED 2003a).

The large increase in transfers was not without problems, especially when coupled with numerous modalities for transferring funds, depending on the sector area and the donor agency. In the late 1990s, there was an increasing awareness of the problems these strictly earmarked funds created for local government efficiency in managing service provision - in terms of lack of autonomy to address local priorities; large administrative transaction costs (multiple budgeting, accounting, and reporting systems); the tendency to focus on upward instead of downward accountability; and so forth. The fiscal decentralization strategy (FDS), developed by the government and approved by the cabinet in June 2002, was designed to address these challenges (box 3.2).

Source: Steffensen and Tidemand 2004. 
This problem was the major reason behind the launching of the fiscal decentralization strategy (FDS) (MoFPED 2002). A comprehensive reform of the entire system of fiscal transfer, started in FY 2003/04, was piloted in 15 local governments and then rolled out in all district and city councils in 2004/05. The FDS is aimed at reducing local government transaction costs and improving allocation efficiency, autonomy, and accountability. Box 3.2 describes the main reforms to the recurrent grant system.

\section{B $\mathbf{0}$ X 3.2 Fiscal Decentralization Strategy: Recurrent Transfer Scheme}

The reform under the recurrent transfer scheme includes the following main activities:

Review sector policies to ensure adherence to the overall decentralization objectives and to enhance local government autonomy and flexibility in the use of grants $(2003 / 04)$.

Review allocation criteria to make them more transparent, poverty sensitive, and needs based and to make them more closely related to sector objectives (review 2003/04, expected implementation from 2005/06, according to interviews with the Local Government Finance Committee). The criteria will make significant changes in the allocation across districts.

Reduce the number of grants, to enhance allocative efficiency and local government autonomy. The grants will be grouped in six or seven sectors to establish common modalities, reporting systems, and so forth. Within each grant, budget lines will determine the spending on various items, especially development (if relevant), recurrent nonwage parts, recurrent wage parts, and projects (such as the National Agriculture Advisory Service), but the number of these earmarked areas will be kept to the bare minimum to ensure sufficient flexibility.

Create flexibility in the use of the grants. In 2004/05 (2003/04 for the pilot), local governments will be allowed 10 percent flexibility in the nonwage parts of recurrent grants within and across the Poverty Action Fund sectors (health, education, agriculture, roads, and water).

- Ensure future links between local government performance and the autonomy over and size of the grants. Systems are being elaborated to increase flexibility with improved local government performance, rewarding governments that perform well in terms of generic administration (planning, budgeting, accounting, transparency, and so on) and sanctioning the nonperformers. Over time, these systems are expected to affect the size of the allocation as well, and they already apply for the Local Government Development Program grants. 
Improve and simplify the reporting and monitoring systems. Common formats and reporting modalities have been elaborated for all grants to reduce the administrative costs of compliance.

Improve planning and budgeting guidelines. Guidelines to enable the local governments to use the increased flexibility and the new fiscal decentralization strategy reforms have been developed, and local governments have been trained in their use.

- Improve central government coordination of the monitoring and mentoring of local governments through two committees, the Local Government Budget Committee and the Local Government Releases and Operations Committee, with representation from key ministries and local governments and involvement and participation of local government representatives in all the above-mentioned initiatives.

- Increase focus on local government revenue-raising efforts through the budgeting process and the performance-based allocation system. The effect of the tax effort on the size of the grants is still limited to the local development grant, but such revenue-raising efforts are being considered for extension to other grants as well.

Source: Steffensen and Tidemand 2004.

\section{Development grants}

For various reasons, the decentralization of development assignments (and related grants) started late in the process of fiscal decentralization, but it has been stepped up in recent years. Development grants have increased from 1 percent of total transfers in $1997 / 98$ to 25 percent in budget 2003/04. Total development grants amount to US $\$ 4$ per capita. The discretionary nonsectoral development grants account for 37.3 percent of development grants and 9.5 percent of all grants to the local governments (Steffensen, Tidemand, and Ssewankambo 2004, annex 4.10). The remaining development grants cover education (the school facility grant), health, water, roads, and agriculture (table 3.5).

Table 3.5 shows that, in the increasing share of the development grants in the total transfers to local governments, nonsectoral discretionary development grants are gradually gaining in relative importance, together with the earmarked funding of agriculture activities. This trend indicates an increased fiscal decentralization, but a decentralization that has hitherto not been matched by increased flexibility in recurrent grants (which have been increasingly earmarked and sectoral).

Sector development grants are typically earmarked for development investments within the sectors. Nonsectoral grants have interesting 
TA B LE 3. 5 Composition of the Development Grants

\begin{tabular}{|c|c|c|c|c|c|c|}
\hline \multirow[b]{2}{*}{ Grants } & \multicolumn{2}{|c|}{ Budget 2001/02 } & \multicolumn{2}{|c|}{ Budget 2002/03 } & \multicolumn{2}{|c|}{ Budget 2003/04 } \\
\hline & U Sh billion & Share (\%) & U Sh billion & Share (\%) & U Sh billion & Share (\%) \\
\hline \multicolumn{7}{|l|}{ LGDP nonsectoral discretionary } \\
\hline grant & 32.0 & 22.1 & 41.9 & 27.4 & 65.0 & 34.7 \\
\hline Primary health care grant & 11.0 & 7.6 & 7.6 & 5.0 & 9.2 & 4.9 \\
\hline School facility grant & 55.0 & 37.9 & 53.8 & 35.2 & 59.8 & 31.9 \\
\hline Road maintenance ${ }^{a}$ & 12.5 & 8.6 & 10.5 & 6.9 & 9.3 & 4.9 \\
\hline \multicolumn{7}{|l|}{ Water and sanitation development } \\
\hline grant & 23.0 & 15.8 & 24.5 & 16.0 & 29.6 & 15.8 \\
\hline Netherlands development grant & 11.0 & 7.6 & 8.7 & 5.7 & 0 & 0 \\
\hline \multicolumn{7}{|l|}{ Other sectoral grants (National } \\
\hline \multicolumn{6}{|l|}{ Agriculture Advisory Service and } & 5.1 \\
\hline \multicolumn{7}{|l|}{ Other nonsectoral grants (such as } \\
\hline $\begin{array}{l}\text { Programme for Modernisation } \\
\text { of Agriculture) }\end{array}$ & n.a. & n.a. & 5.7 & 3.7 & 5.0 & 2.7 \\
\hline Total development grants & $144.5^{b}$ & 100 & 152.7 & 100 & 187.5 & 100 \\
\hline
\end{tabular}

Source: Steffensen, Ssewankambo, Tidemand, and others 2002, annex 2; LGFC 2003.

Note: $n$.a. $=$ not applicable. Totals may not equal 100.0 because of rounding.

a. Fifty percent of the road maintenance grant is estimated to be for development.

b. Based on analyses of data received from the MoFPED, FY 2001/02 and FY 2002/03 budget figures. 
characteristics that deserve further comment, illustrated by the experience with LGDP.

One of the major achievements of the LGDP ${ }^{13}$ is the successful piloting of the central government transfer of development funds to local governments based on a link between development grants, capacity-building grants, and a performance incentive system (see Steffensen, Ssewankambo, and van't Land 2002). Discretionary development funds have been transferred to local governments to the tune of US $\$ 1$ to US $\$ 1.50$ per capita through unique modalities. Apart from the smaller pilot schemes in agriculture, the LGDP has been the only mechanism through which discretionary development funds have been transferred to lower levels of local governments. The major characteristics of the grants are summarized in box 3.3.

The experience with the LGDP has been promising, and the benefits have been tested and proved in various studies (Donor Sub-group on Decentralisation 2001; Steffensen, van't Land, and Ssewankambo 2002). It is, for instance, interesting to observe that the local governments have used the local development grant in areas of particular importance for the implementation of the national poverty reduction strategy (roads, education, water and sanitation, and health), and the annual assessments of local governments have put performance development on the agenda.

\section{Equalization grants}

Equalization grants were perceived to have a significant role and were even detailed in the constitution. They were introduced in 1999/2000 and initially covered 10 districts (at U Sh 2 billion). Some U Sh 500 million was set aside for areas affected by insurgency. The coverage has gradually expanded to 34 districts, 6 municipalities, and 34 town councils in FY 2003/04. A complex distribution formula captures the expenditure needs of local governments (land area, kilometers of roads, and so forth) and proxies for their revenue-raising capacity.

Equalization grants are nonsectoral grants to support the weaker local governments. However, their size (only U Sh 4 billion, less than 1 percent of all grants) and the actual use of the funds have limited their role and effect. In addition, the grants have been criticized for being scattered across too many local governments, for lacking focus, and for lacking monitoring and followup. Finally, their link to other grants has not been clearly worked out. Some of the sectoral grants have poverty and needs-based criteria as well. According to the original calculation of the equalization grant in 1998/99, at least U Sh 12 billion should have been granted to equalize the differences in expenditure needs and revenue potential; however, less than U Sh 4 billion was granted. 


\section{B 0 X 3.3 Main Features of Local Development Grants under the Local Government Development Program}

The main characteristics of local development grants under the LGDP are as follows:

- They include a nonsectoral investment menu (discretionary) but incentives to spend at least 80 percent on national priority areas and reduce investments on non-service-oriented areas.

A certain percentage (15 percent) may be used for investment servicing and monitoring costs, including retooling.

A transparent formula based on two criteria-population size (85 percent) and land area (15 percent) - is included. Urban authorities get a higher per capita amount because of the perceived additional costs of expenditure assignments in urban areas.

- The allocation system distributes grants to all layers of local governments, which ensures that grant allocations reach the lower levels.

- Clear minimum conditions exist as fixed requirements of eligibility to receive the grants.

- There is a direct link between the size of the grant allocation and the performance of local governments, measured by the use of defined and agreed transparent generic indicators of administrative performance and national (external) assessments of local government performance. This link provides strong incentives for local governments to improve their performance.

A link exists between the local development grant and capacity-building grants in the sense that, if local governments fail to comply with the minmum conditions of the local development grant, they may still receive capacity-building grants to enable them to comply as soon as possible.

- The grants contain an incentive (through the performance measures) to enhance local governments' own revenue-raising efforts.

- There is a local government cofunding requirement, which is 10 percent of the grant.

Source: Steffensen and Tidemand 2004.

Therefore, the aim is now to concentrate the disbursement of equalization grant in fewer local governments to make the grant more useful. Initiatives are under way to increase the size of the grant. A review of the equalization grant was part of the review of the allocation criteria under the FDS.

\section{Other transfers of specific interest}

Uganda has designed a number of unique grants. One of the most interesting is the PAF monitoring grant, which sets aside funds for local government monitoring and accountability institutions such as the LGPACs and tender 
boards. These grants have had a positive role in support of the financial management and control system in local governments and have ensured funds for areas that were previously not fully prioritized and funded by them. Furthermore, as part of the new FDS procedures, local governments may spend 5 percent of the recurrent grants on monitoring and supervising projects to ensure proper planning, budgeting, maintenance, and follow-up. Finally, the grant system has been used to pilot various initiatives in some districts, which are rolled out later. An example is the nonsectoral grant under the Plan for the Modernisation of Agriculture.

\section{Other funding flows—on budget and off budget}

On top of these formal, budgeted transfers, historically there have been numerous transfers to specific districts that are neither coordinated nor based on a thorough analysis of needs and poverty concerns (Steffensen, Ssewankambo, Tidemand, and others 2002). Some districts have received development funds from the European Union, the Danish International Development Agency, the Netherlands Local Government Development Program, and the World Bank, on top of other development grants, whereas other local governments have received much less donor funding for development (for an overview of these programs, see MoLG 2002, xxvii; Steffensen, van't Land, and Ssewankambo 2002). Other investments in the districts are made by the central government and NGOs without being incorporated in the district budgets. A review in 2002 showed that U Sh 333 billion was budgeted for investments in local government services and infrastructure in FY 2001/02 (including a share of road maintenance). Only U Sh 145.5 billion (budget 2001/02) was transferred through the local government budgets and accounts in the form of development grants. Numerous studies have documented the problems - in terms of planning, budgeting, budget execution, and accountability constraints - with these multiple funding channels and the lack of information and overview of the funds transferred to local governments.

Resolving these problems calls for a more coherent effort and mainstreamed system to ensure that transfers are done in an objective, fair, equitable, transparent, and budgeted manner. The means identified has been the LGDP-II, which provides a common basis for coordinated and harmonized transfers of development funds to local governments. The LGDP-II is expected to play a strong role in streamlining these channels, in line with the folding in of donor support and sectoral grants to one coherent, on-budget, intergovernmental, fiscal transfer system.

Hence, most district support programs with investment funds have been mainstreamed and brought on budget with the commencement of the 
LGDP-II. The remaining programs with funds for investments in infrastructure and service provision outside the budgetary system are the Northern Uganda Social Action Fund, covering 18 districts and offering support of US\$3 to US $\$ 4$ per capita, and a few smaller district support programs.

\section{Timeliness in Transfers}

The predictability and timeliness of transfers to local governments have been problematic, although the situation had improved until 2002/03, when the increase in defense spending led to cuts that disrupted certain programs and activities (Kragh and others 2003, pp. v and 106). However, most of the grants to the local governments have been largely preserved, because the PAF arrangement has provided a budget shield against major cuts—especially regarding the PAF development expenditures-and the entire system is relatively predictable. Grants released in FY 2002/03 totaled U Sh 657 billion against the budgeted U Sh 670 billion (Kragh and others 2003), and the grants on salary had an overall budget realization of 98 percent. ${ }^{14}$ Some areas with shortfalls were the roads grants and district primary health care grants. Most grants have been at a level of 90 to 100 percent of the budgeted amount in recent fiscal years, ${ }^{15}$ but the transfer installments are sometimes delayed during the fiscal year.

Studies of the financial management performance of local governments show that the delays in transfer of funds negatively affect performance in service delivery, especially as investments are delayed, leading to bottlenecks and problems with contractors and financial management. The reasons for the delays (which typically last one to four months) are many and complex, ${ }^{16}$ but they often emanate from the lack of local government capacity to provide timely reporting (under requirements that are very demanding) on the use of funds already provided and to absorb the cash within the time available. There are also cash-flow problems at the center ${ }^{17}$ some caused by lack of government cofunding of donor development projects and the inefficient banking system. The delays are problematic for the execution of all local government budgets, especially at the beginning and end of the financial year. The last installment of transfers is typically submitted rather late in the financial year (June), thereby forcing local governments to use the funds very hurriedly or send the unused funds back to the MoFPED.

The design of the reporting and accountability system, with its requirements to submit more than 20 elaborated quarterly reports to the center and with various detailed modalities, has also been a major cause of some of these problems. This area is being tackled by the ongoing FDS implementation, 
to streamline, harmonize, and simplify all reporting modalities on the fiscal transfers.

\section{Use of Grants}

A number of factors can improve the use of transfers: strong supervision of local governments' use of conditional grants, as well as monitoring, supervision, and review of the quarterly reporting of grant use, combined with comprehensive expenditure tracking surveys that identify problems and lead to mitigating initiatives (World Bank 2003). For example, an expenditure tracking study conducted in 1996 showed that only 2 percent of public nonwage education spending reached schools in 1991, owing to theft and the use of funds by district councils for purposes other than those budgeted. In 1999, more than 90 percent of the intended funds reached the schools (Therkildsen n.d., based on Ablo and Reinikka 1998 and Collier and Reinikka 2001). Other sectors have also improved, although not yet to the same extent. Studies of the use of the nonsectoral LGDP grants have also shown promising results, if the grants are linked to a reward and sanction system that is based on performance and addresses local government incentives to use funds in the key national target areas.

\section{Allocation Criteria}

Allocation criteria vary greatly by type of grant. Most grant allocation criteria and grant modalities were analyzed in a recent comprehensive study (2002-03) that was part of the FDS, with specific recommendations on criteria and weights to be applied for each grant (LGBC 2003).

The objective is to elaborate new criteria that promote sector policies, that can ensure more equity across the country and that are transparent, objective, needs based, simple, easily understood, and perceived as fair in their effect on distribution. Recommendations from a study team have been scrutinized, and a close dialogue and negotiations have been conducted between the sector ministries and the local governments, represented by their associations. Tentative agreements have been reached on the basic parameters and the transitional schemes (to prevent making some governments losers, the system will be phased in). The criteria are being fine-tuned, and the new criteria are expected to be introduced in FY 2005/06.

So far, the new criteria for the sector-specific conditional grants are not linked to local government performance, revenue mobilization efforts, and 
other incentives. However, such links are being considered for the future system under the FDS.

\section{Local Government Borrowing and Debt}

Traditionally, local government borrowing has been a minor revenue source. According to article 195 of the 1995 constitution, "Subject to the provisions of this Constitution and with the approval of the government, a local government may, for the carrying out of its functions and services, borrow money or accept and use any grants or assistance as parliament shall prescribe."

According to schedule 5, part VI, article 21 of the LGA (as amended in 2001), a local government may raise loans by way of debenture, issue of bonds, or any other method, in amounts not exceeding 25 percent of locally generated revenue, provided that the local government council demonstrates ability to meets its statutory requirements.

Borrowing also needs the approval of the minister of local government if the amount to be borrowed exceeds 10 percent of the total amount the council is eligible to borrow. The auditor general must certify the books of accounts for the preceding year, the report must not be qualified, and the funds must be intended for investments in priority activities as identified by the whole council. Moreover, the executive committee of the local government must guarantee that repayment of the loan will not adversely affect the operations of the council and, in particular, that the council will be able to meet its statutory obligations, including payment of salaries.

Pending revenue receipts, the local government may obtain an advance of money not exceeding 10 percent of the approved budget as a temporary loan or overdraft and as part of the amount to be borrowed to defray that expenditure (LGA, schedule 5, part VI, article 21). There are no restrictions concerning the source of funding.

The newly adopted (2003) Public Finance and Accountability Act contradicts these provisions:

Subject to the provisions of the Constitution, the authority to raise money by loan, to issue guarantees, and to accept grants for and on behalf of the government shall vest solely in the minister [for finance] and no other person, public organisation, or local government council shall, without the prior approval of the minister, raise any loan or issue any guarantee, or take any other action, which may in any way either directly or indirectly result in a liability being incurred by government (part III, article 20). 
The minister for finance decides the terms and conditions. The act also stipulates strong control by the minister for finance, and all loans need prior approval. The issuing of local government bonds may be perceived to be covered by the new Public Finance and Accountability Act and also requires prior approval. In addition, the act prescribes strong involvement of the parliament; any loan terms and conditions-except for the treasury and monetary policy management purposes - need to be laid before parliament and approved by a resolution (article 20, paragraph 3 ). There is, therefore, a need to harmonize the legislative framework in this area.

In practice, local government borrowing is very limited and typically restricted. According to an overview by the MoFPED, the total owed to net nonbank creditors and local government bank loans was U Sh 1.222 million and U Sh 400 million, respectively, in 2001/02-less than 0.2 percent of annual local government revenues and 2 percent of annual local government own-source revenues (MoFPED 2003). Official borrowing is limited for several reasons:

- The amount of own-source revenues is relatively small, and local governments can borrow at most 25 percent of this amount.

- Because of various financial flaws, local governments have problems qualifying for loans.

- The approval procedures are cumbersome.

- The financial market for local government borrowing is lacking.

- Generally, there is a lack of local government creditworthiness.

However, local governments' short-term overdrafts and arrears are significant. Although there are only limited official data and no aggregate consolidated overview, evidence suggests that short-term arrears are a severe problem for many local governments, one that needs to be addressed soon (Kragh and others 2003). A recent financial management study of four local governments revealed that they did not have any bank loans but had significant outstanding payments and credits. Although specific figures were not available, the four local governments estimated their arrears at U Sh 100 million to U Sh 300 million (20 to 40 percent of annual own-source revenues) and some had outstanding arrears of 10 to 20 percent of their total budget—-similar to the amount of own-source revenues for the entire year. Strategy appeared to be weak, and there was no apparent provision in their budgets for clearance of arrears. Oversight of outstanding payments was also weak. Creditor registers and ledgers were sometimes missing and often consisted of only a simple list of creditors, typically not properly updated. 
The authority to make decisions on the prioritization of outstanding payments variously rests with the chief financial officer, the CAO, and the executive committee, but all local governments lacked a systematic policy and procedure for paying creditors. The study concluded that, generally, local governments did not have procedures in place for accounting for and controlling the number of creditors and the size of commitments. It noted a strong need for an appropriate system and guidelines on commitment control.

\section{Financial Management Capacity}

Local governments' financial management performance and accountability have been of great concern in Uganda, especially because a very large and growing proportion of public expenditures is handled at the local government level. However, compared with analyses done three to four years ago, ${ }^{18}$ there has been a significant improvement, especially in basic bookkeeping and accounting procedures. Most local governments submit their plans, budgets (Medium-Term Expenditure Frameworks), and accounts on time and have established internal as well as external control measures. Recent improvements have also been documented in the yearly assessment of the "minimum conditions and performance measures" under the LGDP-II (MoLG 2004).

The main reasons behind these improvements may be seen in the link between the capacity-building efforts and the incentive system in the LGDP grant allocation system, which rewards local governments that show good performance in generic administrative areas, such as financial management and good governance. But a number of challenges and problems still need urgent attention, particularly concerning budgeting, cash management, tender procedures, and downward accountability. Ways and means to strengthen support for capacity development and to create better links to the overall public financial management reforms are being explored (see Steffensen, Tidemand, and Ssewankambo 2004).

Building strong vertical (downward) accountability between the local councils and the citizens has been one of the greatest challenges in the decentralization process. A number of technical tools_-participatory planning and budgeting guidelines, capacity building, and transparency measureshave been launched but have not yet been sufficiently internalized and applied in many local governments. This area needs continuous emphasis over a broad front in terms of helping local governments and civil society build capacity, creating an incentive framework for local governments to be more open and ensure access to participation, and raising awareness. 


\section{Overall Assessment and Lessons}

The experiences from fiscal decentralization provide important lessons for reforms that strengthen the financing of decentralized services.

Experience shows the importance of having a clear delineation of expenditure assignments and a recognition that decentralization of responsibilities must be accompanied by sufficient resources to finance activities. The LGA has been instrumental in this respect, but the tasks and functions of the administrative units (parish and villages) have not been clearly delineated. Furthermore, attempts to cost the decentralized services were made very late in the process, and a number of functions have been transferred without adjusting the general funding flow or tax assignments (leading to unfunded mandates).

Experience shows the importance-but also the severe difficulties—of developing a sustainable system of local government finance with a significant component of own-source revenues to ensure accountability, ownership, efficiency, and the long-term viability and legitimacy of a decentralized system. A number of factors have constrained the mobilization of own-source revenues: lack of a favorable legal framework for local government taxation (especially concerning the property tax) ${ }^{19}$ weak local government capacity in tax administration, and lack of central government support (moral and technical) for boosting local government revenue mobilization. More recently, the large increase in transfers from central to local government seems to have had a crowding-out effect, worsened by strong influence and interference from the top political layer. What the president says during the presidential election campaigns matters in local tax policy, and there is still a lack of a perceived link between tax payments and service delivery benefits. In a situation in which transfers constitute more than 85 percent of all local revenue sources, there have been limited incentives to focus on the smallest part. ${ }^{20}$

Experience also shows a need for concerted efforts-targeting the legislative framework, the capacity of local governments, awareness raising and links to citizens, and especially incentives in the grant system-to significantly increase local governments' own-source revenues. This effort should be combined with a higher level of fairness and equity in the tax collection and legislative framework and with more efficient use of the resources collected.

Local governments that are highly dependent on the central government are especially vulnerable to central government control. There is a risk of reduced ownership and efficiency in local government service provision if this process is not fundamentally reversed. The challenge is to launch technical measures supported by political guidance in a clever and sensible way, 
without distorting economic activities and compromising poverty concerns. Without strong, top-level political support for local government revenue raising, any technical initiative will probably be in vain.

The elaborate system of revenue sharing has ensured that the lower levels of local government have had funding for political activities and some minor service responsibilities. However, the system has not always been adhered to, and it has also led to fragmentation and limited resources for meaningful investments, conflicts between layers of local governments, and waste of funds in areas where lower local governments have less capacity. There has been a tradeoff between involvement and democratization on one hand and economies of scale, efficiency, and capacity on the other.

Uganda's experiences with developing intergovernmental fiscal transfers are unique, especially because of the link between the HIPC initiative, the PAF (ring-fencing of funds for poverty targeted services), and the decentralized system, with local governments as the main institution for service delivery. The conditional grant system is used as an instrument to channel a large increase in funds for service delivery and to ensure that funds are used in key target areas for poverty alleviation. However, strong earmarking of funds also entails pitfalls and costs in compromised downward accountability and high administrative transaction costs from multiple planning, accounting, banking, and reporting systems.

The main lesson is the importance of striking a balance between (a) the need for central government control and monitoring of the achievement of national targets and (b) autonomy for the sake of democratization plus efficiency in local priorities and downward accountability. The balance in Uganda tipped toward control and monitoring-hence the need for the fiscal decentralization strategy in 2002 to address the problems. The FDS is supposed to reduce conditionality and strict control, thereby allowing flexibility in the use of funds across sectors and the establishment of better incentives to improve performance. However, a better balance and delineation of areas to be covered by unconditional and conditional grants should be pursued, closely linked to the type of services the local governments are to perform (delegated and agent functions, devolved functions, and so forth).

Uganda is one of the first countries in Africa to introduce an equalization grant scheme. The lesson has been that the scheme will continue to have a marginal role unless (a) grant objectives are clarified, (b) grant funding is concentrated on the most needy local governments, (c) the scale of the grants is increased, (d) grants are better linked with the conditional grant 
criteria and schemes (which in some cases equalize as well), and (e) data are updated and improved.

Experience with the grant system has proven the importance of clear and transparent allocation criteria, as well as timely and predictable transfers from the central government to the local governments. Although there is still room for improvement, the grant system has improved significantly over the past decade in these respects, increasing the likelihood that local governments will plan, budget, and implement projects. Synchronizing the transfer schemes with the local government budget cycles and well-known indicative planning figures (with a certain predictability) has provided support for hard budget constraints where local priorities are set, moving away from the previous wish-list approach.

The piloting of nonsectoral development grants that are based on local government performance provides important positive lessons. Experiences have shown that when local governments are provided with the proper incentives and support systems, including mentoring and capacity-building support, they can address urgent local service needs by using nonsectoral discretionary development grants. In fact, more than 90 percent of nonsectoral funds have been used within the five priority sectors for national poverty alleviation (education, health, water and sanitation, roads, and agriculture).

A positive side effect has been gradually improved administrative procedures and financial management systems and practices, improved transparency, and good governance, although there is room for further improvement. Performance-linked incentives can lead to significant improvements in the quality of local government processes. The lessons learned from carefully designed grant systems that link the size of the grants to local government performance are very promising. Such incentives have been successfully piloted in other parts of the world as well (Shotton 2004; Steffensen and Fredborg Larsen 2005). There seems to be scope for further testing of these incentive systems within other grant schemes as well, allowing more flexibility and autonomy while enabling improvements in performance and capacity.

Another positive experience has been the attempt to mainstream the vast number of district support programs with government procedures, bringing the programs on budget and harmonizing grant flow modalities. Doing so has reduced transaction costs and provided a better overview of the areas in need of additional support. Experiences from the pilot schemes have been useful in the national scaling-up of area-based systems.

There has been a lack of sufficient hard budget constraints on the use of funds, which is linked to the lack of incentives to mobilize own-source revenue. 
Although there is limited official borrowing, many local governments tend to accumulate liabilities and to neglect operational and maintenance obligations. The problem arises because of a technical need for more operational commitment control systems and a need for stronger incentives to mobilize the required resources on time. It also suggests the need for better oversight and control functions (internally as well as externally).

Financial management performance in all phases, from planning to audit follow-up, is an area of great concern. Improving performance requires a sustained transformation process with continuous efforts and institutional, technical, and structural reforms. Capacity-building and technical tools such as computers and information technology systems are not sufficient alone; they should be combined with incentives for institutions and individuals to improve performance and a stronger focus on downward accountability. Promising steps have been taken in recent years to involve citizens more, through open planning and budget conferences, notice boards with information on the receipt and use of funds, involvement of citizens in project implementation committees and LGPACs, and so forth. However, this area still has great future challenges and needs further attention.

Hitherto, the grant system (except the LGDP) has focused very much on upward accountability (reporting). However, experience has shown that building local accountability is equally important. Ideally, downward accountability should develop automatically as part of the day-to-day interaction between politicians and citizens. However, in the absence of a strong civil society and under the prevailing unbalanced relationship between local government and citizens, the central government can promote, catalyze, and facilitate improved downward accountability by demanding or promoting dissemination of information on local government finance, priorities, and use of funds; participatory planning and budgeting; open meetings; and so forth. These actions may create a positive circle in which disseminating more information to the public leads to more citizen demands. Although this effort will take time, emerging trends show improvement.

National monitoring of developments in local government expenditure and revenues has been problematic because of the fragmentation of databases and the lack of reliable data on local government finance. Fixing these problems should be pertinent first steps in any reform process, to provide a sound basis for making decisions. Initiatives are under way in the LGFC and MoLG to address this gap.

The lessons from Uganda show the value of a clear fiscal decentralization strategy and coordinating institutions. The 2002 FDS, with its implementation arrangements (budget, account, and revenue enhancement 
committees), has ensured better coordination of the grant reforms with the sectors and better coordination of revenue enhancement activities, especially within capacity building. The LGFC, although its capacity and effect were initially weak, has gradually expanded its role as a forum for providing analytical preparatory work for reforms, for bringing urgent issues to the top of the agenda, for coordinating initiatives, and for involving stakeholders from the central and local governments. The associations of local authorities have also been instrumental in this process, representing the interests of local governments and bringing in additional expertise.

However, it is important to clarify the roles of independent committees and forums in the early stages of a reform program. It is also important to ensure sufficient links between the bodies coordinating reforms and the implementing agencies and ministries to make certain that proposals are being properly implemented. Finally, for serious reform initiatives, strong, consistent support is needed for medium- to long-term capacity building.

\section{Notes}

1. Please refer to Steffensen and Trollegaard (2000) for a detailed treatment of the experiences in Ghana, Senegal, Swaziland, Uganda, Zambia, and Zimbabwe and to Steffensen and Tidemand (2004). Some sections of this chapter are based on (or excerpted from) the 2004 study.

2. For elaboration, see Republic of Uganda (1990) or for more details, Tidemand (1994), especially chapter 3.

3. The LGA is being changed.

4. The administrative units are county councils; parishes or wards; and villages, cells, or zones.

5. The chairperson of a city carries the title of mayor.

6. Steffensen and Tidemand (2004), annex 4.1, gives an overview of the share of local governments' expenditure in total public expenditures with or without donor funding. Many official calculations tend to underestimate the local government share, because the local governments have their own revenues in addition to the grants from central government. (The local own-source revenues typically constitute 10 to 15 percent of the total local government revenues.) In the calculations in the text, local government revenues for budget FY 2002/03 are estimated at the level of FY 2001/02 (U Sh 104.8 billion).

7. However, this indicator is only one among many and should not be evaluated in isolation.

8. Based on unaudited data from the Budget Framework Papers.

9. Population figures for rural local governments obtained from UBoS (2002).

10. See Steffensen, Tidemand, and Ssewankambo $(2004,70-80)$ for a detailed description of the reasons behind this development.

11. It appears from schedule 7 that unconditional grants are paid in the amount equal to the amount paid to local governments in the preceding year for the same item 
adjusted for general price changes plus/minus budgeted costs of running added or subtracted services.

12. The problems are extensively dealt with in Donor Sub-group on Decentralisation (2001).

13. The District Development Project (a district support program that was supported by the United Nations Capital Development Fund and piloted in five local governments starting in 1997) and the LGDP-I (which was conducted from 2000 to 2003) provided important lessons for the design of the ongoing LGDP-II. LGDP-II, under the MoLG, is supported by the World Bank, the Danish International Development Agency, the Netherlands, Ireland Aid, and Austria.

14. Study of figures received in the MoFPED.

15. Quick review of the transfer data provided by the MoFPED for 2001-04.

16. See also, for example, the design of a financial management and accountability and reporting system under the fiscal decentralization strategy (Kragh and others 2003).

17. Cash flow problems may arise in the beginning of the year if some funds that cannot be transferred in the first quarter are transferred in the final quarter to "top up," leading to delayed activities and bottlenecks at the local levels.

18. See, for example, Aarnes, Sjolander, and Steffensen (2000) and the first national assessment reports from the LGDP-I.

19. It is well known that the local governments have inherently weak tax bases, which by their nature are unresponsive to growth in local economic activities. However, it is equally well known that most local governments are not using their tax potential (see LGFC 2000a, 2000b, 2002, 2003).

20. See also the findings of Prud'homme (2003) for a theoretical discussion of this problem.

\section{References}

Aarnes, Dag, Stefan Sjolander, and Jesper Steffensen. 2000. Public Financial Management Issues in Uganda-A Joint Review. Norwegian Agency for Development Cooperation, Swedish International Development Cooperation Agency, and Danish International Development Agency.

Ablo, Emmanuel, and Ritva Reinikka. 1998. "Do Budgets Matter? Evidence from Public Spending on Education and Health in Uganda." Policy Research Working Paper 1926. Washington, DC, World Bank.

Collier, Paul, and Ritva Reinikka. 2001. "Recovery in Service Delivery: Evidence from Schools and Health Centers." In Uganda's Recovery: The Role of Farms, Firms, and Government, ed. Ritva Reinikka and Paul Collier, 343-69. Washington, DC: World Bank.

Decentralisation Secretariat, Ministry of Local Government, Republic of Uganda. 1994. Decentralisation in Uganda-The Policy and Its Implications. Kampala: Republic of Uganda.

Donor Sub-group on Decentralisation, Republic of Uganda. 2001. Fiscal Decentralisation in Uganda-The Way Forward: Final Report. Kampala: Republic of Uganda.

Kragh, Ole, Jesper Steffensen, Tim Williamson, Baryabanoka Wilson, Francis Nyanzi, and others. 2003. "Design of the Financial Management, Accountability, and Reporting Systems under Fiscal Decentralization: Strategy and Issues on Local Government Financial Management for Public Expenditure Review (PER).” Kampala: MoFPED. 
LGBC (Local Government Budget Committee). 2003. Fiscal Decentralisation Strategy, Phase II: Allocation Principles and Development of Allocation Formulae-Findings, Recommendations, and Formulae Designs. Kampala: LGBC.

LGFC (Local Government Finance Commission). 2000a. Government Revenue Enhancement Study: Final Report. Vols. I and II. November. Kampala: LGFC.

- 2000b. Revenue Sharing Study: Sharing of Expenditure Responsibilities and Revenue Assignments (Centre-Local Governments). Kampala: LGFC.

- 2002. Revenue Sharing Study Phase II: Final Report, 2002. Kampala: LGFC.

-2003. Final Report on the Inventory of Best Practises in Revenue Mobilisation and Generation. Kampala: LGFC.

MoFPED (Ministry of Finance, Planning, and Economic Development). 2002. "Fiscal Decentralisation in Uganda: Draft Strategy Paper." Prepared by the Fiscal Decentralisation Working Group, Kampala, March.

_.2003a. Medium-Term Expenditure Framework. Kampala: MoFPED. (October)

-2003b. Provisional Report on Local Government Finance Statistics for the Financial Years 1997/98-2001/02. Kampala: MoFPED.

MoLG (Ministry of Local Government). 2002. The Ministry of Local Government Policy Statement 2002/2003. Kampala: MoLG.

- 2004. Assessment of the Minimum Conditions and Performance Measures for Local Governments. Kampala: MoLG.

Onyach-Olaa, Martin. 2003. Lessons from the Experiences in Decentralising Infrastructure and Service Delivery in Rural Areas: Uganda Case Study. Kampala: MoLG.

Prud'homme, Rémy. 2003. "Fiscal Decentralisation in Africa: A Framework for Considering Reform.” Public Administration and Development 23 (1): 17-27.

Republic of Uganda. 1990. "Report of the Public Service Review and Reorganisation Commission.” Republic of Uganda, Kampala.

Shotton, Roger, ed. 2004. Local Government Initiative: Pro-Poor Infrastructure and Service Delivery in Rural Asia. New York: United Nations Capital Development Fund.

Steffensen, Jesper, and Henrik Fredborg Larsen. 2005. "Conceptual Basis for Performance Based Grant Systems and Selected International Experiences.” United Nations Development Programme, New York.

Steffensen, Jesper, Emmanuel Ssewankambo, Per Tidemand, Tim Williamson, and Gerhard van't Land. 2002. Preparation of the Local Government Development Program, Phase II. Annex 1 and 2. Prepared for the Ministry of Local Government, Kampala. September.

Steffensen, Jesper, Emmanuel Ssewankambo, and Gerhard van't Land. 2002. Programme Review of the Local Government Development Programme. Vols. 1 and 2. Kampala: MoLG.

Steffensen, Jesper, and Per Tidemand. 2004. "A Comparative Analysis of Decentralisation in Kenya, Tanzania, and Uganda: A Final Synthesis Report.” World Bank, Washington, DC.

Steffensen, Jesper, Per Tidemand, and Emmanuel Ssewankambo. 2004. A Comparative Analysis of Decentralisation in Kenya, Tanzania, and Uganda: Country StudyUganda. Vols. 1 and 2. World Bank, Washington, DC.

Steffensen, Jesper, and Sven Trollegaard. 2000. Fiscal Decentralisation and Sub-national Government Finance in Relation to Infrastructure and Service Provision: Synthesis Report of 6 Sub-Saharan African Country Studies. Washington, DC: World Bank. 
Steffensen, Jesper, Gerhard van't Land, and Emmanuel Ssewankambo. 2002. Midterm Review - Programme Review of the Local Government Development Programme, Volumes 1 and 2, Final Report. February. Kampala: Ministry of Local Government.

Therkildsen, Ole. n.d. “Uganda's Radical Decentralisation: An Example for Others?” Draft working paper, Centre for Development Research, Copenhagen.

Tidemand, Per. 1994. "The Resistance Councils in Uganda-A Study of Rural Politics and Popular Democracy in Africa.” Ph.D. dissertation, Roskilde University, Roskilde, Denmark.

UBoS (Uganda Bureau of Statistics). 2002. 2002 Uganda Population and Housing Census. Kampala: UBoS.

ULAA and UAAU (Uganda Local Authorities Association and Urban Authorities Association of Uganda). 2003. "Analysis of the National Budget 2003/2004, with Focus on Local Government Finance." ULAA and UAAU, Kampala.

World Bank. 2003. Public Expenditure Review 2003-Supporting Budget Reforms at the Central and Local Government Level. September. Washington, DC: World Bank. 
Local Government

Organization

and Finance: China

\author{
B AOYUN QIAOANDANWAR SHAH
}

China is considered one of the birthplaces of humanity and an important cradle of the world's civilization. China as we know it today was proclaimed by Mao Zedong on October 1, 1949. Situated in the southeastern part of the Asian continent, China is the world's most populous country, with a 2006 population of 1.3 billion, and ranks third in area (9.6 million square kilometers), behind only the Russian Federation and Canada. Constitutionally unitary, China practices "the system of multiparty cooperation and political consultation led by the Communist Party of China" (Preamble, Chinese constitution). The country has enjoyed an average annual growth rate of about 10 percent in real gross domestic product (GDP) since the 1980s, becoming one of the leading exporting countries. However, there are significant differences in the growth rates of provincial income, with rates in the eastern coastal regions outstripping those in the middle and western regions (table 4.1).

China's apex organs of the state are as follows:

- Legislative. The National People's Congress is the legislative organ.

- Executive. The president of the People's Republic of China is the head of the state, and the State Council, chaired by the premier, is the highest organ of state administration. 
T A B L E 4 . 1 Population, Area, and Per Capita GDP across Provinces, 2003

\begin{tabular}{|c|c|c|c|c|}
\hline Region & Province & $\begin{array}{l}\text { Population } \\
\text { (thousand) }\end{array}$ & $\begin{array}{c}\text { Area } \\
\text { (thousand km²) }\end{array}$ & $\begin{array}{l}\text { Per capita } \\
\text { GDP (US\$) }\end{array}$ \\
\hline \multirow[t]{11}{*}{ East Coast } & Beijing & 14,070 & 17 & 3,049 \\
\hline & Fujian & 34,261 & 122 & 1,818 \\
\hline & Guangdong & 77,676 & 179 & 2,076 \\
\hline & Hainan & 7,939 & 34 & 1,003 \\
\hline & Hebei & 66,569 & 190 & 1,271 \\
\hline & Jiangsu & 72,967 & 105 & 2,039 \\
\hline & Liaoning & 41,549 & 150 & 1,728 \\
\hline & Shandong & 89,775 & 158 & 1,652 \\
\hline & Shanghai & 16,061 & 8 & 4,428 \\
\hline & Tianjin & 9,956 & 12 & 2,934 \\
\hline & Zhejiang & 45,934 & 105 & 2,434 \\
\hline \multirow[t]{8}{*}{ Middle } & Anhui & 62,652 & 140 & 751 \\
\hline & Hailongjiang & 37,693 & 460 & 1,408 \\
\hline & Henan & 95,029 & 166 & 884 \\
\hline & Hubei & 59,184 & 186 & 1,091 \\
\hline & Hunan & 65,521 & 212 & 844 \\
\hline & Jiangxi & 41,741 & 167 & 806 \\
\hline & Jilin & 26,684 & 189 & 1,131 \\
\hline & Shanxi & 32,558 & 157 & 898 \\
\hline \multirow[t]{12}{*}{ Western } & Chongqing & 30,713 & 82 & 872 \\
\hline & Gansu & 25,628 & 406 & 607 \\
\hline & Guangxi & 47,661 & 236 & 683 \\
\hline & Guizhou & 37,933 & 176 & 425 \\
\hline & Inner Mongolia & 23,510 & 1,142 & 1,095 \\
\hline & Ningxia & 5,650 & 66 & 805 \\
\hline & Qinghai & 5,225 & 720 & 886 \\
\hline & Shaanxi & 36,314 & 205 & 788 \\
\hline & Sichuan & 85,739 & 484 & 760 \\
\hline & Tibet & 2,638 & 1,202 & 828 \\
\hline & Xinjiang & 18,834 & 1,663 & 1,177 \\
\hline & Yunnan & 42,836 & 384 & 683 \\
\hline Maximum & & 95,029 & 1,663 & 4,428 \\
\hline Minimum & & 2,638 & 8 & 425 \\
\hline Average & & 40,661 & 307 & 1,350 \\
\hline
\end{tabular}

Source: China, State Statistical Bureau 2004.

Military. The Central Military Commission of China, headed by the president, is the supreme national security organ.

- Judicial. The Supreme People's Court is the country's highest judicial organ. 
Procuratorial. The people's procuratorates are state organs for legal supervision. The Supreme People's Procuratorate, headed by the procuratorgeneral, is the country's highest procuratorial organ.

The government of China has a five-tier hierarchical structure, with the central government in Beijing, the capital, at the apex (figure 4.1). The second tier comprises jurisdictions that have provincial status. These jurisdictions consist of 22 provinces; 4 municipalities (Beijing, Chongqing, Shanghai, and Tianjin); 5 autonomous regions (Guangxi, Inner Mongolia, Ningxia, Tibet, and Xinjiang); 2 special administrative regions (Macao and Hong Kong, China); and Taiwan, China.

Provinces and autonomous regions are divided into autonomous prefectures, counties, autonomous counties, and cities. Counties and autonomous counties are divided into townships, nationality townships, and towns. Municipalities directly under the central government and other large cities are divided into districts and counties. Autonomous prefectures are divided into counties, autonomous counties, and cities (see article 30, Chinese constitution). Practically speaking, there are four tiers of local government: provincial-level government, headed by an elected governor and reporting to the State Council; prefecture-level government, the administrative division between province and county; county-level government, the basic administrative division; and township-level government, the basic administrative division in the vast countryside. Village-level

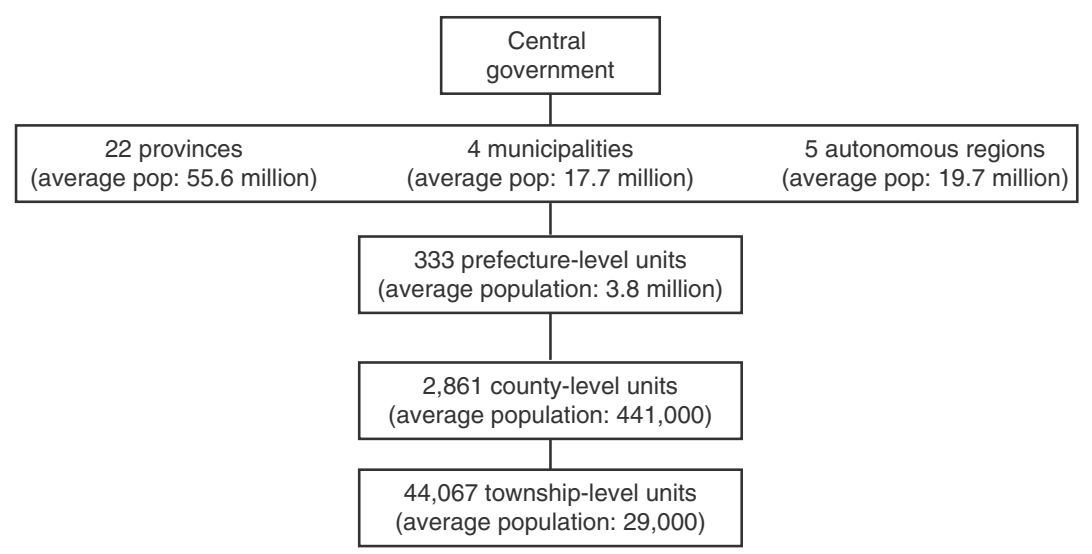

Source: Ministry of Finance of China.

F I G U R E 4 - 1 Structure of Government in China, 2003 
organizations in China also provide public services but are considered community units instead of governments.

Currently, under the constitution, the National People's Congress and the State Council exercise the functions and powers to approve the establishment (article 62) and the geographic division (article 89) of provinces, autonomous regions, and municipalities directly under the central government. The State Council exercises the functions and powers to approve the establishment and the geographic division of governments at the prefecture and county levels. The provincial government determines the establishment and the geographic division of the township governments (see article 107, Chinese constitution).

Although this power is not specified in the constitution, provincial, prefecture, and county governments can be dissolved by the central government, and township governments can be dissolved by the provincial governments. In addition, the central government has the authority to annul local regulations or decisions of the organs of state power of provinces, autonomous regions, and municipalities directly under the central government that contravene the constitution, the statutes, or the administrative rules and regulations. It also has the power to alter or annul decisions and orders issued by local organs of state administration at different levels (article 67 and 89, Chinese constitution).

According to the constitution, the People's Congress and people's government at the province, prefecture (or city), county, and township levels represent the local organs of state legislative power and the executive organs of power. The Communist Party at each level of government provides oversight functions by having a party committee for each governmental unit. Local leaders of the party are appointed by and directly report to the party's committee of the next-higher level of government. Higher-level governments are also empowered to nominate the members of the executives and councils of the lower-level governments. However, the local congress must ratify such nominations. Members of the local congress are elected by universal adult franchise.

The fiscal system of China has five levels, corresponding to the government structure. The central government sets the policy direction. Local governments are responsible for designing and implementing local policies that fit local needs, as long as local policies are not in conflict with the central government's policy. Various local governments also enjoy significant local autonomy in setting priorities; for example, all local governments have independent budgets that are approved by the local people's congress. 
The central government determines the fiscal relation between the central and provincial governments. There are direct fiscal relations between the central government and the provincial governments, ${ }^{1}$ but no such relations with subprovincial governments. Under a unitary tax system, revenue bases are assigned to the central and subnational governments by the central government. The central government also determines the assignment of expenditure responsibilities between the central and the subnational governments. Subprovincial fiscal relations are ordered at the discretion of the provincial government. Although there are many practices, the subnational fiscal system in China can be categorized into two models:

1. "Province managing county" model. The provincial government directly manages the prefectures and counties. There are direct intergovernmental relations between the provincial government and the prefecture governments, and between the provincial government and the county governments, in revenue assignment, expenditure assignment, intergovernmental transfer and subsidies, borrowing, and budgetary allocations and adjustments. This model is a more decentralized one, and there are no fiscal relations between the prefecture governments and the county governments. The model is implemented in Anhui, Fujian, Hailongjiang, Hainan, Hubei, Ningxia, Zhejiang provinces, as well as in Beijing, Shanghai, Tianjin, and Chongqing, the four provincial-level cities, and in Dalian, Ningbo, Qingdao, Shenzhen, and Xiamen, the five separately planned cities where no prefecture government existed at the end of 2005.

2. "Prefecture managing county" model. There are intergovernmental fiscal relations between the provincial government and the prefecture governments in revenue assignments, expenditure assignments, intergovernmental transfers, borrowing, and budgetary allocations. However, there are no fiscal relations between the provincial government and county governments. All provinces except those that apply the "province managing county" model implement this model.

The central government of China encourages the "province managing county" model, and it is expected that more provincial governments will adopt it in the near future. The majority of township governments have their own independent budgets. However, some counties practice a "county replacing township" model, which is encouraged in poorer jurisdictions by the central government to improve government efficiency by decreasing management layers. Under this model, the township government is no 
longer an effective budget unit. Instead, the county government manages the township directly.

\section{Local Government Expenditure Responsibilities}

As defined by the State Council Regulations on the Implementation of the Tax-Sharing System (TSS) in 1993, the central government is mainly responsible for national security, international affairs, the operating costs of the central party and its organs, adjustment of the structure of the national economy, coordination of regional development, and adjustment and control of the macroeconomy. Those responsibilities include national defense; the cost of military police; international affairs and foreign aid; administrative costs of the central government; centrally financed capital investments; technical renovation of central enterprises; new product development costs; agricultural support; debt; costs of central culture, education, and health; price subsidies; and other expenditures. Subnational governments are mainly responsible for the operating costs of the local party and its organs and for local social economic development. Those responsibilities include local economic development; part of the operating costs of the military police and militia; locally financed capital investments; technical renovation of local enterprises; new product development costs; agricultural support; urban maintenance and construction; costs of local culture, education, and health; price subsidies; and other expenditures.

The assignment of responsibilities to subprovincial governments is at the discretion of the provincial government. Although there are differences in the assignment of expenditure responsibilities across provinces, the common practice is for local governments at various levels to share the responsibilities defined as local by the central government. Fundamentally, local governments at any level are responsible for delivering (a) day-to-day public administration; (b) social and public services such as education, public safety, health care, social security, housing, and other local and urban services; (c) local economic development; and (d) local industrial policy (Wong 2000; World Bank 2002). Purely local responsibilities mainly include urban maintenance and construction, environmental protection, city water supply, and community services. They are assigned mainly to prefecture, county, and township governments (table 4.2).

In essence, expenditure responsibilities among governments are not clarified because of wide concurrent expenditure assignments. The major public services are actually carried out by local governments at different levels, especially subprovincial governments, under a hierarchical structure. In particular, the actual responsibilities for such services as education and health care are 
TA B LE 4 . 2 Expenditure Responsibilities of Various Orders of Government

Expenditure items

Central Provincial Prefecture County Township

Shared responsibilities between the central and local government

Government administration

Capital construction

Research and development and state-owned enterprise promotion

Education

Health care

Culture development

Policy reimbursement

Agricultural development and production

Armed police troops

Social welfare

$\begin{array}{lllll}X & X & X & X & X \\ X & X & X & X & X \\ X & X & X & X & X \\ X & X & X & X & X \\ X & X & X & X & X \\ X & X & X & X & X \\ X & X & X & X & X \\ & & & & \\ X & X & X & X & X \\ X & X & X & X & X \\ X & X & X & X & X\end{array}$

Exclusive responsibilities of the central and local governments

National defense

Diplomacy and foreign aid

Geological prospecting

$\mathrm{X}$

Principal and interest payment for debts

Urban maintenance and

construction

Environmental protection

City water supply

Community services

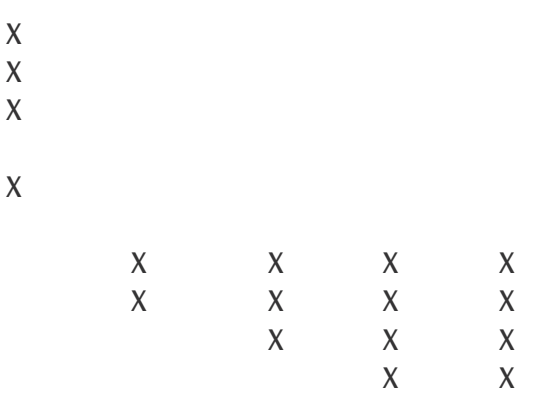

Source: Data from Ministry of Finance of China.

concentrated at the county and lower levels, and such services as social security are administered mainly by the provincial and prefecture governments. Local governments also carry out some central government functions, such as those related to national defense and international affairs (table 4.3).

\section{Education}

Education is primarily the responsibility of local governments. The total government expenditure on education in 2003 was US $\$ 35.6$ billion, of which the local government share was US $\$ 32.7$ billion, amounting to 91.8 percent 
TA B L E 4 . 3 Expenditure Shares of Various Orders of Government, 2003 (percent)

\begin{tabular}{lrccc}
\hline Expenditure items & Central & Provincial & Subprovincial & All orders \\
\hline Capital expenditure & 44.4 & 23.1 & 32.5 & 100 \\
Operational expenditure & 22.7 & 26.2 & 51.1 & 100 \\
$\quad$ Agriculture & 11.9 & 46.5 & 41.6 & 100 \\
$\quad$ Education & 8.2 & 14.6 & 77.2 & 100 \\
Scientific research & 63.5 & 22.8 & 13.7 & 100 \\
$\quad$ Health care & 2.8 & 22.3 & 74.9 & 100 \\
Social security & 11.4 & 39.3 & 49.3 & 100 \\
Public administration & 19.5 & 10.5 & 70.0 & 100 \\
$\quad$ Public security, procuratorial, & & & & \\
$\quad$ and justice & 5.4 & 25.4 & 69.1 & 100 \\
$\quad$ National defense & 98.8 & 1.2 & 0 & 100 \\
$\quad$ Foreign affairs & 87.3 & 12.7 & 0 & 100 \\
$\quad$ Foreign aid & 100.0 & 0 & 0 & 100 \\
Consolidated government & & & & \\
$\quad$ expenditure & 30.1 & 18.5 & 51.4 & 100 \\
\hline
\end{tabular}

Source: Data from Ministry of Finance of China.

of the total. In general, education is divided into basic, higher, and vocational education. Vocational education is mostly left to the market. ${ }^{2}$ Basic education in China includes nine years of compulsory education. The central government is the policy maker and overall planner, and it is responsible for setting up special education funds for subsidizing basic education in the poor minority areas and for subsidizing higher education. Meanwhile, the provincial government has the overall responsibility for formulating the development plan for basic education and providing assistance to counties to help them meet expenditure needs in education. The responsibility for actually implementing basic education, such as financing it, lies (in urban areas) with the cities or the districts of large cities and (in rural areas) with the counties. The education expenditure of county and lower-level governments in 2003 was US $\$ 21.2$ billion, about 60 percent of the total.

Basic education in rural areas has been a major concern of the central government in recent years because of the lack of access in poorer areas. New initiatives, such as the Decision on Strengthening Rural Education, which the State Council issued in September 2003, expanded the expenditure responsibilities of the central government in basic education (schooling up to ninth grade), and defined it as the shared responsibility of the central government and local governments to support students from poor families by 
waiving textbook, tuition, and miscellaneous fees and by subsidizing housing expenditures for elementary and secondary education. The central government, as well as local governments, started to set up special funds to support the program in 2003. It is expected that all students will enjoy the benefit by 2007.

Expenditure responsibility for higher education is different from that for basic education. Access to private higher education, mainly vocational training, is quite limited, and it is regarded as inferior to public higher education. Public higher education organizations are divided into two groups: (a) those belonging to the central government and (b) those belonging to local governments. Expenditure responsibilities for higher education are shared by the central government and the provincial governments. The central government is responsible for planning the national development of higher education and supports the higher education organizations that belong to it. Provincial governments are responsible for planning for provincial development of higher education and support the higher education organizations that belong to them.

\section{Health Care}

The central government continued its commitment to health care and requires that the health care spending of both the central and local governments should grow at a faster rate than overall budgetary expenditures. ${ }^{3}$ In practice, responsibilities for health care are concentrated in local governments, particularly at the county and lower levels. The total government health expenditure in 2003 was US $\$ 9.4$ billion, of which local government expenditures were US\$9.1 billion, accounting for 97.2 percent of the total. In particular, the health care expenditures of county and lower-level governments were more than US $\$ 4$ billion, or 42.6 percent of the total.

The major responsibilities for health care relate to rural health care, because more than 70 percent of the population lives in rural areas. The Decision to Strengthen Rural Health Care, issued in October 2002, clarified the responsibilities of various levels of government. The central government retained responsibility for designing the overall plan, the provincial governments were mandated to implement central plans, and the county or city governments were given overall responsibility for rural public health care.

In addition, the central government is responsible for providing subsidies for the prevention and control of serious infectious diseases, endemic diseases, and occupational diseases in poorer areas, and the provincial 
government is responsible for giving necessary subsidies to counties or cities for public health projects and for paying for planned immunizations and vaccinations. The county or city governments must ensure that all rural public health projects mandated by the central government are carried out in a timely manner.

A new initiative to build a rural collaborative health care system started in January 2003. It expanded the responsibilities of both the central government and the local governments. Starting in 2003, the central government and local governments must pay US $\$ 1.20$ per year for each rural resident in the middle and western regions who joins the system. The sharing arrangement among local governments at different levels is at the discretion of the provincial government.

\section{Social Security}

Social security is mainly the responsibility of local governments. The total government expenditure on social security in 2003 was US $\$ 15.3$ billion, of which the local share was US $\$ 13.5$ billion, accounting for 89 percent of the total. The main component of social security is the expenditure on a minimal living standard for urban citizens. Therefore, expenditure responsibilities are more concentrated in the provincial and prefecture governments, leaving fewer responsibilities for the county and lower levels, where most residents live in rural areas and do not have the same coverage as urban residents under the current system. The social security expenditures of provincial and prefecture governments in 2003 were US $\$ 6$ billion and US $\$ 4.8$ billion, accounting for 39 percent and 32 percent of the total, respectively. The social security expenditure of county and lower levels of government was US\$2.7 billion, accounting for 17.6 percent of the total.

\section{Capital Investment}

Capital investment is a shared responsibility of the central government and local governments. Both play important roles; the higher the government level, the greater its responsibilities. The central government expenditure on capital investment in 2003 was US $\$ 18.5$ billion, accounting for 44 percent of total government expenditure, which was US $\$ 41.6$ billion. The capital expenditures of provincial, prefecture, and county and lower governments were US $\$ 9.6$ billion, US $\$ 9.1$ billion, and US $\$ 4.4$ billion, accounting for 23.1, 21.8 , and 10.7 percent of the total, respectively. 


\section{Agriculture}

Agriculture development is mainly the responsibility of local governments. It is one of the most important tasks of China's government because more than 70 percent of the workforce works directly in agricultural production. In general, local governments at or above the county level are responsible for the relevant agricultural development, and they provide support services for agricultural production and related administrative areas. In particular, local governments at and above the county level are responsible for establishing special agricultural funds for agricultural development, forest cultivation, construction of special projects such as water conservancy facilities, research and development in agricultural science and technology, and agricultural education to promote agricultural development.

Meanwhile, the central government is responsible for nationwide projects and services of agricultural development, production, and administration. In particular, the central government has been mandated to gradually increase overall central government spending on agricultural development, so that the growth rate of annual overall expenditures on agriculture by the national treasury is higher than the growth rate of overall government spending. ${ }^{4}$

In practice, local governments at the county and lower levels assume primary responsibility for agricultural development. In 2003, total government spending on agricultural development was US $\$ 13.8$ billion, while local government spending was US $\$ 12.2$ billion, accounting for 88.1 percent of the total. County and lower governments spent US $\$ 6.8$ billion, accounting for about 50 percent of the total. Local responsibilities and their relative importance are shown in table 4.4.

\section{Distribution of Government Employment}

The current distribution of government personnel shows a significant degree of decentralization. A large majority is concentrated in lower-level governments, as shown in table 4.5 .

As a common practice, most public services are delivered by governments alone. Government organizations can be divided into two groups in accordance with their financing channels. The first group is fully financed by budgetary funds such as the organizations of the party and most of the administrative organs of local governments. Public services delivered by the government alone for this group have no market competition. A few jurisdictions in the eastern coastal regions are experimenting with outsourcing 
TA B L E 4 . 4 Local Responsibilities and Relative Importance, 2003 (percent)

\begin{tabular}{|c|c|c|}
\hline Expenditure responsibilities & $\begin{array}{l}\text { Share in local } \\
\text { expenditure }\end{array}$ & $\begin{array}{c}\text { Local share in } \\
\text { consolidated } \\
\text { government } \\
\text { expenditure }\end{array}$ \\
\hline \multicolumn{3}{|l|}{ Responsibilities shared with the central government } \\
\hline Education & 15.7 & 91.8 \\
\hline Capital construction & 11.1 & 55.6 \\
\hline Government administration & 9.6 & 80.5 \\
\hline \multicolumn{3}{|l|}{ Expenditures for public security } \\
\hline agency, procuratorial agency, and court of justice & 7.1 & 94.6 \\
\hline Social security & 6.5 & 88.6 \\
\hline \multicolumn{3}{|l|}{ Expenditures for supporting agricultural production } \\
\hline \multicolumn{3}{|l|}{ Innovation and science and technology promotion } \\
\hline Health care & 4.4 & 97.2 \\
\hline Social welfare subsidies & 2.9 & 99.0 \\
\hline Price subsidies & 2.2 & 61.5 \\
\hline Expenditures to support less-developed areas & 0.9 & 94.9 \\
\hline Research and development & 0.6 & 36.5 \\
\hline Geological prospecting & 0.5 & 76.1 \\
\hline Armed police troops & 0.1 & 9.2 \\
\hline National defense & 0.1 & 1.2 \\
\hline Diplomacy and external assistance & 0.1 & 12.7 \\
\hline Debt & 0.1 & 0.9 \\
\hline \multicolumn{3}{|l|}{ Purely local responsibilities } \\
\hline Urban maintenance and construction & 4.4 & \\
\hline Environmental protection and city water supply & 0.5 & \\
\hline
\end{tabular}

Source: China, State Statistical Bureau 2004.

some services, such as local public security, to avoid the cost of delivering them through a competitive market. However, the coverage of such experiments is very small, and this option is debated. The other group is financed partly by budgetary funds. These organizations can be paid with lump-sum or matching grants for services such as public utilities or can be compensated for the gap between expenditures and revenues collected from the provision of services such as public schools and public hospitals. The competition from the market for these organizations is limited.

In summary, there are wide concurrent assignments of expenditure responsibilities among governments at different levels. The expenditure 
TA B L E 4 . 5 Government Personnel of Various Levels of Government, 2003

\begin{tabular}{lccccc}
\hline & \multicolumn{2}{c}{ Government } & & \multicolumn{2}{c}{ Military } \\
\cline { 2 - 3 } \cline { 5 - 6 } Level of government & Number (million) & Share (\%) & & Number (million) & Share (\%) \\
\hline Central & 0.9 & 2 & & 2.3 & 100 \\
Provincial & 3.9 & 9 & & 0 & 0 \\
Prefecture & 7.6 & 17 & & 0 & 0 \\
County and lower & 31.1 & 72 & & 0 & 0 \\
\multicolumn{1}{c}{ Total } & 43.5 & 100 & & 2.3 & 100 \\
\hline
\end{tabular}

Source: Data from Ministry of Finance of China.

responsibilities for basic public services are significantly decentralized to local governments, particularly to the county and lower-level governments.

\section{Local Revenues}

Forty-five percent of total revenues (local revenues and shared revenues) go to local governments, where provincial and subprovincial governments represent 11 percent and 34 percent, respectively, of the 2003 total. Most revenues from business, urban maintenance and construction, and agriculture taxes go to the subprovincial governments, as shown in table 4.6.

TA B LE 4.6 Revenue Shares of Various Orders of Government, 2003 (percent)

\begin{tabular}{lrccc}
\hline Revenues & Central & Provincial & Subprovincial & All orders \\
\hline Tax revenues & 58 & 14 & 28 & 100 \\
$\quad$ VAT & 75 & 6 & 19 & 100 \\
$\quad$ Consumption tax & 100 & 0 & 0 & 100 \\
$\quad$ Business tax & 3 & 27 & 70 & 100 \\
Urban maintenance & & & & \\
$\quad$ and construction tax & 0 & 10 & 90 & 100 \\
Enterprise income tax & 60 & 20 & 21 & 100 \\
Individual income tax & 60 & 16 & 24 & 100 \\
Agriculture taxes & 0 & 4 & 96 & 100 \\
$\quad$ Total revenues & 55 & 11 & 34 & 100 \\
\hline
\end{tabular}

Source: Data from Ministry of Finance of China. 


\section{Local Government Own-Source Taxes and Charges}

The legislative power of taxation in China is at the central government level. Tax assignments in some areas, particularly for poorer areas, are still regarded as "feeding finance" (chi fan cai zheng) to meet the government administrative cost. Local governments do not have autonomy in deciding tax bases or rates. However, the central government has defined as local taxes a number of taxes that are collected by local tax agencies as local revenues. They include taxes on urban maintenance and construction, vehicle purchasing, agriculture and animal husbandry, special products, contracts, housing property, urban and township land use, farmland occupation, resources, land appreciation, vehicle and vessel use, fixed asset investments, slaughter, and banquets, as well as the educational surcharge, stamp tax, and pollution charge.

The only legislative autonomy local governments have over these taxes are the choice of introducing the banquet and the slaughter taxes (or not doing so), and the selection of the rate of the tax on urban and township land use, within maximum and minimum legislated rates. In general, local taxes have narrower bases and are less stable than central and shared taxes. Total local taxes accounted for less than 40 percent of total local budgetary revenues in recent years. Table 4.7 summarizes the bases, rates, and relative importance of these local taxes and charges.

Revenue assignment of local taxes among subprovincial governments occurs at the discretion of the provincial government. Although practices differ across provinces, most provincial governments share with prefecture, county, and township governments only the main local taxes, such as those on urban maintenance and construction and on vehicle purchasing. They leave other local taxes to the lower-level governments. The sharing arrangement is generally determined by the status of the enterprises that pay these local taxes. ${ }^{5}$ The lower the government level, the higher the revenues from local taxes. In 2003, local taxes and charges accounted for 17 percent, 36 percent, and 47 percent of local revenues for provincial, prefecture, and county and lower-level governments, respectively.

Local governments have great autonomy in collecting profits from state-owned enterprises (SOEs), administrative charges, penalties and confiscatory income tax, usage charges for sea areas, charges for geological prospecting, and charges for special projects. However, these charges accounted for only a trivial fraction of total local revenues. It is also legal to use extrabudgetary revenue to exert local revenue autonomy. In fact, extrabudgetary revenue is one of the important revenue sources for local 
TA B L E 4 . 7 Bases, Rates, and Relative Importance of Local Taxes and Charges

\begin{tabular}{|c|c|c|c|}
\hline Taxes & Tax base & Tax rate & $\begin{array}{l}\text { Share of local } \\
\text { venue, } 2003(\%)\end{array}$ \\
\hline Urban maintenance and construction tax & VAT and business tax & $1-7 \%$ & 5.55 \\
\hline Vehicle purchasing tax & Vehicle purchase cost & $0.1 \%$ & 4.82 \\
\hline Agriculture and animal husbandry tax & Agriculture and animal husbandry earnings & Average $15.5 \%$ & 4.30 \\
\hline Tax on special products & Cost of identified special agriculture products & $5-10 \%$ & \\
\hline Contract tax & Contract value & $3-5 \%$ & 3.64 \\
\hline \multirow[t]{2}{*}{ Housing property tax } & \multirow[t]{2}{*}{$\begin{array}{l}\text { Assessed value of housing property or rental } \\
\text { income }\end{array}$} & $\begin{array}{l}\text { Assessed value of housing } \\
\text { property: } 1.2 \%\end{array}$ & \\
\hline & & Rental income: $12 \%$ & 3.29 \\
\hline Educational surcharge & VAT, business tax, and consumption tax & $0.03 \%$ & 2.34 \\
\hline Stamp tax & Transaction value on documents & $0.003-0.05 \%$ & 2.18 \\
\hline Pollution charge & Pollution & Varies for different types of pollution & n 0.95 \\
\hline Urban and township land use tax & Occupied urban and town land & $\begin{array}{l}0.2-10 \text { yuan per square meter, based } \\
\text { on location and rank of the land }\end{array}$ & 0.93 \\
\hline Farmland occupation tax & Occupied farmland & 15-150 yuan per acre & 0.91 \\
\hline Resources tax & Gas, oil, minerals, salt & $0.3-60$ yuan per ton & 0.85 \\
\hline Land appreciation tax & Increasing value of real estate transaction & $30-60 \%$ & 0.38 \\
\hline Vehicle and vessel use tax & Vehicle or vessel & $\begin{array}{l}\text { Vehicles: } 2-320 \text { yuan } \\
\text { Vessels: } 0.4-5 \text { yuan per ton }\end{array}$ & 0.33 \\
\hline Fixed asset investment tax & Investment amount & $0-30 \%$ & 0.05 \\
\hline Slaughter tax & Cost of slaughter animals for food & $0.1 \%$ & 0.02 \\
\hline Banquet tax & Payment for banquet & $15-20 \%$ & 0 \\
\hline
\end{tabular}

Source: Data from Ministry of Finance and State Administration of Taxation of China. 
governments. Currently, such revenue comprises revenue from administrative units and institutions, funds raised by township governments, revenue from local fiscal departments, and revenue from SOEs. In 2002, the total local extrabudgetary revenues were US $\$ 41$ billion, or about 41 percent of all local budgetary revenues.

Local governments in China have access to additional revenues that do not form part of budgetary or extrabudgetary channels. They usually take the form of surcharges. The actual volumes of these revenues are difficult to know because local governments can hide this type of revenue.

Local taxes are collected by local tax agencies. Each local government has its own local tax agency, and the agency is supervised by both the local government and the local tax agency of the higher-level government. Although the tax system is harmonized by the unitary tax laws in China, the actual collection, especially of local taxes, is controlled by a model called "tax revenue task." It is still the typical practice that, at the beginning of the fiscal year, the central tax agency, after consulting and bargaining with the provincial tax agencies, assigns as a revenue task to the provincial governments the total volume of tax that needs to be collected in the fiscal year. The provincial governments further divide and allocate the tax revenue tasks to prefecture or county tax agencies. The assigned total volume of revenue becomes the basic task for these agencies.

This approach to tax collection encourages, to some extent, abuse of the tax laws by these agencies. For example, local tax agencies can delay the tax collection to the next fiscal year if the assigned tax revenue task of the current fiscal year has been completed. In fact, delayed tax collection is a very common practice in richer jurisdictions in China, because their wealthier tax bases make it easier to complete the revenue task in advance. However, the tax agencies in poorer jurisdictions may collect tax in advance or delay tax refunds to complete the tax revenue tasks of the current fiscal year. In general, scheduling of tax collection is emphasized more than enforcement of tax laws for tax agencies. As a consequence, the "tax revenue task" model provides ample opportunities for local governments to change the effective tax rate on residents. In addition, the model gives greater discretion to tax officials, thereby opening up opportunities for rent-seeking and corruption.

Other departments besides the tax agencies may also exercise authority to collect revenue (Chen 2003; Ma 2005), other than taxes, at the discretion of local governments. In some extreme cases, a department may collect revenue without any legal authorization. For example, farmers paid US\$14 billion in taxes and fees to local governments in 2003 , or US $\$ 18$ per farmer, a heavy burden by rural standards. Most revenues of this type are not collected through tax agencies, and more than 70 percent may not be legal. 
Recently, China expanded the rural tax and fee reform to all rural areas. With the objective of reducing the tax burden of farmers, the rural tax and fee reform was first experimented with in eastern parts of Anhui province in 1994 and then, two years later, was expanded to 50 select counties in 7 other major agricultural provinces. The government extended the experiment to all of Anhui province in a bid to standardize the tax burden on farmers and to eliminate the growing administrative and arbitrary fees charged to farmers in 2000. In 2002, the Central Party Committee and the State Council pushed the reform further, and the number of provinces embracing it grew to 20 by 2002; 620 million farmers, or three-fourths of the country's total, benefited from the reform. More important, the financial burden on farmers was cut by at least 30 percent.

The Chinese government also decided in late 2003 to abolish, exempt, or lower 15 charges on the country's 900 million farmers in a bid to reduce their excessive financial burden. The list of the 15 charges, published by the Ministry of Finance and the State Development and Reform Commission, included fees for quarantine certificates, licensing for using water resources, education, land-use rights certificates, and fishing boat inspections. In addition, China started a reform to eliminate agricultural taxes in 2004, and the agriculture and animal husbandry tax and the tax on special products were abolished at the beginning of 2006. These measures are intended to create a fairer, simpler, and more transparent local revenue system for rural areas.

\section{Shared Taxes}

Shared taxes represent a significant part of local revenues. Decisions about shared taxes rest with the central government. Under the current fiscal system, the shared taxes include business tax, VAT, enterprise income tax, individual income tax, foreign enterprise income tax, ${ }^{6}$ and stamp tax on security transactions. The sharing arrangement between the central and provincial governments is determined by the central government. The current sharing arrangements between the central and provincial governments—as well as the base, rate, and percentage of total local government revenue for shared taxes-are summarized in table 4.8. In 2003, the local part of shared taxes was US $\$ 75$ billion, accounting for more than 60 percent of local revenues.

Revenue assignment of shared taxes among local governments is at the discretion of the provincial government. The Suggestions on Subprovincial Fiscal Relations, issued by the Ministry of Finance and approved by the State Council in December 2002, provided some guidelines for revenue assign- 
TA B L E 4 . 8 Bases, Rates, Sharing Arrangements, and Percentages of Total Local Government Revenues for Shared Taxes

\begin{tabular}{|c|c|c|c|c|}
\hline Tax & Base & Rate (\%) & $\begin{array}{lr} & \text { Shar } \\
\text { Sharing arrangement } & \text { re }\end{array}$ & $\begin{array}{l}\text { hare of local } \\
\text { revenue, } \\
2003(\%)\end{array}$ \\
\hline Business tax & Services provided & $3-20$ & $\begin{array}{l}\text { All business tax } \\
\text { except for that on } \\
\text { rail transportation } \\
\text { and on headquarters } \\
\text { for banks and } \\
\text { insurance companies }\end{array}$ & $\begin{array}{l}28 \\
\text { s } \\
\text { s }\end{array}$ \\
\hline Value added tax & $\begin{array}{l}\text { Added value of } \\
\text { production and } \\
\text { productive } \\
\text { service }\end{array}$ & $0-17$ & $25 \%$ domestic VAT & 18 \\
\hline Enterprise income tax & Taxable income & 33 & $\begin{array}{l}40 \% \text {, except for tax } \\
\text { on centrally owned } \\
\text { enterprises; local } \\
\text { banks, foreign } \\
\text { banks, and other } \\
\text { financial corporations; } \\
\text { rail transportation; } \\
\text { and headquarters for } \\
\text { banks and insurance } \\
\text { companies }\end{array}$ & s; \\
\hline Individual income tax & Taxable income & $5-45$ & $40 \%$ & 6 \\
\hline $\begin{array}{l}\text { Foreign enterprise } \\
\text { income tax }\end{array}$ & Taxable income & $15-33$ & $\begin{array}{l}\text { Same as enterprise } \\
\text { income tax }\end{array}$ & 3 \\
\hline $\begin{array}{l}\text { Stamp tax on security } \\
\text { transaction }\end{array}$ & $\begin{array}{c}\text { Transaction value } \\
\text { on document }\end{array}$ & 0.003 & $3 \%$ & 1 \\
\hline
\end{tabular}

Source: Unpublished data from Ministry of Finance and State Administration of Taxation of China.

ment for subprovincial governments. However, the key point it stressed was the discretionary role of provincial governments. This arrangement implies that revenue assignments may vary by province. The current practice can be summarized as follows:

- Revenue from the major or key industries belongs to the provincial government; for example, business tax payable by the financial industry belongs to the provincial government (Zhang 2005). 
Major taxes such as VAT (the subnational share), enterprise income tax and individual income tax (the subnational share), and business tax are shared by the provincial, prefecture, county, and township governments.

- It is still common practice that the government gets all the revenues of the enterprises it owns. In 2003, the shared taxes for provincial, prefecture, and county and lower-level governments were US\$23 billion, US $\$ 27$ billion, and US $\$ 25$ billion, respectively, representing 76 percent, 63 percent, and 54 percent of respective total revenues.

The central tax agency is responsible for collecting and administering shared taxes. Each local government has a corresponding branch of the central tax agency that is responsible for collecting central taxes and shared taxes. The local tax agency has the responsibility for collecting local taxes. This model started in 1994 with the TSS reform.

It is worth mentioning that enterprise income tax and individual income tax were defined as local taxes at the beginning of the TSS reform. Consequently, responsibility for collecting these taxes was assigned to local tax agencies. This assignment has remained undisturbed, with only few exceptions, although these taxes were changed from local to shared ones in 2002. As for local government own-source taxes, the "tax revenue task" model also applies in the collection and administration of shared taxes.

In summary, local governments in China have limited legislative tax autonomy, but administrative revenue autonomy is widely practiced, legally or illegally.

\section{Intergovernmental Fiscal Transfers}

There are numerous intergovernmental fiscal transfer programs from the central government to provincial governments and from higher- to lowerlevel local governments. In principle, the central government determines transfers from the central government to provincial governments. Transfers to prefecture and county governments are at the discretion of the provincial government in most cases, but some prefecture governments determine the transfer to county governments. Meanwhile, the county government determines its transfer to township governments. The basic framework of subprovincial transfers is similar to that of transfers from the central government to provincial governments, although there are significant 
diversities in the structure of transfers across provinces because of regional disparities in fiscal resources. Intergovernmental transfer programs can be grouped into general-purpose transfers and special-purpose transfers, as shown in table 4.9.

\section{General-Purpose Transfers}

Besides tax sharing, general-purpose transfers include tax rebates and equalization transfer. Tax rebates have two parts. First, 30 percent of the increased VAT and consumption tax over the preceding year in a province is returned to that province as a tax rebate. ${ }^{7}$ Second, the difference between the base revenue and the provincial shared part of income taxes is reimbursed to the provincial government by the central government.

TA B LE 4 . 9 Intergovernmental Transfers, 2003

\begin{tabular}{|c|c|c|c|c|c|c|}
\hline \multirow[b]{2}{*}{ Transfers } & \multicolumn{2}{|c|}{ Central-provincial } & \multicolumn{2}{|c|}{$\begin{array}{l}\text { Provincial- } \\
\text { prefecture }\end{array}$} & \multicolumn{2}{|c|}{$\begin{array}{c}\text { Provincial/ } \\
\text { prefecture-count }\end{array}$} \\
\hline & $\begin{array}{c}\text { Amount } \\
\text { (US\$ } \\
\text { billion) }\end{array}$ & $\begin{array}{l}\text { Percentage } \\
\text { of total } \\
\text { transfers }\end{array}$ & $\begin{array}{c}\text { Amount } \\
\text { (US\$ } \\
\text { billion) }\end{array}$ & $\begin{array}{c}\text { Percentage } \\
\text { of total } \\
\text { transfers }\end{array}$ & $\begin{array}{c}\text { Amount } \\
\text { (US\$ } \\
\text { billion) }\end{array}$ & $\begin{array}{r}\text { Percenta } \\
\text { of tota } \\
\text { transfer }\end{array}$ \\
\hline \multicolumn{7}{|c|}{ General-purpose grants } \\
\hline Tax sharing & 43.1 & 30.6 & 28 & 28.8 & 13.5 & 20.6 \\
\hline Tax rebate & 41.5 & 29.5 & 20.2 & 20.8 & 15.3 & 23.3 \\
\hline Equalization & 4.6 & 3.3 & 4.8 & 4.9 & 3.7 & 5.6 \\
\hline Subtotal & 89.2 & 63.4 & 53.0 & 54.5 & 32.5 & 49.5 \\
\hline
\end{tabular}

Specific-purpose grants

Higher compensation

for public employees

Rural tax reform

10.9

$$
7.7
$$

9.6

9.9

8.3

12.7

Ethnic minority regions

$3.7 \quad 2.6$

4.0

4.1

4.1

6.3

Prior-1994 subsidies

0.7

0.5

0.2

0.2

0.2

0.3

Ad hoc transfers

1.5

1.1

2.2

2.3

2.0

3.0

Others

29.4

20.9

18.1

18.6

11.9

18.1

Subtotal

5.3

3.8

10.2

10.4

6.6

10.1

51.5

36.6

44.3

45.5

33.1

50.5

Total

140.7

100

97.3

100

65.6

100

Percentage of local

expenditure

67

57

66

Source: Data from Ministry of Finance of China. 
Income taxes, including enterprise income tax, foreign enterprise income tax, and individual income tax, were local taxes before the recent reform; they started to be shared taxes in 2002. The base revenue of income tax is the minimal income tax revenues that the central government set in the reform, on the basis of total provincial income tax revenues in 2001. The rebate rates for local governments at different levels are generally determined by the provincial governments, and they vary across provinces. Most of the provincial governments retain the major part of tax rebates from the central government. The purpose of tax rebates is to smooth the reform by keeping the prereform interests of all stakeholders untouched and to encourage revenue growth.

The equalization transfer is calculated on the basis of the gap between standard revenue and standard expenditure, with coefficients that adjust for the size of the gap. Standard revenue is estimated by using the tax bases and standard tax rates, and standard expenditure is calculated by using myriad categories, including spending on administrative services, public safety, education, city maintenance, social assistance, and heating. The purpose of general-purpose grants is to equalize resources across provinces. The general-purpose transfer is the only formula-driven transfer.

The general-purpose transfer to province $i$ is the following:

(standard expenditure of province $i$-standard revenue of province $i$ ) $\times \beta$,

where standard expenditure equals standard wage expenses plus standard administrative expenses plus agriculture development and administrative expenditures plus other expenditures; standard revenue equals standard local own taxes plus standard local shared taxes plus tax rebate plus revenue returned minus remittances to the central government; and $\beta$ is determined ex post as the ratio of funds available for transfer, divided by the size of the gap.

Standard wage expenses are derived from standard wages, the number of civil servants, and a regional wage level. Standard administrative expenses include personnel and operating costs for fully funded units, such as government administration, police and security, and other government agencies, and lump-sum costs for units that receive only partial funding from the budget. Agriculture development and administrative expenditures are expenditures for agriculture and related departments. Other expenditures include only price subsidies. The tax rebate, the revenue returned, and the remittances to the central government are the actual amount determined by the central government. 


\section{Special-Purpose Transfers}

There are several categories of special transfers. Major ones include the following:

Prior-1994 subsidies. These were the intergovernmental transfers dealing with problems inherited from the pre-TSS system, particularly the problems of poor provinces. Before the TSS reform, 16 provinces, mainly minority-heavy and poor, received subsidies from the central government. These transfers were designed particularly for those provinces, to ensure that every province would have a total nominal revenue no less than that of 1993. Apparently, the purpose of these transfers was to fill the gap before and after the TSS reform to smooth the reform.

- Grants for minority regions. Established in 2000 with US\$12 million to support the development of minority regions, these transfers come from two sources: one is directly from the central budget, with a yearly growth rate equal to that of central VAT revenue; the other is 80 percent of the increased central VAT revenue collected from minority regions. The transfers were designed to fill the fiscal gap for minority regions, which are less developed in general.

- Grants for increasing wages. The purpose of these transfers is to fill the fiscal gap in the middle and western provincial governments caused by the increased wage standards of public sector employees.

- Grants for rural tax reform. China formally started a rural fee-to-tax reform in 1999 and started to abolish the agriculture tax more recently. These reforms decreased local revenues, particularly for the county and lower-level governments, leaving a significant fiscal gap for almost all of them. The purpose of these transfers is to fill the fiscal gap caused by the rural fee-to-tax reform and the abolition of the agriculture tax. The transfers are generally provided to county governments through provincial governments.

Ad hoc transfers. There are hundreds of ad hoc transfers. These transfers typically respond to high-priority emergencies, such as the fiscal stimulus packages, bailouts for local government social protection programs, and partial payments for increases in pension benefits.

Intergovernmental transfer represents a significant part of central expenditures. In 2003, total intergovernmental fiscal transfers from the central government to provincial governments were US\$98 billion, accounting for more than 50 percent of total central expenditures. Intergovernmental 
transfers are important mainly because of mismatching revenue and expenditure assignments in the current fiscal system. The current intergovernmental transfer system is primarily oriented toward filling the gap.

A greater degree of expenditure decentralization coupled with a high degree of tax centralization create vertical fiscal gaps for lower levels of government. In 2003, local governments received 45.4 percent of total fiscal revenues, and their expenditures (mainly concentrated in the county and township levels) accounted for 70 percent of total expenditures. In fact, 47 percent of total local expenditures were financed by intergovernmental transfers in 2003. Specifically, 47, 45, and 58 percent of local expenditures were financed by intergovernmental transfers for provincial, prefecture, and county and lower-level governments, respectively. Table 4.10 shows transfers as a percentage of total local expenditures for different levels of government in 2003.

Intergovernmental transfer is the least transparent area in China's fiscal system. According to the budget process defined by the Budget Law, the lower-level governments submit the approved budget to the higher-level governments and so on to the central government, and the central budget is the last one to be approved. Consequently, the intergovernmental transfer for subnational governments is unknown until the budget of the central government is approved. Apparently, the local budget is not able to take account of intergovernmental transfers; consequently, such transfers are difficult to track through budgets. According to a report by the state audit bureau, only 27 percent of total intergovernmental transfers from the central government were reported in provincial accounts.

The Ministry of Finance is not the only department that determines the size and allocation of intergovernmental fiscal transfers. Several

\section{TA B LE 4. 10 Transfers as a Percentage of Total Expenditures of} Levels of Government, 2003

\begin{tabular}{lccc}
\hline & \multicolumn{3}{c}{$\begin{array}{c}\text { Transfer as a percentage of total } \\
\text { expenditures }\end{array}$} \\
\cline { 2 - 4 } Level of government (consolidated) & Average & Maximum & Minimum \\
\hline Provincial & 47 & 92 & 25 \\
Prefecture & 45 & 98 & 15 \\
County and lower & 58 & 100 & 10 \\
\hline
\end{tabular}

Source: Data from Ministry of Finance of China. 
departments that report to the State Council offer specific-purpose transfers from their own budgets. However, there is no clear procedure in the decision-making process to allocate the resources to provincial and subprovincial governments, and the arbitrary nature of central grant allocations has led to extensive negotiations by local authorities and encourages rent-seeking.

\section{Local Government Borrowing}

Local governments are forbidden to borrow from commercial banks or from the capital market, except with special approval from the central government, according to China's 1994 budget law and related regulations. In addition, local governments are prohibited from direct borrowing. In other words, only the central government can issue bonds or borrow on behalf of local governments from either domestic or foreign banks. The central government issued about US $\$ 75$ billion in domestic bonds and US $\$ 1.5$ billion in foreign bonds in 2003. About 10 percent of these bonds were for local governments.

However, local governments frequently succeed in circumventing these restrictions by borrowing "off the books" through special projects and enterprise accounts. Meanwhile, locally owned enterprises can and do borrow from banks and on the capital market-despite their dependence on government subsidies of various kinds, which often makes them de facto government agencies. Given the still limited direct and indirect transfers from the center to provinces, such borrowing from local commercial banks by enterprises (under the jurisdiction of local governments) actually finances local capital investment and spending. In addition, most local governments provide implicit loan guarantees for SOEs, as the budget law prohibits explicit guarantees. Local governments also provide loan guarantees to the central bank for local financial institutions so that they can avoid financial risk.

Debts to government employees-largely teachers of elementary and secondary school and to vendors providing products or services to governments-are also a main channel of local borrowing. Local governments, particularly county and lower-level governments, are responsible for salaries of teachers in elementary and secondary schools. Because of serious fiscal difficulties, governments at these levels in poor jurisdictions usually are not able to pay the full salaries. The unpaid part becomes the local debt. Local governments in poor jurisdictions may also not be able to pay farmers for their agricultural products. In such cases, farmers who sell their products 
to governments and may get only informal documents showing the government borrowing.

Domestic loans are an important approach to financing capital investment for local governments. Currently, domestic loans are more open to the state-owned units. It is common practice for local governments to freely establish companies that then borrow from the banks to initiate capital investment projects.

Local governments may also borrow through "collective financing," in which they select various groups, such as government employees and employees of local SOEs, to borrow from. The borrowing can be voluntary, but most of the time it is forced by the local government. Most of these borrowings have been used to start local enterprises. However, a significant number of these enterprises have not been successful. The bankruptcy of such enterprises in the middle and western regions, owing to lack of management skills and experience, has left serious debts for local governments, especially county and lower-level ones.

Because local borrowing is prohibited, local governments are reluctant to admit debt. Consequently, it is difficult to know the volume of local borrowing. It is estimated that total local borrowing was more than US $\$ 120$ billion by the end of 2004 (Wei 2004). The deficits of local governments have also accumulated into significant debt, because local deficits are financed by borrowing in general. Currently, debt is a very heavy burden on local governments. According to the audit report to the National People's Congress in June 2002, the total debt for 49 counties (and cities) audited was about US $\$ 8$ billion -2.1 times the yearly disposable fiscal resources. For the county and lower-level governments, it is estimated that total debts were about US $\$ 40$ billion by the end of 2001, while the debts for townships were more than US $\$ 20$ billion. The total debts would be much higher if the implicit debts, such as the unpaid civil servants' salaries and farmers' services, were included.

Local borrowing plays an important role in local economic development and in the alleviation of local fiscal pressures in China. The significant improvement of local infrastructure in almost all jurisdictions in the past decade is attributed partly to local borrowing. This contribution was more significant for richer jurisdictions such as Shanghai and Beijing. Local borrowing also temporarily alleviated local fiscal pressures in poor jurisdictions to finance current needs, because intergovernmental transfers are not well designed to meet fiscal gaps.

However, the negative side of informal local borrowing is very serious. Such borrowing creates contingent liabilities for local governments and is 
less easily controlled than explicit government borrowing, given the lack of transparency. It encourages rent-seeking and weakens local government accountability.

\section{Local Government Administration}

In principle, all local governments at and above the county level have the authority to hire and fire local employees within the ceilings established by the next-higher level of government. ${ }^{8}$ In practice, though, local civil servants enjoy lifelong employment. The organizational structure and the total number of civil servants in provincial governments require approval by the central government. The organizational structure and the number of employees in lower-level governments must be approved by the higher-level governments. The central government sets the basic requirements for local hiring and firing.

However, the principle does not apply to township governments. Township governments do not have the authority to hire and fire local staff members. Instead, hiring and firing must be done by the county government to which a township is subject.

This principle also does not apply to high-ranking officers of a government. In general, the authority to hire and fire high-ranking officers may not belong to the local government that the civil servant works for. Most senior officers in a local government are hired and fired by the next-higher level of government.

Moreover, the principle does not apply to some special departments of local governments. The departments of a local government can be roughly divided into two groups. The first group is exclusively under the leadership of the local government, and the leaders of the department report directly to the leaders of the local government. In this case, the local government determines the hiring and firing of department employees. The second group is under the leadership of both the local government and the same department in the higher-level government. For example, the local tax agency is a department of local government and financed by local government, but it is also under the leadership of the local tax agency of the higher-level government. In that case, the hiring and firing of employees of those departments are determined by the higher-level government.

Local SOEs, public schools, hospitals, and other public service units are also regarded as part of local government. Local governments determine the hiring and firing of their executive bodies, but in general the hiring 
and firing of public service unit employees are determined by the units themselves.

Currently, the degree of autonomy and flexibility in the exercise of executive powers by local governments is high in most jurisdictions, because the party committees of higher-level governments often delegate significant authority to local party leaders. However, the degree of autonomy and flexibility is very unstable and inconsistent across time and across jurisdictions, because this delegation is not formally defined and is at the discretion of the party leaders of the higher-level government.

\section{An Impressionistic View of Local Government Finances in China}

The current system of local government organization and finance in China has some positive features. Local governments assume a predominant role in the delivery of public services. In this role, they are guided primarily by national mandates, yet they have significant opportunity to adapt and innovate to meet local circumstances. They have done a phenomenal job in alleviating poverty. They have also been successful in improving infrastructural deficiencies. Good-quality infrastructure is, afterall, seen as an important inducement to investors to pump capital into their jurisdictions. New investment enables local governments to enlarge their tax bases and local leadership to assume greater political clout. These benefits provide strong incentives for local governments to focus on local economic development policies. They also stimulate a great spirit of competition to uplift local economies.

The local governments in China, nevertheless, suffer from a number of shortcomings. These include lack of clarity in their roles, weak fiscal autonomy, poorly structured system of fiscal transfers, lack of incentives for responsive and accountable delivery of public services, and perverse incentives to focus on private goods, at the expense of essential social services.

China follows a layer cake, or top-down, model of accountability for various levels of government. In this model, policy determination is mostly at the center, and responsibility for service delivery is at the county level and below. The intermediate tiers/orders simply ensure compliance with higherlevel mandates. The efficient working of such a system requires significant clarity in roles, responsibilities, and accountabilities. However, clarity in roles is currently lacking to allow greater flexibility for local-level governments. This works to the detriment of responsive and accountable local governance. 
The revenue autonomy of local governments is fairly constrained. Tax policy is centralized and local governments have no discretion in defining the base and setting rates for local taxes. They have some flexibility only in user charges. This situation creates incentives for over-reliance on fees and user charges to raise additional financing, and thus restricts access of the poor and needy, especially the rural poor, to basic social services such as health services.

Local governments receive two-thirds of their revenues from central transfers that pass through provincial and prefecture governments. These transfers are poorly structured. Their one-size-fits-all design does not recognize the differential needs of urban versus rural areas and size and geographical coverage of various jurisdictions. There is no explicit standard of equalization, and there are too many ad hoc specific-purpose transfers focused on micromanagement by higher levels of government but with no incentive and accountability for results (Shah and Chen 2006).

Some specific-purpose transfers provide perverse incentives and encourage local governments to act as employment-creation agencies or simply direct providers of services rather than purchasers, but not necessarily providers of local public services. In spite of large infrastructure deficiencies, local borrowing is restrained, which encourages off-the-books borrowing by local governments. The absence of a legal framework for fiscal responsibility, fiscal discipline, and fiscal insolvency means that off-the-books behavior will go undetected until a major crisis erupts.

Both local public finance and local economic development concerns lead local governments to assume larger roles in providing private goods directly through local state-owned enterprises (SOEs) and promoting private business development, to the detriment of their primary role in providing local public services especially to the rural poor. Local economic development enhances the national political clout of local leaders. Local ownership of SOEs encourages government to exercise informal power in the private sector, thereby opening doors for opportunistic behavior. The SOEs also help soften budget constraints and weaken local fiscal discipline.

Although local governments should be primarily accountable to local residents, in China their accountability is primarily to the higher levels of government and the local leadership of the Communist Party. To strengthen accountability to local residents, China is experimenting with direct elections of the executive body of township governments in selected jurisdictions. 


\section{Lessons for Developing Countries}

China's experience in local governance is instructive for developing countries. A few important lessons are enumerated below:

A stronger role for local governments can help produce innovative service delivery while improving local economic development. In China, a larger role for local governments in public expenditures has helped promote foreign direct investment, improve efficiency in public resource allocation, and foster economic growth (Lin and Liu 2000). In addition, it has alleviated the incidence of poverty. Meanwhile, stronger economic and political clout, associated with greater effort to levy and collect taxes, has led to faster development of private enterprises and accelerated reform of SOEs (Jin, Qian, and Weingast 1997).

Decentralized public governance can build citizen-state trust by helping the public sector focus on results-based accountability to citizens (Shah 2004). In China, decentralized public governance helped create incentives to improve local public services and responsiveness to local preferences. China's experience supports the argument that decentralized fiscal structures are more suitable in the institutional environment of developing countries, especially if careful attention is paid to the design of institutions vital for the success of decentralization policies. They include the rule of law, an enabling environment for competitive service provision, self-financing, a charter of rights for citizens, effective limitations on the authority of governments beyond their designated spheres of influence, and-most important—accountability to local residents (Shah 1999). The incentives for self-financing and interjurisdictional competition in China led to major transformations in local economies and improved service delivery.

- Interjurisdictional fiscal equity should receive serious attention in a decentralized system of local governance (Shah 1994). Although China as a whole has experienced sustained prosperity over the past decade, the gulf in fiscal disparities across the nation has widened. Public services in rural areas and poorer jurisdictions are not on a par with those in urban areas and richer jurisdictions. Dismantling internal barriers to the mobility of capital, labor, and goods and instituting fiscal capacity equalization with an explicit standard and national minimum standards grants for merit goods-such as education, health, social welfare, and infrastructure-can help in this regard. China has already taken some steps to 
deal with the urban-rural and east-west economic divides, but broader fiscal system reform efforts are needed to develop long-term solutions to these intractable issues.

\section{Notes}

1. The five separately planned cities-Dalian, Qingdao, Shenzhen, Xiamen, and Ningbo-are treated as provincial governments fiscally.

2. See the Implementation Suggestions of the State Council on the Guidelines for the Reform and Development of Education in China, issued in July 1994.

3. See the Decision on Public Health Reform and Development by the Central Committee of the Chinese Communist Party and the State Council, issued in January 1997.

4. See the Agriculture Law of the People's Republic of China, issued in July 1993.

5. Every enterprise in China has a status that shows which government (central, provincial, prefecture, county, or township) it is subject to. This system is inherited from the planned economy. In most cases, the tax revenue collected from an enterprise first goes to the government that the enterprise is subject to. This relationship may or may not correlate with the ownership of the enterprise.

6. To attract foreign investment, China has developed a corporate tax system that treats domestic and foreign investment enterprises separately.

7. More precisely, $\mathrm{TR}_{i t}=0.3 \times \mathrm{TR}_{i(t-1)}\left(\mathrm{CV}_{i t} / \mathrm{CV}_{i(t-1)}-1\right)$, where $i$ stands for province, $t$ stands for year, $\mathrm{TR}_{i t}$ is the tax rebate for province $i$ at year $t$, and $\mathrm{CV}_{i t}$ is the sum of consumption tax and 75 percent of VAT for province $i$ at year $t$.

8. See the Civil Servants Law, published in April 2005.

9. See, for example, Jin, Qian, and Weingast (1999); Lin and Liu (2000); and Zhang and Zou (1998).

\section{References}

Chen, Xiwen. 2003. China's County and Township Public Finance and Farmer Income Growth. Taiyuan, China: Shanxi Economic Press.

China, State Statistical Bureau. 2004. China Statistical Yearbook 2004. Beijing: Statistics Publishing House.

Jin, Hehui, Yingyi Qian, and Barry R. Weingast. 1999. "Regional Decentralization and Fiscal Incentives: Federalism, Chinese Style.” Working Paper SWP-99-013, Stanford University, Stanford, CA.

Lin, Justin Yifu, and Zhiqiang Liu. 2000. "Fiscal Decentralization and Economic Growth in China." Economic Development and Cultural Change 49 (1): 1-22.

Ma, Haitao. 2005. "How to Improve Rural Services Delivery and Decrease Farmers' Fiscal Burden." In Local Public Finance and Governance, ed. Anwar Shah and Chunli Shen, 444-49. Beijing: CITIC Publishing House.

Shah, Anwar. 1994. "The Reform of Intergovernmental Fiscal Relations in Developing and Emerging Market Economies.” Policy Research Working Paper 23, World Bank, Washington, DC. 
—. 1999. "Balance, Accountability, and Responsiveness: Lessons about Decentralization.” Policy Research Working Paper 2021, World Bank, Washington, DC.

- 2004. "Fiscal Decentralization in Developing and Transition Economies: Progress, Problems, and the Promise.” Policy Research Working Paper 3282, World Bank, Washington, DC.

Shah, Anwar, and Chunli Shen. 2006. "Fine-Tuning the Intergovernmental Transfers System to Achieve a Harmonious Society and a Level Playing Field for Regional Development in China." Paper presented at the International Seminar in Public Finance for a Harmonious Society, Beijing, China, June 27, 2006.

Wei, Jianing. 2004. "Local Debt and Policy Options.” Report of the State Council Research Center, Beijing.

Wong, Christine. 2000. "Central-Local Relations Revisited: The 1994 Tax-Sharing Reform and Public Expenditure Management in China." China Perspectives 31 (SeptemberOctober): 52-65.

World Bank. 2002. China National Development and Subnational Finance: A Review of Provincial Expenditures. World Bank: Washington, DC.

Zhang, Tao, and Heng-fu Zou. 1998. "Fiscal Decentralization, Public Spending, and Economic Growth in China." Journal of Public Economics 67 (2): 221-40.

Zhang, Zhihua. 2005. "Policy Options to Decrease the Regional Inequality." In Fiscal Federalism and Fiscal Management, ed. Anwar Shah and Chunli Shen, 179-84. Beijing: CITIC Publishing House. 



\title{
Local Government
}

Organization and

Finance: Urban India

O M P R A K A H M A T H U R

\begin{abstract}
$\mathrm{M}$ unicipal institutions in India have a history of more than 300 years, ${ }^{1}$ which by no consideration is long compared with the rise of the city-state of Athens, or the endowment of a corporate status on cities in the Roman Empire, or even the development of the borough system in England between 1200 and 1500. Beginning with the period preceding Lord Ripon's resolution of 1882, the municipal system in India has seen many landmark developments: the setting up of a municipal corporation in Madras (1688), ${ }^{2}$ followed by the formation in 1726 of municipal bodies for Calcutta and Bombay and the reconstitution of the Madras municipality; the passage of Act X of 1842, which provided the first formal measure of municipal organization; and the passage of Act XXVI of 1850, which made municipalities responsible for conservation, road repairs and lighting, and framing of bylaws and their enforcement by fines and which endowed them with powers of taxation, including the power to levy indirect taxes.

Lord Ripon's resolution of 1882 (see Tinker 1967) occupies an important place in the development of the representative municipal system in India. A key feature of the resolution is its emphasis on political education as the primary function of local government. The resolution reads: "It is not primarily with a view to improvement in
\end{abstract}


administration that this measure is put forward and supported. It is chiefly designed as an instrument of political and popular education" (Tinker 1967). ${ }^{3}$ Lord Ripon's resolution provided for the management of local functions and services to be placed with municipal committees and suggested that the committees be entrusted with adequate financial resources. In the words of Kavalam Madhava Panikkar, "Lord Ripon's reform of local selfgovernment laid the basis of local and municipal self-government, which soon took firm roots in India, and became the groundwork of democratic institutions in higher spheres" $(1961,211)$.

The Royal Commission on Decentralization, set up in 1906, made a number of suggestions on the decentralization of functions and powers. However, it was the government of India's resolution of 1918 that endorsed the suggestions made by the commission and proposed an orderly development of local governments in India. Under the Government of India Act 1919, local government became a budget head. The act laid down the tax powers of local government, which included the power to levy tolls, octrois, terminal taxes, and land taxes, as well as taxes on buildings, vehicles and boats, menials and domestics, animals, trade, professions and callings, and private markets. Taxes on municipal services, such as water supply, lighting, drainage, and public conveniences, were also within the scope of local government. Subsequent developments in local finance have not resulted in a better scheme of local taxation than the one laid down in the 1919 act. The Government of India Act 1935 ended the diarchic administration and assigned local self-government, under a new federal arrangement, to the provinces (now states). The 1935 act enumerated the powers of the central government and the provinces, entrusting the responsibility of defining the functions and tax powers of local governments to the provinces. ${ }^{4}$

Following the model of the 1935 act, the constitution of 1951 allocates the powers and functions of the government between the union (central government) and the state governments. Article 246 on the subject of laws states that parliament has exclusive powers to make laws with respect to any of the matters enumerated in the union list of powers and functions. It asserts that the legislature of any state has exclusive power to make laws for that state or any part of it with respect to any matter enumerated in the state list. It also states that parliament and state legislatures have power to make laws with respect to any matter enumerated in the concurrent list of functions with overriding powers resting with the union government.

Local government-that is, the constitution and powers of municipal corporations, improvement trusts, districts boards, mining settlement authorities, and other local authorities for the purpose of local self-government or 
village administration-is a subject of the state list. Under this provision, state governments have enacted laws governing local governments, including the municipal corporations and other local authorities. In addition, several entries in the state list constitute part of the functional jurisdiction of local governments.

The 74th Amendment Act 1992 marks an important watershed in the development of the municipal system in India. It gives municipalities constitutional recognition (hitherto denied), lays down the parameters for the constitution of municipalities, and defines how these municipalities might be composed. It maintains the prerogative of the state legislature over municipalities' powers, functions, and responsibilities. In schedule 12 , it provides an illustrative list of functions considered appropriate for municipalities, as an institutional arrangement under which the revenue base of municipalities may be determined. However, besides acquiring a constitutional status, legitimacy, and protection, the municipal system in India has not undergone any structural change. Admittedly, local government systems do not change easily, but there are few signs of any redistribution or realignment of powers between municipalities and state governments. For the growth and development of the third tier of governance, the National Commission set up to review the working of the constitution proposed that municipalities should have a set of exclusive functions and that the concept of a distinct and separate tax domain for municipalities should be recognized. Only then, according to the National Commission (2002), will the municipalities be able to serve as institutions of local self-government. The commission's recommendation is under consideration. Acceptance of this recommendation will alter the basic character of the constitution and have major implications for intergovernmental relations. ${ }^{5}$

The 74th amendment divides urban local bodies into three categories: municipal corporation for a larger urban area, municipal council for a smaller urban area, and nagar panchayat for an area in transition from rural to urban. No quantitative criteria have been specified for such terms as larger or smaller. However, the amendment lists five criteria for designating a settlement as an urban local body: population of the area, population density, revenue generated, percentage of employment in nonagricultural activities, and economic importance. Given that those criteria are subject to interpretation, there is considerable variation in the classification of urban local bodies in the states. ${ }^{6}$ The numbers of municipalities and their populations are given in table 5.1.

The amendment requires all seats in a municipality to be filled by people chosen by direct election. A municipality is thus an elected body, with the elected representatives (councilors) as the primary representatives of India's 
TA B LE 5. 1 Numbers of Municipalities and Their Populations

\begin{tabular}{|c|c|c|c|c|c|c|}
\hline \multirow[b]{3}{*}{ Population } & \multicolumn{2}{|c|}{1991} & \multicolumn{2}{|c|}{2001} & \multirow{2}{*}{\multicolumn{2}{|c|}{$\begin{array}{l}\text { Average annual } \\
\text { growth rate (\%) }\end{array}$}} \\
\hline & \multirow{2}{*}{$\begin{array}{c}\text { Urban } \\
\text { local } \\
\text { bodies }^{\mathrm{a}}\end{array}$} & \multirow{2}{*}{$\begin{array}{l}\text { Urban } \\
\text { population } \\
\text { (million) }\end{array}$} & \multirow{2}{*}{$\begin{array}{l}\text { Urban } \\
\text { local } \\
\text { bodies }^{\mathrm{a}}\end{array}$} & \multirow{2}{*}{$\begin{array}{c}\text { Urban } \\
\text { population } \\
\text { (million) }\end{array}$} & & \\
\hline & & & & & 1981-91 & 1991-2001 \\
\hline 100,000 and up & 322 & 122.29 & 423 & 172.04 & 3.87 & 3.41 \\
\hline $50,000-100,000$ & 421 & 28.76 & 498 & 34.43 & 2.66 & 1.80 \\
\hline $20,000-50,000$ & 1,161 & 35.27 & 1,386 & 41.97 & 2.72 & 1.74 \\
\hline $10,000-20,000$ & 1,451 & 21.08 & 1,560 & 22.60 & 1.76 & 0.70 \\
\hline $5,000-10,000$ & 971 & 7.39 & 1,057 & 7.98 & 0.64 & 0.77 \\
\hline Fewer than 5,000 & 289 & 0.97 & 227 & 0.80 & -1.52 & -1.93 \\
\hline Total & 4,615 & 215.76 & 5,151 & 279.82 & 3.14 & 2.60 \\
\hline \multicolumn{7}{|c|}{$\begin{array}{l}\text { Urban } \\
\text { agglomerations of }\end{array}$} \\
\hline
\end{tabular}

Source: 1991 data—statement 1, p. 30, part II-A(ii)-A series, table A4, series 1 of the Census of India for 1991. 2001 data-provided on CD by the Registrar General of India, Census of India 2001.

Note: Data for 1991 do not include the population of Jammu and Kashmir. Data for 2001 do not include the population of 10 urban centers in Gujarat.

a. The terms municipality and urban local body are used interchangeably.

decentralized democracy. A municipal council is headed by a mayor, who conducts the business of the councils. In at least two states, the mayor enjoys executive powers; in others, the executive powers are held either by a commissioner in municipal corporations or by executive officers in other municipalities.

\section{Expenditure Domain of Municipalities}

The state list empowers state governments to lay down the functions, powers, and responsibilities of municipal governments. Accordingly, state governments have assigned to municipalities certain functions and duties out of the powers and responsibilities enumerated for them in the state list. Typically, these responsibilities have consisted of public health and sanitation; burials, cremations, and maintenance of cremation grounds; libraries, museums, and other similar institutions; communications; roads and bridges; water supplies, drainage, and embankments, subject to certain restrictions; ${ }^{7}$ and markets and fairs.

The main functions with which the municipalities are associated and which they generally, though not uniformly, perform include services that 
have the characteristics of both private goods (water supply, sewerage and drainage, conservation, and sanitation) and public goods (street lighting and municipal roads). In addition, the municipalities are vested with a number of regulatory duties and often even with the development of markets, commercial complexes, and the like. Several municipal corporations have a larger functional domain - running hospitals and dispensaries, generating and distributing electricity, and providing bus services. ${ }^{8}$ The key point is that these functions conform to the textbook division of functions, ${ }^{9}$ which suggests that local authorities are best suited to supply local public goods and which owes itself to, among others, Adam Smith. Smith (1776) wrote on this subject, "were the streets of London to be lighted and paved at the expense of the [national] treasury, is there any probability that these would be so well lighted and paved as they were at present" (as quoted in Rattsø 1998, 24).

The domain of municipal functions, however, is neither discrete nor absolute; there is a built-in concurrency between the functional domain of state governments and municipalities. In practice, few municipalities have assumed all these responsibilities, and disparities among jurisdictions are great. The functional domain of municipalities has witnessed periodic shifts and changes, on account of the withdrawal of functions from municipalities (such as water supply and sewerage), or the addition of new responsibilities, such as poverty alleviation and planning for economic and social development.

The 74th amendment incorporates schedule 12 , which provides a list of functions considered appropriate for municipal governments. It is an illustrative list, and the state governments have the option of incorporating the functions into the state municipal laws in part or in full. The incorporation of this list has frequently been understood to mean that the municipal functional domain has acquired some sort of discrete character, apart from an expansion of its portfolio. This interpretation is, however, not accurate.

First, the functions and duties enumerated in schedule 12 are not additional to municipalities' responsibilities before 1992. In fact, there is substantial overlap between the two sets of functions. ${ }^{10}$ Of the 18 functions enumerated in schedule 12, 11 already formed a part of the municipal domain. They are regulation of land use and construction of buildings, roads, and bridges; water supply for domestic, industrial, and commercial purposes; public health, sanitation, conservation, and solid waste management; fire services; provision of urban amenities and facilities such as parks, gardens, and playgrounds; burials and burial grounds; cremation grounds and electric crematoriums; cattle pounds and prevention of cruelty to animals; vital statistics, including registration of births and deaths; public amenities, including street lighting, bus stops, and public conveniences; and 
regulation of slaughterhouses and tanneries. Even the remaining functions in schedule 12 are traceable to either the state list or, as shown later, the concurrent list (see table 5.2). Table 5.3 shows the schedule 12 functions that are linked to municipal functions enumerated in state laws.

\section{TA B L E 5 . 2 Linkage of Schedule 12 Functions with the State List and Concurrent List}

Function Constitutional provision

\section{Urban planning including town planning}

Regulation of land use and construction of buildings

Planning for economic and social development

Roads and bridges

Water supply for domestic, industrial, and commercial purposes

Public health, sanitation, conservation, and solid waste management

\section{Fire services}

Urban forestry, protection of the environment, and promotion of ecological aspects

Safeguarding the interests of weaker sections of society, including people with disabilities

Slum improvement and upgrading

Urban poverty alleviation

Provision of urban amenities and facilities such as parks, gardens, and playgrounds

Promotion of cultural, educational, and aesthetic aspects

Burials and burial grounds, cremations, cremation grounds, and electric crematoriums

Cattle pounds and prevention of cruelty to animals

Vital statistics, including registration of births and deaths

Public amenities, including street lighting, parking lots, bus stops, and public conveniences

Regulation of slaughterhouses and tanneries

Source: Constitution of India, Article 243W and Twelfth Schedule, and Article 246 and Seventh Schedule. Note: Several functions in schedule 12 have no clear link with either the state list or the concurrent list. However, urban planning can be seen as part of regulation of land use, urban poverty alleviation can be considered part of planning for economic and social development, slum improvement and upgrading can be considered part of construction of buildings, and provision of urban amenities can be seen as part of promotion of aesthetic aspects. 
TA B L E 5 . 3 Linkage of Schedule 12 Functions with Municipal Functions Listed in State Laws

\begin{tabular}{|c|c|c|c|c|c|c|}
\hline \multirow[b]{2}{*}{ State } & \multicolumn{6}{|c|}{ Function } \\
\hline & $\begin{array}{l}\text { Safeguarding the } \\
\text { interests of weaker } \\
\text { segments of society }\end{array}$ & $\begin{array}{l}\text { Slum } \\
\text { improvement } \\
\text { and upgrading }\end{array}$ & $\begin{array}{l}\text { Promotion } \\
\text { of cultural, } \\
\text { educational, and } \\
\text { aesthetic aspects }\end{array}$ & $\begin{array}{l}\text { Urban planning, } \\
\text { including town } \\
\text { planning }\end{array}$ & $\begin{array}{l}\text { Planning for } \\
\text { economic } \\
\text { and social } \\
\text { development }\end{array}$ & $\begin{array}{l}\text { Urban forestry, } \\
\text { protection of the } \\
\text { environment, } \\
\text { and promotion } \\
\text { of ecology }\end{array}$ \\
\hline Goa & $\begin{array}{l}\text { Provide for mental } \\
\text { patients, leprosy } \\
\text { patients, and so } \\
\text { forth }\end{array}$ & $\begin{array}{l}\text { Construct sanitary } \\
\text { dwellings for the } \\
\text { poorer classes }\end{array}$ & $\begin{array}{l}\text { Provide music; } \\
\text { contribute toward } \\
\text { construction and } \\
\text { establishment of } \\
\text { educational } \\
\text { institutions, libraries, } \\
\text { museums, and } \\
\text { so forth. }\end{array}$ & & & \\
\hline Haryana & $\begin{array}{l}\text { Establish crèches } \\
\text { for children of } \\
\text { women in need }\end{array}$ & & & & & $\begin{array}{l}\text { Prohibit } \\
\text { cultivation, use of } \\
\text { manure, or } \\
\text { irrigation that is } \\
\text { injurious to health } \\
\text { (continued) }\end{array}$ \\
\hline
\end{tabular}


Karnataka Provide shelter for destitute women; house destitute orphans and destitute people with disabilities

\section{Kerala}

\section{Organize the campaign} for thrift; voluntary workers for participation and collective activities; neighborhood groups and self-help groups with a focus on the poor; campaigns against such issues as dowry, abuse of women and children; and legal awareness
Function

\begin{tabular}{|c|c|c|c|}
\hline $\begin{array}{l}\text { Promotion } \\
\text { of cultural, } \\
\text { educational, and } \\
\text { aesthetic aspects }\end{array}$ & $\begin{array}{l}\text { Urban planning, } \\
\text { including town } \\
\text { planning }\end{array}$ & $\begin{array}{l}\text { Planning for } \\
\text { economic } \\
\text { and social } \\
\text { development }\end{array}$ & $\begin{array}{l}\text { Urban forestry, } \\
\text { protection of the } \\
\text { environment, } \\
\text { and promotion } \\
\text { of ecology }\end{array}$ \\
\hline $\begin{array}{l}\text { Construct, establish, } \\
\text { or maintain } \\
\text { libraries, museums, } \\
\text { and so forth; provide } \\
\text { music or other enter- } \\
\text { tainment in public } \\
\text { places; maintain art } \\
\text { galleries }\end{array}$ & & $\begin{array}{l}\text { Revive or } \\
\text { promote cottage } \\
\text { industries; } \\
\text { promote, form, } \\
\text { extend, or assist } \\
\text { cooperative } \\
\text { societies }\end{array}$ & $\begin{array}{l}\text { Plant } \\
\text { and maintain } \\
\text { roadside trees }\end{array}$ \\
\hline $\begin{array}{l}\text { Promote } \\
\text { communal } \\
\text { harmony; } \\
\text { campaign against } \\
\text { economic offenses }\end{array}$ & $\begin{array}{l}\text { Prepare detailed } \\
\text { town planning } \\
\text { and action } \\
\text { plans }\end{array}$ & $\begin{array}{l}\text { Ensure that } \\
\text { people } \\
\text { participate in } \\
\text { all stages of } \\
\text { development; } \\
\text { develop the } \\
\text { cooperative } \\
\text { sector }\end{array}$ & $\begin{array}{l}\text { Maintain } \\
\text { environmental } \\
\text { hygiene, } \\
\text { including } \\
\text { environmental } \\
\text { awareness of } \\
\text { the need to } \\
\text { seek local } \\
\text { action }\end{array}$ \\
\hline
\end{tabular}




\begin{tabular}{|c|c|}
\hline $\begin{array}{l}\text { Madhya } \\
\text { Pradesh }\end{array}$ & $\begin{array}{l}\text { Provide for } \\
\text { maintenance and } \\
\text { treatment of mental } \\
\text { patients and lepers at } \\
\text { asylums, hospitals, } \\
\text { or houses; establish } \\
\text { ashrams for destitute } \\
\text { people, people } \\
\text { with disabilities, } \\
\text { and elderly people; } \\
\text { establish and } \\
\text { maintain a poor } \\
\text { house }\end{array}$ \\
\hline $\begin{array}{l}\text { Uttar } \\
\text { Pradesh }\end{array}$ & $\begin{array}{l}\text { Remove social disabilities } \\
\text { of weaker segments of } \\
\text { the population; } \\
\text { control beggary }\end{array}$ \\
\hline
\end{tabular}

$\begin{array}{ll}\text { Construct } & \text { Construct, } \\ \text { sanitary } & \text { establish, } \\ \text { dwellings for } & \text { or maintain } \\ \text { the poorer } & \text { educational } \\ \text { classes } & \text { institutions, } \\ & \text { libraries, museums, } \\ & \text { and so forth; } \\ & \text { further educational } \\ & \text { objectives; play music } \\ & \text { in public places }\end{array}$

Plant and

maintain

roadside and

other trees

\author{
Establish and \\ maintain or grant \\ aid to institutions \\ of physical culture; \\ contribute toward \\ construction and \\ establishment of \\ educational \\ institutions, libraries, \\ museums, and so \\ forth
}

Plant and

maintain

trade and other trees 
T A B E 5 . 3 Linkage of Schedule 12 Functions with Municipal Functions Listed in State Laws (continued)

\begin{tabular}{|c|c|c|c|c|c|c|}
\hline \multirow[b]{2}{*}{ State } & \multicolumn{5}{|c|}{ Function } & \multirow[b]{2}{*}{$\begin{array}{l}\text { Urban forestry, } \\
\text { protection of the } \\
\text { environment, } \\
\text { and promotion } \\
\text { of ecology }\end{array}$} \\
\hline & $\begin{array}{l}\text { Safeguarding the } \\
\text { interests of weaker } \\
\text { segments of society }\end{array}$ & $\begin{array}{l}\text { Slum } \\
\text { improvement } \\
\text { and upgrading }\end{array}$ & $\begin{array}{l}\text { Promotion } \\
\text { of cultural, } \\
\text { educational, and } \\
\text { aesthetic aspects }\end{array}$ & $\begin{array}{l}\text { Urban planning, } \\
\text { including town } \\
\text { planning }\end{array}$ & $\begin{array}{l}\text { Planning for } \\
\text { economic } \\
\text { and social } \\
\text { development }\end{array}$ & \\
\hline $\begin{array}{l}\text { West } \\
\text { Bengal }\end{array}$ & $\begin{array}{l}\text { Construct and maintain } \\
\text { old-age homes, asylums, } \\
\text { low-cost dwellings } \\
\text { for socially backward } \\
\text { classes, and shelters } \\
\text { for the homeless; } \\
\text { free and rehabilitate } \\
\text { scavengers; promote } \\
\text { income-generating } \\
\text { activities for women } \\
\text { of socially backward } \\
\text { classes }\end{array}$ & $\begin{array}{l}\text { Regulate limits of } \\
\text { slums or areas of } \\
\text { makeshift housing; } \\
\text { prepare } \\
\text { improvement } \\
\text { schemes; lay out } \\
\text { plans for sanction } \\
\text { of erection of } \\
\text { huts and so } \\
\text { forth; encourage } \\
\text { participation of } \\
\text { owners and } \\
\text { occupiers }\end{array}$ & $\begin{array}{l}\text { Promote music, } \\
\text { physical education, } \\
\text { sports, theater, civic } \\
\text { education, adult } \\
\text { education, social } \\
\text { education, and } \\
\text { so forth. }\end{array}$ & $\begin{array}{l}\text { Prepare a } \\
\text { master plan }\end{array}$ & & $\begin{array}{l}\text { Reclaim } \\
\text { wastelands; } \\
\text { maintain } \\
\text { nurseries } \\
\text { for plants, } \\
\text { vegetables, } \\
\text { and trees; } \\
\text { promote } \\
\text { pisciculture, } \\
\text { horticulture, } \\
\text { poultry, and } \\
\text { so forth; promote } \\
\text { flower shows }\end{array}$ \\
\hline
\end{tabular}

Source: State municipal acts.

Note: Urban poverty alleviation is one of the constitutional responsibilities, but local governments have not been able to incorporate this into their functional domains. 
Second, the significance of schedule 12 functions for municipalities lies not so much in enlarging the scope of municipal operations as in the fact that many of the functions are drawn from the concurrent list of the constitution. At a minimum, this fact would suggest that there is a group of functions wherein concurrency of interests by all three tiers of government exists. The 1992 constitutional amendment, however, is vague; it does not spell out the responsibilities required of local governments regarding such functions as planning for economic and social development, protecting the environment and promoting ecology, and safeguarding the interests of weaker sections of society. Nor does it enumerate the tasks to be performed by the central and state governments.

Third, many of the functions listed in schedule 12 have distributional attributes. This fact both represents a major departure from the past and marks a deviation from the typical Musgrave model of fiscal federalism. It is extensively argued in the literature on fiscal federalism that redistribution in a federal system is a central function. Musgrave (1959), for instance, argued in his seminal book that distributive adjustments at local levels can be nullified by interstate movements, adding that conflicting goals for redistribution between the levels of government could result in a continuous set of adjustments and readjustments without reaching equilibrium. ${ }^{11}$ For this reason, functions such as poverty alleviation, environmental protection and preservation, and even slum upgrading have continued to lie within the ambit of central and state governments, with a minimal role for municipalities. The 74th amendment has altered this position, without any formal or informal suggestion on how these functions might be financed, with what tax bases, and with what intergovernmental transfer arrangements.

The relative importance of expenditure responsibilities varies between states. Comparing the per capita expenditures on different services shows that provision of water supply and conservation and sanitation are the key services, followed by sewerage and drainage and citywide roads. However, though conservation and sanitation are important in all municipalities, there is considerable interstate variation with regard to water provision, because in some states it is entrusted to a state- or city-level parastatal agency. Table 5.4 gives the relative importance of core services, measured in terms of per capita revenue expenditure.

\section{Revenue Base of Municipalities}

The constitution does not lay down the revenue base for municipalities. The power to determine the revenue base- be it the tax authority, tax base, tax 
TA B L E 5 . 4 Per Capita Revenue Expenditure on Core Services (rupees)

\begin{tabular}{|c|c|c|c|c|c|c|c|c|c|c|}
\hline \multirow[b]{2}{*}{ States } & \multicolumn{2}{|c|}{ Water supply } & \multicolumn{2}{|c|}{$\begin{array}{l}\text { Sewerage and } \\
\text { drainage }\end{array}$} & \multicolumn{2}{|c|}{$\begin{array}{c}\text { Conservancy } \\
\text { and sanitation }\end{array}$} & \multicolumn{2}{|c|}{ Municipal roads } & \multicolumn{2}{|c|}{ Street lighting } \\
\hline & $1992 / 93$ & 1997/98 & 1992/93 & $1997 / 98$ & $1992 / 93$ & 1997/98 & $1992 / 93$ & 1997/98 & 1992/93 & 1997/98 \\
\hline Andhra Pradesh & 25.20 & 50.52 & 12.05 & 55.12 & 45.57 & 63.37 & 21.49 & 102.53 & 6.37 & 13.19 \\
\hline Assam & 3.01 & 2.98 & 3.86 & 7.46 & 7.56 & 12.60 & 11.25 & 24.17 & 2.03 & 2.49 \\
\hline Bihar & 4.50 & 4.32 & 26.69 & 40.45 & 32.60 & 39.85 & 4.33 & 2.93 & 2.34 & 1.29 \\
\hline Gujarat & 61.00 & 60.40 & 44.85 & 44.28 & 58.38 & 119.37 & 34.41 & 52.23 & 9.43 & 29.76 \\
\hline Haryana & 64.61 & 191.84 & 34.80 & 89.99 & 58.10 & 108.56 & 99.62 & 57.77 & 22.73 & 30.74 \\
\hline Himachal Pradesh & 78.44 & 89.57 & 19.24 & 36.67 & 149.09 & 251.76 & 71.44 & 304.90 & 0.85 & 15.62 \\
\hline Karnataka & 31.05 & 62.56 & 19.99 & 42.91 & 36.46 & 74.19 & 36.48 & 46.46 & 14.63 & 25.92 \\
\hline Kerala & 1.30 & 2.84 & 4.42 & 8.98 & 26.68 & 66.14 & 37.42 & 46.49 & 8.47 & 8.37 \\
\hline Madhya Pradesh & 30.62 & 79.44 & 21.88 & 31.92 & 40.69 & 37.10 & 20.73 & 27.19 & 7.49 & 13.16 \\
\hline Maharashtra & 117.69 & 230.00 & 84.92 & 155.58 & 115.23 & 195.87 & 79.75 & 117.35 & 33.84 & 43.08 \\
\hline Manipur & - & 0.03 & - & - & 15.46 & 27.05 & 9.01 & 16.38 & - & - \\
\hline Meghalaya & 36.84 & 46.57 & 20.90 & 16.66 & 47.59 & 55.98 & 39.92 & 47.32 & 10.18 & 23.03 \\
\hline Orissa & 4.16 & 9.66 & 26.79 & 42.58 & 48.61 & 67.91 & 11.13 & 16.29 & 7.09 & 13.08 \\
\hline Punjab & 42.43 & 95.38 & 53.13 & 109.70 & 70.43 & 118.44 & 27.75 & 48.67 & 15.61 & 23.35 \\
\hline Rajasthan & - & - & 91.55 & 165.07 & - & - & 7.80 & 12.28 & 2.45 & 5.40 \\
\hline Tamil Nadu & 33.09 & 45.92 & 5.06 & 13.39 & 60.33 & 111.86 & 19.65 & 56.13 & 5.45 & 23.25 \\
\hline Tripura & 1.84 & 0.01 & - & - & - & - & 1.24 & 2.13 & 0.51 & 4.99 \\
\hline Uttar Pradesh & 13.97 & 16.48 & 4.99 & 5.41 & 76.37 & 112.10 & 27.91 & 34.64 & 6.48 & 9.52 \\
\hline West Bengal & 92.19 & 60.01 & 33.12 & 41.58 & 82.16 & 119.48 & 41.53 & 63.71 & 17.85 & 13.72 \\
\hline Average & 73.79 & 125.77 & 50.96 & 93.21 & 76.56 & 123.36 & 43.25 & 70.19 & 17.29 & 23.28 \\
\hline
\end{tabular}

Source: Mathur, Sengupta, and Bhaduri 2000 Note: $-=$ not available. 
rate setting, local tax autonomy, or even the grants in aid and other forms of transfers-rests with state governments. Within this framework, state governments have specified the taxes that municipalities can levy and collect. Historically, ${ }^{12}$ these have comprised taxes on land and buildings; taxes on the entry of goods into a local area for consumption, use, or sale therein (octrois); taxes on advertisements other than those published in newspapers; taxes on animals and boats; tolls; taxes on professions, trades, callings, and employment; ${ }^{13}$ and taxes on entertainment. In addition, there are charges, fees, and fines that form the nontax base of municipalities.

Taxes on property and octrois form the backbone of the municipal tax base. Between the two, municipal governments have shown a preference for indirect taxes and levies such as octrois over direct taxes such as property taxes, even when direct taxes are a suitable form of taxation because their incidence is localized. At one time property taxation was so important that scholars theorized that the expenses of government could be funded from site rents. Henry George (1879), whose work on this subject came to be known as the Henry George Theorem, concluded that at an optimal population size, site rents should equal the cost of collective goods. Octrois are among the more buoyant and elastic of local taxes and are currently levied in parts of Gujarat, Maharashtra, and Punjab. ${ }^{14}$

The revenue base of municipalities in Indian states has shown little sign of change, notwithstanding the 74th amendment; indeed, octrois-a major revenue source for municipalities - have been abolished in many states without being replaced by any other local source, a move that has substantially dented the revenue base of municipalities.

Although the municipal revenue base in India may fulfill the criteria for a local tax base (meeting the principles of residence and benefit taxation, low mobility, and stability over a business cycle), and although it may create a link between service use and tax payment, the municipal revenue base is controlled and regulated by state governments. Rate capping and control over municipal spending and taxation are common. Most state governments lay down local tax policies, including policies relating to the choice of tax rates or the determination of who can be included or excluded from payment of taxes. Absence of autonomy (or low discretion) in matters relating to tax rate setting is a key feature of the functioning of municipal governments in India (table 5.5). ${ }^{15}$

\section{Center-State-Municipal Fiscal Relations}

Until the passage of the 74th amendment, municipal affairs were an exclusive concern of the state governments. Drawing strength from the constitutional 
TA B L E 5 . 5 Revenue Powers of Municipalities across Major States

\begin{tabular}{lll}
\hline & \multicolumn{2}{c}{ Type of tax } \\
\cline { 2 - 3 } State & Compulsory & Discretionary
\end{tabular}

Andhra Pradesh $\quad$ Property: lighting, ${ }^{\mathrm{a}}$
water, ${ }^{\mathrm{a}}$ scavenging, ${ }^{\mathrm{a}}$ drainage, ${ }^{\mathrm{a}}$ general
purposes $^{a}$, vehicles, transfer of immovable property, animals

Advertisement

Advertisement, mutation, registration, market, trade license, compounding, slaughterhouse, license

Assam

Bihar

Transfer of property

Goa
Property: water, ${ }^{a}$ lighting, ${ }^{a}$ drainage ${ }^{a}$ License for carts, carriages, markets, bridge toll, transfer of property

On persons in sole or joint occupation of holding according to their animals, dogs and cattle, boats, betterment, fire brigade, public health

Registration of dogs, carts, vehicles, and vessels
Consolidated property: general, a general water, ${ }^{a}$ lighting, , sanitary, ${ }^{a}$ advertisement, profession, theater circumstances and property; property: water, ${ }^{a}$ lighting, ${ }^{a}$ latrine, ${ }^{a}$ vehicle, animal, professional, dog

Vehicle, boat, animal, dog, garbage treatment, latrine, drainage, special water, pilgrim, special education, octroi 
Gujarat

Haryana

Property, octroi, transfer of immovable property

Himachal Pradesh Property, transfer of immovable properties
Property, vehicle, boat, animal, motor vehicle, octroi, dog, special and general sanitary, lighting, sale of cattle in market, betterment

Professional, vehicle, animal, dog show, boat, electricity consumption

Professional, unmotorized vehicle, animal, dog show, vehicle, boat, electricity consumption, advertisement, building application, education

Property, advertisement, boat, animal, lighting, vehicle, transfer of immovable property

Property: water, ${ }^{a}$ general purpose, ${ }^{a}$ lighting, ${ }^{a}$ drainage, ${ }^{\text {a }}$ sanitary, ${ }^{a}$ professional, animal, vessel, show, advertisement, timber, transfer of property
Registration, license, swimming bath, slaughterhouse, building construction, shop registration, water or connection, cattle pound

License, building application, teh bazari, extension, advertisement, slaughterhouse, cattle pound, registration, street

Pilgrim, drainage, lighting, scavenging, latrine, nature and cost of internal service

License (building, trade, hotel); building betterment; birth and death registration; food and adulteration; slaughterhouse; compounding

License, building, dangerous and offensive trade license, market, slaughterhouse 
Type of tax

State Compulsory

Discretionary

Latrine, conservation, drainage, professional, vehicle, animal, betterment, pilgrim, people occupying houses, building, land, new bridge toll, entertainment, advertisement, terminal

Maharashtra Consolidated property tax: general,a general water, ${ }^{a}$ lighting, ${ }^{a}$ sanitary, ${ }^{a}$ octroi, professional, theater, advertisement

Punjab
Property: latrine, ${ }^{\mathrm{a}}$ water, ${ }^{\mathrm{a}}$ light, ${ }^{\mathrm{a}}$ drainage, ${ }^{a}$ animal, vehicle, professional, poll, octroi, education

Vehicle, boat, animal, dog, latrine, drainage, special water, pilgrim, special educational, fire brigade

Property, professional, vehicle, animal, menial domestic servant, scavenging, building application
Fee

License, market, animal registration, hotel or restaurant license, composting, teh bazari, ${ }^{\text {b }}$ building application, compounding

License, slaughterhouse, building permission, sale of goods, water connection, warrant, prevention of food adulteration license, cattle pound, swimming pool, birth and death registration, betterment and development

License, advertisement, registration, market, slaughterhouse, pound, dog registration, cart stand, building planning

License, slaughterhouse, building application, composition, teh bazari, ${ }^{\text {b }}$ connection, copying 
Rajasthan

Property, octroi, professional and vocationalc

Tamil Nadu

Uttar Pradesh

West Bengal
Vehicle and other conveyance, dog, animal, boat, scavenging, latrine, sanitary, lighting, water, trade and calling, artisan

Property, professional, carriage and animal, care, advertisement, servant

Property, trade, calling, vocation remunerated by salary or fees, entertainment, vehicle, boat, dog, animal, inhabitants assessed on property and circumstances, water, ${ }^{\mathrm{a}}$

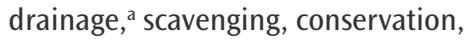
transfer of property
Advertisement, permission, license, registration, cattle pound, bus stand, copying

License (building, hotel, restaurant, dangerous and offensive trade), market, slaughterhouse, cart stand, encroachment

License, advertisement, building planning and development, house connection, permission, market and slaughterhouse, birth and death registration, burning ghats

Source: State municipal acts.

Note: Vehicles imply unmotorized vehicles, unless otherwise specified.

a. Included under a consolidated property tax.

b. Charged to hawkers.

c. Tax on trade and calling differs from professional and vocational tax, which is compulsory. 
provisions, the state governments determined the expenditure responsibilities and fiscal powers and authority of municipalities and defined the degree of autonomy with which they could function. Discussions on how to improve the financial viability of municipalities or streamline the flow of funds to them or carry out municipal tax reform took place within the parameters of state control over municipalities. In principle, the state governments assumed responsibility for the financial viability of municipalities, using transfers as an instrument for bridging the gap between what the municipalities needed to carry out their mandated functions and what their revenue powers yielded. They also assumed responsibility for meeting the financial needs of municipalities with cost disabilities.

Transfers to municipalities before 1992 accrued under two major headings: transfers through tax-sharing arrangements and transfers through grants. Tax-sharing arrangements specified how and in what proportion state taxes were to be shared with municipal governments. Tax-sharing arrangements were thus different from the use of the same tax base, tapped by different levels of governments. Grants were the second, widely prevalent form of transfers. Grants were nonmatching general or unconditional, special-purpose or conditional, and compensatory — that is, given in lieu of tax bases appropriated by the higher levels of governments. Some grants also required matching contributions from the municipal governments.

Transfers through the sharing of tax receipts accounted for a relatively small proportion, approximately 15 to 16 percent, of total municipal revenue incomes before 1992. The share of grants was about 16 to 18 percent. Within grants, the share of general-purpose, nonmatching grants was about 9 to 10 percent, signaling that grants extended for specific purposes were a dominant form of transfers at municipal levels in India. This situation generally prevailed; some states, however, preferred to use tax-sharing arrangements for effecting transfers, and others preferred conditional grants.

The main taxes shared between the state governments and municipalities before 1992 included entertainment taxes, motor vehicle taxes, stamp duties, profession taxes, and entry taxes. The mode of sharing these taxes differed between states. In Tamil Nadu, for instance, where the entertainment tax was shared between the state and municipalities, 65 to 70 percent of the proceeds of entertainment taxes were devolved to municipalities. In Maharashtra, entertainment tax receipts were allocated among different types of municipalities on the basis of varying proportions of revenue collected from their areas: 10 percent of collections to the municipal corporations, 30 percent to larger municipalities, 35 percent to medium-size municipalities, and 40 percent to smaller municipalities. In West Bengal, 50 percent of receipts 
from entertainment taxes were assigned to municipal bodies on the basis of population. In a similar fashion, the mechanism for sharing stamp duties varied between states. The Kerala Stamp Act, for instance, permitted municipalities to levy surcharges on stamp duties on specified instruments related to immovable property situated in their areas. In Tamil Nadu, too, a surcharge was levied on stamp duties that was devolved to municipal bodies after deduction of collection charges. For the motor vehicle tax, there was no fixed pattern for sharing proceeds.

Grants were universally used as a mechanism for transferring financial resources to municipalities. A striking feature of the grant system was the use of several types of grants. For example, in Gujarat, there were as many as 4 general-purpose grants, 16 special-purpose grants, and 4 statutory grants and shared taxes. In Maharashtra, there were 3 general-purpose grants and 18 special-purpose grants, plus 3 taxes that were shared with municipal bodies. What is important is that barring transfers on account of the dearness allowance (an allowance granted to compensate for inflation), primary education, and entertainment, the yield from other grants was extremely low, with most grants yielding no more than 1 or 2 percent of total transfers.

There was thus a high element of diversity in the system of state transfers to municipalities. The diversity was noted not only in the number of transfers made by the different states but also in the share of transfers in the revenue income of municipalities in the different states, the constituents of transfers and their relative transfers, and the criteria used by states for making transfers under different headings.

Studies pointed to the vulnerability of the transfer system on four counts:

The excessively large number of transfers on different accounts made the system costly and difficult to administer and its impact difficult to measure.

The ad hoc and irregular nature of transfers rendered moot any attempt by municipal bodies to realistically assess their total resource position and consequently to plan their activities. The absence of predictability and stability in the level of transfers was one of the most significant weaknesses of the transfer system before 1992 .

Municipal bodies have a natural tendency to substitute their resources and resource mobilization efforts for transfers. On the basis of data from four states, a National Institute of Public Finance and Policy paper estimated that a 1 percent increase in the state transfers to municipalities replaces approximately 0.22 percent of the locally raised revenues (Mehta 1992). Undermining the local tax effort instead of designing the transfer 
system in a way that it strengthened the effort was yet another of the deficiencies noted in the transfer mechanisms.

- The municipal system was overloaded with special-purpose grants for which it was not adequately equipped or which led to diversion from the main statutory tasks. Many of the grants were said to have had a distortionary impact on local priorities.

The 74th amendment and related amendments to the constitution (article 280(3)(c)) have, however, altered the fiscal arrangement between the states and municipalities and established, for the first time, a fiscal link between the central government and municipalities. This link is provided through the institution of the Central Finance Commission, which is now mandated to "suggest measures needed to augment the consolidated fund of a state to supplement the resources of the municipalities on the basis of the recommendations made by the finance commission of states" (Bakshi 2003, 237).

Following this provision, the Central Finance Commission making recommendations for the period $2000-05^{16}$ provided a sum of Rs 20 billion for municipalities to improve the maintenance of civic services such as primary education, primary health care, safe drinking water, street lighting, sanitation, and other common property resources. The grant included a sum of Rs 29.4 million for the creation of databases related to the finances of municipalities and such sums as might be needed by municipalities for proper upkeep and maintenance of their accounts and audits. The 11th Central Finance Commission has established a comprehensive framework for the allocation of grants to states for municipalities. The framework consists of a set of criteria, each criterion assigned a weight (table 5.6).

The principle underlying the framework is that, apart from sizerepresented by population and geographic area-which is a major determinant of the financial requirement of municipalities and which consequently commands a larger weight, the grant should be allocated on the basis of a set of complementary criteria of efficiency and equity. Efficiency is measured by the revenue-raising effort of municipalities, and equity is represented by the difference between the average per capita nonagricultural gross state domestic product (GSDP) and the highest average per capita nonagricultural GSDP. The first is meant to serve as an incentive for municipalities to boost their revenue efforts, and the second provides funds for the fiscally disadvantaged municipalities. An important criterion (which commands a 20 percent weight in the grant allocation) relates to decentralization as 
TA B L E 5 . 6 Criteria Used by the Central Finance Commission for Determining the Allocation of Grants to States for Urban Local Bodies

\begin{tabular}{|c|c|c|}
\hline \multicolumn{2}{|c|}{ Criterion } & $\begin{array}{c}\text { Weight } \\
\text { (as } \% \\
\text { total } \\
\text { allocation) }\end{array}$ \\
\hline \multicolumn{2}{|c|}{ Urban population } & 40 \\
\hline \multicolumn{2}{|c|}{ Geographic area } & 10 \\
\hline & 20 \\
\hline \multicolumn{3}{|c|}{ Own-source revenue efforts of the municipalities in a state, using state's } \\
\hline \multicolumn{2}{|r|}{$\begin{array}{l}\text { Own-source revenue efforts of the municipalities in a state, using gross state } \\
\text { domestic product as an indicator }\end{array}$} & 5 \\
\hline \multicolumn{2}{|c|}{ Index of decentralization } & 20 \\
\hline \multicolumn{3}{|c|}{$\begin{array}{l}\text { Enactment of state municipal legislation in conformity with the } \\
\text { 74th amendment }\end{array}$} \\
\hline \multicolumn{3}{|c|}{$\begin{array}{l}\text { Intervention or restriction in the functioning of the municipal } \\
\text { bodies }\end{array}$} \\
\hline \multicolumn{3}{|c|}{$\begin{array}{l}\text { Assignment of functions to municipalities in the state municipal } \\
\text { legislation according to schedule } 12\end{array}$} \\
\hline \multicolumn{3}{|c|}{$\begin{array}{l}\text { Transfer of functions to municipalities by way of rules or notifica- } \\
\text { tions }\end{array}$} \\
\hline \multicolumn{3}{|c|}{ Orders of state government } \\
\hline \multicolumn{3}{|c|}{$\begin{array}{l}\text { Assignment of taxation powers to municipalities according to state } \\
\text { municipal acts }\end{array}$} \\
\hline \multicolumn{3}{|c|}{ Levy of taxes by municipalities } \\
\hline \multicolumn{3}{|c|}{$\begin{array}{l}\text { Constitution of the state finance commissions and submission of } \\
\text { "action taken" reports }\end{array}$} \\
\hline \multicolumn{3}{|c|}{$\begin{array}{l}\text { Action taken on the major recommendations of the state finance } \\
\text { commission }\end{array}$} \\
\hline \multicolumn{3}{|c|}{ Elections to municipalities } \\
\hline & Constitution of district planning committees & \\
\hline
\end{tabular}

Source: Finance Commission 2000, appendix VIII.2, paragraph 8.24, pp. 312-13.

envisioned in the 74th amendment. An index has been proposed by the 11th Central Finance Commission for measuring decentralization.

The 74th amendment has simultaneously altered the fiscal arrangement between the states and municipalities. Under the new fiscal arrangement, once every five years every state government is required to constitute a state finance commission and entrust it with two tasks: reviewing the financial position of municipalities and making recommendations on the principles that should govern (a) the distribution between the state and the municipalities of the net 
proceeds of taxes, duties, tolls, and fees leviable by the state; (b) the determination of the taxes, duties, tolls, and fees that may be assigned to, or appropriated by, the municipalities; and (c) the grants in aid to municipalities from the consolidated funds of the state.

Apart from serving the larger purpose of strengthening the forces of decentralization in the country, these amendments have three implications:

The system of assigning tax powers and authority to municipalities and sharing the state resources with municipalities was inadequate to meet the financial requirement of municipalities.

As municipalities under the provision of schedule 12 acquire additional expenditure responsibilities, several of which have interjurisdictional implications, a new fiscal system may have to be put in place.

- An institution outside the government framework may be able to better assess the financial requirements of municipalities and devise an appropriate fiscal package for them.

As a result of the constitution of state finance commissions, the system of transfers between the state and municipalities has undergone a dramatic shift, with far greater emphasis being given to stability. Several states, instead of sharing individual tax revenues with municipalities, have opted for "pool sharing" of state resources. This system permits municipalities to benefit from the buoyancy of state revenues. In such states, the relative importance of general-purpose grants has declined. In many states, the system of sharing revenues from individual state-level taxes continues. Table 5.7 gives the share of municipalities in states' resources as recommended by the first state finance commission.

\section{Borrowing by Municipal Governments}

Municipal government borrowing is regulated by the Local Authorities Loans Act $1914 .{ }^{17}$ This act specifies purposes for which local bodies may contract a loan, limits on the amount of the loan, duration of loans, security or collateral, and repayment procedures. Subject to these limits, a state government has the flexibility to determine the framework within which local governments (all forms of local bodies including parastatals) can borrow from the market. The framework laid out in the state-level municipal laws contains rules about (a) the nature of the funds on the security of which money may be borrowed, (b) the works for which money may be borrowed, (c) the manner of applying for permission to borrow, (d) the manner of raising 
TA B L E 5 . 7 Share of Municipalities in State's Resources as Recommended by the First State Finance Commission

\begin{tabular}{|c|c|}
\hline State & Recommended share \\
\hline Andhra Pradesh & $39.24 \%$ of state tax and nontax revenue for all local bodies. \\
\hline Assam & $\begin{array}{l}2 \% \text { of state tax for local bodies, both rural and urban. (The } \\
\text { share of urban local bodies has not been specified.) }\end{array}$ \\
\hline Himachal Pradesh & $\begin{array}{l}\text { An amount equal to Rs } 1.2 \text { billion as grants in lieu of octroi for } \\
1996 / 97 \text {, rising to Rs } 1.79 \text { billion in } 2000 / 01 \text { and centrally spon- } \\
\text { sored scheme grants to accrue to municipalities. }\end{array}$ \\
\hline Karnataka & $\begin{array}{l}5.4 \% \text { of the total nonloan gross own-source revenue receipts for } \\
\text { meeting plan and nonplan requirements. }\end{array}$ \\
\hline Kerala & $\begin{array}{l}1 \% \text { of state revenues (excluding from certain sources) trans- } \\
\text { ferred to local bodies as nonstatutory nonplan grants distrib- } \\
\text { uted between the rural and urban local bodies in proportion to } \\
\text { their population. }\end{array}$ \\
\hline Madhya Pradesh & $8.67 \%$ of the tax and nontax revenues of state government. \\
\hline Maharashtra & $\begin{array}{l}25 \% \text { to } 100 \% \text { of entertainment taxes collected from municipali- } \\
\text { ties of different grades, } 25 \% \text { of vehicle taxes, and } 10 \% \text { of profes- } \\
\text { sion taxes. }\end{array}$ \\
\hline Manipur & $\begin{array}{l}\text { Maintenance grant equal to Rs } 8.83 \text { million to accrue to munic- } \\
\text { ipalities in 1996/97. (The amount varies in subsequent years.) }\end{array}$ \\
\hline Orissa & $\begin{array}{l}\text { Projected transfer (grant) to urban local bodies between } \\
1998 / 99 \text { and } 2004 / 05 \text { of Rs } 17.95 \text { billion. (The deficit of Rs } \\
13.78 \text { billion between the estimated income and expenditure } \\
\text { and an additional requirement of Rs } 3.81 \text { billion for improve- } \\
\text { ment of core civic services should be met by the 11th Central } \\
\text { Finance Commission.) }\end{array}$ \\
\hline Punjab & $\begin{array}{l}20 \% \text { of net proceeds for five taxes-stamp duty, motor vehicle } \\
\text { tax, electricity duty, entertainment tax, and cinematography } \\
\text { shows- to be transferred to municipalities. (The projected gap } \\
\text { of Rs } 3.22 \text { billion should be met by the Central Finance Com- } \\
\text { mission.) }\end{array}$ \\
\hline Rajasthan & $\begin{array}{l}2.18 \% \text { of net proceeds of state taxes. (The division of these pro- } \\
\text { ceeds between rural and urban should be in the ratio of } 3.4: 1 \text {.) }\end{array}$ \\
\hline Tamil Nadu & $\begin{array}{l}8 \% \text { of the state's net tax revenue in } 1997 / 98 \text {; gradually increas- } \\
\text { ing in successive years to } 9 \%, 10 \% \text {, and } 11 \% \text {, reaching } 12 \% \text { in } \\
2001 / 02 \text {. (The division of this amount between rural and urban } \\
\text { should be on the basis of population as shown in the last } \\
\text { census.) }\end{array}$ \\
\hline Uttar Pradesh & $7 \%$ of net proceeds of the state's total tax revenue. \\
\hline West Bengal & $\begin{array}{l}16 \% \text { of net proceeds of all taxes collected by the state. Such } \\
\text { funds should be released to the districts. These proceeds should } \\
\text { be divided between urban and rural based on population. }\end{array}$ \\
\hline
\end{tabular}


loans, (e) the sum to be charged against the funds that form the security for the loan, (f) the attachment of such funds and their disposition, and (g) the accounts to be kept about loans.

The state government formulates rules and procedures for obtaining the sanction of the state government for loans; establishing, investing, and annually examining the sinking fund; attaching corporation funds; and printing debentures. No amendments have been made to the provisions on borrowing since 1992 .

Interstate differences in provisions regulating the process of local governments to borrow are, at best, minor and relate to the limits on borrowingfor example, the percentage of the annual ratable value of land and buildings or the period for which a loan may be contracted. Important to note, however, are provisions on sinking funds and investment of sinking funds into public securities and government-guaranteed securities, as well as provisions on preparation and submission of an annual statement of details on loans contracted and the maintenance of sinking funds. ${ }^{18}$

Under subsection (1) of the 1914 act, local bodies are permitted to borrow (a) to carry out any works that they are legally authorized to carry out, (b) to grant relief and establish and maintain relief works in times of famine and scarcity, (c) to prevent outbreaks and spread of dangerous epidemic diseases, and (d) to repay money previously borrowed in accordance with the law.

Several state governments have stipulated guidelines for local government borrowing, such as the period of local borrowing, which is not to exceed 30 years; interest offered by the municipal bodies, which is to be in tune with the interest on government securities; and adequate provision for debt servicing. Such guidelines may also state that municipal borrowings should have the legal sanction of state governments and that municipal corporations and port trusts are allowed to issue securities.

Generally, municipal corporations are allowed to borrow from the market. Such loans are based on the annual ratable value (ARV) of land and buildings assessable for property taxes. However, all market borrowing requires the approval of the state government. In a few municipal corporations, the total market borrowing, including all outstanding debt, is limited to a fixed percentage of the value of the immovable municipal properties and assets, as prescribed in the municipal corporation acts. In some others, the annual borrowing limit is fixed as a percentage of the ARV of the property. In the Mumbai municipal corporation, the total market debt limit, including all outstanding debt and balances, is prescribed at three times the ARV for the general-purpose budget, slum improvement budget, and education 
budget and two times the ARV for the water and sewerage budget. The total outstanding debt of the Mumbai municipal corporation, therefore, is not to exceed eight times the ARV.

Until the mid-1990s, municipal governments raised loans primarily from financing institutions and specialized institutions such as the Housing and Urban Development Corporation, with guarantees provided by the state governments. In 1996, Credit Rating Information Services of India Ltd. (CRISIL), drawing on the experiences of its U.S. partner, Standard and Poor's Rating Services, undertook an exploratory exercise to evaluate the credit quality of municipal entities. The goal was to explore the feasibility of expanding the horizons of its rating operations and to determine the capacities of municipalities to borrow from the nascent but growing capital market. It engaged the Ahmedabad municipal corporation (AMC) and other municipal corporations in formulating what it called a framework for municipal credit evaluation. It also laid the groundwork for rating the credit of municipalities and project-specific debt issues. CRISIL studied the finances and operations of $\mathrm{AMC}$ and assigned an $\mathrm{A}+$ credit rating to the proposed Rs 1 billion bond issue, indicating a credit risk profile in the adequate safety category. Since then, the bond market in India has seen a noticeable growth in issuers and investors, instruments, and volume of transactions.

Following the example of AMC, a number of municipal entities and parastatals have accessed capital market funds, with the backing of CRISIL and two credit rating agencies- the Investment Information and Credit Rating Agency and Credit Analysis and Research Limited. These two agencies developed their own criteria and systems for evaluating the creditworthiness of municipalities. The fiscal incentives offered by the government of India in the form of tax exemptions for eligible issuers, defined in the Ministry of Urban Development's guidelines for issue of tax-free municipal bonds, have further stimulated the municipal bond market. The guidelines stipulate that the issuers are to maintain a debt-service coverage ratio of at least 1.25 throughout the tenure of the bond. This overcollateralization and the provision of a debt-service reserve account reduce risk to investors. Key features of the tax-free bonds are laid out in table 5.8.

The nine municipal corporations that have accessed the capital market have thus far been able to raise Rs 6.185 billion by issuing bonds. An important feature of municipal bonds is that, except for those issued by the Bangalore Municipal Corporation and Indore Municipal Corporation, they have been issued without a state government or bank guarantee. Traditionally, lenders to entities in the infrastructure sector have sought a state or sovereign guarantee as an important security mechanism. The fact that municipal 
TA B LE 5, 8 Key Features of Tax-Free Municipal Bonds

\begin{tabular}{|c|c|}
\hline Feature & Description \\
\hline Eligible issuers & $\begin{array}{l}\text { Local self-governments, other local authorities, or public } \\
\text { sector companies duly constituted under an act of parlia- } \\
\text { ment or state legislature; other local authorities } \\
\text { constituted under relevant state government statutes } \\
\text { such as a water supply and sewerage board; and } \\
\text { groups of local authorities through a financial } \\
\text { intermediary }\end{array}$ \\
\hline Use of funds & $\begin{array}{l}\text { Capital investments in urban infrastructure--that is, } \\
\text { potable water supply; sewerage or sanitation; drainage; } \\
\text { solid waste management; roads, bridges, and flyovers; } \\
\text { and urban transport if it is a statutory municipal } \\
\text { function }\end{array}$ \\
\hline \multicolumn{2}{|l|}{ Requirements } \\
\hline Project development & $\begin{array}{l}\text { An approved investment plan including phasing and a } \\
\text { financing plan; benchmarks for commencement and com- } \\
\text { pletion, including the milestone dates for the proposed } \\
\text { components of the project; completion of the process of } \\
\text { prequalification of bidders; initiation of the process of land } \\
\text { acquisition and other statutory clearances }\end{array}$ \\
\hline Financial viability & $\begin{array}{l}\text { Generation of a stream of revenues sufficient to finance the } \\
\text { project; creation of an escrow account for debt servicing; } \\
\text { appointment of an independent trustee for monitoring the } \\
\text { escrow account }\end{array}$ \\
\hline Other conditions & $\begin{array}{l}\text { Conformity with laws governing borrowing; maintenance of a } \\
\text { debt-service coverage ratio } 0^{b} \text { of } 1.25 \text { during the bond's tenure }\end{array}$ \\
\hline $\begin{array}{l}\text { Project account and } \\
\text { monitoring }\end{array}$ & $\begin{array}{l}\text { Maintenance of a separate account and establishment of a } \\
\text { separate project implementation cell }\end{array}$ \\
\hline $\begin{array}{l}\text { Investment, maturity, } \\
\text { and buyback }\end{array}$ & $\begin{array}{l}\text { Minimum maturity of five years, with the option of buyback } \\
\text { arrangements of the face value of the bonds }\end{array}$ \\
\hline Ceiling on amount & $\begin{array}{l}\text { Maximum amount as a percentage of total project cost: } \\
33.3 \% \text { or Rs } 500 \text { million, whichever is lower; debt-equity } \\
\text { ratio not to exceed } 3: 1 \text {; contribution of } 20 \% \text { of project cost } \\
\text { from internal resources or grants }\end{array}$ \\
\hline Credit rating & Investment grade rating mandatory \\
\hline $\begin{array}{l}\text { Legal and administrative } \\
\text { requirement }\end{array}$ & $\begin{array}{l}\text { Adherence to guidelines issued by the Securities and } \\
\text { Exchange Board of India }\end{array}$ \\
\hline
\end{tabular}

Source: Author's classification based on Section 10(15) of the Income Tax Act 2001.

a. Public sector company means any corporation established by or under any central, state, or provincial act or a government company as defined in section 617 of the Companies Act 1956.

b. The ratio of net income after meeting all obligations and liabilities of the issuer (except long-term debt obligations) to long-term debt-servicing obligations. 
entities have begun to raise resources in the capital market on the strength of their own credit standing and credit enhancements based on escrowing of cash flows indicates a growing acceptance in India of municipal bonds as an instrument for raising resources for financing infrastructure projects. Municipal bonds in India are securitized debt instruments, providing future revenue flows from the project as collateral.

At the heart of any credit system is a revenue stream that the borrower does not use for day-to-day operations. Borrowing for investment purposes is equivalent to capitalizing an income or revenue stream. The borrower receives funds today to pay for project construction. In return, he or she signs away the right to an annual revenue flow in the future in favor of the lender. The more certain and predictable the revenue stream is, the greater is the security for a loan.

The emergence of a municipal bond market represents an important breakthrough in channeling resources to the urban infrastructure sector. Although municipal bond issuances make up a small fraction of the total bond market, the demonstration effect of these successful issues is important for the urban sector reform agenda. The experience does not merely relate to developing additional sources of finance for investment in the sector. The very fact that more than 40 municipalities have subjected themselves to credit ratings demonstrates an increasing acceptance of the need for independent evaluation and monitoring. Many municipalities have used the credit rating process as an important benchmarking tool to evaluate their performance. This process fosters a competitive spirit among local governments, a positive signal for the urban reform agenda.

\section{The Finances of Municipalities: An Assessment}

Assessing the performance of municipalities is a complex activity. Municipalities are recognized as the third tier of government under the constitution, but their functions, powers, and responsibilities and the degree of autonomy that they are permitted to exercise are determined by state governments. As we noted earlier, there are important interstate differences in municipal functions, powers, and responsibilities and in the state-municipal fiscal relationships. Many municipalities have a larger role in the national and regional economic affairs that affect their revenue base and expenditure patterns. With this framework, we analyze here the performance of municipalities and seek explanations for why municipalities in some states perform differently than those in others. We assume that the performance values reflect the effect of the 74th amendment, as well as of article 280(3)(a) and 
the state and municipal initiatives taken to improve the finances and functioning of municipalities. We begin with an assessment of the size of the municipal sector and follow with an analysis of sector performance on a statewide basis, using three indicators: internal resource generation (own resources), municipal revenue receipts, and revenue expenditures. A number of features are noted.

The size of the municipal sector in terms of what is raised through municipalities' revenue efforts is tiny- 0.63 percent of the gross domestic product (GDP). Between 1997/98 and 2001/02, however, the size of the municipal sector registered a marginal expansion, in terms of both its share in the total publicly raised revenues and combined GSDP. Municipal share in the total revenues of the three tiers of government rose from 2.84 percent in 1997/98 to 3.07 percent in 2001/02, while relative to GSDP, its share increased from 0.61 to 0.63 percent (table 5.9). Municipal own-source revenues (in nominal terms) have risen at an annual average growth rate of 10.32 percent. As a proportion of the combined GSDP, aggregate municipal expenditures have also risen from 0.74 percent in $1997 / 98$ to $0.75,0.77$, and 0.75 percent respectively in the following years.

Revenue expenditure is a proxy for service levels. The higher the expenditure is, the higher are the levels of services. The expenditure levels of municipalities in terms of size and trends, and also in terms of composition are given in table 5.10, in an attempt to distinguish between expenditure on salaries and wages (the nondiscretionary component) and other discretionary spending consisting of expenditures on the operation and maintenance of services.

TA B L E 5 . 9 Revenue Significance of Municipalities

\begin{tabular}{lccccc}
\hline & & \multicolumn{2}{c}{ Relative share of own-source revenues (\%) } \\
\cline { 3 - 6 } & $\begin{array}{c}\text { Municipalities } \\
\text { own-source } \\
\text { revenue } \\
\text { (Rs million) }\end{array}$ & $\begin{array}{c}\text { Percentage } \\
\text { of GDP }\end{array}$ & Municipalities & $\begin{array}{c}\text { State } \\
\text { gevernments }\end{array}$ & $\begin{array}{c}\text { Central } \\
\text { government }\end{array}$ \\
\hline $1997 / 98$ & 84,349 & 0.61 & 2.84 & 33.4 & 63.8 \\
$1998 / 99$ & 94,517 & 0.59 & 2.97 & 34.3 & 62.7 \\
$1999 / 2000$ & 103,727 & 0.59 & 2.80 & 34.4 & 62.8 \\
$2000 / 01$ & 120,184 & 0.63 & 2.98 & 35.1 & 61.9 \\
$2001 / 02$ & 127,481 & - & 3.07 & 39.5 & 57.5 \\
\hline
\end{tabular}

Source: Mathur and Thakur 2004.

Note: $-=$ not available. Figures for municipalities' own-source revenues are adjusted to reflect the revenues for all statutory towns and cities. 
TA B LE 5.10 Per Capita Revenue Expenditure

\begin{tabular}{|c|c|c|c|}
\hline State & $\begin{array}{c}\text { Per capita } \\
\text { revenue expenditure } \\
2001 / 02 \text { (Rs) }\end{array}$ & $\begin{array}{l}\text { Annual growth } \\
\text { rate, 1997/98 to } \\
2001 / 02(\%)\end{array}$ & $\begin{array}{l}\text { Percentage } \\
\text { of GSDP, } \\
2001 / 02\end{array}$ \\
\hline Maharashtra & $1,253.71$ & 6.51 & 1.82 \\
\hline Punjab & $1,008.12$ & 17.22 & 1.15 \\
\hline Himachal Pradesh & 955.45 & 13.02 & $0.38^{\mathrm{a}}$ \\
\hline Gujarat & 865.12 & 7.11 & 1.24 \\
\hline Goa & 604.18 & 13.24 & 0.31 \\
\hline Andhra Pradesh & 508.88 & 14.47 & 0.63 \\
\hline Kerala & 493.17 & 10.65 & 0.39 \\
\hline West Bengal & 487.49 & 10.33 & 0.61 \\
\hline Tamil Nadu & 481.79 & 0.96 & 0.84 \\
\hline Madhya Pradesh & 427.66 & -2.59 & 0.82 \\
\hline Karnataka & 418.29 & 11.32 & 0.67 \\
\hline Uttaranchal & 399.77 & - & - \\
\hline Jammu and Kashmir & 392.69 & 19.86 & $0.52^{\mathrm{a}}$ \\
\hline Rajasthan & 390.36 & 7.30 & 0.56 \\
\hline Chhattisgarh & 376.07 & - & 0.49 \\
\hline Tripura & 356.75 & 7.09 & 0.37 \\
\hline Orissa & 355.06 & 13.87 & 0.43 \\
\hline Uttar Pradesh & 275.18 & 9.54 & 0.49 \\
\hline Haryana & 255.23 & 1.45 & 0.25 \\
\hline Assam & 211.79 & 5.21 & 0.16 \\
\hline Jharkhand & 87.20 & - & $0.11^{\mathrm{a}}$ \\
\hline Bihar & 87.20 & 5.53 & 0.15 \\
\hline Manipur & 81.03 & 4.90 & 0.22 \\
\hline Sample states & 576.71 & 7.36 & $0.85^{a}$ \\
\hline
\end{tabular}

Source: Mathur and Thakur 2004.

Note: - = not available. Sample states refers to those states whose data are contained in the table. a. Figures are for 2000/01.

The performance of municipalities on the criterion of expenditures runs along the same track as that of own-source revenues or even total municipal revenues. Maharashtra, Punjab, Gujarat, and Goa post relatively high per capita expenditures and higher ratios of expenditure to GSDP. Other states show medium levels of expenditures, including Andhra Pradesh, Kerala, West Bengal, and Tamil Nadu. Further examination shows that the expenditure levels are low and depressed in such states as Manipur, Bihar, Jharkhand, Assam, Haryana, and Uttar Pradesh. They are lower compared with the Zakaria Committee norms ${ }^{19}$ even in such states as Himachal Pradesh, Gujarat, Punjab, and Goa. On average, underspending in relation to the Zakaria Committee norm is 130 percent. This factor explains the 
extremely low level of services and, consequently, the deplorable living conditions in cities and towns.

We analyze below the performance of municipalities on the basis of two supplementary criteria: (a) expenditure on salaries and wages and (b) expenditure on operations and maintenance. Note should be made of the staff-intensive activity of municipal operations. For instance, solid waste collection and management is vastly labor intensive, except in a few large cities, where mechanized collection has replaced manual lifting of garbage. Therefore, a high proportion of expenditure on salaries and wages is commonly observed among municipalities in most states. The statewide position is given in table 5.11 .

Expenditure on salaries and wages accounts for 54.2 percent of total municipal expenditure. In Madhya Pradesh, however, it is as high as 80.4 percent.

TA B LE 5, 11 Per Capita Expenditure on Salaries and Wages

\begin{tabular}{lcc}
\hline State & $\begin{array}{c}\text { Salaries and wages, } \\
\text { 2001/02(Rs) }\end{array}$ & $\begin{array}{c}\text { Annual growth rate, } \\
\text { 1997/98 to 2001/02 (\%) }\end{array}$ \\
\hline Maharashtra & 681.72 & 4.73 \\
Himachal Pradesh & 477.14 & 11.92 \\
Punjab & 411.47 & 12.65 \\
Gujarat & 394.46 & 8.07 \\
Goa & 366.34 & 8.23 \\
Jammu and Kashmir & 344.51 & 20.13 \\
Madhya Pradesh & 343.89 & -0.33 \\
West Bengal & 317.70 & 12.80 \\
Tripura & 313.52 & 7.41 \\
Tamil Nadu & 272.16 & 5.87 \\
Chhattisgarh & 263.25 & - \\
Uttaranchal & 254.91 & - \\
Kerala & 247.90 & 14.65 \\
Rajasthan & 246.92 & 7.56 \\
Karnataka & 202.92 & 8.99 \\
Orissa & 179.64 & 11.13 \\
Haryana & 177.93 & -0.51 \\
Andhra Pradesh & 169.34 & 12.08 \\
Uttar Pradesh & 165.11 & 8.35 \\
Assam & 138.19 & 5.71 \\
Manipur & 62.10 & 7.04 \\
Jharkhand & 37.24 & -8.85 \\
Bihar & 37.24 & 6.70 \\
Sample states & 312.58 & \\
\hline
\end{tabular}

Source: Mathur and Thakur 2004.

Note: Sample states refers to those states whose data are contained in the table. 
Other states with high percentages include Haryana (69.7 percent), Orissa (50.6 percent), West Bengal (65.0 percent), Rajasthan (63.2 percent), and Uttar Pradesh (60 percent). Bihar stands with only 43 percent because of unpaid salaries. No norms exist for the division of expenditure between (a) salaries and wages and (b) operations and maintenance; therefore, it is not possible to ascertain whether these proportions are excessive.

Expenditure on salaries and wages in several states exceeds what the municipalities collect by way of taxes, levies, duties, and so forth. These states are unable to recover even the cost of salaries and wages, let alone maintain services. Inability to recover even the cost of salaries and wages from taxes and rates and charges is one of the key failings of municipalities in India. This problem exists in the states of Himachal Pradesh, Madhya Pradesh, Rajasthan, Uttaranchal, Uttar Pradesh, West Bengal, Manipur, and Tripura. Municipalities in such states depend on the state government to meet the cost of salaries and wages, as seen in table 5.12.

An important consideration in assessing the performance of municipalities is the revenue surplus after accounting for salary and wage costs. The higher the surplus is, the greater are the flexibility and discretion in municipalities for operating and maintaining services. Salary and wage costs average 54 to 55 percent of total municipal expenditure. However, several states are able to post a higher surplus and are evidently able to use these surpluses for operation and maintenance of services.

\section{TA B L E 5.12 Cost of Salaries and Wages Exceeds Own-Source Revenue Income, 2001/02}

\begin{tabular}{|c|c|c|c|}
\hline State & $\begin{array}{l}\text { Cost of salaries and wages } \\
\text { (Rs per capita) }\end{array}$ & $\begin{array}{l}\text { Own-source } \\
\text { revenue income } \\
\text { (Rs per capita) }\end{array}$ & $\begin{array}{c}\text { Percentage by } \\
\text { which salary and } \\
\text { wage cost exceeds } \\
\text { own-source } \\
\text { revenue income }\end{array}$ \\
\hline Himachal Pradesh & 477.14 & 335.55 & 42.2 \\
\hline Madhya Pradesh & 343.89 & 188.67 & 82.3 \\
\hline Manipur & 62.10 & 41.55 & 49.4 \\
\hline Rajasthan & 246.92 & 80.68 & 206.0 \\
\hline Tripura & 313.52 & 58.93 & 432.0 \\
\hline Uttaranchal & 254.91 & 113.67 & 124.3 \\
\hline Uttar Pradesh & 165.11 & 79.54 & 107.6 \\
\hline West Bengal & 317.70 & 215.77 & 47.2 \\
\hline Average of sample states & 312.58 & 482.14 & -64.8 \\
\hline
\end{tabular}

Source: Mathur and Thakur 2004.

Note: Sample states refers to those states whose data are contained in the table. 
Operations and maintenance of services such as water supply and sewerage systems, management of solid waste, street lights, and roads are key functions of municipalities. The level of expenditure on operations and maintenance is an important indicator of the quality of services (table 5.13). On average, operations and maintenance expenditure accounts for 39.93 percent of total municipal expenditure. Several states, however, spend substantially higher amounts than the average per capita-Andhra Pradesh, Goa, Gujarat, Himachal Pradesh, Maharashtra, and Punjab among them. The other end, where municipal spending on operations and maintenance is low, both per capita and as a percentage of total expenditure, is represented by Assam, Chhattisgarh, Manipur, Rajasthan, Tripura, Uttaranchal, and West

TA B LE 5. 13 Operations and Maintenance Expenditure

\begin{tabular}{|c|c|c|c|c|}
\hline State & $\begin{array}{c}\text { Expenditure, } \\
2001 / 02 \\
\text { (Rs million) }\end{array}$ & $\begin{array}{l}\text { Percentage } \\
\text { of total } \\
\text { expenditure }\end{array}$ & $\begin{array}{l}\text { Average annual } \\
\text { growth rate, } \\
1997 / 98 \text { to } \\
2001 / 02(\%)\end{array}$ & $\begin{array}{c}\text { Per capita } \\
\text { expenditure, } \\
2001 / 02 \text { (Rs) }\end{array}$ \\
\hline Andhra Pradesh & 62.169 & 65.87 & 16.54 & 335.20 \\
\hline Assam & 1.797 & 33.98 & 6.82 & 71.96 \\
\hline Bihar & 4.316 & 57.29 & 20.91 & 49.96 \\
\hline Chhattisgarh & 4.405 & 30.00 & $8.68^{\mathrm{a}}$ & 112.82 \\
\hline Goa & 0.866 & 39.37 & 25.02 & 237.84 \\
\hline Gujarat & 67.180 & 43.39 & 8.56 & 375.42 \\
\hline Haryana & 4.504 & 30.29 & 11.14 & 77.31 \\
\hline Himachal Pradesh & 2.821 & 50.06 & 16.78 & 478.31 \\
\hline Jammu and Kashmir & 1.199 & 12.27 & 21.47 & 48.18 \\
\hline Jharkhand & 1.494 & 45.19 & $-5.60^{\mathrm{a}}$ & 39.41 \\
\hline Karnataka & 37.693 & 51.49 & 16.49 & 215.37 \\
\hline Kerala & 13.026 & 43.70 & 5.43 & 215.49 \\
\hline Madhya Pradesh & 13.070 & 19.59 & -10.83 & 83.77 \\
\hline Maharashtra & 171.298 & 34.76 & 10.19 & 435.74 \\
\hline Manipur & 0.102 & 23.36 & 0.38 & 18.93 \\
\hline Orissa & 9.178 & 49.41 & 19.76 & 175.42 \\
\hline Punjab & 48.239 & 59.18 & 25.00 & 596.65 \\
\hline Rajasthan & 17.336 & 34.66 & 8.79 & 135.28 \\
\hline Tamil Nadu & 54.258 & 43.51 & 0.24 & 209.63 \\
\hline Tripura & 0.096 & 7.26 & -5.58 & 25.90 \\
\hline Uttaranchal & 2.957 & 36.24 & 9.99 & 144.86 \\
\hline Uttar Pradesh & 26.638 & 29.00 & 16.75 & 79.80 \\
\hline West Bengal & 33.210 & 34.83 & 7.80 & 169.79 \\
\hline Sample states & 57.785 & 39.93 & 10.59 & 230.31 \\
\hline
\end{tabular}

Source: Mathur and Thakur 2004.

a. Annual change for one year. 
Bengal. In per capita terms, the operation and maintenance expenditures are abysmally low in Bihar, Jammu and Kashmir, Jharkhand, Manipur, Tripura, and Uttar Pradesh, manifesting themselves in the poor level of municipal services.

\section{Concluding Remarks}

In sum, the finances of municipalities in India are in an unsatisfactory state. Their own revenue income as a proportion of GDP is abysmally low; even after supplementation with transfers-both revenue-sharing transfers and grants-the level of spending is 130 percent lower than the norms set by the Zakaria Committee. Moreover, more than 50 percent of municipal expenditure is accounted for by salaries and wages, leaving a relatively small amount for operating and maintaining municipal services. An important point is that decentralization initiatives contained in the 74th amendment have made little difference to the country's municipal system except in select states that have tried to rationalize the revenue-sharing arrangements with municipalities. It is a matter of speculation whether decentralization requires a longer gestation period or has encountered indifference in its implementation. Selectively, the property taxation system is being changed in some cities in ways that better reflect market values, compared with the earlier system of ARV. These changes are signals that the municipal system may be strengthened with fresh provisions that may require municipalities to engage city-level stakeholders in formulating budget priorities for different activities and to periodically place this information in the public domain to enhance both transparency and accountability.

\section{Notes}

1. According to Richie Calder, municipal authority was fairly well established during the Indus civilization of 3000 B.C.E. However, municipal institutions in the sense they are understood now owe themselves to Lord Ripon's resolution of 1882 .

2. While recommending the constitution of the Madras Corporation, the directors of the East India Company observed that "the people would more willingly and liberally disburse five shillings towards the public good being taxed by themselves, than six pence imposed by our despotical powers" (see Tinker 1967, p. 25). The expectations of the directors that local self-government would stimulate local taxation were, however, not met. The inhabitants objected to new taxes.

3. Lord Ripon regarded the reform and rejuvenation of local self-government as the greatest achievement of his vice-royalty. He argued that "if local government is to have any vitality, then it should evolve out of local circumstances; if it has to be created artificially, at least it should be planned in detail by local administrators, and not 


\section{Om Prakash Mathur}

be imposed by the central government." However, "the Viceroy was almost alone in his liberalism" (Tinker 1967, p.43).

4. Goa, Diu, and Daman inherited the municipal traditions of Portugal, where a municipal administration is said to have come into being in 1511; in Pondicherry, French traditions dominated, traces of which persist even today.

5. Only a few countries have a discrete list of functions and fiscal powers for municipalities. Brazil and Nigeria are among the countries where municipalities draw powers directly from the constitution.

6. The population criterion has not been specified in the 74th amendment. Criteria were, however, indicated in the 65th Amendment Bill, which specified a population range from 10,000 to 20,000 for a nagar panchayat, 20,000 to 300,000 for a municipal council, and 300,000 or greater for a municipal corporation.

7. Provision of water supply and drainage in several states has either been taken over by state governments (as in Rajasthan) or been transferred to parastatal agencies. It is also a shared responsibility in a few states.

8. The functional domain of municipalities is highly varied and complex, consisting of such subjects and tasks as public administration and establishment, which in the larger municipalities is broken into a department of public administration; an office of the secretary; an audit department; and departments dealing with security, public education, food samples, epidemics, births and deaths, gardens, slaughterhouses, and so forth.

9. The most basic issue associated with expenditure assignment is the division of spending responsibilities. What are the key functions of the government, and which level of government should carry out which functions? There is no best system of expenditure assignment or service decentralization. Local preferences, household mobility, economies of scale, spillover effects, and political considerations suggest what will be feasible for a particular country. International experience shows that stable systems of intergovernmental relations are characterized by clearly stated expenditure assignment rules, rather than by the subjective decisions and murky assignments that define the intergovernmental system in many countries (see Bird, Ebel, and Wallich 1995).

10. Much of the confusion has arisen because many state governments have incorporated the schedule 12 functions into the state laws - as is or in parts-without ascertaining whether they formed part of existing state laws.

11. In many Nordic countries, local governments have the responsibility for redistributional functions typical of a welfare state. Such governments use income taxation as their main source of revenue. In both respects, fiscal federalism in such countries constitutes a departure where the distributive brand of the budget is reserved for central governments, and local governments are assigned a less mobile tax base or are restricted to using only benefit taxes.

12. Multilevel finance is not an old discipline in economics. Before World War II, the subject was treated in connection with taxes on property.

13. In the early years of the 20th century, several local bodies in India levied a tax on individuals that was assessed according to circumstances and property. There was also a tax called the Haisiyat tax. It has been argued that these were local income taxes (see Chand 1944.)

14. Octrois continue to be levied in the municipal corporations of Gujarat and Maharashtra. The government of Punjab, which permits municipalities to levy octrois, is said to have decided to abolish octrois and to be exploring the possibility of 
bringing onto the statute a new tax called the local area development tax. Other states have abolished octrois, notwithstanding their buoyancy, on the ground that they impede the free flow of goods and services and have a cascading effect.

15. State limits on local revenue-raising authority are, of course, not new, nor are they unique to India's federal structure. In the United States, property tax limits began in the 19th century, originating in Rhode Island in 1870.

16. Central Finance Commissions are set up once every five years. Until the amendment of article 280 (under which they are established), their primary task was related to center-state fiscal relations.

17. State government borrowing is regulated by article 293(3) of the constitution. All state government borrowing is subject to approval by the government of India, which is empowered to impose such conditions as are considered necessary.

18. In addition to the Local Authorities Loan Act 1914, which regulates local government borrowing, several other statutes are relevant. The Public Debt Act 1944 empowers the Reserve Bank of India to regulate the primary issuance of debt securities by the central and state governments. The Companies Act 1956 sets out the code of conduct for the corporate sector in relation to the issue, allotment, and transfer of securities. The Securities and Exchange Board of India regulates primary issuance in capital and debt markets, other than government securities, and ensures sound trading practices in the secondary market through stock exchanges.

19. Expenditure norms for municipal services were established in 1963 by a committee headed by Rafiq Zakaria. Although these norms have lost their relevance, they are still widely used in assessing the level of understanding by municipalities.

\section{References}

Bakshi, P. M., ed. 2003. The Constitution of India with Selective Comments by P. M. Bakshi. New Delhi: Universal Law Publishing.

Bird, Richard, Robert D. Ebel, and Christine I. Wallich. 1995. Decentralization of the Socialist State. Washington, DC: World Bank.

Chand, Gyan. 1944. Local Finance in India. Allahabad, India: Kitabistan.

Finance Commission, Government of India. 2000. Report of the Eleventh Finance Commission for 2000-2005. New Delhi: Akalank Publications.

George, Henry. 1879. Progress and Poverty. Reprint, New York: Cosimo, 1997.

Mathur, Om Prakash, Pratishtha Sengupta, and Anik Bhaduri. 2000. "Options for Closing the Revenue Gap of Municipalities: 2000/01 to 2004/05.” Study report for the National Institute of Public Finance and Policy, New Delhi.

Mathur, Om Prakash, and Sandeep Thakur. 2004. "India's Municipal Sector." National Institute of Public Finance and Policy, New Delhi.

Mehta, Shekhar. 1992. "State Grants and Local Fiscal Response." National Institute of Public Finance and Policy, New Delhi.

Musgrave, R. A. 1959. The Theory of Public Finance. New York: McGraw-Hill.

National Commission. 2002. Report of the National Commission to Review the Working of the Constitution. New Delhi: Government of India.

Panikkar, Kavalam Madhava. 1961. Foundations of New India. London: Allen \& Unwin. 


\section{Om Prakash Mathur}

Rattsø, Jørn, ed. 1998. Fiscal Federalism and State-Local Finance: The Scandinavian Perspective. Cheltenham, U.K.: Edward Elgar.

Smith, Adam. 1776. The Wealth of Nations. Reprint, New York: Random House, 1994.

Tinker, Hugh. 1967. The Foundations of Local Self-Government in India, Pakistan, and Burma. Bombay: Lalvani. 
Local Government

Organization and

Finance: Rural India

V. N. A L O K

\begin{abstract}
$A s$ in many other federations, rural local governments in India are supposedly responsible for rendering essential services, including sanitation, drinking water supply, street lighting, and rural roads. They are also empowered to collect certain tax and nontax revenues. In most cases, however, a considerable gap between own resources and requirements can easily be seen. The gap is more noticeable for rural local governments than for their urban counterparts because of their narrower resource base. Hence, rural local governments largely depend on financial support from their state governments.
\end{abstract}

\title{
Evolution of Rural Local Government
}

The rural local government in India is called the panchayat, which literally means an assembly of five persons. These five elderly, nominated persons, over the course of time, were vested with sacred authority and with judicial and executive powers. These village communities were the centers of administration and the custodians of social harmony. Sir Charles Metcalfe, provisional governor general of India from 1835 to 1836, described them as follows: 
The village communities are little republics, having nearly everything they can want within themselves, and almost independent of any foreign relations. They seem to last where nothing else lasts. Dynasty after dynasty tumbles down; revolution succeeds to revolution; ... but the village community remains the same.... This union of the village communities, each one forming a separate little state in itself, has, I conceive, contributed more than any other cause to the preservation of the peoples of India, through all the revolutions and changes which they have suffered, and is in a high degree conducive to their happiness, and to the enjoyment of a great portion of freedom and independence. (Mookerji 1958, p. 2)

Subsequently, Sir George Birdwood echoed that same expression:

India has undergone more religious and political revolutions than any other country in the world; but the village communities remain in full municipal vigor all over the peninsula. Scythian, Greek, Saracen, Afghan, Mongol, and Maratha have come down from its mountains, and Portuguese, Dutch, English, French, and Dane up out of its seas, and set up their successive dominations in the land; but the religious trades-union villages have remained as little affected by their coming and going as a rock by the rising and falling of the tide. (Mookerji 1958, p. 2)

Evidence suggests that self-governing village communities have always existed in India. Their roots can be traced in the Rig Veda ${ }^{1}$ as dating back to approximately $1200 \mathrm{BC}$.

However, the panchayats in ancient India were different in character than the notion advanced in the West:

In ancient India the king was head of the state, but not of the society. He had a place in the social hierarchy, but it was not the highest place. As a symbol of the state, he appeared to the people like a remote abstraction with no direct touch with their daily life, which was governed by the social organization. (Mookerji 1958, p. 4)

With the advent of British rule, attention shifted from rural to urban local bodies. During the struggle for freedom, Mahatma Gandhi stressed the need for village swaraj (independent republic): "My idea of village swaraj is that it is a complete republic, independent of its neighbors for its own vital wants, and yet interdependent for many others in which dependence is a necessity" (Gandhi 1962, p. 31).

Gandhi's vision of village swaraj has had perhaps the most enduring influence on the subsequent debates and discussions on panchayats. In the immediate postindependence period, during the debates on the drafting of India's constitution, sharply discrepant views of panchayats were expressed. In the Constituent Assembly on November 4, 1948, Dr. B. R. Ambedkar, 
chairman of the Drafting Committee, called village community "a sink of localism, a den of ignorance, narrow-mindedness, and communalism" (Malaviya 1956, p. 97). Panchayats did not find a place in the first draft of India's constitution. At the insistence of Mahatma Gandhi, a compromise was arrived at, and panchayats were included only in the nonjusticiable part of the constitution, under Directive Principles of State Policy, which reads, "The state shall take steps to organize village panchayats and endow them with such powers and authority as may be necessary to enable them to function as units of self-government." Without any reference to panchayats, the term local government also crept into item five of the State List in the constitution. These provisions are, at best, only discretionary.

In the early 1950s, Gandhi's village swaraj was kept on the back burner in the overall development plan, which was deeply committed to industrialization, economic growth, and income redistribution (Kohli 1987, p. 62). In the late 1950s, community development projects failed to evoke people's participation. On this issue, a study team headed by Balwantray Mehta recommended that "public participation in community work should be organized through statutory representative bodies" (Government of India, Committee on Plan Projects 1957, p. 23).

A panchayat structure at the district and block levels was also envisioned at this time. On October 2, 1959, India’s first prime minister (Pandit Jawaharlal Nehru) inaugurated independent India's first panchayati raj institution (PRI) at Nagaur in Rajasthan. By the mid-1960s, PRIs began to be established in all parts of India. Ironically, with the passage of time, PRIs were marginalized and weakened. The Asoka Mehta Committee was appointed in 1977 to study the weaknesses of PRIs. The committee recognized the district as the administrative unit in the PRI structure. At the same time, it blamed resistant bureaucracy, lack of political will, and elite capture for undermining earlier attempts to establish PRIs. Another major attempt to regenerate PRIs was made with the appointment of the L. M. Singhvi Committee in 1986. The committee recommended that PRIs should be enshrined in the constitution. In 1989, Prime Minister Rajiv Gandhi proposed to assign constitutional status to PRIs and introduced the 64th Constitutional Amendment Bill. This bill was opposed, because it was viewed as an instrument for the union (central) government to deal directly with PRIs and bypass the state governments. The bill was passed in the Lok Sabha (lower house of parliament) but failed in the Rajya Sabha (upper house of parliament) by two votes on October 15, 1989.

Over time, consensus in favor of PRIs grew among all political parties. The National Front government that came into power for a short period 
introduced a bill for PRIs on September 7, 1990. Finally, the Congress government, which came back to power, introduced a constitutional amendment bill for PRIs in September 1991. After debate and discussion, it became the Constitution (73rd Amendment) Act 1992 (the CAA) on April 24, 1993.

\section{The Legal Framework}

With the passage of the CAA, PRIs were recognized in the statute book as institutions of self-government. ${ }^{2}$ Under the CAA, it became mandatory for each state to enact conformity acts and make the following provisions:

- The establishment of three-tier PRIs with elected members at village, intermediate, and district levels. The intermediate rung need not be constituted in states with a population under 2 million.

- Direct elections to all seats in PRIs at all levels.

- One-third of seats reserved for women and marginalized communitiesscheduled castes (SCs) and scheduled tribes (STs) - in all PRIs, according to the population. This provision also applies to the office of chairperson.

a Aniform five-year term in all PRIs, with elections held within six months in cases of premature dissolution.

- Constitution of a State Election Commission to supervise and organize free and fair elections to PRIs at all levels.

- Setting up of a State Finance Commission at a regular interval of five years to review and revise the financial position of PRIs.

- Establishment of district planning committees.

Establishment of a Gram Sabha (village assembly) in each village, to exercise such powers and perform such functions at the village level as the state may provide by law.

The state is also expected to transfer 29 functions listed in the 11th Schedule, which was appended to the constitution (box 6.1). The state is also required to devolve concomitant powers and authority to PRIs to carry out the responsibilities conferred on them. The legislature of a state may authorize the PRIs to levy, collect, and appropriate certain duties and fees and may assign to them the revenues of certain state-level taxes, subject to such conditions as are imposed by the state government. Further, grants in aid may also be provided to these bodies. As a result of the CAA, the number of PRIs stands at 248,968, of which 242,328 are village panchayats, 6,097 are intermediate panchayats, and 543 are district panchayats (table 6.1). 


\section{B OX 6.1 Classification of Functions Listed in the 11th Schedule}

\section{Core functions}

Drinking water

Roads, culverts, bridges, ferries, waterways, and other means of communication

- Rural electrification, including distribution of electricity

- Health and sanitation, including hospitals, primary health centers, and dispensaries

- Maintenance of community assets

\section{Welfare functions}

- Rural housing

- Nonconventional energy sources

- Poverty alleviation program

Education, including primary and secondary schools

- Technical training and vocational education

- Adult and informal education

- Libraries

- Cultural activities

- Family welfare

- Woman and child development

- Social welfare, including welfare of the handicapped and mentally retarded

Welfare of the weaker sections, and in particular, of the SCs and STS

- Public distribution system

\section{Agriculture and allied functions}

- Agriculture, including agricultural extension

- Land improvement, implementation of land reforms, land consolidation, and soil conservation

Minor irrigation, water management, and watershed development

- Animal husbandry, dairying, and poultry

- Fisheries

- Social forestry and farm forestry

- Minor forest produce

- Fuel and fodder

Markets and fairs

\section{Industries}

- Small-scale industries, including food processing industries

- Khadi, village, and cottage industries.

Note: The 11th National Finance Commission gave these classifications to the functions enumerated in the 11th Schedule. 
TA B LE 6 - 1 Number of Rural Governments by State and Union Territory, April 1, 2005

\begin{tabular}{|c|c|c|c|c|c|}
\hline \multirow[b]{2}{*}{ State or union territory } & \multicolumn{4}{|c|}{ Panchayats by tier } & \multirow{2}{*}{$\begin{array}{c}\text { Average rura } \\
\text { population } \\
\text { per village } \\
\text { panchayat }\end{array}$} \\
\hline & Village $^{a}$ & Intermediate $^{b}$ & District ${ }^{c}$ & Total & \\
\hline \multicolumn{6}{|l|}{ State } \\
\hline Andhra Pradesh & 21,913 & 1,095 & 22 & 23,030 & 2,663 \\
\hline Arunachal Pradesh & 1,747 & 150 & 15 & 1,912 & 527 \\
\hline Assam & 2,489 & 203 & 20 & 2,712 & 9,911 \\
\hline Bihar & 8,471 & 531 & 38 & 9,040 & 9,654 \\
\hline Chhattisgarh & 9,139 & 146 & 16 & 9,301 & 1,959 \\
\hline Goa & 190 & 0 & 2 & 192 & 3,537 \\
\hline Gujarat & 13,819 & 225 & 25 & 14,069 & 2,447 \\
\hline Haryana & 6,034 & 114 & 19 & 6,167 & 2,687 \\
\hline Himachal Pradesh & 3,037 & 75 & 12 & 3,124 & 1,915 \\
\hline Jammu and Kashmir & 2,683 & 0 & 0 & 2,683 & 8,593 \\
\hline Jharkhand & 3,746 & 211 & 22 & 3,979 & 2,256 \\
\hline Karnataka & 5,659 & 175 & 27 & 5,861 & 6,456 \\
\hline Kerala & 991 & 152 & 14 & 1,157 & 24,714 \\
\hline Madhya Pradesh & 22,029 & 313 & 45 & 22,387 & 2,167 \\
\hline Maharashtra & 28,553 & 349 & 33 & 28,935 & 2,067 \\
\hline Manipur & 166 & 0 & 4 & 170 & 10,284 \\
\hline Meghalayad $^{d}$ & 5,629 & 0 & 3 & 5,632 & 366 \\
\hline Mizoram $^{d}$ & 737 & 0 & 3 & 740 & 654 \\
\hline Nagaland ${ }^{d}$ & 1,286 & 0 & 0 & 1,286 & 1,556 \\
\hline Orissa & 6,234 & 314 & 30 & 6,578 & 5,289 \\
\hline Punjab & 12,445 & 140 & 17 & 12,602 & 1,356 \\
\hline Rajasthan & 9,189 & 237 & 32 & 9,458 & 5,187 \\
\hline Sikkim & 159 & 0 & 4 & 163 & 3,357 \\
\hline Tamil Nadu & 12,618 & 385 & 29 & 13,032 & 2,711 \\
\hline Tripura & 537 & 23 & 4 & 564 & 5,198 \\
\hline Uttar Pradesh & 52,028 & 813 & 71 & 52,912 & 2,757 \\
\hline Uttaranchal & 7,227 & 95 & 13 & 7,335 & 924 \\
\hline West Bengal & 3,360 & 333 & 18 & 3,711 & 18,290 \\
\hline \multicolumn{6}{|l|}{ Union territory } \\
\hline \multicolumn{6}{|l|}{ Andaman and } \\
\hline Nicobar Islands & 67 & 7 & 1 & 75 & 3,807 \\
\hline Chandigarh & 17 & 1 & 1 & 19 & 6,172 \\
\hline Dadra and Nagar Haveli & 11 & 0 & 1 & 12 & 17,355 \\
\hline Daman and Diu & 10 & 0 & 1 & 11 & 12,848 \\
\hline $\begin{array}{l}\text { National Capital Territory } \\
\text { of Delhie }\end{array}$ & 0 & 0 & 0 & 0 & - \\
\hline
\end{tabular}


TA B LE 6. 1 (continued)

\begin{tabular}{|c|c|c|c|c|c|}
\hline \multirow[b]{2}{*}{ State or union territory } & \multicolumn{4}{|c|}{ Panchayats by tier } & \multirow{2}{*}{$\begin{array}{c}\text { Average rural } \\
\text { population } \\
\text { per village } \\
\text { panchayat }\end{array}$} \\
\hline & Village $^{\mathrm{a}}$ & Intermediate $^{b}$ & District $^{c}$ & Total & \\
\hline Lakshadweep & 10 & 0 & 1 & 11 & 3,939 \\
\hline Pondicherry & 98 & 10 & 0 & 108 & 3,477 \\
\hline All India & 242,328 & 6,097 & 543 & 248,968 & 3,278 \\
\hline
\end{tabular}

Source: Figure for number of PRIs from Government of India 2006. Ministry of Panchayati Raj and average rural population for 2005 projected from Census of India 2001.

Note: $-=$ not available.

a. In almost all states, it is known as the gram panchayat.

b. The name of the intermediate rung differs from one state to another. It is known as Mandal Parishad in Andhra Pradesh, Anchal Samiti in Arunachal Pradesh, Anchalic Panchayat in Assam, Janpad Panchayat in Chhattisgarh and Madhya Pradesh, Taluka Panchayat in Gujarat, Taluk Panchayat in Karnataka, Panchayat Union in Tamil Nadu, Kshetra Panchayat in Uttar Pradesh and Uttaranchal, and Panchayat Samiti in many states, including Bihar, Haryana, Himachal Pradesh, Jharkhand, Maharashtra, Orissa, Punjab, and Rajasthan. c. It is also known as Zilla Panchayat/Parishad in many states.

d. Figures from Government of India (2000) for traditional village and district councils that exist in these states; however, figure for Nagaland is from Government of India (2004d).

e. PRI has yet to be revived.

The addition of these democratic institutions has broadened the Indian federal system. The PRIs are seen as the third tier of government. They have also made India the most representative democracy in the world. Today, about 2.2 million representatives stand elected to the three levels of PRIs. More than 40 percent are women, and 27 percent belong to SCs and STs. At the village panchayat level, each elected person's constituency comprises about 340 people or 70 families (Government of India 2006).

\section{Functional Domain}

Article $243 \mathrm{G}$ of the constitution empowers PRIs to function as institutions of self-government for the purposes of preparing plans and implementing schemes for economic development and social justice in their respective areas for various subjects, including the 29 functions listed in the 11th Schedule. However, the list is merely illustrative and indicative. Unlike the division of powers and functions enumerated in the Union List and State List, no clear demarcation exists between the state and PRIs. It is for the state legislature to make laws regarding the devolution of powers and functions to the PRIs.

Almost all states and union territories claim that they have transferred functions in varying degrees to the PRIs, by enacting laws in conformity with the CAA. However, the functional domain of PRIs pertains only to traditional 
civic functions in several states. Functional domain is without adequate developmental responsibilities in those states where either the intermediate panchayats or the district panchayats were absent for decades. States where PRIs have existed for a long time have repeated the provisions of the old statutes in their new laws with only marginal adjustments. Moreover, many state governments have not framed relevant rules or guidelines as a followup measure. A few states realized that the transfer of additional functions requires the transfer of concomitant funds and functionaries to PRIs, enabling them to perform the specified responsibilities. However, PRIs are not very clear about the role they are expected to play in the new federal setup. Almost all of the 29 subjects enumerated in the 11th Schedule are state concurrent, involving duplication and overlapping.

Another challenge before the state government has been the allocation of activities to the appropriate tier of the PRI system. Traditionally, the lowest-level panchayat - the village panchayat—has been the most active in almost all states. Generally, the village panchayats carry out major functions, including core functions, whereas intermediate and district panchayats in most states are "allotted supervisory functions or act mainly as executing agents for the state government" (Jha 2004, p. 3). A task force of the Union Ministry of Rural Development on devolution of powers and functions to PRIs has developed an activity-mapping model on the principle of subsidiarity, which states that any activity that can be undertaken at a lower level must be undertaken at that level in preference to being undertaken at any higher level. ${ }^{3}$

The status of activity mapping can be seen in table 6.2. In most states, the functions devolved to PRIs are subjects rather than activities or subactivities. Only "some states like Andhra Pradesh, Kerala, Gujarat, and Madhya Pradesh have broken the 29 subjects into activities and subactivities" (Oommen 2004, p. 7). In Kerala, complementary legislation has even been issued to change the roles of key line agencies (World Bank 2004).

It is a general perception that PRIs are financially and technically underequipped to perform even the core functions, much less the welfare functions and other economic functions related to agriculture and industries (see box 6.1). Hence, many of the core functions that traditionally belonged to PRIs-drinking water, rural roads, street lighting, sanitation, primary health, and so forth-have not been transferred fully in some states; they are being performed by the line departments of the state government or the parallel parastatals. As a result, the per capita total expenditure of PRIs remains abysmally low in most states (table 6.3). ${ }^{4}$ 
TA B LE 6.2 Current Progress on Activity Mapping

\begin{tabular}{|c|c|c|c|}
\hline State & $\begin{array}{l}\text { Number } \\
\text { of subjects } \\
\text { transferred } \\
\text { through } \\
\text { legislation }\end{array}$ & $\begin{array}{l}\text { Number } \\
\text { of subjects } \\
\text { undertaken } \\
\text { for activity } \\
\text { mapping }\end{array}$ & Comments \\
\hline Andhra Pradesh & 17 & 9 & Activity mapping not completed \\
\hline Assam & 29 & 29 & Activity mapping not completed \\
\hline Bihar & 25 & 0 & Consultation process under way \\
\hline Chhattisgarh & 29 & 7 & $\begin{array}{l}\text { Activity mapping completed for } \\
7 \text { subjects }\end{array}$ \\
\hline Goa & 6 & 18 & Activity mapping not completed \\
\hline Gujarat & 15 & 14 & $\begin{array}{l}\text { Activity mapping completed for } \\
5 \text { subjects }\end{array}$ \\
\hline Haryana & - & - & Draft prepared \\
\hline Himachal Pradesh & 26 & - & Consultation process under way \\
\hline Karnataka & 29 & 29 & $\begin{array}{l}\text { Activity mapping completed and } \\
\text { funds devolved for } 26 \text { subjects }\end{array}$ \\
\hline Kerala & 26 & 26 & $\begin{array}{l}\text { Activity mapping completed and } \\
\text { funds devolved for } 26 \text { subjects }\end{array}$ \\
\hline Madhya Pradesh & 23 & 7 & Activity mapping not completed \\
\hline Maharashtra & 18 & - & Activity mapping not completed \\
\hline Manipur & 22 & 22 & $\begin{array}{l}\text { Activity mapping completed for } \\
22 \text { subjects }\end{array}$ \\
\hline Orissa & 25 & 7 & Activity mapping not completed \\
\hline Punjab & 7 & - & Activity mapping not completed \\
\hline Rajasthan & 29 & 18 & Activity mapping not completed \\
\hline Uttar Pradesh & 12 & - & Activity mapping not completed \\
\hline Uttaranchal & 14 & 14 & $\begin{array}{l}\text { Activity mapping not completed } \\
\text { for } 9 \text { subjects, executive orders } \\
\text { issued for } 3\end{array}$ \\
\hline West Bengal & 29 & - & Activity mapping completed \\
\hline
\end{tabular}

Source: Government of India 2006.

Note: $-=$ not available in the given source.

\section{Own-Source Taxes}

The power of PRIs to impose taxes was considered imperative to enshrine in the constitution under article $243 \mathrm{H}$, to impart certainty, continuity, and strength to PRIs. The union minister of state for rural development, while moving the Constitution (73rd Amendment) Bill in parliament, argued "that unless the panchayats are provided with adequate financial strength, it will be impossible for them to grow in stature" (Oommen 2004, p. 1). Devolution of taxes to PRIs can easily be linked with the activities assigned to them, which 
TA B LE 6 . 3 Per Capita Expenditure in PRIs (All Tiers)

\begin{tabular}{|c|c|c|c|c|}
\hline \multirow[b]{2}{*}{ State } & \multicolumn{3}{|c|}{ Per capita (Rs) } & \multirow{2}{*}{$\begin{array}{l}\text { Annual growth of } \\
\text { total expenditure } \\
\text { 1998-2003 (\%) }\end{array}$} \\
\hline & 1990/91 & $2000 / 01$ & $2002 / 03$ & \\
\hline Andhra Pradesh & 205.7 & 792.9 & 898.4 & 11.9 \\
\hline Assam & 1.1 & 3.2 & 3.2 & 2.2 \\
\hline Bihar & 18.2 & 4 & 37.7 & 17.3 \\
\hline Chhattisgarh & - & 360.8 & 353.6 & 11.3 \\
\hline Goa & 30.1 & 198.2 & 418.9 & 31 \\
\hline Gujarat & 399.4 & $1,293.5$ & 782.7 & -1.6 \\
\hline Haryana & 54.7 & 142.1 & 241.1 & 26.7 \\
\hline Himachal Pradesh & 8.6 & 41.2 & 59.2 & 12.7 \\
\hline Jammu and Kashmir & 0.0 & 750 & 851.2 & 9.6 \\
\hline Karnataka & 402.6 & $1,296.2$ & $1,147.2$ & 5.9 \\
\hline Kerala & 46.1 & 644.9 & 742.5 & 0.5 \\
\hline Madhya Pradesh & 44.5 & 113.9 & 103.5 & 2 \\
\hline Maharashtra & 298.4 & 685.8 & 821.2 & 11.1 \\
\hline Manipur & 7.0 & 25.5 & 37 & 21.9 \\
\hline Meghalaya & 81.6 & 51.6 & 25.5 & 4.4 \\
\hline Orissa & 65.0 & 37 & 56.8 & 25.4 \\
\hline Punjab & 70.0 & 85 & 108.3 & 9.7 \\
\hline Rajasthan & 218.9 & 361.6 & 382.3 & 5.7 \\
\hline Sikkim & 0.0 & 78.6 & 74.2 & 17.7 \\
\hline Tamil Nadu & 59.7 & 164.7 & 152.8 & 7.6 \\
\hline Tripura & 5.3 & 186.1 & 252.9 & 5.2 \\
\hline Uttar Pradesh & 40.9 & 46.9 & 43.3 & 5.1 \\
\hline Uttaranchal & - & 49.3 & 45.9 & -2.1 \\
\hline West Bengal & 24.5 & 107.0 & 29.7 & 5.5 \\
\hline All (24 states) & 148.0 & 324.0 & 327.8 & 6.9 \\
\hline
\end{tabular}

Source: Government of India 2000, 2004d; Census of India 1991, 2001.

Note: $-=$ not available. In the absence of consistent data for the relevant years, the growth rate of Bihar, Kerala, Orissa, and Uttaranchal pertains to a shorter duration than indicated.

vary from state to state. From the long list of the 11th Schedule, certain basic functions could be said to be in the exclusive domain of PRIs. Even these essential services require huge funds. To this end, the devolution of taxes to the three tiers of the PRIs needs to be linked to the activity mapping for the devolution of functions and functionaries (Government of India 2004e).

Table 6.4 shows that a variety of taxes have been devolved to different levels of PRIs. The relative importance of these taxes varies from state to state. The intermediate and district panchayats are endowed with powers to collect very few taxes, whereas village panchayats are given substantial taxing powers. In a 
TA B L E 6 . 4 Revenue Power of Rural Governments in States at Each Tier

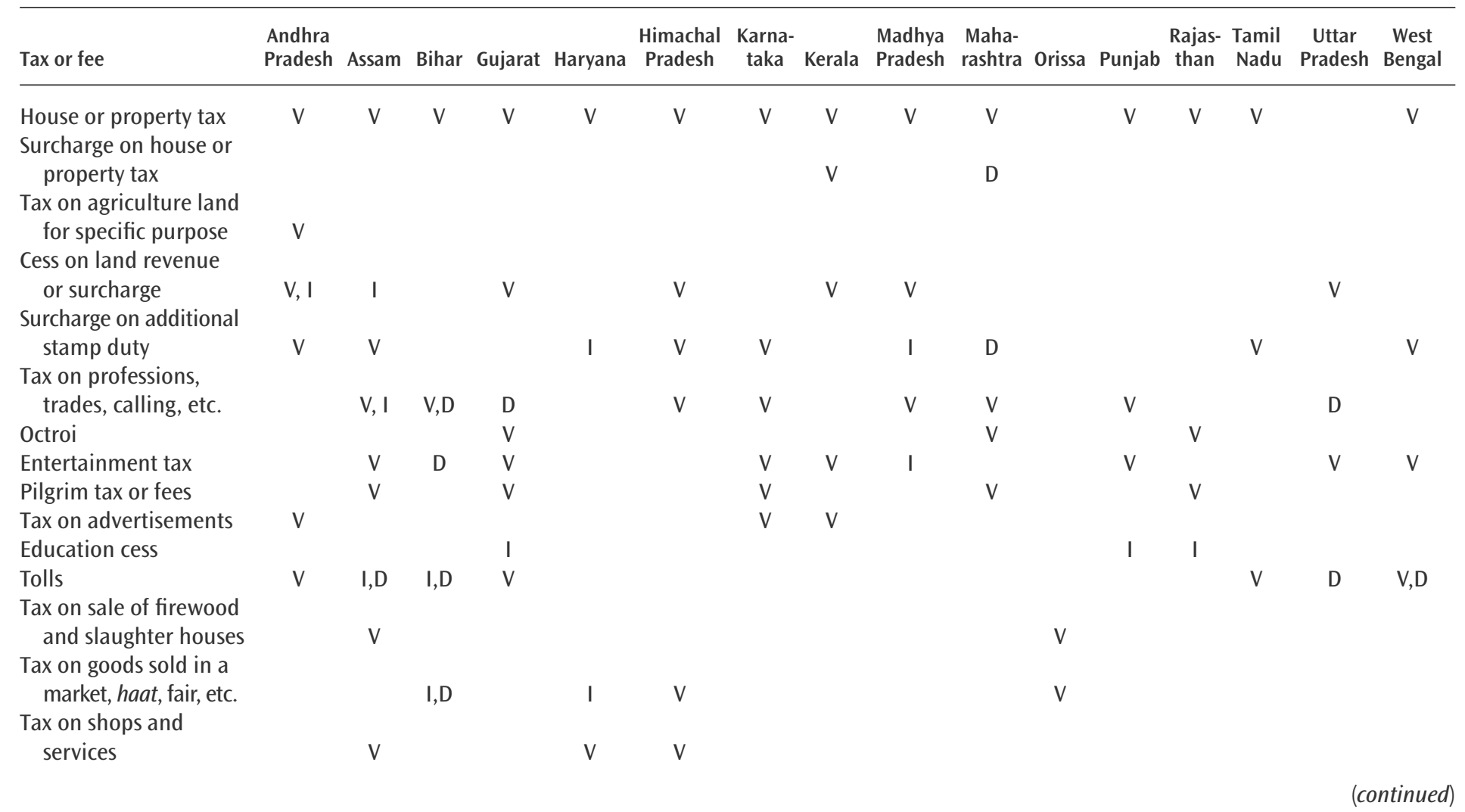


TA B L E 6 . 4 Revenue Power of Rural Governments in States at Each Tie (continued)

\begin{tabular}{|c|c|c|c|c|c|c|c|c|c|c|c|c|c|c|c|c|}
\hline Tax or fee & $\begin{array}{l}\text { Andhra } \\
\text { Pradesh }\end{array}$ & Assam & Bihar & Gujarat & Haryana & $\begin{array}{c}\text { Himachal } \\
\text { Pradesh }\end{array}$ & $\begin{array}{c}\text { Karna- } \\
\text { taka }\end{array}$ & Kerala & $\begin{array}{l}\text { Madhya } \\
\text { Pradesh }\end{array}$ & $\begin{array}{l}\text { Maha- } \\
\text { rashtra }\end{array}$ & Orissa & Punjab & $\begin{array}{l}\text { Rajas- } \\
\text { than }\end{array}$ & $\begin{array}{l}\text { Tamil } \\
\text { Nadu }\end{array}$ & $\begin{array}{c}\text { Uttar } \\
\text { Pradesh }\end{array}$ & $\begin{array}{c}\text { West } \\
\text { Bengal }\end{array}$ \\
\hline Vehicle tax & V & V & & V & & & V & & V & V & V & & V & & V & \\
\hline Animal tax & & & & V & & & & & V & V & V & & & & V & \\
\hline Conservancy rate & V & V & V & V & & & & V & V & & V & V & & & V & V \\
\hline Lighting rate & V & $\mathrm{V}, \mathrm{D}$ & V, I,D & V & & V & & V & V & V & V & V & I & & $\mathrm{V}, \mathrm{I}, \mathrm{D}$ & V, I,D \\
\hline Water rate & V & V, D & V, I,D & V & V, I & V & V & V & & V, I,D & V & V, I & $\mathrm{V}, \mathrm{D}$ & & $\mathrm{V}, \mathrm{I}, \mathrm{D}$ & V, I,D \\
\hline $\begin{array}{l}\text { Drainage rate } \\
\text { Special tax for } \\
\text { community civic }\end{array}$ & V & & & V & & & & V & & & V & & & & V & V \\
\hline services or works & & & & & V & V & & V & V & & & V & V, I & & & \\
\hline $\begin{array}{l}\text { Surcharge on any } \\
\text { tax imposed by }\end{array}$ & & & & & & & & & & & & & & & & \\
\hline village panchayat & I & & & I, D & & & & & & & & & I & & & I \\
\hline
\end{tabular}

Source: Panchayati raj acts of various states; Oommen 2004; Singh, Mishra, and Pratap 1997.

Note: $\mathrm{V}=$ village panchayat, $\mathrm{I}=$ intermediate panchayat, $\mathrm{D}=$ district panchayat. More than one sign indicates the concurrent power of PRIs for the respective tax. 
number of cases, under the tax rental arrangement, the village panchayats collect taxes and pass them on to the higher level of panchayats (Jha 2004). Property tax, cess on land revenue, surcharge on additional stamp duty, tolls, tax on professions, tax on advertisements, nonmotor vehicle tax, octroi, user charges, and the like contribute the maximum to the small kitty of own-source revenue, which contributes only 6 to 7 percent of the total expenditure of PRIs (tables 6.5, 6.6 , and 6.7). In most states, the property tax contributes the maximum revenue. However, this tax remains inelastic because of inefficient administration in its collection. Its assessment is based on the annual rental value of taxation and its associated evil: underdeclaration of rentals. However, some progressive states have reformed the tax structure and use the unit area method in determining the tax base.

After own-source revenues, assigned revenues are the most efficient in the dispensation to PRIs. Such revenues are levied and collected by the state

TA B L E 6 . 5 Own-Source Revenue of PRIs, All Tiers

\begin{tabular}{lrrrr}
\hline & \multicolumn{3}{c}{ Rs million } & \\
\cline { 2 - 4 } State & $1990 / 91$ & $2000 / 01$ & $2002 / 03$ & $\begin{array}{c}\text { Annual growth of } \\
\text { 1998-2003 (\%) }\end{array}$ \\
\hline Andhra Pradesh & 627.0 & $1,516.5$ & $1,708.5$ & 7.6 \\
Assam & 30.1 & 73.2 & 76.1 & 2.0 \\
Bihar & - & 77.1 & 66.7 & 4.2 \\
Chhattisgarh & - & 573.9 & 578.7 & 2.0 \\
Goa & 10.5 & 76.5 & 80.1 & 2.2 \\
Gujarat & 274.5 & 759.2 & 698.6 & -3.1 \\
Haryana & 293.9 & 701.4 & 783.6 & 9.3 \\
Himachal Pradesh & 0.2 & 33.5 & 53.9 & 30.2 \\
Karnataka & 173.3 & 668.3 & 594.6 & 2.0 \\
Kerala & 313.2 & $2,196.6$ & $2,260.1$ & 3.9 \\
Madhya Pradesh & 119.4 & $1,420.9$ & $1,748.1$ & 8.3 \\
Maharashtra & 342.1 & $3,279.8$ & $4,700.7$ & 18.1 \\
Orissa & 59.0 & 90.6 & 55.1 & -9.6 \\
Punjab & 215.6 & 806.7 & 987.7 & 5.7 \\
Rajasthan & 242.8 & 368.9 & 376.8 & 3.6 \\
Tamil Nadu & 157.2 & 572.0 & 654.4 & 5.2 \\
Tripura & 0.1 & 4.9 & 6.0 & 6.8 \\
Uttar Pradesh & 227.5 & 588.3 & 631.7 & 7.5 \\
Uttaranchal & - & 48.7 & 61.0 & 4.9 \\
West Bengal & 142.3 & 325.3 & 312.7 & 2.8 \\
All (20 states) & $3,228.7$ & $14,182.3$ & $16,435.1$ & 8.0 \\
\hline
\end{tabular}

Source: Government of India 2000, 2004d.

Note: $-=$ data not available in the given source. 
TA B L E 6 . 6 Per Capita Own-Source Revenue of PRIs, All Tiers

\begin{tabular}{lrrr}
\hline & \multicolumn{3}{c}{ Per capita (Rs) } \\
\cline { 2 - 4 } State & $1990 / 91$ & $2000 / 01$ & $2002 / 03$ \\
\hline Andhra Pradesh & 12.9 & 27.4 & 30.0 \\
Assam & 1.5 & 3.2 & 3.2 \\
Bihar & - & 1.0 & 0.9 \\
Chhattisgarh & - & 34.5 & 33.5 \\
Goa & 15.2 & 113.1 & 118.8 \\
Gujarat & 10.1 & 23.9 & 21.3 \\
Haryana & 23.7 & 46.7 & 50.2 \\
Himachal Pradesh & 0.0 & 6.1 & 9.5 \\
Karnataka & 5.6 & 19.2 & 16.7 \\
Kerala & 14.6 & 93.2 & 94.1 \\
Madhya Pradesh & 2.3 & 32.0 & 38.0 \\
Maharashtra & 7.1 & 58.8 & 81.9 \\
Orissa & 2.2 & 2.9 & 1.7 \\
Punjab & 15.1 & 50.1 & 59.9 \\
Rajasthan & 7.2 & 8.5 & 8.3 \\
Tamil Nadu & 4.3 & 16.4 & 18.9 \\
Tripura & 0.1 & 1.8 & 2.2 \\
Uttar Pradesh & 2.1 & 4.5 & 4.6 \\
Uttaranchal & - & 7.7 & 9.4 \\
West Bengal & 2.9 & 5.6 & 5.2 \\
All (20 states) & 5.3 & 20.1 & 22.6 \\
\hline
\end{tabular}

Source: Government of India 2000, 2004d; Census of India, 1991, 2001.

Note: $-=$ data not available.

TA B LE 6.7 Contribution of Own-Source Revenue in Total Expenditure of PRIs, All Tiers

\begin{tabular}{lrrrr}
\hline Revenue & $1990 / 91$ & $2000 / 01$ & $2001 / 02$ & $2002 / 03$ \\
\hline Own-source revenue (\%) & 4.5 & 5.9 & 6.0 & 6.8 \\
Othersa (\%) $^{\text {(\%) }}$ & 87.9 & 90.7 & 87.9 & 92.1 \\
\hline
\end{tabular}

Source: Government of India 2000, 2004d.

a. Others includes devolution and grants.

government and are passed on to PRIs for their use. Some states deduct collection charges. The practices in assigning revenue are marked by large interstate variation. However, typical examples of assigned revenue are the surcharge on stamp duty, cess or additional tax on land revenue, tax on 
professions, and entertainment tax. In many states, these taxes form part of the own-source revenue of PRIs.

\section{Borrowing}

No reference is made in the CAA to loans and borrowing by PRIs. Although urban local governments, with the approval of their state governments, have floated bonds in the market, PRIs are not empowered to raise loans from either public or private sources (Jha 2000; Oommen 1995; Rajaraman 2003).

\section{Intergovernmental Fiscal Transfers}

Proceeds from internal sources contribute an abysmal share to the panchayat pool. PRIs rely more on fiscal transfers from the state government in the form of shared taxes and grants (tables 6.7 and 6.8). State taxes are shared according to the recommendations of the State Finance Commission (SFC). Constitution of the SFC at a regular interval of five years is a mandatory requirement for states. ${ }^{5}$ Besides tax sharing, the SFC is assigned the task of reviewing the financial position of PRIs and making recommendations on the assignment of various taxes, duties, tolls, fees, and grants in aid to be given to PRIs from the consolidated fund of the state.

The most critical function of the SFCs is to determine the fiscal transfer from the state to local bodies in the form of revenue sharing and grants in aid. Since the 80th amendment of the constitution, following the recommendation of the 10th Finance Commission (1995-2000), a certain percentage of all union taxes has been devolved to the states. Many SFCs have also adopted this system for the following reasons: First, the system has a self-policy feature; the local government automatically shares in the buoyancy of state taxes and levies. Second, the system has built-in transparency, objectivity, and certainty; local governments can anticipate, at the beginning of each fiscal year, their share in the divisible pool. Third, the system enables local governments to understand the entire economy and take considered views to exercise their own annual budgets. In other words, it induces local governments to generate their own revenue and to mobilize additional resources. Fourth, the state government can be neutral in pursuing tax reforms without considering whether a particular tax is sharable with local governments.

This leads to the issue related to composition of the divisible pool. Table 6.9 reveals wide variations across states in defining the divisible pool and the principle of sharing it among the PRIs and urban local bodies. The SFCs of Andhra Pradesh, Assam, and Goa have included the share of union 
TA B LE 6 , 8 Significance of PRIs' Own-Source Revenue

\begin{tabular}{|c|c|c|c|c|}
\hline \multirow[b]{2}{*}{ Year } & \multicolumn{3}{|c|}{ Share of own-source revenue (\%) } & \multirow{2}{*}{$\begin{array}{c}\text { Own revenue } \\
\text { of PRIs } \\
\text { (Rs million) }\end{array}$} \\
\hline & Union government & State governments & PRIs & \\
\hline 1990/91 & 63.42 & 33.21 & 0.36 & 3,251 \\
\hline $1995 / 96$ & 61.03 & 35.14 & 0.31 & 5,680 \\
\hline 1998/99 & 59.65 & 37.01 & 0.48 & 11,610 \\
\hline $1999 / 2000$ & 60.63 & 36.30 & 0.47 & 13,345 \\
\hline $2000 / 01$ & 59.87 & 37.05 & 0.45 & 14,182 \\
\hline $2001 / 02$ & 57.61 & 39.26 & 0.44 & 14,328 \\
\hline $2002 / 03$ & 59.11 & 38.43 & 0.45 & 16,435 \\
\hline
\end{tabular}

Source: Government of India 2000, 2004d, 2005.

Note: Percentages are worked out by adjusting the own-source revenue of local governments in the total tax revenue (all India).

taxes in the state tax and nontax revenues to form the divisible pool. However, the first SFCs of Kerala, Madhya Pradesh, and Sikkim and the second SFCs of Orissa and Uttaranchal have not included the share of union taxes and have suggested including only the state tax and nontax revenues. The SFCs of Rajasthan, Tamil Nadu, Uttar Pradesh and West Bengal, as well as the second SFC of Kerala and Punjab, have gone a step further, recommending that only the tax revenues of the state form the divisible pool. The Karnataka SFCs have adopted a different mechanism by using the phrase "nonloan gross own revenue receipts" in defining the divisible pool. Table 6.9 highlights only those states where SFCs have recommended the concept of global sharing for transfer of state revenues.

The SFCs of other states have recommended sharing only specific taxes or have awarded a fixed amount to local governments. The first SFC of Punjab, for instance, recommended transferring 20 percent of the net proceeds of five taxes to the local bodies-namely, stamp duty, motor vehicle tax, electricity duty, entertainment tax, and entertainment tax on cinematography. Significant interstate variations can be noted in the mechanisms of revenue sharing because different SFCs made different sets of recommendations.

\section{National Finance Commission}

So that the SFC does not deter the state legislatures in transferring responsibilities and revenue to the local governments, the CAA goes out of the way 
TA B L E 6 .9 SFC Recommendations for Share in State Resources

\begin{tabular}{|c|c|c|c|c|}
\hline \multirow[b]{2}{*}{ State } & \multirow{2}{*}{$\begin{array}{l}\text { Percentage of } \\
\text { divisible pool }\end{array}$} & \multicolumn{2}{|c|}{ Share $(\%)$} & \multirow[b]{2}{*}{ Criteria for inter se distribution among local bodies } \\
\hline & & PRIs & Urban local bodies & \\
\hline \multicolumn{5}{|l|}{ Total state revenue } \\
\hline Andhra Pradesh (SFC I) & 39.24 & 70.00 & 30.00 & Population, backwardness index, poverty \\
\hline Andhra Pradesh (SFC II) & $10.39^{a}$ & 65.00 & 35.00 & Population, area, poverty, revenue mobilization \\
\hline Assam (SFC I) & 2.00 & 75.00 & 25.00 & Population \\
\hline Goa (SFC I) & 36.00 & 75.00 & 25.00 & $\begin{array}{l}\text { Population, geographic area, performance, } \\
\text { backwardness }\end{array}$ \\
\hline \multicolumn{5}{|l|}{ State own-source revenue } \\
\hline Jammu and Kashmir (SFC I) & 13.50 & 67.00 & 33.00 & Not mentioned \\
\hline Kerala (SFC I) & 1.00 & Not mentioned & Not mentioned & Population \\
\hline Madhya Pradesh (SFC I) & 11.579 & 25.13 & 74.87 & Population, area, tax efforts \\
\hline Orissa (SFC II) & 10.00 & 80.00 & 20.00 & $\begin{array}{l}\text { Population, density, number of holdings, revenue } \\
\text { efforts }\end{array}$ \\
\hline Sikkim (SFC I) & 1.00 & 100.00 & 0 & No urban local bodies \\
\hline Uttaranchal (SFC II) & 10.00 & 60.00 & 40.00 & $\begin{array}{l}\text { Population, area, deprivation index, remoteness } \\
\text { index, tax efforts }\end{array}$ \\
\hline \multicolumn{5}{|c|}{ Nonloan gross own-source revenue } \\
\hline Karnataka (SFC I) & 36.00 & 85.00 & 15.00 & $\begin{array}{l}\text { Population, area, illiteracy, road length, persons } \\
\text { per hospital bed }\end{array}$ \\
\hline Karnataka (SFC II) & 40.00 & 80.00 & 20.00 & $\begin{array}{l}\text { Population, area, illiteracy, SCs and STs, persons } \\
\text { per hospital bed }\end{array}$ \\
\hline
\end{tabular}


TA B LE 6 , 9 SFC Recommendations for Share in State Resources (continued)

\begin{tabular}{|c|c|c|c|c|}
\hline \multirow[b]{2}{*}{ State } & \multirow{2}{*}{$\begin{array}{l}\text { Percentage of } \\
\text { divisible pool }\end{array}$} & \multicolumn{2}{|c|}{ Share (\%) } & \multirow[b]{2}{*}{ Criteria for inter se distribution among local bodies } \\
\hline & & PRIs & Urban local bodies & \\
\hline \multicolumn{5}{|l|}{ State own taxes } \\
\hline Kerala (SFC II) & $3.50^{b}$ & 78.50 & 21.50 & Population \\
\hline Punjab (SFC II) & 4.00 & 67.50 & 32.50 & Population, per capita revenue, SCS \\
\hline Rajasthan (SFC I) & 2.18 & 77.30 & 22.70 & Population, poverty \\
\hline Rajasthan (SFC II) & 2.25 & 76.60 & 23.40 & Population, poverty, area, illiteracy \\
\hline Tamil Nadu (SFC I) c & 8.00 & 60.00 & 40.00 & $\begin{array}{l}\text { Population, SCs and STs, per capita own-source } \\
\text { revenue, core services }\end{array}$ \\
\hline Tamil Nadu (SFC II) & 8.00 & 58.00 & 42.00 & $\begin{array}{l}\text { Population, SCs and STs, per capita own-source } \\
\text { revenue, area, asset maintenance, resource gap }\end{array}$ \\
\hline Uttaranchal (SFC I) & 11.00 & 42.23 & 57.77 & Population, distance from rail head \\
\hline Uttar Pradesh (SFC I) & 10.00 & 30.00 & 70.00 & Population, area \\
\hline Uttar Pradesh (SFC II) & 12.50 & 40.00 & 60.00 & Population, area \\
\hline West Bengal (SFC I) & 16.00 & $\begin{array}{l}\text { By district } \\
\text { population }\end{array}$ & $\begin{array}{l}\text { By district } \\
\text { population }\end{array}$ & Population, SCs and STs, illiteracy, area, density \\
\hline West Bengal (SFC II) & 16.00 & $\begin{array}{l}\text { By district } \\
\text { population }\end{array}$ & $\begin{array}{l}\text { By district } \\
\text { population }\end{array}$ & $\begin{array}{l}\text { Population, density, SCs and STs, illiteracy, } \\
\text { infant mortality rate, rural population, per } \\
\text { capita income }\end{array}$ \\
\hline
\end{tabular}

Source: Alok 2004

a. The second SFC of Andhra Pradesh recommended a 10.39 percent share as additional devolution over and above the existing annual devolution.

b. In addition, 5.5 percent of the divisible pool was recommended as grant-in-aid for maintenance of assets under the control of local bodies.

c. In Tamil Nadu the divisible pool called pool B consists of sales tax, motor vehicle tax, state excise revenue, and other state taxes. Pool A consists of levies that rightly belong to local bod-

ies: surcharge on stamp duties, local cess and local cess surcharge, and entertainment tax. The entire proceeds of pool A taxes are recommended to be distributed to the local bodies. 
to provide that the National Finance Commission should suggest measures to augment states' consolidated funds in light of the recommendations of SFCs. So far, three National Finance Commissions (the 10th, 11th, and 12th) have made their recommendations. ${ }^{6}$ All these commissions were severely constrained for reasons emanating partly from the practice and partly from the design of the new fiscal arrangement: the lack of synchronization of the periods covered by the SFCs with those covered by the National Finance Commission; the absence of a timeframe for action by the state government on the recommendations of the SFC; a lack of clarity in assigning functions, finances, and functionaries to local governments; and heterogeneity in approach, content, and period covered by the various SFCs.

Nevertheless, all the commissions recommended ad hoc grants to PRIs. The 10th National Finance Commission made a provision for Rs 43.8 billion, at Rs 100 per capita, to be passed on to PRIs between 1996 and $2000 .^{7}$ In the absence of formal disbursement certificates by the state governments, the national government could release only Rs 35.7 billion. Further, the 11th National Finance Commission recommended a grant of Rs 100 billion for its award period, on the basis of a formula given in table 6.10. Certain institution-building activities such as maintenance of accounts, creation of databases, and audits were made the first charge of the fund. The intention of the grant was to induce the panchayats to act as institutions of self-government. The national government accepted the recommendations, with a caveat compelling PRIs to raise suitable matching resources.

The grant could not be fully utilized. Many state governments and PRIs raised this point during their interactions with the 12th National Finance Commission. ${ }^{8}$ The commission had to emphasize the issue in its report: "The central government should not impose any condition other than those prescribed by us, for release or utilization of these grants" (Government of India 2004d, p. 262). In its recommendations, the commission attempted to adopt the equalization principle and allocated Rs 200 billion to improve service delivery by the panchayats primarily for water supply and sanitation. The grants of the National Finance Commission are generally ordained for operation and maintenance and therefore differ from those of the union ministries and the Planning Commission. Through this transfer, the commission intended for the PRIs to take over all of the central schemes related to drinking water, including Swajaldhra, which had not been operational because funds were not available for operation and maintenance. 
TA B L E 6 , 10 Criteria Adopted by National Finance Commissions for Distribution among Themselves of Grants to States for PRIs

\begin{tabular}{lcc}
\hline & \multicolumn{2}{c}{ Weight assigned by } \\
\cline { 2 - 3 } Criteria & $\begin{array}{c}\text { 11th National } \\
\text { Finance Commission }\end{array}$ & $\begin{array}{c}\text { 12th National } \\
\text { Finance Commission }\end{array}$ \\
\hline Population & 40 & 40 \\
Area & 10 & 10 \\
Distance & 20 & 20 \\
Decentralization index & 20 & Not adopted \\
Revenue efforts & 10 & 20 \\
Deprivation index & Not adopted & 10 \\
\hline
\end{tabular}

Source: Government of India 2000, 2004d.

\section{Centrally Sponsored Schemes}

The union government, through the state governments, provides a majority of panchayat finances in most states. These grant-based transfers from the Planning Commission or union ministries are made in the form of centrally sponsored schemes (CSSs). ${ }^{9}$ These schemes are quite large in number. Many pertain to the 29 subjects being implemented by different ministries and departments of the union government. Table 6.11 reveals that 15 ministries and departments, which primarily deal with functions of the 11th Schedule, have been administering 151 schemes, involving Rs 325.19 billion, which predominantly deal with the functions of PRIs.

The viability of many schemes has been questioned time and again. The Task Force of Officials in Charge of Panchayati Raj in States has given the following summary of the shortcomings of the implementation of CSSs (Government of India 2004c, p. 3):

Rigid conditionalities

- Inconsistent approach to institutional arrangements-CSSs could be panchayat friendly, panchayat parallel, panchayat ignorant, or panchayat unfriendly

- Obsession with financial presentations

- Inefficient and ineffective monitoring and evaluation of outcomes

- Administrative overload on departments leading to inefficiency in processing requests for funding and delayed financial releases

- Lack of transparency in financial releases. 
TA B L E 6 . 11 Schemes of the Union Ministries That Primarily Deal with the Functions of PRIs

\begin{tabular}{lrr}
\hline Name of ministry or department & Number of schemes & $\begin{array}{c}\text { Annual allocation } \\
\text { (Rs million) }\end{array}$ \\
\hline Rural development & 6 & 113,224 \\
Elementary education & 9 & 57,375 \\
Family welfare & 49 & 49,297 \\
Drinking water and rural sanitation & 2 & 33,000 \\
Women and child development & 6 & 21,531 \\
Agriculture & 8 & 12,584 \\
Land resources & 4 & 10,330 \\
Health & 14 & 9,825 \\
Welfare of scheduled castes, other & & \\
$\quad$ backward castes, and minorities & 9 & 5,816 \\
Animal husbandry & 18 & 3,870 \\
Secondary and higher education & 11 & 3,060 \\
Adult education & 4 & 2,375 \\
Nonconventional energy sources & 4 & 1,260 \\
Tribal affairs & 4 & 1,110 \\
Indian systems of medicine and homeopathy & 3 & 533 \\
$\quad$ Total & 151 & 325,190 \\
\hline
\end{tabular}

Source: Government of India 2004c, p. 19.

It has been argued that CSSs should be converted to block transfers. The request of the prime minister, in his speech to all chief ministers on June 29, 2004 , to "consider if we should adopt a system of providing block grants to districts based on their incidence of poverty to plan and implement strategies that optimize their resource potential" (Government of India 2004b, p. 8) can be seen in that perspective. A government task force (Government of India 2004c) has recommended converging the big schemes into seven block funds: antipoverty, water security, public health, education, family welfare and child development, housing, and rural connectivity.

In a landmark development on September 7, 2005, the government of India enacted the National Rural Employment Guarantee Act, to ensure employment of adult unskilled manual workers for a minimum of 100 days in a financial year. With the union and state governments, PRIs at all levels participate actively in the implementation of the act.

\section{Fiscal Autonomy versus Dependency}

Realization is growing that PRIs have an important role to play in deepening democracy by mainstreaming the poor into development. It is also being 
felt that PRIs can help mobilize resources by introducing local solutions and meeting people's basic requirements. However, the degree of success of panchayat raj as an institution of self-government essentially depends on the extent of administrative and financial devolution, coupled with the autonomy within the constitutional framework.

In many states PRIs are, to some extent, burdened with a historical legacy of subservience. For example, at the state level, under the existing budgetary procedures, significant control and discretion for making financial allocations to PRIs rests with the state government officials. Similar powers are vested in district-level officials. As a result, the funds are parked for a considerable period sequentially in the state treasury and then in the district treasury. This practice prevents PRIs from receiving their share of funds in amounts as well as on time. As a consequence, the quality of expenditure is adversely affected. Over time, a dependency syndrome is created. ${ }^{10}$

This example is consistent with one of the points taken for action in the chief ministers' conference:

$[\mathrm{P}]$ anchayats are starved of finances in virtually all states. This has led to a situation where there has been a constitutionally mandated devolution of powers and responsibilities to the local bodies, but with no real means, financial or statutory, with which to implement the plethora of schemes and programmes devolved. This chicken and egg syndrome has led to panchayati raj and municipality administrations almost everywhere being discredited by mainline developmental administration, leaving elected members disillusioned and frustrated by their very powerlessness and impotence. (Government of India 2004a, p. 3)

In many cases, PRIs must seek permission from the local authorities to spend even the available funds. In some cases, they are not subject to any clearance up to a certain amount. For example, PRIs in Kerala and Madhya Pradesh can undertake a project worth up to Rs 100,000 and Rs 300,000, respectively, without any outside clearance (Jha 2004).

However, issues related to the fiscal autonomy of PRIs are subject to debate. It is argued that fiscal autonomy cannot be built into the regime of grants in aid. Tax assignments with clear taxing powers and tax sharing play a more significant role for self-rule and fiscal autonomy than untied funds, public contributions, and project-tied loans (Oommen 1999). Others assert that own-source revenues are not essential for panchayats in their efficient and effective operations. Fiscal transfers from higher level governments can serve this purpose, "so long as the panchayats have the autonomy to decide how the money gets spent" (Johnson 2003, p. 22). 
In practice, devolution of taxation to PRIs poses many difficult political and administrative issues. Manor (1999) has argued, though in an international perspective, that higher-level governments are disinclined to devolve tax-raising powers to local governments, on the one hand, because of perceived apprehensions of power dwindling among central politicians; on the other hand, decentralized authorities are reluctant to impose taxes as it adversely affects their popularity. Lack of administrative capacities at the local level and reluctance on the part of local residents to pay taxes are other impediments to the mobilization of local revenue.

However, the 12th National Finance Commission, in its approach, attempted to strengthen the fiscal domain of local governments and advocated the financing of local public goods by the potential beneficiaries. At the same time, the commission discouraged the reluctance on the part of decentralized authorities to generate revenue: "The principle of equalization extended to the local bodies would mean that while lack of fiscal capacity, at the state level as well as the local level, can be made up, lack of revenue effort should not be made up" (Government of India 2004d, p. 26).

\section{Issues and Lessons}

India's experience with decentralization raises many issues of different dimensions. Some could be relevant for other developing countries. A few are listed below:

- Integrated view and action. Legislative, political, fiscal, and administrative dimensions of decentralization are interwoven and need to be addressed simultaneously. Reforms in one aspect of decentralization need to be accompanied by necessary changes in others. Legislative changes made 10 years ago were not coupled with suitable administrative and fiscal reforms. The administration has persisted in old habits and has been hesitant to devolve functions along with concomitant finances and functionaries. In a sequence, finance should follow function.

- Ability to monitor and evaluate the system. The legislative changes in the form of a central act need to be followed by conformity acts and implementation by various state governments through the creation of an enabling environment for local governments. The union government has to encourage the state governments, through an incentive or reward structure, to create this environment. This action is essential, as the statutory role of the union government is limited to seeing the fulfillment of the mandatory provisions of the constitution. ${ }^{11}$ 
Free and fair local elections. Periodic elections to the PRIs by the State Election Commission provide responsiveness and accountability on broad social issues. However, identification of these issues necessitates providing quality information to the voter. The passage of the Right to Information Act helps the voter make informed choices. Forceful media already exist in India.

- Autonomous institutions. Elected representatives, autonomous SFCs, and other local institutions are the key to decentralized governance. These institutions need to be central and exogenous to the state government for their technical capacity enhancement and true autonomy.

Strong fiscal information system. The system for designing, implementing, and evaluating decentralization policy, including intergovernmental fiscal policy, must be strong. The World Bank (2004, p. 43) commented on the inferior quality of published fiscal data on revenues and expenditures that were drawn in the reports of the national finance commissions and the SFCs: "This data is badly flawed and inflates the funds actually managed by panchayats considerably." 12

- Higher-level government as role model. The higher-level government, particularly the union government, needs to abide by its own rules. Delaying the transfer of funds for PRIs to state governments, affixing strange and ambiguous conditionalities to the fiscal transfers, and consequently retaining unspent funds at the union level erode the foundation of decentralization.

Authority to identify local needs and preferences. The PRIs must have a say in the design of the scheme or grant program. The CAA recognized the significance of identifying local needs and developing capabilities at the local level in the formulation of the PRI's own plan. The provision for a district planning committee was articulated as mandatory under article 243 ZD. Planning must be undertaken at all levels of PRIs; similarly, all urban bodies prepare their own plans. The consolidation of these sets of plans must be undertaken at the district planning committee. The consolidated district plan is then forwarded to the state government for integration into the state plan. Although district planning committees have been constituted in many states, such detailed grassroots planning is undertaken nowhere.

Of late, the concerted efforts of the Ministry of Panchayati Raj have galvanized people's participation to initiate the process of social and political churning to induce the institution of panchayati raj. Enactment of right to information and of rural employment guarantee in 2005 has further strengthened the PRIs, de jure. Also being contemplated is the enactment 
of a law assigning judicial power to PRIs and institutionalizing conventional Nyay (justice) panchayat. This step may be instrumental to reducing the present discrepancy between the de jure and de facto status of the PRIs to acquire the right blend of the "three Fs": functions, finances, and functionaries.

\section{Notes}

1. The Rig Veda is the oldest religious scripture in the world and the most revered of the Vedas. It consists of more than 1,000 hymns addressed to gods. It refers to rituals, such as marriage and funeral rites, that differ little from those practiced today in Hinduism. It is the source of much Indian thought, and many consider its study essential to understanding India.

2. Special legal dispensation under the Panchayats (Extension of the Scheduled Area) Act 1996 is given to the panchayats in tribal areas of nine states: Andhra Pradesh, Bihar, Chhattisgarh, Gujarat, Himachal Pradesh, Madhya Pradesh, Maharashtra, Orissa, and Rajasthan. Accordingly, the provisions of the CAA have been extended to those areas, with certain modifications respecting the traditional institutions of the areas and recognizing the rights of tribal populations over natural resources (Singh 2000).

3. The Union Ministry of Panchayati Raj, created on May 27, 2004, and responsible for the monitoring of the implementation of the CAA, provides technical assistance and expertise if sought by state governments to accomplish activity mapping within the timeframe. There was a consensus, during the roundtables, among all states to complete activity mapping by August 31, 2005 (Government of India 2006, p. 12), on the basis of Government of India (2001).

4. However, the data pertaining to local governments in the reports of National Finance Commissions are not consistent. It must be kept in mind that fiscal data for PRIs from any two sources are not comparable.

5. The Conformity Acts of the CAA provide for the composition of the SFC, the qualifications of its members, and the manner of their selection. Every recommendation of the commission is to be laid before the state legislature. However, many states have not taken these provisions seriously. The 12th Finance Commission and the National Commission to Review the Working of the Constitution have advised those states to provide criteria for the membership of the SFC similar to the provisions of the Union Finance Commission (Alok 2004). Poor treatment of the SFC by many states compelled the prime minister to make this statement: "As far as funds are concerned, the awards of the State Finance Commissions should be fully honored. There are reports that State Finance Commissions are not constituted, of them not giving awards in time, and of these awards not honored when given, all of which erode panchayat raj" (Government of India 2004b). However, all but three states (Arunachal Pradesh, Bihar, and Jharkhand) have received their first SFC report, and a few states (Andhra Pradesh, Haryana, Kerala, Punjab, Rajasthan, Uttar Pradesh, and West Bengal) have even constituted their third commissions.

6. The 10th National Finance Commission was not mandated to make recommendations for local governments. Because the CAA became effective before the commission 
submitted its report, it made recommendations for the newly inserted subclauses of article 280(3) regarding local governments.

7. Rs $45=$ US $\$ 1$ at the beginning of 2006 .

8. State governments also raised this point in the memoranda that they submitted to the 12th National Finance Commission (see http://www.fincomindia.nic.in).

9. The states' contribution to the CSSs was generally 50 percent in the 1980 s, which was reduced to one-fourth in the 1990s because of the tight fiscal situations of the states. The share of the states is being reduced further. Some of the schemes are entirely funded by the national government.

10. Recognizing this problem, the 12th National Finance Commission specified a time limit of a maximum of 15 days for the state governments to transfer the grants to local governments. The commission asserted that the union government should take noncompliance seriously.

11. To facilitate informed review and appraisal by the state legislature, the parliament, civil society, and the public, the Fifth Round Table of Ministers in Charge of Panchayati Raj adopted a resolution that all states would present annual reports on the state of the panchayats, along with a devolution index on the basis of a concept paper presented by Alok and Bhandari (2004).

12. However, the 11th National Finance Commission has initiated the process by advocating for scientific accounts, databases, and computerization. Subsequently, the comptroller and auditor general of India prescribed a format of accounts for the PRIs. Most states have accepted the format.

\section{References}

Alok, V. N. 2004. “State Finance Commissions in Indian: An Assessment." Indian Journal of Public Administration 50 (3): 716-32.

Alok, V. N., and Laveesh Bhandari. 2004. "Rating the Policy and Functional Environment of PRIs in Different States of India-A Concept Paper." Paper presented at the Fifth Roundtable of Ministers in Charge of Panchayati Raj, Srinagar, India, October 28-29. http://www.panchayat.gov.in.

Census of India. 1991. Final Population Totals. New Delhi: Government of India.

- 2001. Final Population Totals. New Delhi: Government of India.

Gandhi, Mohandas K. 1962. Village Swaraj. Ahmedabad, India: Navajivan Publishing House.

Government of India. 2000. "Report of the Eleventh Finance Commission for 2000-2005." Government of India, New Delhi.

- 2001. "Report of the Task Force on Devolution of Powers and Functions upon Panchayati Raj Institutions.” Ministry of Rural Development, New Delhi.

2004a. "Background Note and Action Points." Paper prepared for the Chief Ministers' Conference on Poverty Alleviation and Rural Prosperity through Panchayati Raj, New Delhi, June 29. http://www.panchayat.gov.in.

-. 2004b. "Inaugural Address by the Prime Minister." Chief Ministers' Conference on Poverty Alleviation and Rural Prosperity through Panchayati Raj, New Delhi, June 29. - 2004c. "Report of the Task Force of Officials in Charge of Panchayati Raj in States to Examine the Centrally Sponsored Schemes." Ministry of Panchayati Raj, New Delhi. 
2004d. "Report of the Twelfth Finance Commission (2005-10)." Government of India, New Delhi.

- 2004e. Resolution of the First Round Table of Ministers in Charge of Panchayati Raj, Kolkata, July 24-25. http://www.panchayat.gov.in.

- 2005. Indian Public Finance Statistics, 2004-2005. New Delhi: Ministry of Finance.

- 2006. Annual Report 2005-2006. New Delhi: Ministry of Panchayati Raj.

Government of India, Committee on Plan Projects. 1957. Report of the Team for the Study of Community Projects and National Extension Service. Vol. I. New Delhi: National Development Council.

Jha, Shikha. 2000. "Fiscal Decentralization in India: Strengths, Limitations, and Prospects for Panchayati Raj Institutions." Background Paper 2, Overview of Rural Decentralization in India, vol. 3. Washington, DC: World Bank.

_. 2004. "Panchayats_Functions, Responsibilities, and Resources." Paper presented at the National Institute of Rural Development, Hyderabad, India, January 23.

Johnson, Craig. 2003. "Decentralisation in India: Poverty, Politics, and Panchayati Raj." Working Paper 199, Overseas Development Institute, London.

Kohli, Atul. 1987. The State and Poverty in India: The Politics of Reform. Cambridge, U.K.: Cambridge University Press.

Malaviya, H. D. 1956. Village Panchayats in India. New Delhi: Economic and Political Research Department, All India Congress Committee.

Manor, James. 1999. The Political Economy of Democratic Decentralization. Directions in Development Series. Washington, DC: World Bank.

Mookerji, Radhakumud. 1958. Local Government in Ancient India. Delhi: Moti Lal Banwari Dass.

Oommen, M. A. 1995. "Panchayat Finances and Issues Relating to Inter-Governmental Transfers." In Panchayats and Their Finance, ed. M. A. Oommen and Abhijit Datta, 1-54. New Delhi: Institute of Social Sciences.

_. 1999. "Panchayat Finance and Issues Relating to Inter-governmental Transfers." In Decentralisation and Local Politics: Readings in Indian Government and Politics, vol. 2, ed. S. N. Jha and P. C. Mathur, 142-72. London: Sage.

- 2004. "Basic Services, Functional Assignments, and Own Revenue of PanchayatsSome Issues in Fiscal Decentralization for the Consideration of the Twelfth Finance Commission." Paper presented at the National Institute of Rural Development, Hyderabad, India, January 23.

Rajaraman, Indira. 2003. Fiscal Domain for Panchayats. New Delhi: Oxford University Press.

Singh, S. K. 2000. “Panchayats in Scheduled Areas." In Status of Panchayati Raj in the States and Union Territories of India, ed. George Mathew, 23-33. Delhi: Institute of Social Sciences.

Singh, S. S., Suresh Mishra, and Sanjay Pratap. 1997. Legislative Status of Panchayati Raj in India. New Delhi: Indian Institute of Public Administration.

World Bank. 2004. India: Fiscal Decentralization to Rural Governments. Vol. I. Washington, DC: World Bank. 



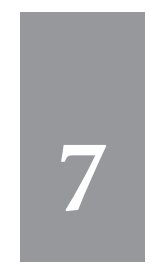

\section{Local Government Organization and Finance: Indonesia}

SEBASTIA N E KARDT A N A N WAR SHAH

I ocal government reforms have dominated the national policy

Lagenda in recent years in Indonesia, and sweeping legislative and administrative changes affecting the organization, finance, and functions of local governments have been introduced since 1999. This chapter provides an overview of and an analytical perspective on the reforms undertaken so far and the unfinished agenda. It also draws lessons from this experience that may have some relevance to other countries contemplating a reform of their fiscal systems.

\section{A Brief History of Local Government in Indonesia}

For most of its modern history, Indonesia was governed through a centralized fiscal and political system, leaving little scope for the development of autonomous local government institutions. ${ }^{1}$ Regional autonomy was largely perceived by the Dutch as a threat to centralized colonial control and by the Sukarno and Suharto administrations as a threat to national unity. The development of Indonesia's local government system dates back to the municipalities (gemeenten) and districts (gewesten) that were created under the late Dutch colonial rule but merely carried out higher-level administrative tasks at the local level. ${ }^{2}$ The first postindependence constitution 
(in 1945) called for the establishment of local governments and the enactment of a local government act within a unitary framework. The republic's first law on regional government (Law 22/1948) continued to maintain a fairly centralized approach. In 1949, the continued struggle for independence eventually led to Dutch recognition of the Federal Republic of the United States of Indonesia.

The federal constitution allowed for significant decrees of autonomy at the level of its 15 federal states but was widely perceived as something inflicted on Indonesia by the Dutch, with the deliberate intent of making the central government weak and the provinces strong so as to prolong Dutch influence on the archipelago. ${ }^{3}$ This situation led Indonesia's national government to reconstitute the state as a unitary state and to recentralize political power only a few months after independence. Then, in 1957, in the wake of rising regional sentiment against the central government, decentralization was invigorated when the Sukarno government enacted a new law on regional government (Law 1/1957), which allowed for much greater local autonomy (Legge 1961). However, in 1959, a presidential decree suspended parliamentary democracy in favor of "guided democracy," which concentrated political power in the hands of the president, leading to the authoritarian rule of President Sukarno.

This trend toward centralization of political power was reinforced when, in 1967, Sukarno's guided democracy was replaced by the "new order" regime under General Haji Mohammad Suharto, which culminated in one of the world's most centralized political systems. Despite some legal steps toward increased local autonomy (namely the enactment of Law 5/1974 on regional autonomy), meaningful decentralization never occurred in practice. As Jaya and Dick (2001, p. 222) observe, "Despite initial high expectations, Law 5/1974 did not reverse the trend towards the centralization of political and financial power."

In fact, before the decentralization policy of the late 1990s, the organizing principle in intergovernmental relations was strictly hierarchical, with the central government exercising significant control over the appointment of local officials and uses of funds by these officials. Regional and local governments mainly functioned as implementing agencies of national policies and programs. In effect, officials in local governments faced strong political and fiscal incentives to be accountable to superiors at higher levels of government, rather than to their communities. The highly centralized fiscal structure contributed to reduced accountability, adversely affected the rates of return on public sector projects, and constrained the development of local institutions (Bastin 1992; Shah and Qureshi 1994; Van den Ham 
and Hady 1988). However, despite these weaknesses, the system prevailed until the collapse of the entire regime.

In the late 1990s, the Asian financial crisis and its aftermath eventually led to the downfall of President Suharto after more than three decades of authoritarian rule. As part of a larger package to reform Indonesia's political system, in May 1999, after only a few months of preparation, the reform cabinet under President Bacharuddin Jusuf Habibie enacted two major laws that stipulated a redistribution of political authorities and financial resources among the country's three levels of government. Through the enactment of Law 22/1999 on regional governance, responsibility for much government expenditure was decentralized-largely to local (district) governments rather than provincial governments. Such a move had been advocated by Shah (1998a), who argued that decentralization to the provincial level might unleash centrifugal tendencies and precipitate the secession of some especially resource-rich units from the nation. Strengthening local governments would facilitate strengthening political and economic union while addressing long-felt local grievances.

Law 25/1999 on fiscal balance between the central government and the regions channeled budgetary flows to the district level. Both laws and the required implementing regulations were supposed to be in force by 2001, only two years after parliament approved them. Indonesia's local government system has remained in a state of flux ever since. Besides numerous government regulations and ministerial decrees specifying the implications of the general decentralization framework, in 2004 a major revision of the decentralization laws took place. In late September, the parliament (Dewan Perwakilan Rakyat) approved Law 32/2004 on subnational governance and Law 33/2004 on fiscal decentralization, thereby reinforcing Indonesia's effort to create a decentralized system of governance.

\section{Current System of Local Governments: Legal, Fiscal, and Political Overview}

Indonesia's political and administrative system consists of four government levels, the central; the provincial level (Daerah Tingkat I, or Dati I); the district level (Daerah Tingkat II, or Dati II); the urban municipalities (cities and towns, or kotamadya); and the villages (kelurahan in urban areas and desa in rural areas). Legally, local and provincial governments are autonomous administrative and territorial entities within the unitary state of Indonesia. At the end of 2004, there were 33 provinces, about 440 districts, about 100 urban municipalities, and approximately 80,000 villages. The average population of 
a province is about 7 million, ranging from fewer than 1 million in North Mollucu to more than 38 million in West Java. The average population under Indonesian local governments (including rural districts and urban municipalities) is about 480,000 people, rather large by international standards. ${ }^{4}$ There is fairly wide diversity in size, from fewer than 25,000 in sparsely populated Sabang to almost 4 million in metropolitan Bandung. Some of these entities might in fact be too large, whereas others might be too small to deliver services efficiently.

Local governments also differ vastly in their geographic and socioeconomic characteristics. Per capita incomes in the richest 20 percent of districts are more than three times higher than in the poorest 20 percent of districts. This uneven distribution of economic activity is reflected in large disparities in living conditions. ${ }^{5}$ Poverty rates range from about 7 percent in the industrialized district of Bekasi at the fringe of Jakarta to more than 40 percent in the West Sumba district in the eastern part of Indonesia. Illiteracy in the East Javanese district of Sampang is still more than 40 percent, though it has decreased to 12 percent for Indonesia as a whole. And though about 98 percent of people in Tanjung Jabung Barat in the province of Jambi have access to primary health care, only 22 percent do in Sintang in West Kalimantan (BPS 2003). Although this heterogeneity potentially increases the benefits of decentralization, it also places considerable pressure on the fiscal system to ensure minimum quantity and quality in and access to public service and to enable the convergence of living conditions across Indonesia's local governments.

Article 18 of the 1945 Constitution Act provides for the creation and maintenance of local governments through the enactment of a local government act. The decentralization laws of 1999 and 2004 and associated regulations are the basis of Indonesia's current local government system. The Second Constitutional Amendment Act, passed in 2000, has embedded parts of the decentralization reforms-for example, the democratic elections of mayors and governors-into the constitution to ensure the long-term stability of the system and to provide political safeguards against arbitrary reversals. ${ }^{6}$

The resources that local governments have at their disposal have been increased through the enactment of article 7 of Law 25/1999, which requires the central government to transfer at least 25 percent of domestic net revenues (total domestic revenue minus revenue sharing) to subnational levels of government. Ten percent of that amount accrues to the provincial governments, and 90 percent to the local governments, which carry out the bulk of expenditure responsibilities. As a consequence, the share of consolidated subnational expenditures in total public expenditures rose from roughly 17 
percent in financial year (FY) 2000 to about 27 percent in FY 2001. In FY 2002, the subnational share rose to more than 30 percent of the total. If national spending on debt service is excluded, subnational expenditures accounted for more than 40 percent of government spending in FY 2002. In absolute terms, local government expenditures and revenues have also been on the rise. As can be seen from figure 7.1, local government expenditures more than doubled in 2001 in real terms and then rose by another 18 percent and 20 percent in 2002 and 2003. Law 33/2004 has increased the subnational share to a minimum of 26 percent of net domestic revenue beginning in 2008. Provincial and local government shares of the total pool are not fixed in these revisions but will be regulated in a government regulation.

Perhaps more important than the quantitative changes are changes in the sources of finance. Before the recent decentralization initiatives, the central government relied heavily on earmarked grants to finance subnational recurrent and development expenditures. ${ }^{7}$ Transfers remain the main source of local government revenues, but the current system relies primarily on untied transfers over which local governments have full discretion. Specifically, the current revenue framework defines four principal revenue categories: (a) own-source revenues, consisting of tax and nontax revenues; (b) the balancing fund, consisting of the General Allocation Fund (Dana Alokasi Umum, or DAU) grant, the Special Allocation Fund (Dana Alokasi Khusus,

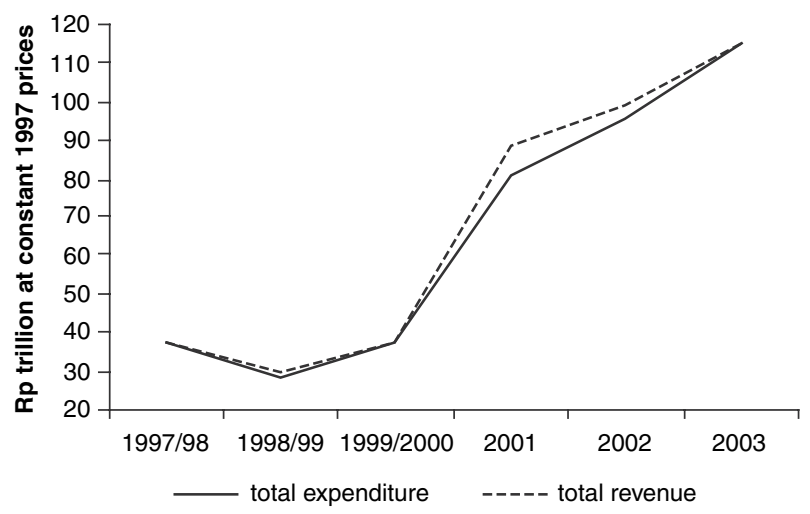

Source: Authors' chart based on data from Lewis and Pradhan 2005.

Note: In 2000 the Indonesian government changed the dates of the fiscal year to be consistent with the calendar year. Fiscal years now start on January 1 and end on December 31. Prior to this change, both calendar years were given for each fiscal year, thus FY 1999/2000 refers to the fiscal year starting on April 1, 1999, and ending on March 31, 2000.

F I G U R E 7 . 1 Local Government Expenditures and Revenues, FY 1997-FY 2003 
or DAK) grant, and shared taxes and revenues; (c) loans and other forms of local borrowing; and (d) other local revenues.

The main thrust of the decentralization policy was to devolve expenditure responsibilities. The tax assignments remained largely unchanged by the decentralization policy. All significant tax bases, including value added $\operatorname{tax}$ (VAT), personal income tax, and corporate income tax, remain under the control of the national government. As a consequence, the vertical fiscal gap between subnational expenditures and revenues is very large, as illustrated by figure 7.2. Own-source tax and nontax revenues of subnational governments together account for only 5.1 percent of total public revenue, and most subnational revenues come from transfers. As can be seen from figure 7.3, own-source revenues are relatively insignificant at the local level. Most local government financing comes from the DAU grant, which accounted for more than 60 percent of total revenues in the past few years. For provincial governments, by comparison, the DAU is considerably less significant. Provinces have control over a number of taxes with significant revenue potential, such as the fuel excise tax, which is reflected in their high share of own-source revenues.

The decentralization legislation also restructured subnational political institutions. It institutionalized democratic elections at multiple levels of government and encouraged the development of pluralistic political parties, the strengthening of legislatures, the creation of local political units, and the formation of public interest groups. The practice of central appointment of

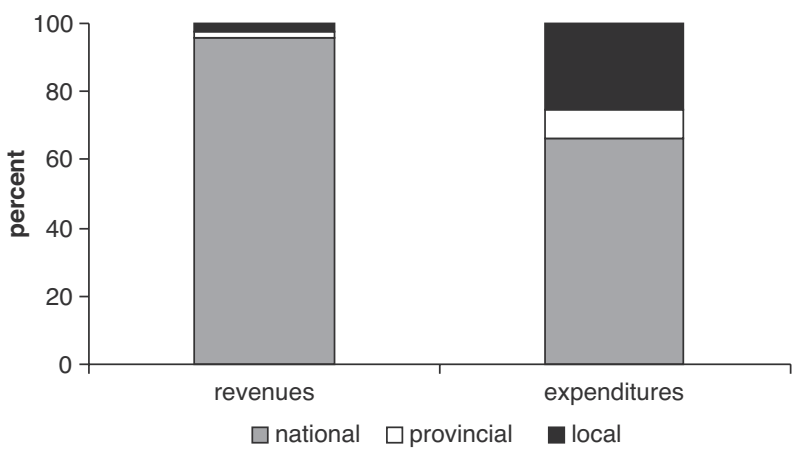

Source: Authors' estimates based on data for 294 local governments from Indonesia, Ministry of Finance 2005.

FI G U R E 7 . 2 Imbalanced Decentralization: Subnational Shares in Total Revenues and Expenditures, FY 2003 


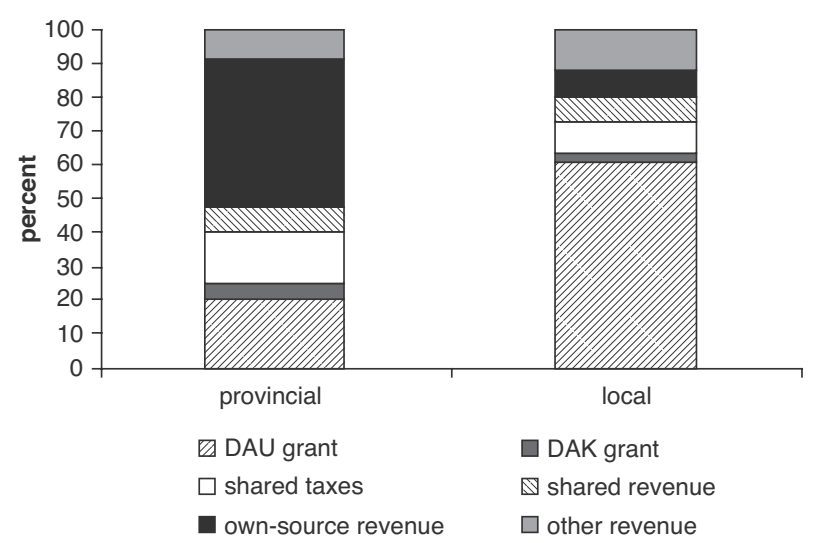

Source: Authors' estimation based on data from Indonesia, Ministry of Finance 2005.

\section{F I G U R E 7 . 3 Subnational Revenue Sources, FY 2003}

subnational government heads was discontinued. Effectively, that change meant that mayors no longer serve as representatives of the central government, held accountable in an upward direction. ${ }^{8}$ These steps transferred substantial political control functions to local (horizontal) accountability systems. ${ }^{9}$

These local accountability systems are basically organized around a triangular relationship between the head of the region (the mayor), the local representative council, and the community (voters). Initially, accountability was organized rather indirectly, with the mayor indirectly elected by and accountable to the representative council (ADB 2004; World Bank 2003). The council members, in turn, are supposed to be accountable to the community through regular multiparty elections. During the first general election in 1999 , members of the local parliaments were elected on the basis of closed party lists, with 10 percent of the seats reserved for the military and the police and party candidates obtaining a seat on the basis of their rank on the party list. Consequently, members of the local representative council were formally mainly accountable to their parties, not to the public, which undermined their accountability. ${ }^{10}$ Recent legislation has reformed both the electoral system and the system of checks and balances in the subnational system. Law $32 / 2004$ has introduced direct election for both mayors and governors. At the same time, the electoral system was changed to an open list system. Both steps are supposed to strengthen the political incentives of local governments to provide the policies and services desired by their constituents. 


\section{Local Government Expenditure Responsibilities}

Indonesia's decentralization policy shifted responsibility for all but five exclusive national functions to regional governments. According to Laws 22/1999 and 32/2004, the national government retained power over five functions that affect the nation: foreign relations, defense and security policy, judiciary and law enforcement, monetary and macroeconomic policies, and religious affairs. Subnational governments are responsible for all residual functions. In addition, Law 22/1999 spells out 11 obligatory functions of local governments (table 7.1). The revised Law 32/2004 removed the omnibus assignment of the residual (not national) functions to regional governments and stipulated 15 obligatory functions and a number of discretionary functions.

Decentralization policy mainly emphasized the third tier of government, because provinces were perceived as potential drivers of political disintegration. Compared with local governments, provinces have far more

TA B LE 7 . 1 Obligatory Functions of Subnational Governments under Laws 22/1999 and 32/2004

\begin{tabular}{|c|c|}
\hline Law 22/1999 functions & Law 32/2004 functions \\
\hline Infrastructure (public works) & Development planning and control \\
\hline Health & $\begin{array}{l}\text { Planning, utilization, and supervision of } \\
\text { zoning }\end{array}$ \\
\hline Education & Public order and peace \\
\hline Agriculture & Providing public means and facilities \\
\hline Communication & Handling of health sector \\
\hline Industry and trade & Education \\
\hline Cooperatives & Social affairs \\
\hline Land administration and zoning & Employment promotion \\
\hline Capital investments & $\begin{array}{l}\text { Facilitating the development of coopera- } \\
\text { tives and small and medium-size } \\
\text { businesses }\end{array}$ \\
\hline Environment & Environment \\
\hline \multirow[t]{5}{*}{ Employment promotion } & Agriculture \\
\hline & Demographics and civil registry \\
\hline & Administration affairs \\
\hline & Capital investment \\
\hline & $\begin{array}{l}\text { Other mandatory affairs as instructed by } \\
\text { the laws and regulations }\end{array}$ \\
\hline
\end{tabular}


limited responsibilities, a fact that is also reflected in their much smaller share of expenditures. The provincial level has a double role as an autonomous regional government and as the regional representative of the national government. Provinces are mainly responsible for supervisory functions and are supposed to intervene in matters that require cross-jurisdictional cooperation. Law 32/2004 explicitly strengthens the coordinating role of provincial governments as regional representatives of the central government, a step that was based on the perception that closer central supervision and oversight are needed to make decentralization work more effectively.

In practice, the distribution of specific responsibilities is regulated by a number of sectoral laws and numerous government regulations and ministerial decrees. ${ }^{11}$ For most sectors, responsibilities are shared among government levels, with the national government involved also in formally decentralized sectors (table 7.2). A national role in most of the sectors listed may be helpful, provided that it does not reinstitute central bureaucratic controls and is instead focused on providing financial and technical support and service delivery oversight. For example, equity concerns might necessitate a strong national role in financing and regulating standards in basic public services, such as education and health.

The sharing of responsibilities is also reflected in expenditure patterns. Table 7.3 shows the distribution of expenditures by sector and level of government for FY 2002. National development expenditures represent more than 60 percent of total development spending, including significant outlays in decentralized service sectors, such as health, education, and infrastructure. This trend suggests that the implementation of decentralization is still lagging in some sectors.

As can be seen in table 7.3, local governments account for roughly half of the total wage bill. With decentralization, wage costs increased significantly, as a consequence of civil servants being transferred to the jurisdiction of subnational governments. These increased costs shifted a significant burden to local government budgets. Indeed, in the aggregate, the expenditure side of local government budgets is dominated by wage costs, which account for about half of total local government expenditures (table 7.4).

There is significant variation across local governments, with wage cost shares ranging from 10 percent to more than 90 percent depending on the district. Local budgets in most districts are heavily skewed toward operating expenditures, leaving few funds for much-needed capital spending. Most local public services are labor intensive, and significant shares of the public payroll are allocated to cover personnel expenses related to service delivery-including the salaries of teachers, doctors, and health care 
TA B LE 7.2 Distribution of Functions across Levels of Government

Subsidies

\section{Regulatory function}

Natural resource management and environmental policy
Central

Province

Local

\section{Exclusively central}

Exclusively central

Exclusively central

Exclusively central

Rice subsidy

Fuel subsidy

Electricity subsidy

Subsidies to national state enterprises

National laws and regulations Legal supremacy of national law over subnational bylaws

Environmental policies and supervision

Sustainable management of natural resources and preservation of environment

Financing reforestation programs through DAK grants
Subsidies to provincial state enterprises

Subsidies to local state enterprises

Provincial bylaws in the framework of national legal system

Supervisory function and cross-district coordination
Local bylaws in the framework of national legal system

Management of local natural resources

Issuance of fishing and mining licenses

Management of local reforestation programs 
Education

Health

Agriculture and irrigation
Educational policies and supervision

Frame curricula for primary and secondary schools

Final national examination for primary and secondary schools

Minimum service standards for primary and secondary schools

Financing infrastructure and school rehabilitation (primary and secondary)

Exclusive responsibility for tertiary education and universities

Exclusive responsibility for religious schools (madradesh)

DAK grants

National health policies

Minimum service standards

Social health programs, including

financing of free health services

for the poor

DAK grants

National programs, extension services, and training

Infrastructure investments

Price regulation and trade through Badan Urusan Logistik (Bureau of Logistics)
Supervisory function and cross-district coordination

Supervisory function and cross-district coordination

Provincial programs, extension services, and training

Infrastructure investments
Management and financing of public schools

Administration and financing of teachers and school staff

Financing and management of teacher qualification

Financing and management of education infrastructure

Management and financing of health service providers

Administration and financing of health sector staff

Management and financing of health service infrastructure

Local programs, extension services, and training Infrastructure investments 
TA B LE 7 . 2 Distribution of Functions across Levels of Government (continued)

\begin{tabular}{|c|c|c|c|}
\hline Function & Central & Province & Local \\
\hline Industry & $\begin{array}{l}\text { National industrial policies } \\
\text { Foreign investment approval } \\
\text { Assignment of special industrial } \\
\text { zones } \\
\text { Promotion of small and } \\
\text { medium-size enterprises } \\
\text { Microfinance schemes and } \\
\text { finance programs for small } \\
\text { and medium-size enterprises } \\
\text { Financing of research and } \\
\text { development in areas of } \\
\text { strategic national interest }\end{array}$ & $\begin{array}{l}\text { Supervisory function and } \\
\text { cross-district coordination }\end{array}$ & $\begin{array}{l}\text { Local economic development } \\
\text { Business licensing } \\
\text { enterprise and cluster } \\
\text { promotion } \\
\text { Industrial zoning }\end{array}$ \\
\hline Transportation & $\begin{array}{l}\text { Financing and management of } \\
\text { national infrastructure } \\
\text { DAK grants }\end{array}$ & $\begin{array}{l}\text { Financing and management of } \\
\text { provincial infrastructure }\end{array}$ & $\begin{array}{l}\text { Financing and management of } \\
\text { local infrastructure }\end{array}$ \\
\hline
\end{tabular}

Source: Law 22/1999, Government Regulation PP 25/2000, and Law 32/2004. Updated from Shah and Qureshi 1994. 
TA B L E 7 . 3 Expenditures by Level of Government, FY 2002

\begin{tabular}{|c|c|c|c|c|c|c|c|c|c|c|}
\hline \multirow[b]{2}{*}{ Type of expenditure } & \multicolumn{2}{|c|}{$\begin{array}{l}\text { Consolidated } \\
\text { government }\end{array}$} & \multicolumn{2}{|c|}{ Nationala ${ }^{a}$} & \multicolumn{2}{|c|}{ Provincial $^{a}$} & \multicolumn{2}{|c|}{ Local } & \multicolumn{2}{|c|}{$\begin{array}{l}\text { Consolidated } \\
\text { subnational }\end{array}$} \\
\hline & Rp billion & Percent & Rp billion & Percent & Rp billion & Percent & Rp billion & Percent & Rp billion & Percent \\
\hline \multicolumn{11}{|l|}{ Classified by sector } \\
\hline Transportation development & $16,818.32$ & 100.0 & $6,892.74$ & 41.0 & $2,481.72$ & 14.8 & $7,443.86$ & 44.3 & $9,925.58$ & 39.0 \\
\hline State apparatus development & $6,619.72$ & 100.0 & $1,378.55$ & 20.8 & $1,243.83$ & 18.8 & $3,997.34$ & 60.4 & $5,241.17$ & $7 \quad 79.2$ \\
\hline Education development & $19,477.22$ & 100.0 & $14,130.12$ & 72.5 & $2,225.27$ & 11.4 & $3,121.83$ & 16.0 & $5,347.10$ & 27.5 \\
\hline Local development & $7,752.27$ & 100.0 & $4,480.28$ & 57.8 & 725.02 & 9.4 & $2,546.97$ & 32.9 & $3,271.99$ & 42.2 \\
\hline $\begin{array}{l}\text { Trade, small and medium-size } \\
\text { enterprise, and cooperative }\end{array}$ & & & & & & & & & & \\
\hline development & $11,996.62$ & 100.0 & $9,305.20$ & 77.6 & 823.25 & 6.9 & $1,868.17$ & 15.6 & $2,691.42$ & 22.4 \\
\hline Health and social services & & & & & & & & & & \\
\hline development & $8,265.18$ & 100.0 & $5,514.19$ & 66.7 & $1,018.39$ & 12.3 & $1,732.60$ & 21.0 & $2,750.99$ & 33.3 \\
\hline Other development & $15,340.43$ & 100.0 & $4,989.00$ & 32.5 & $3,868.64$ & 25.2 & $6,482.79$ & 42.3 & $10,351.43$ & 67.5 \\
\hline \multicolumn{11}{|l|}{ Not classified by sectorb } \\
\hline Wage outlay & $94,177.76$ & 100.0 & $42,196.00$ & 44.8 & $6,453.39$ & 6.9 & $45,528.37$ & 48.3 & $51,981.76$ & $5 \quad 55.2$ \\
\hline Other recurrent & $185,540.84$ & 100.0 & $157,942.00$ & 85.1 & $8,615.43$ & 4.6 & $18,983.41$ & 10.2 & $27,598.84$ & $4 \quad 14.9$ \\
\hline Total & $365,988.36$ & 100.0 & $246,828.08$ & 67.4 & $27,454.94$ & 7.5 & $91,705.34$ & 25.1 & $119,160.28$ & 832.6 \\
\hline
\end{tabular}

Source: Based on data from Indonesia, Ministry of Finance 2005.

a. Excluding transfers to lower levels of government.

b. The Indonesian budgetary system used to broadly divide the spending side of the budget between development and routine expenditures. Only development expenditures are

classified by sector. The accounting system is undergoing a transition to a unified performance-based budgeting system that classifies all spending categories by sector. 
TA B L E 7 . 4 Local Government Expenditure Composition, FY 2001/02

\begin{tabular}{lccccc}
\hline & \multicolumn{2}{c}{ FY 2001 } & & \multicolumn{2}{c}{ FY 2002 } \\
\cline { 2 - 3 } \cline { 5 - 6 } Type of expenditure & Rp billion & Percent & & Rp billion & \multirow{2}{*}{ Percent } \\
\hline Classified by sector & & & & \\
Transportation development & $5,848.8$ & 8.4 & & $7,443.86$ & 8.1 \\
State apparatus development & $3,292.3$ & 4.7 & & $3,997.34$ & 4.4 \\
Education development & $2,336.3$ & 3.3 & & $3,121.83$ & 3.4 \\
Local development & $1,739.2$ & 2.5 & & $2,546.97$ & 2.8 \\
Trade, small and medium-size & & & & \\
$\quad$ enterprise, and cooperative & & & & \\
$\quad$ development & $1,166.4$ & 1.7 & & $1,868.17$ & 2.0 \\
Health and social services & & & & \\
$\quad$ development & $1,196.3$ & 1.7 & & $1,732.60$ & 1.9 \\
Other development & $5,904.4$ & 8.4 & & $6,482.79$ & 7.1 \\
Not classified by sector & & & & \\
Wage outlay & $35,443.0$ & 50.7 & & $45,528.37$ & 49.6 \\
Other recurrent & $13,031.3$ & 18.6 & & $18,983.41$ & 20.7 \\
$\quad$ Total & $69,958.0$ & 100.0 & $91,705.34$ & 100.0 \\
\hline
\end{tabular}

Source: Based on data from Indonesia, Ministry of Finance 2005.

a. The Indonesian budgetary system used to broadly divide the spending side of the budget between development and routine expenditures. Only development expenditures are classified by sector. The accounting system is undergoing a transition to a unified performance-based budgeting system that classifies all spending categories by sector.

workers. However, the country's largely depreciated infrastructure (for example, elementary school buildings and medical equipment) suggests that higher capital expenditures might be needed to provide high-quality services. In the long run, underinvestment in infrastructure will most certainly lead to quality reductions and efficiency losses in public service delivery (World Bank 2003).

\section{Local Government Own-Source Taxes and Charges}

Subnational taxation is regulated by Law 34/2000 on regional taxes. There are four provincial taxes (motor vehicle tax, motor vehicle transfer tax, fuel excise tax, and groundwater extraction and use tax) and seven local taxes (hotel tax, restaurant tax, entertainment tax, advertisement tax, street lighting tax, mining tax for class $\mathrm{C}$ minerals, and parking tax) (table 7.5). The national government determines the tax bases, and there are rate caps for each of these taxes, within which subnational governments can set their rates. 
TA B LE 7.5 Subnational Taxes

\begin{tabular}{|c|c|c|c|}
\hline Type of tax & Level & Tax base & Cap (\%) \\
\hline Motor vehicle tax & Provincial & Vehicle value (annual) & 5 \\
\hline Motor vehicle transfer tax & Provincial & Vehicle resale price (annual) & 10 \\
\hline Fuel excise tax & Provincial & $\begin{array}{l}\text { Fuel consumption (retail price, } \\
\text { excluding VAT) }\end{array}$ & 5 \\
\hline Water excise tax & Provincial & Water consumption & 20 \\
\hline Hotel tax & Local & Turnover & 10 \\
\hline Restaurant tax & Local & Turnover & 10 \\
\hline Entertainment tax & Local & Turnover (admission price) & 35 \\
\hline Advertisement tax & Local & Advertisement rent & 25 \\
\hline Street lighting tax & Local & $\begin{array}{l}\text { Electricity consumption } \\
\quad \text { (retail price, excluding VAT) }\end{array}$ & 10 \\
\hline $\begin{array}{l}\text { Mining tax for class } \mathrm{C} \\
\text { minerals }\end{array}$ & Local & $\begin{array}{l}\text { Market value of extracted } \\
\text { minerals }\end{array}$ & 20 \\
\hline Parking tax & Local & Parking fees & 20 \\
\hline
\end{tabular}

Source: Law 34/2000; World Bank 2003; PWC 2005.

a. Class C minerals include asbestos, slate, semiprecious stone, limestone, pumice, precious stone, bentonite, dolimite, feldspars, halites, graphite, granite and andesite, gypsum, calcite, kaolin, leucite, magnesium, mica, marble, nitrate, obsidian, ocher, sand and gravel, quartz sand, perlite, phosphate, talc, fuller's earth, diatom soil, clay, alum, trass, yarosite, zeolite, basalt, and tracite.

In addition, article 2 of Law 34/2000 states that local governments have the right to impose new local taxes as long as those taxes comply with eight general "good tax" principles:

They are taxes, not user charges.

The tax base is located in the region and immobile.

The taxes do not conflict with public interest.

The tax base is not subject to provincial and national taxation.

The revenue potential is adequate.

The taxes do not exert economic distortions.

Equity concerns are taken into account.

Environmental sustainability is taken into account.

In addition, Law 33/2004 prohibits local governments from establishing own-source revenues that impose high costs on the economy or restrict the mobility of people and goods and services across internal borders or constrain international imports and exports. This provision was introduced in reaction to the imposition of taxes on interjurisdictional trade by some local governments (Ray 2003). The right to impose new taxes and user charges is 
a new subnational authority introduced by Law 34/2000; it was accompanied by fears of mushrooming local taxes. To prevent the issuing of a plethora of subnational charges and taxes, the law requires review and retrospective approval by the national government. ${ }^{12}$ The oversight function resides with an interministerial review team from the Ministry of Home Affairs and the Ministry of Finance.

Lewis (2003b) reports that 916 bylaws on local taxes were enacted in FY 2000 to FY 2002. Of these, 406 were reviewed by the national government, and 113 were rejected on the basis of the outlined criteria. ${ }^{13}$ The government is preparing a revision of Law 34/2000, which apparently includes a list of local taxes and user charges, to reduce the administrative burden of the review process and to prevent inefficient taxation practices.

Accountable local governance requires that local governments be largely self-financed, so that tax burdens and the benefits of local services are obvious to local residents. If local tax rates are flexible, they can signal the costs of local services, at least at the margin, and local residents can choose the level of services they desire. At the same time, residents face greater incentives to monitor performance if services are directly funded from their tax payments. However, in Indonesia, the potential for local governments to raise own-source revenue remains weak under the current legislation. To raise additional revenues, local governments resort to inefficient taxes and charges with small revenue potential and high administrative costs, thus contributing to economic distortions (Ray 2003).

For local accountability to take root, among the most critical issues in the reform of intergovernmental fiscal relations are broadening the local tax bases and reducing the dependence of regional governments on transfers. Two specific reform proposals are under discussion. The first proposal is to assign land and property tax to local governments. Property tax is an obvious candidate for decentralization, because most of the revenue already accrues to regional governments under current sharing arrangements (Kelly 2004; Lewis 2002b; Shah and Qureshi 1994). Moreover, taxes on land and property are particularly well suited as subnational taxes because they are immobile and represent important sources of finance for subnational governments in many tax systems. The second proposal is to give regional governments the option of levying a supplementary rate (for example, up to five percentage points) on the national tax base for personal incomes, with central collection of the supplementary tax (Ahmad and Krelove 2000; Shah and Qureshi 1994). In the medium term, these proposals will not be put into practice, because the revised Law 34/2000 does not devolve significant tax authority to the local level. 


\section{Shared Taxes and Revenues}

The general provisions for the sharing of tax and nontax revenues are regulated by article 7 of Law 25/1999. Government Regulation 104/2000 translates these general provisions into specific sharing arrangements. The sharing arrangement for personal income tax is included in article 31 of Law $17 / 2000$ on income tax. Special arrangements concerning revenue sharing for Aceh and Papua are included in the two special autonomy laws. ${ }^{14}$

Table 7.6 gives an overview of the current sharing arrangements. It shows that though most tax sharing is based primarily on the derivation principle, fishery royalties and property-related taxes use equal shares as an added criterion. The 9 percent national share in the property tax is simply an administrative fee to compensate the national tax administration for collecting and administering the tax. It is noteworthy that in apportioning personal income tax, place of work rather than the almost universally used place of residence is the criterion (Brodjonegoro and Martinez-Vazquez 2002; Hofman, Kadjatmiko, and Kaiser 2004; Shah 1994; World Bank 2003). In addition to the sharing arrangements for national revenues, local governments receive shares of the four provincial taxes: the motor vehicle tax (30 percent), the vehicle transfer tax (30 percent), the fuel excise tax (70 percent), and the groundwater extraction and use tax (70 percent). However, the contributions of these taxes to overall local revenues are relatively small.

Arrangements for natural resource revenue sharing are not a new feature of Law 25/1999 but had been in place for mining and forestry proceeds in the prereform period. However, decentralization increased the share going to local governments. Most revenues from these two resources are returned to the originating provincial or local jurisdictions. The sharing of fishery, oil, and gas revenues was introduced in 2000. The revised Law $33 / 2004$ introduces some slight changes to sharing arrangements. It introduces a new type of shared revenue, proceeds from geothermal mining. It also slightly increases the subnational share of oil and natural gas revenues. Starting in 2009, 84.5 percent of oil revenues will accrue to the central budget, and 15.5 percent will accrue to subnational governments. For gas revenues, 69.5 percent will go to the center, and 30.5 percent to the regions. Subnational governments will receive an extra 0.5 percent of both oil and gas revenues, which are earmarked for increasing local expenditures on primary education.

The sharing of oil and gas revenues was introduced to redress the grievances of the resource-rich provinces that, although they face the development costs and environmental consequences of resource exploitation, all 
TA B LE 7 .6 Arrangements for Tax and Revenue Sharing under Law 33/2004

(percent)

\begin{tabular}{|c|c|c|c|c|c|}
\hline Revenue source & $\begin{array}{c}\text { Central } \\
\text { government }\end{array}$ & $\begin{array}{l}\text { Originating } \\
\text { provincial } \\
\text { government }\end{array}$ & $\begin{array}{c}\text { Originating } \\
\text { local } \\
\text { government }\end{array}$ & $\begin{array}{c}\text { All local } \\
\text { governments } \\
\text { in originating } \\
\text { province }\end{array}$ & $\begin{array}{c}\text { All local } \\
\text { governments } \\
\text { (equal share) }\end{array}$ \\
\hline Personal income tax & 80.0 & 8.0 & 12.0 & n.a. & n.a. \\
\hline Property tax & 9.0 & 16.2 & 64.8 & n.a. & 10.0 \\
\hline Property transfer tax & n.a. & 16.0 & 64.0 & n.a. & 20.0 \\
\hline Mining land rent & 20.0 & 16.0 & 64.0 & n.a. & n.a. \\
\hline Mining royalty & 20.0 & 16.0 & 32.0 & 32.0 & n.a. \\
\hline Forestry license & 20.0 & 16.0 & 64.0 & n.a. & n.a. \\
\hline Forestry royalty & 20.0 & 16.0 & 32.0 & 32.0 & n.a. \\
\hline Fishery royalty & 20.0 & n.a. & n.a. & n.a. & 80.0 \\
\hline Geothermal mining & 20.0 & 16.0 & 32.0 & 32.0 & n.a. \\
\hline \multicolumn{6}{|l|}{ Oil } \\
\hline Base rate & 84.5 & 3.0 & 6.0 & 6.0 & n.a. \\
\hline $\begin{array}{c}\text { Conditional rate } \\
\text { (education) }\end{array}$ & & 0.1 & 0.2 & 0.2 & n.a. \\
\hline \multicolumn{6}{|l|}{ Natural gas } \\
\hline Base rate & 69.5 & 6.0 & 12.0 & 12.0 & n.a. \\
\hline $\begin{array}{l}\text { Conditional rate } \\
\text { (education) }\end{array}$ & n.a. & 0.1 & 0.2 & 0.2 & n.a. \\
\hline
\end{tabular}

Source: World Bank 2003; article 6, Law 22/1999; article 31, Law 17/2000. n.a. $=$ not applicable.

benefits accrue only to the central government. Current revenue-sharing arrangements for oil and gas attempt to strike a delicate balance among the genuine grievances and national equity objectives. These objectives call for resource revenues to accrue to the national government for use in an equalization program.

\section{Intergovernmental Fiscal Transfers}

As discussed earlier, Indonesia's fiscal system relies primarily on central fiscal transfers to finance local government operations. Two types of intergovernmental transfers are in vogue: (a) an unconditional nonmatching transfer or general allocation grant (the DAU grant) and (b) a conditional matching transfer, the special allocation grant (the DAK grant). 


\section{The General Allocation Grant}

The general allocation grant is the main source of revenue for most local governments, accounting on average for roughly 61 percent of total local revenues in FY 2003. The DAU is also the principal instrument for both vertical (across levels of government) and horizontal (across subnational governments) equalization. The allocation of the DAU follows a formula-based approach aimed at aligning fiscal capacity with the fiscal needs of local governments. ${ }^{15}$ Under Law 22/1999, this formula was based on two components: (a) a minimum allocation, which local governments receive regardless of their fiscal gap, consisting of a lump sum equally divided across all local governments and a compensation of civil service wage bills, and (b) a fiscal gap component, estimating the difference between local governments' own fiscal capacity and fiscal needs. ${ }^{16}$ So that the transition from the prereform system would be smoother, the results of the formula-based allocation were adjusted to comply with the "hold harmless" provision. This provision ensured that under the actual allocation no local government would receive less than in the prereform period, taking into account the SDO (subsidi daerah otonomi, or autonomous government subsidy before decentralization) and Inpres (the earmarked capital grant before decentralization) of FY 2000 for the FY 2001 calculation and previous DAU allocations for the subsequent years.

Law 33/2004 calls for a revision of the DAU distribution formula. Under the new formula, to be applied first in FY 2006, the DAU allocation for a district (or a province, for which the structure of the formula is practically identical), denoted $D A U_{i}$, consists of two components: a base allocation compensating for civil service wage costs, denoted Wage $_{i}$, and an equalizing amount to address the fiscal gap by taking into consideration fiscal capacity and expenditure needs, denoted Equal $_{i}$ :

$$
D A U_{i}=\text { Wage }_{i}+\text { Equal }_{i}
$$

Law 33/2004 requires that the DAU grant compensate for all civil service wages, implying that $\mathrm{Wage}_{i}$ equals the actual wage costs of a given district. Hence, the total DAU pool is reduced by the aggregate subnational wage costs, effectively reducing the amount available for the equalizing component. The new rules abolish the equal per municipality lump-sum component that existed under Law 25/1999, and the basic allocation is supposed to be based entirely on the regional civil service wage bill. 
The amount regions receive under the equalizing component depends on the fiscal gap of a given district (FiscalGap $_{i}$, which is defined as the disparity between fiscal needs and fiscal capacity:

$$
\text { FiscalGap }_{i}=\text { FiscalCapacity }_{i}-\text { FiscalNeed }_{i} \text {. }
$$

FiscalCapacity $i_{i}$ is defined as the sum of potential own-source revenues $\left(P A D_{i}\right)$, revenues from shared taxes (SharedTaxes $\left.i\right)$, and shared natural resource revenues $\left(S D A_{i}\right)$ in a given district:

$$
\text { FiscalCapacity }_{i}=P A D_{i}+\text { SharedTaxes }_{i}+\text { Weight }_{S D A} \times S D A_{i} .
$$

Two aspects of this part of the formula are noteworthy. First, the ownsource revenue component $\left(P A D_{i}\right)$ does not refer to actual but potential own-source revenues, which are estimated as a linear function of the average local tax effort and local gross domestic product (GDP). The average local tax effort, in turn, is estimated on the basis of a regression of real own-source revenues against local GDP per district from the preceding fiscal year. This aspect of the formula was introduced to make fiscal capacity neutral relative to the own-source tax effort. Second, as can be seen from the formula, only revenues from shared natural resource royalties are discounted in the calculation of fiscal capacity, in recognition of the fact that resource extraction places additional costs on resource-rich jurisdictions in terms of infrastructure and services and environmental degradation.

The fiscal need for each district ( FiscalNeed $_{i}$ ) is estimated as a function of five indicators of expenditure need: population, area, Human Development Index (HDI), regional per capita GDP, and regional price differentials. The assumption is that these five factors drive expenditure needs. Districts with larger than average population, higher than average poverty, larger than average area, or higher than average prices are assumed to have higher expenditure needs. Specifically the indicators are the following:

1. The proportional population, calculated as the population of the district $\left(P o p_{i}\right)$ divided by the average population of all districts $\left(P_{O P P_{M E A N}}\right)$

2. The relative area, calculated as the district area $\left(\right.$ Area $\left._{i}\right)$ divided by the national average for district area $\left(\right.$ Area $\left._{\text {MEAN }}\right)$

3. The inverse of the relative Human Development Index, estimated as the inverse of the Human Development Index $\left(100-H D I_{i}\right)$ divided by the national average of the inverse of the Human Development Index $\left(100-H D I_{\text {MEAN }}\right)$ 
4. The relative per capita GDP, estimated as district per capita GDP $\left(P C G D P_{i}\right)$ divided by the national average poverty gap (PCGDP $\left.P_{\text {MEAN }}\right)$

5. An indicator to account for price differentials in providing similar services across districts, calculated as the construction price index for each district $\left(\right.$ Price $\left._{i}\right)$ divided by the average construction price index (Price $\left.{ }_{\text {MEAN }}\right)$.

In formal terms, fiscal need can be expressed as follows:

$$
\begin{aligned}
\text { FiscalNeed }_{i}= & {\left[\alpha \times \frac{P_{o p_{i}}}{\text { Pop }_{M E A N}}+\beta \times \frac{\text { Area }_{i}}{\text { Area }_{\text {MEAN }}}+\gamma \times \frac{100-H D I_{i}}{100-H D I_{\text {MEAN }}}\right.} \\
& \left.+\delta \times \frac{P C G D P_{i}}{\text { PCGDP }_{\text {MEAN }}}+\varepsilon \times \frac{\text { Price }_{i}}{\text { Price }_{\text {MEAN }}}\right] \times \frac{A P B D_{\text {TOTAL }}^{\text {PREVOS }}}{N},
\end{aligned}
$$

where, , , and denote the weight assigned to each factor and ++ $+\quad+\quad=1$. The specific weights assigned to the individual indicators are determined on a year-to-year basis. ${ }^{17}$ To determine the actual amount of estimated expenditure needs, the combined need index is multiplied by the average expenditure need, which is calculated as average local government spending in the preceding fiscal year.

The calculation of the equalizing component of the formula varies for districts, depending on whether they have a fiscal gap or excess capacity, as defined in equation (7.2). For districts with excess capacity or fiscal surplus, the equalizing amount is equal to the negative of their fiscal surplus:

$$
\text { Equal }_{i}=\text { FiscalGap }_{i} \text { if FiscalGap } 0 .
$$

For those regions, the amounts are subtracted directly from the wagebased allocation $\left(\right.$ Wage $\left._{i}\right)$ in equation (7.1). This calculation reduces not only the individual allocation but also by definition the aggregate of the wagebased allocation. The excess resources resulting from this step are added to the pool available for the equalizing component for districts that face fiscal gaps. Unlike in the DAU formula, there is no minimum allocation that local governments receive regardless of fiscal capacity.

For districts with negative fiscal gaps, in which fiscal needs surpass fiscal capacity in equation (7.2), the DAU pool available for the equalizing component is distributed as a function of the proportional fiscal gap. The actual allocation is calculated by multiplying the total pool—defined as the sum of residual of the total DAU pool (DAU RESIDUAL $)$ after subtracting total wage costs and the sum of excess capacities from districts with positive fiscal gaps $\left(\Sigma\right.$ ExcessFiscalCapacity $\left._{i}\right)$-by the proportional fiscal gap. The 


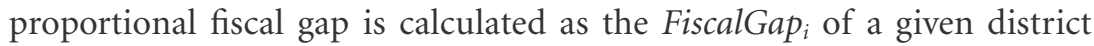
divided by the mean fiscal gap of all districts where expenditure needs exceed fiscal capacity (FiscalGap ${ }_{M E A N}$ ):

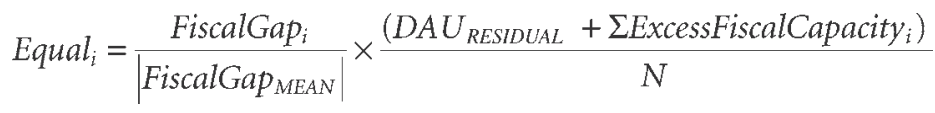

$$
\text { if FiscalGap } p_{i}<0 \text {. }
$$

Because of the hold harmless condition, which applies to the formulabased allocations through FY 2006, the distribution is changed in significant ways. Calculation of the hold harmless allocation requires comparison of the original formula-based allocation for each unit of subnational government with the allocation of the previous fiscal year. For regions that were net beneficiaries of the formula approach, the surplus is deducted. The accumulated surplus is then redistributed to those regions that would have received less according to the formula approach. Law 33/2004 requires that the hold harmless condition be phased out starting in FY 2007.

The DAU distribution formula has the objective of ensuring that additional financing of local governments compensates for fiscal capacity deficiencies without rewarding grantsmanship. Recent refinements, such as the elimination of the equal per municipality component, support this objective by eliminating incentives for local governments to split up to receive additional assistance. Nevertheless, there are several limitations to this formula.

First, although the expenditure need factors used are defensible, their weights are quite arbitrary and indefensible. Combining these fiscal capacity and need factors in a formula may lead to inequitable outcomes across jurisdictions and local governments, with those with identical fiscal capacity receiving widely varying grants. Second, the rationale for including the wage factor is not clear. Its inclusion could create a perverse incentive for padding civil service payrolls, resulting in higher local wage bills. Although this problem existed under the previous formula, it is exacerbated by the required full compensation of wage costs under the new formula. Provisions introduced to circumvent this problem, such as the zero-growth policy in civil service and central government clearances for new local positions, undermine local autonomy in resource allocation. Most important, the formula lacks an explicit standard of equalization, and its allocation is not guided by this standard. As a result, although DAU allocations are expected to vary positively with fiscal need and inversely with fiscal capacity, there is no clarity in the 
degree of equalization achieved by this formula, as will be empirically demonstrated later.

\section{The Special Allocation Grant}

In addition to the formula-driven block grant (DAU), Law 25/1999 and Law $33 / 2004$ authorize earmarked or special allocation grants (DAK grants), that the national government can use to finance special needs, including emergencies, and to promote special national priorities in the regions. The DAK funding is supposed to be prioritized to finance the special needs of local governments with lower than average fiscal capacity. Government Regulation 104/2000 defines the criteria for the DAK grant. ${ }^{18}$

DAK grants can be used to fund activities that are related to national priorities or that cannot be included in the calculation of the DAU grant because they are specific needs of particular regions-for example, emergency relief or specific investments needs in remote localities. DAK funds are usually earmarked to finance capital expenditures; administrative costs, project allowances, research, training, and the like cannot be financed by DAK funds. Moreover, DAK funds are designed as matching grants to ensure that they truly meet local demand by shifting marginal costs to local budgets. Formally, local governments need to match at least 10 percent of the total cost through their own resources. They also need to prove that DAK projects cannot be financed through their own budgets.

In FY 2001 and FY 2002, the use of DAK grants was limited to a reforestation fund. Starting in FY 2003, the central government extended the DAK to finance the maintenance of health and education facilities; infrastructure (including road, irrigation, and water facilities); government property; and projects in the fishery sector. ${ }^{19}$ Although the DAK has seen a steep increase from Rp 2.7 trillion (US\$300 million) in FY 2003 to Rp 9.5 trillion (US\$1.2 billion) in real terms (at 2003 constant prices), so far the funds channeled through it have been relatively small, in the range of Rp 2 billion to Rp 4 billion (US $\$ 190$ million to US $\$ 400$ million). Table 7.7 shows the DAK allocations by sector for FY 2005. For the six sectors, they total less than 10 percent of the sectoral development spending of line ministries in FY 2005.

The allocation of the DAK grants is based on three sets of criteria: general criteria, special criteria, and technical criteria. The first two sets are established uniformly for all sectors by the Ministry of Finance. The general criteria make up an index capturing the net fiscal position of a given district $\left(F N I_{i}\right)$. This measure is calculated by subtracting civil service wages $\left(W_{a g e}\right)$ 
TA B L E 7.7 DAK Allocations by Sector, FY 2005

\begin{tabular}{|c|c|c|c|}
\hline Sector & $\begin{array}{c}\text { Amount } \\
\text { (Rp billion) }\end{array}$ & $\begin{array}{c}\text { National } \\
\text { development } \\
\text { expenditure } \\
\text { (Rp billion) }\end{array}$ & $\begin{array}{l}\text { Number of } \\
\text { receiving regions }\end{array}$ \\
\hline Education & 1,221 & 21,585 & 333 local governments \\
\hline Health & 620 & 7,796 & 331 local governments \\
\hline Infrastructure & 1,533 & 13,081 & 348 local governments \\
\hline \multicolumn{4}{|l|}{ Government } \\
\hline infrastructure & 148 & n.a. & $\begin{array}{l}32 \text { local governments } \\
\text { and } 2 \text { provinces }\end{array}$ \\
\hline Fishery & 322 & 2,028 & 300 local governments \\
\hline Agriculture & 170 & 4,024 & 155 local governments \\
\hline Total & 4,014 & 48,514 & n.a. \\
\hline
\end{tabular}

Source: Indonesia, Ministry of Finance 2005.

n.a. = not applicable.

from total revenues (sum of own-source revenue, DAU revenue, DAK revenue, and shared revenues and taxes, excluding surpluses in FY 2002), denoted $\operatorname{Rev}_{i}$, divided by the national average of the same measure:

$$
F N I_{i}=\frac{\operatorname{Rev}_{i}-\text { Wage }_{i}}{\sum \operatorname{Rev}_{i}-\text { Wage }_{i}} \times N .
$$

Districts that score lower than 1 on this measure are eligible for DAK funds. This measure is sensitive to the resources a region has at its disposal to finance capital expenditures.

The special criteria directly refer to a number of provinces_-including Papua, Aceh, and all provinces in East Indonesia-that are eligible for DAK funds. In addition, coastal areas, conflict regions, less-developed regions, and regions that experience floods and other natural disasters are supposed to receive DAK funds. The regulation remains unclear about how and to what extent these criteria should be used in the allocation process.

The technical criteria are set by the sectoral departments in consultation with the Ministry of Finance and the Ministry of Home Affairs, and they vary across sectors. In the education sector, for example, the number of classrooms in poor condition and the construction price index are used. In the health sector, the technical criteria include the Human Poverty Development Index, ${ }^{20}$ the number of health service facilities, and the construction price index.

Two brief comments on DAK funds are in order. First, despite significant increases in recent years, DAK expenditures remain relatively limited compared with the regular sectoral development expenditures of the central 
governments (deconcentrated development expenditure). In the medium run, sectoral development funds should be migrated into DAK funds. Whether this option proves suitable will depend to a significant degree on the willingness of sector departments to shift resources to the DAK, over which they have considerably less control. Increasing DAK funds that are regionally and functionally targeted could provide an important instrument to establish common minimum service standards and to address disparities in expenditure needs across Indonesia. Unlike deconcentrated development expenditure funds, which are not part of the local budgets, DAK funds are more transparent and can be used complementarily to local spending.

The second comment refers to the distribution of the DAK. With the notable exception of the DAK grant that was allocated to finance government infrastructure in newly established governments, the grants are widely dispersed across large numbers of receiving districts. For example, in FY 2005, 333 local governments received education DAK funds. Allegedly, the allocation process for the DAK funds remains vulnerable to political interference by regional governments, sectoral departments, and the budgeting commission of parliament. In effect, the DAK grants seem to be used to cross-subsidize capital expenditures more generally rather than as transfers specifically targeted to districts that have serious infrastructure deficiencies.

\section{Equalization Performance}

In Indonesia, as in many other countries, the uneven distribution of economic activity and natural resource endowments has resulted in wide disparities in the fiscal capacity of local governments. Table 7.8 documents these disparities using several indicators. The major drivers of fiscal disparities in Indonesia are shared taxes-in particular income tax-and natural resources, which are highly concentrated in a small number of districts. In FY 2003, the industrial town of Bekasi at the fringe of Jakarta received more than 100 times the income tax that the rural district of Lombok Timur received.

Natural resources revenues are even more concentrated. As can be seen in figure 7.4, in FY 2003 about 80 percent of all revenues from shared taxes and natural resources were concentrated in the top 20 percent of recipient local governments. As a result, disparities in revenue levels before the equalizing DAU grants are striking, with a coefficient of variation well above 2. On a per capita basis, the bottom 80 percent of districts receive only 30 percent of total revenues or, conversely, 70 percent of the revenue accrues to the richest 20 percent. A look at differences between maximum and minimum values illustrates the fact. Before the equalizing grants, the ratio between the district with the highest per capita revenues and the district with the lowest is more than 200 to 1. 
TA B L E 7 . 8 Fiscal Disparities across Local Governments, FY 2003

\begin{tabular}{lrrrc}
\hline Indicator (per capita) & Minimum (Rp) & Maximum (Rp) & Mean (Rp) & $\begin{array}{c}\text { Coefficient } \\
\text { of variation }\end{array}$ \\
\hline Own-source revenue & $6,041.7$ & $812,062.8$ & $61,055.6$ & 1.4 \\
Shared taxes & $8,824.9$ & $1,474,758.9$ & $83,391.6$ & 1.6 \\
Shared revenue & 14.2 & $5,872,667.4$ & $138,267.7$ & 3.8 \\
DAK grant & 78.4 & $853,182.6$ & $40,477.7$ & 2.1 \\
Other revenue & 78.4 & $1,443,469.0$ & $74,980.8$ & 1.7 \\
Revenue before & & & & \\
$\quad$ DAU grant & $51,072.4$ & $14,245,060.0$ & $455,649.4$ & 2.4 \\
DAU grant & $110,271.5$ & $2,750,992.6$ & $571,747.2$ & 0.8 \\
$\quad$ Total revenue & $242,335.4$ & $16,882,272.2$ & $1,027,396.6$ & 1.3 \\
\hline
\end{tabular}

Source: Calculations based on data from Indonesia, Ministry of Finance 2005.

Note: Figures were estimated from a nonrandom sample of 311 districts. DAK figures refer only to those local governments that received DAK in FY 2003.

a. Including DAK grant, other revenue, and borrowing.

The DAU grant, the revenue component used for horizontal equalization, to some extent smoothes these fiscal disparities. However, even after equalization, the richest district, Malinau in the province of Kalimantan Timur, has roughly 70 times as much per capita revenue as the poorest district, Bandung in West Java. The bottom 80 percent of districts receive only about half of total revenues on a per capita basis. The conflicting objectives

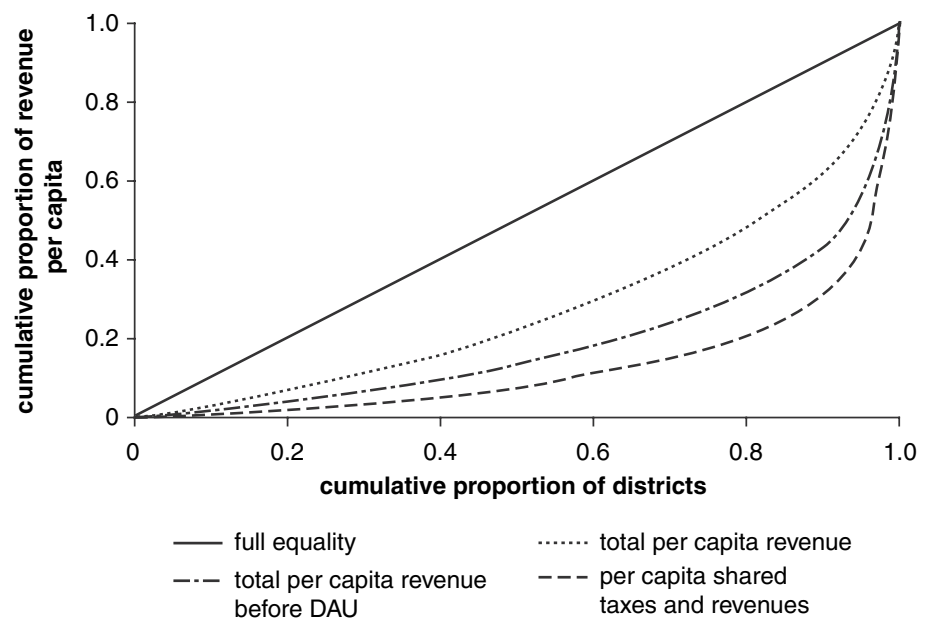

Source: Authors' estimation based on data from Indonesia, Ministry of Finance 2005.

F I G U R E 7 . 4 Lorenz Curves for Per Capita Revenues, FY 2003 
of the grant affect the DAU equalization properties. The fiscal gap approach of the formula does promote equalization. However, at the same time, equalization is undermined by the wage component of the formula and the hold harmless provision, which are useful in balancing revenues and fiscal expenditure needs but reinforce existing differences in expenditure levels.

The combined effect of these mixed objectives is depicted in figure 7.5. There is certainly a positive correlation between a local government's own fiscal capacity (as measured by per capita revenue before DAU) and its per capita DAU allocation. Regions in the upper right quadrant-mostly resource-rich districts with small populations-greatly benefit from the current fiscal system in that they receive high per capita DAU on top of their already high revenues from other sources. Conversely, regions in the lower left quadrant, including some of the most populous districts, such as Bandung and Bogor, receive disproportionately less under the current allocation scheme even though their fiscal capacity is much more deficient.

As a result of these fiscal deficiencies, poorer local governments cannot deliver basic services to their citizens at an acceptable level and quality, and inequality in access to basic services may persist with decentralization. Enhancing the equalization performance of the transfer system is one of the most pertinent issues in the reform of Indonesia's local government system. Moving to a more transparent fiscal equalization system is first a political and then a technical question. First, a political decision is necessary regarding the

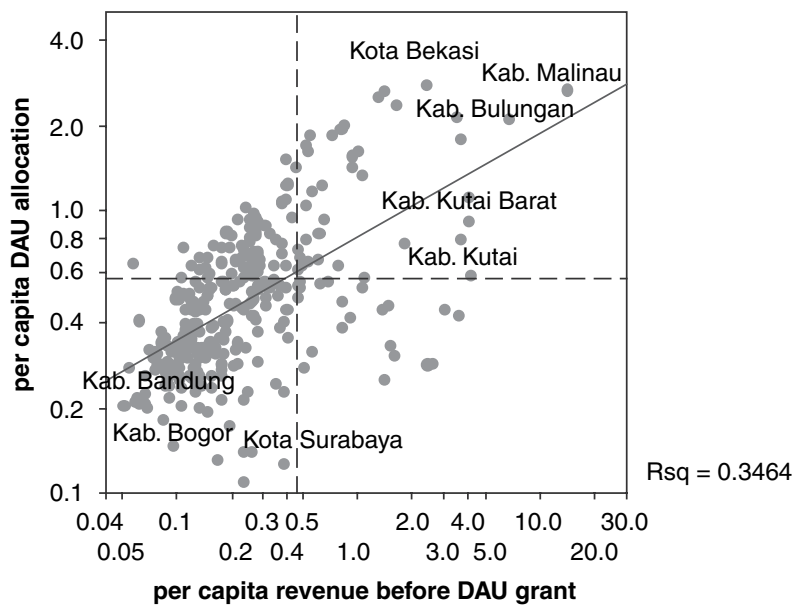

Source: Authors' estimation based on data from Indonesia, Ministry of Finance 2005.

FI G U R E 7 . 5 DAU and Fiscal Capacity, FY 2003

(Rp million) 
socially desired level of equalization in fiscal capacity, and following from that, minimum standards of access and quality of public services are needed across Indonesia. ${ }^{21}$ Such a political consensus is difficult to reach in an atmosphere of political mistrust. Technical questions can be managed relatively easily by focusing on fiscal capacity equalization and by assuming that per capita expenditure needs are similar. Fiscal need compensation is better addressed through output-oriented sectoral grants that use service population in the distribution criteria. Indonesia was a pioneer in the design of such grants and had well-designed Inpres grants for primary education, health, and roads in the prereform period (Shah 1998b).

\section{Local Government Borrowing}

Access to capital markets can help local governments better match expenditures with revenues and can increase efficiency in financing investments that generate long-term benefits. The experiences of some countries, among them Brazil and Argentina in the 1980s, show that, in the absence of fiscal conservatism and market discipline and with the expectation of bailouts, local borrowing can entail considerable macroeconomic and fiscal risks (Fukasaku and de Mello 1997).

In Indonesia, concerns about macroeconomic instability have led the government to carefully regulate the access of regional governments to capital markets. Both Law 25/1999 and Law 33/2004 allow for regional borrowing from both domestic and international sources and allow rupiahdenominated municipal bonds to be issued on domestic capital markets. In addition, regional governments may also guarantee third-party debt. The related government regulation on regional borrowing sets tight limits on debt-revenue and debt service-revenue ratios: the total debt is limited to 75 percent of revenues minus necessary expenditures ${ }^{22}$ and debt service is limited to 35 percent of revenues minus necessary expenditures.

Short-term borrowing (less than one-year maturity) is limited to onesixth of current spending and can be used only for cash-flow management. Long-term borrowing (more than one-year maturity) can be used only for capital expenditures in projects with the potential for cost recovery. Any long- or medium-term borrowing of local governments requires approval by both the local representative council (the Dewan Perwakilan Rakyat Daerah, or Regional People's Representative Council) and the Ministry of Finance.

The regulation also gives the central government the right to intercept the transfer of DAU grants if subnational governments fail to meet their 
debt-service obligations (Government Regulation 107/2000). Local governments do not have direct access to capital from international sources but can borrow from foreign sources through on-lending through the Ministry of Finance. Law 33/2004 explicitly states that there is no sovereign guarantee for regional government bonds, but the law remains unclear on regional government loans that are in default. In practice, a decree of the Ministry of Finance suspended the implementation of these rules and effectively eliminated local borrowing until 2004. Although this restriction was abolished by Law 33/2004, borrowing of local government has not picked up, because parts of the legal framework (for example, sovereign guarantee and the meaning of revenue-generating infrastructure) remain unclear. The Ministry of Finance is currently revising implementing regulations for local borrowing.

Regional government debt in Indonesia has been insignificant by international standards. The cumulative subnational debt-to-GDP ratio for 1978-2004 is 0.33 percent of GDP, significantly lower than, for example, in Mexico (4.9 percent of GDP), South Africa (4.0 percent of GDP), or Brazil (18.8 percent of GDP) (Lewis 2003a; Lewis and Pradhan 2005). As can be seen in figure 7.6, borrowing has not recovered since the sharp drop during the financial crisis in 1998. In the aggregate, local borrowing accounted for a mere 0.2 percent of total subnational revenues in FY 2001 to FY 2003. This low level was mainly a consequence of the uncertain legal environment, which potentially undermined both demand and supply for municipal credit. In the same vein, the market for local government bonds remains underdeveloped. Since 1991, six local government development banks (Bank Pembangunan Daerah) that are jointly owned by provincial and local governments have issued municipal bonds, with medium- to long-term maturities ranging from three to seven years, to finance local infrastructure projects.

As can be seen in figure 7.7, most local government debt is indirect debt of municipal enterprises-mainly regional water suppliers (Perusahan Daerah Air Minum) - accounting for more than three-quarters of the outstanding debt. Figure 7.7 also indicates that repayment performance is poor, with only about half of payments due being settled. Lewis (2003a) has shown that repayment problems are largely a function of regional unwillingness, rather than inability, to repay debts. ${ }^{23}$ In addition to the legal complications, limited creditworthiness hampers the expansion of credit access for subnational governments. In effect, the low level of subnational borrowing potentially constrains infrastructure development, efficient public service delivery, and economic growth. If managed properly, raising capital through loans and the issuance of municipal bonds could enhance 


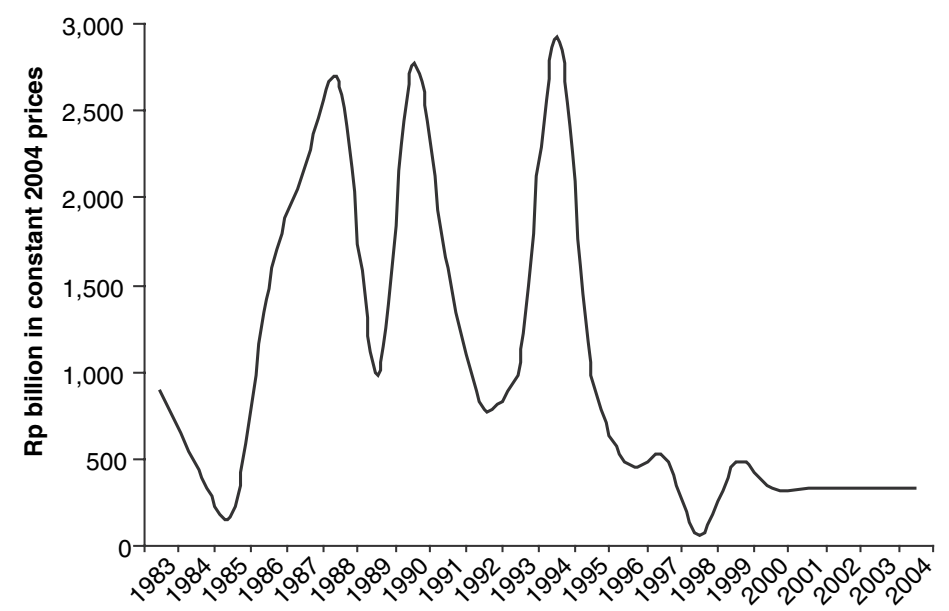

Source: Lewis and Pradhan 2005

F I G U R E 7 . 6 Subnational Government Borrowing, FY 1983-FY 2004

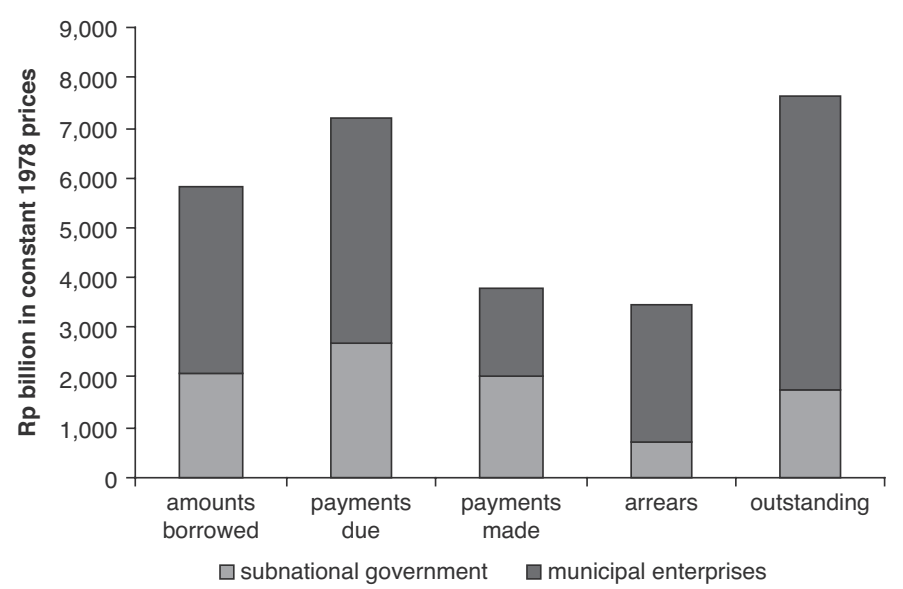

Source: Lewis and Pradhan 2005

F I G U R E 7 . 7 Composition of Subnational Debt, FY 1978-FY 2004

infrastructure development-in particular in better-off regions-without exerting more pressure on the already stressed national budget.

\section{Local Government Administration}

The reorganization of functional responsibilities across levels of government directly affected local government structures and staffing levels. Through 
Law 22/1999, the responsibility for more than 16,000 service providers (schools, public health centers, and so forth) was reassigned to subnational governments. In addition, for newly decentralized functions, the deconcentrated sectoral offices of the national government in the regions (Kanwils) were merged into local government structures. As a consequence, subnational governments absorbed more than 2.4 million national civil servants, including both administrative and functional staff members such as teachers and health care workers. As shown in table 7.9, in 2002 subnational governments employed more than three-fourths of all civil servants.

As regional governments gained control over the newly assigned authorities, a key challenge was to adjust their organizational structures so that they would be capable of managing their new responsibilities and resources efficiently and effectively. Under decentralization, control over many factors related to regional administration and civil service management resides with the regional governments. Law 22/1999 gives districts and provinces the right to determine the size of their civil service and to set up their organizational structure within a framework regulated by the national government: Government Regulation 84/2000 sets limits on the number of departments and other government bodies. The number and structure of government units varies across regional governments, depending on their size, nature, and location. Typically regional government administrations, headed by mayors (bupati or walikota) at the local level and governors at the provincial level, include a regional secretariat (sekda), a planning agency (bappeda), and a number of sectoral departments (dinas), including finance, education and culture, health, infrastructure, agriculture, livestock, fishery, forestry, plantations, industry, social welfare, labor, and tourism (see figure 7.8).

TA B L E 7.9 Distribution of Civil Service Employment across Levels of Government before and after Decentralization

\begin{tabular}{lrrrrr}
\hline & \multicolumn{2}{c}{1999} & & \multicolumn{2}{c}{2002} \\
\cline { 2 - 3 } \cline { 5 - 6 } Level of & Numbernment & Percent & & Number & Percent \\
\hline National & $3,519,959$ & 87.9 & & 930,602 & 23.7 \\
Subnational & 485,902 & 12.1 & & $3,002,164$ & 76.3 \\
\multicolumn{1}{c}{ Total } & $4,005,861$ & 100.0 & & $3,932,766$ & 100.0 \\
\hline
\end{tabular}

Source: Rohdewohld 2003. 


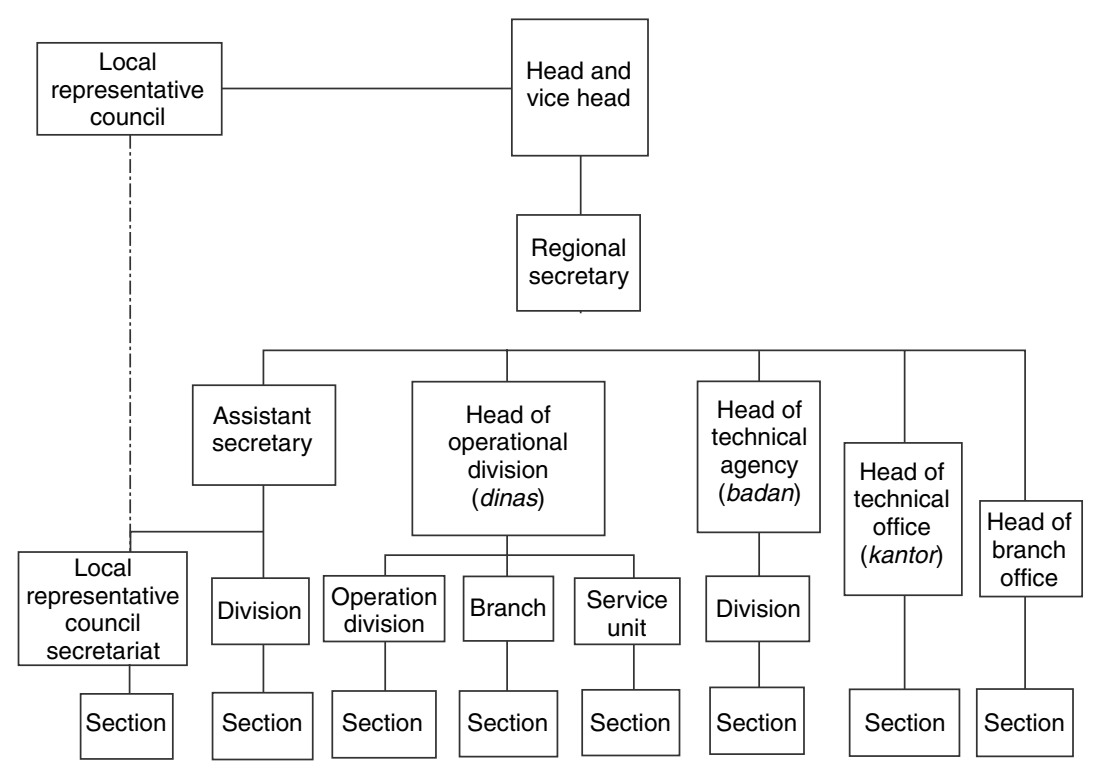

Source: ADB 2004; Government Regulation 84/2000.

\section{F I G U R E 7 . 8 Typical Organizational Structure of Subnational} Government

Law 22/1999 assigned significant responsibilities for management of the local civil service to the local level, while maintaining a unified national civil service. ${ }^{24}$ In contrast, Law 32/2004 has recentralized some responsibilities in civil service management to the provincial level (as the representative of the central government), the Ministry for Administrative Reform (Menteri Pendayagunaan Aparatur Negara, or Men-PAN), and the Ministry of Home Affairs. Men-PAN approval is required to establish new positions with local bureaucracies (see table 7.10). ${ }^{25}$ Men-PAN is preparing to implement government regulations. In addition, a number of other national regulations affect civil service management, including the pertinent civil service law, Law $43 / 1999$, which assigns to the central level fundamental rights related to civil service management. The national level is responsible for determining most aspects of civil service wages, job classifications, and related standards. Qualification requirements are set by the National Civil Service Agency (Badan Kepegawain Negara) for administrative civil servants and by sectoral ministries, such as education and health, for personnel working as service providers, such as teachers and doctors. ${ }^{26}$ 
TA B LE 7.10 Responsibilities in Civil Service Management

\begin{tabular}{|c|c|c|}
\hline Responsibility & National government & Local government \\
\hline Wage policy & $\begin{array}{l}\text { Determination of base } \\
\text { salary, position, and other } \\
\text { general allowances }\end{array}$ & $\begin{array}{l}\text { Possibility for local } \\
\text { extra allowances (for } \\
\text { example, to attract per- } \\
\text { sonnel to remote areas) }\end{array}$ \\
\hline Wage expenditures & $\begin{array}{l}\text { National budget for national } \\
\text { civil service }\end{array}$ & $\begin{array}{l}\text { Local budgets for local } \\
\text { civil service }\end{array}$ \\
\hline Job classification and standards & National framework & Local amendments \\
\hline Staff accountability & & Local responsibility \\
\hline Career development & $\begin{array}{l}\text { Higher-rank echelon } \\
\text { (provincial government) }\end{array}$ & $\begin{array}{l}\text { Lower-rank echelon } \\
\text { (Ib-IIIb) }\end{array}$ \\
\hline Recruitment & $\begin{array}{l}\text { National or provincial } \\
\text { approval to install new } \\
\text { positions; guidelines } \\
\text { for recruitment process }\end{array}$ & $\begin{array}{l}\text { Assessment of staff } \\
\text { needs and } \\
\text { implementation of } \\
\text { recruitment process }\end{array}$ \\
\hline Relocation & $\begin{array}{l}\text { Interdistrict and to } \\
\text { higher levels of government }\end{array}$ & Intradistrict \\
\hline Training & National guidelines & Implementation \\
\hline Pension scheme & & Local responsibility \\
\hline
\end{tabular}

Source: Law 32/2004, authors' translation.

All in all, decentralization has resulted in a structure of civil service management that in fact disperses authority across levels of government and various government agencies. Streamlining the regulatory framework and striking a balance between some desirable degree of national unity in the administrative system while allowing enough flexibility for local adjustment is one of the most critical areas of policy reform.

The transfer of personnel translated into sizable increases in subnational wage bills. Subnational governments are now responsible for paying more than half of the government payroll. There was little scope for adjusting the size and personnel structure of the civil service to the specific needs of subnational governments.

\section{An Overall Assessment of Local Government Finances and Organization Reforms}

Major local government reforms were first implemented in 2001. Although it is too early to pass conclusive judgment on the effects of the reforms, some early results warrant comment. The transition to a significantly more decentralized 
mode of governance was smooth. Local governments assumed responsibility for their new functions as scheduled. More than 2.5 million civil servants were successfully reassigned to the jurisdiction of subnational governments. The central government has continuously increased the pool of resources transferred to subnational governments, in both relative and absolute terms. In 2004, the second round of democratic elections at both national and subnational levels took place without any major interruptions, and local governments are now headed by democratically elected mayors. At the same time, the most significant risks associated with decentralization were minimized. The transition also did not result in a breakdown of service delivery chains, nor did it trigger macroeconomic instability.

There is, however, room for improvement in a number of areas that could further enhance the positive effects of decentralization. The decentralization of expenditure responsibilities should gradually be accompanied with enhanced taxing powers at the local level. The current approach devolves expenditure authority more extensively than tax authority and supports a strong role for the national government on the revenue side. Although the decentralization of expenditures allows for some of the gains from decentralization, such as lower-cost production, informational advantages, and matching of services with local demand, attaining the substantial benefits of fiscal decentralization requires devolution of the power to tax. The prevailing reliance on unconditional transfers to finance local government operations creates incentives that potentially undermine the accountability of subnational governments (see Rodden 2002 for some theoretical considerations and a cross-country analysis).

Broadening local tax bases has a number of potential benefits. If service delivery is more closely linked to local tax payments, citizens face greater incentives to monitor government performance and demand accountability from local governments. Such broadening could further enhance interjurisdictional competition. People choosing low-tax, low-spending jurisdictions over high-tax, high-spending jurisdictions could create powerful incentives for governments to improve spending efficiency. If Indonesia is to benefit from those effects, greater subnational taxation autonomy is a necessary institutional prerequisite.

The assignment of some significant tax bases, such as the property tax or a piggybacked income tax, to finance marginal public good provision could increase efficiency and accountability in local government operations. Only by choosing to pay higher or lower taxes at the margin can residents of subnational jurisdictions choose the level of public services they want. At the same time, assigning more taxation power to lower levels would further 
reduce the revenues of poor regions and cement existing disparities in the region's economic base. The resulting gaps in income and fiscal endowments arguably necessitate a strong federal role in financing national minimum standards of merit goods and equalizing payments.

The Indonesian experience suggests that decentralization alone does not remove inequalities between localities of varying incomes, and quality in poorer communities continues to lag. The large horizontal imbalances in fiscal resources need to be addressed, to ensure that poor local governments have adequate resources to fund their newly acquired expenditure functions. The currently available fiscal instruments-in particular the DAU grant, which is used to pursue partly conflicting purposes (wage coverage and horizontal equalization) - may not be able to satisfy regional equity objectives. While compensating for vertical fiscal gaps, the DAU is associated with positive yet unclear equalization outcomes. The desirable level of equality-or the level of acceptable inequality—is essentially a political question. Therefore, a fiscal equalization system must use an explicit standard of equalization to determine both the total pool and the allocation across jurisdictions.

The DAU does not embody an explicit standard of equalization. Its total pool is arbitrarily determined, and its formula combines multiple factors with arbitrary weights that work at cross-purposes. The equity of the final effect therefore remains uncertain. Identifying a politically sustainable way to reform the fiscal systems naturally involves tradeoffs. A combination of measures that increase local tax autonomy and strengthen the revenue base of fiscally strong regions with a more equalizing DAU system might be a politically suitable tradeoff.

The Indonesian reforms emphasized a gap-filling approach to fiscal transfers that stresses local autonomy, with little concern for local accountability for service delivery. A more balanced approach is needed, one that further strengthens autonomy while creating incentives for accountable local governance. Such an approach can be achieved by instituting output-oriented, national minimum standards grants for merit goods such as education, health, and roads. These grants could be allocated to local jurisdictions on the basis of service population (such as school-age population for education grants) and distributed onward to local public and private providers in accordance with objective indicators of clients served (for example, school enrollment). Continuation of the grant in the future would depend on meeting or improving on baseline service standards, as monitored directly by citizen-customers. Indonesia, in the prereform period, was a pioneer in instituting simple and objective performance-oriented grants for education, health, and roads, and it would be useful to reintroduce similar transfers. 
Inadequate implementation of the administrative decentralization framework has hindered the success of Indonesian reforms. It has saddled local governments with large bureaucracies that eat up precious resources. It has also opened doors for stealth control of local governments by the central government. The ability of local government to hire, fire, and set terms of employment for local employees is an integral element of local autonomy in resource allocation and local accountability for service delivery.

Further clarification is needed of the roles of government levels, especially for shared responsibilities. Although to some extent the distribution of government functions is contested and blurry even in most mature federations, such as Germany and the United States, further clarification and delineation of functional assignments should be promoted in Indonesia. The move away from omnibus assignments-from a negative list of obligatory functions in Law 22/1999 to a positive list in Law 32/2004 - is a step in the right direction. Given the complexity and sensitivity of reorganizing functions, the law sets out only general principles for the allocation of functions, broadly following subsidiarity. To ensure further clarification, policy makers must ensure sectoral laws (on health, education, and so forth) align with these principles. Central government departments in decentralized sectors continue to spend significant funds directly in the regions, at least part of them for functions officially assigned to local governments. This spending creates accountability problems because citizen-customers do not know which level to hold accountable for the quality of service delivery.

\section{Lessons for Developing Countries}

Indonesia's evolving local government system, including its organizational and financial structures, provides a number of lessons on how to design such reforms elsewhere.

\section{Big Bang versus Gradual Reforms}

As in Poland, political consensus for the reform program in Indonesia developed over a long period of time, but reforms were implemented in a relatively short period at a politically opportune moment of a serious fiscal crisis faced by the central government, a moment when resistance to reform was weak and political commitment to reform was strong. Moreover, the reforms were relatively comprehensive and emphasized political, fiscal, and administrative decentralization simultaneously. Some teething problems arose because some provisions were either not implemented or were 
reversed. Although decentralization in Indonesia occurred in a particularly eventful historical context and under extraordinary circumstances, it shows that, with the political will and opportunity, far-reaching changes can be achieved in relatively short periods. Given their sweeping character, the reforms gained substantial political traction and enthusiasm, particularly at the local level. At the same time, decentralizing Indonesia—one of the largest and most diverse countries in the world-posed a tremendous challenge and entailed significant risks. Indonesia's smooth transition to a significantly more decentralized mode of governance without breakdowns in service delivery or macroeconomic instability shows that deliberate attempts to manage those risks can work. A good example is Indonesia's judicious approach toward the issue of subnational borrowing, an approach that emphasizes responsible (fiscal rules) credit market access. Although circumstances in other countries might vary in subtle ways, paying close attention to potential risks and learning from international practice and design principles can guide the design and sequence of reforms and help avoid some of the pitfalls associated with decentralization reforms (see Bahl and Martinez-Vazquez 2005; Shah and Thompson 2004).

\section{Streamline Regulatory Framework}

Decentralization reforms mean changes in the regulatory framework of the local government system. The multidimensional and cross-cutting nature of the reforms means that numerous regulatory areas are affected, ranging from financial management, taxation, and civil service to sectoral issues in health and education. The Indonesian experience shows that such wideranging changes can result in overlapping, unclear, or even conflicting regulations. For example, functional assignments in sectoral laws on education are not yet consistent with the decentralization laws. To prevent such effects, lawmakers must strategize the lawmaking process, identify potential conflicts, and streamline laws and implementing regulations to ensure a sound legal framework for local governments.

\section{Define New Roles of Government Levels}

Striking a balance between decentralization and some desirable level of central oversight is difficult to achieve in practice. The experience in Indonesia shows that there can be stealth centralization, with central line ministries that are involved in formally decentralized functions coexisting with weak lines of intergovernmental coordination and communications. These problems can 
be prevented, however, with sufficient attention to building trust and lines of communication among levels of government.

\section{Strengthen the Supply Side through Capacity Development}

As in other countries, the experience in Indonesia makes it clear that changes in laws and regulations are only part of the story. Beside changes in the legal framework, decentralization requires that governments at all levels have the capacity (and willingness) to cope with their new roles. Regional governments must be able to manage increasingly large financial flows and organizations; they must understand the problems and demands of their communities and deliver a host of complex public services. Central government agencies, at the same time, must shift substantial parts of their operational responsibilities from direct delivery of services to oversight and provision of technical assistance, guidance, and information. The Indonesian experience illustrates that such changes are not readily achieved by changing rules but entail the use of different skills and attitudes by civil servants as well as the establishment of new organizational procedures at all levels of government. From the outset, decentralization reforms should thus incorporate strategies and resource allocations to tackle capacity development and change management at all levels of government.

\section{Strengthen the Demand Side through Voice and Accountability}

Accountability systems matter in decentralization reforms (Shah 1998a). Decentralization alone will enhance public sector performance only if it leads to an environment where there is some sort of accountability for policy choices, expenditure decisions, and service delivery. Clearly, giving authority to local governments that are not responsive to their local populations may not improve outcomes. The initial evidence from Indonesia indicates that local accountability systems-at least in some placescontinue to be frail, thus leading to mismanagement of scarce public resources and, in the long run, potential deterioration of public services. The success of decentralization reforms depends not only on the design of intergovernmental fiscal and administrative relations but also on making local governments accountable to their communities. To this end, systematic attention needs to be paid to institutionalizing and broadening options for voice and participation at subnational levels, thereby allowing citizens to voice their preferences, effectively monitor the performance of the local government, and react appropriately to that performance so that politicians 
and local officials have an incentive to be responsive. Central to these reforms are principles of transparency, accountability, and participation, particularly regarding planning and budgeting. A number of new regulations have been passed lately to make planning and budgeting more participatory, in the context of a medium-term expenditure framework and a performance orientation. In addition, there are strong political dimensions, the development of pluralistic political parties, the strengthening of legislatures and checks and balances, and the encouragement of effective civil society interest groups at the local level.

\section{Notes}

1. Brief overviews of the historical development of local governments in Indonesia are provided by Jaya and Dick (2001), Mackie (1999), and World Bank (2003).

2. In 1903, a colonial law on decentralization provided for the establishment of local authorities. From 1905 onward, urban municipalities (gemeenten) were created, with Batavia, Meester Cornelis, and Buitenzorg taking the lead, soon followed by many others (Mackie 1999).

3. The federal republic comprised 15 territories, only one of which was the Republic of Indonesia, with its capital in Yogyakarta.

4. For example, the average size of municipalities is about 30,000 in China, 45,000 in the Philippines, 130,000 in the United Kingdom, and 150,000 in South Africa.

5. The correlation between per capita gross domestic product and poverty is strong but incomplete, with some resource-rich regions, such as West Papua, exhibiting high levels of poverty. In fact, in 2002, Papua, the third richest region in terms of per capita gross domestic product, had the highest percentage of people living below the poverty line (51.2 percent) (ADB 2005).

6. Whether heads of region are directly or indirectly elected and how are to be determined by law. The stipulation of universal direct elections of regional executives was not accepted. In addition, there is a constitutional provision for special legislation and special status for particular provinces. There is a requirement for justice and equity, as well as consideration of local distinctiveness and diversity, in the financial arrangements for regions.

7. The most sizable component was the SDO (subsidi daerah otonomi, or autonomous government subsidy), which covered recurrent expenditures of regional governments, including salaries of civil servants and government employees. In addition, the center employed sectoral earmarked grants (called Inpres) to finance specific projects or activities in the regions (Shah and Qureshi 1994).

8. In contrast, governors have a double function as representatives of the central government and as heads of the autonomous provinces.

9. In addition to Law 22/1999 on local governance, several aspects of the election laws (Law 3/1999 on general elections and Law 4/1999 on the election of legislatures) and Law 2/1999 on political parties are important in this regard. These three political laws, all passed in early 1999, cover the requirements for forming political parties, the election system, and the composition of the national and local representative bodies. 
10. The law on political parties required parties standing for election to be registered in at least half of the electoral districts, which effectively prevented the establishment of local parties.

11. Article 133 of Law $22 / 2004$ and article 237 of Law 32/2004 require sectoral laws to comply with the principles of decentralization. Government Regulation 25/2000 further delineated functional assignments by defining provincial and central responsibilities.

12. The procedural rules require subnational governments to submit bylaws that establish new charges or taxes with 15 days for review. National government approval or dismissal is supposed to be given within one month (Lewis 2003b).

13. The information draws on two data sets, one from the finance ministry and one from an independent autonomy watch organization (Lewis 2003b).

14. These laws are Law 18/2001 on Aceh's special autonomy and Law 21/2001 on Papua's special autonomy. The differences concern the rules for sharing natural resources for these two regions. The special autonomy laws give 55 percent of oil revenues and 40 percent of natural gas revenues to the provincial government of Aceh and 70 percent of oil and natural gas revenues to the provincial government of Papua.

15. The description of the DAU allocation formula draws on Ahmad (2002); Brodjonegoro and Martinez-Vazquez (2002); Hofman, Kadjatmiko, and Kaiser (2004); and Lewis (2002a).

16. Fiscal needs were estimated as a function of four expenditure need indicatorspopulation, poverty, area, and regional price differentials — reflecting the assumption that these four factors drive expenditure needs.

17. In the past, the weights assigned to different indicators were changed. See Lewis (2002a).

18. These stipulations do not apply to the reforestation fund, which is governed by a separate government regulation (35/2002). This regulation stipulates that 40 percent of the reforestation fund is distributed to local governments on a derivation basis, and the remaining 60 percent is retained by the central government. The reforestation grant works more like revenue sharing.

19. Subnational governments can propose the sector-specific DAK grants to line ministries, which in turn request that the Ministry of Finance consider the stipulation of DAK grants in a ministerial decree. The Ministry Finance is supposed to consult with the relevant technical ministries, the Ministry of Home Affairs, and the National Development Planning Board.

20. The Human Poverty Development Index is a weighted average of the percentage of the population with life expectancy shorter than 40 years, the percentage of the population without access to clean water, the percentage of the population without access to health facilities, and the percentage of malnourished children below the age of five.

21. See UNDP (2004) for evidence on the variation in public services and human development outcomes across local governments in Indonesia.

22. This condition is now directly included in Law 33/2004.

23. Estimating a typical debt-service coverage ratio at 9.5 percent, Lewis (2003a) concludes that local governments have borrowed well within their fiscal capacities to repay.

24. Law 22/1999, articles 75-77. This general direction has been specified by Government Regulation 96/2000, which assigns to the local level the authority for the 
appointment and promotion only of those civil servants in the lowest ranks (Ib-IIIb). In addition, Government Regulation 97/2000 on the formation of civil service gives the mayor the authority to determine the size of the local bureaucracy. Article 129 of Law 32/2004 reinforces those provisions.

25. Men-PAN provides approvals on the basis of recommendations from the governors.

26. Such requirements include base salary, position allowances, and family and rice allowances, which are determined by presidential instruction (World Bank 2003).

\section{References}

ADB (Asian Development Bank). 2004. Country Governance Assessment Report: Republic of Indonesia. Manila: ADB.

- 2005. Report and Recommendation of the President to the Board of Directors on Proposed Loans and Technical Assistance Grant to the Republic of Indonesia for the Local Government Finance and Governance Reform Sector Development Program. Manila: ADB.

Ahmad, Ehtisham. 2002. "Intergovernmental Grants Systems and Management: Application of a General Framework to Indonesia." IMF Working Paper 02/128, International Monetary Fund, Washington, D.C.

Ahmad, Ehtisham, and Russell Krelove. 2000. “Tax Assignments: Options for Indonesia.” International Monetary Fund, Washington, D.C.

Bahl, Roy, and Jorge Martinez-Vazquez. 2005. "Sequencing Fiscal Decentralization." Andrew Young School of Policy Studies, Georgia State University, Atlanta.

Bastin, Johan. 1992. "Financing Regional Development." In Spatial Development in Indonesia: Review and Prospects, ed. Tschangho John Kim, Gerrit J. Knaap, and Iwan J. Azis, 187-218. Avebury: Aldershot, U.K.

BPS (Badan Pusat Statistik). 2003. "Data dan Informasi Kemiskinan Buku 1: Provinsi." BPS, Jakarta.

Brodjonegoro, Bambang, and Jorge Martinez-Vazquez. 2002. "An Analysis of Indonesia's Transfer System: Recent Performance and Future Prospects.” Andrew Young School of Policy Studies, Georgia State University, Atlanta.

Fukasaku, Kiichiro, and Luiz R. de Mello Jr. 1997. "Fiscal Decentralisation and Macroeconomic Stability: The Experience of Large Developing and Transition Economies." Organisation for Economic Co-operation and Development, Paris.

Hofman, Bert, Kadjatmiko, and Kai Kaiser. 2004. "Evaluating Indonesia’s Fiscal Equalization." World Bank, Washington, DC.

Indonesia, Ministry of Finance 2005. "Nota Keuangan, SIKD.” [Regional Financial Information System.] Ministry of Finance, Jakarta.

Jaya, Wihana Kirana, and Howard Dick. 2001. "The Latest Crisis of Regional Autonomy in Historical Perspective." In Indonesia Today: Challenges of History, ed. Grayson Lloyd and Shannon Smith, 216-28. Singapore: Institute of Southeast Asian Studies.

Kelly, Roy. 2004. "Property Taxation in Indonesia." In International Handbook of Land and Property Taxation, Richard M. Bird and Enid Slack, 117-28. Cheltenham, U.K.: Edward Elgar.

Legge, John D. 1961. Central Authority and Regional Autonomy in Indonesia: A Study in Local Administration, 1950-60. Ithaca, NY: Cornell University Press.

Lewis, Blane. 2002a. "Revenue-Sharing and Grant-Making in Indonesia: The First Two Years of Fiscal Decentralization. Research Triangle Institute, Research Triangle, NC. 
. 2002b. "Revisiting the Property Tax in Indonesia: Current Practices, Recent Performance, and Near-Term Potential.” Research Triangle Institute, Research Triangle, NC. - 2003a. "Local Government Borrowing and Repayment in Indonesia: Does Fiscal Capacity Matter?” World Development 31 (6): 1047-63.

_. 2003b. "Some Empirical Evidence on New Regional Taxes and User Charges in Indonesia.” Research Triangle Institute, Research Triangle, NC.

Lewis, Blane, and Menno Pradhan. 2005. "Decentralization Stocktaking and Future Directions.” World Bank, Jakarta, Indonesia.

Mackie, J. A. C. 1999. "National Integration, the State, and Market Forces in the Transition Era, 1945-1965." In Crisis and Continuity: Indonesian Economy in the Twentieth Century, ed. J. A. C. Mackie, 1-13. Yogyakarta, Indonesia: Gadjah Mada University.

PWC. (Pricewaterhouse Cooper). 2005. "Municipal Tax System in Indonesia.” Pricewaterhouse Cooper Global Institute, Geneva.

Ray, David. 2003. “Decentralization, Regulatory Reform, and the Business Climate.” In Proceedings of the Conference on Decentralization, Regulatory Reform, and the Business Climate, ed. David Ray, 1-40. Jakarta: U.S. Agency for International Development.

Rodden, Jonathan. 2002. "The Dilemma of Fiscal Federalism: Grants and Fiscal Performance around the World." American Journal of Political Science 46 (3): 670-87.

Rohdewohld, Rainier. 2003. "Decentralisation and the Indonesian Bureaucracy: Major Changes, Minor Impact?” In Local Power and Politics in Indonesia-Decentralisation and Democratisation, ed. Edward Aspinall and Greg Fealy, 259-74. Singapore: Institute for Southeast Asian Studies.

Shah, Anwar. 1994. The Reform of Intergovernmental Fiscal Relations in Developing and Emerging Market Economies. Washington, DC: World Bank.

. 1998a. "Fostering Fiscally Responsive and Accountable Governance: Lessons from Decentralization." In Evaluation and Development: The Institutional Dimension, ed. Robert Picciotto and Eduardo Wiesner, 83-107. New Brunswick and London: Transaction Publishers.

_. 1998b. "Indonesia and Pakistan: Fiscal Decentralization-An Elusive Goal?" In Fiscal Decentralization in Developing Countries, ed. Richard Bird and François Vaillancourt, 115-51. Cambridge, UK: Cambridge University Press.

Shah, Anwar, and Zia Qureshi. 1994. Intergovernmental Fiscal Relations in Indonesia: Issues and Reform Options. Washington, DC: World Bank.

Shah, Anwar, and Theresa Thompson. 2004. "Implementing Decentralized Local Governance: A Treacherous Road with Potholes, Detours, and Road Closures." In Reforming Intergovernmental Fiscal Relations and the Rebuilding of Indonesia, ed. James Alm, Jorge Marinez-Vazquez, Sri Mulyani Indrawati, 301-37. Cheltenham, U.K.: Edward Elgar.

UNDP (United Nations Development Programme). 2004. Indonesia Human Development Report: The Economics of Democracy-Financing Human Development in Indonesia. Jakarta: UNDP and Badan Pusat Statistik.

Van den Ham, Albert, and Hadiz Hady. 1988. "Planning and Participation at Lower Levels in Indonesia." Prisma 45: 72-83.

World Bank. 2003. Decentralizing Indonesia. Jakarta: World Bank. 


\title{
Local Government Organization and Finance: Kazakhstan
}

M E R U E R T M A K H U T O VA

\begin{abstract}
$\mathrm{t}^{\mathrm{t}}$ the beginning of the 1990s, the local government system in Kazakhstan was based on the former system of local soviets. Reform of the local government system before 1993, when the first post-Soviet constitution was promulgated, aimed at a gradual shift from a system of local authorities, accountable to the local population, to a system hierarchically organized from the bottom to the top, up to the president.

The process of reforming the local government in Kazakhstan began with the adoption of the Law on General Principles of Local Government and Local Economy in 1990, in the former Soviet Union. In accordance with the Law on Property in the Kazakh SSR, which was adopted on December 15, 1990, any property could be classified in one of three categories: federal, national, or local (communal). In the case of communal property, administrative and territorial units were identified and authorized by the population, through which the property could be owned, used, and controlled by the local government body-the soviet. Moreover, the property owned, used, and controlled by the local soviets included any national property on the governed territory.

According to the Law on Local Self-Government and Local Soviets in the Kazakh SSR, which was adopted on February 15, 1991,
\end{abstract}


members of the soviets were elected by the citizens. The law established a principle of supremacy of representative bodies. In doing so, it established local executive bodies, and the chair of a local soviet was simultaneously assigned to chair an executive committee. In parallel, the law recognized the soviets as local self-government bodies. Thus, there was no distinction between local state government and local self-government.

\section{Local Government Structure in the New Republic}

On January 13, 1992, a law amending the Law on Local Self-Government and Local Soviets in the Kazakh SSR was passed. This law, which applied during the transition period, substituted the principle of supremacy of representative bodies for the principle of differentiation between the functions and powers of representative and executive bodies.

On the same day, the Supreme Soviet adopted the Law on Suspension of the Validity of Certain Kazakh SSR Constitution Standards, which was also to apply during the transition period. That law introduced a new institution: a head of local administration, who was accountable to the president or the head of oblast (regional) administration and who was not controllable by the local soviet. The local soviets (of any level) no longer had the right to review issues related to the competence of heads of administration, and heads of local administration were no longer entitled to review issues on the competence of the respective local soviets.

On February 7, 1992, the president of Kazakhstan signed the Decree on Improving the Organization and Activities of Public Administration Bodies under the Conditions of Economic Reform. This decree established for the first time a uniform structure of executive administration, from the president to the heads of local administration, and stipulated the responsibilities of the Cabinet of Ministers in the strategic supervision of all executive power. Thus, a vertical structure of executive power was created.

The first constitution of the Republic of Kazakhstan as an independent state, which was adopted on January 28, 1993, by the Supreme Soviet, preserved local representative bodies and even declared their right to make independent decisions within their competence.

This structure of local government was identified by the Law on Local Representative and Executive Bodies, which the Supreme Soviet adopted on December 10, 1993, immediately before dissolving itself. This law designated completely new approaches, among which the following have become most important: First, representative assemblies (maslikhats) no longer constitute local executive bodies. Second, a head of local administration represents 
the president, not local citizens. Third, representative bodies are formed at the oblast and rayon (district) levels only, not in rural villages (auls). Fourth, representative bodies are no longer called local self-governments, although they are considered representative bodies of the population. Fifth, the concept of local self-government is no longer recognized in the law; the concept of executive bodies established by the soviets was also removed from the law.

The present constitution, ${ }^{1}$ which was adopted on August 30, 1995, recognized the system of government that was identified by the Law on Local Representative and Executive Bodies. Article 85 recognizes local state government, and article 89 recognizes self-government.

Local bodies of public administration include oblast, rayon, and city maslikhats; oblast, rayon and city akimats (local executive branch); and rural akims (local executive). Local bodies of state government exist as follows:

At the oblast level, there are 14 oblasts and 2 cities with special status (Almaty and Astana) with state government bodies.

- At the rayon level, there are 159 rayons and 37 cities that have the same status as rayons with state government bodies.

- At the rural level, the settlements, auls (villages), and aul districts have only executive bodies.

As of January 1, 2006, the administrative and territorial contour of the country was as shown in table 8.1.

In January 2001, the Law on Local Public Administration in Kazakhstan was adopted. ${ }^{2}$ The law includes the following basic concepts:

Local public administration is defined as activities carried out by local representative and executive bodies to implement or develop state policy on local territory, within their competence, as determined by legislation.

- The local executive branch, or akimat, is headed by an oblast-level akim (for a city of national value and the capital) or a rayon-level akim (for cities of oblast value) and implements local public administration in the respective territory within its competence. The akim represents the president and government of Kazakhstan and the head of the local executive body (if there is one), and is responsible for implementing state policy within the local territory. The akim provides for the functioning of all the territorial bodies funded from the budget, and is responsible for the economic and social development in the given territory.

- The local representative body, or maslikhat, is elected by the inhabitants of the oblast (for a city of national value and the capital) or rayon (for a city of oblast value). It expresses the will of the citizens, determines measures 
TA B LE 8 . 1 Administrative and Territorial Units in Kazakhstan, January 1, 2006

\begin{tabular}{|c|c|c|c|c|c|c|c|c|}
\hline \multirow[b]{2}{*}{ Territory } & \multirow[b]{2}{*}{ Oblasts/rayons } & \multicolumn{3}{|c|}{ Cities and towns } & \multicolumn{2}{|c|}{ Counties } & \multicolumn{2}{|c|}{ Rural settlements } \\
\hline & & Total & $\begin{array}{l}\text { Subordinate } \\
\text { to oblasts }\end{array}$ & $\begin{array}{l}\text { Subordinate } \\
\text { to rayons }\end{array}$ & Towns & Villages & Towns & Villages \\
\hline Republic of Kazakhstan & $168^{\mathrm{a}}$ & 86 & 39 & 45 & 161 & 2,336 & 167 & 7,262 \\
\hline Akmolinskaya & 17 & 10 & 2 & 8 & 13 & 245 & 14 & 669 \\
\hline Aktubinskaya & 12 & 8 & 1 & 7 & 2 & 136 & 2 & 424 \\
\hline Almatinskaya & 16 & 10 & 3 & 7 & 14 & 237 & 15 & 769 \\
\hline Atyrauskaya & 7 & 2 & 1 & 1 & 11 & 62 & 11 & 184 \\
\hline East Kazakhstan & 15 & 10 & 6 & 4 & 24 & 231 & 25 & 826 \\
\hline Zhambylskaya & 10 & 4 & 1 & 3 & 10 & 143 & 12 & 367 \\
\hline West Kazakhstan & 12 & 2 & 1 & 1 & 5 & 154 & 5 & 477 \\
\hline Karagandinskaya & 9 & 11 & 9 & 2 & 38 & 168 & 39 & 498 \\
\hline Kostanayskaya & 16 & 5 & 4 & 1 & 8 & 255 & 8 & 740 \\
\hline Kyzylordinskaya & 7 & 3 & 1 & 2 & 12 & 133 & 12 & 265 \\
\hline Mangistauskaya & 4 & 3 & 2 & 1 & 5 & 32 & 5 & 48 \\
\hline Pavlodarskaya & 10 & 3 & 3 & n.a. & 6 & 166 & 6 & 403 \\
\hline North Kazakhstan & 13 & 5 & 1 & 4 & n.a. & 204 & n.a. & 727 \\
\hline South Kazakhstan & 12 & 8 & 4 & 4 & 11 & 170 & 11 & 865 \\
\hline Almaty city ${ }^{b}$ & 6 & 1 & n.a. & n.a. & n.a. & n.a. & n.a. & n.a. \\
\hline Astana city ${ }^{b}$ & 2 & 1 & n.a. & n.a. & 2 & n.a. & 2 & n.a. \\
\hline
\end{tabular}

Source: Republic of Kazakhstan Statistical Agency.

Note: n.a. = not applicable.

a. Including eight rayons within cities.

b. The cities Almaty and Astana have a special status. 
to implement this will, and controls that implementation in accordance with legislation. Villages and small towns do not have maslikhats.

Other powers are granted to the local executive and representative bodies of those cities in the Law on the Status of the Capital City of Kazakhstan and the Law on the Special Status of Almaty City.

The president appoints akims of oblasts and of the cities of Almaty and Astana, after nominations are submitted by the prime minister. The power of the president over akims takes priority over the power of the government, in conformity with the right of the president "to dismiss akims on his own decision" (article 87 of the 1995 constitution).

Parliamentary control over the activity of local government bodies is not stipulated by the legislation. The Senate has the right to preschedule the dissolution of the maslikhat at the request of the prosecutor general. The government controls the implementation of the laws within the constitutional powers. The Ministry of Justice and its territorial divisions register the acts of local bodies. Bodies specified by the central government, as well as other bodies, supervise the subdivisions of local executive bodies.

Because the executive bodies are structured vertically, so, correspondingly, is control carried out from upper to lower levels. The hierarchy subordinates the lower body to the higher one and ensures that implementing decisions are directed from the higher bodies to the lower ones.

Maslikhats are not bound by the vertical correlations, but the decisions of the higher maslikhats are binding. Decisions of maslikhats that do not comply with the constitution and legislation of the Republic of Kazakhstan can be canceled by the maslikhat itself or in a legal proceeding.

The akimat issues regulations signed by the akim. The akim issues regulatory and legal decisions, as well as regulations on administrative and managerial matters and on urgent and individual problems. The acts of the akimat and akim are binding on the whole territory of the administrative and territorial unit (article 37 of the Law on Local Public Administration). Acts that concern the rights, freedoms, and obligations of citizens (except acts containing state secrets of the Republic of Kazakhstan and other secrets protected by law) must be published officially in newspapers and other periodicals specified by maslikhats and akims. Acts that have common power or interdepartmental character or that concern the rights and obligations of citizens are subject to state registration by the territorial administrations of the Ministry of Justice of the Republic of Kazakhstan, according to the legislative procedures. The validity of akimats' and akims' acts can be suspended completely or partially by the president, the government of the 
Republic of Kazakhstan, a higher-level akimat or akim, or the akimat or akim themselves, as well as by a court decision.

Regulatory legal acts of local representative and executive bodies are enforced after being signed by the authorized officials. The local representative bodies, or maslikhats, express the will of the population of the respective territories. They consider general state interests to identify measures required for realizing those interests and controlling the implementation of those measures (article 86 of the 1995 constitution).

Maslikhats are elected for four-year terms directly by the population of the respective territories. The number of deputies in a maslikhat is determined by the central election commission of the Republic of Kazakhstan within the following limits: for the oblast-level maslikhat and maslikhats of Astana and Almaty, up to 50 deputies; for the city-level maslikhat, up to 30; for the rayon-level maslikhat, up to 25 .

The local executive body is headed by the akim of the respective territory, who simultaneously represents the president and the government (according to article 87 of the 1995 constitution). At the request of the prime minister, the president nominates akims of oblasts and of Almaty and Astana. The president also dismisses them. The authority of akims expires when a new president is elected, but they continue to perform their functions until a new akim is nominated. Akims of other territories are nominated or elected in accordance with the procedure determined by the president. Until recently, all the lower-level akims were nominated by akims of the next higher level: the akims of Almaty and Astana nominated the akims of the city rayons; the oblast-level akims nominated the rayon-level akims and akims for oblast-level cities; and the rayon-level akims nominated the akims for villages and settlements. However, in the fall of 2001, in accordance with the decree of the president, experimental elections of village district akims took place: two akims in 14 oblasts were elected in indirect elections.

Many mistakenly assumed that pilot elections of akims in 28 village districts signified a creation of a local self-government (Makhmutova 2004). Those elections did not result in any change, though. Any elected akim, as before, represents the government: he or she is a government employee who is subordinate to a rayon akim and is a staffer of the rayon akimat. It was assumed that akims would be elected for a two-year term. By now their terms have lapsed, but the government does not comment on the success or failure of the pilot elections.

Figure 8.1 shows the structure of the government administration in Kazakhstan. 


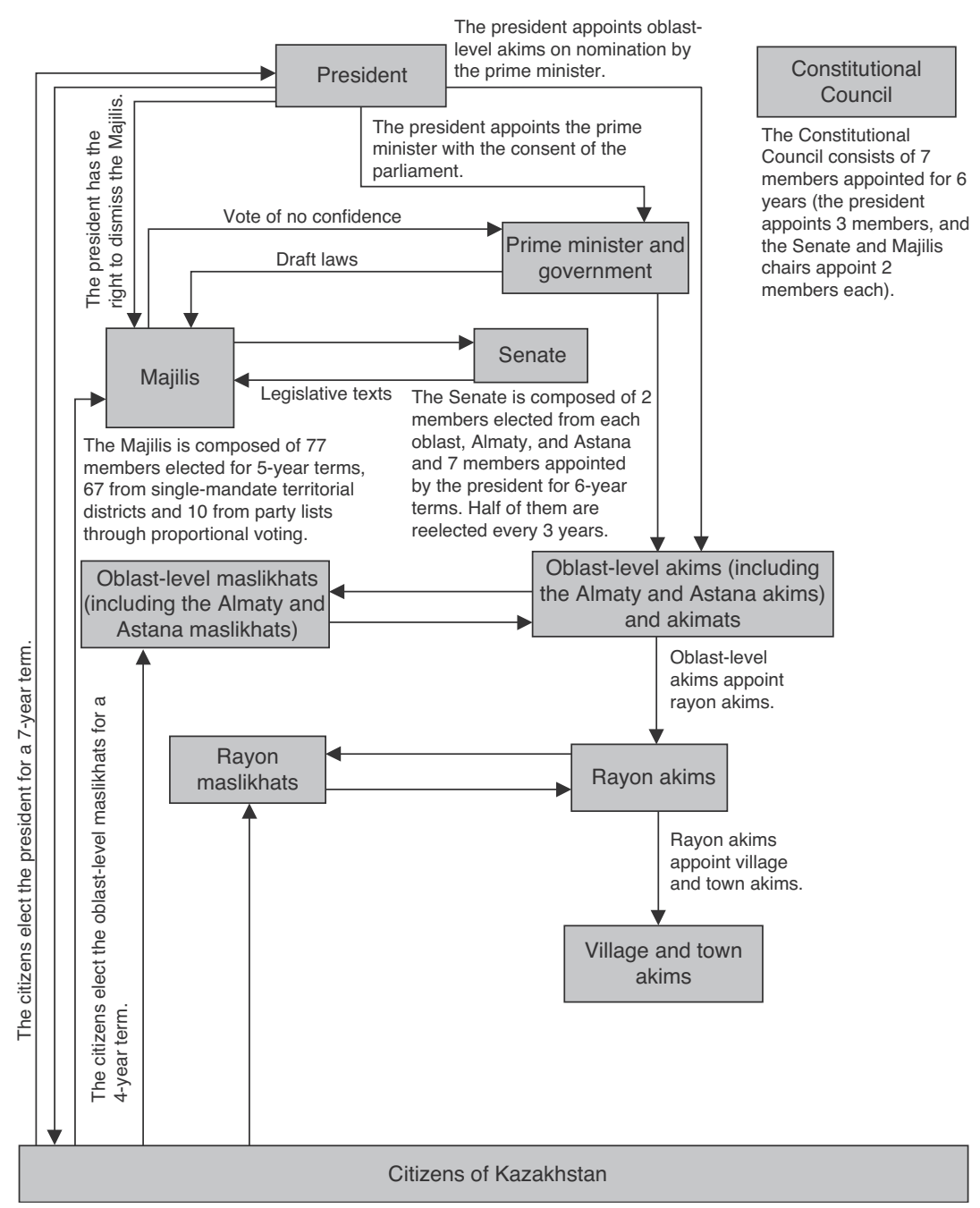

Source: Makhmutova 2001.

F I G U R E 8 . 1 Structure of Public Administration in Kazakhstan

\section{Local Government Expenditure Responsibilities}

In Kazakhstan, one of the distinct problems in reforming intergovernmental fiscal relations is the distribution of expenditures among the levels of the budget system - that is, between the national and oblast budgets and between the oblast and rayon budgets. All three levels incur expenditures. 
Until 2005, delimitation of functions among oblast and rayon levels in each oblast was established by the oblast akims at their discretion. For example, health services and education in certain oblasts were financed by oblast budgets, whereas in others they were financed by rayon and city budgets. The lack of clear delimitation of functions among oblast and rayon or city levels made it difficult to evaluate the adequacy of citizen services and the effectiveness of budget expenditures.

Since 2005, however, a new Budget Code $^{3}$ fixed expenditures for the oblast and rayon levels. Provision of health care, secondary education, and potable water and sewerage services is the responsibility of oblast authorities. In accordance with article 51 of the Budget Code, oblast budgets finance the following expenditures: general public service; defense, public order, and security; education; health care; social welfare; housing and utilities; culture, sports, tourism, and information; agriculture, water resources, forestry, and environmental protection; architecture and construction activities; transportation and communication; regulation of economic activity; and so forth (see annex 8A for details).

According to article 52 of the Budget Code, expenditure responsibilities in the budgets of Astana and Almaty, which are cities with special status, are wider than those in oblast budgets. Under article 53, the expenditures of a rayon (and town) of local significance are designated for the following purposes: general public services; defense, public order, and security; education; social welfare; housing and utilities; culture and sports; agriculture; transportation and communications; and so forth (see annex $8 \mathrm{~B}$ for details).

In 2001, the local budget share of consolidated (national and local) expenditures was 82 percent for education, 78 percent for health care, and 16 percent for social welfare. In 2002, the corresponding shares were 86.4 percent for education, 83.1 percent for health care, and 17.8 percent for social welfare. These three items made up 50.7 percent of the expenses of local budgets. Accordingly, in 2002, only 13.6 percent of total budget expenses for education, 16.9 percent of health care expenses, and 82.2 percent of social welfare expenses were financed from the national budget.

In 2005, the local budget share of consolidated expenditures remained about the same: 83 percent for education, 81 percent for health care, and 10 percent for social welfare. The local budget share of social welfare expenses in the consolidated budget fell as a result of growing expenses from the national budget in 2005 during the presidential preelection term. These three items made up 50 percent of local budget expenditures.

Table 8.2 shows central and local budget expenditure trends from 2002 to 2005 . 
TA B LE 8 . 2 Central and Local Budget Expenditures, 2002-05

\begin{tabular}{|c|c|c|c|c|}
\hline Type of expenditure & 2002 & 2003 & 2004 & $2005^{a}$ \\
\hline $\begin{array}{l}\text { Central government } \\
\text { expenditures as a } \\
\text { percentage of gross } \\
\text { domestic product }\end{array}$ & 14.2 & 14.8 & 15.5 & 20.6 \\
\hline $\begin{array}{l}\text { Central government } \\
\text { expenditures as a } \\
\text { percentage of the } \\
\text { consolidated budget }\end{array}$ & 68.0 & 70.4 & 73.2 & 79.0 \\
\hline $\begin{array}{l}\text { Local budget } \\
\text { expenditures as a } \\
\text { percentage of the } \\
\text { consolidated budget }\end{array}$ & 48.0 & 48.2 & 49.0 & 40.3 \\
\hline
\end{tabular}

Source: Ministry of Finance 2005.

a. Data for 2005 are preliminary.

\section{Local Governments' Own Taxes and Charges}

Local authorities in Kazakhstan are not independent with respect to their taxation powers; they cannot fix tax rates or determine the bases for taxation. Only the land tax is an exception to this rule. On the basis of land zoning projects conducted in accordance with the country's land legislation, local representative bodies can increase or decrease land tax rates that are fixed in the Tax Code (article 338).

The responsibility for tax collection falls to the Tax Committee of the Ministry of Finance and its territorial divisions (the tax committees of Almaty and Astana; the inter-rayon tax committees; and the tax committees for rayons, cities, and rayons in cities). These tax committees are responsible for remitting all tax revenues and other obligatory payments to the budget. They do not report to any local government authority but are vertically subordinated to the correspondingly higher level of tax committee (article 15 of the Tax Code).

At present, Kazakhstan's legislation does not recognize the concept of local taxes. The Law on Taxes and Other Payments to the Budget, which was adopted in 1995, determined basic types of taxes to be levied. The distribution of taxes between different levels of the budget system was excluded from tax legislation in 1999. The various types of taxes and payments are enumerated in the Tax Code, and tax and other revenue to be paid to the national and local budgets are described in the Budget Code. Chapter 7 of the Budget Code defines revenue distribution among budget levels. 
Article 47 of the Budget Code describes the tax and nontax revenues in the oblast budget (see annex $8 \mathrm{C}$ for details). Revenues included in the budget of Almaty, a city of national significance, and Astana, the capital city, are somewhat different and are found in article 48 . Article 49 describes the tax and nontax revenues in the rayon (and town of oblast significance) budget (see annex $8 \mathrm{D}$ for details).

Table 8.3 outlines the structure of local budget revenue and the role that tax revenues, nontax earnings, and revenues from capital transactions play. The share of the social tax in total revenues is rather significant (table 8.3). The social tax, which was introduced in 1999, amounts to almost a third of revenues. Since 2004, the rate of the social tax was changed from a fixed 21 percent to a sliding rate of 7 to 20 percent depending on the level of salary. As a result, the share of the social tax in local budget revenues fell to 26.3 percent in 2005. The share of personal income tax in local budget revenues is also significant. In 2004 the rate was reduced from 30 to 20 percent of income, as reflected in the decline in revenues from 19.5 to 16.4 percent between 2003 and 2004.

The share of corporate income tax grew from 12.6 percent in 1999 to 26.3 percent in 2000 (see table 8.3). In 2001, that share decreased to 20.3 percent, with the establishment of the National Oil Fund of the Republic of Kazakhstan, because a portion of the tax had to be paid to the fund. Since 2002, corporate income tax has been transferred entirely to the national budget.

\begin{tabular}{lrrrrrrr}
$\begin{array}{l}\text { T A B L E 8.3 Structure of Local Budget Revenue } \\
\text { (percent) }\end{array}$ & \multicolumn{7}{l}{} \\
\hline Type of revenue & 1999 & 2000 & 2001 & 2002 & 2003 & 2004 & 2005 \\
\hline Taxes & 80.2 & 82.9 & 83.5 & 77.7 & 70.5 & 61.5 & 58.2 \\
$\quad$ Corporate income tax & 12.6 & 26.3 & 20.3 & n.a. & n.a. & n.a. & n.a. \\
$\quad$ Personal income tax & 16.0 & 16.0 & 17.8 & 20.0 & 19.5 & 16.4 & 16.4 \\
$\quad$ Social tax & 31.4 & 25.3 & 32.2 & 35.3 & 32.9 & 28.0 & 26.3 \\
$\quad$ Property tax & 10.9 & 8.3 & 8.6 & 8.7 & 7.5 & 7.2 & 6.9 \\
$\quad$ Value added tax & 3.8 & 3.8 & 2.4 & 2.5 & 1.9 & 1.4 & n.a. \\
$\quad$ Excise duties & 1.8 & 1.3 & 1.1 & 5.6 & 4.4 & 3.6 & 3.1 \\
Nontax earnings & 5.0 & 3.2 & 3.4 & 1.1 & 1.1 & 1.5 & 1.3 \\
Revenues from capital sale & 0.0 & 0.0 & 0.7 & 0.9 & 1.3 & 2.2 & 3.4 \\
Official transfers & 14.7 & 13.8 & 12.4 & 20.3 & 25.7 & 34.8 & 37.1 \\
$\quad$ Total & 100.0 & 100.0 & 100.0 & 100.0 & 100.0 & 100.0 & 100.0 \\
\hline
\end{tabular}

Source: Ministry of Finance 2005.

Note: n.a. = not applicable. 
TA B L E 8 . 4 Tax Bases and Rates for Various Taxes

\begin{tabular}{|c|c|c|}
\hline Tax & Base & Rate \\
\hline Personal income tax & Personal income & $\begin{array}{l}5 \text { to } 20 \text { percent depending } \\
\text { on income level }\end{array}$ \\
\hline Social tax & $\begin{array}{l}\text { Salary expenses of legal } \\
\text { entities }\end{array}$ & $\begin{array}{l}7 \text { to } 20 \text { percent depending } \\
\text { on level of salary expenses }\end{array}$ \\
\hline Property tax of legal entities & Assets and fictitious assets & 1 percent of value \\
\hline Personal property tax & Property of person & $\begin{array}{l}0.1 \text { or } 1 \text { percent depending } \\
\text { on property value }\end{array}$ \\
\hline Excise duties & $\begin{array}{l}\text { Excisable production of } \\
\text { enterprisers or importers }\end{array}$ & $\begin{array}{l}\text { Government approves the } \\
\text { rate as a percentage of } \\
\text { good value }\end{array}$ \\
\hline Land tax & Land & Rate depends on zoning \\
\hline Transportation tax & Means of transport & $\begin{array}{l}\text { Rate depends on power, } \\
\text { motor volume, producer }\end{array}$ \\
\hline
\end{tabular}

Source: Tax Code.

Social tax, personal income tax, and excise duties compose almost half of local tax revenues. Taxes on property are not significant; they constitute only 6.9 percent of local budget revenue. Nontax earnings amount to only 1.3 percent of local budget income. In contrast, more than a third of all local budget revenues derive from official transfers from the national budget.

Table 8.4 shows current rates and tax bases for some of the more important taxes.

\section{Shared Taxes}

At present, taxes are not shared between national and local budgets in Kazakhstan. Until January 1, 2002, revenues from the corporate income tax, excise duties on alcohol, and payments for environmental pollution were allocated evenly between the levels of the budget system. When, in 2002, corporate income tax was transferred entirely to the national budget, local budgets were replenished with revenues from excise duties on alcohol and payments for environmental pollution.

Nevertheless, the loss of revenue from corporate income tax significantly decreased local budget revenue. As a result, the number of oblasts that withdrew funds from the national budget significantly decreased, and the number of oblasts that received subsidies from the national budget correspondingly increased. 
According to the Budget Code, since 2005 social and personal income taxes are shared between oblast and rayon budgets in accordance with the oblast maslikhat's decision.

\section{Intergovernmental Fiscal Transfers}

Because different regions contribute to the national budget at different levels, it is necessary to equalize their budget incomes. Oblasts with a higher level of industry have a higher tax potential. Where agriculture dominates the economy, oblasts have lower revenues.

Thus, the government has long had a policy of redistributing finances through the national budget. From the early 1990s to 1998, a share percentage for tax divided between the national and local budgets was applied to determine how revenues would be allocated. Subsidies from the national budget were allocated to those oblasts whose total revenues were not sufficient to finance necessary expenditures.

Starting in 1999, the mechanism changed. Oblasts with high revenuegenerating capacity have a part of their income deducted and paid into the national budget; only afterward are subsidies from the national budget allocated to low-income oblasts.

Moreover, subsidies are transferred only to eliminate a gap between income and expenditures. For each oblast, a level of expenditures is calculated on the basis of the previous year's data, with adjustments for inflation. Oblasts that generate higher amounts of revenue and that therefore make contributions to the national budget simply retain the amount they need to cover their anticipated expenditures. Oblasts with lower revenue-generating capacity receive whatever additional funds they require from the national budget.

In 1999, total withdrawals made by oblasts to the national budget amounted to T 37 billion, and the subsidies transferred amounted to T 24.8 billion (table 8.5). In 2001, withdrawals increased to T 84 billion and only T 35.5 billion was transferred as subventions. That change marked an improvement in the general economic situation. In addition, high world prices on raw materials, Kazakhstan's main export, led to higher incomes in the oblasts that make contributions to the national budget, and the government increased the level of those contributions: the difference between contributed earnings and subsidies in 2001 amounted to almost $\mathrm{T} 50$ billion.

In 2002, when corporate income tax ceased to be included in local budget revenue, the number of subsidized oblasts increased from seven to nine. In 2005, 11 oblasts received subventions from the national budget. 
TA B L E 8 . 5 Withdrawals to and Subventions Received from the National Budget, by Oblast (tenge million)

\begin{tabular}{lrrrrrrr}
\hline Oblast & 1999 & 2000 & 2001 & 2002 & 2003 & 2004 & $2005^{\text {a }}$ \\
\hline Akmolinskaya & 3,928 & 4,153 & 4,391 & 7,192 & 9,353 & 14,112 & 13,864 \\
Aktubinskaya & $(1,646)$ & $(1,830)$ & $(3,626)$ & $(569)$ & $(429)$ & 2,131 & $(1,373)$ \\
Almatinskaya & 5,891 & 6,055 & 8,298 & 10,289 & 10,125 & 14,425 & 15,419 \\
Atyrauskaya & $(6,766)$ & $(13,227)$ & $(28,790)$ & $(19,601)$ & $(20,115)$ & $(22,669)$ & $(28,989)$ \\
East Kazakhstan & 275 & $(1,279)$ & $(2,460)$ & 5,190 & 9,348 & 15,010 & 15,469 \\
Zhambylskaya & 2,286 & 3,158 & 4,866 & 6,877 & 10,470 & 15,065 & 15,058 \\
West Kazakhstan & 335 & 254 & $(887)$ & 1,286 & $(497)$ & 5,657 & 7,665 \\
Karagandinskaya & $(3,939)$ & $(5,820)$ & $(9,856)$ & $(81)$ & 1,835 & 6,998 & 5,026 \\
Kostanayskaya & $(363)$ & $(377)$ & 841 & 4,182 & 5,191 & 8,892 & 9,478 \\
Kyzylordinskaya & 3,169 & 2,403 & 1,262 & 6,645 & 8,972 & 10,909 & 11,009 \\
Mangistauskaya & $(4,844)$ & $(4,262)$ & $(10,629)$ & $(9,000)$ & $(10,651)$ & $(10,139)$ & $(15,989)$ \\
Pavlodarskaya & $(3,539)$ & $(1,590)$ & $(2,106)$ & $(1,896)$ & $(974)$ & 1,043 & 1,259 \\
North Kazakhstan & 2,971 & 3,192 & 3,732 & 5,202 & 6,206 & 11,468 & 11,461 \\
South Kazakhstan & 5,959 & 7,902 & 12,115 & 12,901 & 19,072 & 28,685 & 27,317 \\
Almaty city & $(16,162)$ & $(21,867)$ & $(25,801)$ & $(17,915)$ & $(24,964)$ & $(32,061)$ & $(45,358)$ \\
Astana city & $\mathrm{n} . \mathrm{a}$. & $\mathrm{n} . \mathrm{a}$. & $\mathrm{n} . \mathrm{a}$. & $\mathrm{n} . \mathrm{a}$. & $\mathrm{n} . \mathrm{a}$. & $(1,804)$ & $(3,301)$ \\
Total withdrawals & $(37,259)$ & $(50,251)$ & $(84,155)$ & $(49,065)$ & $(57,630)$ & $(66,673)$ & $(\mathbf{9 5}, 009)$ \\
Total subventions & $\mathbf{2 4 , 8 1 4}$ & $\mathbf{2 7 , 1 1 8}$ & $\mathbf{3 5 , 5 0 4}$ & $\mathbf{5 9 , 7 6 3}$ & $\mathbf{8 0 , 5 1 3}$ & $\mathbf{1 3 4 , 3 9 5}$ & 133,028 \\
\hline
\end{tabular}

Source: Ministry of Finance 2005.

Note: n.a. $=$ not applicable. Withdrawals are in parentheses.

a. Data are provisional.

If we look at the total volume of local budget revenues, amounts transferred from the national budget to subsidized oblasts amount to 15 percent; if we look at the total shares of expenditures, they amount to 11 percent. But, certainly, if each oblast is examined separately, there are significant differences between them. For instance, in 2003, 71 percent of income in Zhambylskaya oblast was received in the form of a subvention from the national budget, which allowed the oblast financing of up to 72.5 percent of its expenditures. This high level of subvention is related to an earthquake experienced by the oblast in 2003. In 2002, the subvention in Zhambylskaya oblast amounted to 57 percent of income. In 2003, the subvention in South Kazakhstan amounted to 52 percent and allowed the financing of 52.5 percent of oblast expenditures.

Annual allocations of special transfers to local budgets for building schools, hospitals, and water supply systems to implement the drinking water program have been in effect since 2002. 
In 2005, withdrawals deducted from the Atyrauskaya oblast budget amounted to 49 percent of all budget expenditures, but, they were partly refunded in the form of a special transfer to the oblast budget ( 9 percent of income). Withdrawals from the Almaty city budget amounted to 39 percent of expenditures. These amounts were partly refunded in the form of a special transfer to the municipal budget (14.5 percent of income).

Since 2005, the Budget Code has provided a new legal framework. The code defines official transfers, which are subdivided into general transfers, target-oriented current transfers, and transfers targeted at development. Budget subventions and budget withdrawals are identified as general official transfers. They are established in absolute terms for a three-year period (that is, they are subject to change every three years) with the following breakdown:

Between the national budget and the budgets of oblasts and the cities of Almaty and Astana—by law

Between the oblast budget and the budgets of rayons (and towns of oblast importance)—by oblast maslikhat decision.

\section{Local Government Borrowing}

Local budgets can run deficits. Local representative and executive bodies bear responsibility for balancing the appropriate local budgets. Budget deficits are covered from borrowing. At the request of oblast akims and the akims of Astana and Almaty, the Ministry of Finance may provide budget loans to local budgets from the national budget to fund investment programs and to cover cash gaps. The same is true at the rayon level. Rayon executive bodies can borrow from the oblast budget to cover a budget deficit, a cash gap, or the implementation of an investment program.

Until 2005, borrowing by local executive bodies was carried out as a form of loan contract or as a capital issue by the local executive bodies. The procedures for concluding loan contracts and issuing government securities by local executive bodies were defined by the government.

In 1999, regions started issuing their own bonds. The issuers are not municipalities but oblast-level local executive authorities. In each case, resolutions were adopted by the government that determined procedures for issuing, floating, and redeeming bonds. Between 1999 and 2003, overall improvement in the macroeconomic situation and reduction of the refinancing rate by the National Bank permitted interest rates to gradually decrease and terms of borrowing to increase. 
From 1999 to 2002, banks and pension funds were the major holders of securities of local executive agencies. In 2002, the Ministry of Finance announced that the government would reduce the level of borrowing by local authorities. In 2003, in accordance with new regulations, pension funds were advised to limit investments in securities of local executive authorities to no more than 5 percent of their assets. This change influenced the decrease in the activities of local executive agencies related to capital issues.

International rating agencies have awarded investment ratings to all oblasts except East Kazakhstan. The oblasts received ratings that varied between $\mathrm{B}+$ and BBB-. East Kazakhstan was excluded because of the strong dependence of its local budget income on the KazZinc enterprise: a considerable amount of taxes and payments are received from (ensured by) this enterprise.

On the whole, the government strictly controls the growth of local borrowing. The major obstacle to local borrowing is the absence of reliable medium-term and long-term budget planning at the local level, because of the uncertainty surrounding the government policy concerning the allocation of taxes between the national and local budgets and the rate of budget withdrawals.

In general, local borrowing for capital investments will be expedient only if local agencies have actual instruments for managing local budget revenues.

Article 202 of the Budget Code prohibits local borrowing from the capital market. Local executive bodies of the oblasts and the cities of Almaty and Astana can obtain loans from the government of Kazakhstan to finance budget deficits and to cover cash gaps. Rayons that need to borrow to finance a budget deficit, cover a cash gap, or implement an investment project can obtain loans from the oblast authorities.

The Budget Code defines the fundamental rules of borrowing by local executive bodies and controls the volumes of borrowing as follows:

The debt limit of a local executive body may not exceed 25 percent of local budget income for the appropriate financial year.

The volume of expenses in connection with paying off the debt service of local executive bodies may not exceed 10 percent of local budget income for the appropriate year.

\section{Local Government Administration}

The Law on Civil Service, which was enacted in 1999, provides for the categorization of civil servants into political and administrative employees. ${ }^{4}$ 
Oblast akims; their deputies; and akims of cities, rural settlements, and auls are recognized as political civil servants at the regional level. The grounds and the procedure for dismissal of a political civil servant are defined by the president. Akims of oblasts and of Almaty and Astana, akims of cities and rayons, and akims of city rayons are assigned to their positions by akims of higher ranks, as agreed upon with the president and the prime minister. Dismissal of deputies of oblast akims and akims of cities and rayons is carried out only after coordination with the chief of the president's administration and government.

All the other positions in the executive department are recognized as administrative, and they make up some 96 to 97 percent of the total number of civil servants. Administrative civil servants are divided into A, B, C, D, and $\mathrm{E}$ categories. Local-level administrative civil servants are in category $\mathrm{D}$ if they work for agencies of local government departments and category E if they work for local executive bodies (Baimenov 2000). Mandatory competition has been introduced for entrance to and promotion in the administrative civil service. This condition is aimed at allowing citizens to exercise the right to equal access to civil service employment.

The competition is conducted by a public agency that has a vacant position or by the Agency for Civil Service in an open or closed form, after the competition is advertised in the national media. Any citizen of the country may take part in an open competition. Only administrative employees are admitted to closed competitions.

In the case of the maslikhats, the activities of civil servants are carried out in compliance with the Law on Civil Service. The activities of civil servants are not terminated even if the term of office of the maslikhat is terminated or new deputies are selected. This procedure ensures organizational, legal, logistical, and other support for the maslikhat and its agencies. It renders assistance to deputies in discharging their commissions. The maslikhat is a public institution, financed from the local budget. Limits on the number of its public service staff members are established in accordance with the number of deputies-a proportion of one employee for every three to seven deputies.

\section{An Overall Assessment of Local Government Finances}

The operating system of local finances does not create incentives for accountability for ensuring local public services. Local authorities are accountable only to higher government bodies and do not actually depend on the opinion of citizens. Actually, akims who allow an offense or are 
an accessory to corruption are merely appointed as akims of other regions and bear practically no responsibility for the outcomes of their work.

The high level of income centralization reduces the autonomy of local authorities. Since 2005, only 3 of 15 local budgets fulfill their expenditure obligations out of their own income. All other local budgets depend on subsidies transferred from the national budget.

The concept of a local tax can relate only to the land tax, for which local authorities may reduce or increase the rates. But its share in receipts is insignificant ( 1 or 2 percent).

Allocation of charges between the levels of the budget system was decentralized in the mid-1990s. At that time the government, which had to strive to maintain budget deficits at the level demanded by the International Monetary Fund, was "throwing off" all social expenses to local budgets. As a result, a nonsymmetric fiscal decentralization took placeexpenditures, but not income, were decentralized. But this does not mean local governments could independently determine how their budgets were spent. The system of allocating charges between the levels of the budget system turns local authorities not into partners of the government (which ensure financing and perform important duties), but into clients petitioning for resources.

The system of leveling income among the oblasts does not have clearly defined criteria that are based on financing a minimum standard of social or other services. Thus, the system results in some disproportion: charges for one pupil or one patient can be very different in different oblasts.

The division of expenditures into operational and capital ones (the socalled developmental budget) is also questionable. In international practice, capital expenses are financed by raising loans or by issuing capital. In Kazakhstan, financing of capital expenses is possible only at the expense of government transfers earmarked for a special purpose. Efforts of local executive bodies to issue bonds failed. The Budget Code stipulates that local executive bodies have the right to borrow only from higher budgets.

Local agencies have sufficient expertise to ensure local public services. But effectiveness in ensuring such services has not yet been a paramount goal of local authorities, because such authorities do not depend on citizens' good opinion about the quality of services provided.

\section{Lessons for Other Developing Countries}

Over the past 15 years, Kazakhstan's budget system has undergone significant changes: sources of forming the national and local budgets have been 
determined, and directions for spending these funds have been defined precisely. However, the weak links in the budgetary process are as follows:

- Inadequate planning and forecasting of budgets for all levels

- Lack of stable income sources for local budgets

- Poor incentives for budget implementation at the local level

- Weak mechanisms for leveling through subventions and withdrawals

- Weak management of communal property at the local level

- Inadequate monitoring of implementation and control of local budgets.

Kazakhstan has a highly centralized system of local public administration. Under this system, local executive bodies dominate the representative bodies. Representative bodies act as a democratic façade in the system of public administration.

The amount of resources reallocated by the government increases annually. Such increases might have been justified during the transitional period from Soviet rule, when resources were exceedingly limited. But now local authorities must bear responsibility to the population for the inadequate level and quality of services provided.

The problem is that in Kazakhstan there are practically no mechanisms for ensuring the accountability of local authorities to the population: authorities do not depend on the good opinion of citizens regarding the quality of the work they perform. In other countries, local authorities are accountable to the local electorate by way of democratic procedures.

In Kazakhstan, however, akims of all levels are appointed from the top. Thus, akims are accountable to the people who appointed them. Although the constitution recognizes the right to establish local self-government, no adequate law concerning local self-government has been enacted in the past 11 years. Accordingly, no institution of local self-government is in operation in Kazakhstan.

The cardinal problem is that the constitution, having included local representative bodies in the system of local public administration, brought about a contradiction, which does not allow the establishment of a fully accountable institution of local self-government. The maslikhats must be the local self-government authorities: they are elected by the population and they approve the budget.

Draft versions of the Law on Local Self-Government proposed by the government, the latest of which was withdrawn from the parliament in 2000, provided for establishing local government at the level of a public organization—without budget and ownership. 
One of the key challenges is absence of full-fledged accountable authorities at the rural level. In accordance with the law, the akim is a representative of government authorities at the rural level. Establishing local representative authorities — maslikhats and also akimats at the rural level — is not provided by the law. Rural management does not have a budget-only an estimate, included in the rayon budget. However, the majority of social and economic problems appear at the rural level. Many of them are a result of reforms carried out in the 1990s. Given that 44 percent of Kazakhstanis live in the countryside, solving these problems is a task of great importance for further development of the country. Rural akims, who enjoy only limited powers and do not have a budget, will not be able to resolve these problems alone.

Hence, it is necessary to provide rural akim with an appropriate budget. Experience shows that almost three-quarters of the problems related to improving local living conditions result from problems the authorities faced in the development of the territory. These problems can be successfully resolved jointly with the residents, who know the problems best and may take the most active part in resolving them.

The Budget Code has been signed. It employs a new mechanism of reallocating taxes between the levels of the budget system, dividing obligations for expenditures between oblasts and rayons. On the whole, the Budget Code regulates the budgetary process. But it failed to resolve a matter of principleestablishing an independent rural budget.

Worldwide, local government is a basis for regional development. To solve the problem of strikingly different regional development levels in Kazakhstan, policy makers must employ all possible mechanisms, including the constitutionally recognized right of self-governing bodies to regulate a considerable part of public affairs and to manage themselves, acting under the laws, on their own responsibility and in the interests of the local population. As world practice shows, only mechanisms for control and accountability of authorities and stimulation of citizens' activities can improve the provision of public services.

In the case of Kazakhstan, the absence of political will needed to carry out real reforms at the local level impedes the establishment of a legal framework capable of ensuring these reforms. The result is a vicious circle. We propose to create necessary preconditions for the development of local self-government in Kazakhstan by taking maslikhats out of the system of local public administration and recognizing them as local self-government authorities. At the lowest level of government, it is necessary to provide for the establishment of maslikhats and, later, for the election by the deputies of the akim, who will head the executive body of local government. We hope that this will break the vicious circle and allow discussion of further steps to begin. 


\section{Annex 8A: Oblast Budget Expenditures}

According to article 51 of the Budget Code, oblast budgets finance the following expenditures:

1. General public service

- Functioning of local representative and executive agencies at the oblast level

- Midterm economic planning

- Budget planning at the oblast level

- Oblast budget execution

- Management of oblast property

2. Defense, public order, and security

- Provision, under the universal military service program, of military commissariats with equipped recruiting premises, medicine, instruments, medical and business property, vehicles, means of communication, medical and technical staff, and support staff, plus establishment of medical commissions

- Mobilization training and mobilization at the oblast level

- Prevention and elimination of emergency situations that have an impact on oblasts

- Operation of water rescue services

- Provision of public order and public security on the territory of oblast

- Public defense activities at the oblast level

\section{Education}

- Purchase and delivery of textbooks for state oblast education organizations

- Supplementary sports training for children and youth

- Organization and provision of primary vocational education

- Specialized curricula in secondary education

- Organization and provision of secondary education for gifted children in specialized education institutions

- Organization of school competitions at the oblast level

- Organization and provision of vocational education

- Improvement of qualifications and retraining of personnel at the local level 
- Examination of the psychological health of children and youth and provision of psychomedical, pedagogical consultative assistance to the population

- Rehabilitation and social adaptation of children and youth with development problems

4. Health care

- Provision of a healthy, sanitary situation for population

- Provision of other health services with the exception of those funded from the budget of the republic

- Procurement of vaccines and immunobiological and other medical preparations in accordance with the laws of the Republic of Kazakhstan

5. Social welfare

Social welfare of orphans and care for children without parents

- Social provision for elderly people and people with disabilities, including children with disabilities

6. Housing and utilities

- Provision of gas to settlements

7. Culture, sports, tourism, and information

- Organization of sports events at the oblast level

- Provision of a local archives for preservation purposes

Operation of oblast libraries

- Implementation of the state information policy at the local level through mass media

- Development of the state language and other languages of Kazakhstan

- Implementation of regional programs in the area of youth policy

- Support for theaters and music of local significance

- Training of oblast teams in various sports and their participation at national and international sports competitions

- Regulation of tourism at the local level

- Preservation of historical and cultural heritage of local significance and assurance of access to such history and culture

8. Agriculture, water resources, forestry, and environmental protection

- Provision of functioning water facilities owned by local authorities

- Maintenance, preservation, and restoration of forests and forest growth 
- Construction and maintenance of special storage facilities (burial grounds)

- Preservation of fauna

- Maintenance and preservation of local areas under special protection

- Establishment of water preservation zones and zones of water facilities and water supply systems

- Building and reconstruction of water pipelines of oblast significance

- Ecological examinations, other than examinations funded from the national budget

- Restoration of water supply facilities and hydroreclamation systems of oblast significance that are in emergency state

- Organization of the use of land in the course of establishing borders of rayons and towns of oblast significance

- Conduct of ecological control and other nature preservation activities

9. Architecture and construction activities

- Organization and control of architecture, city-building, and construction activities other than expenses funded from the national budget

10. Transportation and communications

- Organization of transportation on socially important inter-rayon (intercity) routes

- Construction, reconstruction, and maintenance of roads of the oblast importance

11. Regulation of economic activity

- Small business support

12. Other areas

- Official transfers to rayon (and town) budgets of oblast significance

- Official transfers into the national budget

- Servicing of local government debt.

\section{Annex 8B: Rayon Budget Expenditures}

According to article 52 of the Budget Code, the budgets of rayons of local significance finance the followig expenditures:

1. General public services

- Functioning of local representative and executive agencies at the rayon (and town) level 
Economic and budget planning

- Execution of the rayon (and town) budget

- Assessment of property for tax purposes

Management of communal property at the rayon (and town) level

2. Defense, public order, and security

Activities related to mandatory military service and to provision of military commissariats with equipped recruiting points that have an impact on rayon (and town), medicine, instruments, medical and business property, vehicles, means of communication, medical and technical staff, and support staff, plus establishment of medical examination commissions

- Prevention and elimination of emergency situations

- Assurance of public order and public security

- Functioning of medical sobering-up stations and orphanages

\section{Education}

- Organization and provision of preschool education

- Organization and provision of compulsory free secondary education of citizens in state educational institutions, including evening (parttime) education and secondary education provided in boarding schools

- Organization of school competitions at the rayon (and town) level

- Purchase and delivery of textbooks for state education organizations

- Organization of additional optional education

4. Social welfare

Housing assistance

- Social welfare provided at home

- Social adaptation of individuals without permanent place of residence

- Provision of employment opportunities

- Targeted state social assistance

- Social assistance provided to some categories of indigent citizens by decisions of local representative organizations

5. Housing and utilities

Demolition of poor and old housing in accordance with the laws of the Republic of Kazakhstan

- Construction of municipal housing

- Preservation of housing funds of rayon (and town) importance 
Provision of housing to certain categories of citizens in accordance with the laws of the Republic of Kazakhstan

- Support of cultural and entertainment services at the local level

- Impoundment (redemption) of land plots for state needs in accordance with the laws of the Republic of Kazakhstan

- Construction and reconstruction of water supply facilities; water treatment and drainage systems; and sewage, heating, and electricity networks that are municipal property

- Provision of sanitation to settlements

- Maintenance of cemeteries and burial of people without relatives

- Illumination of streets in settlements

- Establishment and vegetation of settlements

6. Culture and sports

- Operation of local libraries

- Development of national and popular sports

- Organization of sports competitions at the rayon (and town) level

- Training of teams of a rayon (and town) in various sports and their participation in oblast sports competitions

- Operation of zoos and dendro parks

- Implementation of the state information policy at the local level through mass media

- Development of the state language and other languages of Kazakhstan

- Implementation of youth policy

7. Agriculture

- Organization of the use of land in the course of establishing borders of villages and towns of rayon significance

- Work related to shifting agricultural land from one category into another

- Organization of the use of land in inhabited areas

- Sanitary slaughter of sick animals

- Construction and maintenance of special storage facilities (burial grounds) to be used in livestock farming

- Organization of land zoning

8. Transportation and communications

- Construction, reconstruction, repair, and maintenance of rayon (and town) roads

- Organization of intervillage (intertown) and inter-rayon public transportation 
9. Other areas

- Official transfers to the National Fund of the Republic of Kazakhstan

- General official transfers into the oblast budget

\section{Annex 8C: Oblast Budget Tax and Nontax Revenues}

According to article 47 of the Budget Code, oblast budget revenues include the following taxes:

- Personal income tax (in accordance with the rates established by an oblast maslikhat)

- Social tax (in accordance with the rates established by an oblast maslikhat)

- Charge for environment pollution

- Fee for travel on certain oblast roads

- Charge for the placement of outdoor (visual) advertising in the public right of way on public roads of local significance and in inhabited areas

Fee for the use of groundwater resources

- Fee for the use of forestry

- Fee for the use of specially protected natural territories.

The following are nontax revenues in the oblast budget:

Receipts from municipal property

- Receipts from a portion of net income of municipal state enterprises that were established in accordance with a decision of the oblast akim administration

- Dividends on the government shareholding of oblast municipal property

- Income from share interest in legal entities that are oblast municipal property

- Receipts from oblast municipal property leasing

- Remuneration (interest) on credits issued from the oblast budget

- Remuneration (interest) received from placement in deposits of temporary free budget funds

- Other revenues from the oblast municipal property

- Receipts from sales of goods, works, or services by state institutions that are financed from the oblast budget

Entry of money from state procurements organized by state institutions funded from the oblast budget 
- Fines, penalties, sanctions, and recoveries imposed by state institutions financed from the oblast budget

- Other nontax revenues payable to the oblast budget.

Revenues from sales of fixed capital are included in the oblast budget if they consist of funds from sales of state property assigned to state institutions that are financed from the oblast budget. Official transfers from the budgets of rayons (and towns of oblast significance) and from the national budget are included in oblast budgets. Also credited to the oblast budget are revenues from repayment of credits issued from the oblast budget, sales of financial assets that are the oblast's municipal property, and loans of local executive bodies of oblasts.

\section{Annex 8D: Rayon Budget Tax and Nontax Revenues}

According to article 49 of the Budget Code, the budget of a rayon (and town of oblast significance) includes the following tax revenues:

- Personal income tax (in accordance with the rates established by an oblast maslikhat)

- Social tax (in accordance with the rates established by an oblast maslikhat)

- Tax on property owned by individuals, legal entities, individual entrepreneurs

- Land tax

- Single land tax

- Tax on means of transportation owned by legal entities and individuals

- Excise taxes on the following goods produced on the territory of the Republic of Kazakhstan: all types of spirits; alcohol products; tobacco and articles containing tobacco; sturgeon and salmon caviar; jewelry made of gold, platinum, or silver; firearms and air guns (other than those acquired for the needs of government authorities); passenger cars (other than cars with hand-operated controls specially designed for people with disabilities)

Excise taxes on gambling businesses, the organization of lotteries, gasoline (with the exception of aviation fuel), and diesel fuel

- Charge for the use of land parcels

- Fee for state registration of individual entrepreneurs

- Licensing fee on certain types of business;

- Fee for state registration of legal entities 


\section{Auction fee}

- Fee for state registration of mechanical means of making transactions and trailers

- Fee for state registration of real estate rights and transactions

- Charge for the placement of outdoor (visual) advertising in the public right of way on public roads of local significance and in inhabited areas.

- Stamp duty, except for a consular fee and stamp duty paid to the national budget.

The following nontax revenues are included in the budget of a rayon (and town of oblast significance):

Receipts from municipal property consisting of the following: part of the net profits of municipal state enterprises that were established in accordance with the rayon akimat's decision, dividends on government shareholdings that are municipal property of the rayon, income on share interest in legal entities that are the municipal property of the rayon, receipts from lotteries held in accordance with a decision of local representatives of the government of the rayon, receipts from municipal property leased by the rayon, remuneration (interest) on credits issued from the rayon), fees from the sale of leasing rights of land parcels, and other revenues from the municipal property of the rayon

Revenue from sales of goods, works, or services by state institutions financed from the rayon budget

Entry of money from state procurements organized by state institutions funded from the rayon budget

- Fines, penalties, sanctions, and recoveries imposed by state institutions and financed from the rayon budget

Other nontax revenues payable to the rayon budget.

Revenues from sales of fixed capital are included in the rayon budget if they consist of funds from sales of state property assigned to state institutions that are financed from the rayon budget or revenue from the sale of land parcels. Official transfers from the oblast budget to the budget of a rayon are included. Also credited to the rayon budget are revenues from repayment of credits issued from the rayon budget, sales of financial assets of the state that are the municipal property of the rayon, and loans of a local executive body of the rayon. 


\section{Notes}

1. Constitution of the Republic of Kazakhstan, adopted August 30, 1995, and amended October 7, 1998.

2. Law on Local Public Administration, adopted January 23, 2001, and amended May 11, 2004.

3. Budget Code of the Republic of Kazakhstan, enacted April 24, 2004, no. 548-II, Oficialnaya Gazeta nos. 21-22, May 2004.

4. Law on Civil Service, adopted July 23, 1999.

\section{References}

Baimenov, Alikhan. 2000. "Reform Does Not Accept Stereotypes." Kazakhstanskaya pravda 43 (February 22): 1-3.

Makhmutova, Meruert. 2001. "Local Government in Kazakhstan." In Developing New Rules in the Old Environment: Local Government in Eastern Europe, Caucasus, and Central Asia, vol. 3, ed. Igor Munteanu and Victor Popa, 403-68. Budapest: Open Society Institute.

—. 2004. "Developing Local Self-Government: Strategic Issues." Policy Studies 2. Almaty: Public Policy Research Center.

Ministry of Finance. 2005. Statistical Bulletin of the Ministry of Finance of the Republic of Kazakhstan 12 (84). 


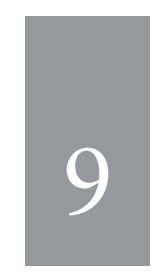

\section{Local Government Organization and Finance: Poland}

P A W E L S W I A N I E W I C Z

$\mathbf{B}_{\text {space for local self-government. Local administration was hierar- }}^{\text {efore }}$ chically dependent on upper tiers and branch ministries of the central government, and local discretion to decide any financial issues or forms of service delivery was next to none. The constitutionally dominant position of the Communist Party limited any reforms that were aimed at real democratization of the local political process. Nevertheless, the inefficiency of the centralist system had been seen for many years. The Polish Communist Party tried to introduce some forms of decentralization and local government in laws of 1983 and 1988. But those limited reforms did not change the doctrinal base of the centralist state, so they could hardly result in more democratic or effective local government.

The turning point was the roundtable negotiation between the Solidarity opposition and the ruling Communist Party in 1989. Local government reform was one topic of discussion. It is worth stressing that it was the only topic on which final agreement was not reached and a "statement of disagreement" was signed. Nevertheless, the main directions of future reform had already been drawn by the Solidarity opposition. 


\section{Local Government System}

The local government structure in Poland is a result of two waves of decentralization reform. The first wave took place in 1990, when the local government system was introduced on a municipal (gmina) level. Local government reform was one of the main priorities for the first postcommunist government, which was formed in September 1989. Quick but intensive preparations allowed the passage of the new Local Government Law in March 1990, which was followed by local elections in May 1990 and a radical decentralization of financial regulations in January 1991. The 1990 reform introduced elected local government on the municipal (gmina) level only; upper tiers of territorial divisions remained managed by the state administration. This solution was treated as a provisional one. It was argued that the division into 49 small regions (województwa) introduced by the Communist administration in the mid-1970s was dysfunctional and required modifications. It was assumed that new, elected regional governments should be introduced with the reform of the territorial division. However, for a number of reasons that are not discussed in this chapter in depth, the introduction of upper tiers of local governments was postponed for several years.

The second stage of the reform introduced two new tiers of elected subnational governments in 1999: powiat (county) and województwo (region).

\section{Territorial Organization}

Currently there are three tiers of territorial governments: almost 2,500 municipalities (gminy); 315 counties, plus 65 cities with county status; and 16 regions, which replaced the earlier 49 smaller units. On both a municipal and a county level, self-government is the only form of public administration. State functions, such as registration of births and marriages, are delivered by local government as delegated functions financed by specific grants. On a regional level, there is a dual structure—elected self-government and a governor (wojewoda), appointed by the prime minister, with his or her own administrative apparatus. However, functions of regional state and self-government administrations are clearly separated, and there is no hierarchical subordination between them. The size of local government units is presented in table 9.1.

\section{Autonomy and Constitutional Protection}

The goal of the reform was to clearly separate functions and policy areas between tiers of government and to eliminate vertical (hierarchical) dependency of the lower tier on the higher. This goal has been achieved 
TA B L E 9 . 1 Territorial Division of Poland, Average Sizes and Ranges

\begin{tabular}{lccc}
\hline & $\begin{array}{c}\text { Municipalities } \\
\text { (gminy), including } \\
\text { cities with county } \\
\text { status }\end{array}$ & Counties (powiaty) & $\begin{array}{c}\text { Regions } \\
\text { (województwa) }\end{array}$ \\
\hline Indicator & About 2,500 & $\begin{array}{c}315 \text { and } 65 \text { cities } \\
\text { with county status }\end{array}$ & 16 \\
Number of units & \multicolumn{3}{c}{} \\
$\begin{array}{l}\text { Area (square kilometers) } \\
\text { Average }\end{array}$ & 125 & 826 & 19,540 \\
Minimum & 2 & 13 & 9,412 \\
Maximum & 625 & 2,987 & 35,598 \\
$\begin{array}{l}\text { Population } \\
\text { Average } \\
\text { Minimum }\end{array}$ & 15,500 & 104,000 & $2,420,000$ \\
Maximum & 1,300 & 22,000 & $1,024,000$ \\
\hline
\end{tabular}

Source: Author's calculations based on data from Bank Danych Regionalnych, Glówny Urząd Statystyczny (Bank of Regional Data, Main Statistical Office).

for the three levels of subnational self-government. Municipal, county, and regional levels cooperate-for example, in economic development policies-but in terms of specific service delivery, the separation is close to perfect. The situation is much more complicated in the relationship between the central and local government levels. In some cases (such as education or some social welfare benefits), nationwide regulations are so strict that local government's role is to a huge extent reduced to being an agent of central government and implementing central policies.

Municipal governments are protected by the Polish constitution, which offers them a general competence clause and specifies that a procedure to change municipal boundaries or liquidate a municipality must include public consultations (although the results of such consultations are not binding for the central government). Other tiers of territorial self-government are not named in the constitution, and their existence depends on laws adopted by the Polish parliament.

The constitution also defines basic rules of local government autonomy. It specifies that state supervision of their activity is limited to checking the legality of decisions made by local councils and local administration. It also specifies that local governments must have revenues adequate to their functional responsibilities and that new responsibilities must be accompanied by new sources of revenues. It also says that local governments have a right to set the rates of local fees and taxes, within limits established by the laws. 


\section{Local Elections: Council and Executive Bodies}

Local government councils of all three tiers are elected the same day for a period of four years. However, election rules differ slightly for different tiers.

On the municipal level, there are the following two systems:

1. In municipalities with no more than 20,000 inhabitants, there is a majority system, in which one to five councilors are elected in each ward. In practice, in most small local governments, there is one councilor per ward.

2. In municipalities with more than 20,000 citizens, there is a proportional representation system. Between 8 and 10 councilors are elected in each ward (until the April 2001 amendment 5 to 10 seats were allocated in a single ward), and seats are distributed among political organizations (usually parties) proportionally to the number of votes gained in a ward.

At the county and regional levels, a proportional representation system is also in place, but there is an additional threshold of 5 percent of votes (that is, parties that get fewer votes in the scale of the whole local government unit are not taken into account when seats in the council are allocated). The number of councilors is defined by law and depends on the population of the local government unit.

At all three levels, a council may be dissolved before the end of its term as a result of a local referendum. The referendum can be initiated by at least 10 percent of eligible voters in a municipality or county or at least 5 percent of eligible voters in a region. The turnout in the referendum must be at least 30 percent to be valid. It should be mentioned that other types of decisions might be made by the local community through a referendum.

Since 2001, local councilors must not be members of parliament, councilors in another tier of local government, or high-level executive directors of state or local government administration. There are also limitations on working in the local administration of a councilor's own local government unit.

All meetings of the council and of council committees are open to the public. Also, every citizen may have access to minutes and other written documents produced by the council and its committees.

Every council has a chairperson, whose role is to call meetings and chair them. Everyday council work is organized through commissions (such as those for education, economic development, and the like). The number, names, and sizes of commissions depend entirely on decisions made by each 
council. The only commission that is obligatory in every local government is the scrutiny commission (komisja rewizyjna). All political groups represented in the council must be represented in the scrutiny commission.

Each local government has its own executive board and its own administration. Until 2002, the councilors elected the head of the executive board. Such is still the case at the county and regional tiers, but at the municipal level, a mayor is directly elected by popular vote. The elected mayor may appoint his or her deputies.

In counties and regions, the executive board consists of up to five people (including the head), who are elected by the councilors. The head of the executive board may be elected from among the councilors or may be appointed from outside the council. (There is an assumption that in such a case, the head of the board is a management specialist rather than a politician, but it does not always work that way in practice.)

Two other important people in local government administration are the secretary and the treasurer. They both participate in the executive board meetings, but they do not vote. The secretary is usually responsible for the daily operation and supervision of the city (county, region) hall. Both are appointed by the council, but their names are suggested by the mayor.

The directly elected city mayor may be recalled (before the end of his or her four-year term) by referendum only; county or regional executive boards may be recalled by a council. Recent amendments of relevant laws make such an early termination of executive boards much more difficult. Such terminations now require a decision by the vast majority (three-fifths of all elected councilors) of councilors, and there are also restrictions on the frequency of no-confidence votes.

The internal organization of the local administration (the names and number of departments) depends entirely on local bylaws.

\section{Local Government Expenditure Responsibilities}

The reforms granted a wide range of functions to municipal governments and greatly shortened the list of county functions. The aggregate county budget is only a small fraction (about a quarter) of aggregate municipal budgets (see figure 9.1). The currency used throughout the chapter is the Polish zloty (Zl).

Such a division of functions is possible because of the relatively large size of municipal units in Poland. ${ }^{1}$ As seen in the preceding section, at the beginning of the 1990s, Poland, unlike many other countries in Central and Eastern Europe (such as the Czech Republic, Hungary, or the Slovak 


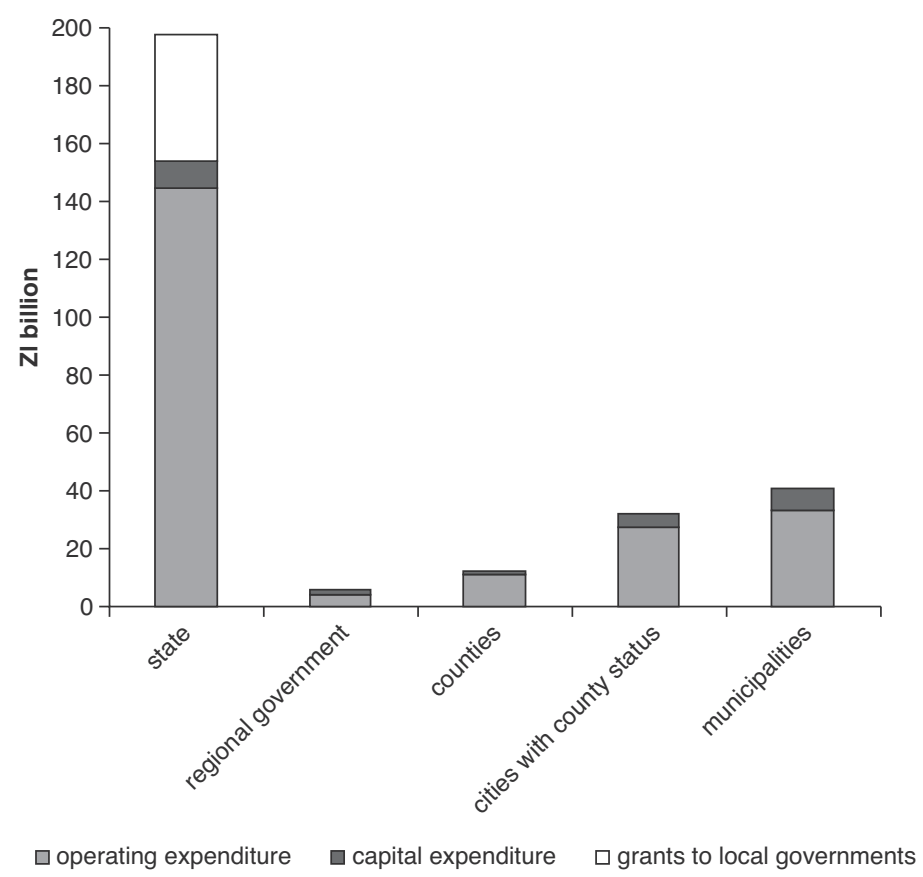

Source: GUS 2005.

Note: US\$1.00 = about ZI 3.20 .

\section{F I G U R E 9 - 1 Budget Spending by Tier of Government, 2004}

Republic), avoided radical territorial fragmentation. As a consequence, the average gmina has about 16,000 inhabitants in 125 square kilometers. Thus, a Polish municipality is quite big compared with others in Europe. Although it is much smaller (in terms of population) than Lithuanian, Swedish, or U.K. municipalities, it is similar to Danish, Dutch, or Norwegian ones and much larger than Czech, French, Hungarian, Italian, or Slovak, ones. Only a few Polish municipalities have populations under 2,000, and none have fewer than 1,000 inhabitants.

Data from 2002 show that local governments spend 10.6 percent of Polish gross domestic product (GDP), or 38 percent of total government expenditures. This level of spending is a clear increase from 5.5 percent of GDP and 16 percent of total government expenditure spent by local governments in 1991. Almost 77 percent of self-government budgets are spent at the municipal level (including big cities having county status), 18 percent at the county level, and only 5 percent at the regional level. The evolution of 
the role of local government spending in the Polish economy and in the public finance system is presented in table 9.2.

Polish municipal governments are responsible for providing a wide range of municipal services. They include water supply and sewage treatment; street cleaning, refuse collection, and waste disposal; local public transportation; street lighting; district central heating; maintenance and construction of local roads; maintenance of green areas; municipal housing; education services, including kindergartens and primary schools; culture, including local libraries and leisure centers; numerous services within the social welfare sector, including services for elderly, handicapped, and homeless people, as well as housing benefits; and physical planning and granting of building permits.

During the 1990s, there were two significant changes in the scope of functions provided by municipal governments. In 1993, extended functions were granted to the largest cities (mostly those exceeding 100,000 people), as a part of the so-called pilot program. With some amount of simplification, we may say that those functions were identical to those that are now provided by county governments (see the list below). The second change concerned responsibility for primary schools. In 1990, several factors (including fear of teachers' trade unions) caused a delay in transferring school responsibility to local governments. The transfer was delayed until 1994; until then schools were locally managed only in those localities that applied to do so. Later, the deadline for the schools transfer was delayed to 1996, when primary education (including financing teachers' salaries) was passed to municipal governments. The method of school financing is described in the following sections.

\section{TA B LE 9 . 2 Role of Local Government Finance in the National Economy}

\begin{tabular}{|c|c|c|c|c|c|c|c|c|}
\hline \multirow{2}{*}{$\begin{array}{l}\text { Spending or investment } \\
\text { spending as a percentage of }\end{array}$} & \multicolumn{4}{|c|}{ All subnational governments } & \multicolumn{4}{|c|}{ Municipalities } \\
\hline & 1991 & 1995 & 1999 & 2004 & 1991 & 1995 & 1999 & 2004 \\
\hline \multicolumn{9}{|l|}{ Total budget } \\
\hline expenditures & 16.3 & 19.0 & 38.0 & 39.1 & 16.3 & 19.0 & 30.5 & 31.9 \\
\hline Gross domestic product & 5.5 & 6.9 & 10.5 & 10.9 & 5.5 & 6.9 & 8.4 & 8.3 \\
\hline Total investments & 6.9 & 9.8 & 9.7 & 12.1 & 6.9 & 9.8 & 8.4 & 10.3 \\
\hline Total public investments & - & 17.6 & 25.8 & - & - & 17.6 & 22.3 & 一 \\
\hline Total budget investments & 42.6 & 53.5 & 62.5 & 63.0 & 42.6 & 53.5 & 54.0 & 56.6 \\
\hline
\end{tabular}


County governments are responsible for providing a number of services. These include secondary education; health care (only hospital and clinic buildings; the health care reform implemented with the 1998 local government reform created independent health authorities that are responsible for most medical operations); roads of county importance; several social services; labor offices (offices coping with unemployment); natural disaster protection; consumer protection; land surveying; and sanitary, building, and other inspections.

The role of regional self-government in direct delivery of services is very limited (although there are examples: higher education, maintenance and construction of main roads, organization of regional railway services). Regional governments are mostly focused on strategic planning and regional development programs.

All the functions enumerated above are treated as "own functions" of local governments. In addition, local government also performs functions that are delegated by the state-mostly administrative tasks such as birth and death registration, issuance of drivers licenses, and car registration. Delegated tasks are financed through separate specific grants, which in theory are sufficient to perform the tasks, although in practice local governments often complain that they need to subsidize the grants from their own revenue sources. Delegated tasks play a moderate role in municipal budgets (about 10 to 12 percent of total municipal spending) but are much more important in counties.

In municipalities, education (mostly primary schools) is the most significant current function. It constitutes nearly half of operating expenditures. Transportation (local road construction, bus and tram purchases) is the most important local capital expenditure. Capital expenditures on transportation have been rising steadily over the past few years, despite the decreasing size of total local government investments. Thanks to this trend, investments in transportation became the most significant part of capital budgets, supplanting communal services (water, sewerage, solid waste disposal, street lighting, and central heating), which dominated throughout most of the 1990s. The relatively low importance of communal services in operational spending requires additional explanation. A large proportion of current expenditures on these services is financed by user charges, which are collected by the municipal companies or in-house departments that provide services. These revenues are not reflected in local budgets. But for capital expenditures, subsidies from municipal budgets are much more common.

Education (secondary schools) is also a dominant function at the county level. Three sectors (county roads, health care, and education) 
consume similar shares of the counties' tiny capital budgets. Transportation is also the most expensive regional function.

Figure 9.2 illustrates the evolution of local government investment expenditures. It is worth stressing that municipal governments—-despite the drop in their investments during the past few years-remain the most significant public investors (their investments are considerably higher than those of the central budget). The decreasing slope of subnational investments was reversed only in 2004, to a large extent because of the increasing availability of European Union (EU) funds for local capital spending.

It is extremely difficult to discuss the effectiveness and efficiency of local service provision in general. Among almost 3,000 local government units, any one may have examples of both very efficient spending and resource wasting. But on average, the picture seems positive, and decentralization reform is commonly seen as among the most successful element of the Polish transformation. A good (although a bit simplistic) illustration is the progress in the development of local technical infrastructure, especially in rural areas. Although much remains to be done to reach the

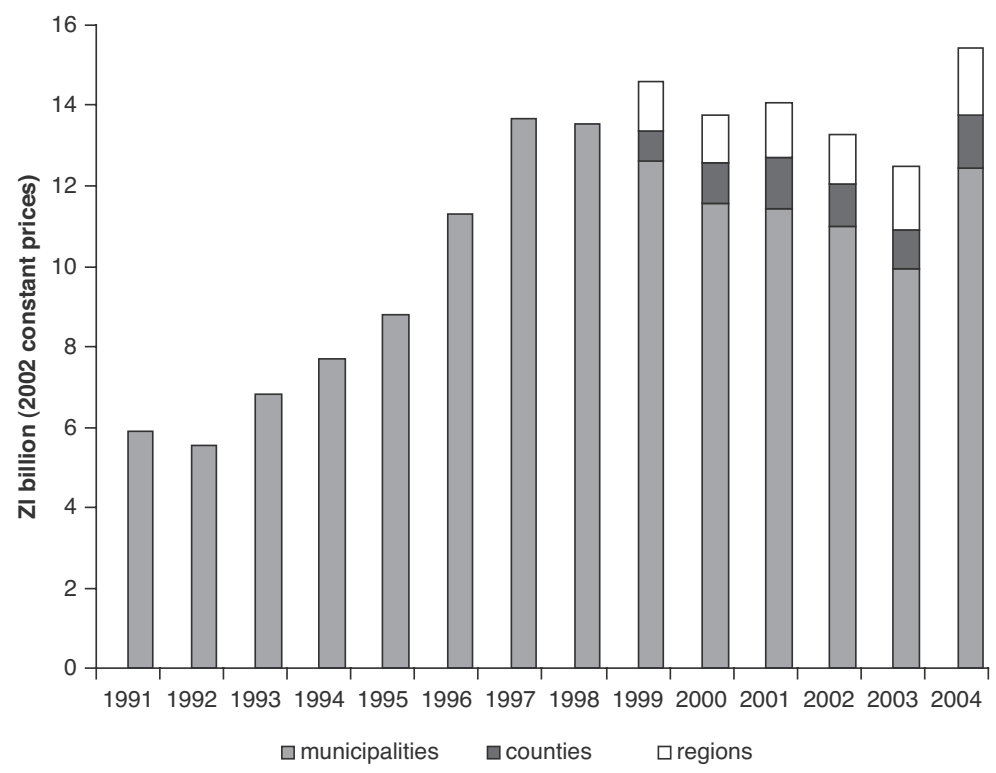

Source: Author's calculations based on financial reports of local governments. Note: US\$1.00 = approximately ZI 3.20.

FI G U R E 9 . 2 Local Government Investment, 1991-2004 
standard required in the European Union, local governments' progress over the past decade has been tremendous. During the first term of democratic local governments (1990-94) alone, the length of the water provision network increased by 58 percent, and the capacity of communal sewage treatment plants increased by 73 percent. Between 1990 and 1999, the number of rural households connected to a water, sewage, or gas network increased about threefold. Recent experiences with EU preaccession funds shows that the majority of local governments have been able to learn and implement complicated procedures required to take advantage of the opportunities that are arising. These simple data illustrate that most local governments are able to cope with management of the services that they are responsible for.

\section{Local Governments' Own Taxes and Charges}

Local governments in Poland are financed through a mixture of (a) local taxes and other own-source revenues, (b) local shares in central taxes, and (c) central general-purpose and specific grants. In this section, we concentrate on the first category of revenues.

The municipal government is the only tier of local government that has a limited power of taxation. Both county and regional governments are financed mostly by central general and specific grants, with a considerable contribution of shares in central taxes and a few very minor own-source revenues. One may even question whether this system of county and regional finance complies with the requirements of the constitution, which in article 168 states that "territorial self-government units have a right to set rates of local fees and taxes, within limits decided in the law." We return to this issue in the last section of the chapter.

The following local taxes are revenues of the municipal tier: property tax, tax on agriculture, tax on vehicles, forest tax, tax on dog owners, tax on civil legal activities, tax on legacies and donations, and tax on small businesses. With the exception of the last three (which are collected by the state tax administration), local taxes are administered and collected by the municipal administration.

The general rule is that the maximum rates of local taxes are decided in the central legislation, although local governments may set their own rates that are equal to or lower than the ceiling level. Local governments can also use other instruments of their own tax policies; these instruments are discussed later. 


\section{Property Tax}

Without doubt, property tax is by far the most important source of own local revenues. Both physical persons and legal entities must pay it. The most important items subject to the tax are (a) buildings or their parts, (b) plots of land that are not subject to agriculture or forest taxes, and (c) plots of agricultural land or forests that are used for commercial activity other than agriculture or forestry.

The general rule is that property tax is paid by the owner of the property (and not, for example, by the tenant of a flat). For most categories, the tax is paid per square meter. The only exception is made for "other architectural structures" (budowle, such as antenna masts, airports, and sewage treatment plants), for which the tax base is the value used for depreciating these assets. If the taxpayer does not depreciate the asset, the tax base is the market value. But this category provides an insignificant portion of revenues from property tax.

As mentioned above, the maximum rates are decided by the central legislation and are annually adjusted against inflation. ${ }^{2}$ For example, in 2003, the ceiling rates were $\mathrm{Zl} 0.51$ per square meter for housing and $\mathrm{Zl} 17.31$ per square meter for commercial buildings.

Local governments are responsible for property tax collection and administration. For individual taxpayers, the local government is obliged to deliver information on the amount to be paid (that is, the homeowner who has not received such information from the town hall does not need to pay). For legal entities, the taxpayer is obliged to calculate and pay tax regardless of whether such a notification has been received.

\section{Tax on Agriculture}

Tax on agriculture is the second most important local tax. The basic tax rate is defined centrally, but the local council may reduce the tax rate. The tax is typically paid by the owner of the farm or by the farmer who rents the farm. A farm is defined as an area larger than one hectare that is used as arable land, that contains a pond, or that contains a building used for farming activity. According to the tax regulations, it does not matter whether the area is actually cultivated or not.

The tax is paid per hectare, but the area is additionally weighted by the following factors: (a) quality of soil and (b) economic and climatic environment for farming activity. In practice this second factor is reflected by the farm's location in one of four major tax regions (Brzeszczyńska and 
Kaźmierski 1997). The rate for one (weighted) hectare is equal to the average market price of 250 kilograms of rye during the first three-quarters of the preceding year.

\section{Tax on Vehicles}

Tax on vehicles is paid to the municipal government where the taxpayer lives or, for companies, where the owner of the vehicle is registered. Until 1998, it was a significant source of local revenue because it was levied on every motor vehicle. But since 1998, the tax base has been limited. Now, the tax is levied only on owners of trucks with a load capacity over two metric tons, on owners of tractors and buses, and on owners of trailers with a load capacity over five tons.

For tractors, the rate of tax depends on the capacity of the engine; for trucks and trailers, it depends on load capacity; and for buses, it depends on the number of seats.

\section{Size of Revenues from Local Taxes}

There are theoretical arguments suggesting that own-source revenues (especially local tax revenues) should constitute a considerable proportion of local budgets. Such a situation supports local government accountability, exerts pressure on "value for money" in local policies, allows local fiscal policies to be adjusted to local preferences, and reduces an excessive demand for public spending. ${ }^{3}$ As illustrated by table 9.3, own-source revenues constitute a significant but over the past decade decreasing share of municipal revenues. There are two reasons for this diminishing role:

1. The scope of local tasks has been gradually increasing. The most important, but not only, change is related to local governments taking over responsibility for primary schools (the process that started in 1991 and finished in 1996). New functions were usually financed through new components of the general-purpose grant or sometimes through the increase in the local share in central taxes, but they were almost never financed by adding new sources to the list of local own-source revenues.

2. The local tax base has sometimes been weakened by the central legislation. The most salient example of such an occurrence was a change in the tax on vehicles legislation. Tax on private cars and motorcycles was abolished as a local tax and compensated for by an increase in the excise tax on petrol. The loss of local revenues was compensated for by a new component of the general-purpose grant. 
TA B LE 9 . 3 Structure of Revenues in Different Types of Local Governments, 2004

\begin{tabular}{lrrrrrr}
\hline & \multicolumn{3}{c}{ Municipal government } & \multicolumn{3}{c}{$\begin{array}{c}\text { Counties } \\
\text { (excluding } \\
\text { cities }\end{array}$} \\
\cline { 2 - 4 } Type of revenue & $\begin{array}{c}\text { Cities with } \\
\text { county status }\end{array}$ & $\begin{array}{l}\text { Other } \\
\text { cities }\end{array}$ & $\begin{array}{c}\text { Rural } \\
\text { municipalities county } \\
\text { status) }\end{array}$ & Regions \\
\hline Total (Zl million) & $32,179.7$ & $22,783.1$ & $17,524.8$ & $12,554.7$ & $37,04.6$ \\
Own source (\%) & 35.4 & 38.6 & 26.6 & 11.7 & 2.3 \\
Property tax (\%) & 13.8 & 18.6 & 13.1 & n.a. & n.a. \\
Shares in central taxes (\%) & 27.5 & 18.7 & 9.8 & 11.1 & 55.9 \\
General grants (\%) & 23.6 & 28.1 & 48.2 & 49.5 & 18.1 \\
Conditional grants (\%) & 13.5 & 14.5 & 15.4 & 27.7 & 23.7 \\
\hline
\end{tabular}

Source: Author's calculations based on financial reports of local governments.

Note: n.a. = not applicable. Local government revenues do not include (a) most fees and charges for local services, which are collected by budgetary enterprises or other service delivery units, and (b) local borrowing and privatization of municipal assets, which are accounted as "sources to cover budget deficit, defined as total expenditures - total revenues" (Law on Public Finance).

As shown in table 9.3, in small rural governments, the local tax base is usually weaker, while in midsize towns and cities, the largest proportion of the total budget comes from own-source revenues. Property tax is the only important source of revenue. Tax on agriculture brings significant revenues, but only in rural areas (almost 4 percent of total revenues). All remaining local taxes make up insignificant shares in local budgets, usually less than 1 percent. (Tax on civil legal activities, which has a 1.4 percent share in total revenues, is an exception, but tax on vehicles brings in only 0.7 percent of revenues, and all other local taxes are less than 0.5 percent.)

Compared with the situation in most other European countries, property tax revenues in Poland constitute a significant proportion of GDP (close to 1 percent). Although the share is considerably lower than in France, Spain, and the United Kingdom (especially if we include U.K. revenues from nondomestic rates, which do not constitute a local government tax), it is much higher than in most other European countries. It is more than twice as high as the share in the Czech Republic and about three times higher than in Hungary.

The importance of property tax is greatest in midsize cities; it is much less important in rural communities-especially the smallest ones (see table 9.3). The relatively low significance of property tax in the budgets of the largest cities (cities with county status) is a result of the strong domination of state grants in county revenues. 
TA B LE 9 . 4 Revenues from Physical Persons and Legal Entities, by Size of Local Government, 2000 (percentage of revenues)

\begin{tabular}{|c|c|c|c|c|c|c|}
\hline \multirow[b]{2}{*}{ Source of revenues } & \multicolumn{6}{|c|}{ Number of inhabitants } \\
\hline & $\begin{array}{c}\text { Fewer } \\
\text { than } 5,000\end{array}$ & $\begin{array}{l}5,000- \\
10,000\end{array}$ & $\begin{array}{c}10,000- \\
20,000\end{array}$ & $\begin{array}{c}20,000- \\
50,000\end{array}$ & $\begin{array}{l}50,000- \\
100,000\end{array}$ & $\begin{array}{c}\text { More than } \\
100,000\end{array}$ \\
\hline Individual taxpayers & 30 & 34 & 32 & 24 & 20 & 16 \\
\hline Legal entities & 70 & 66 & 68 & 76 & 80 & 84 \\
\hline
\end{tabular}

Source: Author's calculations based on financial reports of local governments.

Which categories of properties contribute to budget revenues in the most significant way? Unfortunately, we do not have precise information on revenues from housing properties, plots used for commercial activities, and commercial buildings. But we can make some estimations from data on revenues from physical persons (individuals) and from legal entities. The information is not precise because many small firms operate as physical persons, without legal entity status. But with a risk of some simplification, we may say that revenues from legal entities represent property tax paid on commercial activity, whereas revenues from physical persons represent property tax paid on buildings used for housing and on empty plots of land allocated for housing purposes. If we take into account the structure of property tax rates, it should not be surprising that the dominant share-about 80 percent of the total tax yield —of revenues comes from legal entities (that is, from properties used for commercial activities).

Revenues from legal entities are especially important in big cities, whereas in small communities revenues from individual taxpayers play a more significant role (table 9.4).

\section{Local Tax Policies}

In general, local governments may express their local tax policies in three different ways:

1. They can set local tax rates, within limits decided in the central legislation.

2. They can grant tax exemptions to certain categories of taxpayers, other than those listed in tax exemptions decided in the central legislation.

3. The local mayor can grant individual tax releases or reductions to individual taxpayers. 
In practice, most local governments levy taxes close to the maximum rates, but in some cases rate reductions are quite significant. For most local taxes, actual revenues are more than 10 percent lower than they would be if no rate reductions or tax releases were granted by the local government.

What is the significance of local tax policies? Property tax is the only local tax that might be important for businesses' location decisions. ${ }^{4}$ This tax also has significant political importance, because the tax rate on housing properties is often a hot issue in local communities. Hence, property tax policy is analyzed more carefully in the following section. In some rural local governments, debate over the rate of tax on agriculture is also of some political importance.

In every year since the beginning of the 1990s, actual revenues from property taxes have been more than 10 percent lower than would have been possible if no rate reductions or tax exemptions were granted by local councils and executive mayors. The results of reductions in tax rates are usually much more important (more than two-thirds of the total amount) than tax exemptions and individually granted tax releases.

There are important differences between tax policies implemented in small rural communities and those implemented in big cities. In general, tax rates are usually much lower in small municipalities. In big cities, rates are usually very close to the maximum, and the main instrument of property tax policy is related to tax exemptions and individual tax releases. These differences are illustrated in table 9.5. Until the end of 2003, small jurisdictions (fewer than 10,000 citizens) had an additional incentive to levy taxes at low rates: the reduction of revenues related to lowering rates was to a large extent compensated for in the equalization grant.

TA B LE 9 . 5 Results of Reductions, Exemptions, and Releases from Property Tax, by Size of Local Government, 2001 (percentage of maximum available revenues)

\begin{tabular}{|c|c|c|c|c|c|c|}
\hline \multirow[b]{2}{*}{ Result } & \multicolumn{5}{|c|}{ Number of inhabitants } & \multirow{2}{*}{$\begin{array}{c}\text { Cities with } \\
\text { county } \\
\text { status }\end{array}$} \\
\hline & $\begin{array}{l}\text { Fewer than } \\
5,000\end{array}$ & $\begin{array}{l}5,000 \\
10,000\end{array}$ & $\begin{array}{l}10,000- \\
20,000\end{array}$ & $\begin{array}{c}20,000- \\
50,000\end{array}$ & $\begin{array}{c}\text { More than } \\
50,000\end{array}$ & \\
\hline Overall reductions & 20 & 21 & 19 & 14 & 8 & 8 \\
\hline Results of rate reductions & 15 & 16 & 13 & 9 & 4 & 3 \\
\hline $\begin{array}{l}\text { Results of tax exemptions } \\
\text { and tax releases }\end{array}$ & 5 & 5 & 6 & 5 & 4 & 5 \\
\hline
\end{tabular}

Source: Author's calculations based on financial reports of local governments. 


\begin{tabular}{|l|l|l|l|}
\cline { 3 - 4 } \multicolumn{2}{c|}{} & \multicolumn{2}{|l|}{ Taxes relating to business activities } \\
\cline { 3 - 4 } \multicolumn{2}{|l}{$\begin{array}{l}\text { Taxes affecting } \\
\text { most of voters }\end{array}$} & Low & High \\
\cline { 2 - 4 } & High & Conservative & Populist \\
\hline
\end{tabular}

Source: Swianiewicz 1996.

a. Conservative in terms of fiscal policy. An alternative label might be liberal, but because of different meanings of this label, I suggest using the term conservative.

\section{F I G U R E 9.3 Typology of Local Tax Policies}

We know also that in small local governments, property tax reductions are more often offered to individual taxpayers, whereas in big cities, tax policy instruments are more often focused on legal entities and their commercial activities.

From the political economy point of view, one may distinguish between two types of local taxes in Poland:

1. Taxes paid by most local voters (property tax on housing and, in many rural governments, tax on agriculture)

2. Taxes levied on local businesses (property tax on buildings and plots used for business activity and tax on trucks and buses).

Taking into account this distinction, we might classify the tax policies as in figure 9.3. If local taxes on businesses are high but taxes on voters are low, such a policy may be called populist, because the main rationale is to seek the support of voters. But sometimes the opposite is true-taxes affecting most voters are relatively high, but taxes on businesses are kept at a low level. Because such a tax structure is generally used to stimulate the local economy, we might call this type of policy stimulating.

Lower rates of local taxes are often found in small local governments. It is interesting to note that although populist types of policies are more typical for small, rural villages, stimulating policies are identified more often in midsize urban governments. ${ }^{5}$ This observation is based on research conducted in 1995 (Swianiewicz 1996), but more recent analysis (Pszczola 2003) seems to confirm the most important conclusions.

\section{Fees and User Charges}

User charges, such as for kindergartens, water provision, wastewater, solid waste collection, and public transportation, are usually collected by the 
servicing unit, with or without the mediation of the collector. Quite often these revenues are not shown in the municipal budget, because they are kept by the delivery unit (the budgetary unit, a municipal company) and used to cover the costs of service provision. In some cases, local government may subsidize these services or the local budget may receive the surplus, so what can be found in the budget is simply a balance of charges collected and amounts spent on actual delivery. For some services (for example, solid waste collection), the local government may also set a maximum rate or the charge that the private provider may collect.

During the past decade, local governments and local delivery organizations have been gradually gaining more discretion over fees and charges for services. The present situation in the most important services may be summarized in the following way:

City transportation. The local council decides on the price for tickets. Private competitors (if they exist) are free to decide on their own tariffs.

Water and sewage. The local council decides on the price on the basis of general rules set by the central government. ${ }^{6}$

Central heating. The price is set by the entity delivering the service, on the basis of general rules set by the government. Prices are subject to control by the Office for Energy Regulation.

Waste collection and disposal. Tariffs are negotiated between the provider and the client. The local council may decide (but until now has rarely done so) on the maximum price per unit.

- Rent in communal housing. The local council decides on rent levels on the basis of general rules set in the central legislation. In practice, for political reasons, the council decides to set rent below the real cost in most cases (with some exceptions).

Most other services. The price is freely negotiated between the providers and the client.

\section{Local Taxes in Poland: An Evaluation}

The future of the most important local tax - property tax - is a subject of debate. There are two important lines of criticism of the present system. One stresses that the tax in its current form does not raise sufficient revenues, especially in big cities. The other focuses on the fairness of the tax. These critics find it unfair that the tax depends on the type and area of the property rather than on its value. They ask why the owner of a poor village house in the countryside, far from any urban center, should pay the same tax 
as the owner of a similar-size but many times more valuable house in the center of Warsaw.

The most typical conclusion from both lines of criticism is that a reform is needed leading to an ad valorem property tax. Typically, U.S. Agency for International Development (USAID) and World Bank advisers have agreed with this assessment during the past decade. The Ministry of Finance prepared a draft of new regulations for an ad valorem property tax, which was approved by the government in 1995 (Nowecki 1996). But a negative public reaction has since halted preparation for the reform. Most people are afraid that the new tax will significantly increase their tax burden. In a 2000 survey by the Center for Public Opinion Research, 31 percent of respondents declared that the new property tax regulations would be less fair than the current ones, while only 27 percent expressed a positive opinion on the fairness of the new tax. Some 29 percent of respondents expected that the reform would negatively affect them, while only 4 percent expected a positive change (Kasperek 2002).

Both the negative public reaction and technical difficulties have slowed the pace of reform significantly, although ad valorem property tax remains an official long-term goal of the government. But nobody expects that the reform will be introduced quickly, and the actual date remains unknown. Introducing the new tax will be a long and costly process, which will require the valuation of many thousands of properties.

An alternative short- or medium-term solution might be based on a variation in the maximum rate depending on the location of the property (for example, different maximum rates for rural villages and for big cities, as well as different rates in the city center and in the suburbs). The first step toward such a change has been taken in a recent amendment that allows the local government to differentiate the actual tax rate depending on the location of the property in an individual zone of a city. However, this first step is not sufficient, because maximum rates remain at the same level for the whole country. A solution similar to that discussed here has been applied in the Czech Republic and in the Slovak Republic. For example, in the Slovak Republic (see Kling, Niznansky, and Pilat 2002), the maximum rate per square meter depends on the size and function of the settlement unit, which to a large extent reflects the variation in the value of land and properties.

It should be remembered, however, that in both the Czech Republic and the Slovak Republic the overall capacity of the property tax is a few times lower than in Poland. The suggested alternative solution might combine the relatively high overall fiscal capacity of the current property tax in Poland with the approach to variation of tax rates adopted in the current Czech or Slovak regulations. 
How can the Polish local tax system be assessed against theoretical "fiscal federalism" criteria (see Swianiewicz 2003a)?

The allocation of tax yields is not proportional to the allocation of functions. The negative assessment applies primarily to the situation of county and regional governments, which do not have their own tax revenues. The situation is much better on the municipal level: the ratio of own-source revenues to total budget revenues is somewhat lower than in some western European countries (such as Denmark and Sweden), but similar or even higher than in most others (such as the Netherlands, Spain, and the United Kingdom). A negative aspect, however, is the gradually diminishing role of own-source revenues in municipal budgets. Such revenues constituted about 47 percent of total budget revenues in 1992 but were down to 40 percent in 1995 and were only 33 percent in 2001.

- The geographic distribution of the tax base is uneven. There are significant differences in distribution of the local tax base. In 2001, own-source revenues constituted well over 40 percent of budgets in cities but just over 20 percent of budgets in rural areas. If we take into account inequalities between regions, the variation is even larger. But probably this level of inequality is inevitable regardless of the selection of local taxes.

The system of local taxes is fragmented and complicated. There are many small local fees and taxes (such as a tax on dog owners) that do not raise significant revenues but are costly to collect and unnecessarily complicate the system.

Taxation is well defined in terms of geographic space. Polish local taxes do not produce major problems in this respect. If we take into account tax sharing, there are problems with defining the local share of corporate income tax from companies that are registered in one municipality but operate branches in various locations. A partial answer to this problem is provided by a regulation that suggests allocating tax revenues to municipalities in a way that is proportionate with the number of employees working in each local branch, but this solution is far from perfect. ${ }^{7}$

Most local taxes are visible.

- The elasticity of tax yields against inflation is low. Property tax, tax on vehicles, and small local fees and taxes are not elastic against inflation. Perhaps the only exception is a tax on agriculture that is related to the market price of crops.

The tax base is relatively immobile. This principle is definitely followed by the property tax, which is by far the most important tax levied by local government. 
Recommended changes should be in the following two directions:

- They should simplify the system. This recommendation could lead to the elimination of tax on dog owners and perhaps some other minor local fees and taxes.

- They should strengthen the local tax base (perhaps at the expense of tax sharing), first at the county and regional levels but then at the municipal level.

It is necessary to stress that the overall level of tax burden for citizens and enterprises should not increase as a result of the reform. The reform of local taxes can never be discussed in the abstract, in the context of the broader change in public finance in general. If the overall burden of local taxes increases, it must be compensated by the reduction of some central taxes. Note that such a scenario would not lead to an additional burden at the central level, because strengthening the local tax base would enable reductions in state transfers, which should focus on a principle of equalization, rather than a general vertical equalization.

Finally, it should be stressed that such a positive evolution is not very likely. Most discussions and lobbying of local government organizations are focused on securing additional funds for local governments through the taxsharing system rather than on extending local taxation powers.

\section{Shared Taxes}

In the official budget classification and reporting, revenues from shares in central taxes are treated as part of own-source revenues. However, because local governments have no direct discretion to influence these revenues, this classification cannot be accepted; therefore, shares are discussed separately here. ${ }^{8}$ In fact, tax sharing has some negative consequences, typically for ownsource revenues (because it contributes to increased disparities between poor and rich jurisdictions). Moreover, it lacks positive features, such as stimulating local government accountability. Nonetheless, extending the tax-sharing system has been the main direction of reforms discussed and implemented in local government finance.

Two main income taxes-personal income tax and corporate income tax-are collected by the treasury office. Fixed shares are then transferred to the local government units. The Law on Local Government Revenues, enacted in November 2003, considerably increased the proportion transferred to municipalities, counties, and regions. Its effects are illustrated in table 9.6. 
TA B LE 9.6 Shares of Local Governments in Revenues from Personal and Corporate Income Taxes

(percent)

\begin{tabular}{lrrrrrr}
\hline & \multicolumn{2}{c}{ Personal income tax } & & \multicolumn{2}{c}{ Corporate income tax } \\
\cline { 2 - 3 } \cline { 5 - 6 } Level of government & 1999-2003 & Since 2004 & & 1999-2003 & Since 2004 \\
\hline Municipality & 27.6 & 39.34 & & 5.0 & 6.71 \\
County & 1.0 & 10.25 & & 0 & 1.40 \\
Region & 1.5 & 1.60 & & 0.5 & 15.90 \\
\hline
\end{tabular}

Source: Author's calculations based on financial reports of local governments.

A few features of the tax-sharing system are worth stressing. These features distinguish it from tax-sharing systems in several other transition countries:

There is no territorial redistribution mechanism; that is, shares feed the budgets of local governments on whose territory the tax has been collected. A horizontal redistribution mechanism was in place for allocating personal income tax shares at the beginning of the 1990s, but it was liquidated in $1998 .^{9}$

- Unlike in some other countries in Central and Eastern Europe, the personal income tax is residence based (that is, it goes not to the jurisdiction in which one is employed but to the one in which one lives). It is paid by the vast majority of the adult population, regardless of whether they are paid workers, pensioners, or self-employed. Private farmers constitute the only large group that is exempt from personal income tax.

- The share that each tier of local government gets is decided in the Law on Local Government Revenues. Shares have been relatively stable for several years and are not subject to decisions made under the annual budget law.

In theory, the corporate income tax is a poor candidate for local government revenue, because it is often difficult to determine which authority is entitled to the yield exacted from each taxpayer. ${ }^{10}$ Many companies have branches in various regions, or their headquarters may be located in a different jurisdiction than that in which goods or services are actually produced. Hence, when an enterprise has activity in many localities, revenue from corporate income tax is shared among those localities in a way that is proportionate to the number of people employed in each jurisdiction. 


\section{Grants to Local Governments}

Several theoretical arguments are frequently quoted for the existence of state grants to subnational governments (for their review in a Central and East European context, see Swianiewicz 2003a). It is very difficult to say which of these arguments has been most important in the formation of the contemporary grant system, because they have never been clearly spelled out by politicians. We can only try to guess from the general tone of discussions that have been carried out during different stages of the decentralization reforms.

Securing minimal standards of important services has played a very important role in the design of the system. This argument is sometimes closely connected with the horizontal equity argument. Minimum standards are definitely at the heart of such important elements of the grant system as the education grant received by all tiers of self-government and- to a lesser extent-other parts of the general-purpose grant (discussed below). Also, the logic behind the equalization grant follows the same argument.

Certainly the argument for stimulating spending for preferred merit goods is favored by sectoral ministries, and it has been behind the quick development of special-purpose grants. (Sectoral ministries were especially successful in reaching this goal in 1998, when the system of financing county and regional governments was formed.) But such a goal has never been intentionally formulated by any governments; instead it has been a side effect of the strength of central bureaucracy. The other arguments, such as reducing spillover effects and increasing location efficiency, were hardly present in public discussions and cannot be considered significant for the Polish system.

But probably vertical equity has been the single most important argument. The revenue power of local governments is not sufficient to cover the expenses necessary to provide the compulsory functions that are allocated to subnational tiers. This problem occurs not only in certain geographic areas (which is inevitable, because the tax base is always unevenly allocated across the country regardless of which revenues are defined as local taxes) but also on an aggregate level. So-called own-source revenues are not sufficient to cover the minimal needs related to functions performed even in relatively affluent local governments. There are only a few exceptions to this rule. In such circumstances, the role of grants is simply to support the local revenue base.

This function of the grant system has been more and more visible throughout the past decade. At the beginning of the 1990s, a relative balance existed between the revenue power and the scope of functions of 
municipal governments. But several functions have been transferred to local governments since then, with almost no parallel increase in the scope of local own-source revenues. Instead, new functions were financed through the grant system. The most powerful example of this phenomenon is a transfer of responsibility for primary schools. This function, which in some local governments consumes more than half of the total budget, is meant to be financed first and foremost by the general-purpose grant. When responsibility for the schools was transferred to the municipal level, the amount of the grant increased significantly, and the share of ownsource revenues in the total municipal budget decreased significantly.

Moreover, the typical compensation for a loss of own-source revenue source has also been an increase in the general-purpose grant (instead of an alternative local tax or an increase in the capacity of existing own-source revenues). The elimination of tax on passenger cars is a good example of this process. Similar exemptions from local taxes introduced by the parliament have been compensated by the grant system. As we will see in the following sections, since 1999 there has even been a separate part of the generalpurpose grant, called the compensating part. Interestingly, despite the official own-source revenues ideology, local governments and their national associations have usually not protested such a change in the revenue structure, provided that the grant compensation was sufficient to cover the financial loss of own-source revenue power. From a political point of view, a high dependence on intergovernmental transfers may be sometimes more convenient for local politicians. Such a dependence makes it possible to avoid unpopular decisions such as a local tax increase; resultant reductions in local services may be more easily blamed on central government.

As may be seen from the discussion above, the actual role of the grant system is both a result of consciously formulated purposes and (to some extent) the spontaneous development of the financial system, influenced by various actors with their specific interests.

The most fundamental aspect of the system of grants to local governments is the distinction between general-purpose (subwencja) and specific (dotacja) grants. According to the Law on Revenues of Territorial SelfGovernments, each local government receives the general-purpose grant. Among specific grants, there is a meaningful distinction between grants that are a source of local revenue and grants that can be the source of local revenue. The first are received by each local government; the second are received by some governments only. Details of the grant system are discussed in the following sections. 
Apart from tax sharing, the system of general-purpose grants is the part of the local revenue system that has been the most significantly changed by the November 2003 regulations. After a brief description of the current system, we present a brief conclusion, including an assessment of the direction of changes.

\section{General-Purpose Grant from 2004}

In November 2003, following changes in the shares in revenues from central taxes, the Law on Local Government Revenues was passed. The law made significant changes to the general-purpose grant system. In general, the changes go in two directions: (a) enlarged shares lead to larger inequalities in the local revenue base, so the new grant scheme provides more radical equalization; and (b) the new system tries to incorporate more factors related to expenditure needs.

The general-purpose grant consists of the following four major parts:

1. A part dedicated to education

2. An equalizing part

3. A balancing part (równoważqaca), for municipal and county governments

4. A regional part, received by regional governments.

As shown in table 9.7, the shares of the four parts are not equal. The education part of the grant plays by far the most important role, while the balancing and regional parts are the smallest pieces of the pie. The new system is described briefly below.

\section{Education part}

Unlike the situation in 1999-2003, the total amount of the new education grant is not defined by the Law on Local Government Revenues, but is decided by the Annual Budget Law. ${ }^{12}$ This change reduces the predictability of local government budgets and opens the possibility of bargaining every year. The law does not determine the precise criteria for allocation, but it delegates this task to an ordinance to be issued by the Ministry of Education. The law gives only general instructions, suggesting that the formula should take into account the number of pupils attending schools located in a given jurisdiction, the types of schools, and the formal qualifications of teachers (which influence level of their salaries). The law further specifies that the grant should not take into account needs related to transporting pupils to 
TA B L E 9 . 7 Structure of the General-Purpose Grant, 2004 (percentage of total grant)

\begin{tabular}{|c|c|c|c|c|c|}
\hline Part & Total & Municipalities & $\begin{array}{l}\text { Cities with } \\
\text { county } \\
\text { status }\end{array}$ & Counties & Regions \\
\hline Education & 81.5 & 76.4 & 98.0 & 83.2 & 36.6 \\
\hline Equalizing & 14.7 & 21.3 & 0.6 & 10.3 & 39.6 \\
\hline Balancing & 2.3 & 1.3 & 1.4 & 6.5 & 0 \\
\hline Regional & 1.0 & 0 & 0 & 0 & 23.8 \\
\hline $\begin{array}{l}\text { Payments related to parts } \\
\text { of the grant liquidated } \\
\text { after } 2003\end{array}$ & 0.5 & 1.0 & & & \\
\hline Total & 100.0 & 100.0 & 100.0 & 100.0 & 100 \\
\hline
\end{tabular}

Source: Author's calculations based on financial reports of local governments.

local schools and the number of children in kindergartens (which are supposed to be financed from own-source revenues and other elements of the general-purpose grants).

The algorithm used for allocating this grant is subject to some changes almost every year. The changes are discussed by the Joint Central-Local Government Commission, in which major local government organizations are represented. Basically, the bulk of allocation is based on the weighted number of pupils attending schools in a given locality (which is not necessarily equal to the number of pupils living there). For example, in 2004, the most important weights included the following:

1.48 for pupils in rural local governments. This weight was higher than it should have been, according to a comparison of spending needs in urban and rural areas, and therefore it had an equalizing effect on local revenues. What is controversial is that the weight is identical for all rural areas, despite differences in population density or other factors influencing real spending needs.

1.25 for pupils in small towns (up to 5,000 inhabitants). The ministry argues that although unit costs in small towns are not higher than in the larger cities, this weight is justified by the government's priority to support the development of small towns.

1.50 for pupils with disabilities attending special schools, and 1.25 for pupils with disabilities attending regular schools. 
1.20 for schools where national minority languages are taught.

1.15 for most vocational schools.

Until 2000, the local government was obliged to subsidize nonpublic schools in amounts not lower than 50 percent of the normative per pupil cost in the public school (the subsidy for nonpublic schools might be higher if the local council chose), but since 2001, the subsidy to nonpublic schools has been equalized with that paid to schools run by local governments.

\section{Equalizing part}

The equalizing part consists of two elements: the basic element (podstawowa) and the supplementary element (uzupelniajqca). Basic equalization is related to per capita revenues from local taxes and shares in revenues from central taxes.

B A S I C E L E M E N T. For municipalities, the basic element is received by local governments whose per capita revenues from own-source and shared taxes are lower than 92 percent of the national average. The law takes into account the revenues that would be collected if maximum tax rates were applied by the local government and no tax exemptions were granted. In that way, the equalization formula refers to the local tax base and is neutral from the point of view of local tax policies. The equalization is not complete, but the scale is progressive. For units in which actual revenues per capita are between 75 and 92 percent of the national average, the scheme provides 75 percent of the difference to a threshold level of 92 percent. However, for municipalities with revenues between 40 and 75 percent of the national average, the scale of equalization grows to 80 percent of the difference, and for the least affluent units (below 40 percent of the national average), it grows to 90 percent of the difference.

So, for example, for a unit with own-source and shared per capita revenues equal to 30 percent of the national average, the basic equalization formula is as follows:

$$
[(40-30) \times 0.9]+[(75-40) \times 0.8]+[(92-75) \times 0.75]=49.75 \text {. }
$$

Consequently, such a municipality would receive a basic equalizing grant per capita equal to 49.75 percent of the national average of local and shared taxes per capita.

For counties, the calculation is very simple. The grant is received by every county with per capita shared revenues lower than the national average. The county is compensated for 88 percent of the difference from the average level.

Regions with shared (per capita) revenues below the national average are compensated for 70 percent of the difference from the average. However, this scheme applies only to regions with a population of fewer than 3 million. 
It is very difficult to find any rational explanation for this limit. Its practical consequences are minimal: at the moment there are only three regions with larger populations, and all three are relatively affluent. But-as we will see later-the absolute population size is applied also in other parts of the regional grant scheme in a way that promotes smaller units. This preference for smaller jurisdictions contradicts official government policy (supported by several experts' opinions), which says that territorial organization requires further consolidation, rather than fragmentation. In the present system, it may sometimes be beneficial (in terms of the amount of grants received) to split one big region into two smaller ones.

S U P P L E M E N T A R Y E L E M E N T. For municipalities, this additional element is received by local governments that meet the following criteria:

Their per capita own-source and shared taxes are lower than 150 percent of the national average. ${ }^{11}$

The population density on their territory is lower than the national average.

The assumption behind these criteria is that the unit costs of several services are higher in sparsely populated regions (for example, transportation of pupils to local schools or maintenance of local roads). The precise formula relates this element of the grant to the difference between population density in the municipality and the average population density.

In counties, units with high levels of unemployment (more than 110 percent of the national average) qualify for this part of the transfer. The amount of the transfer is calculated on the basis of the formula, which progressively takes into account the actual unemployment rate in the local government.

For regions, this element is a per capita supplement, but it is constructed in a way that favors regions with populations less than 2 million, disfavors those with populations greater than 2.5 million, and excludes regions with more than 3 million inhabitants.

\section{Balancing part}

Although the equalizing part of the general-purpose grant represents vertical equalization (that is, it is financed by the state budget), the balancing part introduces horizontal equalization between local governments. For municipalities, it is financed by payments made by local governments whose per capita local and shared taxes are higher than 150 percent of the national average. Such municipalities pay to the balancing fund 20 percent of the "surplus" over 150 percent of the average. The richest governments (with per capita revenues higher than 300 percent of the national average) pay 30 percent of the surplus. 
As with the education part, the law does not provide a clear picture of the grant allocation of the balancing part; instead it delegates precise regulations to an ordinance to be issued by the Ministry of Finance. The law says only that the formula should take into account needs related to social welfare services and, in particular, to housing subsidies paid to the poorest tenants.

As for municipalities, the balancing part introduced horizontal equalization between local governments at the county level. But for counties, the "Robin Hood" type of payment is much more severe. Counties with revenues higher than 110 percent of the national average pay as much as 80 percent of their surplus. For those with revenues higher than 120 percent of the average, the scale rises to 95 percent, and for those with revenues higher than 125 percent of the average, it rises to 98 percent. As a result, the level of equalization is very high - much higher than for municipalities. The precise allocation of the balancing grant is decided by the ordinance of the Ministry of Finance, and the formula takes into account needs related to social welfare services and road maintenance.

\section{Regional part}

The regional part tries to introduce elements of the government's regional policy into the general-purpose grant scheme. As with the balancing part described for municipalities and counties, the regional part is based on horizontal equalization — that is, financed through payments made by the most affluent regions. The scale of payments is not as progressive in regions as it is in the counties, but it is more progressive than in the municipalities. Regions in which per capita revenues from shared taxes are higher than 110 percent of the national average pay 70 percent of the surplus, whereas for regions with revenues higher than 170 percent of the national average, the rate of this Robin Hood tax rises to 95 percent.

The amount collected is allocated in the following ways:

20 percent is allocated among regions with unemployment rates higher than 110 percent of the national average.

- 10 percent is allocated among regions with GDP per capita levels lower than 75 percent of the national average.

40 percent is allocated among regions with higher than average density of regional roads.

30 percent is allocated following the Ministry of Finance ordinance, which takes into account needs related to regional rail passenger transportation. 


\section{Special-Purpose Grants}

In talking about special-purpose grants, we need to distinguish between three basic types: grants for current spending on tasks delegated to local government administration, grants related to current expenditures on local government functions, and specific grants for local government investments.

\section{Grants for current spending on tasks delegated to local government administration}

The only relevant regulation in the Law on Local Government Revenues is that the amount of these grants should be calculated in the same way as similar expenditures of the central government administration. Not surprisingly, this imprecise regulation was not sufficient to prevent several disagreements between central and local governments. Local governments frequently complain that many of the functions that are delegated to them are underfunded and that grants received are hardly enough to cover even the salary costs of required personnel. Therefore, a delegation of new functions has sometimes been seen as a method to decentralize budget problems. The central government usually defends its position by saying that similar amounts were sufficient for the provision of services before services were passed to local governments and that decentralization should lead to some efficiency gains and related savings in necessary spending. (Local governments themselves made this argument many times in general discussions about the scope of decentralization, but in case of disagreements over the amount of grants it works against its proponents.) What the central government fails to add is that, although it spent a similar amount before, the amount was often not sufficient to prevent arrears in payments. Sometimes the central government was also cheating with inflation: for most of the past decade the inflation rate was underestimated in official predictions, which also provided an occasion to "save" something on grants for delegated tasks.

As a consequence, local governments quite commonly "subsidize" delegated functions by using their own revenues or resources from generalpurpose grants that are supposed to support the provision of their own municipal functions. Grants on current spending related to delegated tasks are the most important in the revenue structure of county governments, where they constitute more than a quarter of total revenues (see data presented in the section on local government own-source taxes and revenues). On a municipal level, their importance is more limited, although still quite significant. In cities with county status, such grants constituted 14 percent of total revenues in 
2000. Their significance is the lowest for regional governments, in which their contribution to the overall budget in 2000 was just under 4 percent.

\section{Grants related to current expenditures on local government functions}

This category is probably the most difficult to describe, because the regulations are extremely fragmented and unclear. Grants related to various functions are regulated by several sectoral acts (related to education, social protection, housing, and so forth). Only in a minority of cases do the regulations clearly define the amount of the grant and how it should be allocated among individual local governments. The grant to support housing benefits for poor tenants is a good example of a clear regulation, although even in this case, bargains and discussions over the methodology and accuracy of government calculations cannot be avoided. In most other cases, the central bureaucracy has high discretion to make a decision, and not surprisingly, the final allocation is the result of a bargaining process between central and local governments.

However, at the beginning of the decentralization reform, there was an assumption that specific grants for local government functions should be the exception rather than the rule, and that local governments should be financed mostly by their own revenues and the general subsidy (which is based on clear, transparent criteria). This assumption was fulfilled during the first few years of the past decade. In 1991, this category of grants provided just 0.3 percent of total revenues, and the share in 1994 was still very similar. But in the second half of the decade, the system of financing gradually was spoiled. Currently, the share of specific grants for current spending in municipal governments is more than 3 percent of total revenues. It is characteristic that the change was not due to a change in official policy. It was rather a result of incremental changes-a series of small victories by the central sector bureaucracy, which would like to exert more strict control of the local government spending structure. Compared with the initial assumptions of the authors of the decentralization reforms, the share of this category of revenues in county and regional budgets is disastrous (well over 10 percent).

\section{Specific grants for local government investments}

This part of the grants is the most regulated in local government legislation, although its allocation criteria are still far from transparent. Until 2000, grants for investments were distributed by wojewodowie (regional governors) after consultation with the elected regional council (sejmik wojewodzki). 
Allocation between regions and among wide sectors of budget classification was decided in the annual state budget. The criteria for allocating this type of grant were neither stable nor clear. Normally, the investment grant cannot exceed 50 percent of the total investment cost; however, there are some exceptions to this rule. For example, if municipal revenues are lower than 60 percent of the national average or if the municipality is located in a region on a government list of regions affected by structural unemployment, then the investment grant may be up to 75 percent of the total investment cost.

Despite some efforts to standardize and clarify the allocation criteria, much still depended on the decisions of individual governors. There was not even any consensus on the main criterion. To what extent should the allocation of capital grants be based on the historical and predicted effectiveness of individual local government investments? Should it be allocated first and foremost to localities with the poorest infrastructure and the highest investment needs? Or should it be distributed on a per capita basis or another similar method? In such circumstances, as one might suspect, it was very difficult to find any clear pattern in the actual allocation. There was no significant correlation between capital grants received and the affluence of local communities and local governments, so the distribution had no equalizing effect. There was also a lack of clear regional patterns- that is, it was not that poor regions were getting more or less (per capita) capital grants. The regional distribution was not even either, but looked chaotic and subject to fluctuations in time that were difficult to follow. One might hardly expect that the efficiency criteria were the most significant, because there was no agreed-on methodology for assessing the economic consequences of past investments, and cost-benefit analysis methods (such as calculation of net present value or internal return rate) were not commonly known and were rarely applied to planned, future investments.

The main change came in 2001. Since then, the investment grant can be allocated only to investments that were specified in the regional development strategy and that are related to goals formulated in the regional contract (signed between the regional self-government and the central government).

At the beginning of the past decade, capital grants were much more important than grants for current expenditure, and authors of the reform assumed that they would be the main (and, with some limited exceptions, the only) type of specific grants. In 1991, capital grants constituted more than 1 percent of total municipal revenues, and in 1994, they constituted more than 3 percent. However, recent developments challenged this assumption. During the past few years, capital grants to municipal governments decreased 
in both absolute and relative terms, and in 2000, they were more than twice as low as grants for current spending on local government functions.

In the middle of the past decade, the share of central government capital grants in total municipal government investments was just below 20 percent, but later it dropped, and in 2000, it was between 10 percent (in urban local governments) and 12 percent (in rural areas). However, such grants remain the major source of capital investments by the higher tiers of government-more than 50 percent in counties and more than 80 percent in regions.

Last, but not least, it should be added that investment grants from the state budget are not the only form of state support for local government capital spending. Another, perhaps even more important, form is provided through national special-purpose funds. The most significant funds are a national fund for environmental protection and 16 regional funds for the same purpose. Environmental protection funds provide support for local governments in the form of both grants and preferential (subsidized) loans (see Kopańska and Levitas 2004).

The new element of the puzzle is the increasing importance of EU funds in financing local government investments. Preaccession and later structural and cohesion funds became significant in 2002, and their role has been gradually increasing. In 2004, EU funds constituted more than 20 percent of the investment spending in rural municipalities, about 17 percent of that in counties, and close to 10 percent of that in regions and the largest cities (Swianiewicz 2005). It is expected that their share may become even larger in the next few years.

\section{Grants Mechanism Reassessed}

In reassessing the grants mechanism, we can identify both strengths and weaknesses. The strengths include the following:

Allocation of the general-purpose grant is based on a formula that depends on objective and easily measurable criteria. Therefore, the system is not influenced by subjective decisions of bureaucrats or political clientelism. It helps build real, not just nominal, autonomy of local policies.

- The basic formula allocation has been pretty stable in recent years. The changes that were introduced had rather marginal meaning. Coupled with the objective criteria mentioned above, this characteristic of the allocation provided stability to local finance and allowed local governments to make long-term financial forecasts. 
In all municipal governments, the grant mechanism takes into account the local tax base, not the actual revenues; consequently it is neutral from the point of view of local tax policies.

Nevertheless, the grants mechanism has several weaknesses, which include:

The relationship between the allocation formula and spending needs is not sufficient. The equalization mechanism mostly equalizes revenues, with very limited attention to equalizing spending needs or unit costs. Disregard for spending needs in big cities was a good example of this phenomenon. Only in the case of the education subsidy were varied spending needs considered. That subsidy gives higher weights to rural schools, although without distinction between very different categories of rural areas and with some imperfect regulations in the supplementary part and the balancing part of the general-purpose grant. Also, some of the criteria refer to an existing network of services rather than to the variation in local needs. This reference may help preserve the actual network, which is often far from optimal.

- Too many decisions about details are left to ordinances issued by sector ministries, thus making the allocation formula vulnerable to annual bargaining and political manipulation.

- The fundamental strengths described above pertain to the generalpurpose grant, whereas most of the weaknesses pertain to specialpurpose transfers. The overall amount of special-purpose transfers is not defined by law, making them vulnerable to the annual state budget bargaining process.

- The criteria for special grants allocation are also much less clear (with some exceptions, such as support for housing benefits paid by local governments). The lack of clear criteria has led to subjective decisions and some apparent political clientelism. There is no doubt that adopting clear, sharp criteria for specific grants (especially those related to capital investments) is much more difficult than for general-purpose grants. It is difficult to find a country in which an ideal system exists. But it seems there is still much to be done in Poland in the direction of a more transparent and fair system.

The structure of local government revenues in general and the structure of government grants in particular have been gradually worsening throughout the past decade. First, the proportion of own-source revenues in the total budgets of municipal governments has been gradually decreasing (whereas the proportion of state transfers has been increasing), and on a county and a regional level, it is extremely low. Second, the negative factor in the structure of transfers is the 
gradual increase of specific-purpose grants. In opposition to the initial assumptions of reformers, the specific-purpose grants became less and less an instrument to support specific investment needs and more and more an element of financing the current tasks of local governments. This trend is very visible on a county level, but can be seen on a municipal level as well.

It is hard to find any explanation for disfavoring larger (as measured by population) regions in the regional equalization grant scheme. Doing so may even produce an incentive for territorial fragmentation-that is, it may work against official central government policy and the opinion of the majority of experts.

We have identified more weaknesses than strengths; however, we should stress that the strengths are fundamental and that the Polish grant system is probably among the best in the transition countries of Central and Eastern Europe.

\section{Local Government Borrowing}

Legal regulations do not specify a purpose for borrowing. ${ }^{13}$ Consequently, local governments can borrow both for capital and for operational expenses. In other words, the regulations do not respect the "golden rule" of the balanced budget. Potential execution of the golden rule would be very difficult anyway, because Poland does not have a clear separation of operating and capital budgets. Nevertheless, in practice, local governments take credits or issue bonds first to cover the costs of capital investments. Borrowing to cover current expenses is relatively rare. It has happened only once on a massive scale, when several local governments had severe problems financing a compulsory increase in teachers' salaries in 2000. (In that case, the central government failed to secure extra funds for local governments to finance the increase, which was introduced by the central legislature.) Such credits were taken by 710 local governments and constituted almost a quarter of the credits taken by local governments in 2000 (Jerzmanowska 2001). Although this case was an exceptional one caused by exceptional difficulties, it should be noted that 2002 also saw a negative tendency in this respect: in 70 counties and about 100 municipalities, new credits were higher than investment spending (see Swianiewicz 2004). Thus, at least part of the debt was used to cover current expenses. The problem concerns a still very limited group of local governments (about 5 percent of them), but this negative tendency could be dangerous if it continues. 
The size of local government debt (other than short-term, which needs to be repaid within the same budget year) is limited by regulation in the following ways:

- The constitution states that the overall public debt cannot be higher than 60 percent of GDP. If debt is larger than 50 percent of GDP, special limitations apply that make new borrowing very difficult.

- Individual local government debt cannot be higher than 60 percent of annual revenues.

Debt service in a given year must not exceed 15 percent of total budget revenues.

These regulations are among the most rigid in Central and Eastern Europe (see Swianiewicz 2004).

In the first half of the 1990s, local governments were very reluctant to borrow money. Later, however, many municipalities expanded their activity on the capital market. There are several reasons for this change of attitude, including the following:

Macroeconomic stabilization (decrease in the inflation rate; GDP growth, which gave local governments a greater amount of certainty about their revenue projections)

- Strengthening of national banking systems

- Increasing financial management skills among local government staff members

- Relative stabilization of local government revenues (in terms of legal regulations) and continuous growth of real revenues (especially in the 1992-98 period). This stability made local governments more courageous in their financial decisions and improved bankers' perceptions of creditworthiness

- Advice (or sometimes even pressure) from international financial institutions and donor organizations (the roles of the World Bank and USAID were probably the most important).

It should be noted that until recently the dominant share of local government loans was in the form of preferential loans (with interest lower than commercial loans) offered by state funds, especially by the national and regional funds for environmental protection. Procedures used by environmental protection funds played a significant educational role, preparing local governments to operate on the commercial market as well. Since 2001, 
the aggregate sum of debt in private banks and in the form of bonds is larger than the amount of loans offered with preferential conditions.

However, most local governments are still very prudent, and the level of debt is usually far below legal limits. By the end of 2001, the average level of debt was between 10 percent (in rural governments) and 23 percent (in the biggest cities) of annual revenues. In 2002, the overall local debt increased by more than 30 percent, but the general picture of prudent local governments is still valid, and the negative examples mentioned earlier are the exception rather than the rule.

Figure 9.4 illustrates the development of local borrowing in recent years. The dominant form of borrowing is commercial credit. In big cities, it is more typical to issue bonds, but these are usually private issues, often bought by the underwriting bank, and in fact they do not differ very significantly from bank credits.

In macroeconomic terms, local government debt in Poland is still very low (below 2 percent of GDP). It is also lower than in most EU countries (see Swianiewicz 2004). But one of the most important barriers to local borrowing at the moment is the level of public debt. Although the local debt is very low, the overall debt of the public sector exceeded 50 percent of GDP in 2004. This high level initiated special restrictions on borrowing, as described

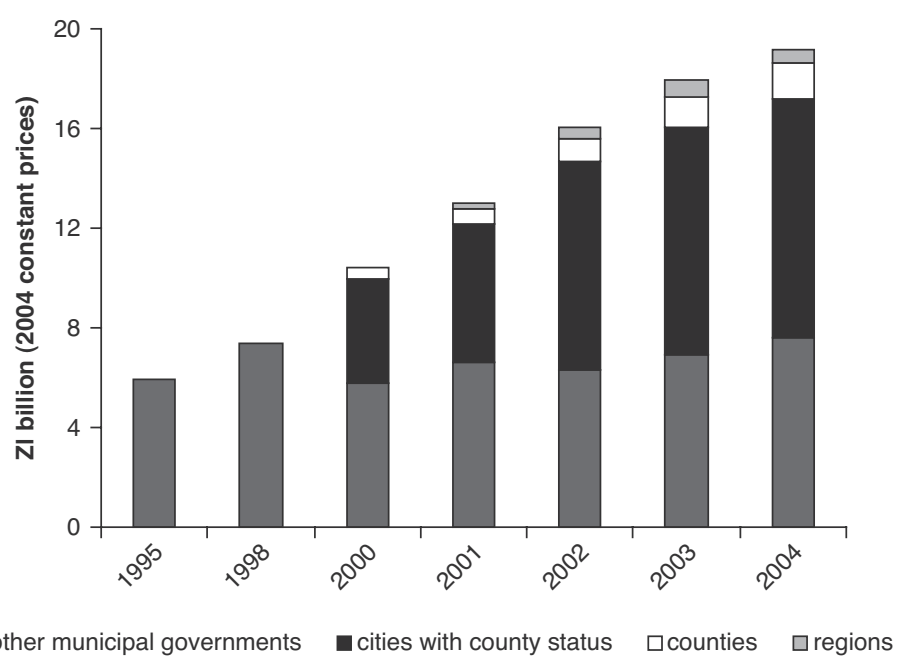

Source: Author's calculations based on financial reports of local governments.

Note: For 1995 and 1998, cities with county status and other municipal governments are shown together.

F I G U R E 9 . 4 The Dynamics of Local Government Debt, 1995-2004 
in the Law on Public Finance. This structure of public debt exists even though local governments finance well over 50 percent of total public investments. In simple terms, local governments (usually) borrow to finance investments, whereas the central government issues bonds or takes credits to finance social spending. To some extent, the ability of local governments to use credit instruments is limited, despite their generally prudent policies, because of central government policies that eat up the dominant share of the public debt limit set in the constitution. This problem may be especially dangerous in the next few years, when local governments may need these borrowed resources to use EU preaccession and then regional structural funds. The short-term solution might be to change the definition of public debt (the Polish definition is more rigorous than that applied in official EU statistics, and convergence would lower the size of Polish public debt by about four percentage points). In the long term, however, a deep reform of the whole public finance system is required. ${ }^{14}$ It is amazing that this major problem is often overlooked, while central government attention is focused on the "standard" borrowing limits established for local governments in the Law on Public Finance. The central government has adopted a regulation that lifts borrowing limits on money lent to cofinance projects sponsored by EU funds. But this regulation does not address the much more dangerous issue of the overall public debt level, which is quickly approaching the constitutional limit.

Although the Polish local borrowing market is among the best developed in Central and Eastern Europe, several weaknesses should be addressed:

As mentioned before, the Polish law does not distinguish between borrowing for operating expenditures and borrowing for capital expenditures.

The legal limits of indebtedness are related to budget size only, not taking into account real borrowing capacity, which is related more to the size of the operating surplus. As a result, there are cities that cannot legally borrow, although their financial standing would allow them to do so safely, and there are local governments that can borrow, despite their lack of operating surplus.

- The lack of clear regulations related to the potential bankruptcy of local governments and recent cases of special state support for local governments in trouble may produce moral hazards for the policies of both borrowers and lenders.

The debt of municipal companies, which are formally separate legal entities and which are important service delivery units in big cities, is not monitored. 


\section{Local Government Administration}

More than 140,000 people work in local government administration in all three tiers. Unlike the situation in some other countries of postcommunist Europe, Polish local government administration is clearly separated from the state administration and also from the local administration of other tiers of self-government.

As mentioned earlier, the state administration operates only on the central and regional levels. Thus, on the regional level, there is both state and self-government administration. However, the two forms of administration are separate and are responsible for different tasks. There is no hierarchical subordination between state administration and regional self-government administration. Similarly, local self-government administration depends on the relevant local council only, and there is no hierarchical subordination to other tiers of administration. For example, the city treasurer is subordinated to the city mayor and city council, and he or she is by no means subordinated either to the Ministry of Finance or to the regional financial department.

Hence, local government has considerable discretion in hiring and firing its staff, as well as in deciding on its organizational structure and the salaries of its clerks. Salaries are defined in national legislation, but only in a very broad framework, within which there is huge scope for local discretion. Until 2001, the salaries of local mayors and heads of county or regional administration were not limited but were set by the respective local councils. However, these salaries have been capped since 2001. This relatively broad discretion in setting administrative spending is reflected in the considerable variation of actual administrative costs incurred by local governments of similar sizes and identical functions. For example, the extreme values for midsize (5,000 to 10,000 inhabitants) rural local governments in 2001 ranged from Zl 90 (about US\$22.50) to Zl 508 (more than US\$125) per inhabitant (for more detailed data on spending on administration, see Swianiewicz 2003b).

\section{Overall Assessment and Lessons for Other Countries}

Decentralization reform is commonly considered one of the most successful aspects of the Polish transformation. In general, local governments are effective providers or organizers of local public services-or, at least, they are more effective than the deconcentrated state administration in the former system. Also the far-ranging decentralization and relative stability in the system of public finance, introduced at the beginning of the 1990s, enabled 
the gradual development of local skills in long-term financial planning, the growth of the local borrowing market, and impressive progress in the development of local infrastructure. These general positive remarks should be supplemented with more critical observations. Not all local governments perform in a satisfactory manner; there are cases of corruption in local administration or wasteful decisions on resource allocation. Both in the management of intergovernmental reforms and in the system of local finance are elements that may be recommended as positive lessons as well as experiences that should be avoided.

\section{Lessons to Follow}

The Polish experience offers many positive lessons, including the following:

Crucial elements of the financial system should be included in stable laws adopted by the parliament. It is not advisable to rely on more current regulations (for example, through annual budget laws) or on secondary legislation such as ordinances issued by ministries. Ministry ordinances give more flexibility and might be acceptable (or sometimes even recommended) in the well-established democracies of developed countries. But in transition countries, they would be too vulnerable to political manipulation and would lead to a lack of stability —stability that is necessary for developing habits of modern long-term financial planning.

The time allowed for implementing decentralization reform is often very short. Therefore, reforms need to be introduced quickly, even at the expense of careful preparation. This claim is well illustrated by the following comment from Michal Kulesza (2002, pp. 204-5), one of the main authors of the Polish decentralization reforms:

The favourable moment during which the central bureaucracy ([which] is usually defending its position) is weak enough to allow any substantial changes is usually very short. Question of time is crucial. If the reformers are not ready to present their concept and its particulars exactly when it is needed and possible (from the viewpoint of the political situation), then a proper time is probably over. ... [Y] oung democracies do not like big structural reforms, which hit economic and political interests of many parties and groupings by destroying their positions and mechanisms present in the functioning of the state, economy, and politics. ... In 1998 the reformers had only six months to implement the reform. . . . [M] y aim was to implement the reform even when quality would suffer. ... In my opinion we managed to achieve even 80 percent of the target, which is a lot. As for the rest, it must be done by local governments in their constant struggle with state centralism, still vivid in Poland. 
Avoiding excessive territorial fragmentation creates a positive environment for more radical decentralization of functions. Such fragmentation has been a serious problem in several countries of Central and Eastern Europe (including Armenia, the Czech Republic, Estonia, Georgia, Hungary, the Slovak Republic, and Ukraine).

An institutional forum should be created for discussion of relevant legislation with representatives of local governments. In Poland, this forum takes the form of the Joint Central-Local Government Committee, which gathers representatives of major local government associations. The committee discusses and assesses relevant pieces of legislation before they are voted on in parliament. Although the system does not always work perfectly, it provides a model worthy of analysis by other countries.

- There are also several interesting regulations concerning various pieces of local government revenues:

- Many regulations concern the size of local borrowing. In general, the market is not overregulated and is among the most developed and healthy in countries of Central and Eastern Europe.

-Considerable discretion is allowed with respect to local taxes, which constitute a significant part of municipal budgets and are administered and collected by local government administration.

- Several regulations concern general-purpose grants, such as a relatively stable and transparent method of allocation that is not subject to political manipulation and is based on clear, objective criteria and an amount of municipal equalization that secures the basic needs of the weak but does not work as a counterincentive for revenue collection in the most affluent jurisdictions.

\section{Lessons to Avoid}

The Polish experience also offers some valuable lessons in problems best avoided. These include the following:

Strong domination by state transfers in the budgets of county and regional governments is a problem. An almost total lack of revenue-raising capacity is harmful not only for financial autonomy but also for local governments' accountability.

- Reluctance to broaden the local tax base of municipalities can be a problem, as can basing current reforms on extending the tax-sharing system. Such an approach does not support accountability or the balance of the overall public finance system. 
Oversimplification of the grant system can be a problem. The system sufficiently recognizes the equalization of revenues, but almost disregards equalization of spending needs and justified unit costs.

- Ignoring the golden rule of the balanced budget can be a problem. As a consequence, there is a growing (although still low) number of local governments that borrow to finance their current spending. Closely related is the lack of a clear separation between current and capital budgets.

\section{Notes}

1. A similar observation in a wider European perspective was made by Page and Goldsmith (1987), who noticed that territorial organization is very much related to the allocation of functions. Small (fragmented) local governments are usually unable to take over responsibility for many services, which need to be delivered by upper tiers of governments.

2. The maximum rate for year $t$ is adjusted by the annual inflation rate during the first three quarters of the year $t-1$.

3. For more detailed discussion of theoretical arguments referred to in this chapter, see King (1984) or Musgrave (1959). For discussion of these arguments in the context of postcommunist Europe, see Swianiewicz (2003a).

4. It should be added that, according to most analysis, local tax policies play only a marginal role in location decisions (Domański 2001; Swianiewicz and Lukomska 2004).

5. For an extensive discussion of the typology of local tax policies, see Swianiewicz (1996, 1997).

6. From 2003, municipal entities (most typically companies) providing water and sewage services propose the tariff. The role of the local council is to approve it. The rules set by government refer to the method of calculation on the basis of justifiable operational costs. For a long time, there has been discussion of the extent to which local companies and local governments should be allowed to include in tariff calculations the cost of necessary investments. This complicated issue goes beyond the scope of this chapter. Some more light is thrown on the issue by Potkanski and others (2001).

7. The issue of tax sharing is discussed in the following section.

8. For an extensive discussion of the definition of own-source local revenues, see Swianiewicz (2003a).

9. However, as described in the section on grants to local governments, revenues from tax sharing are taken into account in the horizontal equalization mechanism.

10. It is worth noting that for this criterion value added tax (VAT) is an even worse candidate as a source of local revenue. For technical reasons, VAT cannot be shared on the basis of origin. The only possibility is to define a share at the national level and then redistribute it among local governments on some basis other than origin. But in such a situation, the revenue would be much closer to a general grant than to a shared tax or own-source revenue of the local government. Nevertheless, one of the most frequent demands of local governments is a local share in VAT revenues. 
11. Also, in this case, the law refers to the local tax base rather than to actual revenues from local taxes.

12. A more developed discussion of the educational grant and, more generally, of financing spending expenditures by local governments, can be found in Levitas and Herczynski (2002). It should be stressed again that, despite its name, the educational grant is still part of the general-purpose grant; therefore, it may be spent on many purposes selected by the local council. The name derives from the method of calculation. A separate story is that most local governments see the education grant as insufficient and frequently subsidize school operations from their own revenues. Levitas and Herczynski (2002) calculate that in 1999 only about 75 percent of educational expenses were covered by the education grant. But opposing cases (of local governments spending part of the education grant for other purposes), although not numerous, can be found. For example, in 1994, 17 percent-and in 2000, about 1 percent - of local governments that were running schools used part of the education grant to finance other services (Ćwikla 2001; Swianiewicz 1996).

13. For more detailed information on the regulation and practice of local government borrowing in Poland, see Kopańska and Levitas (2004).

14. However, this issue goes well beyond the scope of this chapter and is not discussed in further detail.

\section{References}

Brzeszczyńska, Stella, and Aleksander Kaźmierski. 1997. Podatki samorzq̨adowe: Egzamin doradcy podatkowego. Warsaw: C. H. Beck.

Ćwikla, Michal. 2001. "Finansowanie oświaty przez samorządy w Polsce.” Master's thesis, Institute of Economics, Katolickiego Uniwersytetu Lubelskiego, Lublin, Poland.

Domański, Boleslaw. 2001. Kapitał zagraniczny w przemyśle Polski. Kraków, Poland: Uniwersytet Jagielloński.

GUS (Główny Urząd Statystyczny). Various years. Rocznik Statystyczny. Warsaw: GUS.

Jerzmanowska, Elżbieta. 2001. "Kredyty zaciagane przez jednostki samorządu terytorialnego na sfinansowanie skutków nowelizacji Karty Nauczyciela." Finanse Komunalne 2: $30-49$.

Kasperek, Joanna. 2002. "Podatek od nieruchomości w dochodach gmin: Ewolucja znaczenia i koncepcje zmian.” Master's thesis. Institute of Economics, Katolickiego Uniwersytetu Lubelskiego, Lublin, Poland.

King, David. 1984. Fiscal Tiers: The Economics of Multi-Level Government. London: Allen \& Unwin.

Kling, Jaroslav, Viktor Niznansky, and Jaroslav Pilat. 2002. "Separate Existence Above All Else-Local Self-Governments and Service Delivery in Slovakia.” In Consolidation or Fragmentation? The Size of Local Governments in Central and Eastern Europe, ed. Pawel Swianiewicz, 101-66. Budapest: Open Society Institute.

Kopańska, Agnieszka, and Tony Levitas. 2004. "The Regulation and Development of the Subsovereign Debt Market in Poland: 1993-2002.” In Local Government Borrowing: Risks and Rewards, ed. Paweł Swianiewicz, 25-78. Budapest: Open Society Institute.

Kulesza, Michal. 2002. "Methods and Techniques of Managing Decentralization Reforms in CEE Countries: The Polish Experience." In Mastering Decentralization and Public 
Administration Reforms in Central and Eastern Europe, ed. Gábor Péteri, 189-216. Budapest: Open Society Institute.

Levitas, Tony, and Jan Herczynski. 2002. "Decentralization, Local Governments, and Education Reform in Post-communist Poland." In Balancing National and Local Responsibilities, ed. Kenneth Davey, 113-190. Budapest: Open Society Institute.

Musgrave, Richard A. 1959. The Theory of Public Finance. New York: McGraw-Hill.

Nowecki, Grzegorz. 1996. "Kataster fiskalny." Przeglad Podqtkowy 6: 31.

Page, Edward C., and Michael J. Goldsmith. 1987. Central-Local Government Relations: A Comparative Analysis of Western European Unitary States. London: Sage.

Potkanski, Tomasz, Grzegorz Dziarski, Krzysztof Choromanski, and Józef Pawelec. 2001. "Poland." In Navigation to the Market: Regulation and Competition in Local Utilities in Central and Eastern Europe, ed. Tamás M. Horváth and Gábor Péteri, 305-88. Budapest: Open Society Institute.

Pszczola, Urszula. 2003. "Polityką podatkowa samorzadów w województwie lubelskim.” Studia Regionalne i Lokalne 1: 149-70.

Swianiewicz, Pawel. 1996. Zróznicowanie polityk finansowych władz lokalnych. Gdańsk, Poland: Gdańsk Institute for Market Economics.

- 1997. "Financial Policies of Polish Local Governments, 1991-1994: Learning While Doing." In Developing Organizations and Changing Attitudes: Public Administration in Central and Eastern Europe, ed. Jak Jabes, 299-327. Bratislava: Network of Institutions and Schools of Public Administration in Central and Eastern Europe. 2003a. "Foundations of Fiscal Decentralization: Benchmarking Guide for Countries in Transition." LGI Discussion Paper 26, Open Society Institute, Budapest. -. 2003b. "Najtańszy urząd." [The Cheapest Office.] Wspólnota 9. , ed. 2004. Local Government Borrowing in Central and Eastern Europe: Risks and Rewards. Budapest: Open Society Institute.

2005. “Ile naprawde inwestuja polskie samorządy?” Finanse Komunalne 11:5-13.

Swianiewicz, Paweł, and Julita Lukomska. 2004. "Wladze samorządowe wobec lokalnego rozwoju gospodarczego: które polityki są skuteczne?” Samorząd Terytorialny 6: $14-33$. 



\section{Local Government \\ Organization and \\ Finance: Argentina}

M I G UEL A NGEL A S E N I O

The origin of local governments in Argentina dates back to the foundation of cities by Spanish colonists. The occupation of the area that would later make up the Argentine Republic proceeded from different geographic fronts. The dispersed scenario of these early cities had Asunción (in present-day Paraguay) and Potosí (in present-day Bolivia) as focal points.

Consequently, during the stage before the 18th century when the importance of Buenos Aires as a port city was heightened, the most urbanized, populated, and dynamic area of the geographic space that would later constitute Argentina was the northwest. In the country's geographic core, Córdoba was a hub of economic and cultural activity that would grow in importance, along with Mendoza, to the west.

This history is relevant in relationship to the importance and organization of urban governments in Argentina, given the significance of Buenos Aires during the past two centuries. The original founding of Buenos Aires in 1536 was frustrated and had to be put off until the late 16 th century. ${ }^{1}$

The role that Buenos Aires later played was dominant. Throughout subsequent economic, social, and political events, the city's importance has been a constant, differentiating Argentina 
from such countries as the United States. U.S. economic history is viewed as a constant "march to the western border." In comparison, a keen observer remarked that "Argentina doesn't have a border but a city: Buenos Aires" (Scobie 1972). ${ }^{2}$

Consequently, the present town structure results from the slow historical spread of effective territory occupation. Shifting from their original dominance in the northwest, most of the population ended up settling in the Pampean area, leaving half-deserted stretches such as the vast Patagonia, where population density barely reaches 1 percent.

The variety of sizes of the cities shows the significance of government management and corresponding service demands. The size problem, generally linked simply to the magnitude of the population, is connected to the importance of the economic activity developed in those populations, which produces further demands for urban public goods to be satisfied through local government activity.

In Argentina's case, like others in international experience, functional differences among the various city centers originated in the diversity of urban center building purposes (old exchange areas, mere entrepôts, administrative centers, border posts, and so forth). Such differences in purpose led to functional profiles of the local governments that were related to the type of services required for diverse functions of such urban centers and for the regional environments those urban centers serve.

In other countries that have more than one level of local government, such as the United States and various European countries, diverse forms of local government exist. However, in Argentina, the present federal system encompasses towns as a third level of government that is clearly differentiated. This situation does not prevent the existence of other organizational structures such as departments, which resemble U.S. counties but are usually deconcentrations from provincial governments.

In Argentina, the original constitutional system (passed in 1853) had a dual nature in the tradition of other major federations, such as Australia, Canada, and the United States. This dual nature means that the constitution recognized the existence of municipalities, but as part of the provinces, which must ensure the municipal regime. ${ }^{3}$

The new constitutional system established in 1994 granted Buenos Aires a particular status that brings it close to being an urban province. ${ }^{4}$ As a rule, the system established municipal autonomy, but in the terms settled by the corresponding provincial constitutions (Title II, article 123, 1994 constitution).

Thus, the role of municipalities in the constitutional system has been enhanced through a second-level autonomy, insofar as those institutions act 
within the restraints imposed by provincial constitutions. We also conclude that the dualism derived from the constitution still holds, but in a moderated fashion that acknowledges the importance of decentralization. ${ }^{5}$

\section{An Overview}

By Latin American standards, Argentina is a highly urbanized country and reached that status long before other countries of the region. The urban population share, according to the latest national census, is near 90 percent. However, the significance of this urban density is small if Greater Buenos Aires, a conurbation of more than 11.4 million inhabitants, is not included. Along with major economical and political asymmetries, harboring significant regional imbalances, the country has major urban asymmetries that display substantial differences in the kind and nature of functions that local governments perform.

In the past decade, a certain regularity in its number has been established when local governments are considered as a whole. This regularity conceals the effect of depopulation from small towns, villages, and rural communes, which lose demographic weight to large cities. For this reason, although local governments in the legal sense have not dwindled, small urban centers isolated within the territory have tended to depopulate and thus decline in density.

Early in the 21st century, 2,157 local governments were recorded, of which 1,179 were municipalities and the rest communes. Whether a local government is a municipality depends mainly on its population size (municipalities are larger than communes), as provided in each provincial constitution. ${ }^{6}$ Table 10.1 gives the number of local governments by province and differentiates the two major categories of local governments: municipalities and communes.

Local governments are thus composed of those with municipal status and those without municipal status. Fifteen of the 23 provinces include a form of local government other than the municipality, which also indicates population disparities. Some urban centers have a scantier population, which raises concerns about the logic of building government structures for such small groups.

If local governments are categorized as small, medium, and large (up to 10,000 inhabitants, from 10,000 to 250,000 inhabitants, and more than 250,000 inhabitants, respectively), 82 percent can be found in the first group (table 10.2). By contrast, just 1.1 percent of the local governments hold 40 percent of the population. Furthermore, 51 percent of local governments 
TA B L E 1 0 . 1 Number of Municipalities and Communes, December 2003

\begin{tabular}{lrrr}
\hline Provinces & Municipalities & Communes & Total \\
\hline Buenos Aires & 134 & 0 & 134 \\
Catamarca & 36 & 0 & 36 \\
Chaco & 68 & 0 & 68 \\
Chubut & 23 & 22 & 45 \\
Córdoba & 249 & 178 & 427 \\
Corrientes & 66 & 0 & 66 \\
Entre Ríos & 69 & 183 & 252 \\
Formosa & 27 & 10 & 37 \\
Jujuy & 21 & 39 & 60 \\
La Pampa & 58 & 21 & 79 \\
La Rioja & 18 & 0 & 18 \\
Mendoza & 18 & 0 & 18 \\
Misiones & 75 & 0 & 75 \\
Neuquén & 34 & 21 & 55 \\
Río Negro & 38 & 37 & 75 \\
Salta & 59 & 0 & 59 \\
San Juan & 19 & 0 & 19 \\
San Luis & 56 & 8 & 64 \\
Santa Cruz & 14 & 7 & 21 \\
Santa Fe & 19 & 315 & 363 \\
Santiago del Estero & 18 & 1 & 71 \\
Tierra del Fuego & 179 & 93 & 3 \\
Tucumán & 28 & & 112 \\
\multicolumn{1}{c}{ Total } & 19 & 157 \\
\hline
\end{tabular}

Source: DNCFP 2004, 1.

Note: Communes comprise communes, municipal commissions, juntas de gobierno, and comisiones de fomento, according to the municipal regime of each province.

administer populations of less than 2,000, and 71 percent administer populations of less than 5,000. This "situation has led to the trend in significant urban areas toward Argentine "inframunicipalism" (Iturburu 2001b).

Moreover, the provinces with the largest number of local governments are Córdoba, Santa Fe, and Entre Ríos. Those governments constitute 48 percent of the country's urban governments and cover 22 percent of the population. Not considered here, however, are the municipal delegations in use in the province of Buenos Aires; the municipal delegations are organizational dependencies of the municipalities and do not reach the status of a local government. 
TA B LE 1 0 . 2 Distribution of Local Governments by Size

\begin{tabular}{lrrc}
\hline Size & Average population & Number & Percentage of total \\
\hline Small & 2,257 & 1,770 & 82.2 \\
Medium & 39,986 & 360 & 16.7 \\
Large & 469,140 & 24 & 1.1 \\
\hline
\end{tabular}

Source: Author's adaptation from Iturburu 2001b.

The average population per local government in Argentina, although lower than that of such countries as Brazil, is larger than some European experiences of micromunicipalism, as in Italy, France, Germany, and Spain. ${ }^{7}$ As mentioned earlier, trends show a higher population growth in medium or large cities and a decrease in small towns. ${ }^{8}$

However, as in other countries, some cities have gone through "metropolitanization" - that is, urban developments have tended to absorb neighboring urban areas, bordering towns, or areas that previously were "suburbanized." This trend has led to the building of larger conglomerations, in some cases designated as "great conglomerations," which have developed as metropolitan areas. In essence, rather than "inframunicipal" 10 urban areas and structures, metropolitanization brings about "supramunicipal" organizational spaces and forms.

\section{Constitutional Status and Institutional Aspects}

The legal status of Argentine municipalities is considered in the provincial constitutions. However, the national constitution is explicit about this requirement, stating that the national government guarantees provincial autonomy, provided that provinces ensure primary education, the administration of justice, and the "municipal regime."

In essence, municipalities are self-governed. This self-government includes an assembly, an executive, and courts that rule on misdemeanors or minor infractions that affect urban coexistence. Basically, municipal organization provides for two of the republican powers granted to the federation and to the provinces, the executive and the legislative, but scarcely a sprout of the judiciary. Justice in its full sense is the purview of the higher levels of government.

The decentralization implicit in the existence of local governments in Argentina shows a greater depth than that reached in other countries of Latin America, which mostly lack a federal system. Consequently, the 
increase in the effective authority of municipalities recently observed in the region was seen in Argentina decades ago. Particularly, Argentine local governments, in their executive and legislative branches, are made up of elected officers. As a result, the intendentes (mayors) and the concejales (councilors) ${ }^{11}$ are appointed through free elections held autonomously or coinciding with provincial or national elections.

The nature of the intendentes' and concejales' powers can be found in two fundamental pieces of legislation: the provincial constitutions and the provincial laws regulating municipal organization. In the new Argentine federal framework, the effective autonomy of municipalities depends on the scope granted to them by the provincial constitution. Thus, loss of status as a municipality depends on compliance with the constitutional requirements established for municipalities.

In fact, the accountability of municipal authorities as people's representatives lies in two domains, that of the municipality's voters and that of the province whose constitution regulates the municipality's operation. As a consequence, besides accounting for the efficiency and effectiveness of their activity before the voters, municipalities are subject to intervention from provincial governments if they do not properly carry out their duties. This intervention can entail removing authorities from office and replacing them with others appointed provisionally by a higher level of government.

Municipalities are financed through their own taxes (tributos), through transfers from other government levels, and through credit. The term tributo includes taxes and other duties based on the benefit principle. This explanation is important, since most Argentine municipalities levy tasas (rates), unlike the central and middle levels of the federation, which have undisputed access to a broad range of tax revenues (including those based on the ability-to-pay principle).

Public expenditure reflects traditional functions, as shown later, and a given distribution between current spending and investment (which experienced a reduction between the late 1990s and 2001). This resources and expenses structure is shown in table 10.3.

\section{Spending Responsibilities of Local Governments}

Delimitation of powers among the three levels of the federal system does not always derive from a flawless constitutional framework. Delimitation of powers between nation and provinces in Argentina results from a constitutional setup that is detailed for the central or federal government and less so 
TA B LE 1 0 . 3 Local Government Revenue and Expenditure: Budgetary Performance, 2001

\begin{tabular}{lcr}
\hline Item & $\begin{array}{c}\text { Amount } \\
\text { (Arg\$ million) }\end{array}$ & Percent \\
\hline Total revenue & $7,222.6$ & 100.0 \\
Current revenue & $7,149.3$ & 98.9 \\
$\quad$ Tax revenue & $3,612.4$ & 50.0 \\
$\quad$ Shares and transfers & $3,495.5$ & 48.4 \\
$\quad$ Other & 41.4 & 0.6 \\
Capital revenue & 73.3 & 1.0 \\
& & 100.0 \\
Total expenditure & $7,774.3$ & 89.9 \\
Current expenditure & $6,979.1$ & 10.2 \\
Capital expenditure & 795.2 & 9.9 a \\
Outcome (deficit) & -771.6 & \\
\hline
\end{tabular}

Source: Author's adaptation from DNCFP 2004.

a. Out of total expenditure.

for provincial governments. This setup is complemented by the principle that provinces "keep all the power and functions not delegated to the nation" (Title II, article 121, 1994 constitution).

Provincial constitutions usually detail the functions of the provincial governments and do not describe them as deeply for local governments. The organic laws regulating the operation of local governments attempt to correct these shortcomings; in those laws, in some cases it has been possible to find highly comprehensive and detailed functional restraints that, depending on when they were passed, evince strong aspirations to a thorough decentralization.

In practice, the "who does what" so clearly expressed by Richard Bird and François Vaillancourt (1998) to point out the expenditure assignment problem in federal systems is deeply linked in local governments to the problems of urban service size and the demands related to the historical processes shaping those local governments. In Argentina, as in other countries, it is clear that size determines private urban functions and those of the city governments.

Those differences are also reflected in the new constitutional framework. For this reason, Buenos Aires has been an autonomous city since 1994, reaching a status similar to that of provinces, with powers to dictate its own statutes, elect its own authorities, and set out its internal organization. This 
situation raises an issue pointed out in the literature: when it comes to the assigning of functions exercised by their governments, major cities tend to resemble intermediate or regional governments, whether provinces, states, or autonomous regions. ${ }^{12}$

In this regard, the asymmetries mentioned earlier come into play. Major cities of Argentina provide services at the municipal level that elsewhere are provided by provincial or even central governments. ${ }^{13}$ It is customary for urban governments to play many roles, often focusing on services on behalf of residents, such as public street lighting, cleaning and sweeping, waste treatment, municipal vehicular traffic management, urban planning, and building regulations. There is no uniformity concerning other services, such as drinking water supply; they are provided by the municipality in some cases and by the province in others. Table 10.4 outlines a budgetary and broad classification of those functions.

The current "functional space" of Argentine local governments is a consequence of historical processes, in accordance with which the provision of some typical public services was organized. Immediately after World War II, large utilities were nationalized. National public enterprises took over the supply and production of services such as water and sanitation, power, natural gas, and telecommunications (natural monopolies).

Between the late 1970s and early 1980s, when these services were decentralized, they were transferred to the provinces, not to the municipalities. For this reason, though there are enterprises or cooperatives that provide such services in the municipal sphere, the criterion originally chosen for assigning powers restricted the extent of decentralization and the functional scope of local governments. Table 10.5 contains a proxy of this local profile.

The way these services were provided turned the role played by local governments in some cases into one of policy making, management, and execution, and in others into one of only outlining frameworks for action

TA B LE 1 0 . 4 Expenditure Assignment in Local Governments, 1999

\begin{tabular}{lcc}
\hline Item & $\begin{array}{c}\text { Amount } \\
\text { (Arg\$ million) }\end{array}$ & Percent \\
\hline General management & 2,497 & 33.5 \\
Social services & 4,044 & 54.2 \\
Economic services & 840 & 11.2 \\
Debt amortization & 84 & 1.1 \\
\hline
\end{tabular}

Source: Zapata, Bertea, and Iturre 2000. 
T A B L E 1 0 . 5 Local Government Spending by Main Categories, 1999

\begin{tabular}{lcc}
\hline Category & Percent & Order \\
\hline Urban services & 28.3 & 1 \\
Higher management & 14.0 & 2 \\
Health & 9.9 & 3 \\
Transportation & 8.1 & 4 \\
Welfare & 6.3 & 5 \\
Fiscal management & 6.0 & 6 \\
Legislation & 5.2 & 7 \\
Education and culture & 5.0 & 8 \\
Housing and urban planning & 3.8 & 9 \\
\hline
\end{tabular}

Source: Author's adaptation from Zapata, Bertea, and Iturre 2000.

and overseeing execution, entrusting the effective provision of services to the private sector (Shah 1999a). Where privatization of particular city services has been extensive or regular, oversight is essential for ensuring satisfaction and accountability in the effective delivery of such services to citizens.

In this respect, even though functions such as education or health care are performed in some major municipalities, the rule is that such roles are reserved for the provinces. Gray areas, of course, exist, but these should be surmounted in order to improve the effectiveness of public service provision at both the municipal and provincial levels. ${ }^{14}$

In addition, there is a trend toward the development of new functions as local governments gradually become involved in areas that, in the face of a certain lack of definition, were taken care of at the regional level. We refer to local economic development and that of the surrounding area, as well as such categories as housing and welfare. ${ }^{15}$ In Santa Fe, several municipalities have partnered in developing and maintaining a highway infrastructure common to them. ${ }^{16}$

In turn, some provincial constitutions define a functional framework that differentiates exclusive powers from nonexclusive ones. For the province of Buenos Aires, the constitutional charter distinguishes between "specific and nondelegable functions," functions "concurrent with the provincial state level," and functions "concurrent with the private sector" (see Urlezaga and Basile 1997).

Table 10.6 outlines the functional profile of Argentine local governments following the categories suggested by Shah (1994).

On balance, local government involvement in the Argentine public sector is not as significant as that found in other federations. On the whole, local 
TA B LE 10 . 6 Functional Profile of Local Governments

\begin{tabular}{ll}
\hline Type of service & Frequency of provision \\
\hline Air and water pollution & Occasional \\
Fire protection & Occasional \\
Garbage collection & Normal \\
Hospitals & Infrequent \\
Local legislation & Normal \\
Local libraries & Occasional \\
Parks and leisure & Normal \\
Police protection & Infrequent \\
Power supply & Occasional \\
Primary education & Infrequent \\
Public health & Infrequent \\
Refuse disposal & Occasional \\
Regional parks & Infrequent \\
Regional planning & Infrequent \\
Secondary education & Infrequent \\
Sewerage & Occasional \\
Soil use planning & Normal \\
Special libraries & Infrequent \\
Special police & Infrequent \\
Street maintenance & Normal \\
Traffic department & Normal \\
Transportation & Occasional \\
Urban traffic & Normal \\
Water supply & Occasional \\
\hline
\end{tabular}

Source: Author's elaboration based on present norms and practices.

government expenditure does not exceed 10 percent of the total expenditure in all levels of government, compared with more than 30 percent in the case of the provinces and more than 50 percent in the case of the central government. This fact suggests feasible space for the spread of decentralization into the third level of government. ${ }^{17}$

\section{Local Governments' Taxation and User Charges}

The resources of local governments in Argentina, apart from public debt, derive from three sources: (a) local government taxes levied according to constitutional and legal powers; (b) transfers from other levels of government and shares of national and provincial taxes; and (c) fines, rates, and duties levied for providing services to residents. Of these three sources, the 
last is comparatively insignificant; the first two sources rule the local financial scenario. Moreover service fines, rates, duties, and other user charges, though quite numerous, generate additional collection and supervision administrative costs, and their output is poor. However, along with the first two sources of revenue, they represent resources specific to local government and are indicative of the decision-making power at that level.

We turn now to the two main revenue sources. The first consists of taxes and other duties collected as part of specific functions. In this group, taxes prevail. The second encompasses resources received as transfers or grants from the central government and the provinces. This group includes a share in higher-level taxes (known in Argentina as coparticipación), which takes the form of a transfer. Indeed, taxes make up nearly two-thirds of local revenue, with the rest made up of the duties, fines, and user charges with lower output (see table 10.7).

The taxation ability of municipalities has been a major constitutional issue, and there is no uniform stance among jurists and legal experts. For years and before an important case to which one of the country's main municipalities was a party, the Supreme Court judgment that regarded municipalities as "territorially based, financially autonomous entities" prevailed. According to that decision, municipalities lacked full autonomy within the federal order, being administered under laws issued by provinces (organic laws) within the framework of provincial constitutions and the national constitution.

TA B LE 10,7 Local Government Revenue Structure, 2001

\begin{tabular}{lrrr}
\hline Item & $\begin{array}{c}\text { Collection } \\
\text { (Arg\$ million) }\end{array}$ & $\begin{array}{c}\text { Percentage } \\
\text { of total }\end{array}$ & $\begin{array}{c}\text { Percentage } \\
\text { by category }\end{array}$ \\
\hline Own-source revenues & $3,716.7$ & 51.5 & 100.0 \\
Taxes & 184.8 & 2.6 & 5.0 \\
Other tributes and charges & $3,427.6$ & 47.5 & 92.2 \\
$\quad$ Rates and charges & $3,305.6$ & 45.7 & 88.9 \\
$\quad$ Royalties & 122.0 & 1.7 & 3.3 \\
Others & 41.2 & 0.6 & 1.1 \\
Own capital revenue & 63.1 & 0.9 & 1.7 \\
Revenue from other levels of government & $3,505.7$ & 48.5 & 100.0 \\
Share in national and provincial taxes & $2,799.5$ & 38.8 & 79.8 \\
Current and capital transfers & 706.2 & 9.8 & 20.2 \\
\multicolumn{1}{c}{ Total } & $7,222.4$ & 100.0 & n.a. \\
\hline
\end{tabular}

Source: DNCFP 2004.

Note: n.a. $=$ not applicable. 
With the approval of the 1994 constitutional reform, municipal autonomy was recognized, but that autonomy must be defined in the provincial constitutions. Therefore, despite the undeniable development of the status of local governments, the scope of their autonomy is still in the hands of the provinces.

Even before the constitutional reform, some provinces had already approved constitutions that established the autonomy of their local governments. However, several of the most important provinces still regard municipalities as financially autonomous entities and have not regulated a wider autonomy. ${ }^{18}$ Therefore, there is still a certain confusion concerning the legal status of municipalities, which impinges on the consideration of their powers and competence. Table 10.8 shows a detailed structure of local taxes, charges, and fines.

Nevertheless, a determining factor exists regarding whether local governments are able to exert full taxing powers (that is, by raising, modifying, and eliminating taxes): the leyes convenio (agreement acts) and intergovernmental tax agreements arranged between the central government and the provinces. Within this framework, the Tax-Sharing Law (Ley de Coparticipación) of 1988 and the Federal Tax Agreement of 1993 have restricted that power.

TA B LE 1 0 . 8 Main Taxes, Charges, and Fines of Local Governments, 1997

Item Percentage of total revenue

General rate 40.4

Inspection, safety, and sanitation fee 24.0

Miscellaneous 13.3

Fines and charges 4.0

Public health 3.6

Highway maintenance $\quad 2.8$

Betterment tax $\quad 2.4$

Electricity charges $\quad 2.4$

Office duties 2.3

$\begin{array}{ll}\text { Occupation } & 1.6\end{array}$

Building permits $\quad 1.4$

Advertising fees $\quad 1.1$

$\begin{array}{ll}\text { Traffic violation } & 0.6\end{array}$

Total

100.0

Source: DNCFP 1999. 
These pieces of legislation force provinces to set limits on local taxing powers; municipalities, hence, are not able to raise taxes analogous to the national taxes distributed through the sharing mechanism. Under the TaxSharing Law, the tax-sharing regime is defined by the provinces and applied to the local governments under their jurisdictions. If such a regime is not implemented, local governments do not receive their share of the national taxes laid down in this law.

Debate surrounding the self-financing or autonomy of municipalities had influence when the 1994 constitution was being written. Before the current constitutional legislation outlining the organization of the federation, municipalities were regarded in Supreme Court decisions as self-financed entities. They were not vested with the power to levy taxes but were empowered to raise rates of compensation for services, a notion that was bolstered by the Federal Tax Agreement of 1993. However, according to recent interpretations of the 1994 constitution, local governments were not banned from raising taxes, as long as they met the important requirement of being in keeping with those levied by the nation and the provinces and complied in the main with the key "analogy principle" laid down in the Tax-Sharing Law of 1988. Table 10.9 reflects the picture related to those powers.

Yet in practice, even though a majority of provinces have regulated local government autonomy, these governments use the taxing powers implied by that autonomy in a restricted way as a consequence of the restraints alluded to earlier. These restraints have regulated the unstable interjurisdictional tax balance and the trends toward overlap caused by attempts to "take up tax room" and have ensured compliance with the analogy principle of the TaxSharing Law.

Accordingly, the most important taxes continue to be (a) the municipal property rates (known also as real estate taxes) that finance services such as street lighting and cleaning, and (b) rates for inspection, safety, and sanitation. ${ }^{19}$ Both have reached nearly two-thirds of own-source municipal revenue and, in some cases, more than 70 percent of own-source municipal revenue.

The tax bases that are applied effectively turn these two taxes into hidden or disguised taxes. In the first case, the tax is levied on the cadastral value of property; its base is equivalent to that of the provincial real estate tax. In the second case, the base relies on the gross income of taxpayers or of the economic activity; the tax base is the same as that for the provincial gross income tax, which is a sales tax with a cascade effect (see table 10.10).

In practice, this situation violates the principle of correspondence between the rate value and the production costs of local governmental 
TA B LE 1 0 . 9 Assignment of Taxing Powers to Argentine Municipalities

\begin{tabular}{lllll}
\hline & & \multicolumn{2}{c}{ Real estate } & \\
\cline { 3 - 4 } Province & Gross income & Urban & Rural & Motor vehicle \\
\hline Buenos Aires & Province & Province & Province & Province \\
Catamarca & Province & Province & Province & Province \\
Chaco & Province & Municipalities & Municipalities & Municipalities \\
Chubut & Municipalities & Municipalities & Municipalities & Municipalities \\
Córdoba & Province & Province & Province & Municipalities \\
& & & & and province \\
Corrientes & Province & Province & Province & Province \\
Entre Ríos & Province & Province & Province & Province \\
Formosa & Province & Municipalities & Province & Municipalities \\
Jujuy & Province & Province & Province & Municipalities \\
La Pampa & Province & Province & Province & Province \\
La Rioja & Province & Province & Province & Province \\
Mendoza & Province & Province & Province & Province \\
Misiones & Province & Province & Province & Province \\
Neuquén & Province & Province & Province & Province \\
Río Negro & Province & Province & Province & Province \\
Salta & Province & Municipalities & Province & Municipalities \\
San Juan & Province & Province & Province & Province \\
San Luis & Province & Province & Province & Municipalities \\
Santa Cruz & Province & Municipalities & Province & Province \\
Santa Fe & Province & Province & Province & Province \\
Santiago del Estero & Province & Province & Province & Province \\
Tierra del Fuego & Province & Municipalities & Province & Municipalities \\
Tucumán & Province & Province & Province & Province \\
\hline Sorce & & & & \\
\hline
\end{tabular}

Source: Zapata, Bertea, and Iturre 2000.

a. Does not include agreements about distribution of the tax base.

services. The Federal Tax Agreement of 1993 tried to solve this problem by providing that provinces should induce local governments not to charge rates for services that would outrun the costs of providing such services. Results have been weak. ${ }^{20}$

In some instances redistributional principles have been used in regulating safety and sanitation fees; that is, different rates have been applied to certain sumptuary activities. Similarly, higher real estate tax rates have been applied to match the socioeconomic standard of urban areas. The use of such rates implies a differentiation approach that takes into consideration the range of such governments, in view of the provisions of the fiscal federalism theory (see Shah 1999c). 


\section{TA B L E 10 . 10 Structural Characteristics of Some Local Taxes and Rates}

Type of tax

Gross income tax ${ }^{\mathrm{a}}$

Real estate tax ${ }^{b}$

Motor vehicle tax

Street lighting and cleaning charges

Inspection, safety, and sanitation fees

Betterment tax

Rate on sanitary services ${ }^{d}$

Traffic violations

Electricity charges
Tax base

Income from sales of goods and services

Cadastral value of real estate property

Value assessed on motor vehicles

Cadastral value of real estate property Income from sales of goods and services Increase in value of property attributable to public works

Cubic meters consumed or property size

Graded according to violations

Electric power consumed

Source: Author's elaboration based on organic laws and fiscal codes.

a. Chubut.

b. Chaco, Chubut, Formosa, Salta, Santa Cruz, and Tierra del Fuego.

c. Chaco, Chubut, Córdoba, Formosa, Jujuy, Neuquén, Salta, Santa Cruz, and Tierra del Fuego.

d. Water and sewerage.

The so-called betterment tax attempts to detect the value added by improving certain town areas through public works. Although this tax is a resource for potential exploitation, its significance within the structure of specific taxes is not relevant in the Argentine environment (see DNCFP 1999; Lukszan 1988).

The structure of local government resources is shown in the tables mentioned above, where the outlined trends appear.

\section{Tax Sharing with Local Governments}

As mentioned, Argentina's national tax-sharing system transfers resources from the national tax collection to the provinces and, through them, to the municipalities. This system is based on laws that require provinces to create a similar system with their local governments.

All provinces have tax-sharing systems that meet the federal law; if they did not, they would risk losing the right to the shared taxes distributed under that law. In keeping with federal tax sharing, systems of sharing with local governments are the main instrument of fiscal relations between the levels of government, and transfers are made without conditions. Such systems do not prevent less significant transfers that originate in the provinces or at the national level.

These systems in the provinces often enjoy constitutional status. The provincial constitutions provide that the shared funds be made up of both 
national and provincial revenue resources, as can be seen in specific laws passed within the framework of such constitutional regulations. These laws establish the distribution of national or provincial revenues and also other resources from some intermediate governments, such as the royalties collected by provinces on natural resources such as oil, gas, or hydroelectricity, and the revenues from privatized services (see DNCFP 1999).

Like the national tax sharing with provinces, provincial tax sharing with local governments is based in some important cases on the idea of "tax union" expressed by authors such as Jarach (1985). ${ }^{21}$ The revenues of all taxes collected by a level are bundled together and distributed among the participants on a pro rata basis. Tax sharing in a stricter sense is also practiced in some provinces. In this type of tax-sharing system, revenue from each tax is shared individually on a "tax-per-tax" basis.

In a tax-sharing scheme, a distinction can be drawn between two distributions. First, a primary allocation is made, involving a split between the provincial government and the local governments as a whole. Then, a secondary allocation is made, consisting of the apportionment among local governments of that primarily allocated share. The tax union approach is sometimes imperfect because some national and provincial taxes are set apart at the higher level and thus are not part of the common revenue pool of the tax-sharing regime. In Argentina, both the nation and the provinces reserve certain taxes from allocation in this way. ${ }^{22}$

Taxes shared by the provinces with their municipalities can be split into two major groups: national taxes and provincial taxes. National taxes may be unconditional or may be earmarked for specific purposes. If they are unconditional, the provinces share them with the municipalities, but earmarked taxes cannot be shared. National taxes include the value added tax and income tax, as well as capital taxes, such as the tax on personal property. Provinces similarly set aside certain taxes aside from the common revenue pool so that they can be used for specific purposes. For example, the stamp tax is not subject to allocation in a significant group of provinces (Catamarca, Córdoba, Chubut, Entre Ríos, Misiones, Río Negro, Santa Cruz, Santa Fe, and Tucumán). Provincial taxes that are shared include the gross income tax, real estate tax, and motor vehicle tax.

The proportions of national and provincial taxes shared with local governments vary by province. In some provinces, proportions are significantalmost a full grant to the local level. In Santa Fe, for instance, 90 percent of the motor vehicle tax is shared with municipalities, but only 50 percent of the real estate tax (table 10.11). ${ }^{23}$ 
TA B L E 1 0 . 11 Revenue Sharing with Local Governments (percent)

\begin{tabular}{|c|c|c|c|c|c|c|c|c|}
\hline \multirow[b]{2}{*}{ Province } & \multirow{2}{*}{$\begin{array}{c}\text { National } \\
\text { taxes }\end{array}$} & \multirow[b]{2}{*}{ Royalties } & \multirow{2}{*}{$\begin{array}{c}\text { Gross } \\
\text { income }\end{array}$} & \multicolumn{2}{|c|}{ Real estate } & \multirow{2}{*}{$\begin{array}{l}\text { Motor } \\
\text { vehicle }\end{array}$} & \multirow[b]{2}{*}{ Stamp } & \multirow[b]{2}{*}{ Others } \\
\hline & & & & Urban & Rural & & & \\
\hline Buenos Aires & 16.1 & & 16.1 & 16.1 & 16.1 & 16.1 & 16.1 & 16.1 \\
\hline Catamarca & 8.5 & & 10.0 & 10.0 & 10.0 & 70.0 & & \\
\hline Chaco & 15.5 & & 15.5 & & & & 15.5 & \\
\hline Chubut & 10.0 & $14.4^{b} / 16.0^{c}$ & & & 24.0 & & & \\
\hline Córdoba & 20.0 & & 20.0 & 20.0 & 20.0 & & & \\
\hline Corrientes & 12.0 & & 12.0 & 100.0 & 12.0 & 100.0 & 12.0 & 12.0 \\
\hline Entre Ríos & 14.0 & $50.0^{b}$ & & & 24.0 & 60.0 & & \\
\hline \multicolumn{9}{|l|}{ Jujuyd } \\
\hline La Pampa & 10.7 & & 21.0 & 21.0 & 21.0 & 21.0 & 21.0 & 2.0 \\
\hline La Riojae & & & 20.0 & & & 50.0 & & \\
\hline Mendoza & 14.0 & $12.0^{b, c}$ & 14.0 & 14.0 & 14.0 & 70.0 & 14.0 & \\
\hline Misiones & 12.0 & & 12.0 & 12.0 & 12.0 & 78.0 & & \\
\hline Neuquén & 15.0 & $15.0^{c}$ & 15.0 & 15.0 & 15.0 & & 15.0 & \\
\hline Río Negro & 10.0 & $10.0^{c}$ & 40.0 & 40.0 & 40.0 & 40.0 & & 40.0 \\
\hline Salta & 12.0 & $20.0^{c}$ & 12.0 & & 12.0 & & 12.0 & 12.0 \\
\hline \multicolumn{9}{|l|}{ San Juan ${ }^{f}$} \\
\hline San Luis & 8.0 & & 16.0 & 16.0 & 16.0 & 16.0 & 2.4 & \\
\hline Santa Cruz & 11.0 & $7.0^{c}$ & 40.0 & & & & & \\
\hline Santa Fe & 13.4 & & 13.4 & 50.0 & 50.0 & 90.0 & & 20.0 \\
\hline \multicolumn{9}{|l|}{ Santiago del } \\
\hline Estero & 15.0 & & 25.0 & 25.0 & 25.0 & 40.0 & 25.0 & 25.0 \\
\hline \multicolumn{9}{|l|}{ Tierra del } \\
\hline Fuego & 25.0 & $20.0^{c}$ & 45.0 & & & & & \\
\hline Tucumán & 23.1 & & & 19.0 & 19.0 & 86.2 & 45.0 & \\
\hline
\end{tabular}

Source: DNCFP 1999.

a. Not including the multilateral agreement for taxation of gross income.

b. Hydroelectric royalties.

c. Oil royalties.

d. Regime suspended by emergency laws.

e. Regime partially suspended because of financial agreement.

f. Regime suspended because of financial agreement with municipalities.

In provinces endowed with natural resources, revenue from those resources is often shared with the municipalities. Specifically, royalties on oil, gas, and hydroelectricity, typical of Argentine Patagonia and the western provinces, are shared with the provinces. The hydrocarbon royalties are shared at variable rates. Two provinces, La Pampa and Formosa, do not share this resource with municipalities, however. Hydroelectric royalties are not shared with local governments, except in Mendoza and Entre Ríos. 
The quantification criteria for the primary allocation, derived from the laws regulating it in each province, are not explicit. Speculations have been made about the growth of this allocation, which is based on an approach that looks at overall fiscal need rather than strict considerations about the cost of the divisible services delivered by local governments. Secondary allocation, however, takes into account various apportionment elements, with the prevailing elements being those that emphasize origin, such as population or own resources. Nine provinces make the allocation to municipalities on the basis of a single criterion; the rest distribute it on the basis of various criteria according to the type of shared tax.

\section{Other Transfers to Local Governments}

National and provincial tax sharing with municipalities and other local governments constitutes the main type of unconditional transfer between the two subnational levels of government in Argentina. However, some minor types of transfers or grants also exist. These transfers are intended to alleviate fiscal needs and to generate fiscal equilibrium among the municipalities. They deserve particular attention, especially because in some cases they are distributed for specific purposes.

The most widespread transfers or grants are the so-called nonrefundable contributions or contributions from the treasury. Such contributions may be unconditional or conditional, and they may come from the provincial treasury or the national treasury.

The contributions from the national treasury come from a grant category established in the Tax-Sharing Law and must be used when an emergency or a fiscal imbalance arises within the provincial governments. However, the Ministry of the Interior, the authority in charge of the transfer of such resources, exercises a comprehensive approach to their allocation, and a good deal of these resources are passed on to local governments through provincial governments.

Other transfers from provinces to local governments consist of the provincial share in agreements governing joint activities. In these agreements, the province contributes the funds for infrastructure and the municipality or commune sees to management and execution. These grant methods are used relatively frequently. In Santa Fe, this method has been used to build and maintain highway and hydraulic infrastructure. In Buenos Aires, this method was used to create the Conurbation Fund, which copes with shortfalls in public works and services in Greater Buenos Aires. Greater Buenos Aires is an urban conglomerate that reaches 
past the boundaries of the federal district to the vast, densely populated surrounding area.

A more typical means of allocating transfers to Argentine local governments is through current transfers and capital transfers. Altogether, current and capital transfers do not add up to more than 10 percent of the total revenue of the local governments. The great majority of that percentage is made up of current transfers.

Table 10.12 shows the funds related to the tax sharing derived from the federal and provincial levels. Using a comprehensive notion of transfer, tax sharing represents nearly 39 percent of total revenue for local governments.

TA B L E 1 0 . 12 Significance of Transfers in Local Governments' Finances (percentage of total revenue)

\begin{tabular}{lrrccc}
\hline Province & $\begin{array}{c}\text { Total } \\
\text { transfers }\end{array}$ & $\begin{array}{c}\text { Current } \\
\text { transfers }\end{array}$ & $\begin{array}{c}\text { Capital } \\
\text { transfers }\end{array}$ & $\begin{array}{c}\text { Tax } \\
\text { sharing }\end{array}$ & $\begin{array}{c}\text { Transfers } \\
\text { and shares }\end{array}$ \\
\hline Buenos Aires & 3.2 & 3.2 & 0 & 36.0 & 39.2 \\
Catamarca & 55.4 & 55.2 & 0.3 & 34.7 & 90.1 \\
Chaco & 0.7 & 0.7 & 0 & 68.5 & 69.2 \\
Chubut & 6.7 & 6.7 & 0 & 14.6 & 21.3 \\
Córdoba & 4.1 & 4.1 & 0 & 37.2 & 41.3 \\
Corrientes & 11.7 & 11.7 & 0 & 51.9 & 63.6 \\
Entre Ríos & 8.5 & 8.5 & 0 & 38.8 & 47.3 \\
Formosa & 5.7 & 5.7 & 0 & 75.0 & 80.7 \\
Jujuy & 80.0 & 80.0 & 0 & 0 & 80.0 \\
La Pampa & 20.4 & 20.4 & 0 & 33.0 & 53.4 \\
La Rioja & 91.6 & 91.5 & 0.1 & 3.5 & 95.1 \\
Mendoza & 5.2 & 5.2 & 0 & 63.5 & 68.7 \\
Misiones & 1.8 & 1.8 & 0 & 52.3 & 54.2 \\
Neuquén & 1.4 & 1.4 & 0 & 26.4 & 41.2 \\
Río Negro & 5.2 & 5.1 & 0.1 & 46.8 & 52.0 \\
Salta & 6.6 & 6.6 & 0 & 48.3 & 54.9 \\
San Juan & 84.9 & 84.9 & 0 & 0 & 84.9 \\
San Luis & 0.8 & 0.8 & 0 & 58.6 & 59.4 \\
Santa Cruz & 19.4 & 19.4 & 0 & 36.0 & 55.5 \\
Santa Fe & 4.7 & 3.4 & 1.4 & 42.8 & 47.5 \\
Santiago del Estero & 4.8 & 4.8 & 0 & 75.8 & 80.6 \\
Tierra del Fuego & 0.1 & 0.1 & 0 & 73.2 & 73.3 \\
Tucumán & 20.6 & 20.6 & 0 & 42.2 & 62.8 \\
\multicolumn{1}{c}{ Total } & 9.8 & 9.6 & 0.1 & 38.8 & 48.5 \\
\hline
\end{tabular}

Source: Author's elaboration based on DNCFP 2004. 
Total tax shares and other transfers amount to 48.5 percent of the total revenue of the local governments.

\section{Fiscal Imbalances and Relative Financial Autonomy}

Vertical and horizontal fiscal imbalances exist in the bulk of the Argentine subnational governments (both provincial and local). In this sense, the resources of the federal government dominate, amounting to about 80 percent of total fiscal revenue, including social security contributions (Asensio 1990, 2000, 2003; Gómez Sabaini and Gaggero 1997; Rezk 1999).

Here we try to estimate this imbalance in a subgroup within the subnational conglomeration encompassing the second and third levels of government. The attempt is significant because there is substantial debate about the fiscal imbalance of Argentine provinces, but such debates do not always occur with regard to municipalities and communes.

Thus, it is important to analyze the parallel existence or absence of financial autonomy on the local level in Argentina. This idea will be considered in the sense outlined by Shah (1994), whose ultimate purpose involves determining the capacity of a level of government to meet its expenditure needs with its own resources rather than through transfers and tax shares received from other levels of government.

Table 10.13 shows that the vertical fiscal imbalance of all Argentine local governments is not significant enough to conceal a relatively satisfactory degree of financial autonomy. About 55 percent of local government disbursements are financed with the local government's own resources. Thus, the "margin of financial action" on the whole cannot be deemed negligible. ${ }^{24}$

However, when we look at the situation is specific provinces, significant nuances appear. Table 10.13 shows that there are major differences between the vertical imbalance and the degree of financial autonomy for the country as a whole (local governments nationwide) and those for local governments in individual provinces.

The financial autonomy of local governments in larger and moredeveloped provinces is much greater (and therefore their imbalances are less), whereas local governments in provinces with less development have greater dependence on transfers and shares, indicative of significant vertical imbalance.

Although the municipalities and communes of Buenos Aires and Córdoba finance, respectively, about 63 and 66 percent of their disbursements with their own resources, those of Catamarca and San Juan finance only 15 and 25 percent, respectively, which leaves them dependent on transfers and 
TA B LE 10.13 Imbalances and Financial Autonomy in Argentine Local Governments

(percent)

\begin{tabular}{lcc}
\hline Province & Vertical fiscal imbalance & Financial autonomy \\
\hline Buenos Aires & 37.3 & 62.7 \\
Catamarca & 85.2 & 14.8 \\
Chaco & 62.2 & 37.8 \\
Chubut & 19.7 & 80.3 \\
Córdoba & 33.6 & 66.4 \\
Corrientes & 56.2 & 43.8 \\
Entre Ríos & 45.0 & 55.0 \\
Formosa & 65.9 & 34.1 \\
Jujuy & 73.5 & 26.5 \\
La Pampa & 53.6 & 46.4 \\
La Rioja & 95.5 & 4.5 \\
Mendoza & 60.7 & 39.3 \\
Misiones & 45.4 & 54.6 \\
Neuquén & 37.0 & 63.0 \\
Río Negro & 52.7 & 47.3 \\
Salta & 49.6 & 50.4 \\
San Juan & 75.0 & 25.0 \\
San Luis & 61.8 & 38.2 \\
Santa Cruz & 56.7 & 43.3 \\
Santa Fe & 45.9 & 54.1 \\
Santiago del Estero & 66.2 & 33.8 \\
Tierra del Fuego & 100.0 & 0 \\
Tucumán & 55.9 & 44.1 \\
\multicolumn{1}{c}{ Total } & 45.1 & 54.9 \\
\hline
\end{tabular}

Source: Author's elaboration based on DNCFP 2004.

shares to cover the vertical fiscal imbalance. Clearly, such financial weakness is closely related to horizontal fiscal imbalances, which are connected, in turn, to interregional imbalances in the level of economic development and the tax bases.

When both notions are put in perspective, changes in the period between 1993 and 2001 can be observed (see table 10.14). Indeed, an increase in the level of financial autonomy of 2 percent can be seen, with a parallel decrease in vertical imbalance. Even though the position of local governments was best in 1995, the level in 2001 was satisfactory given the systemic crisis environment in which it was reached. 
TA B L E 1 0 1 4 Financial Autonomy and Vertical Imbalance of Local Governments (percent)

\begin{tabular}{lcc}
\hline Year & Financial autonomy $^{\mathrm{a}}$ & Vertical imbalance $^{\mathrm{b}}$ \\
\hline 1993 & 52.8 & 47.2 \\
1995 & 56.2 & 43.8 \\
1998 & 54.5 & 45.5 \\
2000 & 54.1 & 45.9 \\
2001 & 54.9 & 45.1 \\
\hline
\end{tabular}

Source: Author's elaboration based on DNCFP 2004.

a. Own resources/Total expenditure.

b. Tax sharing + Current transfers + Capital transfers/Total expenditure. (See Shah 1994.)

\section{Local Government Borrowing}

Financing through the use of credit allows local governments to enlarge their revenues beyond the framework enabled by their taxation powers, the resources derived from other levels of government, and their administrative capacity to collect the first and manage the second (see King 1988). Experiences in developed countries differ, but the significance attached to the "golden rule" is well known: local borrowing should be restricted to schemes related to mediumand long-term investment or increase in share capital (for experience in Europe, see Dexia 1998 and European Union, Committee of the Regions 2001).

Multiple options are available for controlling subnational debt. It is possible to distinguish five methods for achieving properly coordinated behavior by actors in a scheme with multiple levels of government. The most extreme methods are a straightforward application of market discipline or an absolute ban on contracting debt obligations. Between these extremes are cooperation among government levels, administrative controls, and rulebased approaches (see Ahmad 1999; Ter-Minassian and Craig 1997; World Bank 2000).

Implicit in these options is a strong assumption that higher levels of government will not resort to bailouts. Bailouts could lead to a relaxation of the fiscal discipline by the treasury departments involved, which would not be subject to the pressure of a strict budget constraint (see World Bank 2000, which describes Brazil's approach to state debt handling and stresses the differences in Argentina before 2001). The difficulties governments have faced in sticking to that resolve when there have been borrowings from the financial system must be acknowledged, however. ${ }^{25}$ 
As a rule, according to the constitution, the federal government is responsible for the arrangement of the foreign debt. The provinces, in turn, can contract debt obligations within the limits set by their constitutions. When those obligations are contracted abroad they require the authorization of the national government, embodied in regulations that provide for the intervention of the National Ministry of Economy and the Central Bank. For three decades, federal laws and statutes have regulated the intervention of the Ministry of Economy in the process of accessing the foreign finance market, as have other rules issued by the monetary authorities. ${ }^{26}$

During the 1990s, several provinces assumed debt obligations in the financial system, a situation that gradually worsened. It resulted in a federal agreement in 2001, under which the national government assumed provincial debts if the provinces met certain requirements, thereby becoming indebted to the central government in an operation that was known as debt exchange. It should be pointed out that several municipal governments had issued bonds in foreign currency. ${ }^{27}$

Accordingly, the debts of provinces and local governments were distributed in a framework larger than that of the banking system. It also included public bond holders. The debt exchange covered those debts assumed by the banks. As it turned out, the arrangement eased but did not eliminate the financial obligations of the provincial governments. It could not prevent either the financial or the economic crisis that ensued at the end of 2001, which also involved the national government.

Later, the national government repeated the procedure implemented with regard to the banking system in order to replace specific debts that provinces had assumed with the population when issuing bonds or compulsory certificates that functioned as quasi-money. Again the national government chose to rescue the provinces by assuming the debt instruments, and the provinces, though no longer indebted to the individuals and corporations holding the bonds, assumed a new indebtedness to the central government. ${ }^{28}$

Concerning local governments, borrowing is within the powers established by the provincial constitutions or organic laws from the same source. Despite the ever-increasing presence of borrowing, its use is not as widespread as other means (see López Murphy and Moskovits 1998). Often legislatures grant authorization to incur debts, though in other instances the councils of the respective local governments issue bylaws allowing local government executives to conclude credit-use transactions.

The constraints on running up debt are both quantitative and related to the use the funds must be put to. Quantitative restraints consist of specific limits in relation to another relevant financial variable within the structure 
of local finances. The "golden rule" or other principles govern restraints on the use of funds. In addition, it is common to require special majorities for the municipal assembly to vote to raise loans. ${ }^{29}$

In the province of Buenos Aires, the largest in the country, the provincial constitution provides that loan amortization and interest services cannot make up more than 25 percent of the unconditional ordinary funds (quantitative boundary). Contracting must be authorized by means of a bylaw $^{30}$ and must be used exclusively for the following purposes: betterment or public interest works, responses to acts of God, and debt cancellation. For foreign loans, additional authorization from the provincial legislature is required, and national government intervention is also necessary (López Murphy and Moskovits 1998).

However, in Buenos Aires, a provincial law is in force, according to which the Bank of the Province of Buenos Aires, one of the oldest banks in Argentina, must aid municipalities in its territory with an amount not less than the lowest average daily balance of local governments' deposits kept by the institution. Thus, a legally based arbitration clause is set by which the provincial bank lends money to municipal governments in proportion to the contribution those governments make to overall bank liquidity. ${ }^{31}$

In another major province, Santa Fe, the organic laws issued by the provincial legislature regulate (in line with the powers granted by the constitution), the prerogatives of local governments to contract debts. Usually, that legislature must pass a law to grant the municipal or communal government access to the use of credit.

However, during the past decade and even earlier, framework laws have been passed in Santa Fe regulating the procedures for municipalities and communes to raise loans, both from the foreign and national bank systems and from the provincial government, without the intervention of the provincial government. The purpose of such loans is important in this context, including the correction of temporary imbalances in the local finances.

Table 10.15 presents some typical requirements for local government borrowings, as established in the provincial constitutions.

\section{Local Government Administration}

We have pointed out that the organization of urban governments contemplates the existence of an executive branch, a branch of deliberative nature, and a judiciary in embryo for misdemeanors and minor infractions. This structure must be complemented with a bureaucracy or administration that will be responsible for providing local public goods to the residents. 


\section{T A B L E 1 0 . 15 Provincial Constitutional Framework for Local Borrowing}

\begin{tabular}{|c|c|}
\hline \multicolumn{2}{|l|}{ Enforcing authorities ${ }^{\mathrm{a}}$} \\
\hline Municipal assembly & 13 \\
\hline \multicolumn{2}{|l|}{ Provincial law } \\
\hline Intraprovincial debt & 5 \\
\hline Extraprovincial and external debt & 2 \\
\hline Regulations about special majorities ${ }^{b}$ & 12 \\
\hline With special majority & 12 \\
\hline Without special majority & 1 \\
\hline Limit and boundaries for the resources ${ }^{c}$ & 18 \\
\hline Over the total resources & 8 \\
\hline Over ordinary resources & 10 \\
\hline \multicolumn{2}{|l|}{ Earmarked or special-purpose resources } \\
\hline Golden rule & 5 \\
\hline Specific purposes & 9 \\
\hline Mixed purposes ${ }^{d}$ & 5 \\
\hline \multicolumn{2}{|c|}{$\begin{array}{l}\text { Source: Author's elaboration based on Binetti } 2004 \text { and Lódola and Tappatá } 1997 . \\
\text { a. For foreign borrowing, requirements of the national government should be added. } \\
\text { b. The affirmative vote of two-thirds of the municipal councils is generally required. } \\
\text { c. In general, between } 20 \text { and } 25 \text { percent of the total resources (wider) or the ordinary resources (more } \\
\text { restricted). } \\
\text { d. Normally, manifestations of the golden rule (such as public works, debt conversion or consolidation, and } \\
\text { extraordinary situations). }\end{array}$} \\
\hline
\end{tabular}

Arguments often arise in connection with the capacities of local administrations to manage particular activities or provisions of services efficiently. In Argentina, as in other settings, doubts have been cast on such capacities facing a stronger decentralization.

Responsibilities can be distributed at the regional and central levels, and the private sector can also be involved, splitting up the roles of "provision" and "production." The available institutional patterns are diverse, ranging from a separate provision for each level of government to several central-local or regional-local combinations. Moreover, outsourcing and agreements with the private sector for the performance of such functions are also options. ${ }^{32}$

In Argentina, some of those institutional patterns occur frequently. It is common in many municipalities to contract out refuse collection and treatment, and the same happens with other infrastructure services. ${ }^{33}$ Moreover, some services (such as cemetery maintenance) are delivered by private companies under local regulation. 
Nevertheless, questions remain about the efficiency of other administrative services. A significant example is tax administration on the local level. Using Mikesell's (2003) taxonomy, we know that local taxes can be administered centrally, locally, or by means of agreements or coadministration among the levels of government. Such patterns are found in Argentina regarding local taxes. In some instances, current obligations are legislated and collected by one level and overdue amounts are managed by another. However, there is a considerable sense, in this respect, that it is possible to improve collection efficiency. ${ }^{34}$

The increase in size and dimension of difficulties suggests that in the larger municipalities a critical mass has been developing, endowed with abilities to manage more complex services. In some small localities, there are examples of outstanding local management as well, both in efficiency and in results.

With reference to human resources, there is room to improve qualifications in the local environment, enhancing skills in improving services for citizens. However, although the recruitment and career attributes of personnel are established by municipal and communal regulations, the progressive introduction of collective bargaining agreements to local civil service has set some constraints on decision making at that level. Anyway, within the general requirements of the legal framework, the municipality is empowered to appoint and dismiss personnel, as well as to punish them if they do not comply with the regulations relating to their careers.

Yet in the broader picture, national, regional, and local administration in Argentina has marked features of formalism that keep it deeply rooted within a Weberian bureaucratic framework. Newer public management models or those boosted by incentives and encouragements such as the management-for-results model have yet to be perceived in Argentina in the appropriate measure, and they are even less recognized within the realm of local governments. ${ }^{35}$

In many municipalities, budgetary management reforms, such as the introduction of budgeting of programs and results, have been pursued. ${ }^{36} \mathrm{In}$ small human settlements-sometimes hardly reaching a hundred peoplecertain administrative complexities appear idealistic, when the daily challenges involve coping with cleaning the streets, keeping road access clear, controlling traffic, and maintaining a drinking water supply and street lighting and a minimum of public health.

However, a view filled with a certain Manichaeism based on the alleged lack of skill in local government has delayed feasible devolution measures that could have strengthened the processes of decentralization by providing for accountability at the local government level. 


\section{Overall Assessment of Local Finances}

This analysis of local finances in Argentina could be subject to variations if the use of other institutional patterns were to increase. In that case, it is likely that developments in both supramunicipal and submunicipal senses could be perceived.

This point bears on the advantage of studying new institutional patterns for service provision, some of which enjoy practical effectiveness but require a stronger legal framework. Consider the case of a metropolitan area tasked with providing a service like public transport; improving services to citizens may require a higher institutional development that is capable of adequate differentiation of property rights in both collective and private senses.

Indeed, there are regions where the effective fiscal correspondence of local governments is not low and the extent of accountability is significant. Municipalities in such provinces as Chubut, Neuquén, Buenos Aires, and Córdoba are examples. However, in other provinces, such municipalities are fewer, and the extent of the fiscal responsibility of those local administrations narrows substantially. This is the case of the local governments in northwestern provinces such as Catamarca and La Rioja.

However, if fiscal correspondence is not the only source of incentives to enhance accountability in the execution and provision of services to citizens, the overall institutional framework that defines the powers of local governments must be considered (Shah 1998). Among other aspects, there is significant scope in the population size that provincial constitutions require for granting municipality or commune status. This scope has an effect on the degree of representation. Furthermore, a setting in which two or more local governments perform activities jointly can improve the economic scale for the provision of several services.

The form of government is also important with respect to accountability. Given the democratic structure of local governments in Argentina, in which representatives are elected directly by citizens, a powerful incentive exists to enhance the accountability of elected officials. They are accountable to their electorate in a direct way, but they are also accountable to their provincial governments for compliance with provincial constitutions and submission to the organic laws that the provinces pass for local governments so that they may exercise their autonomy as granted by the national constitution of 1994 .

The structure of the formal control and audit mechanisms also merits some improvement. In some provinces, the tribunal of accounts is charged with financial control of local governments. The tribunal of accounts is an institution that has its origin in continental Europe but has taken on certain 
Hispanic characteristics. Generally a constitutional body, the tribunal of accounts must control at the same time the provincial government and a myriad of local governments. In the case of larger municipalities, the tribunal of accounts finds its source in the local laws. The existence of the tribunal does not undermine the role of the respective local assemblies.

From a financial point of view, however, there is scope for restructuring the current type of intergovernmental decentralization, which entails a new relationship with the provinces as intermediate levels of government. The financial scheme of Argentine local governments would change substantially if functional obligations (expenditure assignment) were redistributed downward, with municipalities assuming totally or partially some provincial functions, including, perhaps, services such as education, health care, and security, which are currently in the hands of the regional governments. The same could happen with respect to certain urban services whose regulation has not been delegated to municipalities. ${ }^{37}$

\section{Lessons for Developing Countries}

The Argentine case offers some particular features for comparative analysis. One is the incomplete adoption of both the benefit principle and the payment capacity (ability to pay) in terms of municipal taxation. Indeed, there is probably significant room for providing some services under the benefit approach, a move that could improve the financial profile in the face of other approaches in which fiscal resistance can wear away the tax bases of local governments. ${ }^{38}$

With respect to full tax autonomy, the effective assumption by Argentine local governments of the capacity to levy taxes must fit into a fiscal federalism scheme that accords that capacity with those existing on the national and provincial levels. ${ }^{39}$ The current dominant mix of rates ${ }^{40}$ and taxes indicates a phase of intergovernmental fiscal coordination that must be perfected.

A remarkable diversity exists in the degree of autonomy or "margin of financial action" of local authorities. This fiscal capacity is significant in some cases, despite some degree of transfer dependence. The difference between communes and municipalities that are endowed and those that are fiscally incapable is quite evident.

In a general sense, however, although the national average vertical fiscal imbalance is significant, the performance of many local governments is better than that of many of their provincial governments. Some of these municipalities could take on greater expenditure responsibilities, thereby increasing the overall efficiency of the system. 
A critical aspect is again the coordination with the higher levels of government. Overlapping activities and little accuracy in the correct delimitation of certain functional responsibilities are features of the Argentine intergovernmental scene.

Even though it is not new to federations, the importance of enhancing and improving the procedures of agreement and coordination should be stressed. A significant step would be the suitable application or improvement of regulations and procedures fitted to new legislation on fiscal responsibility, as has taken place in other federal and nonfederal environments. ${ }^{41}$

\section{Notes}

1. Buenos Aires was founded for the second time in 1580 by Juan de Garay, who by 1573 had also founded Santa Fe, about 300 miles north, on the Paraná River.

2. Other historical models matching Argentina, such as those of Australia and Canada, underwent strong crowding in major cities. But in Australia, Sydney has been offset by Melbourne. In Canada, Toronto has surpassed Montreal, and other major urban centers exist such as Vancouver, Edmonton, and Calgary. Buenos Aires, with its huge disparity relative to Rosario, Córdoba, Tucumán, and Mendoza, is a special case, bearing in mind the Latin American trend toward building "megacapitals" such as Mexico City or Santiago.

3. We espouse here the idea of dualism as expressed in Bahl and Linn (1992) and Shah (1994).

4. In this sense, the regime established in Buenos Aires does not differ from other constitutional regimes that grant the federal district a particular role. Consequently, for the purpose of fiscal and financial analysis, Buenos Aires is not considered among local governments in Argentina.

5. That is to say that local governments operate within the legal framework created by provinces but in a position of autonomy stronger than existed before the constitution of 1994.

6. The dominant element in establishing the size at which a population is rated a municipality is the number of inhabitants, and the number varies from province to province. In Córdoba, a municipality need have only 2,000 inhabitants, but in Santa Fe only towns with more than 10,000 inhabitants are municipalities.

7. See Iturburu $(2001 b, 52)$. The data should be considered carefully, because populations of the larger municipalities can conceal big differences in the grouping of small local governments.

8. The case of Río Cuarto, in the province of Córdoba, with an average population growth of 1.8 percent per year, runs counter to the case of small towns of about 200 inhabitants, where the population decreases at an average rate of 3 percent per year (Ponce 1997).

9. Suburbanization is the process of developing suburbs, in many cases caused by the migration to the outskirts of citizens and trades originally established in the downtown area, in search of a social environment and the peace and quiet that presumably has deteriorated in the most crowded urban areas. 
10. We differentiate what in Spain is known as inframunicipalism, a trend toward building local governments in small towns, from "inframunicipal" organic forms- that is, areas with a size smaller than a municipality.

11. Intendente is the synonym of alcalde in the Spanish tradition (both meaning mayor). The concejales or ediles (councilors or aldermen) are the members of a town council or assembly.

12. The "urban province" status of Buenos Aires was mentioned earlier. As Bahl and Linn (1992) point out in the cases of Calcutta, Mexico City, and Rio de Janeiro, this status covers many functions not delivered by small cities.

13. Some Argentine cities get involved in primary health care, setting up public hospitals. This takes place in an environment where the next higher government level, the provincial state, usually takes on these and other responsibilities (such as security) that in some models are also part of an urban government role.

14. Functions such as environmental protection usually entail some overlap, though there is a provincial predominance in regulation and oversight, whereas localized activities such as garbage collection, street cleaning, urban planning, and building construction are typically covered by municipalities.

15. A specific case relates to the province of Córdoba. See Iturburu (2001a).

16. These partnerships are known as highway consortiums. In another instance, such consortiums have been allowed to collect tolls.

17. The cycles of decentralizing national services toward subnational levels have affected the provinces more than the local governments, which have seen an increase in the amount of social and health care spending (Iturburu 2001a).

18. This is the case for the provinces of Santa Fe and Buenos Aires, which are first and second in population size in the Argentine Republic. By contrast, Córdoba, the third most populous province, has established municipal autonomy.

19. Rates are taxes collected in exchange for divisible services delivered to residents. The cost of service provision is a factor in measuring the magnitude of the benefit that each user receives.

20. It is relevant to point out that adhering unrestrictedly to the principle, without additional grants from the provincial government, could cause significant financial imbalances for Argentine local governments. The existence of indirect costs adds complexity to the issue.

21. Dino Jarach wrote one of the first proposals for tax sharing between the nation and the provinces. For an in-depth examination of transfers from an international point of view, see Shah (1999b).

22. Allocation is thought to narrow the freedom of the donating government level, which endeavors to keep exclusive revenue separate.

23. In this case, the proportion that makes up the primary allocation does not have its source in the province's tax-sharing law; it derives directly from the provincial constitution.

24. Here we refer to the European view of local governments' capacity to fund themselves with resources of their own (Dexia 1998).

25. In Brazil the federal government's fear of a widespread crisis of the banking system encouraged the intervention of the Central Bank in the São Paulo case (see Dillinger and Webb 1999; World Bank 2000).

26. We refer to National Law 19,328 and to Decree 3532/75. More recently, the Ministry of Economy issued Resolutions 1075/93 and 277/95, on payment obligations in 
foreign currency. Such legislation, in addition to providing for the intervention of the ministry, requires that the Central Bank be notified.

27. Among others, the municipalities of General Pueyrredón and La Plata in Buenos Aires, Río Cuarto in Córdoba, Bariloche in Río Negro, and Guaymallén in Mendoza did so (Lódola and Tappatá 1997).

28. These are procedures fully in use at the time of writing this chapter.

29. The term loan is widely used and includes borrowing or credit use. The term comprises both the issuing of bonds and borrowing from the banking system.

30. Bylaws are the legal acts issued by local government councils or assemblies.

31. This provision was established by Law $10,753 / 88$. Statistics show that the use of borrowing in that province, even if directed mostly to public investment, was also applied to current expenditure (Lódola and Tappatá 1997). It can thus be construed that such credits are founded on the grounds of responses to acts of God or force majeure.

32. We could add to this list of options the possibilities of association among local governments, establishment of local authorities that embrace several municipalities, municipal development corporations, franchising, and so on (Bird 1995; Bird, Litvack, and Ahmad 1998).

33. In some cases, services operated by utilities are contracted out.

34. There are varied experiences concerning the management of local taxes, from instances originated in a centralist past, as in Spain, to some other cases with a definite autonomist tradition, as in the United States. See Mikesell (2003) and Monasterio and Suárez Pandiello (1998).

35. Within the framework of new public management models, management for results implies that the managerial level is evaluated on the basis of outcomes produced, not mere adherence to procedures and rules.

36. Experiences such as "participative budgeting" show an alternative that must be evaluated or tested in the light of actual application and effects.

37. As expressed earlier, in Argentina there was a leap from monopolistic public services delivered by the national and provincial governments to services delivered by the private sector, without passing through local governments.

38. We allude to a greater significance of user charges within the structure of resources.

39. We have mentioned before the use of "rates" as concealed taxes.

40. We think this English word is the most appropriate for the similar word in Spanish, tasa.

41. Argentina enacted a Law of Fiscal Solvency in 1999, before the issuance of the wellknown Law of Fiscal Responsibility of Brazil in 2000. On that occasion, subnational governments were encouraged to emulate the law, but progress has been slow, as it is on the local level. During 2004, Argentina enacted the Fiscal Responsibility Law, which includes budgetary, transparency, and borrowing provisions.

\section{References}

Ahmad, Junaid. 1999. “Decentralizing Borrowing Powers.” In Decentralization Briefing Notes, ed. Jennie Litvack and Jessica Seddon, 32-38. Washington, DC: World Bank Institute. 
Asensio, Miguel Angel. 1990. Coparticipación de Impuestos y Coordinación Fiscal Intergubernamental en la Argentina. Buenos Aires: Centro de Estudiantes de Ciencia y Tecnología.

- 2000. Federalismo Fiscal: Fundamentos: Análisis Comparado y Caso Argentino. Buenos Aires: Ciudad Argentina.

- 2003. Descentralización y Federalismo Fiscal en la Unión Europea y el MERCOSUR: Una Aproximación Preliminar. Santa Fe, Argentina: Editorial UNL.

Bahl, Roy, and Johannes Linn. 1992. Urban Public Finance in Developing Countries. Washington, DC: World Bank and Oxford University Press.

Binetti, Elizabeth. 2004. Los Tributos Municipales Frente al Federalismo. Master's thesis, Universidad Nacional del Litoral, Santa Fe, Argentina.

Bird, Richard M. 1995. "Fiscal Federalism and Federal Finance." In Anales Jornadas de Finanzas Públicas 28. Córdoba, Argentina: Facultad de Ciencias Económicas, Universidad Nacional de Córdoba.

Bird, Richard M., Jennie Litvack, and Junaid Ahmad. 1998. "Rethinking Decentralization in Developing Countries.” Discussion Paper, World Bank, Washington, DC.

Bird, Richard, and François Vaillancourt. 1998. Fiscal Decentralization in Developing Countries. New York: Cambridge University Press.

Dexia. 1998. “Las Finanzas Locales” en los Quince Países de la Unión Europea. Brussels and Paris: Dexia.

Dillinger, William, and Steven Webb. 1999. Fiscal Decentralization and State Debt Crisis in Brazil. Research Working Paper 2138, World Bank, Washington, DC.

DNCFP (Dirección de Coordinación Fiscal con las Provincias, Ministerio de Economía). 1999. 10 Años en la Relación Fiscal Nación, Provincias y Municipios. Vol. II. Buenos Aires: Ministerio de Economía.

—.2004. Sector Público Municipal Consolidado, Años 2000-2001. Buenos Aires: Ministerio de Economía.

European Union, Committee of the Regions. 2001. Regional and Local Government in the European Union: Responsibilities and Resources. Luxembourg City: European Union.

Gómez Sabaini, Juan C., and Jorge Gaggero. 1997. "Propuestas para la Reforma del Sistema Tributario Argentino." Aplicación Profesional 16.

Iturburu, Mónica Silvana. 2001a. Municipios Argentinos: Potestades y Restricciones Constitucionales para un Nuevo Modelo de Gestión Local. Buenos Aires: Ediciones del Instituto Nacional de la Administración Pública.

_. 2001b. "Nuevos Acuerdos Institucionales para Afrontar el Inframunicipalismo Argentino." In Cooperación Intermunicipal en Argentina. Buenos Aires: Ediciones del Instituto Nacional de la Administración Pública.

Jarach, Dino. 1985. Finanzas Públicas. Buenos Aires: Editorial Cangallo.

King, David. 1988. Economía de los Gobiernos Multinivel. Madrid: Instituto de Estudios Fiscales.

Lódola, Agustín, and Mariano Tappatá. 1997. "Endeudamiento de los Municipios en la Provincia de Buenos Aires.” In Anales Jornadas de Finanzas Públicas 30: 9.1-9.31. Córdoba, Argentina: Facultad de Ciencias Económicas, Universidad Nacional de Córdoba.

López Murphy, Ricardo, and Cynthia Moskovits. 1998. "Desarrollos Recientes en las Finanzas de los Gobiernos Locales en Argentina.” Working Paper 58, Fundación de Investigaciones Económicas Latinoamericanas, Buenos Aires. 
Lukszan, Alberto. 1988. "Recursos Fiscales Municipales.” In Gobierno de la Ciudad y Crisis en la Argentina, ed. Hilda Herzer and Pedro Pirez. Buenos Aires: International Institute for Environment and Development and Grupo Editor Latinoamericano.

Mikesell, John L. 2003. "International Experiences with Administration of Local Taxes: A Review of Practices and Issues." Prepared for the World Bank Thematic Group on Taxation and Tax Policy, Washington, DC.

Monasterio, Carlos, and Javier Suárez Pandiello. 1998. Manual de Hacienda Autonómica y Local. Barcelona, Spain: Ariel.

Ponce, Carlos. 1997. "El Sector Público Municipal en la Provincia de Córdoba: Algunas Características Cuantitativas.” In Anales Jornadas de Finanzas Públicas 30: 2.1-2.26. Córdoba, Argentina: Facultad de Ciencias Económicas, Universidad Nacional de Córdoba.

Rezk, Ernesto. 1999. "Experiences of Decentralisation and Intergovernmental Fiscal Relations in Latin America." In Fiscal Decentralisation in Emerging Economies: Governance Issues, ed. Kiichiro Fukasaku and Luiz R. de Mello. Paris: Organisation for Economic Co-operation and Development.

Scobie, James S. 1972. Argentina: Una Ciudad y una Nación. Buenos Aires: SolarHacchette.

Shah, Anwar. 1994. Intergovernmental Fiscal Relations in Developing Countries. Washington, DC: World Bank.

- 1998. "Balance, Accountability, and Responsiveness: Lessons about Decentralization.” Policy Research Working Paper 2021, World Bank, Operations Evaluation Department, Country and Regional Evaluation Division, Washington, DC.

_. 1999a. "Expenditure Assignment." In Decentralization Briefing Notes, ed. Jennie Litvack and Jessica Seddon, 19-22. Washington, DC: World Bank Institute.

_. 1999b. "Intergovernmental Transfers and Grants." In Decentralization Briefing Notes, ed. Jennie Litvack and Jessica Seddon, 27-31. Washington, DC: World Bank Institute.

—. 1999c. "Issues in Tax Assignment." In Decentralization Briefing Notes, ed. Jennie Litvack and Jessica Seddon, 23-26. Washington, DC: World Bank Institute.

Ter-Minassian, Teresa, and J. Craig. 1997. "Control of Subnational Government Borrowing." In Fiscal Federalism in Theory and Practice, ed. Teresa Ter-Minassian. Washington, DC: International Monetary Fund.

Urlezaga, Federico, and Mirta Basile. 1997. "Municipios: Funciones y Financiamiento." In Anales Jornadas de Finanzas Públicas 30: 20.1-20.28. Córdoba, Argentina: Facultad de Ciencias Económicas, Universidad Nacional de Córdoba.

World Bank. 2000. Entering the 21st Century: World Development Report 1999/2000. New York: Oxford University Press.

Zapata, Juan A., Aníbal O. Bertea, and Teresa B. Iturre. 2000. “Sistema de Supervisión Multilateral para un Federalismo con Responsabilidad Fiscal.” Paper presented at Reunión Anual ABA-Expobank, Buenos Aires, November. 



\section{Local Government \\ Organization and Finance: Brazil}

J O S É R O B ER T O RO D R I G UES A F O N S O

A N D ERIKA A MORIM A R A Ú J O

$\mathrm{B}^{\text {razil is organized as a federal republic with a presidential }}$ system. ${ }^{1}$ The national constitution defines the federation as a sum of the three tiers: the central government (called the union and also referred to as the federal government); the intermediate governments (called states, also referred to as state governments, consisting of 27 units including the federal district); and the local governments (called municipalities, also referred to as municipal governments, currently consisting of 5,564 units). This chapter addresses only the last tier, the municipal governments. ${ }^{2}$

With its continental dimensions, Brazil is the fifth largest territory and has the sixth biggest population on the planet. Its political structure is a democratic federation in every sense of the word, both in theory and in practice. The main political option for decentralization was adopted by the constitutional assembly, which drafted and approved the constitution that has been in force since October 1988. This constitution is considered a benchmark in Brazilian federalism. It deepened the process of decentralizing, rather than merely deconcentrating, revenue mobilization and expenditure functions. Greater autonomy was granted to states and municipalities in debt and expenditure management and control. It was the 
basic framework for the process of redemocratization after 20 years of military dictatorship.

The idea was that the reduction of the fiscal and financial power of the central government and the corresponding strengthening of that power in the state and municipal governments-especially in the less-developed regions - should form a kind of financial arm of a broader political movement. As a consequence, the most outstanding feature of the Brazilian fiscal system is that its decentralization is not based on political and economic policies that are formulated and implemented under the orders of the central government. On the contrary, most of the intergovernmental relations cannot be established or modified by the federal political and economic authorities according to their own wishes.

As a consequence, Brazil is a much decentralized federation. The states and municipalities together account for more than one-third of national tax revenue collection, two-fifths of total government spending, and almost 35 percent of the public sector's net debt stock. Revenue mobilization capacity is concentrated in the more prosperous states and municipalities of the south and southeast regions, and some equalization of expenditure capacity has been pursued through mandated revenue sharing. Political and administrative decentralization is also extensive. Each state and local government has its own directly elected legislature and executive branches, as well as an independent judiciary. The central government has limited control over subnational tax administration; budget formulation, execution, and oversight; and wage and investment policies.

The number of municipalities is 5,564 and the population distribution is very heterogeneous. In 2005, the population was estimated at 184.2 million. The city with the biggest population is São Paulo, with 10.9 million inhabitants, and the smallest is Borá with 823 . There are 35 cities with more than 500,000 people, or 28.6 percent of the national population. At the other extreme, 2,672 cities have fewer than 10,000 inhabitants, equivalent to 7.6 percent of the national population. Distribution among the municipalities is shown in table 11.1.

Each municipality is integrated into the territory of a state. There is no pattern for the creation or distribution of the number of units per state. The states with the most municipalities are Minas Gerais (853), São Paulo (645), and Rio Grande do Sul (496). The states with the fewest local governments are Roraima (15 units), Amapá (16), and Acre (22).

The municipalities have a particular political status. They are not integrated units or members of the state governments, unlike in most federations. However, the creation, consolidation, or dissolution of a municipality 
TA B LE 11. 1 Municipalities by Group of Inhabitants, 2005

\begin{tabular}{lcccr}
\hline $\begin{array}{l}\text { Group of } \\
\text { inhabitants } \\
\text { (per 1,000) }\end{array}$ & $\begin{array}{c}\text { Number of } \\
\text { municipalities }\end{array}$ & $\begin{array}{c}\text { Population } \\
\text { of group } \\
\text { (per 1,000) }\end{array}$ & $\begin{array}{c}\text { Distribution of } \\
\text { municipalities } \\
\text { (\% of total) }\end{array}$ & $\begin{array}{c}\text { Distribution of } \\
\text { population } \\
\text { (\% of total) }\end{array}$ \\
\hline Up to 2 & 125 & 204 & 2.2 & 0.1 \\
$2-5$ & 1,237 & 4,336 & 22.2 & 2.4 \\
$5-10$ & 1,310 & 9,435 & 23.5 & 5.1 \\
$10-20$ & 1,298 & 18,679 & 23.3 & 10.1 \\
$20-50$ & 1,026 & 31,001 & 18.4 & 16.8 \\
$50-100$ & 313 & 22,132 & 5.6 & 12.0 \\
$100-200$ & 130 & 17,995 & 2.3 & 9.8 \\
$200-500$ & 90 & 27,629 & 1.6 & 15.0 \\
$500-1,000$ & 21 & 14,756 & 0.4 & 8.0 \\
1,000 & 14 & 38,015 & 0.3 & 20.6 \\
Total & 5,564 & 184,182 & 100.0 & 100.0 \\
\hline
\end{tabular}

Source: Authors from data provided by the Brazilian Institute for Geography and Statistics.

is done through state law. This process is regulated by national norms such as publishing of municipal viability studies and approval by plebiscite of the population of the original municipality, including the area to be emancipated (1988 constitution, article 18, fourth paragraph). The central government cannot create or dissolve municipalities.

The Brazilian constitution that was promulgated in October 1988 innovatively established municipal government as a third tier of government (article 18). Municipalities were given the same status as members of the federation as the intermediate government, sharing the same rights and duties of states. ${ }^{3}$ The three-tier federation inscribed and detailed in the constitution reflects the long tradition of local autonomy.

All Brazilian municipal governments enjoy the same legal status. The official definition of the municipality encompasses all municipal and district areas, as well as rural and urban ones, although they vary enormously in every aspect. The definition of urban places is merely for administrative purpose, regardless of their size.

Every municipal government holds its own elections. The mayor (chief executive) and the municipal council members (local legislative tier) are selected directly by the voters for a four-year term. The mayor can be reelected once. In municipalities with more than 200,000 voters, a secondrun election must be held if no candidate achieves a majority. As in the national and state legislative body, municipal councilors are elected through 
the system of open-list proportional representation. The number of councilors varies according to the municipality's population. After the promulgation of the 1988 constitution, each municipality became entitled to issue its own constitution, known as the organic law.

In 1980, there were 3,991 municipalities in Brazil. This number increased to 4,491 in 1990 and to 5,564 in 2006 . About 1,500 units were created in Brazil after the 1988 constitution, thereby increasing outlays on personnel and administration, in addition to transfers to their legislatures, at the expense of more productive spending on, for instance, social programs and urban infrastructure. A lack of specific criteria for the creation of municipalities was an additional factor contributing to the proliferation of municipalities in the early 1990 s.

In recent years, local governments have become increasingly important in Brazilian federalism. Their role is changing significantly, not only because of their increased revenue mobilization capacity, but also because of their more active role in service delivery, particularly in the social area. It has been argued that the fiscal decentralization provision in the 1988 constitution was essentially a process of municipalization of revenue mobilization and service delivery.

The municipalities enjoy broad autonomy in regard to levying taxes and collecting other forms of income; making expenditures; and even hiring public employees, setting their salaries, and contracting debts. The budgets and corresponding rendering of accounts are submitted to the legislative powers of the local governments themselves and do not depend on ex ante or ex post authorizations or evaluations by the federal government. Local governments have a reasonable amount of leeway with regard to larger transfers from central and state governments connected with fundamental education and public health programs, which operate as general-purpose grants. The so-called voluntary transfers and possible loans obtained from federal bodies are exceptions and therefore have little weight in the current fiscal system.

To give an initial idea of the size of the local governments, table 11.2 shows the preliminary consolidation of revenues and expenditures in 2004. Total revenue was US $\$ 45$ billion, equivalent to 7.44 percent of gross domestic product (GDP): one-third from the state's own revenue and two-thirds from transfers received from federal and state governments. The total expenditure was US $\$ 44$ billion, equivalent to 7.26 percent of GDP, 44 percent spent on payroll and 11 percent on investments. The overall surplus was US\$1 billion, equivalent to 0.19 percent of GDP and 2.5 percent of total revenue. 
TA B LE 11.2 Municipal Revenues and Expenditures, 2004

\begin{tabular}{|c|c|c|c|}
\hline Statement of operations & US\$ billion & $\begin{array}{c}\text { Percentage } \\
\text { of GDP }\end{array}$ & $\begin{array}{c}\text { Percentage } \\
\text { of total } \\
\text { revenue }\end{array}$ \\
\hline GDP & 603.9 & & \\
\hline Revenues & 44.9 & 7.44 & 100.0 \\
\hline Own-source & 15.6 & 2.58 & 34.7 \\
\hline Tax collected & 10.8 & 1.78 & 24.0 \\
\hline Transfers & 29.3 & 4.86 & 65.3 \\
\hline Shared tax transfer & 10.6 & 1.76 & 23.6 \\
\hline Mandatory tax transfers & 11.9 & 1.97 & 26.4 \\
\hline $\begin{array}{l}\text { Health system } \\
\text { (regular grants) }\end{array}$ & 3.7 & 0.62 & 8.3 \\
\hline Expenditures & $(43.8)$ & -7.26 & -97.4 \\
\hline Compensation of employees & $(17.5)$ & -2.90 & -38.9 \\
\hline Social security benefits & $(2.3)$ & -0.39 & -5.2 \\
\hline Consumption of goods and services & $(15.3)$ & -2.53 & -34.0 \\
\hline Interest & $(0.8)$ & -0.14 & -1.8 \\
\hline Acquisition of fixed assets & $(5.0)$ & -0.82 & -11.0 \\
\hline Other expenses & $(2.9)$ & -0.48 & -6.5 \\
\hline Gross operation balance (surplus) & 1.1 & 0.19 & 2.5 \\
\hline Primary surplus & 1.9 & 0.32 & 4.3 \\
\hline \multicolumn{4}{|l|}{ Net borrowing (gross loan } \\
\hline amortization) & $(0.4)$ & -0.06 & -0.8 \\
\hline Borrowing (new operations) & 0.4 & 0.07 & 1.0 \\
\hline Net operation balance (surplus) & 0.8 & 0.13 & 1.8 \\
\hline
\end{tabular}

Source: Authors from data provided by the Brazilian Institute for Geography and Statistics (GDP) and National Treasury (balance sheets consolidated for 4,579 municipalities).

Note: Values in local currency converted to the U.S. dollar according to the midyear exchange rate $(\mathrm{R} \$ 1.00=$ US\$2.93). Parentheses indicate disbursements.

\section{Local Government Expenditure Responsibilities}

The distribution of expenditure responsibilities by tier of governmentdistinguishing between the responsibilities to legislate and to provide services-is very important in qualifying the Brazilian federation as highly decentralized. ${ }^{4}$ The constitution determines which activities should be performed or regulated exclusively by the central government and which should be dealt with by local governments. It explicitly reserves certain 
powers for the central government while providing a broad and general mandate to states and municipal governments. However, there are specific areas over which more than one tier of government has responsibility, whereas other activities are not clearly assigned to any tier.

Municipal governments have played an increasingly important role in Brazilian federalism in recent years. These local governments have been enjoying greater autonomy in service delivery, particularly in the provision of social services such as health care and education, with positive effects on social indicators.

Like Brazil's earlier political structure, the constitution of October 1988 explicitly reserves certain powers for the federal government, while providing a broad and general mandate to states and municipal governments. The constitution determines which activities should be performed or regulated exclusively by the federal government (articles 21 and 22) and by the municipal governments (article 30). States may carry out all functions not prohibited to them by the constitution. Several activities are executed concurrently by the three tiers of government. To legislate about such activities, the federal law must be limited to general norms (article 24), but it prevails if it conflicts with state and municipal legislation.

States and municipalities have broad constitutional mandates. Table 11.3 shows the concurrent and local spending assignments. States are granted "all powers not otherwise prohibited to them by this constitution" (article 25, first paragraph). Municipalities are assigned "the power to legislate over subjects of local interest" and to provide "services of local public interest" (article 30). States, therefore, cannot compel or prohibit actions by municipalities within their jurisdictions. Some functions are exclusive or almost exclusive to the federal government (defense, foreign affairs, environmental management, and labor). For some others (social insurance, energy, and sectoral policies), expenditures are concentrated at the federal tier. Public security is a state function, whereas housing and urbanization are municipal ones. The three tiers of government share responsibilities for education and for health and sanitation.

Although the constitution also indicates some division of responsibilities among tiers of government, there is a big distance between theory and practice. Regional disparities and insufficient or inadequate federal capacities to coordinate intergovernmental relations explain some of those difficulties. In practice, activities overlap, above all because of the great differences between regions, not only in economic and social conditions but also in the executive capacity of the state and municipal public administrations. 
TA B LE 11.3 Local Expenditure Responsibilities

\begin{tabular}{ll}
\hline Level of government & Spending category \\
\hline Federal-state-local (shared) & Health and social welfare \\
& Services for people with disabilities \\
& Historic, artistic, and cultural preservation \\
& Protection of the environment and natural resources \\
& Culture, education, and science \\
& Forests, fauna, and flora protection \\
& Agriculture and food distribution \\
& Housing and sanitation \\
& Combating of poverty and social marginalization \\
& Exploitation of minerals and hydroelectricity \\
& Traffic safety \\
& Small business improvement policies \\
& Tourism and leisure \\
Mainly local & Preschool and primary education \\
& Preventive health care \\
& Historic and cultural preservation \\
& Inner-city public transportation \\
Only local & Land use \\
\hline
\end{tabular}

Source: Souza 2001.

The central government has not been able to perform its role of coordination satisfactorily. As a result, state and municipal governments have tended to adopt autonomous policies. If the central government or even some states reduce their participation in long-term investments and programs, they fail to transfer personnel and properties to state or local units, thus generating an unforeseen increase in aggregate public spending.

It is important to note that most of the state-and especially the localexpenditures do not correspond to tasks delegated by upper tiers of government. The lower tiers of government assume such expenditures—even when no official act or law formally gives them responsibility for such outlays-in order to take care of the interests and needs of the local community. Take transportation as an example: municipalities are spending more than the central government on this function, so much so that investments in national transportation systems dropped (and municipal expenditure should be concentrated on the operating costs of providing urban passenger transportation, including through the use of subsidies).

Table 11.4 shows municipal outlays by function of government in 2004 and the distribution among the tiers of government, according to their 
T A B L E 11 . 4 Municipal Outlays by Function of Government, 2004

\begin{tabular}{|c|c|c|c|c|c|c|c|}
\hline \multirow[b]{3}{*}{ Outlays by function of government } & \multicolumn{3}{|c|}{ Local government } & \multicolumn{4}{|c|}{ General government } \\
\hline & \multirow[b]{2}{*}{ US\$ billion } & \multirow{2}{*}{$\begin{array}{l}\text { Percentage of } \\
\text { GDP }\end{array}$} & \multirow{2}{*}{$\begin{array}{c}\text { Percentage of } \\
\text { total outlays }\end{array}$} & \multirow{2}{*}{$\begin{array}{c}\text { Percentage of } \\
\text { GDP }\end{array}$} & \multicolumn{3}{|c|}{ Percentage of total tiers of government } \\
\hline & & & & & Local & State & Central \\
\hline Education & 9.3 & 1.54 & 23.7 & 4.36 & 35.3 & 50.1 & 14.6 \\
\hline Primary (elementary) & 6.8 & 1.12 & 17.2 & 2.02 & 55.4 & 43.0 & 1.6 \\
\hline Preprimary (for children) & 1.3 & 0.22 & 3.4 & 0.23 & 97.9 & 1.4 & 0.7 \\
\hline Health & 8.5 & 1.40 & 21.6 & 3.46 & 40.6 & 39.1 & 20.3 \\
\hline Preventive activities & 3.5 & 0.58 & 8.8 & 0.72 & 80.1 & 16.1 & 3.8 \\
\hline Hospital services & 3.9 & 0.65 & 10.0 & 1.55 & 41.8 & 53.2 & 5.0 \\
\hline General public services & 7.6 & 1.25 & 19.3 & 12.36 & 9.1 & 21.8 & 69.1 \\
\hline Administration & 5.4 & 0.90 & 13.8 & 2.28 & 39.5 & 38.4 & 22.1 \\
\hline Legislative & 1.3 & 0.21 & 3.2 & 0.73 & 28.6 & 43.9 & 27.6 \\
\hline Public debt transactions & 0.9 & 0.15 & 2.3 & 9.36 & 1.6 & 10.0 & 88.4 \\
\hline Urban services and community amenities & 4.9 & 0.81 & 12.4 & 0.93 & 86.6 & 9.7 & 3.8 \\
\hline
\end{tabular}




\begin{tabular}{lrrrrrrr} 
Social security & 2.3 & 0.38 & 5.8 & 11.07 & 3.4 & 12.0 & 84.6 \\
$\quad$ Retirement and pension & 1.8 & 0.30 & 4.6 & 3.67 & 8.2 & 32.4 & 59.4 \\
Transport & 1.4 & 0.22 & 3.5 & 0.97 & 23.1 & 58.4 & 18.4 \\
$\quad$ Road transportation & 0.8 & 0.13 & 2.0 & 0.50 & 26.4 & 56.1 & 17.5 \\
Social assistance & 1.1 & 0.19 & 2.9 & 1.00 & 18.9 & 9.3 & 71.8 \\
Sanitation & 1.0 & 0.17 & 2.6 & 0.30 & 55.0 & 44.8 & 0.3 \\
Housing & 0.3 & 0.06 & 0.8 & 0.12 & 45.7 & 40.5 & 13.8 \\
Public order and safety & 0.3 & 0.05 & 0.8 & 1.32 & 3.7 & 85.6 & 10.6 \\
Others & 2.7 & 0.44 & 6.8 & 7.42 & 7.7 & 22.3 & 69.9 \\
$\quad$ Total outlays & 39.3 & 6.51 & 100.0 & 43.31 & 15.0 & 26.1 & 58.9 \\
\hline
\end{tabular}

Source: Authors from data provided by the Brazilian Institute for Geography and Statistics (GDP), National Treasury (consolidated balance sheets), and Afonso 2006.

Note: Values in local currency converted to the U.S. dollar according to the midyear exchange rate $(\mathrm{R} \$ 1.00=$ US\$2.93). General government refers to the consolidation of central govern-

ment, state governments, and local governments, excluding the transfers between different tiers of government. Expenditures in each tier of the government is the outlay by the

respective function of government, not including transfers to other governments. 
importance in local finance. Local outlays were equivalent to 6.51 percent of GDP and to 15.0 percent of general government expenditures. In the vigorous expansion of municipal budgets, it is worth highlighting the sizable increase in spending on health (even though dependence on nontax transfers from the central government was still high) and also the maintenance of education as the most important function. Expenditures on those two functions account for about half of the consolidated municipal budget. Note in particular the local participation in the general government outlay: 98 and 55 percent of national expenditures were spent on preprimary and primary education; 80 and 42 percent on preventive health activities and hospital services. The size of spending on housing and urbanization is worth noting; it includes typically local services such as refuse collection, public street lighting, and maintenance of urban roadways, followed in smaller proportions by transportation.

By category of expenditure, the share of local spending in total spending is also more relevant in looking at current consumption and national fixed investment expenditure: these two categories account for 30 percent of the active civil servants payroll and 45 percent of total public gross capital formation, according to national accounts for 2003. Note in particular that the central government's share in total nonfinancial spending is only higher than that of subnational governments in social security outlays.

\section{Taxes and Charges Levied by Local Governments}

The financing of the three tiers of government is provided by a set of taxes, as well as fees and contributions. ${ }^{5}$ Each governmental unit has the right to institute the taxes assigned to the respective tier of government by the national constitution, to fix the rates, and to manage the collection. The constitution clearly defines the assignment of tax responsibilities to each tier of government, so there is no possibility of overlapping responsibilities. The proceeds of many federal and states taxes are shared with other tiers. Municipal taxes are not shared. The constitution details a series of basic rules for the collection of state and local taxes, which ensure great autonomy for those tiers of government. All government tiers have authority to establish and to collect fees for the exercise of police power and for the use of public services, contributions for improvements, and contributions for defraying social security and assistance costs for its workers. 
The municipal tax function began with the constitution of 1934 . The 1988 constitution assigns municipal governments the power to impose taxes, fees, and improvement charges. ${ }^{6}$ A summary of the revenues that municipalities received from these sources in 2005 is provided in table 11.5. The local tax burden was 2.16 percent of GDP (US\$17 billion): one-third from tax on services and one-fourth from urban property tax. The taxes, fees, and improvement charges are described below.

\section{Taxes}

Taxes levied by municipal governments comprise tax on personal and professional services, property tax on urban buildings and urban land, and tax on the transfer of real property.

\section{Tax on services}

Tax on personal and professional services is the major tax levied by municipal governments, but it is collected mainly by major cities that offer modern services. Cities of more than 500,000 people are responsible for two-thirds of all collections. As defined by national law, the tax is imposed on all services

TA B LE 11.5 Municipal Tax Burden, 2005

\begin{tabular}{lccc}
\hline Local taxes collected & US\$ billion & $\begin{array}{c}\text { Percentage } \\
\text { of GDP }\end{array}$ & $\begin{array}{c}\text { Percentage of } \\
\text { total collected }\end{array}$ \\
\hline GDP & 793.9 & & \\
Tax on services & 5.8 & 0.73 & 33.7 \\
Urban property tax & 4.1 & 0.52 & 24.2 \\
Social security contributions & 1.4 & 0.18 & 8.3 \\
Fees & 1.2 & 0.15 & 6.8 \\
$\quad$ Public services & 0.8 & 0.10 & 4.7 \\
Income tax withheld at source & 1.0 & 0.13 & 6.0 \\
Contribution for public illumination & 0.8 & 0.10 & 4.7 \\
Tax on transfer of real estate & 0.8 & 0.10 & 4.7 \\
Other taxes & 2.0 & 0.25 & 11.5 \\
$\quad$ Total (municipal taxes) & 17.1 & 2.16 & 100.0 \\
\hline
\end{tabular}

Source: Authors based on Afonso and Meirelles 2006, using a preliminary projection of the 2005 tax burden. Note: Values in local currency converted to the U.S. dollar according to the midyear exchange rate $(\mathrm{R} \$ 1.00=$ US\$2.43). Other taxes are taxes, plus interest and penalties collected for late payment or nonpayment of taxes, that are not identifiable by tax category. 
except communications and interstate and intercity public transportation; taxes on those services are levied through the state tax on the circulation of goods. The tax is generally imposed as a fixed percentage of the retail price of the service provided, although alternative, simpler methods of assessment are used for self-employed individuals.

The legislation is designed to avoid overlap with the federal corporate income tax and the state value added tax. In the banking sector, for example, the tax is imposed on services other than lending, such as annual credit card fees, automated teller fees, and check issuing, but not on the interest charged on loans. In bus transportation, the tax is imposed on intramunicipal buses but not on intercity or interstate buses, which are subject to the state value added tax. Individual municipalities set the tax rates, subject to ceilings set by the federal government. Rates can vary considerably across sectors. The national law fixed the minimum rate at 2 percent and also the maximum rates, which are differentiated by service - the most common rate is 5 percent on gross revenue. In the municipality of São Paulo (the biggest city), for example, private schools are taxed at a rate of 2 percent; hotels, restaurants, banking, and safety services at 5 percent; and nightclubs at 10 percent.

\section{Urban property tax}

The property tax on urban buildings and urban land is more important in medium-size cities, so this tax is less concentrated than the service tax. Urban property tax is imposed on the capital value of all land and buildings within the legally designated urban areas of each municipality. Like the other local tax, urban property tax is administered by each municipal government, which enjoys total autonomy in legislating, charging, and collecting the tax and in bringing defaulters to trial. Each municipality, through its own laws, fixes its own rates. The general trend has been between 0.2 and 1.5 percent.

Municipal governments have been trying to increase collection of the tax by revising registers and updating property valuations. Property valuations are based on the physical characteristics of each property, translated to an estimate of market value through the use of construction cost data and surveys of neighborhood land values. These valuations are adjusted each year on the basis of an inflation index. Bills are typically payable at the beginning of each year and are, thus, relatively resilient in the face of inflation during the billing year. Where taxpayers have the option of paying in installments, each installment is also subject to indexation. 


\section{Tax on the transfer of real estate}

This tax is levied on transfers (sales) of legal ownership of real estate in cases in which the state tax on property transfers from inheritance, legacy, or donation does not apply. It is not an important source of local tax revenue. As in the case of urban property tax, each local law fixes the rates. The most common rate is 2 percent.

\section{Fees and Improvement Charges}

Fees are charged for the use of public services and for the exercise of police power. Fee collection is more important in smaller municipalities. Usually, the most important and common fees collected by municipalities are the ones that finance garbage collection, streetlight maintenance, and economic activity licenses. A recent constitutional amendment (42/2003) changed the fee collected by municipalities to finance public illumination, which is now denominated as a specific contribution. The improvement that resulted from this change was irrelevant-US\$55 million or 0.07 percent of GDP. Only a few municipalities, mainly in the south region, levy these fees.

\section{Local Revenues from Other Governments}

In addition to the high level of decentralization of tax assignments, the Brazilian constitution also establishes rules for the distribution of revenues of a decentralizing nature and creates intergovernmental transfers to correct regional inequalities. ${ }^{7}$

With its large territory and regional diversity, Brazil experiences serious vertical and horizontal imbalances. Distributions and transfers are necessary for a better balance between receipts and disbursements in the federation. So, intergovernmental transfers are intended to reduce horizontal imbalances that are reflected in interregional income differences between governments of the same tier. In this way, the richer regions with more-developed economic bases generate more collections, which are transferred to regions that have lower economic potential.

To strengthen the administrative, political, and financial autonomy of the tiers of government, the constitution defines a system of unconditional transfers between federal, state, and municipal governments. It specifies the applicable percentages, indicates the limitations on the use of the transfers, and in some cases provides detailed criteria for their apportionment. 
Sharing of tax assignments in Brazil does not follow typical formats seen worldwide. There are two constitutional forms of sharing tax revenues collected by higher tiers of government. The first form determines that a proportion of certain tax revenues belongs to lower tiers of government (further explained in the following section). The second form requires that higher tiers of government must donate a percentage of certain taxes collected to lower tiers (further explained below). The Brazilian literature always treats both of these forms as a tax, a mandatory or intergovernmental constitutional transfer. To enable international comparisons, we distinguish between shared taxes and transfers of tax revenue.

Beyond shared taxes, there are basically two types of transfers: (a) the constitutional or legally mandated ones, which are automatically performed following the collection of revenues, and (b) the nonconstitutional ones, whether discretionary or related to the public health system, which depend on agreements and political will among governments. Such transfers can be direct or indirect (through the creation of special funds).

Tax-sharing revenue corresponds to 84 percent of total resources received by municipalities from other tiers of governments (see last column of table 11.6). These transfers (shared tax plus tax transfer) are considerable: US $\$ 54$ billion in 2005, equivalent to 6.8 percent of GDP and 15 percent of the gross global tax burden, estimated at 38.9 percent of GDP in this year. The transfers are from the upper tiers to the lower ones; the municipalities received US $\$ 36$ billion, equivalent to 4.5 percent of GDP (equal the difference between amounts in the last row of table 11.7). From the perspective of the transferring governments, that is equivalent to 58 percent from state taxes and 42 percent from federal taxes; from the perspective of the receiving government, municipalities received twice as much as their own tax collection.

Municipal revenues from the national health system are very significant: in 2005 , they were more than US $\$ 5$ billion, which is equivalent to 0.66 percent of GDP and 12 percent of total transfers (see table 11.6). Revenues from the national health system constitute the fourth biggest transfer category. Discretionary transfers from central government amount to only US\$1.4 billion, equivalent to 0.18 percent of GDP.

This diagnosis of subnational governments involves significant variations between government units, mainly because of profound economic and fiscal inequalities. The extent to which each unit depends on transfers from federal taxes is directly related to its level of development. Consequently, when the evolution of own income is very different from that of resources transferred from other tiers, the characteristics of subnational finances are also very different. 
TA B LE 11.6 Revenue Sharing and Transfers to Municipalities, 2005

\begin{tabular}{lrrr}
\hline Transfers category & US\$ billion & $\begin{array}{c}\text { Percentage } \\
\text { of GDP }\end{array}$ & $\begin{array}{r}\text { Percentage } \\
\text { of total } \\
\text { transfer }\end{array}$ \\
\hline GDP & 793.9 & & \\
Shared taxes & 15.6 & 1.97 & 36.9 \\
Quota state tax on circulation of goods (25\%) & 13.5 & 1.70 & 31.7 \\
Shared state tax on property vehicles (50\%) & 2.1 & 0.27 & 5.0 \\
Shared federal tax on rural property (50\%) & 0.1 & 0.01 & 0.1 \\
Shared federal tax on gold assets (70\%) & 0 & 0 & 0 \\
Mandatory transfers & 20.1 & 2.53 & 47.3 \\
Municipal participation fund (22.5\% federal tax) & 11.0 & 1.38 & 25.8 \\
Fund for improving elementary education & 7.3 & 0.92 & 17.2 \\
Royalties & 1.0 & 0.13 & 2.4 \\
Quota federal fund on tax compensation (25\%) & 0.4 & 0.05 & 1.0 \\
Quota state fund on exports (25\%) & 0.2 & 0.03 & 0.5 \\
Quota state contribution on fuels (25\%) & 0.2 & 0.02 & 0.4 \\
Transfers from federal health system & 5.3 & 0.66 & 12.4 \\
Hospital services & 2.4 & 0.31 & 5.8 \\
Preventive activities & 2.3 & 0.29 & 5.4 \\
Strategic actions & 0.5 & 0.06 & 1.2 \\
Discretionary federal transfers & 1.4 & 0.18 & 3.4 \\
$\quad$ Total transfer & 42.4 & 5.34 & 100.0 \\
\hline
\end{tabular}

Source: Authors based on Afonso and Meirelles 2006 and data from the National Treasury and Ministry of Health. Note: Values in local currency converted to the U.S. dollar according to the midyear exchange rate $(\mathrm{R} \$ 1.00=$ US\$2.43). For state transfers, a preliminary projection was used for tax-sharing revenues; information on discretionary transfers was not available.

\section{Shared Taxes}

Municipalities are entitled to state and federal taxes according to the following breakdown:

25 percent of the state tax on operations related to the circulation of goods and on the provision of interstate and intermunicipal transportation services and of communication services (in principle, this is a value added tax). The tax is shared among municipalities according to value added through operations in their territories (at least 75 percent of the amount to be shared) and criteria fixed in state law (maximum of 25 percent of the amount shared; some of the most common criteria are population, area, wildlife reserves, local tax collection, and number of cities). 
50 percent of the state tax on motor vehicles. The tax is shared among municipalities according to the number of licensed vehicles in their jurisdictions.

- 50 percent of the federal tax on rural land and property. The tax is shared among municipalities according to properties localized in their territories.

70 percent of the federal financial operations tax on gold, which is considered a financial asset. The tax is shared among municipalities according to the amount of gold extracted in their territories.

- 100 percent of the income tax withheld at source on income payments made by local governments to persons or legal entities abroad.

The income tax withheld at source is a special shared tax. It is actually a federal tax, with national legislation and rates; when it is collected by a state or a municipality at source, however, it does not go to the central government. The amount collected should be treated as tax revenue of the collecting government (as shown in table 11.5).

\section{Constitutional or Legally Mandated Transfers}

Constitutional or legally mandated transfers are of two types: (a) transfers under the revenue-sharing system and (b) compensation and cooperation transfers, including a special case in the health system. The amount transferred by the central government to municipalities in 2005 is shown in table 11.6.

\section{Federal equalization transfer}

Municipalities benefit from the municipal participation fund, formed by 22.5 percent of the central government collection of income tax and industrial products tax. The fund is split into two parts: 10 percent for the state capital municipalities and 90 percent for the other municipalities. (This distribution favors small municipalities because the state capitals have about two-fifths of the national population.) For state capital municipalities, the individual quota is directly related to population and inversely related to the state's per capita income. For other municipalities, the individual quota is set by indexes derived from a formula that favors the less populated municipalities. The index varies from 0.6 for those with fewer than 10,188 inhabitants to 4.0 for municipalities with more than 156,216 inhabitants. In between, 16 population brackets form a distribution of individual indexes that grow at decreasing rates, thus allowing for smaller per capita transfers as population increases. 
TA B L E 11. 7 Federative Division of the National Tax Burden, 2005

\begin{tabular}{|c|c|c|c|c|c|c|}
\hline \multirow[b]{2}{*}{$\begin{array}{l}\text { Tier of } \\
\text { government }\end{array}$} & \multicolumn{3}{|c|}{ Own-source tax collection } & \multicolumn{3}{|c|}{ Disposable tax revenue } \\
\hline & US\$ billion & $\begin{array}{l}\text { Percentage } \\
\text { of GDP }\end{array}$ & $\begin{array}{l}\text { Percentage } \\
\text { of total } \\
\text { collected }\end{array}$ & US\$ billion & $\begin{array}{l}\text { Percentage } \\
\text { of GDP }\end{array}$ & $\begin{array}{l}\text { Percentage } \\
\text { of total } \\
\text { collected }\end{array}$ \\
\hline GDP & 793.9 & & & 793.9 & & \\
\hline Central & 211.8 & 26.68 & 68.5 & 178.5 & 22.49 & 57.8 \\
\hline State & 80.2 & 10.10 & 25.9 & 77.7 & 9.79 & 25.2 \\
\hline Local & 17.1 & 2.16 & 5.5 & 52.8 & 6.66 & 17.1 \\
\hline Total & 309.1 & 38.94 & 100.0 & 309.1 & 38.94 & 100.0 \\
\hline
\end{tabular}

Source: Authors based on Afonso and Meirelles 2006, using a preliminary projection of the 2005 tax burden. Note: Values in local currency converted to the U.S. dollar according to the midyear exchange rate $(\mathrm{R} \$ 1.00=$ US\$2.43). The data in the table are based on the national accounts, which include taxes, contributions, charges, and rates, including those of the private unemployment insurance fund, as well as active debt and interest. Own-source revenues consist of inflow under direct tax jurisdiction by each tier of government. Available revenues correspond to the amount collected, plus or minus tax revenue sharing, excluding other transfers related to the health system and discretionary transfers.

Generous revenue-sharing provisions have been cited as an important factor leading to a rapid increase in the number of municipalities. Because the state share in revenue-sharing funds is fixed (similar to the municipal participation fund), the creation of municipalities has led to a net loss in revenues through state government transfers in those municipal jurisdictions that were divided.

\section{Cooperation transfers}

Municipalities receive compensation and cooperation transfers according to the following outline:

25 percent of the state quota in the federal fund, formed by 10 percent of industrial products tax collection. This amount is shared according to the value of exports of industrial goods; states redistribute it among municipalities according to the same criteria used for sharing the tax on operations related to the circulation of goods and services.

25 percent of the amount transferred by the central government to each state, as compensation for revenue losses associated with changes in the state tax on operations related to the circulation of goods and services (specifically an exemption for exports of primary and manufactured goods through a national law promulgated in 1996). This transfer is administered differently than the previous one: the central 
government transfers resources directly to municipalities, but the amount is shared among them according to the same distribution of municipal quota as for the tax on operations related to the circulation of goods and services.

- 25 percent of the state quota originating from a participation of 29 percent in the contribution levied on fuels. This amount is allocated to investments in transportation, is collected by the central government, and is shared according to criteria established by national law.

- from the national intergovernmental financial cooperation fund for improving elementary education, to guarantee a specified minimum amount of spending per student enrolled in public elementary schools all over the country. Instituted in 1996 (by constitutional amendment 14/1996), the fund is formed by earmarking percentages from shared taxes: 15 percent of the three federal transfers-the municipal participation fund (deriving from the federal tax on income and industrial products), the fund related to industrial exports (deriving from the federal tax on industrial products), and transfers to compensation exemptions from state tax-as well as 15 percent of the state collection of the tax on operations of goods and services. If the money collected from these sources is not enough to guarantee the minimum spending established by law, the central government is responsible for providing supplementary transfers. The fund related to education is distributed between the state and each municipality according to the number of students enrolled in municipal or state-owned elementary schools.

- from social contributions that are collected by the central government as an additional source of resources for cooperation in financing public elementary education come from a payroll social contribution payable by private companies.

royalty compensation for the exploitation of petroleum and natural gas, hydroelectricity, and other mineral resources in the territory or coastal waters.

\section{Transfers from the national health system}

The 1988 constitution consolidated the national health care system and ensured universal access to publicly provided services. The system combines centralized financing with decentralized service delivery, because the central government reimburses private health care providers and subnational governments, particularly municipalities, for providing health care and maintaining public hospitals and clinics. In 2005, the central government 
transferred to local government US $\$ 5.3$ billion, which is equivalent to 0.66 percent of GDP, in addition to what it collected through tax on services, the biggest local tax.

The biggest part of this transfer is for payment of hospital servicesUS $\$ 2.4$ billion. In the past, transfers from the national health system were based exclusively on the cost of services provided, rather than needs, and on trends in state budget allocations. As a result, the health care system did not ensure equalization of spending across municipal jurisdictions. More prosperous municipalities - where a wider range of more sophisticated, costly health care services is provided-receive more transfers on a per capita basis than poorer municipalities. For medium-size municipalities and for the bigger ones, transfers from the health fund may be much higher than transfers from the municipal participation fund. Better equalization has nevertheless been pursued in recent years through increases in budget allocations for poorer states, where coverage has been extended.

The national health policy changed to benefit preventive activities and strategic actions (such as the AIDS program). In 2005, municipalities received US $\$ 2.8$ billion for these purposes, more than half of the transfers related to the health system. Funding for basic and preventive health care programs has also increased, thereby benefiting poor municipalities. More important, minimum per capita transfers have been implemented for a number of preventive care programs, including prenatal care, oral hygiene, and immunization.

\section{Discretionary Transfers}

Because no provision exists in the constitution or other law for the transfers described below, they depend on political will and agreements among governments. Discretionary transfers arise out of allocations in the federal budget. They are mainly one-off transfers and are oriented toward financing small-scale activities or investments at the local level. In small cities, they are a large source of finance for investments, but they are highly irregular.

These transfers from the central government are irrelevant to the consolidated municipal budget; they covered only US $\$ 1.4$ billion or 0.18 percent of GDP in 2005, for example, about the same amount collected as social security contributions payable by local civil servants. The discretionary transfers are concentrated in two ministries: education and social assistance (54 percent and 31 percent of the total transferred, respectively). 


\section{Federative Imbalance}

The distribution of revenues is designed to reduce vertical imbalances and eliminate disparities between the tiers of government and the members of the federation regarding capacity to tax and expenditure responsibilities. ${ }^{8}$ Some taxes are better administered at the central level, and some expenses are better administered at the local level. In general, expenditure policy is better when designed and controlled by local governments, because they are closer to citizens and their basic needs. The intergovernmental transfers have a crucial role in reducing both vertical and horizontal imbalances. In 2004, 67 percent of all municipal expenditures (which were equivalent to 7.3 percent of GDP) were financed with transfers received (4.9 percent of GDP) from other tiers of government (see amounts in table 11.2).

\section{Vertical Imbalances}

The division of the main fiscal flows and stocks among the different levels of government—central, state, and municipal—highlights the considerable relative importance of the subnational levels. After a more global diagnosis of intergovernmental financial relations, we concentrate our analysis on the tax system, since the constitutional distribution of the revenues that local governments received from tax sharing plus tax transfers amounted to 4.5 percent of GDP in 2005, accounting for 84 percent of their transfer revenue (table 11.6). Municipalities have traditionally depended on transfers from other tiers of government.

Revenue mobilization has been strengthened at the municipal level. The municipalities were the main beneficiaries of the decentralization of tax bases after 1988 and the increases in revenue-sharing transfers from the federal and state governments. The states and municipalities directly collected 31.4 percent of the high global tax burden (5.5 percent by local government), which was estimated to amount to 38.9 percent of GDP in 2005 (table 11.7). The municipal tax burden is also relatively low (2.16 percent of GDP), reflecting primarily the narrowness of the municipal tax bases, but has almost doubled since the last tax reform-both the tax burden and the share of total revenues (in 1988 municipal tax collection was only 0.61 percent of GDP, equivalent to 2.7 percent of the national tax burden). As a result, total municipal revenue collection, excluding revenue sharing, now exceeds the mandated federal transfers to the municipal governments allocated from the central government to the principal revenue sharing fund (municipal participation fund). 
After the mandatory revenue-sharing transfers are made, the subnational government proportion of the national tax burden rises to 42 percent (equivalent to 16.4 percent of GDP). The municipalities' available tax revenue in 2005 was US $\$ 53$ billion, equivalent to 6.66 percent of GDP and 17 percent of total taxes collected in the country, as shown in table 11.7.

Improvements in municipal tax administration are needed if municipal governments are to fully exploit their tax bases. Municipal tax collections are sometimes low because of poor tax administration rather than widespread tax delinquency. Despite regional discrepancies in tax bases, local demands and needs are best met through local revenue mobilization rather than through grants and transfers from higher tiers of government, so as to close the gap between the costs and benefits of local government service provision and delivery. Also, reducing vertical imbalances in intergovernmental fiscal relations will tend to preserve central government finances from fiscal imbalances at the subnational level. Moreover, local revenue mobilization is associated with social capital development at the local level and with stronger accountability in local government.

Municipal governments have progressively taken on the expenditure functions assigned to them by the constitution, particularly in social welfare. They have often required financial assistance from the federal government, in addition to the mandated revenue-sharing arrangements. Additional federal assistance not only has reduced the risk of disruption in service when capacity was limited at the local level but also has ensured the timely transfer of funds to service delivery agents. (Health care, discussed below, is an example.) More important, transfers based on minimum per capita spending levels have been a key incentive in many programs, particularly in primary education and preventive care. As local governments strengthen their role in service delivery, it is expected that federal outlays will be reduced for those programs for which spending assignments overlap across government levels.

From a historical perspective, the states have lost much relative importance. The relative share of the states in total government revenues has fallen since 1988. In 1960, they received 34 percent of national tax revenues (when the tax burden was only 17.4 percent of GDP), but because they were the tier most affected by the centralization of the military government, this proportion went down to 25 percent by 2005 . Now the states transfer to the municipalities in their jurisdictions more than they receive from the federal government through revenue sharing (the difference was equivalent to 0.3 percent of GDP in 2005). States' own tax revenue collection has also suffered from the relatively poor performance of the state value added tax, 
which has been adversely affected by tax competition among the states. Likewise, the earmarking of revenues to finance outlays on primary education (and health care, more recently) has benefited the municipal governments rather than the states. By increasing the coverage of their primary education system, the municipalities became eligible for the funds that had hitherto been transferred to the states to finance the provision of primary education services.

The municipalities, in contrast, were the main beneficiaries of the tax reform. Their proportion of national tax revenue increased from 6 percent in 1960 to 13 percent in 1988 (the last year before the last tax reform) and to 17 percent of in 2005 . This process made some question whether, in practice, the reform was giving rise to a federation of municipalities.

Since the external crisis of the late 1990s, the advance of the central government brought with it marginal losses for the municipalities and, principally, the states. The current federal tax policy gives an unprecedented degree of priority to the collection of social and economic contributions, which are not shared with other tiers. The central government created a high-yield levy on financial transactions and increased the rates on the existing social contributions on enterprise sales and earnings, which are not shared with the states and municipalities. This policy acts to the detriment of the relative and absolute importance - at constant values—of the revenue from income tax and, above all, from tax on industrial products, which is distributed through the participation funds.

The situation at the local levels of government did not deteriorate in recent years only because local governments obtained an increased share of state income tax through the redistribution effected by the fund for improving elementary education. Account should also be taken of the increasingly large transfers from the health system to municipalities. Consequently, if the federation is considered to be going through a crisis, it would be a structural crisis at the intermediate tier of government.

\section{Horizontal Imbalances}

There has also been an equally important and intense process of horizontal decentralization of revenues. The concentration of central tax revenues in the more-developed regions of the country has been offset by a system of central tax sharing with subnational governments. This system is basically designed to benefit the less-developed regions without considering the greater participation of these regions in the division of direct central spending in basic social programs. ${ }^{9}$ 
However, there are discrepancies according to the category of municipalities, because of the big differences in the financing model. When the local balance sheets are grouped in categories according to the number of inhabitants, the municipal participation fund accounts for almost 60 percent of the available tax revenue, or half of the current income of the municipalities with fewer than 5,000 inhabitants. As the population grows, this dependency goes down, but even in the case of cities with 50,000 to 100,000 inhabitants, that fund alone represents one-fourth of the available tax revenue and onefifth of total revenue.

The overdose of transfers brought additional distortions to the federation. As the amount transferred by the municipal participation fund increased and its distribution privileged the smallest cities, the imbalance already in place grew. Budgets per capita in small municipalities reached levels three times higher than corresponding figures for densely populated urban areas and big metropolitan cities. In 2004, for example, Borá, the smallest Brazilian municipality, had per capita revenue of US $\$ 1,219$, of which three-fourths came from the central government through the municipal participation fund; São Paulo, with more than 10 million people, presented per capita revenue of only US $\$ 394$, of which less than 1 percent came from that fund.

Differences in the composition of local government financing also reflect the huge regional disparities in Brazil. In core cities of the developed southeast region, own-source revenues cover about half the budget, but core cities in the less-developed north and northeast regions rely heavily on shared revenues and other transfers. Although municipalities in adjacent areas, as for a metropolis, must be considered, differences in per capita revenues attributable to distortions accumulated over time in revenue sharing and other intergovernmental transfers represent an obstacle to cooperation in matters of common interest, especially in metropolitan areas.

Decentralization caused a growing mismatch between revenues and responsibilities. Socioeconomic dynamics led to the increasing concentration of modern economic activities and of population in medium cities and large urban centers in the more-developed industrial areas of the country. Criteria for distributing fiscal and financial resources acted in the opposite direction, however, with money flowing in greater proportion to less dynamic and sparsely populated rural regions. Thus, because a high proportion of public money was diverted to administrative and low-priority expenditures, financial means to attend to demands for urban and basic social services in more needy places could not be found.

Despite the disincentive built into the revenue-sharing system to make local fiscal efforts, a significant improvement in tax collections at the 
municipal level was observed recently, with practically all municipalities showing some effort to make use of their local tax bases. Better municipal tax administration would reduce the regional concentration of revenue collection. Despite the improvements in revenue performance in recent years, collection is concentrated in large municipalities, particularly state capitals, and in local governments in the most prosperous states. Although large municipalities tend to depend less on grants and transfers from higher levels of government, they also face a growing demand for local goods and services. Expenditure needs are high in large metropolitan areas, where the main municipalities often cater to the residents of neighboring jurisdictions, particularly in the provision of regional public goods such as health care. Rather than aiming at a rapid increase in municipal revenues in the short term, improvements in tax administration should focus on longerterm, permanent, self-sustained increases in revenue mobilization capacity, particularly in those municipalities that depend more on revenue sharing to finance local spending. Municipal capacity to mobilize revenue should also be resilient to changes in local governments and interruptions of federal technical and financial assistance.

Progress in implementing information technology systems has been remarkable at the local tier. It is interesting to note that the more prosperous jurisdictions are not necessarily the ones that use the best systems and have the highest standards of tax administration and expenditure management and control. Some poorer state and municipal governments also use state-of-the-art systems and equipment. Various types of e-government systems have also been implemented, not only for the dissemination of information and public relations initiatives, but also for service delivery and quality control.

\section{Local Government Borrowing}

Local governments are allowed to borrow funds in accordance with national limits and criteria. They are allowed to take loans from domestic and foreign banks, as well as to issue bonds in domestic and foreign bond markets. The higher government does not have the right to interfere, but it is necessary to register the operation with the central government (the Ministry of Finance). Despite the local autonomy, the relative importance of borrowing for local finance is minimal nowadays (see table 11.2). ${ }^{10}$

Despite Brazil's extensive and complex legislation for controlling state and municipal government debt, the country suffered, until the mid-1990s, from the uncontrolled indebtedness of states and municipalities, induced 
sometimes by economic policy and sometimes by improper recording of the debts. Two major reasons explain the debt growth and the failure of the existing system. First, the rules on debt rollover were extremely permissive. Second, the federal government had become accustomed to bailing out insolvent state and local governments. However, the restructuring of the government in mid-2000 culminated in the approval of the Fiscal Responsibility Law, which applied to all three spheres of government and resulted in a turnaround in the fiscal, economic, and social spheres. A discussion of local government borrowing in Brazil must begin with a description of this background and the recent reforms.

\section{Background and Recent Reforms}

State and municipal debt was of major importance until the mid-1990s, when several federal measures were undertaken to address the issue. The states were the largest debtors. The debt problem was exacerbated by the Real Plan, which is heavily based on high interest rates; however, there was also a lack of fiscal discipline on the part of state and municipal governments, particularly state governments. Municipal borrowing was, and still is, relatively unimportant; exceptions were the big cities such as São Paulo and Rio de Janeiro.

Important institutional reforms have been implemented in the past few years to maintain the primary fiscal results (total revenues and expenditures, excluding interest payments) at appropriate levels and to ensure the sustainability of the debt. This adjustment resulted from two sets of reforms: the debt refinancing agreement signed with state and local governments and the introduction of fiscal rules in the context of the Fiscal Responsibility Law, which was enacted in May 2000. Those reforms constituted the two most important changes in the fiscal regime since the promulgation of the 1988 constitution: they substantively changed public sector fiscal behavior.

After the creation in 1994 of the new currency, the Brazilian real, the central government embarked on a new and definitive process of renegotiation and assumption of all debts by the National Treasury-even those debts with banks and those for movable property. In return, among other things, a fiscal adjustment program was signed with each state and municipality; these programs included performance goals and the prohibition of new indebtedness until the total debt was reduced to a national maximum. ${ }^{11}$ The program also provided for the payment to creditors of a monthly debt service quota as a fixed proportion of current income and-as the main 
condition - the provision of solid guarantees (blocking and automatic withholding of constitutional transfers and own-source income).

Twenty-five of Brazil's 27 states signed agreements to restructure their debts. According to the agreements, states refinanced their debts for 30 years, with a fixed real interest rate of 6 percent. The federal government issued federal securities to redeem the existing state debts and became the creditor of the states. Following the state models, the federal government also restructured local government debt incurred before May 2000. This program was approved by law and benefited the 183 municipalities that were responsible for more than 95 percent of local government debt. In this case, the federal government also took the municipalities' own-source revenue (including state and federal transfers) as a guarantee and required a monthly payment equivalent to 13 percent of the municipalities' net current revenues.

By December 2004, the total state and public debt restructured by the central government still amounted US $\$ 140$ billion, equivalent to 16.5 percent of GDP, ${ }^{12}$ resulting in an annual flow of payment (principal plus interest) of more than US $\$ 6$ billion. Note that the municipal debt restructured was smaller: US $\$ 17.7$ billion, equivalent to 2.1 percent of GDP.

On May 5, 2000, one day after the signing of the series of debt refinancing programs, the Fiscal Responsibility Law was published. It prohibited the granting of new credits by the union and the signing of new agreements regarding what had already been renegotiated (with the sole exception of guarantees for foreign loans, provided that sufficient and suitable collateral existed). In the view of some, this provision alone was sufficient to ensure the success of the law. Indeed, once the umbilical cord between the federal government and the subnational governments was cut, it was possible to combine autonomy and responsibility for the first time in the history of the Brazilian federation. It is no easy matter to amend this law, which is a complementary law, because doing so would require the assent of an absolute majority of each chamber of Congress.

The Fiscal Responsibility Law sets a general framework for budgetary planning, execution, and reporting for the three tiers of government. The law calls for sustaining the structural adjustment of public finances and for constraining public indebtedness. It comprises three types of fiscal rules: general targets and limits for selected fiscal indicators, corrective institutional mechanisms in case of noncompliance, and institutional sanctions for noncompliance. It imposes limits on outlays on personnel and public sector indebtedness; determines that targets are set for revenue and expenditure control; establishes that no government authority may create continuous 
expenditures (or, in other words, spending programs with a duration of more than two years) without indicating a corresponding source of revenue or reducing existing spending; and defines additional mechanisms for controlling public finances in election years.

Since 2000, there has been a considerable ongoing flow of payments against the renegotiated debt. In only a very few cases has some state or municipal government failed to pay the monthly installment on the debt. Such failure results in the blocking of that government's resources by the National Treasury. Because the access of the larger subnational governments to the credit market was practically eliminated and the service payments of the renegotiated debt were regularized, the states began to generate substantial and growing primary surpluses.

So, decentralization has not prevented the formulation and implementation of a far-reaching policy of fiscal austerity. The burdensome intergovernmental transfers, which formed both the basis for the calculation of the debt service quotas and a guarantee for the retention and transfer of net values, helped directly and decisively to make the subnational governments take part in the national fiscal program. The transfers make it possible to increase the size of the quotas to be paid and to ensure the payment of the subnational debts renegotiated with the central government, which represent almost the whole amount owed by the states and municipalities.

In the adjustment of the public sector borrowing requirement, in accordance with the methodology defined by the International Monetary Fund, 1998 was the last year in which the subnational governments registered primary deficits, although GDP went down by 0.2 percent because of the poor results of the states. The following year, there was a primary surplus of 0.2 percentage points. This surplus continued to grow in subsequent years until it reached 1.1 percent of GDP in December 2005, of which 0.2 percent was generated by municipalities. The net debt of the subnational governments, however, increased from 14.1 percent to 17 percent of GDP between 1998 and 2005, of which 98 percent referred to debt renegotiated by the National Treasury. This increase in net debt was not due to primary deficits but to the correction of debts renegotiated with the National Treasury, for which an overinflated index was used in periods of currency devaluation. The application of the contractual price index superior to inflation does not affect the amount paid monthly by the subnational governments (calculated as a proportion of their income), but it can lead to an increase in the amount that must be refinanced at the end of the period originally contracted.

It is interesting to observe the differences in behavior between the municipalities and the states, which are much more heavily indebted and 
are also obliged to achieve larger primary surpluses. Although the budget of the states is not even twice that of the municipalities, the primary surplus of states is almost five times larger than that generated by the municipalities: 0.9 percent versus 0.2 percent of GDP in 2005 . The same proportion is observed in the case of indebtedness: 14.9 percent versus 2.1 percent of GDP. Despite their significant and growing loss of participation in the distribution of national tax revenue, the states generated a primary surplus equivalent to 9.1 percent of their available tax income in 2005; for municipalities, the surplus corresponded to only 3.2 percent of that income. The states are making a big sacrifice to pay for the sins of previous administrations.

\section{State and Municipal Indebtedness}

The Fiscal Responsibility Law pays special attention to the registration, control, and limitation of public sector debt. Certainly the most important innovation has been the prohibition against the central government financing state and local governments. The importance of this restriction is that it not only regulates the future behavior of state and local governments, thus preventing intergovernmental bailouts, but also preserves the existing contracts - that is, it prohibits any changes in the financial clauses of the existing debt restructuring agreement, thereby enforcing the maintenance of the existing sound fiscal policy at the subnational level.

Another important innovation of the fiscal rules was the definition of debt ceilings for each tier of government. These ceilings must be approved by Senate resolution (on the basis of an executive branch proposal) and are defined as a percentage of the net current revenue of each government. In case of economic instability or drastic changes in monetary or exchange rate policy, the federal government can submit to the Senate a proposal for changing the limits. Any excesses must be eliminated within one year. While the excess persists, new financing and discretionary transfers from the federal government are prohibited. A list of the governments that exceed the limit must be published by the Ministry of Finance on a monthly basis. Although the ratio of debt to net revenue varies significantly among state and municipal governments, the Fiscal Responsibility Law requires the same ceiling for each state and each municipality.

The federal Senate (Resolution 43, 2001) fixed limits and conditions on the internal and external credit operations of state and local governments, including the granting of guaranties, their limits, and the conditions for authorization. Under the resolution, at the end of 2016, the net consolidated debt of the states may not exceed two times net current revenues (200 percent), 
and that of the municipalities may not exceed one and two-tenths times (120 percent). Any amounts in excess of those limits are to be reduced by at least one-fifteenth in each fiscal year. At the moment, however, the Senate has not set a required limit for the central government. Indeed the lower house also failed to approve another law that would fix a specific limit on debt in the form of treasury bonds.

The subnational governments are not permitted to carry out the following operations: receipt of amounts from companies in which the public authority, directly or indirectly, holds a majority voting stock position, with the sole exception of profits and dividends paid according to the terms of the legislation; direct assumption of commitments, acknowledgment of debt, or like operations with suppliers of goods, merchandise, or services, through issue, acceptance, or endorsement of credit securities; assumption of liabilities with suppliers for a posteriori payment of goods and services, without the necessary budget authorization; formalization of credit operations that constitute violations of refinancing agreements signed with the federal government; and granting of any subsidy or exemption. The latter includes any reduction of the calculation base; any presumed credit, incentives, amnesties, or remissions; any rate reductions; or any other tax, fiscal, or financial benefits that may conflict with provisions of the constitution.

The so-called golden rule was expanded and detailed in the Fiscal Responsibility Law. It had existed for some time, including in the form of a constitutional order prohibiting "the carrying out of credit operations that exceed the amount of capital expenditure," except for exceptions approved by the absolute majority in the legislature (article 167, III). If this clause had been respected to the letter, then certainly Brazil would not have so many debts today. In practice, the principle was applied only to the preparation of the budget and ignored in the budget's execution. For this reason, the law later detailed the steps to be followed and respected by legislators and administrators, not only when preparing the budget but also when carrying out spending plans, and it also created institutional and personal punishments if the rules were not respected. Note that the same principle was extended by this law to revenues from privatization; it requires that the proceeds of any transfer of goods, furnishings, or property by a government be used for capital expenditure.

\section{Local Government Administration: Personnel Spending}

Within limits defined in national law, the municipalities are free to hire and fire public employees, as well as to set the terms of employment and the 
wages. ${ }^{13}$ The Fiscal Responsibility Law imposed limits for personnel spending for each tier of government, distinguishing sublimits by branches (executive, legislative, and judiciary). For municipalities, according to this law (article 20, III), the ceilings on personnel outlays cannot exceed 60 percent of net current revenues, as follows: 6 percent for the legislative branch, including the budget courts, and 54 percent for the executive branch. Should the governing authority exceed these personnel spending limits, it will have a period of eight months in which to bring accounts into line with the terms of the law. After this period, if the necessary corrections have not been made, penalties are applied. As of May 5, 2000, when the law went into effect, it provided for a twoyear transition period during which excess outlays on personnel could be eliminated, with at least 50 percent of the excess being eliminated in each year.

As with the debt limit, failure to fulfill obligations imposed by the law regarding personnel spending limits can lead to several administrative penalties, including, in accordance with an additional law, personal incrimination. More serious misbehavior may be punished by loss of mandate, bans from working in public service, fines, and even imprisonment. It is worth emphasizing that all levels of government have to abide by the conditions established in this law.

\section{Local Government Accountability to Citizens}

The decentralization has not been limited to a transfer of policy implementation to local governments. ${ }^{14}$ It has also meant a transfer of some decisionmaking responsibility to local communities. The 1988 constitution provided several mechanisms to give grassroots movements access to participation in some decisions and oversight of public matters, especially at the local level. Local governments are carrying out several experiments in participation.

Local government views on what participation entails vary considerably, with differing interpretations and a great variety of experiments. Local communities have been taking part in the decision-making process at the local level, ranging from a more restricted approach, such as giving greater voice to local citizens, to a broader one, such as empowering people as a way to change social and political inequalities. Two paths are followed in participatory policies. One is through community councils, in which representatives of local inhabitants or service users have a seat. The other is through what has become known as participatory budgeting.

Participatory institutions, which were given official sanction in the 1988 constitution and were implemented in a variety of formats at the local level, link civil society activists to formal political society. The 1988 constitution 
decentralized political authority, thereby granting municipal administrations sufficient resources and political independence to restructure policy-making processes. Coalitions of civil society organizations and political reformers have taken advantage of this flexibility to experiment with new institutional types.

The increase in popular participation is an important aspect of the recent tax decentralization. Not only has participation through direct election of leaders of the executive and members of the local legislature seen growth. The growing direct participation of representatives from labor unions, urban communities, and civil society organizations, which supply free services directly to individuals, has also increased. Moreover, those organisms support government action in some special areas, such as primary schooling, public health, environmental policies, and emergency activities.

Organized citizens are seeking to overcome social and political exclusion through public deliberation, promotion of accountability, and implementation of their policy preferences. The new actors and their political allies institutionalized their strategies and practices in participatory decision-making systems, thereby creating a new sphere of deliberation and negotiation called participatory publics.

Participatory policies have been adopted in Brazil over the past two decades with varying results. Stimulated by federal legislation, federal programs, multilateral organizations, or local government, participatory forums are widespread in Brazil's local communities. The implementation of participatory and innovative policies shows that party matters in the Brazilian experience, inasmuch as federal government matters in creating incentives to expand the role of local government in implementing social policies. Otherwise, transparency is emphasized in the Fiscal Responsibility Law as a condition for social control of the actions of governments, to make taxpayers conscious of the use public administrators make of resources raised from taxation.

\section{Community Councils}

During Brazil's transition to democratic rule in the 1980s, citizens worked in voluntary associations and social movements to develop innovative strategies for confronting traditional local politicians in hopes of surmounting legacies of clientelism, patronage, and corruption. Those strategies led to new political practices, including the establishment of neighborhood assemblies and local councils. With the advent of competitive elections, civil society activists linked with politicians and political parties to encourage the institutionalization of decision-making venues that would provide opportunities for citizens to deliberate on policy proposals. 
The constitution of community councils is required either by federal legislation or by multilateral organizations when they finance or transfer resources to a given program. The role of community councilors is to make decisions about resource allocation and to control the use of resources in general. For each social policy area, a different council is required. There are two types of community councils, one related to policy areas and the other to defense of collective or individual rights. Among the first are councils for health care, primary education, employment, welfare services, rural development, environment, urban management, drugs, and poverty alleviation. Among the second are councils for the rights of children and adolescents, blacks, women, people with disabilities, and the elderly.

Evaluations of community councils have become an important area of academic research. According to several studies, the existence of a council is insufficient to make the councilors perform their role as policy makers and controllers of resource allocation.

\section{Participatory Budgeting}

Brazil is home to some of the most successful experiences of participatory local government. The proliferation of civil society organizations in Brazil during the transition to democratic rule was accompanied by the development of new political values and strategies that fostered institutional renewal at the municipal level.

Unlike community councils, participatory budgeting is not the result of policy induced by the federal government or multilateral organizations, but an initiative taken by local governments. However, as much as community councils, participatory budgeting is a top-down government initiative, although decisions are made locally. Participatory budgeting has been praised, both nationally and internationally, as an example of good local governance. The experiences with participatory budgeting show how the emergence of participatory publics spawned innovative institutional formats. Important characteristics of the participatory budgeting format include increased and sustained participation, public deliberation and negotiation, and distribution of public resources to poorer neighborhoods.

\section{Lessons for Developing Countries}

The Brazilian fiscal federation is a mirror of the nation's economy, society, and political system. State and municipal governments participate to a very high degree in the direct generation of resources and even more so in tax 
revenue allocation and expenditure on personnel, goods, and services, and they manage their budgets with only minimum interference from the federal government. However, there is no organized and carefully planned fiscal decentralization program capable of reconciling revenue redistribution with shared responsibilities. The result has been an increasingly complex system of federative relations that undermines attempts to achieve economic efficiency and quality in the provision of public services. In addition, there are enormous differences in tax burdens among the more- and less-developed states.

Brazil is a highly decentralized federation. Subnational government spending accounts for about 18 percent of GDP, approximately 40 percent of national government expenditure (or one-half of the total, excluding interest expenditure). These shares are comparable to the average for the countries of the Organization for Economic Co-operation and Development and far exceed the Latin American average. States and municipalities together collect nearly 31 percent of national tax revenues; after mandatory transfers, the disposable revenue goes up to 42 percent of the total. Vertical imbalances are sizable: states and municipalities together receive almost a third of their revenues as transfers and grants from the central government. Horizontal imbalances are also important, reflecting to a large extent the limited efforts in equalizing expenditure capacities at the subnational level.

The 1988 constitution conferred greater autonomy to subnational governments (states and municipalities) in debt and expenditure management and control, devolved important tax bases to subnational governments, and reformed the country's revenue-sharing system. In the absence of strict budgetary oversight and fiscal discipline at the subnational level, decentralization in the early 1990s was detrimental to macroeconomic stability. More recently, emphasis has been placed on ensuring that decentralization is compatible with, and supportive of, the consolidation of fiscal adjustment and macroeconomic stability.

The innovation in the ongoing decentralization trend in Brazil is the emphasis on the municipalities, rather than the states, as key agents of service delivery, particularly in social services and public investment. This trend is particularly important given that local governments are, in principle, best able to extract information on local preferences and needs. Reform in Brazilian federalism had been motivated by the need to improve macroeconomic governance, and little attention had been devoted to allocative efficiency and equity in service delivery. To strengthen subsidiarity, policy makers have favored municipality-oriented decentralization in recent social policies. Emphasis has been placed on poverty reduction and human development 
through a concerted policy effort in local tiers of government. It is widely accepted that accountability has been strengthened in the process.

The Brazilian experience also shows that local governments are trying to reconcile two contrasting views on their role. The first sees local government as the main locus of service provision, particularly social services. The second sees local government as a locus to practice democracy by pursuing a more equitable balance between those who decide and those who are affected by decisions, thereby contributing to the creation of social capital.

The role of municipal governments is changing significantly, not only because of their increased revenue mobilization capacity but also because of their more active role in service delivery, particularly in the social welfare area. The main challenges facing municipal governments are (a) to avoid a rise in payroll expenditures relative to outlays on more productive programs, particularly in social and urban infrastructure; (b) to improve the efficiency of public spending by, for instance, reducing outlays on the legislature and administration; and (c) to boost local revenue mobilization, particularly in light of growing demands for social security spending at the local tier.

Recent reforms in funding arrangements for social programs are likely to reduce financing shortfalls at the state and municipal levels, but rigidities in their budgets may be at odds with ongoing efforts to grant them policymaking autonomy. Social programs have focused on strengthening vertical, rather than horizontal, intergovernmental fiscal relations. Solutions to the underprovision of regional public goods, as well as to other problems related to multilevel policy making, could involve closer coordination among states and municipalities. In the absence of more cooperative federalism, institutional rigidities have worsened. Extensive earmarking has been used to prevent shortfalls in transfers from the federal government and to encourage state and municipal governments to take on the expenditure functions assigned to them by the constitution. At the same time, earmarking of state and municipal revenues has been used to prevent financing shortfalls, after the expenditure functions have been accepted. Yet more earmarking has been used to circumvent these rigidities and to allow for swifter fiscal adjustment at the federal level by withholding a percentage of the federal revenues that are shared with state and municipal governments.

A key policy question is whether Brazil has achieved a cooperative federalism solution. Recent legislation has also favored rules-based policy making. Rather than initiating modifications, the Fiscal Responsibility Law consolidated changes that had already been made. Brazil has a legal device almost without parallel in other countries. Much more important than the 
law itself was the change in mentality that it provoked, which made it possible to create greater awareness of the need for macroeconomic stability, on which there is now practically national consensus.

The key provisions in the Fiscal Responsibility Law and complementary legislation preclude, at least in principle, discretion in fiscal policy making, particularly at the state and municipal levels. The legislation contains the key incentives for fiscal probity at all tiers of government, as well as formal sanctions for noncompliance. Important challenges remain. The implementation of the new legislation may prove difficult, given the technical capacity required for the states and municipalities to make the new fiscal rules operational and for the federal government to monitor compliance. The new legal framework may not be conducive to, and supportive of, horizontal coordination in multilevel policy making. Instead, it may strengthen an already rigid, predominantly vertical system of intergovernmental fiscal relations.

Hence, it follows that recent changes in the legislation have laid the foundations for a rules-based system of decentralized federalism that leaves little room for discretionary policy making at the state and local levels. This system has been motivated by the recognition that market control over subnational finances should be strengthened by fiscal rules as well as appropriate legal constraints and sanctions for noncompliance at all levels of government. More importantly, top-down coordination in intergovernmental fiscal relations has been preferred to more horizontal, collegial forms of multilevel fiscal policy making.

\section{Notes}

1. This section is based on Afonso (2004), Afonso and de Mello (2000), Rezende and Afonso (2006), Souza (2001), and World Bank (2002).

2. This chapter uses subnational governments to refer to both state and municipal governments for analytical purposes. It is important to note that in contrast to the use of this term commonly found in international literature, it is neither an official term nor an expression used by Brazilian analysts.

3. There is an exceptional case: the federal district (Brasília) can collect state and municipal taxes and fees and can receive transfers by sharing in federal tax revenue as a state and as a municipality.

4. This section is based on Afonso (2006); Afonso, Araújo, and Biasoto (2005); Afonso and de Mello (2000); Rezende and Afonso (2006); and Souza (2001).

5. This section is based on Afonso and Meirelles (2006), Ministry of Finance (n.d.), and Rezende and Garson (2004).

6. The constitution of 1988 assigned to the municipalities the tax on the retail sales of liquid and gaseous fuels, except diesel oil. However, this tax was eliminated in 1993 (constitutional amendment no. 3, article 4). 
7. This section is based on Afonso (2004), Afonso and de Mello (2000), Afonso and Meirelles (2006), Ministry of Finance (n.d.), Rezende and Garson (2004), and Varsano and Mora (2001).

8. This section is based on Afonso (2004), Afonso and de Mello (2000), and Serra and Afonso (1999).

9. For example, the southern region is responsible for approximately 64 percent of total social and economic contributions. However, central government outlays on basic social activities in the region are far below that figure: 23 percent on rural social security, 32 percent on continuous social assistance benefits, and 37 percent on the major primary health care programs. In the northeast, which accounts for about 7 percent of the national inflow of those contributions, participation in the aforementioned social security and assistance programs comes to approximately 46 and 42 percent, and participation in primary health care programs is 34 percent.

10. This section is based on Afonso (2004); Afonso, Araújo, and Biasoto (2005); Giambiagi and Ronci (2004); Goldfajn and Guardia (2003); Rezende and Afonso (2006); and Ter-Minassian (1997).

11. The approach to fiscal policy changed dramatically in 1998, when the federal government's fiscal stabilization program was announced. This program comprised four initiatives: (a) a frontloaded fiscal adjustment, which was designed to increase the primary surplus of the consolidated public sector; (b) institutional reforms, notably the social security system and administrative reform; (c) a redesign of the fiscal federalism structure based on a comprehensive debt refinancing agreement with states and local governments; and (d) a reform of the budgetary process and introduction of fiscal rules.

12. The state and municipal components of the net debt evolved less favorably at the turn of the decade, not because of the generation of a deficit or the past placement of paper at excessive spreads, but because of the recognition of old debts that had not been properly recorded and, above all, because the element used for indexing the refinancing contracts with the National Treasury-the general price index-internal supply calculated by the Getulio Vargas Foundation-was much higher than the consumer price indexes, mainly because that element is more sensitive to exchange rate devaluation.

13. This section is based on Afonso, Araújo, and Biasoto (2005) and Rezende and Afonso (2006).

14. This section is based on Afonso (2004), Wampler and Avritzer (2004), Souza (2001), and World Bank (2002).

\section{References}

Afonso, José Roberto. 2004. "The Relations between Different Levels of Government in Brazil.” Cepal Review 84: 133-55. http://www.eclac.cl/publicaciones/SecretariaEjecutiva/8/LCG2258PI/G2258iRodriguesAfonso.pdf. - 2006. "Novos Desafios à Descentralização Fiscal no Brasil: As Políticas Sociais e as de TransferÊncias de Renda.” Paper presented at the 18th Regional Seminar on Fiscal Policy, organized by the Economic Commission for Latin America and the Caribbean, 
Institute of Economic and Social Planning, Santiago, Chile, January 23-26. http://www.eclac.cl/ilpes/noticias/paginas/5/22145/26Jan07-JRAfonso-Brasil.pdf.

Afonso, José Roberto, Érika Amorim Araújo, and Geraldo Biasoto Jr. 2005. Fiscal Space and Public Investments in Infrastructure: A Brazil Case Study. Texto para Discussão n. 1141. Brasília: Institute of Applied Economic Research. http://www.ipea. gov.br/ pub/td/2005/td_1141.pdf.

Afonso, José Roberto, and Luiz de Mello. 2000. “Brazil: An Evolving Federation.” In Managing Fiscal Decentralization, ed. Ahmad Ehtisham, and Vito Tanzi, 265-85. London and New York: International Monetary Fund. http://www.federativo.bndes.gov.br/ bf_bancos/estudos/e0001367.pdf.

Afonso, José Roberto, and Beatriz Barbosa Meirelles. 2006. Carga Tributária Global no Brasil, 2000/2005-Cálculos Revisitados? Caderno para Discussão NEPP (Núcleo de Estudos de Políticas Públicas) 61. Campinas, Brazil: State University of Campinas. http://www.nepp.unicamp.br/cadernos/caderno61.pdf.

Giambiagi, Fabio, and Marcio Ronci. 2004. "Fiscal Policy and Debt Sustainability: Cardoso’s Brazil, 1995-2002.” Working Paper 04/156, International Monetary Fund, Washington, DC. http://www.imf.org/external/pubs/ft/wp/2004/wp04156.pdf.

Goldfajn, Ilan, and Eduardo Refinetti Guardia. 2003. "Fiscal Rules and Debt Sustainability in Brazil.” Technical Notes 39, Central Bank of Brazil, Brasília. http://www.bcb. gov.br/pec/notastecnicas/ingl/2003nt39RegraFiscSustentDivBrasili.pdf.

Ministry of Finance. n.d. “The Brazilian Tax System.” Ministry of Finance, Brasília. http://www.receita.fazenda.gov.br/principal/Ingles/SistemaTributarioBR/Brazilian TaxSystem/default.htm.

Rezende, Fernando, and José Roberto Afonso. 2006. "The Brazilian Federation: Facts, Challenges, and Prospects." In Federalism and Economic Reform: International Perspectives, ed. Jessica Wallack and T. N. Srinivasan, 143-88. New York: Cambridge University Press.

Rezende, Fernando, and Sol Garson. 2004. "Financing Metropolitan Areas in Brazil: Political, Institutional, and Legal Obstacles and Emergence of New Proposals for Improving Coordination." Paper presented at the international meeting "O Desafio da Gestão das Regiões Metropolitanas em Países Federativos," Chamber of Deputies, Brasília, March 30-31.

Serra, José, and José Roberto Afonso. 1999. "Fiscal Federalism Brazilian Style: Reflections." Paper presented at the Forum of Federations, International Conference on Federalism, Mont Tremblant, Quebec, Canada, October 6-8. http://www.federativo.bndes.gov.br/bf_bancos/estudos/e0001792.pdf.

Souza, Celina. 2001. "Brazil's System of Local Government, Local Finance, and Intergovernmental Relations.” Paper commissioned by the International Development Department of the School of Public Policy, Birmingham, U.K. http://federativo. bndes.gov.br/bf_bancos/estudos/e0001985.pdf.

Ter-Minassian, Teresa. 1997. "Brazil." In Fiscal Federalism in Theory and Practice, ed. Teresa Ter-Minassian, 438-56. Washington, DC: International Monetary Fund.

Varsano, Ricardo, and Mônica Mora. 2001. "Fiscal Decentralization and Subnational Fiscal Autonomy in Brazil: Some Facts of the Nineties.” Instituto de Pesquisa Econômica Aplicada, Brasília. http://federativo.bndes.gov.br/bf_bancos/estudos/ e0001757.pdf. 
Wampler, Brian, and Leonardo Avritzer. 2004. "Participatory Publics: Civil Society and New Institutions in Democratic Brazil." Journal of Comparative Politics 36 (3): 291-312.

World Bank. 2002. "Brazil: Issues in Fiscal Federalism.” Report 22523-BR, World Bank, Washington, DC. http://www.federativo.bndes.gov.br/bf_bancos/estudos/ e0001888.pdf. 


\title{
Local Government \\ Organization and Finance: Chile
}

\author{
LE O N A R D O LE T E L I E R S .
}

he Chilean version of the lowest level of government (munici-
pality) originated in the colonial town councils, ${ }^{1}$ which came into existence in Santiago right after the foundation of the capital city in 1541. They represented the last link in the colonial administrative chain. The functions they performed included maintaining and improving public facilities and hospitals, adorning and decorating public spaces, controlling the artisans union, administering justice, and maintaining the local militia. As in other Spanish colonies at the time, these functions were rather broad. However, they were substantially curtailed as far as the administration of justice is concerned as a result of the creation of the Real Audiencia in 1606. The Real Audiencia was the tribunal that administered justice in the Spanish colonies before they became independent.

A significant landmark in the development of the Chilean municipal system was the inclination given to it by the constitution of 1833 , which explicitly established that "there should be one municipality in all departments' capitals and in those settlements in which the President so decides" (Martner 1993). Although municipalities were assigned very specific functions, they were still subject to the governor's authority. Such a centralist tendency experienced an important revision in a new municipal organic law 
enacted in 1887. That law deprived the central government and its representatives of most of its authorities in the municipal field. Nevertheless, the central government continued to intervene in the municipal elections until 1891, when the Law of the Autonomous Community was passed. Later, the constitution enacted in 1925 established that municipalities were subject to the surveillance of the provincial assemblies. Moreover, although the municipal mayor was freely elected by local residents, mayors of highly populated cities could be appointed by the president of the country.

The next breakthrough in the history of Chilean subnational governments was the establishment of 12 regions and 1 metropolitan area in 1974 (Ferrada 2003). Although at that time all subnational governments' authorities were appointed by the central government in a fully discretionary way, ${ }^{2}$ this administrative reform became the starting point of a deep process of fiscal decentralization in the years that followed. Municipalities were delegated important new functions in 1980. Such functions included primary health care and schooling, as well as the administration of important social subsidies intended to target the poor through a focused approach immersed in the spirit of the subsidiary role of the state. Municipal governments were seen as closer to the population in need and better able to identify the type of local public goods people would require.

Both in health and in education, municipalities were empowered to choose between two administration structures. The first consisted of direct administration through administrative departments of health and education. The second consisted of leaving the administration of schools, primary health care centers, and so forth in the hands of private entities. These entities would be nonprofit organizations in the legal form of corporations. They would be run by a board that was headed by the local mayor. Other board members would be representatives of other local state organizations and the private sector. The advantage of the corporation lies in its more flexible legal status, which avoids control by the treasury inspector's office. The only formal control is by the municipal council, because of the contributions made by the municipality in addition to the funds directly transferred to the corporation from the central government. The corporation option was taken by only 53 municipalities before a constitutional court decided in 1981 that municipal functions that had been carried out since 1980 could not be performed by private entities.

Regions are headed by a centrally appointed regional governor, who is advised by the remaining members of the regional council (the consejo regional, or CORE). Except for the governor, all members are indirectly elected through the municipal councils. Each province is given the benefit of 
choosing two advisers, with a maximum of 10 representatives in provinces with fewer than 1 million inhabitants and 14 advisers in provinces with a higher population. Municipalities have a mayor who is the head of the municipal council (consejo municipal), whose members are elected by the local constituency. Although provinces were maintained as a reminder of the old structure, they are simply coordinating offices for the central government's deconcentrated services. Chile is formally organized into 12 regions and 1 metropolitan area, 51 provinces, and 345 municipalities. Although 70 percent of the municipalities have a population lower than 25,000, 10.7 percent host fewer than 5,000 inhabitants, and the remainder have fewer than 1,000.

\section{Local Governments' Responsibilities}

Chilean regional governments have multiple functions. All may be considered agent tasks of the central government. Each region is meant to design its own long-term development plan, which has to be compatible with the guidelines given by the central government. From the viewpoint of fiscal autonomy, the regions' most important function is to rank feasible regional investment projects. This function is assumed to capture local preferences insofar as new public infrastructure is concerned. Selected projects are funded through various decentralized funds made available by the central government. This process is technically supported by the regional secretariat of planning and coordination (secretaría regional de planificación y coordinación, or SERPLAC), which is a deconcentrated branch of the Ministry of Planning and Cooperation (Ministerio de Planificación y Cooperación, or MIDEPLAN), and the CORE itself.

Regional governments also look after the functioning of local public services, the promotion of local economic activities, the correct implementation of norms related to the environment and public transportation, and the encouragement of culture and social development. In all functions other than determining the final destiny of decentralized investment funds, the regional government coordinates and is deeply involved in the implementation of national policies at the regional level. In promoting local economic activities, the regional government defines priorities in terms of sectors being favored, stimulates regional tourism, and encourages scientific research.

As far as social and cultural development is concerned, the regional government defines aims in a broad set of issues, which includes poverty reduction plans, intermunicipal distribution of funds, and encouragement of regionally related cultural activities. Although the provincial level only coordinates the delegated services of the central government, its supervising 
power and degree of influence on the allocation of regionally decided investment funds were expanded significantly in 2002.

Municipalities have 6 exclusive and 12 nonexclusive functions. Local governments are allowed to execute complementary activities with other levels of government and public or private external organizations (box 12.1). With the exception of exclusive functions 3 and 6 in box 12.1, the municipal level plays an important role in the enforcement of general norms on the construction industry and in urbanization and transportation. Municipalities find a wider and more flexible range of potential activities to develop among the nonexclusive functions. Two functions delegated to municipalities in

\section{B 0 X 12.1 Municipal Functions}

\section{Exclusive Functions}

1. Preparation, approval, and modification of the municipal development plan according to the legal norms in force

2. Local planning, regulation, and design of the building regulation according to the legal norms in force

3. Promotion of community development

4. Enforcement of norms on transportation and public transit on the basis of the general laws defined by the corresponding ministry

5. Implementation of local arrangements for construction and urbanization on the basis of general laws defined by the corresponding ministry

6. Community cleaning and adornment

\section{Nonexclusive Functions}

1. Education and culture

2. Public health and environmental protection

3. Legal and social assistance

4. Job training, employment, and productive promotion

5. Tourism, sport, and recreation

6. Urbanization and urban and rural roads

7. Construction of social housing and sanitary infrastructure

8. Public transportation and transit

9. Risk prevention and assistance in emergencies or catastrophic situations

10. Support, promotion, and enforcement assistance for town security measurements

11. Promotion of equity between men and women

12. Development of common interest local activities 
1980 are the administration of schools and primary health care centers. In support of those functions, municipalities are assigned significant categorical grants. Municipalities are also a fundamental part of the state social welfare net. Although they do not finance social benefits, they play a fundamental role in administering funds and identifying beneficiaries.

\section{Local Governments' Taxes and Charges}

Municipalities are the only tier of subnational government in Chile allowed to tax residents and also charge for the services they provide. It should be said that the normative power they have to define rates and introduce new taxes is very limited. The most important municipal tax revenue in Chile is the property tax. This tax is applied at a fixed rate that ranges between 1.2 and 2.0 percent of the fiscal value of rural and urban properties. Nevertheless, the law establishes numerous tax rebates and surcharges. A second important local tax is the one on car licenses. Because this tax is payable in any municipality regardless of where the car's owner resides, municipal governments actively compete to attract potential taxpayers. The tax rate, however, is uniform across the country and depends on the car's value.

Regarding local charges, a business license must be purchased for commercial activities undertaken in a municipality. In this case, municipalities have an important degree of freedom in establishing the rate. Organizations related to charity, religion, culture, self-assistance, fine arts, nonprofessional sports, and promotion of community interests are exempt from this payment. Other municipal charges include the one on garbage collection, urbanization and construction permissions, occupation of public spaces by private activities, removal of street debris, installation and construction of various kinds of local public spaces, street publicity, drivers' license delivery, transfer of vehicles, and mobile street trading. In some cases, water supply resources belong to the municipality, in which case it is also charged for locally. Although the law establishes some limits and exceptions to the payment of these duties, municipalities have rather wide latitude to fix the rates they charge.

In a third category of revenues, we find myriad small payments. They comprise traffic fines, payments for commutation of sentences, interests and rents on assets owned by municipalities, income from the sale of confiscated goods, and similar items. Also in this category is the revenue from privately administered municipal real estate, as in the case of municipal beaches and other recreation areas.

Local governments are-in principle—not allowed to borrow or take out loans of any kind. This prohibition probably results from the deep 
concern of policy makers regarding the national fiscal balance in light of the long and dramatic period of fiscal adjustment over the second half of the 1970s. This historical episode certainly remains a factor worth considering in the current administration of the state. Interestingly, municipal governments do borrow in practice. First, they very often delay the payment of wages and other labor-related benefits to teachers and primary health care center officers. Second, they also postpone payment of contracts and other inputs in some cases. Finally, leasing contracts abound between municipal governments and private providers. ${ }^{3}$ These factors have made the prohibition rather inapplicable. Some future reforms in this regard are now being considered.

Regions have no taxes of their own, but the law explicitly assigns them an "equivalent amount" of the revenues collected from regional mining licenses. In this way, the law circumvents the constitutional prohibition against hypothecated taxes that fund specific geographic areas or particular activities. ${ }^{4}$ Unlike local business license fees charged by municipal governments, which retain the revenues, mining licenses are governed by a law that establishes that 70 percent of the amount collected is to be added to the share of the National Fund of Regional Development (described later) and assigned to the region where the tax was generated. The remaining 30 percent is given to those municipalities where the mining activity is located.

\section{Structure of Subnational Government Financing}

Table 12.1 provides an overview of the current structure of subnational government financing. Because only municipalities have revenues of their own, they are the only tier explicitly referred to. The regions' share is captured through their participation in decentralized public investment grants. As regards municipalities, their budget net of grants is in the range of 8.5 percent of general government revenues, of which 70 percent comes from local taxes. Municipal taxes occupy more than 75 percent of the total budget. When all grants are considered, a measurement of total decentralized funds (TDF) shows that roughly 30 percent of the general government's budget is transferred to lower tiers.

Three types of grants are clearly identified. One type is meant to cover the expenses of publicly supported schools and municipal primary health care centers. As mentioned earlier, these two areas of state action were handed over to the municipal level in 1980, and they may be gathered under the label of "delegated functions." It should be noted, though, that more than 40 percent of the educational subvention is given to publicly supported 
T A B L E 12. 1 Decentralized Public Funds, 1999-2003 (2002 US\$ million)

\begin{tabular}{lrrrrr}
\hline Item & 1999 & 2000 & 2001 & 2002 & 2003 \\
\hline Municipal revenues net of grants & $1,252.1$ & $1,269.3$ & $1,287.8$ & $1,338.8$ & - \\
$\quad$ Percentage of TDFs & 31.5 & 30.3 & 29.4 & 27.9 & - \\
Operation revenues & 52.5 & 56.3 & 57.4 & 60.7 & - \\
Tax revenues & 929.1 & 957.1 & $1,005.7$ & $1,049.5$ & - \\
Other revenues & 270.5 & 256.0 & 224.8 & 228.6 & - \\
& & & & & \\
Grants & $2,719.3$ & $2,915.7$ & $3,097.3$ & $3,459.6$ & $3,635.3$ \\
$\quad$ Percentage of TDFs & 68.5 & 69.7 & 70.9 & 72.1 & - \\
Delegated functions & $1,669.4$ & $1,804.7$ & $1,904.8$ & $2,174.3$ & $2,268.5$ \\
$\quad$ Percentage of all grants & 61.4 & 61.9 & 61.3 & 62.8 & 62.4 \\
Social aid and productive & & & & & \\
$\quad$ promotion & 479.0 & 489.8 & 503.2 & 513.2 & 509.4 \\
$\quad$ Percentage of all grants & 17.6 & 16.8 & 16.2 & 14.8 & 14.0 \\
Decentralized public investment & & & & & \\
$\quad$ funds & 570.9 & 621.2 & 689.3 & 772.1 & 857.4 \\
$\quad$ Percentage of all grants & 21.0 & 21.3 & 22.3 & 22.3 & 23.6 \\
$\quad$ Total decentralized funds & $3,971.4$ & $4,185.0$ & $4,385.1$ & $4,798.4$ & - \\
$\quad \begin{array}{l}\text { Percentage of grants on TDFs } \\
\text { Percentage of TDFs on the general }\end{array}$ & 68.5 & 69.7 & 70.6 & 72.1 & - \\
$\quad$ government's revenue & 29.0 & 27.8 & 28.1 & 30.6 & - \\
$\begin{array}{l}\text { Percentage of municipal revenue } \\
\text { on the general government's revenue }\end{array}$ & 9.1 & 8.3 & 8.2 & 8.4 & - \\
\hline
\end{tabular}

Source: Public Budget Law.

Note: $-=$ not available. TDFs $=$ total decentralized funds.

a. TDFs $=$ municipal revenues net of grants + grants.

private schools. This point is illustrated in figure 12.1 which shows that, regardless of the decentralized nature of the public school subvention, not all of it goes through the municipal administrative structure; part of it is granted to private school "sustainers." Myriad complementary categorical grants to which schools apply on a competitive basis are also available (discussed later under "Transfers from upper levels of government").

Funding for primary health care is made up of two parts. One is a population-based grant, and the other is a supplement to deal with idiosyncratic health characteristics of each municipal area. Although education and health-related transfers represent about 62 percent of all grants (table 12.1), school subventions represent on average more than 75 percent of the resources expended for these two delegated functions. 


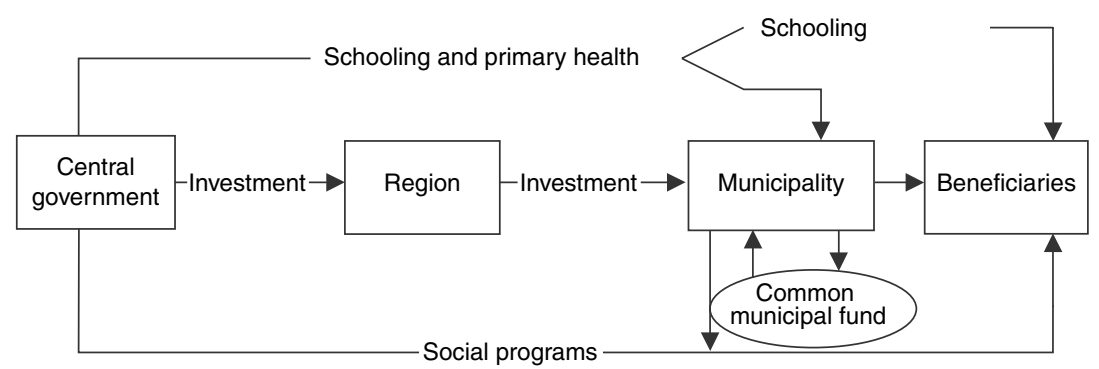

Source: Author's representation.

F I G U R E 12 . 1 Government's Decentralized Funds in Chile

Because municipalities are deeply involved administering most state social welfare programs, a second group of grants covers a wide range of subsidies and local development funds. They are conceived as a part of the general approach to focus social aid in order to reach the poorest population. Like schooling and primary health care, this group is made up of purely categorical transfers. Although the grants are given directly to beneficiaries (figure 12.1), municipalities provide administrative support and generate the information needed to implement the aid programs. Such grants represent roughly 15 percent of all subnational government grants.

Finally, investment funds may be grouped in a third clearly distinguished category. As can be seen in figure 12.1, the distribution of these grants among different projects is a regional responsibility. However, it is the local level that identifies specific needs, designs the project, and requests the funds from the regional government. Decentralized investment funds currently represent almost 23 percent of all grants. As can be seen in table 12.1, they are the item with the highest proportional increase between 1999 and 2003.

The redistribution fund called the Common Municipal Fund (Fondo Común Municipal, or FCM), which redistributes revenues from rich to poor municipalities, deserves separate mention. Although the FCM is the most controversial aspect of the current municipal financial structure (see "Transfers between Municipalities"later in this chapter), it partially levels off the huge differences across municipal governments in their sources of locally generated revenues. Approximately 37 percent of all municipal revenues net of grants are redistributed through the FCM (see Transfers between Municipalities).

From the viewpoint of the degree of maneuverability subnational governments have in allocating grants, most grants can be defined as 
categorical. On one extreme are grants for social aid and local development, for which municipalities merely identify and contact beneficiaries, having no role in deciding what type of subsidy to give. At the other extreme, both the subvention to schools and the grant for primary health care are physically transferred to local governments. Although municipalities are committed to use this funding for these two specific purposes, local authorities very often delay the actual payment of expenses incurred in these delegated functions. A slightly higher degree of freedom is the one observed in the regional allocation of decentralized investment funds. Although roughly half of these funds are also geared toward centrally defined targets, a substantial number are freely allocated by regional and municipal governments, as discussed in the following section.

\section{The Case of Regions and Provinces}

Regions have an important role in the allocation of public investment funds. Both the amount of these funds and a broad definition of the type of projects to be executed with them are determined at the central level. With varied degrees of autonomy, depending on the fund at stake, regional governments decide on the specific investments to be made. The so-called national investment system establishes a procedure for evaluating each project on the basis of its present net social benefit. In the same way as a social discount rate is determined, shadow prices of the foreign currency and the cost of labor are recalculated regularly.

Three administrative bodies are in charge of identifying and proposing projects to the COREs. They are the municipal councils, the regional branches of specific national ministries (secretarías regionales ministeriales, or SEREMIS), and the provincial governors, who are empowered to influence the ranking of investment proposals. In most cases, the SERPLAC makes the economic evaluation of the project at stake and sends a report to the regional government. All municipalities with more than 100,000 inhabitants have a SERPLAC. Smaller municipalities appoint a municipal officer who provides the technical support.

Four categories of funds can be identified (table 12.2) (SUBDERE 2004). The most important one is the National Fund for Regional Development (Fondo Nacional de Desarrollo Regional, or FNDR), which accounts for more than 52 percent of the regionally decided public investment (RDPI). The FNDR was designed as a mechanism to standardize the access across regions to public investment funds. ${ }^{6}$ Originally, it was fully funded by the central government. Thereafter, additional funding was provided by the 
Inter-American Development Bank (IDB). In principle, the FNDR resembles a noncategorical grant to support RDPI, but some minor restrictions and broad definitions regarding the use of the fund should be considered. Generally, the FNDR is not allowed to target current expenses, donations to private or public institutions, and financial investments. The part of the fund provided by a credit from the IDB cannot be used to build prisons or pay for other justice sector-related projects. The freely allocated share of the FNDR - almost 46 percent of it - is complemented with provisions that take the form of categorical grants, whose allocation is centrally determined by the ministries involved. For 2003, 14 categorical provisions were assigned to specific uses in a wide range of areas. Although the secondary distribution of the fund as well as the regional allocation to specific projects is decided at the regional level, at least 50 percent of the projects prioritized by the provincial governors are considered in the regional FNDR investment budget.

The second type of investment grant is the specific-sector regionally allocated investment (inversión sectorial de asignación regional, or ISAR). In this case, donor ministries define the rules for project eligibility. Nevertheless, the regional government decides the interregional allocation of funds. At least 80 percent of the proposals made at the provincial level must be considered in the regional ISAR budget. The total cost of each project may be cofunded by the ministry and the regional government.

TA B LE 12, 2 Decentralized Public Investment Funds: Primary Distributive Criteria

\begin{tabular}{|c|c|}
\hline Fund & Primary distribution \\
\hline $\begin{array}{l}\text { National Fund for Regional } \\
\text { Development (FNDR) }\end{array}$ & $\begin{array}{l}\text { Allocation made by the Undersecretariat of } \\
\text { Regional and Administrative Development: } \\
90 \% \text { is assigned on the basis of a set of socio- } \\
\text { economic and territorial indicators. } 10 \% \text { covers } \\
\text { emergency situations and stimulates efficiency } \\
\text { in the use of the assigned regional budget. }\end{array}$ \\
\hline $\begin{array}{l}\text { Specific-sector regionally } \\
\text { allocated investment (ISAR) }\end{array}$ & Defined by the donor ministry \\
\hline $\begin{array}{l}\text { Locally allocated regional } \\
\text { investment (IRAL) }\end{array}$ & Defined by the donor ministry \\
\hline Programmatic agreements & Defined by the donor ministry \\
\hline
\end{tabular}

Source: Author's classification. 
Four active ISAR funds were available for 2003. The Ministry of Internal Affairs, through the Undersecretariat of Regional and Administrative Development (Subsecretaría de Desarrollo Regional y Administrativo, or SUBDERE), administers an ISAR called the Neighborhood Improvement Program, which finances basic local infrastructure and is generally oriented toward extremely poor communities. Municipal governments play a fundamental role in identifying the potential projects at the local level, promote the communal social organization, look after the collection of complementary funds, ${ }^{7}$ make the acquisition or sale of assets involved, and improve the water supply conditions in small communities. The second ISAR is the Urban Improvement and Rainwater Evacuation Program. This program is sponsored by the Ministry of Housing. As its name states, the program finances new investment, contributes to the maintenance of old pavement, and supports the creation of urban facilities intended to evacuate rainwater. The Ministry of Public Infrastructure offers an ISAR called the Rural Drinkable Water Program, which develops water facilities in rural areas. This program makes the community responsible for maintaining these facilities through the creation of a Rural Drinkable Water Committee. Finally, the National Sport Institute administers the Chile Sports Program, which funds the building and improvement of sport facilities. The share of ISARs in all regional investment funds has been declining systematically since 1999; for 2003, the share is slightly higher than 10 percent.

In 1996, a line of regional investment funding began to operate, giving municipalities full responsibility to decide on specific projects to be undertaken. This funding is called the locally allocated regional investment (inversión regional de asignación local, or IRAL). Two IRALs are currently operating. One is the Urban and Communal Equipment Improvement Program (Programa de Mejoramiento Urbano y Equipamiento Comunal, or PMU). Administered by SUBDERE, the PMU is intended to fund small projects that generate local employment and improve residents' quality of life. Like many other initiatives, it is used to finance sport facilities, sidewalk maintenance, social community centers, and the like. In practice, only 75 percent of the PMU is strictly allocated as an IRAL, with the remaining 25 percent left at the disposal of governors for use in emergencies. Every CORE decides which municipalities will receive the funding and in what amounts. Thereafter, each local council informs SUBDERE about the characteristics of the investments to be made.

The second IRAL is intended to promote local productive development by supporting small entrepreneurs. This IRAL is run by the Social Investment and Solidarity Fund (Fondo de Solidaridad e Inversión Social, or 
FOSIS), which operates as a branch of MIDEPLAN. It is called the Support Program for Income Generation from Economic Activities and covers productive investment, local specialized services, access to credit, and local business environment development.

Projects under the label of programmatic agreements are the result of a cofinancing contract between the region and the ministry that sponsors the fund. Investment proposals should be part of the regional long-term development strategy. An example of such a project is the Participative Pavement Projects Program, which is intended to reach groups of urban dwellers who organize themselves into a committee and request the local branch of the Ministry of Housing to pave a road or install a missing sidewalk.

Similar funds subsidize the acquisition of houses for workers, small communities, and extremely poor individuals who are either unable to maintain minimum savings or have no access to credit. Examples are the Special Workers' Project Program, the Minimum Standard Social Housing Subsidy, and the Chile Neighborhood Program. Specific local needs are also being served through the Sport Fund, River Banks Defense Program, and Citizens Security Program. Most of these programs not only finance improvements in physical infrastructure but also give technical advice and facilitate the implementation of cooperative efforts to reach the targets being pursued.

As can be seen in table 12.2, the only clearly established secondary distribution criteria are those used for the FNDR. Remaining funds are distributed by the donor ministries on the basis of the regional endowment - or observed deficit-in areas in which a particular ISAR is meant to be used. Although this regional distribution mechanism may be labeled discretionary, it is far from being arbitrary—as long as it is based on a centrally defined set of factors.

The genesis of investment proposals rests on those local public institutions geared to capture residents' needs. Neighbors organize into local committees that provide information on their specific demands. This information is channeled through the local municipality, the deconcentrated branches of central government ministries, or the regional and provincial governments. With very few exceptions, proposals are handed over to the SERPLAC, which evaluates projects in the context of the national investment system (SUBDERE 2003). After a proposal is given technical approval, it is returned to the regional government, which then prioritizes all feasible proposals according to the regions' interests and requests the funding from SUBDERE or other ministries. Big investment projects have to be evaluated by MIDEPLAN directly, centralizing the process for the whole public sector.

Despite all these funds being labeled as RDPI, only the nonprovisioned share of the FNDR - which amounted to slightly more than 50 percent of all 
TA B L E 12 . 3 Regionally Decided Public Investment Funds, 1999-2003

(2002 US\$ million)

\begin{tabular}{lrrrrr}
\hline Item & 1999 & 2000 & 2001 & 2002 & 2003 \\
\hline FNDR & 256.3 & 249.7 & 295.6 & 355.1 & 449.3 \\
ISAR & 139.0 & 134.0 & 141.9 & 150.6 & 90.4 \\
IRAL & 37.8 & 52.6 & 53.7 & 47.0 & 40.0 \\
Program agreements & 137.8 & 184.9 & 198.1 & 219.4 & 277.8 \\
$\quad$ Total & 570.9 & 621.2 & 689.3 & 772.1 & 857.5 \\
$\quad$ Share of national public & & & 46.3 & 47.3 & 50.2 \\
$\quad$ investment (\%) & 36.9 & 44.4 & 46.3 & & \\
\hline
\end{tabular}

Source: Data from SUBDERE.

RDPI (see table 12.3)—might be genuinely defined as a noncategorical investment grant. The share of the RDPI in total public investment has increased from about 13 percent at the beginning of the 1990 s to 50.2 percent in 2003 . This change responded to the current political will favoring a more decentralized public investment allocation. The fact that this measurement is discretionary implies that nothing precludes this share from being reduced - or increasedin the future (Letelier 2003). Nevertheless, this trend in the share of RDPI is the most significant recent achievement as far as decentralization is concerned. Over the past 13 years, there has been an active devolution of public investment funds to the regional and the local levels; however, this shift has not been accompanied by a similar evolution in institutional structure. Generally, the range of responsibilities and rights held by regional governments has remained the same since 1993, when regional governments were formally created.

\section{The Case of Municipalities}

\section{Transfers between Municipalities}

The structure of grants to municipalities has a compensating mechanism that redistributes income from rich local governments to poor ones. This mechanism operates in a way similar to the redistribution funds that is often observable in federal countries and is fed by provincial or state taxes, which are then assigned by the central government on the basis of an agreed-upon rule. In Chile, the mechanism takes the form of the Common Municipal Fund, or FCM. The FCM considers redistributive elements both at the revenue-generating stage and in the way the fund is allocated. The purpose of 
TA B LE 12 . 4 FCM Resources, 1999-2003

\begin{tabular}{ccc}
\hline Year & $\begin{array}{c}\text { Amount } \\
\text { (2002 US\$ million) }\end{array}$ & $\begin{array}{c}\text { Share of FCM in } \\
\text { municipal expenditure (\%) }\end{array}$ \\
\hline 1999 & 392 & 31.8 \\
2000 & 394 & 30.4 \\
2001 & 445 & 34.8 \\
2002 & 492 & 37.0 \\
2003 & 515 & $36.6^{\text {a }}$ \\
\hline
\end{tabular}

Source: Author's estimation based on data from SUBDERE.

a. Author's estimation.

the FCM is defined in the nation's constitution as a "solidarity redistributing mechanism of self-generated resources between municipalities."

Table 12.4 shows the magnitude of the resources being distributed. The total amount reached US\$515 million in 2003. Data for years recorded in the table show that this fund has been rising as a proportion of total municipal expenditures. To an important extent, this phenomenon has been caused by a significant increase in the value and the number of properties being taxed and the stock of vehicles for which circulation permission was charged between 1999 and 2003. All provide significant revenue to the fund (box 12.2). It should

\section{B OX 12.2 The Common Municipal Fund}

\section{Sources of Funding of the FCM}

1. Sixty percent of property tax (all municipalities)

2. Fifty percent of revenue collected for car circulation permission charges

3. Fifty percent of the 1.5 percent of the selling price rate charged for vehicles being transferred

4. Fifty-five percent of revenues collected by Santiago, and 65 percent of that collected by Providencia, Las Condes, and Vitacura, for payments for local business licenses

5. Central government contribution

\section{Distribution of the FCM}

1. Ninety percent based on social coefficients, re-estimated every three years

2. Ten percent as a function of emergency events and municipal management performance 
be pointed out that in practice the central government's contribution does not exist; hence, the FCM is a purely redistributive device among municipalities. Figures 12.2 and 12.3 indicate the important degree of inequity between Chilean municipalities as far as local government revenues are concerned. Only 51 local governments were net contributors to the fund in 2002; the remaining 290 where net beneficiaries. Another aspect worth noting is that among the contributors, a few were very big relative to the rest.

Several weaknesses have been detected in the operation of the FCM. One is that all municipalities are legally committed to give away part of their revenues according to the rules described in box 12.2, though few of them are net contributors. Because in most cases municipalities are refunded an amount larger than their contribution, the whole operation of transferring the money to the central government and receiving the corresponding assignment of funds is a waste of time and resources. Municipal governments very

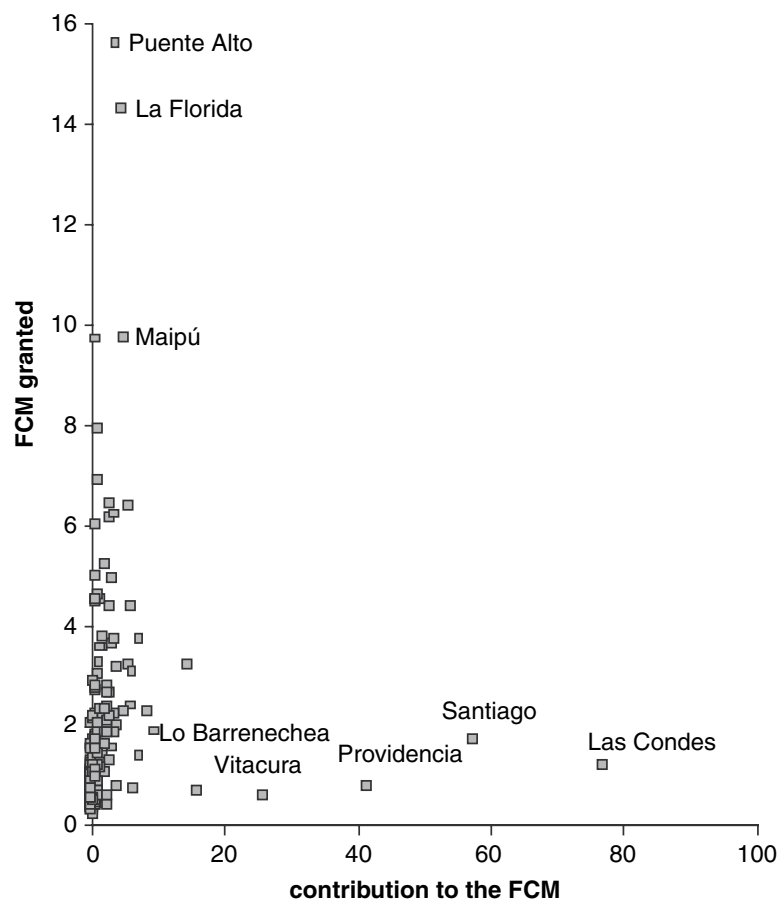

Source: Data from SUBDERE 2003.

F I G U R E 12.2 Municipal Contribution to the FCM versus Grant Received (2002 US\$ million) 


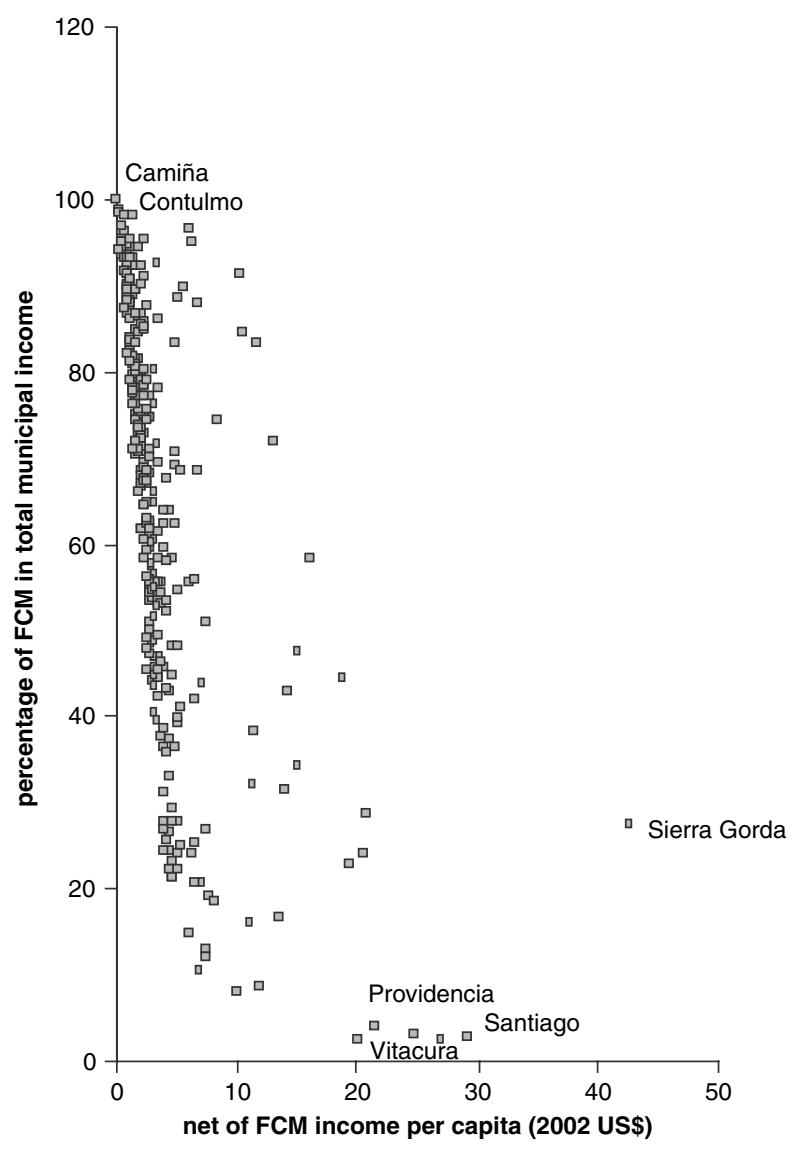

Source: Data from SUBDERE 2003.

F I G U R E 12 . 3 Share of FCM in Municipal Income versus Net of FCM Municipal Income Per Capita

often delay the payment of their contributions because of the net benefit they are likely to get. The net effect is that, strictly speaking, only 58 percent of the resources collected by the FCM are redistributed. The remaining 42 percent of resources are returned to the contributors.

Another weakness has been noted in the structure of the FCM. It has been argued that although the FCM is a redistributive device, it also assigns some weight (10 percent) to management performance and catastrophic events. Although this portion of the fund appears to be an important source of 
revenues for some small municipalities, it is a clear deviation from the general aim of targeting redistribution. Some of the outliers observed from figures 12.2 and 12.3 may be explained in light of the FCM not being a purely redistributive mechanism. Figures also show that most municipal governments are net beneficiaries. Only 15 percent of municipalities were net contributors in 2002. SUBDERE is now considering a redesign of the fund. Although there is no single proposal, all potential improvements are meant to deal with these problems.

\section{Transfers from Upper Levels of Government}

Three basic sources of grant-related funds can be said to represent transfers from higher tiers of governments to municipalities. One source is the share of IRAL assigned by each region to specific municipalities. Another source is that municipalities are also granted funds to support delegated functions in education and health (table 12.1). Although all receive local populationbased funding on this account, numerous additional categorical grants are also assigned to specific municipalities. In some cases, local governments apply for these grants; in other cases, the central government decides which municipality will receive the funds. Another source falls under the label of "social aid and productive promotion" (table 12.1). These funds are given directly to the beneficiaries and cover a wide range of categorical grants that support a variety of socially oriented municipal functions. This section describes separately the case of delegated functions of schooling and primary health care and the case of social aid and productive promotion.

\section{Delegated functions of schooling and primary health care}

The central government grants for primary health care are estimated on the basis of a theoretical local population whose characteristics are assumed to fit the last national population survey. In 1995, a new scheme began to operate, which is based on the costs of a number of health services per capita. The grant given to each municipality is estimated in accordance with the following two steps: First, a basic per capita cost is estimated, on the basis of a package of primary health care services needed to fulfill a family health plan (Duarte 1995). Second, this basic cost per capita is multiplied by a factor that discriminates between rural and urban municipalities and, within each group, between poor and not poor municipalities. In addition to the per capita grant, primary health care centers are potential beneficiaries of 22 complementary transfers within the so-called Strengthening Attention Program. These transfers range from management improvement funds to a variety of preventive health programs. In most cases, they are centrally 
assigned by the Ministry of Health on the basis of specific primary health characteristics of selected communities. As can be seen from table 12.5, the share of primary health care in all public health expenditures is slightly more than 10 percent. Although no systematic information is available for all years, complementary funds, in addition to the basic per capita, amount roughly to one-third of primary health care funding.

As for the financing of schools, primary and secondary education in Chile is provided under three alternative schemes: schools that are fully funded privately, state-supported private schools, and municipal schools. As with primary health care services, municipalities were made responsible for the administration of schools in 1980. The publicly supported (private and municipal) schools receive a categorical grant in the form of a voucher per student, which is paid monthly on verification of the student's attendance in classes. Although there is a basic educational subvention unit, the law distinguishes 17 teaching modalities, among which the monthly subvention per student differs. The first broad differentiation is between half-day and fullday attendance regimes. Although the Chilean system is moving toward a full-day attendance regime, most public schools are still limited in their physical infrastructure and still operate under a half-day modality. Further differentiation is made on account of the level of school education being

TA B L E 12.5 Delegated Functions, 1999-2003 (2002 US\$ million)

\begin{tabular}{|c|c|c|c|c|c|}
\hline Indicator & 1999 & 2000 & 2001 & 2002 & 2003 \\
\hline Schooling & $1,494.0$ & $1,623.0$ & $1,706.3$ & $1,957.8$ & $2,022.6$ \\
\hline $\begin{array}{l}\text { Subvention to municipal } \\
\text { schools }\end{array}$ & 815.7 & 880.0 & 929.3 & 980.0 & $1,071.5$ \\
\hline Subvention to publicly & & & & & \\
\hline supported private schools & 499.3 & 558.2 & 578.9 & 701.8 & 691.6 \\
\hline Special School Program & 179.0 & 184.8 & 198.1 & 276.0 & 259.6 \\
\hline Primary health centers & 175.4 & 181.7 & 198.5 & 216.5 & 245.9 \\
\hline Total & $1,669.4$ & $1,804.7$ & $1,904.8$ & $2,174.3$ & $2,268.5$ \\
\hline $\begin{array}{l}\text { Share of schooling in the } \\
\text { central government's } \\
\text { expenditures on education (\%) }\end{array}$ & 6) 70.5 & 70.1 & 70.1 & 71.9 & 71.7 \\
\hline $\begin{array}{l}\text { Share of public health care } \\
\text { in the central government's } \\
\text { expenditures on health (\%) }\end{array}$ & 11.2 & 10.7 & 10.8 & 12.4 & 14.1 \\
\hline
\end{tabular}

Source: Public Budget Law. 
provided (primary or secondary), the type of education (technical or scientific), the location of the school (rural or urban), and the type of students attending (regular students, students with disabilities, adult students, and so forth). Additionally, in 1991, municipal schools were given the option of charging students. The voucher assigned to schools that take this option is inversely related to the fee charged. ${ }^{8}$

The logic of this system lies in the potential benefits of "exit"-rather than "voice" - as a way to enhance the accountability of school managers and municipal authorities. Because funding from the central government depends entirely on the number of students attending, poorly administered schools are theoretically condemned to run out of students. Although municipalities make voluntary contributions to complement this grant, most of the money comes from the voucher-related source. All voucherbased funding is given on a variable basis and thus certainly produces substantial differences in quality of education across the country, making Chile a rather unique case. Regardless of the voucher-based funding, it has been argued that this system is inconsistent with the Teachers' Statute, which has applied since 1991 (González 1998). This statute governs the contractual responsibilities between teachers and municipalities, and it establishes substantial obstacles to the removal of teachers if municipalities no longer need them. In so doing, the statute fixes the cost of labor in a context of a fully variable voucher-based revenue source.

In addition to the voucher per student, the Ministry of Education distributes a variety of categorical grants intended to strengthen schools by addressing specific weaknesses of the educational system. ${ }^{9}$ In most cases, schools apply for these funds by proposing a project that suits the target being promoted. The Ministry of Education uses a more discretionary allocation procedure in other cases. It considers socioeconomic factors such as local poverty and social vulnerability. Currently, 15 such programs are available to schools, and numerous other ones continue to transfer money to schools. Programs of this kind are generally framed for the purpose of decentralizing the process of education by giving more leeway to school administrators in designing development plans. Most have been developed to deal with particular aspects of the so-called educational reform, which started in 1990 and launched an ambitious national plan to improve schools.

Three categories of special programs may be identified. One category has been designed to improve access to education. A first line of action is being developed through a program called School for Everyone, which targets the need to prevent school desertion. Once the school diagnostic is done, central authorities contribute the funds needed to develop a case-specific development 
plan. The plan considers the distribution of scholarships, infrastructure improvement, pedagogic development, school community participation, and personal psychological support to students.

Another program in this category is the Complete Journey School Program. This initiative aims to progressively incorporate schools into the socalled complete journey regime. ${ }^{10}$ School administrators may apply for this funding by proposing a development plan that considers various aspects of the learning process. Selected schools are granted a higher subvention per student and a complementary bonus for maintaining the physical infrastructure. This program has been formally evaluated by Raczynski (2001), who found that the implementation of the new scheme coupled with a lack of personnel and physical resources produced difficulties for some schools in the current development of their activities. The supply of lunches for students attending schools that were newly switched to the full-time regime was a significant problem in some cases.

Initiated in 2003, the Chile Qualifies Program, another program in this category, is designed to promote three education-related areas in which Chile still lags behind: equity, competitiveness, and job opportunities. This assists adults by allowing them to complete school. Private enterprises whose workers are potential beneficiaries are given a tax rebate for workers who enroll. Publicly supported schools apply to be accredited as executive units by proposing a plan of action and showing that they fulfill a number of basic requirements.

In a second category, we find some efforts to improve the quality of education. An important initiative is the Educative Improvement Projects (Proyectos de Mejoramiento Educativo, or PME), which began in 1992. The PME finances rather small projects that are intended to improve the quality of education through more autonomous and innovative educational management. Applicants are selected on the basis of an open contest in which all publicly funded schools are potential beneficiaries. Preference is given to socially vulnerable schools attended by the poorest. The PME has been formally evaluated (DIPRES 2002). Resources given per school were found to be too small to serve the goal of promoting innovation among teachers and school managers. Interestingly, a former program called Montegrande, which was explicitly designed to favor innovation in school practices by giving significant grants to very few highly selected beneficiaries, appears to have achieved more successful results (DIPRES 2001a).

Since 2002, another program in this category, the Reading, Writing, and Arithmetic (Lectura, Escritura y Matemática, or LEM) Program, has aimed to strengthen students' language and mathematical abilities. It involves a rather wide range of complementary actions such as teacher training, 
improvement of school libraries, direct assistance to 66 low-performance schools in metropolitan areas, a pilot plan in 20 selected schools, and a number of promotional activities to reach parents.

To ensure access to the latest knowledge, a program called Links was also initiated in 1992. Its goals are the intensive use of technology and a substantial improvement in students' access to computers. Practical problems in the achievement of such goals have ranged from lack of electricity or access to telecommunications and uncertainty about computer platforms to lack of knowledgeable and qualified personnel. By 2005, Links had installed more than 75,000 pieces of equipment in 88 percent of primary public and 85 percent of secondary schools. The program is ongoing.

Along the same line, the development of Centers of the Learning Resources attempts to improve access to libraries. The Ministry of Education distributes books and reading material to primary schools, which are invited to participate by applying for the funds. School selection is based on the characteristics and general conditions of the applicants, such as educational performance of the schools, socioeconomic vulnerability of the students, and other similar factors.

A third type of program is intended to strengthen or rectify specific habits and values of students. Five programs fit into this general definition. One is the Drug Prevention Program, which distributes informative reading material and teaching guidelines to registered schools. This program is part of a comprehensive effort to control drug addiction. Similar programs are being developed for sexual education, environmental education, and antibullying behavior. The Intercultural Program deserves special mention; it was created in 1995 to integrate indigenous cultural elements, such as language and history, into the regular school curriculum. Scholarships are available for students from indigenous groups.

An overview of the specific magnitude of decentralized resources on education can be seen in table 12.5. Of all public expenditures on education, slightly more than 70 percent is decentralized either in terms of the basic voucher-related subvention or in the form of other categorical grants. Nevertheless, the basic subvention is - on average-more than 80 percent of the whole transfer. It also appears from the table that the significant increase in total expenditures in recorded years has been basically the result of a significant increase in assignments to the Special School Program. The roots of this program lie in the educational reform launched at the beginning of the 1990s, whereby education quality was to be addressed through various specific initiatives. The data show that, despite government health care being a considerably less decentralized function, related grants have been rising significantly over the period under analysis. 


\section{Social aid and productive promotion}

Over the past 30 years, the Chilean approach to social aid has seen to increase emphasis on focusing social assistance from the government. Systematic efforts have been made to take the benefits of the social assistance net as close as possible to those in real need. An aspect of this approach worth mentioning was the implementation in 1980 of an instrument intended to identify at the municipal level both the types of local residents needing social assistance as well as the types of social problems they face. This effort was called the Ficha de Caracterización Social (File of Social Characteristics, or CAS-1 File), and it provides an individual profile of life quality.

An improved recording procedure is currently applied as the CAS-2 File (MIDEPLAN 2004). The information is gathered from a survey of potentially eligible residents. The initial diagnostic in 1984 showed that only 14 percent of social expenditures reached the very poor. Every person interviewed is given a score, which depends on 13 variables related to housing, education, occupation, and income. Although the national and regional governments supervise the process, the municipality is responsible for implementing the survey. Assigned subsidies based on the CAS-2 File are of two kinds. One is meant to provide support to individuals below the poverty line who are incapable of reaching a minimally acceptable life standard by themselves. A second kind is geared to assist either small local entrepreneurs or municipal governments as a unit to enhance their capacity to produce goods and services.

Among the first kind of subsidies there is a well-evaluated program that provides financial support for drinkable water. The program subsidizes the consumption of water and the use of sewer systems among families (DIPRES 2001b). Although SUBDERE administers the program, the payment of benefits is directly made by the Ministry of Finance to private and public water suppliers. Regions are assigned these funds on the basis of centrally defined criteria. Once the annual primary distribution across regions is decided, each CORE allocates the regional share of the subsidy among municipalities, which in turn select the specific families to be awarded the funds. The percentage of the bill that is subsidized ranges between 30 percent and 80 percent, with a maximum consumption level of 15 cubic meters of water per month, regardless of the family profile. An aspect worth mentioning - and probably one of the reasons why the subsidy has been successfulis that companies that supply the water are allowed to design the administrative procedures to activate the subsidy on behalf of benefiting families. Because suppliers are interested actors in this case, the number of subsidies being given increased dramatically since this mechanism was implemented. 
Social aid also takes the form of assistance pensions (pensiones asistenciales, or PASIS), which cover a variety of specific targets. The elderly assistance pension assigns a minimum income to those who are older than 65 and have a family income lower than 50 percent of a centrally defined minimum pension. Similarly, the assistance pension for persons with disabilities benefits those who are older than 18 and have a disability. The beneficiary receives a subsidy that amounts to approximately US\$50 per month. In addition to receiving the cash benefit, the recipient is automatically granted free primary health care through the public health system and his or her recognized dependents are assigned complementary aid. Under the label family subsidies are various assistance programs directed toward children and mothers in extreme poverty. The sole family subsidy supports individuals younger than 15 who are classified as extremely poor, have no other cash benefits, and are dependent on an adult who has no source of income. It pays approximately US $\$ 4.50$ a month per head. Mothers of these beneficiaries may be granted an equivalent stipend called a mother's subsidy. A one-time US\$46 grant is given to selected pregnant women (called a maternal subsidy). Once the baby is born, the mother may apply for the just born benefit, a type of monthly assistance that extends for the first 10 months of the baby's life.

In contrast to the rather specific target-oriented nature of the aforementioned subsidies, the Ministry of Education sponsors two permanent actions intended to promote equity in access to school. One is channeled through the National Committee of School Assistance and Scholarships (Junta Nacional de Auxilio Escolar y Becas, or JUNAEB), which provides feeding support and health assistance to socially vulnerable children. The program reaches 400,000 beneficiaries in 10,000 schools. It has been running since 1964 and has been very successful in reaching the very poor. One out of 10 beneficiaries is almost exclusively fed by the program, and 5 out of 10 would stop attending school if the program did not exist. ${ }^{11}$

A second line of action is the one developed by the National Board of Playgrounds (Junta Nacional de Jardines Infantiles, or JUNJI). Its main target is the provision of free food and general social care to children between three months and five years of age. In most cases, aid is channeled through private providers, which are often supported by the municipality. However, the JUNJI also supervises and accredits the functioning of privately funded operators, regardless of the social condition of children. For the JUNAEB as well as the JUNJI, beneficiaries are selected according to a focused procedure executed by municipalities, whereby information on children's social vulnerability is collected. 
Despite the significant reduction in the share of the population below the poverty line over the past 10 years, ${ }^{12}$ further progress has been difficult to achieve since 1996. As a result, a new initiative was started in 2003, whereby families in extremely poor conditions would be offered a comprehensive assistance package. The Chile Solidarity System is a family-based program intended to target that part of the poorest population that is usually excluded from the regular social assistance net. A fundamental feature of the program is the social and physiological support given to beneficiaries: technical personnel regularly visit selected families and establish a bridge between the target population and the available social aid.

This Bridge Program is jointly executed by FOSIS ${ }^{13}$ and the local municipality. The families sign a contract with the government. Beneficiaries commit to make use of any social benefits available from the state, and the government puts at the disposal of the family an additional well-defined package of benefits, including a monthly cash subsidy, which the family receives for two years after the contract has been signed. The logic of having families sign a contract lies in the need to ensure that members of benefiting families can personally apply to the local government bureau in charge of delivering the particular social benefit they require.

Although the implementation of the Chile Solidarity System became a major political issue, the system's effect on the public budget is difficult to measure. Most of the effect is captured in the magnitude of the social subsidies described in table 12.6.

T A B L E 12. 6 Social Programs Allocated by the CAS-II Card, 1999-2003 (2002 US\$ million)

\begin{tabular}{lrrrrr}
\hline Program & 1999 & 2000 & 2001 & 2002 & 2003 \\
\hline Social subsidies & 475.8 & 485.1 & 495.9 & 506.0 & 500.2 \\
PASIS & 249.2 & 242.3 & 241.7 & 240.9 & 235.3 \\
Family subsidies & 62.7 & 63.5 & 61.4 & 63.2 & 61.3 \\
Unemployment subsidy & 2.4 & 2.3 & 2.5 & 2.0 & 1.8 \\
Drinkable water subsidy & 26.0 & 31.0 & 34.0 & 34.0 & 35.0 \\
JUNJI & 19.8 & 21.8 & 25.2 & 27.6 & 26.8 \\
JUNAEB & 115.8 & 124.2 & 131.1 & 138.3 & 139.8 \\
Productive promotion & 3.2 & 4.7 & 7.3 & 7.2 & 9.2 \\
PRODESAL & 3.3 & 3.3 & 3.8 & 4.5 & 5.6 \\
PROFIM & $\mathrm{n} . \mathrm{a}$. & 1.4 & 3.5 & 2.7 & 3.6 \\
\multicolumn{1}{c}{ Total } & 479.0 & 489.8 & 503.2 & 513.2 & 509.4 \\
\hline
\end{tabular}

Source: Public Budget Law.

Note: n.a. = not applicable. 
Productive development is also being promoted by specific local assistance programs. Although they do not formally belong to the social assistance net, these programs can be grouped with the abovementioned grants insofar as they are aimed at poor small entrepreneurs and low-income municipal governments. One is the Municipal Institutional Strengthening Program (Programa de Fortalecimiento Institucional Municipal, or PROFIM). In 1994, the Chilean government signed an agreement with the World Bank whereby selected municipal governments would be given support in developing their managerial capacities to carry out functions defined by law. PROFIM implicitly recognizes that Chilean local governments are very heterogeneous in their managerial capacities and human endowments, which together represents a serious obstacle to achieving a minimum national standard as far as the quality of local public services is concerned. In light of this, PROFIM targets municipal strengthening in local planning, financial management, administration of human resources, primary health care, and municipal education. Selected municipalities are chosen on the basis of six indicators: population, poverty, municipal revenues, growth between national population surveys, distance from the regional capital, and number of municipal officers.

Private economic activities are also promoted by the Local Development Program (Programa de Desarrollo Local, or PRODESAL), which is intended to support small low-income farmers. PRODESAL is funded and administered by the Institute of Agriculture Development (Instituto de Desarrollo Agropecuario, or INDAP), a branch of the Ministry of Agriculture. It provides technical advice in specific areas, as well as help in accessing other state instruments and complementary funds intended to improve the quality of life of the beneficiaries.

\section{Lessons to Be Learned from the Chilean Case}

As far as the positive features of the Chilean approach to decentralization, at least two important lessons can be learned. One hinges on the benefit of focusing socially oriented subsidies by giving municipalities an active role in the administration — albeit not in the funding — of the state social assistance net. Although no systematic evidence exists that favors this particular approach as an effective mechanism to reduce poverty, the Chilean experience has been quite successful in this respect. Between 1990 and 1998 alone, the poverty rate declined from 38.6 percent of the population to 21.7 percent. Although these years saw relatively good performance in terms of growth, some credit should also be given to the way in which social public policies 
were organized. Second, the purpose of encouraging innovation in school administration has been clearly present in some of the educational support programs. Because publicly supported schools compete for the funding, they usually offer quite original projects.

Four weaknesses of the Chilean case should be mentioned. One relates to the rather unarticulated and heterogeneous structure of grants to subnational governments. There are more than 35 programs supporting school education (though currently schools may only apply for 15 of these programs), 22 primary health care categorical grants, and 4 basic types of investment grants. All have numerous specific funds. And there are myriad other socially oriented categorical grants. The relative abundance of conditional transfers reinforces a low degree of fiscal decentralization. An interesting step forward in this respect is the consolidation of most specific programs into block grants. This effort will expand the range of choice for local representatives, taking the allocation of public resources closer to local and regional constituencies.

The second weakness hinges on the mechanism in force to redistribute revenues among municipal governments. As stated above, the geographic redistribution of public funds is made through the FCM, which collects municipal revenues from all municipalities-with higher rates applied to the four richest - and then distributes the funds according to an equalization formula. The fact that this redistribution tool is in the process of being refurbished is a sign of the inconvenience of having a fund to which all contribute. The obvious lesson is that benefiting local governments, as well as net contributors, should be identified beforehand and given the net share directly.

Third, the current prohibition on borrowing by municipal governments is clearly inconvenient. Indirect borrowing through leasing contracts or by delaying the payment of current expenditures makes that norm difficult to enforce.

Fourth, although the process of making school education and primary health care a municipal responsibility in 1980 was a big step forward as far as decentralization was concerned, the financing mechanism has two important weaknesses. First, because in most cases the educational subvention grant and the per capita grant for primary health care are given to the municipal government and not to the particular administration unit in charge, resources are very often diverted from the intended use. This problem is certainly caused by the lack of other genuinely noncategorical grants among available transfers. An interesting innovation in this regard would be the introduction of educational districts, as exist in various developed countries. A related 
problem is that the Teachers Statute is certainly incompatible with the flexibility that is needed in the structure of municipal costs for the voucher system to operate efficiently.

\section{Conclusions}

Although Chile formally has three tiers of subnational government, only the regional and the municipal levels are genuinely decentralized. They both have local representative councils that decide on the allocation of centrally assigned public funds. Their range of choice is, however, limited for two reasons. One is the fact that a significant share of transfers to subnational governments come in the form of categorical grants. This limitation is particularly clear at the municipal level, where funding is complemented by myriad centrally designed categorical grants intended to strengthen specific aspects of municipal functioning. In addition to the fact that regional governments do not have a budget of their own, the second limitation to real fiscal subnational autonomy relates to the rather rigid structure of municipal rates and tax bases and the formal prohibition against municipal borrowing.

Grants assigned to subnational governments are of three general types. In one group are the funds to finance what we have called delegated functions in education and health. They include basic funding and numerous programs that strengthen specific areas of schooling and primary health care. A second group is made up of a wide range of subsidies and assistance transfers that are given directly to the beneficiaries. Municipal participation in this group is limited to the identification of individuals in need and the administration of these programs. A fund for redistribution among municipalities also exists. It collects taxes from rich municipalities and reallocates them to the poor ones. The design of this mechanism is under revision. A third group is formed by decentralized public investment funds. It should be acknowledged that the share of regionally decided public investment has been rising systematically for some years. However positive this increase may be from the viewpoint of fiscal decentralization, it is a potentially reversible trend. These funds are discretionarily decided every year through the formulation of the national budget, which is formally proposed by the central government.

Two positive aspects of the Chilean approach to decentralization are worth mentioning. One is the role played by municipalities in the administration of socially oriented grants and its likely contribution to reducing poverty. Second, some of the educational support programs have encouraged innovation on the part of schools. 
The downside of the Chilean case might be summarized in three points. The first is the unarticulated structure of grants. A comprehensive improvement of the whole system hinges on the design of block transfers rather than the existing categorical grants. Second, a clear gain in transparency might be achieved by giving municipalities permission to borrow. The current prohibition is inefficient and difficult to enforce. Finally, the municipal redistribution fund contains perverse incentives. Instead of having a fund to which all municipalities contribute regardless of income, net beneficiaries and contributors should be identified first and then receive or contribute their corresponding share.

\section{Notes}

1. Cabildos in the Spanish literature.

2. The Chilean military government was in power between 1973 and 1989.

3. The estimated Chilean municipal debt is about 9 percent of the national municipal budget.

4. The constitution allows exceptions to this rule in the case of taxes collected explicitly to finance expenses of well-defined subnational government functions. Municipal property tax is such an exception.

5. Sustainers are the school administrators. They may be either private or municipal ones. Each sustainer usually administers various schools.

6. See the Constitutional Organic Law 19.175 on the administration and government of regions.

7. In some cases, beneficiaries also make a minimum contribution.

8. This permission to charge is intended to focus the government's funding effort on the population in need, taking advantage of the willingness to pay of selected families. However controversial, this mechanism has been successful in collecting additional resources for municipal education (González 1998).

9. Most of these programs are available for municipal and publicly supported private schools alike.

10. Most municipal schools are currently used in two shifts, so that students attend either morning or afternoon classes.

11. See http://www.juneb.cl, the Web site of the National Committee of School Assistance and Scholarships.

12. The share of the population under the poverty line has been reduced to a half over the past 10 years.

13. FOSIS is formally a branch of MIDEPLAN.

\section{References}

DIPRES (Dirección de Presupuestos). 2001a. "Informe Final de Evaluación del Programa Montegrande." Ministerio de Educación, Santiago. 
2001b. “Informe Final de Evaluación del Programa SAP, Programa Subsidio de Agua Potable y Alcantarillado.” Subsecretaría de Desarrollo Regional y Administrativo, Ministerio del Interior, and Ministerio de Planificación, Santiago.

— 2002. "Informe Final de Evaluación del Programa Fondo de Proyectos de Mejoramiento Educativo.” Ministerio de Educación, Santiago.

Duarte, Dagoberto. 1995. "Asignación de Recursos Per Cápita en la Atención Primaria: La Experiencia Chilena.” Working Paper 8, Corporación de Promoción Universitaria, Santiago.

Ferrada, Juan Carlos. 2003. "Valorización de las Experiencias de los Gobiernos Regionales." In A Diez Años de la Creación de los Gobiernos Regionales: Evaluaciones $y$ Proyecciones. Santiago: Subsecretaría de Desarrollo Regional y Administrativo.

González, Pablo. 1998. "Financiamiento de la Educación en Chile." In Financiamiento de la Educación en América Latina. Santiago: PREAL-UNESCO (Programa de Promoción de la Reforma Educativa en América Latina y El Caribe and United Nations Educational, Scientific, and Cultural Organization).

Letelier, Leonardo. 2003. "La Descentralización Fiscal en el Contexto de los Gobiernos Regionales Chilenos." In A Diez Años de la Creación de los Gobiernos Regionales: Evaluaciones y Proyecciones. Santiago: Subsecretaría de Desarrollo Regional y Administrativo.

Martner, Gonzalo. 1993. Descentralización y Modernización del Estado en la Transición: Reforma Municipal. Santiago: LOM Ediciones.

MIDEPLAN. 2004. "Ficha Familia: Más y Mejor Focalización en una Nueva Etapa del Desarrollo Social del País.” División Social de MIDEPLAN, Santiago.

Raczynski, Dagmar. 2001. "Estudio de Evaluación de la Jornada Escolar Completa." Dirección de Estudios Sociales, Universidad Católica de Chile, Santiago.

SUBDERE (Subsecretaría de Desarrollo Regional y Administrativo). 2003. Fuentes de Recursos para el Desarrollo Regional. Santiago: SUBDERE.

- 2004. “Instrumentos de Inversión de Decisión Regional—2004.” Working Paper, Santiago: SUBDERE. 



\section{Index}

Boxes, figures, notes, and tables are indicated by $b, f, n$, and $t$, respectively.

Ablo, Emmanuel, 125

accountability of local governance, 20-25

Admad, 248

administration, 104, 240

adult education, 225

advertisement tax, 215, 247, 358

Afonso, José Roberto Rodrigues, 381-418

agriculture, 104, 151, 209, 215, 225, 240,

243,256

Ahmad, Ehtisham, 368

air pollution, 10, 65, 356

airports, 65

akim, 277-82, 288-99

akimats, 277-81, 293, 301

Akmolinskaya, 278, 287

Aktubinskaya, 278, 287

alcalde, 376

alcohol, excise on, 13

Almatinskaya, 278, 287

Almaty city, 278, 287

Alok, V. N., 205-32

amusement facilities, 65

Andaman Island, 210

Andhra Pradesh, 182, 191, 221

Andrews, Matthew, 22

animal husbandry, 151, 209, 225

Araújo, Erika Amorim, 381-418

Argentina, 34-35, 37-38, 347-80, 375n

administration, 370-72

borrowing, 368-70, 376n-377n

categories of local government

spending, $355 t$ communes, $350 t$

constitutional status, 351-52, 376n

distribution of local governments, $351 t$

expenditures, 353t-354t

fines, $358 t$

fiscal imbalances/autonomy, 366-68, $367 t, 376 n$

functional profile, local governments, $356 t$

municipalities, $350 t$

provincial constitutional framework, borrowing, $371 t$

revenue sharing, $363 t$

revenue structure, $357 t$

spending responsibilities, 352-56, 376n

tax sharing, 361-64, 376n

taxation, 356-61, 361t, 376n

taxing powers, $360 t$

user charges, 356-61, 376n

Arunachal Pradesh, 210

Asensio, Miguel Angel, 347-80

Assam, 182, 191, 221

Astana city, 278, 287

Atkinson, Doreen, 51

Atyrauskaya, 278, 287

auls, 277, 290, 298

Australian model, 32-33

badan, $266 f$

Bahl, Roy, 72-73, 89, 269

Bailey, Stephen, 2, 17-18

Baimenov, Alikhan, 290 
Bakshi, P. M., 188

banquet tax, 151

Bantustan, 48, $90 n$

bappeda, 265

Basile, Mirta, 355

Bastin, Johan, 234

beaches, 65

betterment tax, 358

betting tax, 13

Bihar, 182, 200, 217-18

billboards, 65

Bowman, Ann, 32

Boyne, George, 18

Brazil, 34-35, 37-38, 381-418, 415n

borrowing, 404-09, 416n

citizens, accountability to, 410-12, 416n

community councils, 411-12

cooperative transfers, 397-98

discretionary transfers, 399

expenditures, 385-90, 385t, 387t, 415n

federal equalization transfer, 396-97

federative imbalance, 400-04, 416n

function of government, municipal outlays by, 388-89t

horizontal imbalances, 402-04, 416n

improvement charges, 393

legally mandated transfers, 396-99

national health system, transfers from, 398-99

participatory budgeting, 412

personnel spending, 409-10, 416n

population, $383 t$

revenue sharing, $395 t$

revenues, $385 t$

from other governments, 393-99, $416 n$

services, tax on, 391-92

shared taxes, 395-96

taxes, 390-93, 391t, 415n

transfer of real estate, tax on, 393

urban property tax, 392-93

vertical imbalances, 400-02

Breton, Albert, 17

bridge fiscal gap, 15

British model, 29-30

Brodjonegoro, Bambang, 249

Bruechner, Jan, 5

Buchanan, James, 5

budowle, 313
Buenos Aires, 350, 360, 363, 365, 367

building permits, 358

building regulations, 65

bupati, 265

burials, 174

business tax, 13, 154

cabildos, $446 n$

campaign for thrift, 176

carbon tax, 13

career development, 265

Catamarca, 350, 360, 363, 365, 367

cattle pounds, 174

Caulfield, Janice, 17

cemeteries, 65

Central Uganda, 94

Chaco, 350, 360, 363, 365, 367

Chandigarh, 210

Chen, Xiwen, 152, 164

Chhattisgarh, 197-98, 210, 213-14, 217-18

chi fan cai zheng, 150

child care facilities, 65

Chile, 34-35, 37-38, 419-47, 446n

common municipal fund, $432 b$

decentralized funds, $425 t, 426 f$

distributive criteria, $428 t$

municipal functions, $422 b$

municipalities, 431-43

transfers between, 431-35

provinces, 427-31, 446n

public investment funds, $431 t$

regions, 427-31, 446n

responsibilities, $421-23$

social aid, 440-43, 446n

subnational government financing, 424-27

taxes, 423-24, 446n

China, 34-35, 37-38, 137-68

administration, 162-63, 166n

agriculture, 147, 166n

borrowing, 160-62

capital investment, 146

education, 143-45, 166n

expenditures, 142-49, 143t, 144t

finances, 163-64

general-purpose transfers, 156-57, 166n

government employment, distribution of, 147-49

government personnel, $149 t$ 
health care, 145-46, 166n

intergovernmental fiscal transfers, 155-60

intergovernmental transfers, $156 t, 159 t$

local taxes, $151 t$

own-source taxes, 150-53, 166n

population, $138 t$

responsibilities of local governance, $148 t$

revenues for shared taxes, $154 t$

shared taxes, 153-55, 166n

social security, 146

special-purpose transfers, 158-60

structure of government, $139 \mathrm{f}$

subprovincial revenue shares, $149 t$

Chinese model, 31

Chubut, 350, 360, 363, 365, 367

citizen-centered governance, 23-24t

citizen-centered local governance, 22-25

civil law, 9

Collier, Paul, 125

comisiones de fomento, $350 t$

communal housing, rent in, 319

communication, 240

comparative perspective, local

government, $34 f$

concejales, 352, 376

conceptual perspective, local

governance, 3-26

conditional grants, 111, 115

consejo municipal, 421

consejo regional, 420

contract tax, 151

cooperative federalism, 6

cooperatives, 240

coparticipación, 357

Córdoba, 350, 360, 363, 365, 367

corporate income tax, 12, 112

Corrientes, 350, 360, 363, 365, 367

cottage industries, 209

Craig, J., 368

credit, local access to, 40-41

credit ratings, 194

cremation, 174

criminal law, 9

cruelty to animals, prevention of, 174

cultural activities, 209

cumul des mandates, 29
Dadra, 210

dairying, 209

Daman, 210

Dana Alokasi Umum Fund grant, 258

de Mello, Luiz R., 260

decentralization, 4, 116, 224

deprivation index, 224

desa, 237

Dewan Perwakilan Rakyat, 234

Dexia, 368

Dick, Howard, 234

dinas, 265, $266 f$

disaster relief, 77

Diu, 210

division of powers within nations, 25-26

dogs, licensing of, 65

Dollery, Brian, 2, 18-20

Donor Sub-group on Decentralisation, 116

dotacja, 325

drainage rate, 216

drinking water, 209, 225

driver's licenses, 13

Duarte, Dagoberto, 435

East Kazakhstan, 278, 287

Eckardt, Sebastian, 233-74

ediles, 376

educational services, 104, 209, 240, 243, 245-46, 250, 256

effluent charges, 13

Eichenberger, Reiner, 4

electric crematoriums, 174

electricity, 10, 56, 65, 358

elementary education, 225

employment promotion, 240

energy sources, 209, 225

energy taxes, 13

enterprise income tax, 154

entertainment tax, 215, 247

Entre Ríos, 350, 360, 363, 365, 367

entrepôts, 348

environment, 8,240

equalization grants, 111, 115

European Union, Committee of

Regions, 368

evolving roles of local governments, 1-46

expenditures, representative assignment of, 8-9t 
fairs, 209

Fan Wei, 27, 46

farmland occupation tax, 151

fencing, 65

Ferrada, Juan Carlos, 420

ferries, 65

fire protection, 10, 65, 174, 356

fiscal equivalency, principle of, 3

fiscal imbalances/autonomy, $368 t$

fiscal information system, 228, 230n

fisheries, 209, 250, 256

fixed asset investment tax, 151

forest produce, 209

forestry license, 250

Formosa, 350, 360, 363, 365, 367

French model, 29

Frey, Bruno, 4

fuel excise tax, 247

Fukasaku, Kiichiro, 260

Gaggero, Jorge, 366

gambling tax, 13

Gandhi, Mohandas K., 206

garbage collection, 356

gas reticulation, 65

gemeenten, 235, 273n

George, Henry, 181

geothermal mining, 250

German model, 29

gewesten, 235

Gildenhuys, Burgert C., 63

gmina, 304, 308

Goa, 175, 182, 221

González, Pablo, 437

Goss, Sue, 2, 16

graduated taxes, 112

Gram Sabha, 210

Gujarat, 180, 183, 217-18

Hady, Hadiz, 234

Haisiyat tax, 202n

Haryana, 175, 180, 183, 217-18

health services, 65, 104, 120, 209, 240, 256,355

heating, 319

Heymans, Chris, 47-92

highway maintenance, 9, 358

Himachal Pradesh, 183, 191, 217-18

Hofman, Bert, 249 homeopathy, Indian system, 225

Horn, Murray, 19

hospitals, 10, 356

hotel tax, 247

Humes, Samuel, 29

immigration, 9

implementation mechanisms, 5

importance of local governments, 33-34

income tax, 154

independent agents, orders of government as, 26

India, 34-35, 37-38

rural, 205-32 (see also rural India)

urban, 169-204, 201n-202n (see also urban India)

Indian model, 30-31

Indonesia, 34-35, 37-38, 233-74

administration, 262-65, 272n-273n

borrowing, 260-62, 272n

civil service employment, $263 t$

civil service management, $265 t$

debt, subnational, composition of, $262 f$

decentralization, $238 f$

equalization performance, 257-60, $272 n$

expenditures, 237f, 240-46, $272 n$

composition, $246 t$

by level of government, $245 t$

fiscal capacity, Dana Alokasi Umum Fund grant, $259 f$

fiscal disparities, local governments, $258 t$

general allocation grant, 251-55

government, distribution of functions, 242-44t

history of local government in, $233-35,271 n$

intergovernmental fiscal transfers, 250-60, 272n

legal system, 235-39, 271n, 272n

Lorenz curves, per capita revenues, $258 f$

own-source taxes, 246-48, $272 n$

reforms, 265-68

revenue sharing, $250 t$

shared taxes, 249-50

special allocation grant, $255-57,272 n$

subnational government

borrowing, $262 f$

obligatory functions, $240 t$

organizational structure of, $264 f$ 
subnational revenue sources, $239 f$

subnational taxes, $247 t$

industrial policy, 9

Inman, Robert, 11

institutions of public governance, 18-19

intendentes, 352, 376

intergovernmental grants, 56

intergovernmental transfers, $39 t$

international conflicts resolution, 8

interstate commerce, 8

inversión regional de asignación local, 429

inversión sectorial de asignación regional, 428

Iqbal, Farrukh, 31

irrigation, 209, 243

Jammu, 197-98, 200, 210, 214, 221

Japanese model, 31-32

Jarach, Dino, 362

Jaya, Wihana Kirana, 234

Jha, Shikha, 212, 217, 219, 226

Jharkhand, 197-98, 200, 210

Jin, Hehui, 165

Johnson, Craig, 226

judiciary, 242

Jujuy, 350, 360, 363, 365, 367

juntas de gobierno, $350 t$

Kadjatmiko, 249

Kaiser, Kai, 249

kantor, $266 f$

Kanwils, 265

Karagandinskaya, 278, 287

Karnataka, 176, 183, 191, 221

Kashmir, 197-98, 200, 210, 214, 221

Kazakhstan, 34-35, 37-38, 275-302

administration, 289-90, 302n

administrative territorial units, $278 t$

borrowing, 288-89

expenditures, 281-83, 283t, 296-99, $302 n$

intergovernmental fiscal transfers, 286-88

new republic, local government structure, 276-81, 302n

public administration, structure of, $281 f$

revenue, $284 t$

shared taxes, 285-86

tax bases, $285 t$ taxes, 283-85, 299-301

withdrawals, subventions, national budget, $287 t$

Kearney, Richard, 32

Kelly, Roy, 248

kelurahan, 237

Kerala, 176, 183, 191, 221-22

Kincaid, John, 32

King, David, 368

Kohli, Atul, 207

komisja rewizjna, 307

Kostanayskaya, 278, 287

kotamadya, 237

Kragh, Ole, 124, 127

Krelove, Russell, 248

Kulesza, Michal, 341

Kyzylordinskaya, 278, 287

La Pampa, 350, 360, 363, 365, 367

La Rioja, 350, 360, 363, 365, 367

Lakshadweep, 211

Lakszan, 361

Larsen, Fredborg, 131

Lectura, Escritura y Matemática, 438

legal status, local governments, 33

Legge, John D., 234

levies, 59

Lewis, Blane, 248, 261

Ley de Coparticipación, 358

leyes convenio, 358

libraries, 10, 209, 356

lighting rate, 216

Lin, Justin Yifu, 165

Liu, Zhiqiang, 165

local expenditures, share of national gross domestic product, $35 f$

local governance, definition, 1

local governments, definition, 1

local public services, $10 t$

local revenues, 37-40

local spending responsibilities, 35-37

local tax revenues, $38 \mathrm{f}$

López Murphy, Ricardo, 369-70

lotteries, 13

Madhya Pradesh, 177, 184, 191, 221

Maharashtra, 184, 191, 217-18

Makhmutova, Merueret, 275-302

Malaviya, H.D., 207 
Mangistauskaya, 278, 287

Manipur, 180, 191, 197-200, 210, 213-14

Martinez-Vazquez, Jorge, 249, 269

Martner, Gonzalo, 419

maslikhats, 276-81, 286-88, 290-93, 299-300

Mathur, Prakash, 169-204

McMillan, Melville, 32

medicine, 225

Meghalaya, 180, 210, 214

Mendoza, 350, 360, 363, 365, 367

Mikesell, John, 372

military, 138

mining tax, 247, 250

Misiones, 350, 360, 363, 365, 367

Mizoram, 210

Mookerji, Radhakumud, 206

Moore, Mark, 16

Moskovits, Cynthia, 369-70

motor fuels tolls, 13

motor vehicles, 13, 247

municipal systems improvement grants, 77,80

Muramatsu, Michio, 31

Musgrave, Richard, 179

Nagaland, 210

Nagar Haveli, 210

nagar panchayat, 171, 202n

National Capital Territory of Delhi, 210

National Electrification Programme, 76-77

natural gas, 250

natural resources, 9, 242

neighborhood development partnership grant, 76

Netherlands development grant, 120

network forms of local governance, 19-20

new vision of local governance, $43 t$

Nicobar Island, 210

Nodal, 79

noise pollution, 65

Nordic model, 27-28

North American model, 32

North Kazakhstan, 278, 287

numberdar, 30

Nyay, 231
Oates, Wallace, 3-5

oblast, 276-300

octrois, 170, 181, 182f, 191, 202-03n, 219

Oganda, 34

oil, 250

Olson, Mancur, 3

Oommen, M.A., 212-13, 219, 226

operating revenues for local authorities, $38 f$

Orissa, 184, 191, 221

own-source revenues, $14 b$

Palmer Development Group, 61, 66-67, 92

panchayat, 30, 207-10, 212-33

parking fees, 13, 247

parks, 9-10, 356

Pavlodarskaya, 278, 287

payroll tax, 12

pension, 265

pensiones asistenciales, 441

personal income tax, 12, 250

pilgrim tax, 215

podstawowa, 328

Poland, 34-35, 37-38, 303-46

administration, 340

agriculture, tax on, 313-14

borrowing, 336-40, 344n

constitutional protection, 304-05

corporate income taxes, $323 t$

education, 326-28, 344n

elections, local, 306-07

exemptions, $317 t$

expenditures, 307-12, 308f, 343n

fees, 318-19, 343n

general-purpose grant, 326-30, 327t

grants, 331-32

to local governments, 324-36

investments, 332-34

local tax, 316-18, 318f, 319-22, 343n

overview of local government, 304-07

property tax, $313,343 n$

revenues, 314-16, 315t, 316t, 343n

role of local government finance, $309 t$

shared taxes, 322-23, 343n

special-purpose grants, 331-34

taxes, 312-22

territorial division, $305 t$

territorial organization, 304

user charges, 318-19, 343n

vehicles, tax on, 314 
police protection, 9-10, 356

poll tax, 13

pollution charge, 151

Pondicherry, 211

population, covered by local governments, 34-35

population per local authority, $37 t$

poultry, 209

poverty alleviation programs, 77, 209

power supply, 356

powiat, 304, 305t

Pradhan, Menno, 261

primary agents of citizens, local governments as, 25-26

primary education, 10, 356

property rates, 56, 59, 69

property tax, 13, 38, 113, 151, 215, 250

Proyectos de Mejoramiento Educativo, 438

public advertisements, 65

public choice, 17-18

public health, 10, 174, 356, 358

public management, 16-17

public nuisances, 65

public transportation, 10, 76

Punjab, 184, 191, 222

Pycroft, Chris, 63, 92

Qian, Yingyi, 165

Qiao, Baoyun, 137-68

Qureshi, Zia, 234

racetrack taxes, 13

Raczynski, Dagmar, 438

Rajaraman, Indira, 219

Rajasthan, 185, 191, 222

Rattsø, Jorn, 173

Ray, David, 247-48

rayon, $277-300$

recreation, 65

refuse collection, 10, 65, 356

Reinikka, Ritva, 125

religious policy, 242

relocation, 265

Republic of Kazakhstan, 278

Republic of South Africa, 71, 92

responsibilities of local governments, 5-25

restaurant tax, 247

restructuring grant, 77

Rhodes, R. A. W., 2
Rig Veda, 208, $231 n$

Río Negro, 350, 360, 363, 365, 367

road maintenance, 104, 120, 174, 209

Rodden, Jonathan, 266

rural India, 205-32

activity mapping, $213 t$

borrowing, 219

centrally sponsored schemes, 224-25, $230 n$

fiscal autonomy, 225-27

functional domain, 211-13, 229n

intergovernmental fiscal transfers, 219-20, 229n

legal framework, 208-11, 229n

National Finance Commission, 220-24, 229n, 230n

number of rural governments, $210-11 t$

own-source revenue, $217 t, 218 t, 220 t$

own-source taxes, 213-19

per capita expenditures, $214 t$

per capita own-source revenue, $218 t$

resources, 221-22t

revenue power, 215-16t

rural local government, evolution of, 205-8, $229 n$

union ministries, $225 t$

S., Leonardo Letelier, 419-47

Sabaini, Gómez, 366

Salta, 350, 360, 363, 365, 367

San Juan, 350, 360, 363, 365, 367

San Luis, 350, 360, 363, 365, 367

sanitation, 209, 358

Santa Cruz, 350, 360, 363, 365, 367

Santa Fe, 350, 360, 363, 365, 367

Santiago del Estero, 350, 360, 363, 365, 367

sarpanch, 30

schools, 120

secondary education, 10, 356

sejmik wojewodzki, 332

sekda, 265

sewage disposal, 10, 319, 356

Shah, Anwar, 1-46, 137-68, 233-74, 355, $360,366,373$

Shah, Sana, 1-46

Shotton, Roger, 131

Singh, S. K., 210, 214, 221

size distribution, municipal governments, $36 t$ 
slaughter tax, 151

Smith, Adam, 173

soil use planning, 356

Solomon, David, 72-73

South Africa, 34-35, 37-38, 47-92

administration of local government, 59 apartheid local government, 48-49, 90n assessment, 83-87

autonomy of local government, 51-55

borrowing, 80-83, $83 t$

constitutional framework, 52-54, $91 n$

cooperative intergovernmental governance, 55

direct transfers as share of expenditures, $74 t$

equitable shares, $79 t$

expenditures, 64-67

expenditures assignment, 65-67

expenditures budgets, $57-58$

formal assignments, 64-65

functions, local government, $65 t$

history, 47-51

intergovernmenal regions, $52 f$

intergovernmental transfers, 73-80

jurisdictional challenges, 84

local revenue, elements of, 69-70t

municipal budget trends, $56 t$

municipal fiscal viability, 85

national transfers, $76-77 t$

postapartheid era, 49-51, 90n

property rates, $68-71$

revenue from, $59 t$

recurrent grants, $78-80$

regulation of local government, 54

revenue, $58-59,91 n$

collection, $73,91 n$

revenues/expenditures, 55-59, 91n

specific-purpose capacity building, 78-80

specific-purpose capital grants, 78

streamlining intergovernmental relations, $84-85$

surcharges, 73

taxes, 67-73

unconditional equitable share, 75-78, $91 n$

user charges, 72-73

South Kazakhstan, 278, 287

sport facilities, 65
Ssewankambo, Emmanuel, 96, 119, 121, 123,128

stamp tax, 151, 154

Steffensen, Jesper, 93-136

Stigler, George, 3

Stoker, Gerry, 2

stormwater systems, 65

street lighting, 65, 247

street maintenance, 10, 356

street trading, 65

subsidi daerah otonomi, 253, 273n

subwencja, 325

Swianiewicz, Pawel, 303-46

Swilling, Mark, 49, 92

Swiss model, 28

Tamil Nadu, 185, 191, 222

tasas, 352

taxing powers, $12-13 t$

teh bazari, 183-84t

telecommunications, 8

Ter-Minassian, Teresa, 368

Therkildsen, Ole, 125

Thompson, Theresa, 269

Tidemand, Per, 96, 98, 119, 123, 128

Tiebout, Charles, 5

Tierra del Fuego, 350, 360, 363, 365, 367

Tinker, Hugh, 169

tobacco excise, 13

tourism, 65

traditional fiscal federalism perspectives, 6-16

traffic management, 10, 65, 356, 358

transit service, 10

transportation, 244-46, 319, 355-56

tribal affairs, 225

tributo, 352

Tripura, 180, 197-200, 210, 214, 217-18

Trollegaard, Sven, 116

Tucumán, 350, 360, 363, 365, 367

Uganda, 35, 37-38, 93-136, 133n

autonomy of, 94-98

borrowing, 126-28

budget approval, 109

city council, administrative structure, 100

conditional recurrent grants, 117-19

constitution, 95 
constitutional review, 97-98

criteria for grant allocation, 125-26

debt, 126-28

development grants, 119-21, 120t, $122 b, 134 n$

district council, administrative structure, 100

elections, 100

equalization grants, 121-22

expenditures, 101-04, 102f, 104-09, $104 f, 133 n$

financial management capacity, $128,134 n$

fiscal decentralization strategy, $118 b$

functional assignments, local services, 105-08t

grants, $115 t, 125$

intergovernmental fiscal transfers, 111-24

layers of government, 101

legal revisions, 97-98

local council elections, $99 f$

Local Government Act of 1997, 95-96, $133 n$

oversight functions, 100-01

own-source revenues, 109-11, 110t, $133 n$

local government autonomy over, 111

political structures, 98-100, 133n

poverty action fund, $117 b$

reforms of local government structure, 101

revenues, 102-04, 103f, 109-28, $133 n$

sector legislation, Local Government Act and, 96

structure of local governments, 98-101, 133n

tax autonomy, 112-13t

timeliness, 124-25, 134n

unconditional grants, 114

urban India, 169-204

borrowing, 190-95, 203n

expenditures, $172-79,202 n$

fiscal relations, 181-90

grants, $189 t$

maintenance expenditures, $200 t$ municipalities

finances of, 195-201, 203n

revenue significance of, $196 t$

per capita revenue expenditures, $180 t$, $197 t$

population, municipalities, $172 t$

revenue base, municipalities, 179-81, $202 n, 203 n$

revenue powers, $182-85 t$

salaries

own-source revenue income, $199 t$

per capita expenditures on, $198 t$

Schedule 12 functions, 174t, 175-78t

share in state's resources, for municipalities, $191 t$

tax-free municipal bonds, $194 t$

Urlezaga, Federico, 355

Uttar Pradesh, 177, 185, 191, 222

Uttaranchal, 197-99, 221-22

uzupelniajaca, 328

Van den Ham, Albert, 234

van't Land, Gerhard, 121, 123

vehicle tax, 216

village swaraj, 208-09, 232

wage expenditures, 245-46, 265

Wajidi, Muhammad, 30

walikota, 265

Wallis, Joe, 2, 18-20

wastelands, 178

water services, 56, 65, 76, 174, 247, 319

wealth taxes, 12

Wei, Jianing, 161

Weingast, Barry R., 165

Werner, Jan, 27

West Bengal, 178, 185, 191, 222

West Kazakhstan, 278, 287

Whelan, Paul, 68, 73, 92

Williamson, Oliver, 19

wojewoda, 304

wojewodowie, 332

województwa, 304, $305 t$

województwo, 304

Wong, Christine, 142

Zhambylskaya, 278, 287

Zhang, Tao, 154

Zheng, Yingpin, 27, 46 


\section{ECO-AUDIT \\ Environmental Benefits Statement}

The World Bank is committed to preserving endangered forests and natural resources. The Office of the Publisher has chosen to print Local Governance in Developing Countries on recycled paper with 30 percent postconsumer fiber in accordance with the recommended standards for paper usage set by the Green Press Initiative, a nonprofit program supporting publishers in using fiber that is not sourced from endangered forests. For more information,

visit
Saved:

- 18 trees

- 13 million BTUs of total energy

- 1,600 pounds of net greenhouse gases

- 6,641 gallons of waste water

- 853 lbs of solid waste 

his book focuses on the big decentralization topic of the next decade, the role of local governments. If fiscal decentralization is your subject, Shah's book ought to be on your shelf.

- Roy Bahl, Dean and Professor of Economics and Public Administration, Andrew Young School of Policy Studies, Georgia State University, Atlanta, United States

ocal governance in a globalized environment will be the most challenging issue for politics in this century. Inspired by citizen-centered governance, Anwar Shah and his colleagues offer fascinating, and first-ever, comparative scientific analyses of the successes, failures, and challenges of local governments on four continents.

- Thomas Fleiner, Professor of Constitutional and Administrative Law, University of Fribourg, Switzerland, and Director, Institute of Federalism, Fribourg

his panorama of analytical and policy-relevant essays on local governance in 10 developing countries put together by Anwar Shah should not be missed by either academics or practitioners.

- M. Govinda Rao, Director, National Institute of Public Finance and Policy, New Delhi, India

ood governance, not only better local governments - that is the message Anwar Shah conveys in this new and timely book. Drawing on theoretical reasoning and actual experience, he calls for governments that adhere to citizens' preferences, properly manage their financial resources, and are accountable to their electorates. This book is essential reading in a time when globalization and the information revolution have again put the local government issue in the spotlight.

- Fernando Rezende, Professor of Public and Business Administration, Getúlio Vargas Foundation, Rio de Janeiro and Brasilia, Brazil

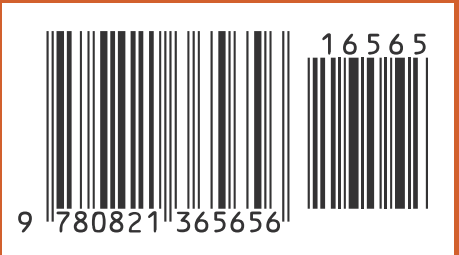

ISBN 0-8213-6565-7 